\title{
UNIVERSIDAD POLITÉCNICA
}

\section{DE VALENCIA}

\section{FACULTAD DE BELLAS ARTES DE SAN CARLOS} DEPARTAMENTO DE ESCULTURA

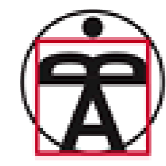

LA ORFEBRERIIA EN LA CREACIÓN ESCULTÓRICA VENEZOLANA CONTEMPORÁNEA.

ALEXIS DE LA SIERRA 1976-2010.

TESIS DOCTORAL

Presentada por:

Lic. María Graciela García Guillén

Dirigida por:

Dra. Elisa Lozano Chiarlones

Tutor:

Dr. Gerardo Sigler Vizcaino.

15 de Julio de 2013. 
AGRADECIMIENTOS

...Satisfecha con demasía, por la colaboración de una gran cantidad de personas que ayudaron no solo con el desarrollo, sino que pudiese llevarse a termino esta investigación... 


\section{CAPÍTULO 1}

\section{MARCO TEÓRICO}

\subsection{PANORAMA DE LA ORFEBRERÍA Y ESCULTURA}

EN VENEZUELA.

1.1.1 BREVES ANTECEDENTES HISTÓRICOS.

1.2 CONTEXTO ARTÍSTICO DE LA ORFEBRERÍA VENEZOLANA.......... 6

1.2.1 PERSISTENCIA DE LA ORFEBRERÍA................................... 10

1.2.1.1 Aproximación hacia una orfebrería artística..................... 14

1.2.1.2 Resurgir de la orfebrería venezolana en Manos de Alexis De la Sierra..

1.2.2 ÉPOCA ACTUAL. Generalidades.

1.2.2.1 Centros oficiales y talleres de enseñanza de orfebrería. Generalidades.

1.2.2.2 Cronología de bienales y salones de arte que incluyan la modalidad de Orfebrería. 57

\subsection{CONTEXTO ARTÍSTICO DE LA ESCULTURA}

VENEZOLANA.

1.3.1 APROXIMACIÓN HACIA UNA NUEVA ESCULTURA................. 58

1.3.2 LA ESCULTURA MODERNA EN MANOS DE

FRANCISCO NARVÁEZ. 63

1.3.3 DEVENIR DE LA ESCULTURA CONTEMPORÁNEA

VENEZOLANA 65

1.3.4 NUEVAS VERTIENTES PARA LA ESCULTURA

VENEZOLANA 73

1.3.5 ÉPOCA ACTUAL. Generalidades............................................. 84

1.3.5.1 Centros oficiales de enseñanza de Artes Plásticas.......... 95 


\section{CAPÍTULO 2}

VISIÓN ACTUAL Y PERSPECTIVAS DEL ORFEBRE

VENEZOLANO..

\subsection{EL ORFEBRE VENEZOLANO ACTUAL. Propuesta}

nacida de una investigación de campo

2.1.1 DATOS DE LA POBLACIÓN ENCUESTADA.

Características más importantes. 103

2.1.2 RESULTADOS DEL CUESTIONARIO APLICADO.

Muestra de Gráficos. Generalidades. 104

2.1.3 PERFIL DEL ORFEBRE VENEZOLANO ACTUAL.

Valoración personal.. 113

\subsection{LA ORFEBRERÍA EN LA CREACIÓN ESCULTÓRICA}

VENEZOLANA. Clasificación por tendencia de los

principales orfebres. MUESTRA DE ESQUEMA.

Generalidades.

2.2.1 TENDENCIA ORNAMENTAL. Aspectos técnicos,

formales y conceptuales. Valoración personal.

2.2.2.TENDENCIA ESCULTÓRICA. Aspectos técnicos,

formales y conceptuales. Valoración personal. 165

\section{CAPITULO 3}

ALEXIS DE LA SIERRA. PIONERO DE LA ORFEBRERÍA

ESCULTÓRICA EN VENEZUELA.. 235 3.1 VIDA Y ENTORNO. 
3.2 FORMACIÓN ARTÍSTICA. Influencias

3.2.1 EN ORFEBRERÍA. Generalidades.

3.2.2 EN ESCULTURA. Generalidades.

\subsection{DESEMPEÑO COMO DOCENTE.}

3.3.1 ESCUELA. Inicio como centro de enseñanza.

3.3.2 ENSEÑANZA. Desarrollo de las actividades.

3.3.3 APORTE DE LA ESCUELA DE ORFEBRES ALEXIS DE

LA SIERRA. Repercusión en medios expositivos y en otros centros de enseñanza

3.4 PRODUCCIÓN ARTÍSTICA. Evolución hacia la

orfebrería escultórica. Generalidades 264

3.4.1 PRODUCCIÓN EN ORFEBRERÍA. Aspectos técnicos, formales y conceptuales. Valoración personal. 265

3.4.2 CATALOGACIÓN DEMOSTRATIVA SOBRE LA

EVOLUCIÓN EN ORFEBRERÍA 285

3.4.3 PRODUCCIÓN EN ESCULTURA. Aspectos técnicos, formales y conceptuales. Valoración personal.. 345

3.4.4 CATALOGACIÓN DEMOSTRATIVA SOBRE LA EVOLUCIÓN EN ESCULTURA 362

3.4.5 CRONOLOGÍA SOBRE LOS ASPECTOS MÁS IMPORTANTES EN SU PRODUCCIÓN ARTÍSTICA 397

CONCLUSIONES 404

BIBLIOGRAFÍA. 407

ÍNDICE DE IMÁGENES. 419

GLOSARIO DE TÉRMINOS 450

RESUMEN. 456 
RESUM..

ABSTRACT ... 458 
Considerando la importancia que ha cobrado la disciplina de la orfebrería en el contexto artístico venezolano, gracias a la obra e influencia del orfebre Alexis De la Sierra desde la década del 70 al 2010, nos hemos planteado como objetivo general de esta investigación el estudio de la orfebrería en la creación escultórica venezolana contemporánea desde el año de 1976 hasta el año 2010.

La presente Tesis Doctoral, refiere a la continuación de la anterior investigación con la cual se obtuvo el Diploma de Estudios Avanzados (DEA), en la Universidad Politécnica de Valencia, España; fundamentada en la "Producción Artística de Alexis De la Sierra en la Venezuela actual"; cumpliendo con el plan de formación del Doctorado en Escultura dentro del programa: "Corrientes Experimentales en la Escultura Contemporánea"; con el fin de obtener el Título de Doctor, en la misma Universidad. Del mismo modo, hemos planteado algunos objetivos específicos, los cuales ayudarán a desglosar dicha investigación:

- Conocer cuáles son las características más importantes de la orfebrería venezolana.

- Identificar cuáles han sido los principales factores que han impulsado la orfebrería venezolana hacia una tendencia escultórica

- Elaborar un análisis técnico, formal y conceptual de las obras más significativas de orfebres venezolanos con el propósito de explicar cómo ha evolucionado la orfebrería hacia una tendencia escultórica.

- Conocer, difundir y catalogar la obra del artista Alexis De la Sierra, fundamentalmente en la tendencia de la orfebrería y escultura, de manera que pueda conocerse como ha sido su producción y como esta, ha confluido hacia la orfebrería escultórica. Así como también, conocer y difundir su desempeño como docente ya que su escuela y producción, han sido trascendentales para el desarrollo de esta disciplina en el país.

El nombre del artista plástico venezolano Alexis De la Sierra, va unido a la orfebrería y es esta disciplina con la que inicia su transitar en las artes; el esfuerzo, la atención y dedicación con la que la ha abordado, le ha permitido, seguir su evolución hacia la tendencia escultórica. El público que conoce su obra, sabe con 
certeza que su lenguaje plástico no se desarrolla únicamente en este medio.

“... Alexis De la Sierra significa orfebrería al más alto nivel en Venezuela...

...Contando con más de cuarenta años de intensa vida artística, este creador fue ampliando su propio lenguaje a través de la escultura y el arte cibernético. Libre de preconcebidos academicismos, siempre analítico, investigador y a la vez espontáneo, nos sorprende con nuevas visiones y con la creación de nuevos géneros de expresión plástica. De allí que nos despierta el interés por aproximarnos a la creación del género Orfebrería Escultórica"1.

La variedad de metales, técnicas, materiales, conceptos y formatos utilizados por éste prolífico artista, constituye un proceso de experimentación que contempla desde sofisticadas joyas, estupendos objetos mágico-religiosos, candelabros, mesas lumínicas escultóricas, esculturas desde pequeños hasta monumentales formatos, ciber-pinturas e instalaciones multimatéricas; donde cada medio expresivo es autónomo. Sin embargo, para comprender la evolución de su producción artística es imprescindible relacionar los conceptos subyacentes de los diversos tipos de obras. Quizá las palabras que mejor definen la labor que ha llevado a cabo este artista por cuarenta años son: perseverancia, disciplina, innovación y búsqueda de la belleza con la perfección técnica; pilares fundamentales con los cuales ha levantado la estructura de su trabajo.

Alexis De la Sierra se ha ganado mucho respeto en el mundo artístico venezolano, principalmente en el campo de la orfebrería; no solo con su obra, sino como docente en su escuela de orfebrería, aunque en estos momentos, su producción artística está dedicada más a la pintura cibernética y sobre todo a la docencia en orfebrería y diseño digital, su influencia se hace notar en las obras elaboradas por sus alumnos; pues, asiduamente en el campo expositivo, sus obras demuestran con convicción, la pericia con que dominan las técnicas, la facilidad con que abordan cualquier tópico, y el excelente acabado que promociona con demasía su enseñanza.

${ }^{1}$ García, M. (2010). “Alexis De la Sierra Orfebrería sin límites”. Revista. Arte facto (Edición Especial). № 3 . p: 036 . 
En su trayectoria artística, se le pueden conocer muchas facetas: luminito, actor, orfebre, escultor y ciber-pintor; y de cada una de estas fases, ha sabido aprovechar lo máximo posible. Se le ha visto aplicar y fusionar técnicas de otras disciplinas artísticas con aquellas propias de la orfebrería, que ha sido siempre el centro de su obra y es la que gran esfuerzo y esmero ha dedicado.

Debido a que este artista ha logrado una convergencia entre las disciplinas de la orfebrería y la escultura, se toma esta premisa cómo punto de partida de la orfebrería en la creación escultórica venezolana y se presenta una periodización breve del contexto artístico sobre cómo ha sido el desarrollo de ambas disciplinas en Venezuela y la confluencia de la orfebrería hacia la escultura.

Dentro de este contexto, el trabajo artístico de Alexis De la Sierra, ha sido sustancial para el progreso de esta convergencia artística y podemos considerarlo como una pieza fundamental para la historia de la orfebrería escultórica, como una nueva corriente artística en Venezuela. De esta forma, en la presente Tesis Doctoral, se estudia y se analizan los aportes de este artista, que han contribuido al desarrollo de la convergencia entre orfebrería y escultura desde el período en que él se introduce en el campo expositivo en el año 1976, hasta el año 2010.

Alexis De la Sierra comienza la búsqueda de un lenguaje propio que lo hace el pionero en la orfebrería escultórica contemporánea venezolana, no sólo por su magnífica producción, sino también, como docente en esta disciplina en su propia escuela. La importancia de destacarlo como artista, se debe a la trayectoria artística que comienza desde el año 1968, pues desde un principio, marca con su obra un estilo diferente al que existía en esa época. En el año 1985 crea la "Escuela de Orfebres Alexis De la Sierra" en la ciudad de Caracas, en la cual se han formado ya más de 3000 profesionales en esta área y hemos comprobado que efectivamente su escuela, es el primer eslabón de la gran cadena de talleres de enseñanza de orfebrería que existen actualmente en el país.

Este artista se inicia en las artes a los catorce años de edad por medio del teatro, pero al poco tiempo, su inconformismo ante los medios imperantes de esa disciplina hace que incursione en el campo de la orfebrería. Los primeros siete años trabaja como autodidacta. Sin embargo, la fascinación que ejerce la orfebrería en él, lo anima a realizar unos seminarios en Londres sobre "Corrientes Antiguas de la Orfebrería". Luego por méritos curriculares, en Venezuela le otorgan una beca para estudiar en la Universidad Pontificia Católica de Chile, donde obtiene el título en 
Artes Plásticas con mención en Escultura y en Color; con esta formación, consigue integrar la escultura a la orfebrería y logra un lenguaje plástico que lo caracteriza.

La razón de la elección del tema de estudio, es una motivación particular hacia la orfebrería como disciplina artística utilizada en la creación escultórica venezolana contemporánea De este modo, dejar unas bases sólidas en donde demuestren que ésta, es una disciplina artística autónoma y puede ser apreciada como una de las nuevas tendencias del arte actual.

Otra motivación importante para realizar el estudio sobre la orfebrería en la creación escultórica venezolana contemporánea, se debe a la producción artística de Alexis De la Sierra, puesto que a través de su obra, la orfebrería en Venezuela se considera como obra de Museo; y su nueva manera de abordarla se adapta y se apropia de las nuevas corrientes artísticas, pues, obtiene la "Medalla de Oro Magnus Laurentis Medicis" en la Bienal Internacional de Arte Contemporáneo en Florencia, Italia, en el año 2000. De igual importancia conseguimos en su labor como docente, puesto que, esta nueva concepción de la orfebrería, es transmitida a sus alumnos y la inducción de éstos, al medio expositivo, ha sido fundamental para la difusión y promoción de esta nueva orfebrería. Por ello, su influencia en el país, ha logrado que poco a poco la orfebrería se apropie de semblantes cada vez más artísticos/escultóricos, y que otros talleres de enseñanza, centren su educación con convicción y seriedad; para que sus alumnos, se enfrenten con propiedad ante las exigencias del medio expositivo actual.

Debido a la repercusión actual de la orfebrería como creación escultórica en Venezuela, nos hemos planteado el estudio exhaustivo de cómo ha sido el desarrollo de dicha disciplina en el país; considerando la importancia de la primera y única publicación existente en Venezuela "Historia de la Orfebrería en Venezuela" escrita por el historiador y crítico de arte Carlos Duarte, que data del año 1970; en la cual se enfoca sobre el desarrollo de la orfebrería en Venezuela a partir de la colonización española hasta esa fecha: contexto este, resultó en magníficas obras artísticas para las iglesias en todo el territorio nacional. Sin embargo, en la presente tesis, hemos obviado esta publicación fundamentándonos en argumentos más actualizados como la investigación de la Tesis para obtener la licenciatura en Historia de Victmary Dávila, en el año 2000 titulada: "Panorama de la Joyería Artística Contemporánea. Década 70, 80, 90 de Venezuela”; en la cual, hace una periodización sobre el desarrollo de la orfebrería en Venezuela, revelando las principales características de la 
producción de algunos orfebres venezolanos durante las décadas del setenta, ochenta y noventa.

Del mismo modo, abordamos el contexto de la escultura en Venezuela, argumentándonos con la publicación de Juan Palenzuela "Escultura en Venezuela 1960-2002" del año 2002 cuyos datos, hemos favorecido considerablemente, en su actualización con imágenes y otros datos fidedignos, con la cual, lograremos armar y crear un marco teórico que de inicio al tema de estudio de la presente Tesis Doctoral.

Consideramos importante destacar, que en la presente investigación, el compendio que abordaremos dentro del contexto artístico de la orfebrería y escultura hablaremos exclusivamente sobre el desarrollo de ambas tendencias en Venezuela, debido al tema de estudio que transcurre y repercute directamente sobre artistas venezolanos dentro de ese país.

La presente investigación abordará en una primera instancia bajo la tipología de la investigación exploratoria, debido a que es un tema poco estudiado; por lo tanto, la recopilación de la información en gran parte, será en base a entrevistas, encuestas y afines. Así como también, se establece que la investigación abordará bajo la tipología de la investigación descriptiva y analítica. Considerando que la documentación recopilada, resultará en el desarrollo de ambas tendencias en el país y con ello facilitar el análisis tanto de las obras como de los factores que han repercutido en el desarrollo de la disciplina de la orfebrería hacia una tendencia escultórica. En tal sentido podemos afirmar, que la metodología seguida en esta investigación se basará en la recopilación, descripción y el análisis de la orfebrería venezolana desde el periodo de la colonia hasta la fecha del 2010. Siguiendo los lineamientos metodológicos para la consecución de la Tesis Doctoral, nos fundamentaremos en los siguientes pasos:

Se elaborará una revisión bibliográfica con respecto a la disciplina de la orfebrería en Venezuela para saber desde que punto daremos inicio a esta investigación y poder establecer unas bases teóricas que sustenten el inicio del tema de estudio.

- Se recolectará información de la orfebrería venezolana a través de algunos textos, diarios, revistas, páginas web, catálogos de exposiciones, revistas e inclusive, material inédito como entrevistas personales, telefónicas o por correo electrónico. 
- Se realizará un trabajo de campo, en base a un cuestionario aplicado a orfebres para poder conocer, las características más importantes con respecto a su formación, y producción, para abordar de manera fidedigna los datos que se utilizarán para crear el perfil del orfebre venezolano actual.

- Se mostrará la información obtenida por décadas para una mayor comprensión de la evolución de la orfebrería venezolana.

- Se elaborará un análisis técnico, formal y conceptual de las obras de algunos orfebres, fundamentándonos exclusivamente en aquellos orfebres cuyas obras han sido expuestas en salones y algunos han resultado ganadores: así pues, poder revelar la influencia de Alexis De la Sierra dentro de este contexto artístico.

- Se elaborarán las conclusiones, conjuntamente al aporte que derive dicha investigación.

Ahora bien, el trabajo se desarrolla en tres capítulos. El primer capítulo tiene que ver con el marco teórico y para ello, se desarrollan dos ideas: se dedica una visión del panorama de la orfebrería y de la escultura venezolana; dicho contexto, aborda unos antecedentes históricos que trata desde la época de los indígenas, antes de la colonización española; como fue el desarrollo durante el periodo de la colonia y cómo ha progresado hasta el año 2010. En este sentido, dentro del contexto de la orfebrería, demostramos como Alexis De la Sierra ha sido sustancial para la evolución de esta tendencia, con su obra e influencia, a través de la enseñanza en su escuela de orfebres.

El segundo capítulo tiene que ver con el objeto de estudio que se fundamenta en la orfebrería en la creación escultórica contemporánea venezolana. Para ello, lo dividimos en dos apartados. El primero de ellos, trata sobre el orfebre venezolano actual, el cual se logra mediante la aplicación de un cuestionario, con el cual pudimos crear un perfil del orfebre venezolano actual. El segundo apartado, trata sobre la orfebrería en la creación escultórica, centrándonos en las obras expuestas y premiadas en salones de arte. Tomando en cuenta que las obras varían entre la tendencia ornamental y la escultórica, elaboramos un esquema donde se clasifican dentro de cada tendencia y a su vez según su estilo. Todo esto, consideramos necesario, para poder exponer de manera ordenada un análisis técnico, formal y conceptual, de la producción de estos orfebres. El tercer y último capítulo, trata 
sobre el pionero de la orfebrería escultórica en Venezuela quien es Alexis De la Sierra; el cual, dividimos en cinco apartados. En el primero, se muestran los datos más importantes de su vida y entorno. En el segundo, se abordan los aspectos más significativos en su formación artística, así como también las influencias que han repercutido en el desarrollo de su obra. En el tercero, se toman en cuenta algunos aspectos significativos que tienen que ver con el desarrollo de su labor como docente en su escuela de orfebrería, y el aporte que ha generado en el progreso de la orfebrería venezolana. En el cuarto, se exponen las características más importantes de su producción artística tanto en orfebrería como en escultura, en donde hacemos un análisis

fundamentándonos en los aspectos técnicos, formales y conceptuales, tomando en cuenta cómo evoluciona hacia la orfebrería escultórica y exponemos una catalogación evolutiva de algunas obras, tanto en orfebrería como en escultura desde sus primeras obras que datan de 1970 hasta la fecha del 2010. En el quinto y último apartado, presentamos una cronología sobre los aspectos más importantes en su producción artística. 
CAPÍTULO 1

MARCO TEÓRICO

1.1 PANORAMA DE LA ORFEBRERÍA Y ESCULTURA EN VENEZUELA.

1.1.1 BREVES ANTECEDENTES HISTÓRICOS

Esta parte de nuestra investigación, aborda tanto la disciplina de la orfebrería como la de escultura; ya que en definitiva consideramos que ambas, siempre han estado emparentadas como representación artística. Por ello, se requiere exponer a continuación algunos datos de interés del tema en cuestión.

Según estudios arqueológicos, puede corroborarse sobre el proceso de cómo fue poblado el territorio venezolano el cual se divide en dos períodos, el Período Antiguo (del 12000 a. C. al 1498 d. C.) y el Período de Contacto o Indo-hispánico (del 1498 al 1600 d.C.). En tal sentido, podemos aseverar que el Período Antiguo es la etapa más larga de la historia de Venezuela. Éste, comprende desde la llegada de los primeros pobladores quienes se trasladaron por el área del Occidente hace unos 12.000 años, hasta la invasión de los conquistadores españoles en 1498. En dicho período, conseguimos que sus pobladores fueran cazadores especializados de animales prehistóricos como mastodontes $u$ otras especies menores. Esos animales, eran cazados con instrumentos de piedra de gran tamaño, los cuales fueron posteriormente perfeccionados con filos perfectos e incorporados al arco de flecha lo cual facilitó la cacería ${ }^{1 .}$

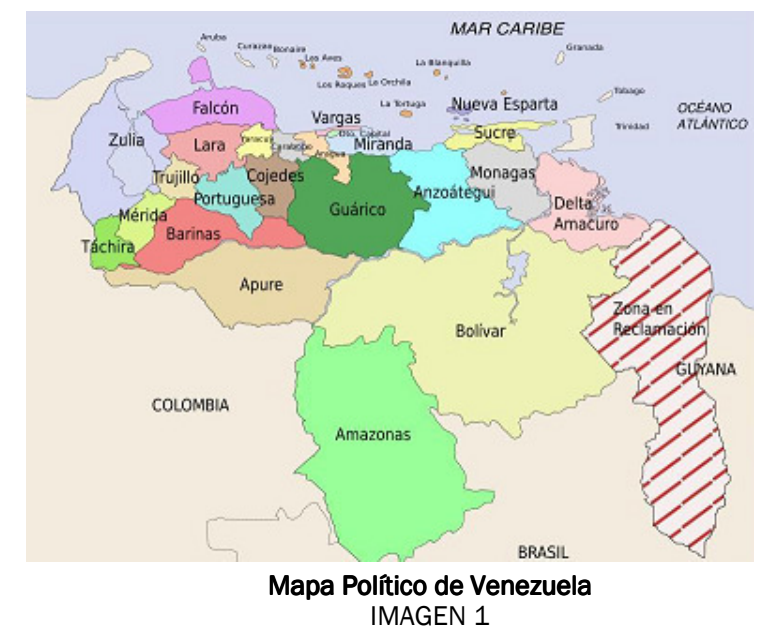

Estos primeros pobladores, inicialmente se ubicaron en el occidente de Venezuela en lo que hoy corresponde al estado Falcón, -señalado en, Mapa Político de Venezuela (IMAGEN 1). Del

1 Jiménez, M. (1997). “Historia de Venezuela 7”. pp: 3-5 
mismo modo, se evidencia que del Período de Contacto o Indohispánico es la etapa en la cual se produjo el encuentro entre las culturas americana y europea. Antes de la llegada de los hispanos, se fueron integrando otros grupos de indígenas como los Caribes y Arawacos, que comenzaron a practicar la agricultura y la alfarería, cuya forma de vida sedentaria se expandió desde las riberas de río Orinoco hacia el centro y occidente de Venezuela (estados Falcón, Lara, Portuguesa, Barinas y Apure).

Sobre la base del análisis de numerosos yacimientos, se establecen las áreas habitadas por los indígenas venezolanos cuyos rasgos los identifica y diferencia. En tal sentido, se considera importante citar brevemente puesto que, algunas de estas características se mantienen arraigadas en las obras de los orfebres actuales.

Tal y como comenta Jiménez, M. en el texto “Historia de Venezuela 7" los del Área Norte, correspondiente al Área de la Costa Caribe. Es la zona del norte de Venezuela (desde península de Paria al Este del estado Sucre hasta el estado Yaracuy) que corresponde a la región de las costas. Esta área era habitada por los indígenas de la etnia de los Caribes. Ellos, consideraban al sol y la luna como sus dioses; efectuaban ritos y ceremonias, usaban poca vestimenta (guayuco) y adornaban sus cuerpos con collares, pulseras, pendientes, zarcillos, elaborados con plumas de diversas aves autóctonas. Los del Área de los Andes corresponden a la región montañosa de los Andes, conformada por los Estados Táchira, Mérida, Trujillo y parte de Lara. Esta región estaba habitada por la etnia de los Timoto-cuicas, considerados hoy en día como la comunidad más avanzada. Trabajaron especialmente la piedra y alfarería. Poseían vestimenta debido al frío de la zona. Eran fieles creyentes, por lo que rendían culto a numerosos dioses a los cuales, comúnmente ofrecían rituales.

Los del Área de la Costa Nor-oeste las cuales corresponden a los estados Zulia, Lara y Carabobo habitada por los indígenas de la etnia Wayuu ó Guajiros, su artesanía varía entre diferentes objetos en cerámica gris con fines ceremoniales y utilitarios. Así como también, las figurillas de tierra cocida, con una variadísima tipología; en su mayoría, figuras femeninas tal y como podemos observar en la Venus de Tacarigua (IMAGEN 2), con clara evidencia del sexo, de extremidades inferiores gruesas, deformación artificial del cráneo, convertido en una enorme cabeza más ancha que el contorno de sus hombros y

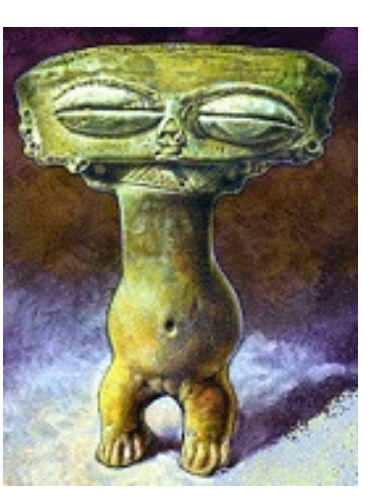

Venus de Tacarigua IMAGEN 2 
los enormes ojos abultados y alargados del tipo grano de café. El Área del Sur, la región del Amazonas (el Orinoco) estaba habitada por la etnia de los Arawakos, los cuales se encontraban asentados por todo el recorrido del río Orinoco. Esa área es la más extensa del territorio nacional y desde el punto de vista cultural la más importante. Se evidencia una cerámica con decoración incisa de temas geométricos. En el Orinoco medio se destacan pequeñas figurillas elaboradas en oro, de temática animal en los que sobresale un Dios "cocodrilo"2.

Hemos comprobado que, los indígenas venezolanos desarrollaron algunas industrias, como la cestería, la alfarería, los tejidos e hilados. No conocieron el trabajo con los metales, excepto el oro, el cual obtenían de las arenas de sus ríos, o por comercio (trueque), para utilizarlo como adorno.

Tal y como comenta Francisco Suárez en su investigación "La enseñanza de los oficios artesanales como alternativa tecnológica para el desarrollo: Los Talleres Artesanales de la Universidad de los Andes", los estudios localizados de las actividades de la cultura indígena, el oficio artesanal era primordial para su subsistencia. En este sentido, una huella imponente son los trabajos realizados en cerámica, piedra, madera, con bejucos, ramas de algunas palmas, tinturas naturales, fibras vegetales y con minerales. Estos hallazgos, manifiestan de modo original, la combinación de materiales para crear utensilios domésticos, armas de caza y pesca, vestidos, objetos para rendir culto, joyas y hasta viviendas ${ }^{3}$.

Con el devenir del tiempo, esta cultura artesanal se fue nutriendo de diversos legados de otras razas y de otros continentes. De este modo, se hizo mucho más rica, variada y creativa. Ahora bien, en la historia del arte venezolano se revela que el desarrollo de las manifestaciones artísticas, se inicia a partir del proceso histórico de la conquista. En 1492, cuando Cristóbal Colón descubre América, se inicia la conquista en Venezuela por la Isla de Cubagua (Isla vecina de Margarita, estado Nueva Esparta). En los primeros años del siglo XVI, los conquistadores se establecen en esa aldea que luego se fundó con el nombre de Nueva Cádiz. Según el Historiador Venezolano Carlos Duarte, empezaron a llegar al país numerosos artesanos atraídos por la leyenda de "El Dorado", (abundancia de oro y perlas), en su mayoría procedentes de España y de Portugal. Los artesanos radicados en Nueva Cádiz establecen la creación de gremios artesanales los cuales estaban

2 Ibid. pp: 7-9.

3 Suárez. F. (1999). "La enseñanza de los oficios artesanales como alternativa tecnológica para el desarrollo: Los Talleres Artesanales de la Universidad de los Andes". Universidad Pedagógica Experimental Libertador. VIII Jornadas sobre Investigación y Docencia en la Ciencia de la Historia. Conferencia. pp: $4-5$ 
constituidos por excelentes maestros entre carpinteros, ebanistas, tallistas, constructores de retablos, alarifes, escultores, metalisteros, plateros, orfebres, etc. Cada gremio debía fomentar la instrucción para su desarrollo y es así como se establece el inicio de la producción del arte colonial.

Las obras se realizaron en un estilo ceñido a los cánones del Barroco que imperaba en ese entonces en Europa. Estos procedimientos, no variaron en sus métodos ni en su aplicación y fueron conservados durante toda la época de la colonia. Del antiguo continente viajaron las piezas artísticas de los mejores talleres Sevillanos, las cuales se convirtieron en un poderoso elemento de fascinación sobre las poblaciones indígenas a quienes se debía evangelizar. El contenido imaginario de las obras fue capaz de arraigar la fe cristiana, junto con la devoción a los santos y a la Virgen. Las necesidades del culto religioso en la primitiva sociedad venezolana, fueron cubiertas también con obras importadas de México, Ecuador y Guatemala. El aumento de dicha producción se llevó a cabo en el siglo XVII dentro de los templos, los conventos y las haciendas. Las obras elaboradas en su mayoría de talla en madera de cedro, estaban inspiradas en la Virgen, la Santísima Trinidad y en la agonía de Jesús. La talla en madera de cedro, cuyos ornatos en oro y plata mantuvieron los procedimientos técnicos derivados de la tradición hispana y como ya comentamos, no variaron en su aplicación siendo conservadas durante toda la época de la colonia4.

Ya para finales del 1700, la sociedad colonial entra en conflicto; desde entonces, inician los primeros movimientos independentistas que persiguen la liberación del yugo español. Durante toda esa época de lucha, no había tiempo para la artesanía en ninguno de sus ámbitos, sólo interesaba conseguir fondos para la lucha. Hemos corroborado que muchas de estas obras en metales preciosos, elaborados durante la época de la colonia fueron fundidas e intercambiadas por armamento. Finalmente en el año 1810, el país declara su independencia y la guerra con España, en 1824 culmina la revolución y a partir de 1830 comienza la etapa republicana con José Antonio Páez. Desde ese entonces el país, se encuentra bajo el dominio de estos próceres que contribuyeron a la liberación.

Todo esto resume que, al iniciarse el siglo XIX la producción artesanal se mantuvo invariable con respecto a los siglos anteriores. Sin embargo, a raíz de la guerra defensora, la escultura tradicional, el artesanado y los gremios desaparecen como otras tantas derivaciones de la tradición económica.

4 La escultura de la antigua provincia de Venezuela. Hernández, J.M.

http://museosdevenezuela.org/Documentos/Revista/Conservacion2.shtml 
La historiadora Victmary Dávila en su tesis de Licenciatura “Panorama de la Joyería Artística Contemporánea. Década 70, 80, 90 de Venezuela" (2000) basa sus clasificaciones en el libro de Carlos Duarte "Historia de la Orfebrería en Venezuela" (1970)5.

"Las repetidas guerras civiles en Venezuela
necesitaban hombres y esfuerzos materiales
para la lucha. No había tiempo, ni dinero, ni
personas que pudieran dedicarse a la
enseñanza. Además, a los caudillos no les
interesaba que la gente supiera
demasiado..."

Podemos aseverar que, la artesanía no tuvo desarrollo durante toda la época de lucha. Puesto que, la causa solo tenía un fin y era el poder político.

Desde el dominio absoluto de la República, los próceres eran retratados en lienzos, cuya temática representa a los hechos ocurridos durante la batalla de liberación.

A partir de entonces, la pintura comienza a cobrar un auge sin precedentes, ya que los aristócratas de la colonia se hacian retratar por artistas españoles y franceses, o por algunos artistas criollos que surgen del legado europeo. El realismo era uno de los rasgos particulares que imperaba en la pintura europea de ese entonces y por ende en el país. Así pues, la escultura de la época colonial quedó aislada de toda tradición al romperse la continuidad de la práctica de la talla en madera.

Ahora bien, a partir del año 1870 con el General Guzmán-Blanco en el poder el panorama del país cambia. De su gobierno destacan una serie de decretos que ayudaron de manera radical y significativa para el progreso, todo esto debido a que Guzmán Blanco vivió muchos años en París, por lo que percibió muchos de los cambios que se produjeron durante el siglo XIX. Cuando Guzmán-Blanco llega al poder, implementa una serie de ordenanzas con el interés de modernizar a Venezuela y fundamentalmente la ciudad de Caracas, según lo que relatan los historiadores, se impuso en proporcionarle "cualidades parisinas" por lo que el país progresa significativamente en todos los ámbitos incluyendo el artístico.

1.2 CONTEXTO ARTÍSTICO DE LA ORFEBRERÍA VENEZOLANA.

\footnotetext{
5 Primer trabajo que se hace sobre la "Historia de la Orfebrería en Venezuela".

${ }^{6}$ Dávila, V. (2000). “Panorama de la Joyería Artística Contemporánea. Década 70, 80, 90 de Venezuela". Tesis para licenciatura. p: 14
} 
Tal y como comenta Graterol en su conferencia:"De la Colonia hasta nuestros días", la educación de la orfebrería en Venezuela", tras la colonización española en territorio venezolano, se conoce que los primeros artesanos radicados en la Isla de Cubagua fueron Cristóbal del Espinal y María Vázquez, ambos, plateros sevillanos. Constituyen talleres de enseñanza en la Iglesia de Santiago. A esta Iglesia, llegan las primeras alhajas de plata que servirían de modelo para los aprendices. Con el paso del tiempo, estos talleres se rigieron por la Real Cédula emitida por la Corona Española el 12 de Octubre de 1776 , donde se describen una serie de ordenanzas a seguir por los orfebres.

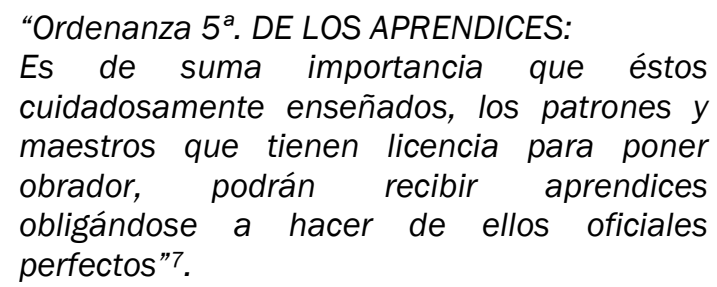

Dicha ordenanza manifiesta la importancia que tenía el arte de trabajar los metales preciosos, no sólo por el material valioso sino porque las obras debían mostrar una belleza extraordinaria que produjera admiración. Lo minucioso, el perfecto acabado y otras características eran de gran significación. Por ello, estos maestros debían formar oficiales perfectos para que los máximos representantes de la iglesia y otras personalidades importantes pudieran disponer de sus habilidades. En tal sentido, podemos apreciarlo en las obras que dejaron en Capillas, Iglesias y Catedrales, donde se evidencia la agilidad y destreza en el uso de técnicas y el manejo de los metales nobles.

Gran parte de esa enseñanza, dependió, de la habilidad manual del aprendiz; las técnicas, métodos y estilo, se llevaron a cabo, no sólo al ver las obras que venían de fuera; sino también, observando cómo las elaboraban sus maestros. De igual modo, estos artesanos contaban con la ayuda de textos y grabados sobre la materia. Podemos afirmar, que es por ello que se establece en nuestro país, el estilo Barroco imperante en ese entonces en Europa. Hemos comprobado que, la temática religiosa en la producción de obras en los siglos XVI al XIX también depende en parte, de la presencia de sacerdotes capuchinos, jesuitas y franciscanos españoles que eran orfebres. Estos sacerdotes, al ser destinados como misioneros en los pueblos recién fundados, imparten sus conocimientos en diversas técnicas de orfebrería. La iglesia, se convierte entonces en mecenas de artistas y artesanos

7 Graterol, C. (2007). “De la Colonia hasta nuestros días. La Educación de la Orfebrería en Venezuela". Ciclo de Conferencias conmemorativas al 34 Salón Nacional de las Artes del Fuego. Material inédito. Correo electrónico cvzla@yahoo.es 
y hace que los orfebres trabajen hermosas joyas de uso litúrgico como las custodias, jarras, platos, cálices y otros objetos alegóricos para los obispos o para adornos de las iglesias. Según los historiadores venezolanos, las leyes Españolas vigentes en la época de la colonia, la profesión se divide en diferentes grupos técnicos: forjadores, hiladores, tiradores, vaciadores, lapidarios, abrillantadores, batihojadores, filigraneros y relicarios. Se presume que la mayoría de las obras de esa época, se realizaron con plata procedente de México y esmeraldas procedentes en su mayoría de la zona del Muzo, Colombia. Así como también, se dice que con frecuencia las piedras preciosas eran obtenidas mediante trueque por café o cacao Venezolano.

Según Dávila8, reseña que de los datos obtenidos del etnógrafo Gaspar Marcano, "Etnografía Precolombina de Venezuela" la explotación aurífera y el uso de prendas de oro por parte de los indígenas, ocurrió justo con la llegada de los españoles. Puede afirmarse, que los indígenas prehispánicos que habitaron el territorio venezolano explotaron y utilizaron el oro, pero es difícil determinar la destreza en las técnicas de fundición, repujado y batido, que fueron hermosamente ejecutadas por los orfebres indígenas Taironas, Sinúes, Quimbayas, Caucas y Muisca que habitaron el actual norte colombiano. Sin embargo, se afirma que, en el documento firmado por Diego de Losada -Fundador de la Ciudad de Caracas en 1567- se nombran varios Indios que vivían en la Sierra. Dicho documento señala, que el indio principal "Guaratil" era platero aunque, no se comenta cómo se formó en este oficio. Esto supone, que los indígenas venezolanos dominaban el arte de la orfebrería mucho antes de la llegada de los españoles.

Ahora bien, fundamentándonos en lo anterior comentado, podemos afirmar que durante la época colonial, se establece el inicio de la historia de la orfebrería venezolana. Sin embargo, por diversas causas son pocas las obras que existen de esta época. En primer lugar, debe mencionarse el devastador terremoto de Caracas ocurrido en 1812. En segundo lugar, vale la pena mencionar el periodo comprendido entre 1810-1824, donde ocurre la Guerra de Independencia de Venezuela contra el dominio español. Así pues, en este período gran cantidad de bienes culturales que conformaron los inventarios y testamentos de obras de arte desaparecen. Durante esta contienda cuantiosas obras se fundieron para conseguir con ello, fondos para la lucha. De igual manera, las nuevas tendencias de la estética artística, consiguen que estos objetos se fundan para su transformación. Según Dávila9, puede asegurarse que fueron pocas las obras que

8 Dávila, V. (2000). “Panorama de la Joyería Artística Contemporánea. Década 70, 80, 90 de Venezuela". Tesis para licenciatura. p: 12

9 Ibid. p: 18 
subsistieron y que por tanto fueron menospreciadas. Afortunadamente, varios coleccionistas se han dedicado al rescate de esos objetos y es gracias a esto que puede conocerse parte de esa historia del arte venezolano.

De la investigación de Victmary Dávila se evidencian los datos de los primeros trabajos de orfebrería en Venezuela, que provienen del siglo XVII. En primer lugar se cita, una obra del platero Vicente Díaz; se trata de un Relicario, encargado éste por el Gobernador y Obispo de la ciudad de Coro. Coro en esa época era por decirlo así,

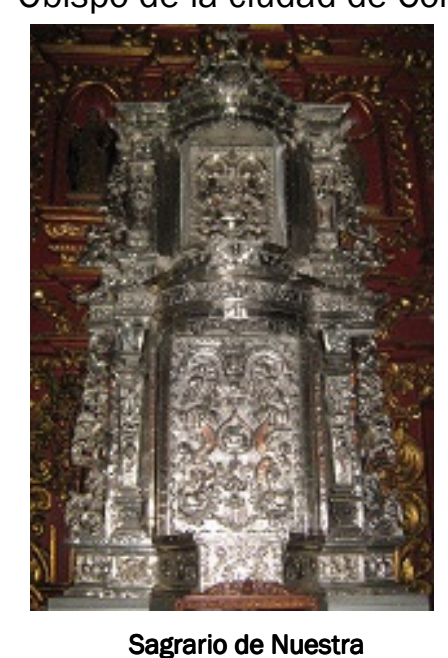

Sagrario de Nuestra IMAGEN 3
IMña Como sede de los poderes reales y eclesiásticos. En segundo lugar se cita una obra elaborada por el platero Domingo Vicente Núñez en el año 1756, la cual puede afirmarse, es la que posee mayor dimensión de gran esplendor con gran significado religioso y artístico único en el país. Se trata del Sagrario de Nuestra Señora de Coromoto (IMAGEN 3), encargado para el altar mayor de la Basílica Catedral Parroquia Espíritu Santo de la ciudad de Guanare; estado Portuguesa. Pudimos corroborar que, esta magnífica obra se compone de tres sagrarios.

En la parte inferior, se encuentra bajo llave, el sagrario Santos de los Santos de la nueva alianza. El segundo sagrario dispuesto en la parte central de la pieza, corresponde al lugar donde se guarda la custodia del Santísimo. Y el tercer sagrario, corresponde a la parte superior donde antiguamente, servía para custodiar la imagen de Nuestra Señora de Coromoto. Además verificamos que, esta obra tiene las dimensiones de tres metros treinta y cuatro centímetros de alto por un metro setenta y uno de ancho por cincuenta y siete de profundidad, elaborada íntegra con lámina de plata -excepto algunos detalles fundidos en plata en su cúspide-. El estilo Barroco se presenta colmado en detalles inspirados en la naturaleza. Podemos observar en la imagen que demuestra el (Detalle de repujado de la parte central inferior del Sagrario de Nuestra Señora de Coromoto IMAGEN 4), la agilidad de este maestro en las técnicas del martillado, repujado y cincelado, cuyos relieves formalmente impecables exaltan las formas orgánicas. Formas éstas, dispuestas de manera simétrica tal y como exige el estilo Barroco- que conforman una estructura erigida en tres secciones espectaculares. Las líneas sinuosas ceñidas a dicho estilo, demuestran el alto grado de perfección técnico de este platero de origen español. 
Sobre la parte superior del Sagrario, posa una cúspide con una cruz latina fundida (Detalle de la Copa del Sagrario de Nuestra Señora de Coromoto IMAGEN 5). Ésta, es elevada por dos ángeles -también macizoscuyas alas perfectamente estilizadas nos revelan un impoluto fundido en plata. Los dos ángeles se aferran a una lámina que contiene una leyenda escrita en alto relieve. En ella, se indica la fecha de ejecución y el nombre del autor. Ahora bien, unificando todo el conjunto vemos como de manera exquisita se engalana el altar mayor. En contraste, con el
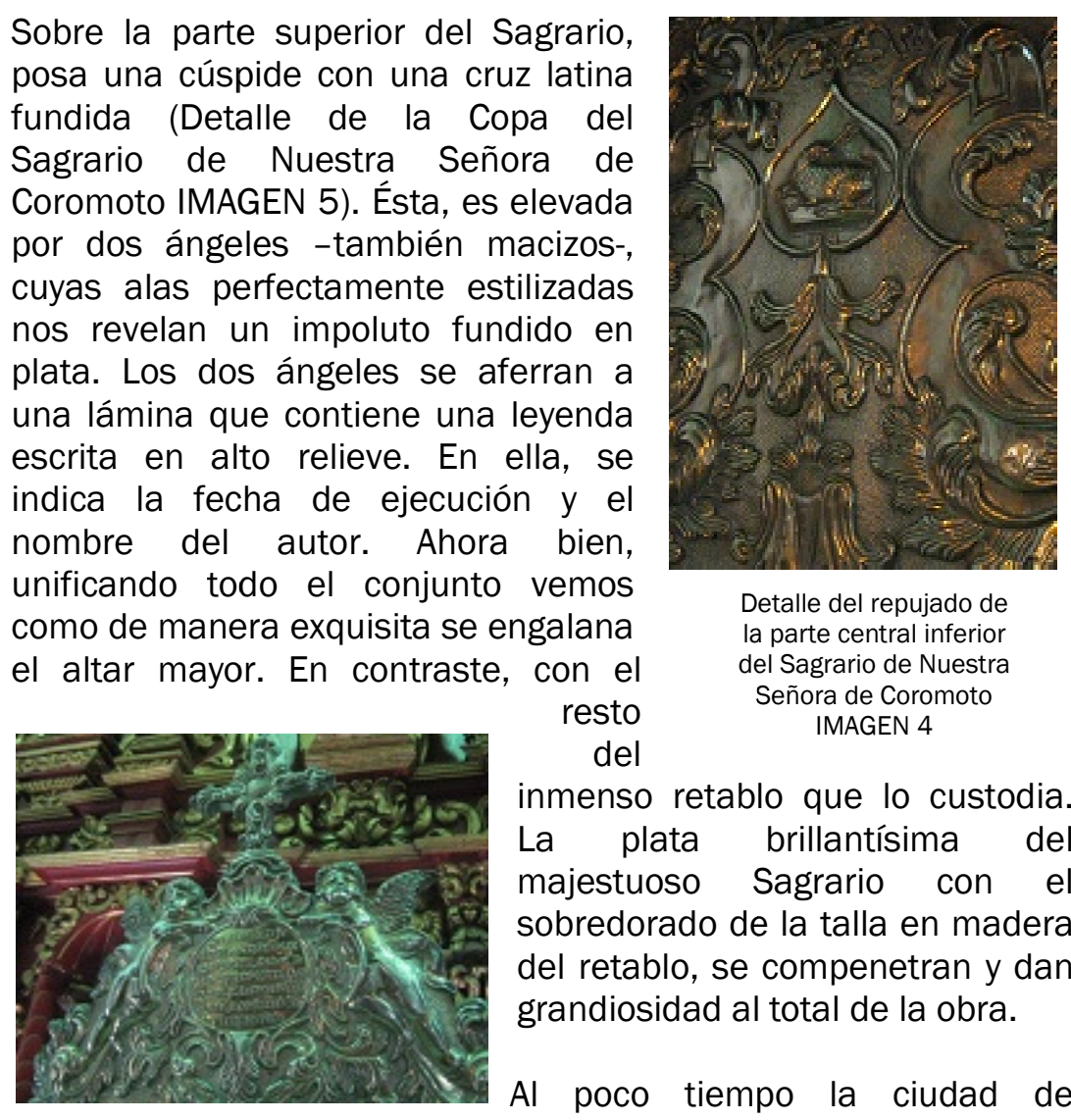

del

la parte central inferio

Señora de Coromoto

Detalle de la Copa del Sagrario de

Nuestra Señora de Coromoto

inmenso retablo que lo custodia. La plata brillantísima del majestuoso Sagrario con el sobredorado de la talla en madera del retablo, se compenetran y dan grandiosidad al total de la obra.

Al poco tiempo la ciudad de Caracas, ya entonces capital de Venezuela, toma un nuevo impulso cuando se ordena hacia ella el

traslado del poder de la iglesia. Es así como innumerables artífices y plateros formaron un núcleo importante y se congregaron en la capital. Entre los nombres que más destacan se pueden citar a el Maestro de la Filigrana Agustín de Aguilar, Juan Picón, Juan Landaeta, Sebastián de Ochoa, Pedro Ignacio Ramos, Luis Vicente López, Pedro Fermín Arias y Domingo Tomás Núñez. Los cuales dejaron magníficas obras en las iglesias capitalinas. De igual modo, se formaron otros grupos de orfebres, plateros y alarifes en ciertas ciudades del interior del país los cuales elaboraron obras significativas para sus iglesias; todo esto concluye, que las obras de estos magníficos orfebres, adquieren un carácter artístico cada vez más acentuado. Así pues, se establece que el arte de la platería en Venezuela, inicia su perfeccionamiento en la segunda mitad del siglo XVI; alcanzando su máximo esplendor, en la segunda mitad del siglo XVIII.

Sagrario, para llevar el viático (IMAGEN 6) es un ejemplo de una de esas magníficas obras. Nuevamente, el platero Domingo Tomás 
Núñez ${ }^{10}$ nos deja evidencia de ello con una obra de su autoría. Su parte central -la puerta- se exhibe una lámina martillada y repujada. Su copón y aleros hechos por fundición, de igual modo exteriorizan esas espectaculares formas. El diseño elaborado bajo estrictos elementos sinuosos se establecen en magníficas y zigzagueantes formas orgánicas. Enaltecidas éstas, con un perfecto sobredorado en oro de 24 quilates. Esta hermosa obra realizada en el año 1796 , antiguamente pertenecía a la colección de

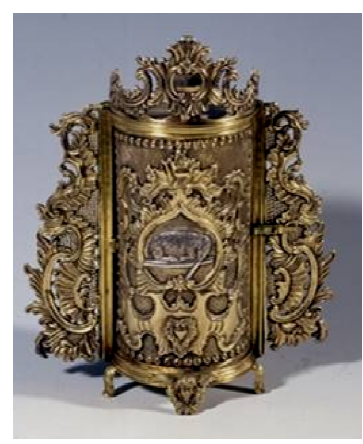

Sagrario, para llevar el viático la Catedral de la ciudad de Caracas. En la actualidad, se encuentra resguardada en el Museo de Arte Colonial en la misma ciudad.

Según Dávila11, el arribo de la era industrial comenzó a generar cambios en todos los ámbitos. El arte de la orfebrería se comienza a ver afectado ya que salía más económico adquirir artesanía de fuera, sustituyendo las obras altamente elaboradas en metales preciosos por obras procesadas industrialmente. A fin de cuentas, pareciera que interesaba más la cantidad y diversidad de objetos procesados en serie, que la calidad de estos objetos pudieran representar. Existen otros factores que influyeron en el descenso del oficio como por ejemplo, la clausura de los conventos y la extinción de las cofradías es por ello que la producción de joyas comenzó a disminuir debido a la falta de fuentes de trabajo. Podemos observar, un debilitamiento del arte del orfebre durante el siglo XIX alcanzando hasta principios del XX, que es la época en que los historiadores revelan cuando comienza a dejar precedentes como representación artística. Pese a todo esto, los estilos, y las técnicas empleadas por los orfebres de los siglos anteriores, se mantuvieron por generaciones y esto se cree debido al hecho de que casi todos los artesanos de esos gremios estaban emparentados entre sí.

\subsubsection{PERSISTENCIA DE LA ORFEBRERÍA.}

Según los antecedentes de la historia del arte venezolano en el año de 1940 se crea "El Salón Oficial Anual de Arte Venezolano" ("SOAAV"), en la ciudad de Caracas. Esto genera perspectivas diversas sobre las bellas artes, donde la pluralidad de las obras

10 La obra del Sagrario, para llevar viático (IMAGEN 4) en un principio se decía que fue elaborada por el platero Pedro Ignacio Ramos. Sin embargo, tras las investigaciones pudieron corroborar la autoría de Domingo Tomás Núñez.

11 Dávila, V. (2000). “Panorama de la Joyería Artística Contemporánea. Década 70, 80, 90 de Venezuela". Tesis para licenciatura. p: 18 
ganadoras se unen para mostrar nuevas expresiones estéticas. Es por ello que, existe un gran entusiasmo en la enseñanza de las artes plásticas y más aún en sus creadores. Este hecho cobra importancia como suceso cultural a nivel nacional. Puesto que, en el año 1943, la Escuela de Artes Plásticas Arturo Michelena en Valencia; estado Carabobo, crea el "Salón Arturo Michelena" ("Salón Michelena"). Cuyos premios estaban reservados -en un principio- para sus alumnos. Así pues, podemos afirmar que para la época con este nuevo salón quedan instaurados los dos únicos Salones de Arte en Venezuela12.

Ahora bien, a principios de los años cuarenta en Venezuela La Escuela de Artes Plásticas y Artes Aplicadas de la Academia de Bellas Artes de Caracas y la Escuela de Artes Plásticas Arturo Michelena de Valencia, eran las únicas instituciones formales que se encargaban de la enseñanza en Artes Plásticas. El aumento considerable de personas que se integran a esta disciplina, resulta entre sus creadores, una búsqueda de nuevas tendencias para aplicar en sus representaciones. La Escuela de Artes Plásticas y Artes aplicadas de la Academia de Bellas Artes de Caracas, fue la primera en incluir asignaturas en manifestaciones artísticas -no tradicionales- en las artes mayores tales como: la cerámica, el vidrio, el esmalte sobre metal y la orfebrería. Este entorno trasciende en sus creadores; ya que, sucede algo significativo y fructífero para quienes se encuentran en el desarrollo de esa nueva tendencia artística. Tal y como comenta el orfebre Carlos Graterol, en su ponencia "De la Colonia hasta nuestros días. La educación de la orfebrería en Venezuela"13. En el décimo "SOAAV" realizado en el año 1949 le otorgan el Premio Oficial de Artes Aplicadas al joyero español José María Gallofré. Y, al año siguiente obtiene el mismo galardón, David Vallmitjana también joyero de origen español. Con estos dos casos, queda un antecedente importante, pues una vez cerrado el ciclo histórico de la orfebrería colonial en Venezuela, éste oficio emerge nuevamente en manos de dos orfebres, de origen español. Lamentablemente no se puede aclarar si estos dos joyeros en particular, fueron producto de la enseñanza del oficio tras varias generaciones, de los artesanos españoles Ilegados a Venezuela durante la época colonial; o se trata de cierto grupo de artistas que emigraron a Venezuela después de su independización. De igual modo, no existe evidencia documentada sobre esas obras. Sin embargo, consideramos que la investigación de Graterol está bien sustentada al respecto. Por ello, resulta interesante, que en manos

12 La Historia Fraguada en Fuego. Fritz Küper. (1994). http://galeria.uc.edu.ve/resenas. php?id=50\&idexpo $=53 \&$ actual $=1$

13 Graterol, C. (2007). “De la Colonia hasta nuestros días. La Educación de la Orfebrería en Venezuela". Ciclo de Conferencias conmemorativas al 34 Salón Nacional de las Artes del Fuego. Material inédito. Correo electrónico cvzla@yahoo.es 
de estos dos joyeros españoles, la orfebrería venezolana inicie como representación artística en salones de arte.

Tanta importancia cobra esta nueva tendencia en el arte para la época de los cincuenta que, los esmaltistas Ricardo Arrúe Valle, Miguel Arroyo y Sergio González, se dedicaron a la enseñanza del Esmalte sobre metal. Realizan esta actividad en la ciudad de Caracas en la Escuela de Artes Plásticas y Artes Aplicadas de la Academia de Bellas Artes de Caracas, en el Taller Libre de Arte y en la casa de la Cultura Mariano Picón Salas. Este periodo de florecimiento en las artes creó un movimiento en el que el esmalte sobre metal, la cerámica, el diseño de joyas y la joyería, obtuvieron vías alternativas, dentro de la enseñanza y la inclusión de dichas técnicas en las obras de sus creadores.

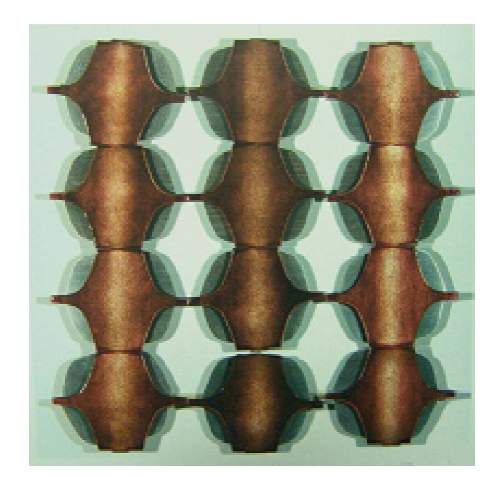

$\mathrm{S} / \mathrm{T}$

Otro aspecto importante que interviene en el desarrollo de los esmaltes al fuego en Venezuela durante esa misma década, es la presencia del mexicano Francisco Porras. Quién inicia labor docente en su propio taller con las técnicas de esmalte sobre metal, con particular énfasis en el diseño escandinavo influencia que trae de Suecia. La (IMAGEN 7) es una obra S/T de su autoría, allí se aprecia un diseño depurado con líneas simples bajo un estilo minimalista. Así pues,

Porras manifiesta verdadero interés en las formas simples con acento geométrico, plasmados en metal con esmaltes al fuego. Apuesta por un diseño limpio, inspirado en la simetría con formas caladas y repujadas, cuyo esmalte color ocre degrada en su superficie. Formas estas se superponen de láminas metálicas de color gris mate, consiguiendo un impecable contraste entre sus formas ${ }^{14}$.

El orfebre Porras, obtiene un Premio en el primer "SNAF" en la tendencia de Esmaltes al Fuego en el año 1971; con este premio, transmite a sus alumnos la importancia de esta técnica aplicada en grandes superficies, logrando con ello una expresión artística.

Esta influencia, repercute en la formación de un amplio y nutrido grupo de esmaltistas en el país, así como también, a artistas que se encuentran de tránsito en esta disciplina. Las nuevas alternativas permitieron la reunión de los artistas consagrados en ese entonces como: Ricardo Arrúe Valle, Miguel Arroyo, Sergio

14 Graterol, C. (2007). “De la Colonia hasta nuestros días. La Educación de la Orfebrería en Venezuela". Ciclo de Conferencias conmemorativas al 34 Salón Nacional de las Artes del Fuego. Material inédito. Correo electrónico cvzla@yahoo.es 
González, Alejandro Otero, María Luisa Zuloaga, Adela Rico de Poléo, Cristina Mercan, Tecla Tofano, Rubén Núñez, Reina Herrera, María Carlota Soriano, María Tallián y Mercedes Pardo.

Todo lo anterior comentado, apunta que se fueron integrando un importante número de artistas, que se dedicaron a la enseñanza del esmalte sobre metal. Llamó tanto la atención el esmaltado al fuego en cobre y plata, que poco a poco se fueron creando y sumando otros centros de enseñanza. Entre éstos deben mencionarse: el Instituto Pedagógico de Caracas, el cual fundó la Cátedra de esmalte. La Facultad de Arquitectura y Urbanismo de la Universidad Central de Venezuela en Caracas. En donde, organizaban cursos, talleres y seminarios en las disciplinas de cerámica, orfebrería, vidrio y esmalte sobre metal. La Escuela de Artes Visuales Rafael Monasterios en la ciudad de Maracay, en donde se creó el taller permanente de esmalte sobre metal. La Universidad Simón Bolívar en Caracas, en sus talleres libres de Arte, incluye la enseñanza de esmalte sobre metal y orfebrería. También conseguimos, el Retén Judicial del Junquito en Caracas, en donde dan inicio a otras actividades educativas, y hacen apertura del taller de orfebrería. Y por último, mencionaremos a la Universidad de los Andes, en Mérida. Allí se creó un taller permanente de grabado. Así como también, la fundación de los Talleres Artesanales en cerámica, orfebrería y textil. Con esto dejamos evidencia, de cómo estas disciplinas fueron cobrando cada vez más importancia, encontrándose de un modo paralelo a las manifestaciones artísticas convencionales.

Presuntamente, otro suceso que significó un verdadero impulso para el desarrollo en estas disciplinas; "tuvo que ver en el año 1959, con la edición XVII del "Salón Michelena", cuando integraron la cerámica, esmaltes al fuego sobre metal y porcelana en las bases de participación de dicho salón. De este modo, por primera vez, pudieron ser expuestas obras en este tipo de material conjuntamente a las ya acostumbradas (pintura y escultura). La cerámica y los esmaltes permanecen en este salón desde ese entonces. Sin embargo, existía un colectivo que insistía que el "Salón Michelena" no era el escenario más apropiado para mostrar el gran potencial adquirido por esta especialidad. Por lo que con los años, sus creadores, consideraban que no se prestaba la atención que merecían sus obras. Los años sesenta se mantienen en esta sombría situación. Para el año de 1969 el "SOAAV" interrumpe su labor de difusión y promoción de las artes, quedando en el país sólo el "Salón Michelena" "15.

Según tenemos entendido, para mediados de los años sesenta, la enseñanza de la orfebrería en las escuelas de arte quedó

15 La Historia Fraguada en Fuego. Fritz Küper. (1994).

http://galeria.uc.edu.ve/resenas. php?id=50\&idexpo $=53 \&$ actual $=1$ 
relegada. Pero se desconoce, si se debió a que se eliminó como asignatura o que eran pocos los artistas que se adiestraban en estas disciplinas. Lo que si no hay duda, es que desde entonces, pasó a ser una iniciativa de talleres privados, e impartida principalmente, con fines ocupacionales. Estas personas que tomaban los cursos -en muchos casos- no estaban implicadas formalmente en las artes y otras personas que se iniciaban en estas disciplinas, no eran capaces de costear los enormes gastos que implicaba la práctica de este oficio.

Un caso particular que vale la pena mencionar, es que paralelo al declive que venía sintiendo la enseñanza de estas otras manifestaciones en la ciudad de Caracas, en el año 1965 en la Universidad de Los Andes en la ciudad de Mérida, fue nombrado como su Director de Cultura el Artista Plástico Oswaldo Vigas. Vigas fue uno de los miembros que conformaron el grupo de los Disidentes ${ }^{16}$. Su concepción particular en el arte, tiene resonancia inmediata en la máxima casa de estudio merideña. Según Suárez ${ }^{17}$, se instaura el Centro Experimental de Arte. Este centro cuenta ya, con el taller de Dibujo y Grabado al que posteriormente se le incorpora el taller de Cerámica, Danza y Música, así como también el taller de Metales, a cargo del Escultor/Orfebre/Pintor José Benítez. A través de la enseñanza de Benítez, se promueve un acercamiento entre la orfebrería y escultura. Sin embargo, la orfebrería merideña no tuvo resonancia en los salones de arte a nivel nacional. Con el devenir del tiempo, se fueron integrando otras asignaturas en el Centro Experimental de Arte. Finalmente se separan, quedando en los Talleres de Producción Artesanal la enseñanza en cerámica, vidrio, textil, carpintería, galvanoplastia y orfebrería. De este modo, Los Talleres de Producción Artesanal de la Universidad de los Andes, se centran en la enseñanza en Orfebrería, Cerámica, Textil, Vidrio y Galvanoplastia. Y, forman parte de las asignaturas optativas de las Escuelas de: Diseño Industrial, Farmacia y la Facultad de Arte y Diseño Gráfico. El acceso a esos talleres, también está abierto a personas ajenas a los estudios en dicha Universidad.

1.2.1.1 Aproximación hacia una orfebrería artística.

Llega la década de los años setenta y con ello un nuevo impulso para la orfebrería venezolana. En el año de 1970, el Historiador y Crítico de Arte Carlos Duarte, publica su libro "Historia de la orfebrería en Venezuela", dentro del marco de la publicación

16 Sobre la agrupación de los "Disidentes" se comenta en el punto 1.3 que trata del Contexto Artístico de la Escultura Venezolana.

17 Suárez. F. (1999). "La enseñanza de los oficios artesanales como alternativa tecnológica para el desarrollo: Los Talleres Artesanales de la Universidad de los Andes". Universidad Pedagógica Experimental Libertador. VIII Jornadas sobre Investigación y Docencia en la Ciencia de la Historia. Conferencia. pp: $4-5$ 
realiza la exposición "La Orfebrería Colonial en Venezuela" en la Sala de Exposiciones Fundación Eugenio Mendoza ("Sala Mendoza") en la ciudad de Caracas. Así pues, esta exposición contó con setenta y tres obras elaboradas en la Época de la Colonia en Venezuela.

Diadema de la Imagen de Nuestra Señora de los Dolores (IMAGEN 8) es una de ellas; elaborada en plata sobredorada y data del año 1776. Esta magnífica diadema se forma entre exquisitas formas martilladas, repujadas y cinceladas. De su base martillada en forma de media

luna, serpentean delicadas líneas orgánicas que brotan de pequeños trozos de vidrio

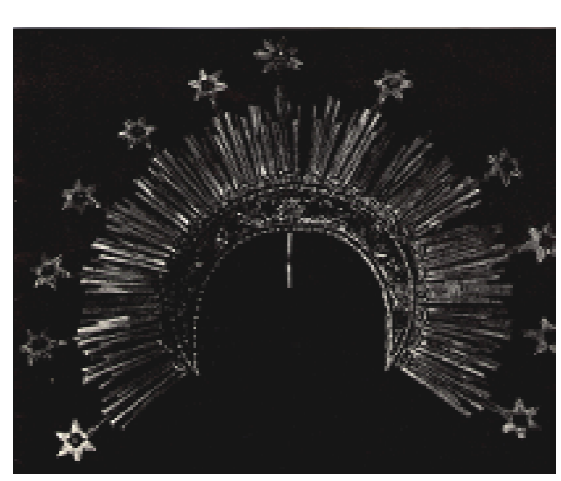
Diadema de la Imagen de Nuestra Señora de los Dolores

engastado. Como destellos de luz, salen fascinantes láminas plisadas, desde donde, espectaculares estrellas se aferran en puntos equidistantes. Desde su centro, lucen pequeños trozos de vidrios de colores engastados en bisel. El baño de oro amarillo que la cubre, fulgura entre la combinación de tonalidades de los vidrios que se aferran a ella con delicadas garras.

El resto de las obras expuestas en "La Orfebrería Colonial en Venezuela" resultó un éxito, lo cual se convirtió en un trascendental estímulo ante este arte milenario. Exposición esta, retoma un período que se vio interrumpido en la enseñanza de este oficio en las Escuelas de Arte. A partir de ese momento, se genera una agrupación sólida de artistas que desarrollan su obra entre cerámica, orfebrería y esmalte sobre metal. Este colectivo, une esfuerzos en desarrollar un proyecto para el cual las artes del fuego puedan tener un salón donde poder mostrar el potencial de sus creadores.

1971 es el año en que la Escuela de Artes Plásticas Arturo Michelena y el Ateneo de Valencia toman en cuenta el proyecto presentado por este colectivo de artistas y lo someten a consideración ante el Instituto Nacional de Cultura y Bellas Artes. El Instituto para ese entonces, cuenta con el artista Oswaldo Vigas al frente de la dirección, por lo que éste considera necesario un salón dedicado a las artes del fuego, como manifestación autónoma con características propias. Hemos comprobado que, en ese entonces sólo existía la "Sala Mendoza" en la ciudad de Caracas. Ésta, era la única propuesta a nivel de salón en estas artes; en donde, únicamente participaban las clases elitistas y no existía una amplitud de participación. Así pues, el Instituto 
Nacional de Cultura y Bellas Artes, logra concretar en la ciudad de Valencia; Venezuela, el "Salón Nacional de las Artes del Fuego ("SNAF") e incluyen las especialidades de Cerámica, Esmalte sobre metal, Vitrales y Joyas. La confrontación resultó una sorpresa tanto por las propuestas presentadas, como por la confirmación de que realmente existía un grupo importante de artistas y creadores. Se supone que al instaurar el salón como un plan nacional, debía realizarse al siguiente año. Sin embargo, no fue así, ya que deciden trasladar la muestra de la exposición, a la ciudad de Puerto Ordáz (ciudad Guayana) y por desacuerdos políticos/culturales, no lograron llevarlo a cabo. Es entones, en el año 1974, cuando reorganizan la confrontación del interrumpido "SNAF". Para ello, interviene la Universidad de Carabobo, a través de su Dirección de Cultura, conjuntamente con el Instituto Nacional de Cultura y Bellas Artes, la Escuela de Artes Plásticas Arturo Michelena y el Ateneo de Valencia e inclusive se consigue que el Ateneo de Valencia sea su sede permanente. Siendo éste en la actualidad uno de los salones más importantes para la confrontación y difusión artística en el país ${ }^{18}$.

Del mismo modo, hacia 1974 se comenzó a gestar un movimiento de artesanos que coincidieron en la ciudad de Mérida; Venezuela. Ese movimiento se caracterizó por un trabajo sencillo, espontáneo, no académico y apegado a las raíces populares. Podría decirse que este grupo tenía una especie de lema del que se valían para desarrollar sus obras -el retorno a la tierra y revalorización de trabajo manual-. Según Pereira 19 -uno de los fundadores de este movimiento-, consiguieron en Mérida una cultura muy rica en la que se fomentaba la tradición indígena de la zona de los andes. La cual se enriquecía de los conocimientos que circulaban en torno a los viajeros que en algunos casos se establecían allí. Algunos de estos artesanos llegaron de Sur América, Centroamérica y otros de Europa. De este movimiento, surgió la "Agrupación de Artesanos de Mérida" (“AGRUPAM") y crearon el primer mercado artesanal. Esta agrupación estaba integrada por tejedores, ceramistas, pintores, metalisteros, jugueteros y otras manifestaciones artísticas. En dicho mercado artesanal se desarrollaban actividades culturales y prácticas de algunos oficios en los que sobresalió la orfebrería. Entre los orfebres de "AGRUPAM" se encontraban: Pedro Hoffman, Alfonso Poblete y su esposa María, Mario Franchesquini, Jorge Fernández, Pocho el Peruano, Alberto Landeo, el Chino Camargo, Herbert Maldonado, Francisco Paniagua, Luis Rodríguez y Duglas Pereira.

18 La Historia Fraguada en Fuego. Fritz Küper. (1994). http://galeria.uc.edu.ve/resenas.php?id=50\&idexpo $=53 \&$ actual $=1$

19 Pereira, D. (2007). "Orfebrería en Venezuela". Material inédito. Correo electrónico duglaspereira609@hotmail.com 
El campo artístico se siente cautivado por la disciplina de la orfebrería y es por ello que en el año 1976, el Crítico de Arte Rafael Pineda estuvo a cargo del "I Salón de la Nueva Orfebrería Venezolana", en Ciudad Bolívar. La idea de realizarlo en esa ciudad, nace como iniciativa para destacar esa región minera; así pues, informar sobre la importante actividad que se desarrolla en torno al oro que se extrae de esa región y con ello, fomentar el proceso de la orfebrería. Así como también, esta exposición pueda servir de orientación no solo al ámbito minero sino al artístico sobre las ventajas de contar con esta riqueza nacional20. Este primer salón, reunió a un grupo de artistas importantes de la plástica nacional, que para ese entonces, se encontraban también, trabajando en orfebrería. Así pues, la selectiva muestra contó con la participación de María Teresa Torras, José Benítez, Yuye de Lima, Mélida Torres, Panchita Labady, Harry Abend. Alexis Rodríguez Llerandi -Alexis De la Sierra-, Enrique Cohén, Marisa Iturriza, Nicole Michalcup, Dafne Ríos, Carmen Montilla y Teresa Calderón. La muestra se trasladó al Museo Emilio Boggio en la ciudad de Caracas y se unen otros artistas importantes como: Sigala, Matías Herrera y Zelia Stoddart.

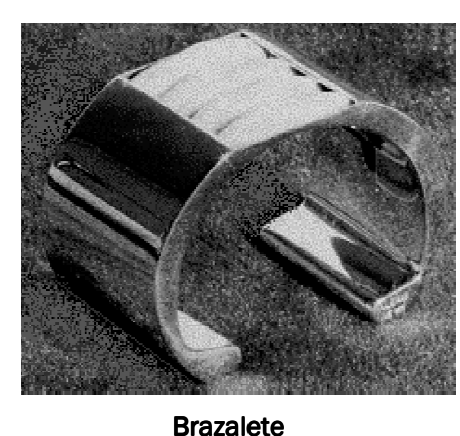

IMAGEN 9

Brazalete (IMAGEN 9) es una de las joyas que formó parte de esta exposición de la autoría del orfebre Alexis De la Sierra. En ellas, se reveló su habilidad en el oficio; en donde, demuestra la perfección de sus líneas y el ingenio de sus diseños, destacando todavía más la belleza de la joya con el exquisito brillo de la plata.

conseguimos en esta exposición las joyas del Artista Plástico Harry Abend -Premio Nacional de Escultura en el año 1963 en el "SAAV"- Abend presenta una atrevida colección de joyería basada en el concepto de la escultura a menor escala. El par de Yuntas (IMAGEN 10) nacen de la yuxtaposición de cubos vaciados en oro amarillo. De sus estructuras en hierro que habitan el espacio, pasa al oro macizo para engalanar con sus volúmenes al cuerpo humano.

A pesar del éxito que produjo este salón, no

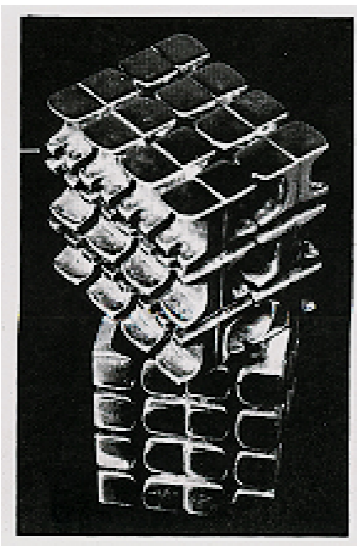

Yuntas

20 Pineda, R. (1978). “La Tierra Doctorada”. p: 494. 
tuvo continuidad. Sin embargo, aprovechando el impulso, algunos de estos artistas se suman a la única confrontación para las artes del fuego en aquel tiempo.

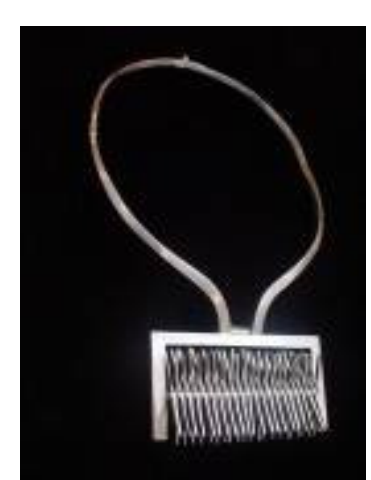

Collar

Las nuevas tendencias en la orfebrería inician con buenos fundamentos, así se puede evidenciar en el "SNAF" en el año 1976, cuando le otorgan el Premio Nacional de las Artes del Fuego en la tendencia de Orfebrería a la artista plástico María Teresa Torras, con un Collar (IMAGEN 11), elaborado en Plata 925. Los hilos planos que lo constituyen, se encuentran unidos por medio del recurso técnico del ensamblaje. Este collar vanguardista de por su estructura, sime .................. sale de

los cánones clásicos de las joyas, conocidos para ese entonces. La producción artística de Torras desde sus inicios, se ha desarrollado en el campo de la escultura. Sin embargo, "la incursión en el medio de la orfebrería fue de gran importancia al demostrar que se puede trasladar un diseño escultórico a una joya sin que ésta pierda el carácter de uso"21. Para Torras, en ambos lenguajes plásticos existen rasgos característicos como constante en su producción, tales como, el estilo geométrico, la repetición de algún elemento y el ensamblaje. Su diseño es poco ostentoso y se vale de la utilización de un solo material. El concepto minimalista se refleja en sus estructuras, quizá por ello recurre a la técnica de construcción a partir de láminas e hilos, unidos por soldaduras o remaches. En algunos casos utiliza el vaciado a la cera perdida. Su obra ha sido exhibida en diversos museos y galerías de Venezuela, Cuba, Puerto Rico, España, Polonia, Suiza, Francia y Estados Unidos, entre otros y ha sido merecedora de importantes reconocimientos en Venezuela, Japón y Polonia.

21 Dávila, V. (2000). “Panorama de la Joyería Artística Contemporánea. Década 70, 80, 90 de Venezuela”. Tesis para licenciatura. p: 47 
Al observar los catálogos del "SNAF", pudimos darnos cuenta la participación esporádica de los artistas Américo Bastos, Alecia de Izturriaga, Silvia Carpio, Enrique Cohén, Víctor Rodríguez, José Sigala, Nicki, María Teresa Torras, José Benítez, Ovidio Morillo, Dafna Riess, Esther Salazar, Carlos Prada, Alexis De la Sierra y Carlos Zerpa. Unos de una manera particular como el caso de Carlos

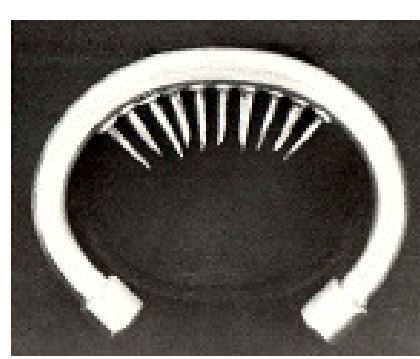

Antijoya en homenaje a Man Ray

Zerpa, en donde enfatiza el concepto de la joya que no puede usarse o elaborada con materiales inusuales. Antijoya en homenaje a Man Ray (IMAGEN 12); es precisamente éste, el nombre con que elabora sus joyas. Elaboradas éstas, con materiales inusuales como crítica al concepto de la alta joyería donde solo hay cabida para metales preciosos.

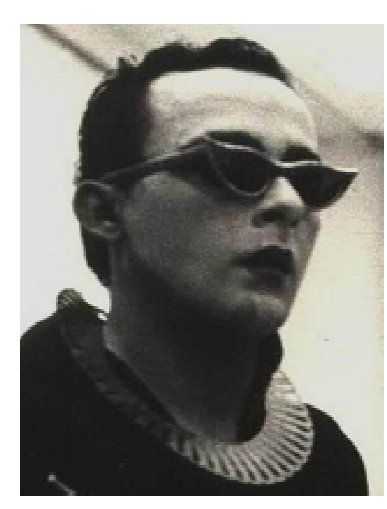

Gargantilla de hojillas Gillete

Utiliza materiales poco usuales, como el aluminio en unión con tachuelas de hierro; en donde su elaboración convierte una pulsera que, por sus características deja de ser ornamental y se convierte en una joya que no se puede usar. Zerpa elabora esas joyas bajo la perspectiva de una antijoya, que por sus características resulta ser imposible ser utilizada como ornamento al cuerpo humano. Estas antijoyas, se convierten en parte del vestuario para sus performances. Tal es el caso del performance "Ceremonia con armas blancas” en donde el artista Carlos Zerpa lleva puesta una Gargantilla de hojillas Gillete (IMAGEN 13) de su autoría 22 .

Por el contrario, tenemos las joyas del artista Alexis De La Sierra, cuyo lenguaje plástico está centrado en la disciplina de la orfebrería. Destaca la destreza en las técnicas especializadas con metales preciosos, dejando evidencia de su interés en lo ornamental y preciosista.

Acercándose al final de los años setenta, en las ediciones del "SNAF" se observa un declive en la participación en la modalidad de orfebrería. Sin embargo, Alexis De la Sierra, ha sido constante, y se mantiene desde ese entonces investigando, fusionando y aplicando en y con la disciplina de la orfebrería.

22 Zerpa, C. (2010). "Imagen y datos de Antijoya en Homenaje a Man Ray y Gargantilla de hojillas Gillete". Material inédito. Correo electrónico carloszerpa@gmail.com 
1.2.1.2 Resurgir de la orfebrería venezolana en manos de Alexis De la Sierra.

Tal y como se ha comentado, desde finales de los años setenta, la orfebrería se introdujo en una especie de receso. La productiva participación de artistas en esta disciplina perdió interés y las causas se desconocen. Sin embargo, en las obras aceptadas en el "SNAF", se observa la constante participación y Premios obtenidos en la tendencia de Orfebrería de obras de Alexis De la Sierra (1979 al 1986), en donde el perfecto acabado, la dimensión de sus joyas como la preocupación de la perfección en la técnica ha sido una de las principales características que demuestran su autoría. Así pues, dichas característica convierte sus joyas desde ese entonces, como punto de referencia de la orfebrería venezolana. En el año de 1985 en la ciudad de Caracas, este artista creó la Escuela de Orfebres Alexis De la Sierra, dentro de los espacios de su "Galería de Alexis De la Sierra". Para ese entonces, De la Sierra comenta que siente una gran responsabilidad de revivir el arte de la orfebrería en el país. En el año 1986, obtiene el Premio Nacional de las Artes del Fuego -máximo galardón- en la tendencia de Orfebrería en el "SNAF" con un conjunto de cinco pectorales en plata.

Impacta con un montaje que asoma las corrientes de la nueva joyería, donde incorpora en el trabajo del orfebre, el diseño, la expresividad y la teatralidad en su presentación. Le cinquiéme plaisir d'argent (IMAGEN 14); esta joya y el resto del conjunto, están realizadas en plata Britania23 con aplicación de técnicas sofisticadas como el granulado, el proceso manual del tejido en macramé, la cera perdida, la texturización mecánica y el ensamblaje. Consideramos que uno de los aspectos interesantes de sus diseños, tienen que ver en su

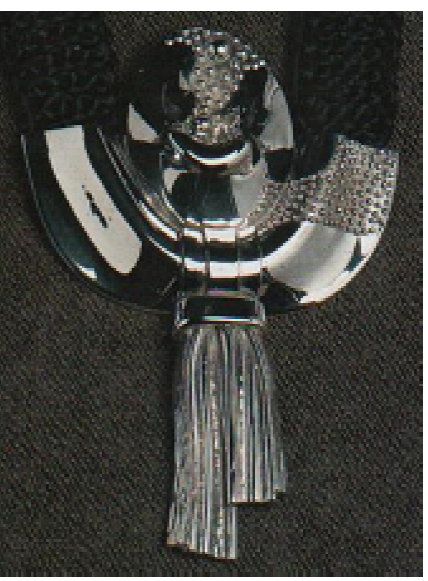

Le cinquiéme plaisir $d^{`}$ 'argent IMAGEN 14

ejecución; ya que, utilizando técnicas totalmente manuales enfatiza la alta joyería y aún así, se adaptan a diseños contemporáneos ${ }^{24}$.

A partir de la obtención del Premio Nacional de las Artes del Fuego,

23 La plata Britania es una aleación que contiene 95,84\% de plata pura, siendo el resto por lo general de cobre.

${ }^{24}$ Currículum de Alexis De la Sierra. (1986).

http://galeria.uc.edu.ve/actual.php?id=45 
su escuela se convierte en un verdadero impulso para esta disciplina y es prácticamente el único sitio donde se podía acceder para educarse y formarse en la orfebrería. "Prueba de este esfuerzo se pudo apreciar en la exposición "El Taller de Alexis De la Sierra, crisol de la nueva generación de orfebres venezolanos" llevada a cabo en el Museo de Arte Contemporáneo Francisco Narváez" ${ }^{25}$. En esa muestra no sólo dio a conocer formalmente la escuela sino, que el público, críticos de arte y demás personas vinculadas a este medio, pudieron evidenciar su labor docente y el éxito de sus alumnos dentro del campo expositivo ya que, con sólo dos años de su fundación, las obras de sus alumnos, eran aceptadas en el importante Salón Nacional de las Artes del Fuego de arte e inclusive merecedoras de premios en dicho salón ${ }^{26}$.

Nos comenta el orfebre Pereira ${ }^{27}$, que a finales de los años ochenta, se destacaban varios centros importantes para la difusión de la orfebrería en el país. En primer lugar, se encuentra la Isla de Margarita, por ser un centro perlero, especialmente en la población de San Juan Bautista; sus diseños mantenían la tradición del trabajo con perlas y conchas marinas desde la época de la colonia. En segundo lugar, destaca la zona aurífera del estado Bolívar en la población del Callao; allí también, se mantenían diseños y técnicas de la orfebrería tradicional heredada de la colonización. Sin embargo, establecieron un diseño emblemático que caracterizaba a los orfebres de esta zona. Se trata de la orquídea flor nacional- elaboradas con oro de 24 quilates y una perla.

Otra referencia importante para la orfebrería nacional la encontramos en la ciudad de Mérida; por un lado tenemos los Talleres Artesanales de la Universidad de Los Andes, en donde enseñaban cerámica, textil y orfebrería y por el otro lado se encontraba un gremio formado por artesanos llamado "AGRUPAM", donde se congregaron ceramistas, tejedores, orfebres y otros; donde, no sólo se reunían para comercializar su artesanía sino intercambiaban opiniones de cada oficio con lo que enriquecieron su semblante.

En la ciudad de Caracas, crean la "Asociación Venezolana de las Artes del Fuego" ("AVAF"). Del mismo modo, en la ciudad de Caracas, surgen talleres de enseñanza por orfebres formados por

25 Rodríguez. B. (1987). "100 Horas, 100 Obras. Alexis de la Sierra". Museo de Arte Contemporáneo Francisco Narváez. Catálogo. p: 54.

26 Sobre los datos concernientes al aporte de la enseñanza de Alexis De la Sierra, son abordados dentro del Capítulo 3.

27 Pereira, D. (2007). “Orfebrería en Venezuela". Material inédito. Correo electrónico duglaspereira609@hotmail.com 
Alexis De la Sierra, como es el caso del Taller $\mathrm{OH}$, el Taller de Maritza Alayón entre otros 28 . Fundan el Taller Héctor Poleo, donde incluyen la enseñanza de orfebrería. Así como también, pueden mencionarse la Escuela de Artes Visuales Cristóbal Rojas, que incluyen la especialización en Artes del Fuego, mención en orfebrería, la Academia Arte y Fuego, del ceramista Cándido Millán y por supuesto la Escuela de Orfebres de Alexis De la Sierra.

Tal y como comenta el orfebre Carlos Graterol, en su ponencia29, desde finales de los años ochenta la disciplina de la orfebrería gana campo en Venezuela. Comienza a dejar frutos con la apertura de nuevos talleres de enseñanza en esta disciplina. Así como también, reiteradamente se han mantenido en el campo expositivo los alumnos formados por Alexis De la Sierra, manteniendo activa la disciplina.

La década de los noventa fue fructífera para la orfebrería venezolana; ya que, empezaron a propagarse talleres de orfebrería tanto en la ciudad de Caracas como en algunas otras ciudades del interior del país. A consecuencia de esto, el campo expositivo aumenta y comienza a hacerse un énfasis en la labor educativa en esta especialidad. A partir de este momento, se abre paso a los nuevos valores en la orfebrería contemporánea.

En la entrevista realizada al orfebre Duglas Pereira ${ }^{30}$, nos comenta que en el año de 1990, los orfebres de "AGRUPAM" Ilevan su arte a la Galería Viva México en la ciudad de Caracas. Luego en el año 1991 tiene lugar en la ciudad de Mérida, -Venezuela- la celebración del encuentro de "Las tres Mérida del Mundo" Venezuela, México, España-. Dentro del marco de dicha celebración, invitan a participar como representación venezolana a los orfebres de "AGRUPAM" para que expongan su arte en La Casa de la Cultura Juan Félix Sánchez ubicada en esa misma ciudad. Del mismo modo, la Galería Sin Límite en la ciudad de San Cristóbal; estado Táchira, los invita a exponer en sus espacios. Ya en el año de 1994 logran algo muy significativo para su agrupación puesto que, exponen todos sus miembros en el "Museo de Arte Contemporáneo de Caracas Sofía Imber" lo cual obviamente, repercute significativamente para la disciplina y a esa agrupación. En el año 1993, la Asociación Venezolana de las Artes del Fuego "AVAF", como fundadora de las disciplinas que la

28 En el apartado 1.2.2.1 se expone la estructura de algunos talleres de enseñanza de orfebrería en Venezuela.

29 Graterol, C. (2007). “De la Colonia hasta nuestros días. La Educación de la Orfebrería en Venezuela". Ciclo de Conferencias conmemorativas al 34 Salón Nacional de las Artes de Fuego. Material inédito. Correo electrónico cvzla@yahoo.es

30 Pereira, D. (2007). "Orfebrería en Venezuela". Material inédito. Correo electrónico duglaspereira609@hotmail.com 
constituyen: Cerámica, Esmalte sobre metal, Orfebrería y Vidrio, crea el Taller de Orfebrería de la AVAF. La "AVAF" tuvo su inicio desde 1980, pero no es sino hasta esta fecha, que bajo la tutela del orfebre Ursicinio Galletti deciden crear dicho taller. Así pues, lo constituyen con la finalidad de formar nuevos orfebres, así como también, actualizar y especializar los ya existentes.

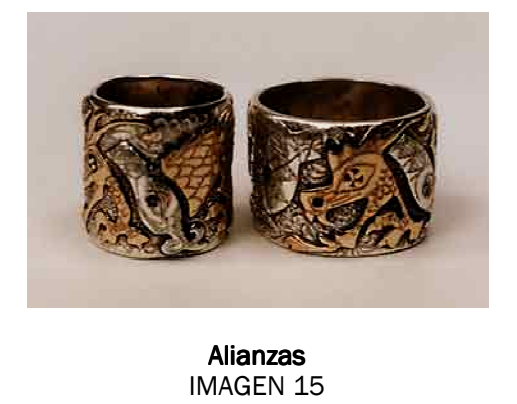

Entre los beneficios que lograron a través del Taller de Orfebrería de la "AVAF" fue el intercambio con orfebres internacionales tales como: Mary Ann Scherr, Jean Tudor, Stell Shevis, Fay Rooke, Federico Capponi, Suzane Lipson. Orfebres éstos, de gran trayectoria con importantes aportaciones en el ámbito de la joyería ${ }^{31}$. Como por ejemplo, la Diseñadora/Profesora/joyera Mary Ann Sherr. Alianzas (IMAGEN 15) es un conjunto de anillos de su autoría, que exhibe los estupendos grabados en oro y plata. Esta joyera, desarrolló un proceso único para el grabado y se demostró por primera vez con la empresa Río Grande / Albuquerque en Tucson, Arizona. Esto, le permitió escribir un capítulo sobre Grabado en "El Libro de la joyería Penland", Editorial Lark. y su proceso de grabado aparece en el libro de Oppi UNtracht, "Conceptos JOYERÍA Y TECNOLOGÍA", Publishers Doubleday. Su obra forma parte de la colección permanente en importantes instituciones museísticas en muchos lugares del mundo 32 .

Puede considerarse, que a partir de esos intercambios, el orfebre venezolano se introduce ante el nivel expositivo internacional. Así como también, amplitud de difusión para orfebres ya consagrados como para los orfebres emergentes. En la actualidad la "AVAF" continúa desarrollando sus actividades educativas, sobre todo durante el marco de celebración del Salón Nacional de las Artes del Fuego.

Según las fuentes citadas en esta investigación, coinciden en que la orfebrería venezolana se encuentra en boga durante toda la década de los noventa. Las galerías e instituciones museísticas, dan prueba de ello. Puesto que, se dan a la tarea de promocionar obras en orfebrería. Sin embargo, el orfebre Duglas Pereira

31 Graterol, C. (2007). "De la Colonia hasta nuestros días. La Educación de la Orfebrería en Venezuela". Ciclo de Conferencias conmemorativas al 34 Salón Nacional de las Artes del Fuego. Material inédito. Correo electrónico cvzla@yahoo.es

32 Mary Ann Scherr: Designer, Educator, Goldsmith, Jeweler. (2011).

www.maryannscherr.com/ 
comenta33 que, las gestiones burocráticas y los procesos de selección en los salones de arte no permiten que se pueda mostrar la obra de una gran cantidad de orfebres. En consecuencia, crea ciertas molestias en sus creadores, es así como en el año 1996, el representante de "AGRUPAM" el orfebre Pereira, sugiere y presenta un proyecto ante la Dirección Nacional de Artesanía. La idea central era llevar a cabo una muestra que se fundamentara en un plan a nivel nacional. Así pues, llevan a cabo la exposición en el "Museo Luisa Cáceres de Arismendi" de La Asunción, estado Nueva Esparta. La participación no fue en pleno. No obstante, estuvo conformada por los afiliados de "AGRUPAM" y algunos nativos de la zona, enfatizando los métodos tradicionales en el trabajo con perlas y conchas marinas. Pese a todo esto, por desacuerdos entre los participantes no pudo concretarse una continuidad con el supuesto "Salón Nacional".

En el año 1994 el orfebre Víctor Rodríguez, obtiene el Premio Nacional de las Artes del Fuego del "SNAF" en la tendencia de Orfebrería con la obra: Lo que hice y donde lo hice. Conjunto: collar Laudan y el taller de Vulcano (IMAGEN 16) elaborados ambos en plata, bronce, cobre, y aluminio. Para la realización de esta obra, el orfebre recurrió a la construcción y forjado en metal basada en laminado, trefilado así como también, a la cera perdida. Con el Premio Nacional de Rodríguez, se refuerza el valor de la disciplina de la orfebrería como representación artística, donde se

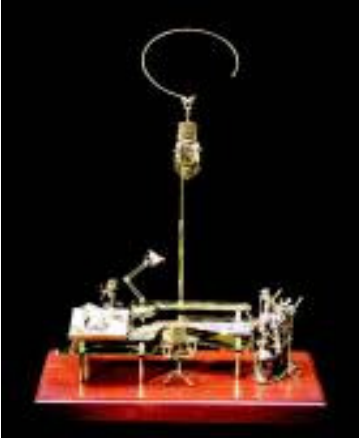

Lo que hice y donde lo hice. Conjunto: collar IMAGEN 16

evidencia el dominio del oficio, aplicado a la escultura en menor escala y a la conceptualización del objeto como arte. Este artista ha participado en los salones de las artes del fuego desde $1974 \mathrm{e}$ inclusive en 1975 y 1978 obtuvo algunos Premios en la tendencia de Orfebrería. Su obra se basa en la orfebrería escultórica en pequeño y mediano formato. En ocasiones ha realizado reducciones de las obras de pintores y escultores Venezolanos como: Oswaldo Vigas, Marcos Castillo, José Luis Guerrero, Carlos Zerpa; por lo que ha tenido que recurrir a innumerables técnicas de la orfebrería, como el calado, la cera perdida, cincelado, forjado, etc, conjuntamente a las propias del oficio de la escultura como: el modelado, soldadura en hierro o la talla en madera, entre otros materiales. De este modo, logra exitosamente la similitud con dichas obras ${ }^{34}$.

33 Pereira, D. (2007). "Orfebrería en Venezuela". Material inédito. Correo electrónico duglaspereira609@hotmail.com

34 Currículum de Víctor Rodríguez. (1994). http://galeria.uc.edu.ve/actual.php?id=53 


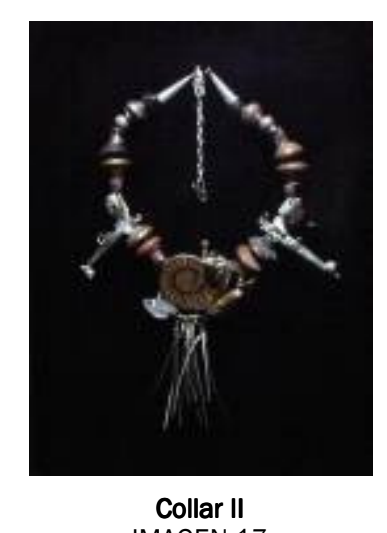

En el año 1996, la orfebre Lourdes Silva, obtiene el Premio Nacional de las Artes del Fuego en la tendencia de Orfebrería, con un conjunto espectacular de 3 collares; siendo uno de ellos Collar II (IMAGEN 17) elaborado en oro y plata con aplicaciones de perlas barrocas, cristal, ébano fósil, cuernos de búfalo, madera petrificada y camafeo de coral. La artista recurrió a técnicas totalmente manuales como el forjado, el embutido, el repuiado, la cera Collar II
IMAGEN 17 perdida y el $\mathrm{Kl}$ apreciarse uni

puede

formas orgánicas, piedras y metal; consiguiendo fc asimétricas con particularidad emotiva. Así mismo, se aprecia el dominio que tiene sobre los procedimientos técnicos conjugándolos en espectaculares ornamentos. Dávila comenta en su investigación ${ }^{35}$, que Silva fue gratificada con la solicitud que le hiciera el Presidente de La República de Venezuela Rafael Caldera en el año 1996. Fue elegida para elaborar una Cruz, como obsequio al Papa Juan Pablo II, en su visita a Venezuela, durante el acto de Beatificación de la Madre María de San José. La cruz se elaboró en oro, plata y piedras preciosas. Donde, reluce la Virgen de Coromoto. Esta cruz, se encuentra actualmente en el Vaticano.

En el año 2005 la fusión entre escultura y orfebrería se hace protagonista en el "SNAF", cuando Ana Mercedes Carvallo obtiene el Premio Nacional de las Artes del Fuego con la obra Trigal de maíz transgénico (IMAGEN 18) la cual se basa en representaciones de la naturaleza. Dicha obra fue elaborada con láminas de cobre, bronce e hilos de plata. La artista

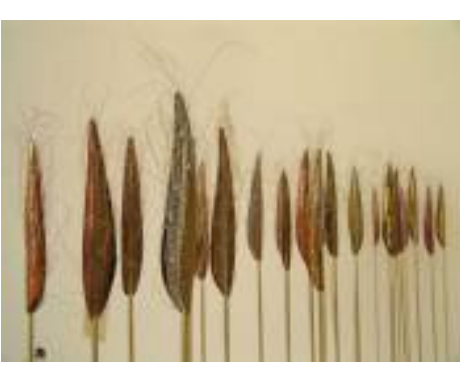
Trigal de maíz transgénico IMAGEN 18

consigue las similitudes de las formas, colores y texturas de las ramas del trigo, a través de técnicas como el martillado, embutido, la yuxtaposición de mallas metálicas con los esmaltes al fuego sobre metal. Los elementos en serie que componen la obra, presentan pequeñas variaciones entre cada uno, dispuestos desde una base de madera de forma ascendente. Carvallo aplica en esta obra, la técnica tradicional de esmalte en colores traslúcido, sobre una base en lámina de cobre repujada, su acabado es satinado y

35 Dávila, V. (2000). “Panorama de la Joyería Artística Contemporánea. Década 70, 80, 90 de Venezuela”. Tesis para licenciatura. p: 58 
se presenta en dos gamas de tonos cálidos entre marrones y naranjas; jugando con tonalidades vivas, en contraste con la belleza y frialdad de la plata. La textura que aparentan estos hilos de plata sobre el material del bronce y el cobre es muy original, se transforma en superficies aparentemente moldeables. El dominio del trabajo con esmaltes al fuego ha hecho merecedora de importantes premios en dicho salón; así como también, la participación en exposiciones internacionales especializadas en esta técnica, tanto en Venezuela como en Japón, USA, España y Argentina, donde nos demuestra su calidad y perseverancia en la consecución de su lenguaje plástico36.

El año 2005 significa un gran impulso para la orfebrería en Venezuela, no sólo por los resultados del "SNAF" cuando una propuesta en esta modalidad se lleva el Premio Nacional de las Artes del fuego; ya que, ese mismo año logran crear el "Salón Nacional de Orfebrería" en la ciudad de Caracas. Este salón surge de un esfuerzo que se mantuvo desde el año 1996 por algunos orfebres entre ellos Duglas Pereira. Es necesario recordar, que Pereira como representante de "AGRUPAM", pretendió para ese entonces crear un salón a nivel nacional, dedicado exclusivamente a la orfebrería. Sin embargo, la propuesta no fraguó. Aunque durante nueve años se mantuvo la iniciativa, no es sino hasta el año 2005, con la Licenciada Heufife Carrasco en su condición de Directora de la Secretaría Nacional de Artesanía del Ministerio de la Cultura, cuando deciden llevar adelante el proyecto presentado por este orfebre. De este modo, nace el "I

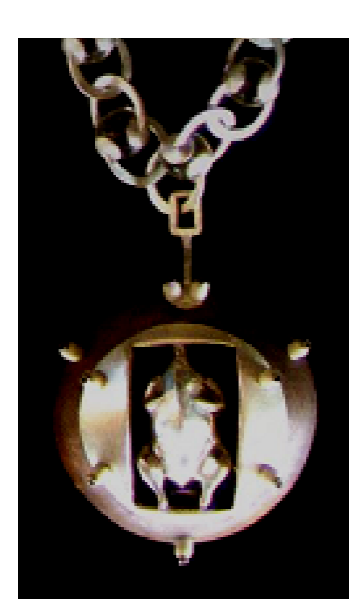

Primordialmente metal IMAGEN 19 Salón Nacional de Orfebrería” (“SNO”).

En el I "SNO" del año 2005, resulta ganador del Primer Premio, el orfebre Rafier Vera con la pieza Primordialmente metal (IMAGEN 19)

Este collar está elaborado en plata, madera y eslabones con esferas de vidrio. La pieza central del collar se transforma en un espectacular y enorme dije. Éste, se establece en una circunferencia de madera que contiene una lámina de plata embutida, dejando al descubierto un espacio rectangular del cual se sujeta la figura de un pollo vaciado en plata. El orfebre Viera comenta, que ${ }^{37}$, con esta obra demuestra la necesidad de recrear la orfebrería desde la

36 Currículum de Ana Mercedes Carvallo Parés. (2005). http://galeria.uc.edu.ve/actual.php?id=9

37 Vera, R. (2006). "La orfebrería como medio de expresión plástica". II Salón Nacional de Orfebrería. Ciclo de Foros -En la Candela- Gta. Conferencia. Material inédito. Correo electrónico. abelardotucapel@gmail.com 
perspectiva de la antijoya, convirtiéndola en un objeto artístico. Al apreciar este collar se evidencia como el recurso técnico del ensamblaje, constituye una de las características que predomina su obra.

La obra Deformaciones por conectividad (IMAGEN 20) de la orfebre Samantha Fung, apuntala la disciplina de la orfebrería con el Premio Nacional de las Artes del fuego en la tendencia de orfebrería el año 2006. Esta obra fue elaborada en plata 900 y ensamblada con imanes. Los imanes le aportan a esta joya, la condición de obtener dimensiones variables (50 piezas); es por ello, que la forma puede ser transformada por su portador a conveniencia, lo que le otorgará versatilidad. De este modo, el collar, puede transformarse en prendedor

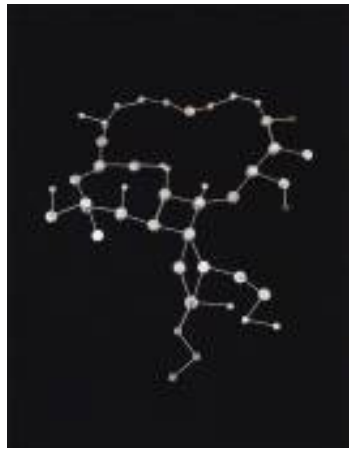

Deformaciones por conectividad
IMAGEN 20

cuya forma, se la da el propio portador. La originalidad de esta joya nos muestra cómo Fung fusiona los metales nobles con el uso de cualquier tipo de material y en este sentido, recurre a técnicas de la orfebrería junto con materiales comúnmente usados en la escultura como lo es el metacrilato. La obra de esta artista no sólo desarrolla el concepto funcional donde lo escultórico repunta en sus propuestas novedosas. La -antijoya- insiste en dejar a un lado lo funcional para hacerse expresiva, se crea la duda, si la joya propiamente dicha se adapta al cuerpo o si es, en cambio, un trabajo de orfebrería para ser admirado como obra de arte. Algunas de sus obras están cargadas de ironía, mensajes subliminales representados con alguna frase grabada en el metal; o en una forma descontextualizada para mostrar uniones paradójicas como lo puede ser una joya en oro 18 quilates con algún detalle engastado en papel. La tendencia abstracta y geométrica son características que definen su línea de producción.

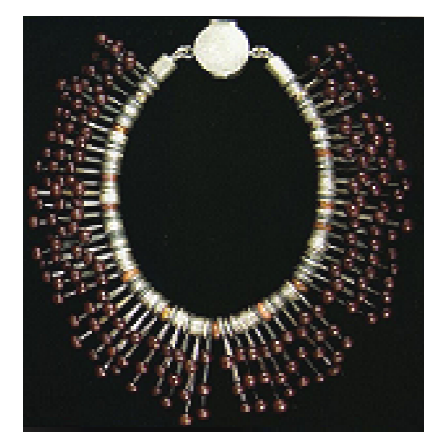

Semillero, 2006 IMAGEN 21

Es gracias al esfuerzo de los propios artistas de las artes del fuego, que hoy en día, el país cuenta ya, con dos salones especializados en esta disciplina. Así como también, en varios salones de arte han incluido la orfebrería en las modalidades participantes. Podemos darnos cuenta que poco a poco la orfebrería va integrándose de manera significativa en las artes en Venezuela. Según evidenciamos en el catálogo del II 
"SNO" en el año $2006^{38}$, se plantea bajo la temática de "Identidad Nacional". El Primer Premio es otorgado a la orfebre Elina Peduzzi, con el collar Semillero, 2006 (IMAGEN 21) el cual está elaborado en plata con aplicaciones de oro, cobre y semillas de palma. Dentro del contexto de identidad nacional la joya está muy bien representada, ya que, la substitución de piedras preciosas por el uso de materiales orgánicos y nos remite a una época primitiva; donde los materiales cumplen una función determinante en y para el diseño. El collar de la orfebre Peduzzi nos deleita con su sensibilidad ante los materiales autóctonos, elegidos y colocados minuciosamente. Éstos, enaltecen la combinación de la plata extremadamente pulida, con el tono rojo vino de las semillas, transformándose en un espectacular collar; el diseño se establece en una composición seriada original y demuestra la destreza técnica de la autora.

El artista del fuego ha desarrollado su propio lenguaje expresivo buscando un sitio dentro de las artes reconocidas. Esto lo ha logrado con esfuerzo y respeto ante la disciplina. Podemos dar fe que el orfebre venezolano se introduce cada vez más en una tendencia artística más que en el simple objeto ornamentaldecorativo Cada obra, cada pieza y cada trabajo es una confirmación de las tendencias del momento del proceso plástico que se produce con el artista y su época.

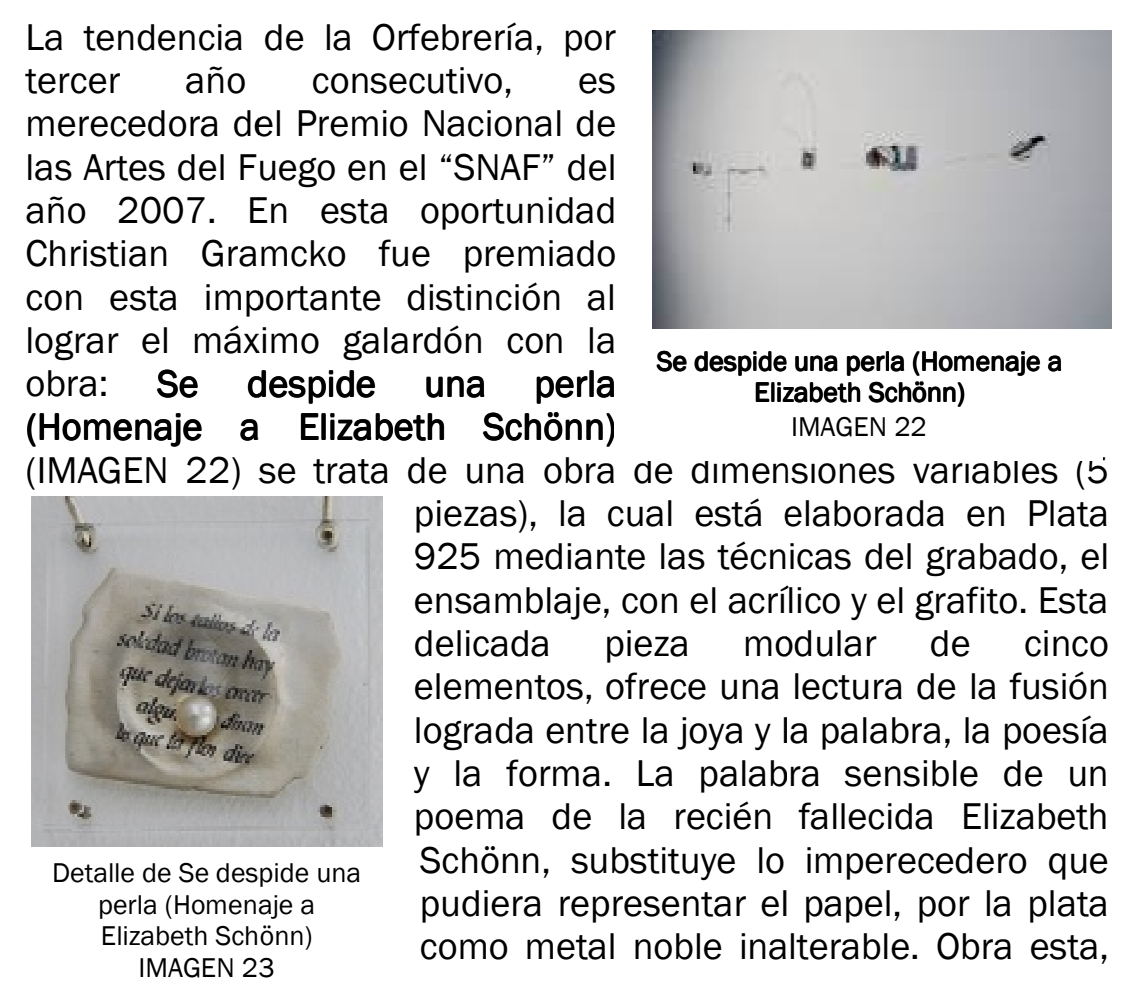

38 Instituto de las Artes de la Imagen y el espacio y Mota, J. (2006)."Il Salón Nacional de Orfebrería" Museo de la Estampa y del Diseño Carlos Cruz-Diez Catálogo. p: 57 
dispuesta en una secuencia horizontal sobre la pared a manera de un poema en pleno desarrollo; donde se suple, en gran parte, la palabra escrita con grafito por el delicado hilo de plata. Un fragmento rasgado, del poema en papel Detalle de Se despide una perla (Homenaje a Elizabeth Schönn) (IMAGEN 23), se encuentra entre láminas de acrílico transparente, ostentando entre su líneas una espectacular perla, que yace cómodamente estableciendo un dialogo con el poema39.

Se hace evidente en esta propuesta, que la orfebrería se adapta como cualquier otra disciplina, a representaciones artísticas actuales. El orfebre Gramcko, se encuentra en el medio expositivo a nivel nacional e internacional desde principios de los años ochenta. Como miembro de la "AVAF" ha ayudado incesantemente en la difusión y promoción de la disciplina de la orfebrería en el país. En el año 1996, el profesor Carlos Duarte bajo su condición de museógrafo, Curador de arte, Investigador y Director del Museo de Arte Colonial de

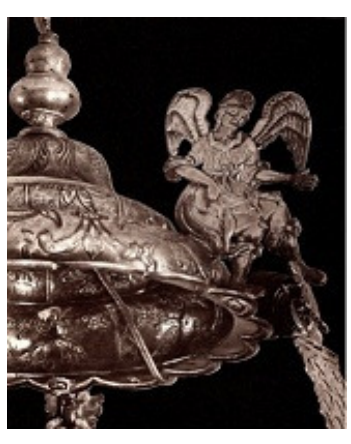

Lámpara del Sagrario IMAGEN 24 Caracas, le encarga a este orfebre la restauración de la Lámpara del Sagrario (IMAGEN 24). Obra ésta, de la época de la colonia elaborada en su totalidad con lámina de plata. Se presume, que la lámpara del Sagrario fue ejecutada por el platero Pedro Ignacio Ramos a mediados del Siglo XVIII. Esta petición, demostró la maestría que posee Gramcko como para dejar en sus manos una obra de tanta significación para la orfebrería venezolana ${ }^{40}$.

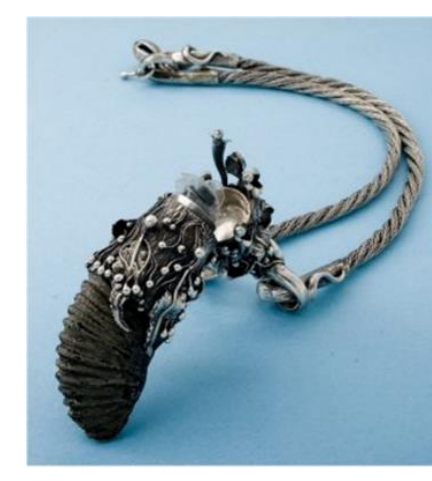

Tiempo, retrospectiva y un secreto que me protege IMAGEN 25

De igual modo, conseguimos en el año 2007 en la III edición del "SNO", donde, el Primer Premio se lo lleva el orfebre Edecio Barazarte con su collar: Tiempo, retrospectiva y un secreto que me protege. (IMAGEN 25). Se trata de un collar en plata que se establece en un dije con un enorme fósil amonite. Aprovechando su gran dimensión, en su cavidad se encuentra un cofre oculto; sie

39 Exposiciones anteriores. 34 Salón Nacional de las Artes del Fuego. (2007). http://galeria.uc.edu.ve/actual.php?id=72

40 Gramcko, C. (2010). "Imagen de la obra restaurada en 1996". Material inédito. Correo electrónico. christiangramcko@gmail.com 
constituye de una apretada filigrana en plata entorchada tan firme, que semeja una guaya de acero. La pátina que ennegrece la plata realza las texturas y consigue contrastar sus fascinantes formas.

Para la edición del "SNAF" del año 2008, la tendencia de la Orfebrería nuevamente se lleva el Premio Nacional de las Artes del Fuego. Se trata de una obra de la autoría de la orfebre Yolanda Sucre, quien asiduamente ha participado en sus últimas ediciones obteniendo Premios en la tendencia de Esmaltes al fuego.

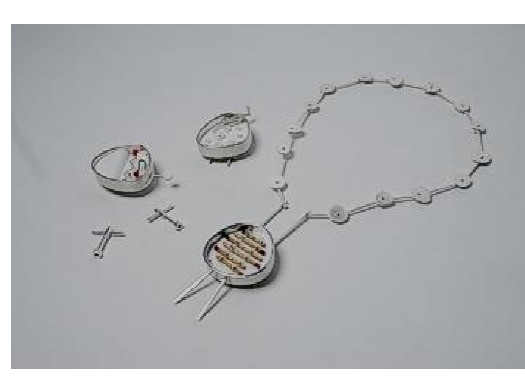

A buen entendedor

Sin embargo, el Premio Nacional de las Artes del Fuego, lo obtiene con la tendencia de Orfebrería. A buen entendedor (IMAGEN 26), se constituye en un juego de collar con tres dijes intercambiables, elaborados de una manera ingeniosa e impecable, donde cada detalle es cuidadosamente elaborado en plata, polímeros y esmaltes al fuego. El paso de esta artista por la Escuela de Orfebres Alexis De la Sierra, deja en evidencia - una vez más- que sus alumnos son el reflejo de su magnífica instrucción.

La artista Yolanda Sucre ha demostrado asiduamente en el campo expositivo venezolano y en el extranjero, su convicción ante el uso de los esmaltes al fuego y en esta edición, deja evidente su praxis ante otras tendencias y materiales.

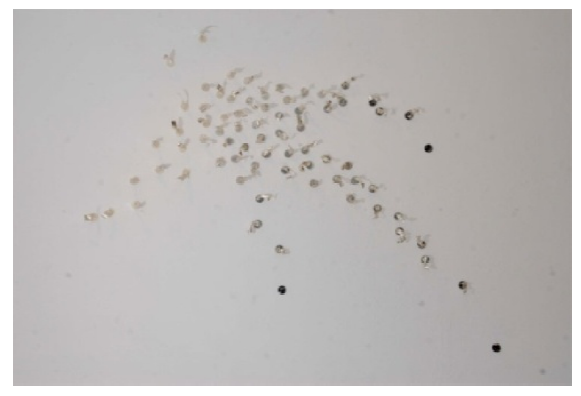

En vía de extinción

vía de extincion

En el "SNAF" del año 2009 la

obra En vía de extinción (IMAGEN 27) de la artista

Nadia Karroum obtuvo el

Premio en la tendencia de

Orfebrería. Esta obra de

dimensiones variables $(73$

piezas) se presenta de

manera bidimensional

sobrepuesta en la pared. El punto de partida de esta

creación es componer una joya bajo una tendencia conceptual desvinculándose de lo ornamental. El baño de plata que recubre las setenta y tres láminas de cobre, crea un brillo impoluto que las engalana. La superposición de éstas sobre la pared de un blanco opaco impecable, crea un fugaz esbozo sobre ella. Estos pequeños objetos decorativos elaborados uno a uno, sirven de vehículo para 
dejar perenne el gesto creador de Karroum, ante el proceso manual de fabricación ${ }^{41}$.

De igual modo, en la edición del año 2010 del "SNAF", la obra: Caracas: ciudad portátil, mi sueño en blanco y negro (IMAGEN 28) de la orfebre Liliana Benítez obtiene un importante premio. Se vale de la plata 925 para materializar su universo con materiales industriales como la resina sintética, el acrílico, papel fotocopiado y fotografía 42 . Su obra se sustenta sobre un plano fragmentado $y$

fotocopiado en blanco y negro,

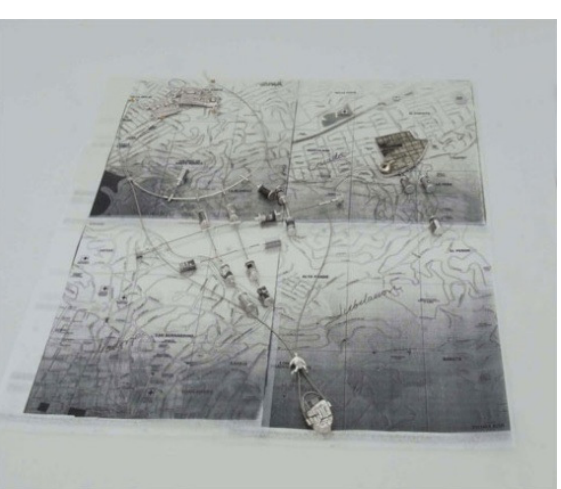

Caracas: ciudad portátil, mi sueño en blanco y negro

de la ciudad de Caracas, de las zonas donde ha desarrollado su vida. Benítez Subraya la madurez de un proceso creativo donde vincula las formas con sus ideas.

Estamos en un momento en que las artes visuales tienen una función importante en todo el mundo, tanto por la formulación de nuevas representaciones como por la búsqueda de nuevos planteamientos artísticos. El artista Venezolano ha conseguido con la disciplina de la orfebrería, las bases para establecer un diálogo poético desde la intuición a lo real como arte contemplativo y utilitario. Con este lenguaje plástico a través de la joyería, muchos orfebres, desplazan el concepto tradicional de las joyas y las convierten en objetos artísticos. En tal sentido, esto podemos confirmarlo al observar que en siete oportunidades, el Premio Nacional de las Artes del Fuego en el "SNAF" se han volcado hacia las obras de magníficos trabajos en la tendencia de Orfebrería (1976, 1986, 1994, 1996, 2005, 2006, 2007 y 2008). Esto demuestra que no se trata de una casualidad; por el contrario, es evidente que la alternativa cuenta con un gran potencial artístico.

Hemos podido evidenciar, que desde hace algunos años, se aprecia en las obras de los participantes en el "SNAF", una profundización conceptual; un manejo propio y más seguro de los materiales. Así como también, una mejor utilización de los metales nobles y las técnicas propias de la orfebrería. Una vez más, se deja evidencia en el campo expositivo venezolano, que la orfebrería

41 Exposiciones anteriores. 36 Salón Nacional de las Artes del Fuego. (2009). http://galeria.uc.edu.ve/actual.php?id=85

42 Exposiciones anteriores. 37 Salón Nacional de las Artes del Fuego. (2010). http://galeria.uc.edu.ve/actual.php?id=89 
funciona y se adapta a las necesidades expresivas artísticas actuales. Puesto que, estas joyas, se han apropiado de lo escultórico, que es lo tridimensional para ser exhibidas.

De lo anterior podemos resumir que, la dinámica actual, demanda competir en un medio más exigente con mayor formación en sus creadores. Por esta razón, el dominio de nuevas técnicas y conocimientos básicos han servido como herramienta para potenciar el talento creativo y poder aplicarlo exitosamente a otras áreas como es el caso de la escultura.

\subsection{2 ÉPOCA ACTUAL. Generalidades}

1.2.2.1 Centros oficiales y talleres de enseñanza de orfebrería. Generalidades.

Como hemos dejado en evidencia en esta investigación, la enseñanza de la orfebrería en Venezuela aún no ha sido tomada en cuenta como las otras disciplinas del arte, como la pintura, el dibujo, la escultura, la fotografía, entre otros. Sin embargo, hemos podido afirmar que esta disciplina ha tomado un auge sin precedentes desde el año de 1985. Puesto que, en ese año, Alexis De la Sierra funda la Escuela de Orfebres en la ciudad de Caracas. De este modo, un grupo de personas -ajenas al mundo del artese introducen en este campo. A su vez, hemos comprobado que alumnos formados por él, han aperturado otros talleres de enseñanza. Ya para principios de los años noventa, otro grupo de orfebres se han dado a la tarea de fundar sus talleres propios. Así pues, se considera a la Escuela de Orfebres Alexis De la Sierra, como el primer eslabón de una cadena de talleres de enseñanza que existen en Venezuela en la actualidad.

Ahora bien, tomando en cuenta esto y la importancia que supone en esta investigación, hemos decidido insistir sobre la enseñanza de esta disciplina tanto a nivel universitario, institutos de educación superior como talleres privados en la actualidad. En tal sentido, hemos podido confirmar que de manera experimental, se ha ido introduciendo esta disciplina en carreras universitarias como en institutos privados. Por ello, serán mencionados dichos centros educativos y las ciudades donde están ubicadas.

Del mismo modo, se mencionarán aquellos que son subsidiados en su totalidad con título avalado por el Ministerio de Educación Superior, a éstos, los llamaremos: Gratuitos con titulación. Los que son privados pero obtienen un título avalado por el Ministerio de Educación Superior, los llamaremos: Privados con titulación, y los que son privados sin titulación, los llamaremos: Privados sin titulación. Así pues, mencionaremos a continuación las diferentes ciudades y los centro de estudio, siguiendo un orden alfabético. 
Ciudad Bolívar, estado Bolívar.

Universidad de Oriente. Escuela de Minas. (Asignatura de Gemología, talla en piedras). Gratuito con titulación.

Caracas, Distrito capital.

Universidad Central de Venezuela (Talleres y Seminarios de Arte: esmalte al fuego, orfebrería). Gratuito con titulación.

- Universidad Metropolitana. (Asignatura electiva: Orfebrería).Privado con titulación.

Instituto Universitario Pedagógico de Caracas. (Asignatura electiva: Orfebrería). Gratuito con titulación.

- Universidad Santa María. (Asignatura electiva: Orfebrería). Privado con titulación.

- Instituto tecnológico de Arte Héctor Poleo (Asignatura: Orfebrería). Privado con titulación.

- Escuela Técnica de Artes Visuales Cristóbal Rojas. (Artes del Fuego. Mención: Orfebrería). Privado con titulación.

- Consejo Nacional de la Cultura -CONAC- (Orfebrería y talleres de especialización). Gratuito con titulación.

- Instituto Nacional de Capacitación y Educación Socialista. (INCES). (Orfebrería y talleres de especialización). Gratuito con titulación.

Mérida, estado Mérida.

- Universidad de Los Andes. Facultades de Arquitectura, Farmacia y Bioanálisis. (Asignatura electiva: orfebrería, esmaltes al fuego). Gratuito: si está como electiva de alguna carrera / Privado con titulación: si se toman los cursos regulares.

La Asunción, estado Nueva Esparta.

- Escuela de Arte Pedro Ángel González. (Asignatura: orfebrería). Privado con titulación.

Maracaibo, estado Zulia.

- Escuela de Artes Plásticas Julio Árraga. (Esmalte sobre metal, Joyería). Privado con titulación.

Valencia, estado Carabobo.

- Fundación Universidad de Carabobo (Diplomado en Artes del Fuego). Privado con titulación. 
Del mismo modo, podemos asegurar que entes gubernamentales desarrollan actividades las cuales incluyen la enseñanza de técnicas especializadas por orfebres de renombre a nivel nacional como internacional. Así pues, a continuación serán mencionadas las ciudades - por orden alfabético-

Barquisimeto, estado Lara.

Ateneo de Barquisimeto.

Caracas, Distrito Capital.

Museo de Bellas Artes.

- Galería de Arte Nacional.

Sede de Corp Banca.

Museo de la Estampa y el Diseño. Carlos Cruz-Diez.

Centro de Arte La Estancia.

- Instituto Nacional de Capacitación y Educación Socialista (INCES)

Maracaibo, estado Zulia.

Museo de Arte Contemporáneo Lía Bermúdez.

Mérida, estado Mérida.

- Casa Bosset.

Puerto la Cruz, estado Anzoátegui.

- Galería Municipal de Arte Moderno de Puerto La Cruz.

Valencia, estado Carabobo.

- Galería Universitaria de Arte Braulio Salazar.

- Fundación Universidad de Carabobo.

Como hemos dejado en evidencia, la enseñanza de la orfebrería se ha ido introduciendo poco a poco en el campo de las artes. En conversaciones con Lunes Rodríguez, Director de la Galería Braulio Salazar - promotor del Salón Nacional de las Artes del Fuego y el Diplomado en las Artes del Fuego- comenta que, se encuentran en revisión curricular y elaboración del Pensum de estudios para la licenciatura en Artes del Fuego con sus respectivas menciones en: Cerámica, Vidrio, Esmaltes al Fuego y Orfebrería, la cual será la única en el país.

A continuación, mencionaremos y mostraremos algunos Talleres de orfebrería privados. Para ello, hemos decidido hacerlo de manera formal ya que, estos pequeños talleres han realizado una labor verdaderamente importante en la difusión y promoción de la orfebrería en el país; pues, gracias a ellos es que la orfebrería en Venezuela ha tomado tanto auge. Así como también, han convertido a estos orfebres en verdaderos orfebres integrales. Los fundadores de estos talleres, se interesan en que dominen y 
apliquen gran cantidad de técnicas. Esto, conlleva una fusión de técnicas con otras disciplinas y conceptos. Lo que ha permitido una diversidad rica entre joyas o piezas de orfebrería escultórica.

Esta nueva visión de la joyería contemporánea venezolana, atrae cada vez más personas a este fascinante oficio. Sin embargo, a pesar de la importancia que estos talleres de enseñanza suponen en las artes, su enseñanza no ha sido tomada en cuenta por organismos educativos.

Es necesario aclarar, que en Venezuela en la actualidad existe una gran cantidad de talleres privados de enseñanza de orfebrería establecidos desde hace varios años. Así pues, a continuación presentaremos algunos de ellos. Presentaremos en orden cronológico dichos talleres. Para ello, hemos resumido su actividad pedagógica de una manera concisa. Los datos e imágenes presentados a continuación, fueron conseguidos personalmente, a través de los fundadores (exceptuando los Talleres Artesanales de la Universidad de los Andes; sin embargo entrevistamos al coordinador de los talleres); Tomando en cuenta los datos aportados de la programación en la enseñanza, hemos elaborado un diseño sencillo, para que sean apreciados en un mismo orden. 


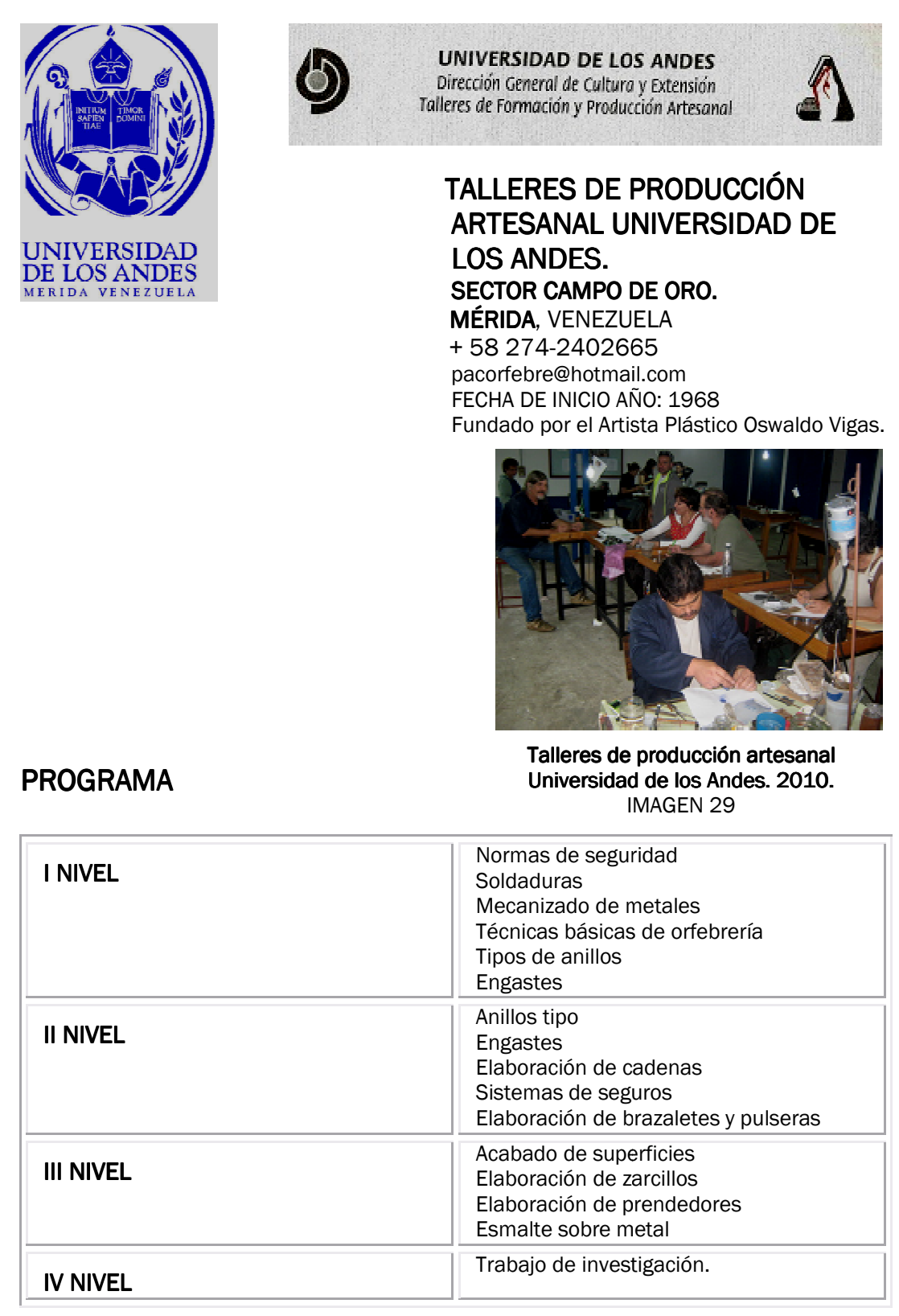

Cursos de especialización:

- Cera perdida.

- Engastes.

- Esmalte sobre metal.

- Kum-Boo.

Tejido con metales.

-De los alumnos egresados de dicho taller, el orfebre David García ha obtenido premios en el "SNAF" en diferentes ediciones así como también, en la "Bienal de Artes Plásticas para Estudiantes de la ULA y en La Bienal de Arte de Puerto la Cruz. 


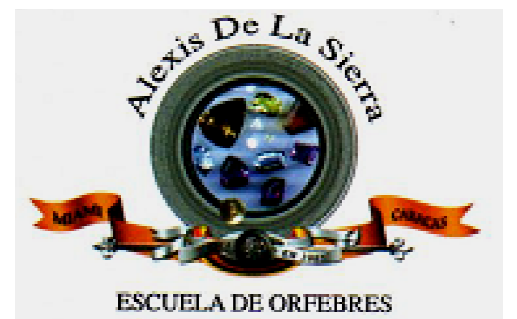

ESCUELA DE ORFEBRES

ESCUELA DE ORFEBRES

ALEXIS DE LA SIERRA

C.C. TERRAS PLAZA. TERRAZAS DEL

CLUB HÍPICO.

CARACAS, VENEZUELA.

CARACAS, VENEZUE
+58 212-9784660

58 212-9784660

artmanager@alexisdelasie

www.alexisdelasierra.com

Orfebres Alexis De la Sierra

FECHA DE INICIO: 1985

Fundada por:

- Orfebre: Alexis De la Sierra

- Manager: Ion Pervilhac Fournier.

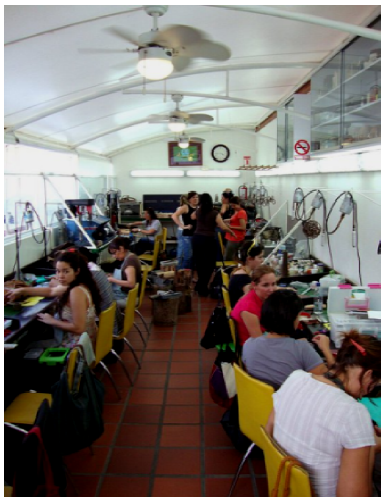

Escuela de Orfebres ADLS.

2009.
IMAGEN 30

PROGRAMA

Boceto para piezas sencillas.

Reporte de dibujos al metal en lámina (bronce/cobre).

NIVEL I Joyería plana

Técnicas básicas: calado, esmerilado,

lijado, texturización con martillo

manual y fresadora, soldadura,

pulitura.

NIVEL II Joyería en relieve

Esferas y domos.

Trefilado en plata.

Cincelado, repujado.

cidos.

nsamblaje/construcción de piezas

multi-elementos.

Engaste sencillo para piedras.

Técnicas opcionales.

Boceto en 3D elaborado a mano o

computadora.

Talla y modelado en ceras.

Confección de moldes.

Fundición a la cera perdida.

Técnicas opcionales.

NIVEL IV Introducción a la alta

Engaste de piedras preciosas.

Introducción al electroforming.

Esmalte sobre metal.

Logística de exhibición para eventos

expositivos.

Cursos adicionales sobre técnicas opcionales: 
- "Clase especial vidrio". Demostración de técnicas básicas de vidrio plano dirigida a orfebres.

- Cera perdida: utilización de diversos tipos de cera para modelar o tallar.

- Confección de cadenas bizantinas. Aplicación del trefilado manual y mecánico.

- Construcción de tubos (charnelas) de diferentes diámetros, en plata y oro. Aplicación de métodos manuales y mecánicos.

Engaste con martillo eléctrico.

- Ensarte de cuentas para la realización de collares y brazaletes.

Fabricación de tornillos y tuercas con metales preciosos.

Forja de metales preciosos.

Gemología.

Instrumentos de medición aplicables en el campo de la orfebrería.

- Reconstitución de piedra y diversos tipos de aplicaciones a una joya.

Sellos de ley.

Soldaduras para tipos diversos de cadenas.

Talla en azabache.

- Tallado y fundición en sepia (Jibia). Aplicación con y sin modelo.

- Técnicas de esmaltes al fuego. Aplicación en oro, plata y cobre. Sobre piezas macizas o en construcción con soldaduras.

- Tipos de soldadura para cada metal y su aplicación en orfebrería, utilización de diferentes tipos de sopletes y métodos diversos para soldar.

-La Escuela de Orfebres Alexis De la Sierra, es el primero establecido formalmente en el país.

-La Escuela realiza exposiciones anuales de los alumnos en la Galería de la Escuela desde el año 1986.

-La Escuela realiza exposiciones en otras Galerías y Museos de la ciudad de Caracas y fuera del país.

- La Escuela participa en obras benéficas como: Bandesir, Cruz roja entre otras, con las piezas de sus alumnos y realiza donaciones en metálico con las ventas de sus obras.

- De los alumnos egresados de dicha escuela, los siguientes orfebres han obtenido premios en el "SNAF":

- Duglas Pereira.

- Julia Ferreira.

- Liliana Benítez. 


\section{Patricia Querini.}

Patricia Benfele.

Simón Sorondo.

Yolanda Sucre.

- De los alumnos egresados de dicha escuela, los siguientes orfebres han obtenido premios en el "SNO":

- Jaghanat Rodríguez.

Patricia Querini.

Yolanda Sucre. 
Pa्d

PATHOS JOYAS ${ }_{\mathrm{CA}}$

TALLER DE ORFEBRERÍA METTA

\& PATHOS JOYAS, C.A.

LA PEDREGOSA/ C.C. LAS TAPIAS, 1ER

PISO. PASILLO CENTRAL.

PEO. PASILLO CENTRAL.

MERIDA, VENEZUELA.
+58 04247347969 / 274- 7893444

metta888ve@yahoo.es

pathosjoyas@gmail.com

FECHA DE INICIO: 1990

Fundada por la orfebre

María De los Ángeles Flames

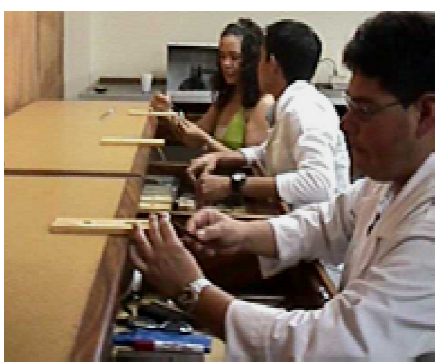

Taller de orfebrería Metta. 2008. IMAGEN 31

\section{PROGRAMA}

\begin{tabular}{|l|l|}
\hline I UNIDAD Diseño y modelado & $\begin{array}{l}\text { - Aplicar técnicas de diseño e } \\
\text { incorporación de herramientas } \\
\text { tecnológicas. } \\
\text { - Traslado del diseño a material especial } \\
\text { de modelado y crear pequeña escultura. }\end{array}$ \\
\hline \hline II UNIDAD Fundición & $\begin{array}{l}\text { Elaboración de moldes de yeso, colado o } \\
\text { casting. } \\
\text { Módulo de técnicas de fabricación. }\end{array}$ \\
\hline III UNIDAD Moldes silicona/ \\
Vulcanización & $\begin{array}{l}\text { Estructuración de moldes matrices para } \\
\text { la producción en serie. }\end{array}$ \\
\hline IV UNIDAD Terminado & $\begin{array}{l}\text { Corte de ductos, decapado, limado, lijado } \\
\text { y pulido. }\end{array}$ \\
\hline V UNIDAD Administrativa & $\begin{array}{l}\text { - Planificación estratégica de } \\
\text { departamentos y desarrollo de planes de } \\
\text { trabajo en cada uno de ellos. }\end{array}$ \\
\hline \hline VI UNIDAD Comercialización & $\begin{array}{l}\text { Desarrollo y conocimiento de } \\
\text { herramientas para el estudio de } \\
\text { mercado, canales de comercialización y } \\
\text { distribución. Su aplicación y el manejo de } \\
\text { imagen empresaria, corporativo y del } \\
\text { producto. }\end{array}$ \\
\hline
\end{tabular}




\section{PROGRAMA}

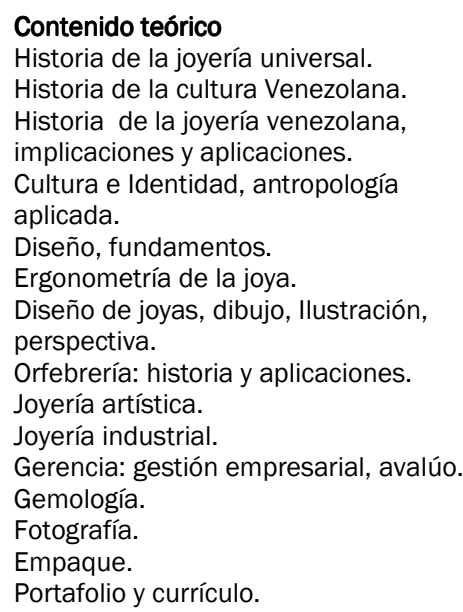

\section{Contenido práctico}

Diseño

Técnicas de fabricación Gerencia de producción Administrativo.

- El taller ofrece diplomado en diseño de joyas.

- El taller ofrece cursos a domicilio, trasladándose con su equipo necesario para su desarrollo.

- El taller ofrece expo-venta de obras de sus alumnos en su tienda en la ciudad de Mérida.

-La orfebre fundadora del Taller de Orfebrería Metta \& Pathos joyas es ex alumna de La Escuela de Orfebres Alexis De la Sierra. 
ESCUELA TALLER DE

ORFEBRERÍA ANTICLASSIC.

PAMPATAR, (ISLA DE MARGARITA).

NUEVA ESPARTA, VENEZUELA.

+58 $412-1954246$

ivan6558@hotmail.com

anticlassic-taller-escuela@hotmail.com

www faceor com Anticlasic Talor Escuela

www.facebook.com Anticlassic Taller Escuela

Fundada por el orfebre: Iván Cedeño

PROGRAMA

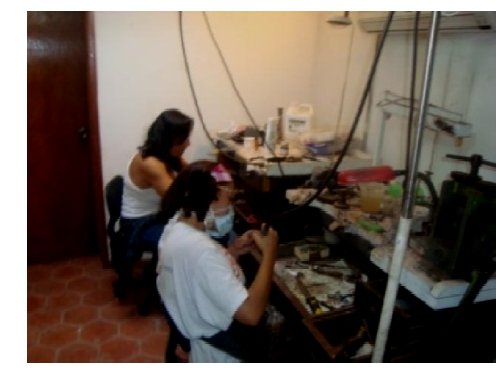

Escuela Taller de Orfebrería Anticlassic. 2010
IMAGEN 32

\begin{tabular}{|c|c|}
\hline & IMAGEN 32 \\
\hline I MÓDULO Cera perdida & $\begin{array}{l}\text { Modelado en ceras blandas. } \\
\text { Talla en ceras duras. } \\
\text { Colocación de pines } \\
\text { desgacificantes y de colada. } \\
\text { Tara de ceras y conversión en } \\
\text { metales. } \\
\text { Aleaciones en plata. } \\
\text { Aleaciones en bronce. } \\
\text { Fundición y vaciado en metales, } \\
\text { manual y mecánico. } \\
\text { Limpieza y acabados de piezas, } \\
\text { manual y mecánico. } \\
\text { Microfundición para esculturas. } \\
\text { Moldes macizos. } \\
\text { Moldes huecos. }\end{array}$ \\
\hline II MÓDULO Orfebrería tradicional & $\begin{array}{l}\text { Uso y manejo de equipos y } \\
\text { herramientas para técnicas } \\
\text { básicas. } \\
\text { Calado, limado, lijado, pulido. } \\
\text { Aleaciones para soldaduras en } \\
\text { plata y otros metales. } \\
\text { Laminado en plata. } \\
\text { Trefilado en plata. } \\
\text { Uso de cobre y latón en lámina e } \\
\text { hilos. } \\
\text { Engastes sencillos. }\end{array}$ \\
\hline III MÓDULO Alta joyería & $\begin{array}{l}\text { Diseño de joyas manual a color. } \\
\text { Modelado y talla en ceras con } \\
\text { inclusión de piedras. } \\
\text { Vaciado en metales varios. } \\
\text { Engastes. } \\
\text { Quilataje de metales nobles. }\end{array}$ \\
\hline IV MÓDULO Gemología & $\begin{array}{l}\text { Piedras preciosas. } \\
\text { Piedras semi-preciosas. } \\
\text { Piedras sintéticas. } \\
\text { Quilataje de piedras. } \\
\text { Talla en piedras. }\end{array}$ \\
\hline
\end{tabular}




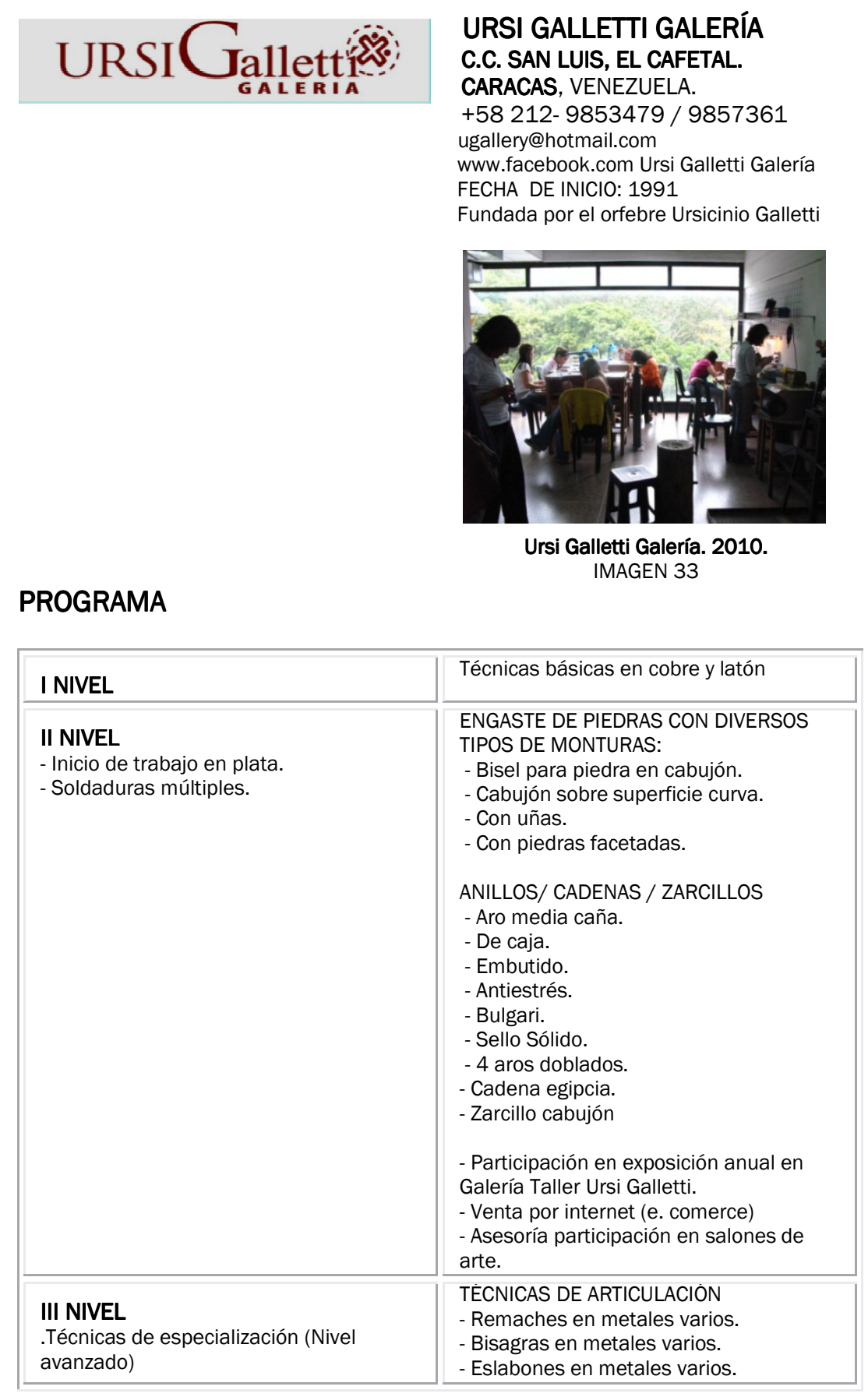

\section{Cursos especiales}
Accesorios con cuentas y cristales.
Alambrismo.
Art Clay.
Bisutería en plata.
Cadenas y/o Cordones.
Cera perdida.
Diseño de joyas. 
- Engaste de grano.

Esmalte sobre metal.

- Filigrana.

- Grabado con ácidos.

Resina por inclusión.

El orfebre Ursi Galletti es miembro de la "AVAF", siendo el fundador del Taller de orfebrería de dicha Asociación. Ofrece talleres de especialización durante el marco de celebración del Salón Nacional de las Artes del Fuego. Asi como también, ofrece cursos de especialización, en Talleres de enseñanza de orfebrería de otras ciudades de Venezuela

- El Taller realiza permanentemente exposiciones colectivas tanto en la Galería Ursi Galletti; así como también, en otras Galerías de arte en la ciudad de caracas.

- El Taller participa en medios televisivos a nivel nacional, con la instrucción de técnicas de orfebrería.

- El Taller posee una Galería virtual.

- De los alumnos egresados de dicho taller, la orfebre Mildred Maury obtuvo un premio en el "SNAF". 


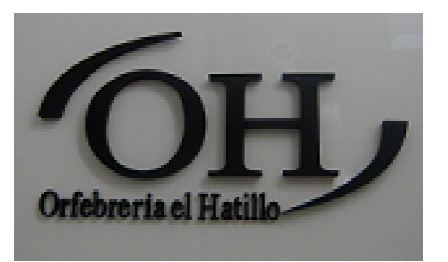

GALERÍA TALLER ORFEBRERÍA

EL HATILLO

C.C. GALERÍA LOS NARANJOS

NIVEL PLAZA

CARACAS, VENEZUELA

\begin{tabular}{l}
+58212 - 9851511/ 9851013 \\
\hline
\end{tabular}

orfebreriaoh@yahoo.com

FECHA DE INICIO AÑO 1993

Fundada por las orfebres:

- Betsy Dao.

- María Alexandra Dao.

- Elizabeth Cruz.

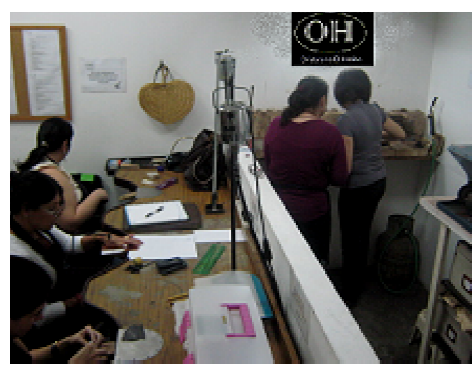

PROGRAMA

Galería Taller Orfebrería el Hatillo. 2010.

\begin{tabular}{|l|l|}
\hline NIVEL BÁSICO & $\begin{array}{l}\text { Normas de seguridad en el taller. } \\
\text { Técnicas Básica: Calado, limado, lijado y } \\
\text { pulido. }\end{array}$ \\
\hline \multirow{2}{*}{ NIVEL MEDIO } & $\begin{array}{l}\text { Soldaduras. } \\
\text { Domos. }\end{array}$ \\
\hline \multirow{2}{*}{ NIVEL INTERMEDIO } & $\begin{array}{l}\text { Martillado. } \\
\text { Embutido. } \\
\text { Granulación. } \\
\text { Reconstitución. }\end{array}$ \\
\hline \multirow{2}{*}{ NIVEL AVANZADO } & $\begin{array}{l}\text { Confección de Cajas. } \\
\text { Engastes. } \\
\text { Trabajos con hilos. } \\
\text { Diferentes tipos de anillos. }\end{array}$ \\
\hline
\end{tabular}

Diplomados de 4 a 5 Meses

\begin{tabular}{|l|}
\hline Alta joyería, Micro mecánica \\
\hline Cera perdida \\
Modelado \\
Tallado \\
Esculpido \\
vaciado \\
\hline Filigrana \\
\hline
\end{tabular}

- Anualmente se realiza una exposición colectiva de alumnos, en la Galería del Taller OH. 
- El Taller OH, posee una línea comercial en joyas casuales, aros de boda y diademas para novias.

- En el año 2003, los alumnos del Taller OH elaboraron 75 joyas con diseños del Artista plástico venezolano Carlos Cruz Diez, a petición del propio artista.

- Las orfebres fundadoras del Taller OH son ex alumnas de La Escuela de Orfebres Alexis De la Sierra. 
TALLER MARITZA ALAYÓN

LOS PALOS GRANDES

CARACAS, VENEZUELA

maritzaalayon@hotmail.com

www.facebook.com Maritza Alayón

FECHA DE INICIO: 1995.

Fundada por la orfebre Maritza Alayón

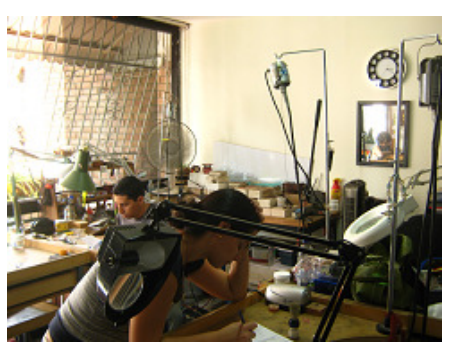

Taller Maritza Alayón. 2010.

IMAGEN 35

\section{PROGRAMA}

\begin{tabular}{|c|c|}
\hline I NIVEL & $\begin{array}{l}\text { TÉCNICAS BÁSICAS } \\
\text { Trazado, calado, limado, lijado, pulido. En } \\
\text { Cobre y Bronce. } \\
\text { Soldadura en metales varios. } \\
\text { Preparación y aplicación. } \\
\text { Construcción de figuras geométricas } \\
\text { huecas con lámina en bronce, cobre y } \\
\text { plata. } \\
\text { Laminado. }\end{array}$ \\
\hline II NIVEL & $\begin{array}{l}\text { Elaboración de joyas partiendo de figuras } \\
\text { geométricas en metales. } \\
\text { Matrimonio de metales y su aplicación en } \\
\text { joyas. } \\
\text { Martillado. } \\
\text { Embutido. } \\
\text { Trefilado. } \\
\text { Engastes. }\end{array}$ \\
\hline III NIVEL & Desarrollo de lenguaje personal. \\
\hline
\end{tabular}

- La orfebre Maritza Alayón es miembro de la "AVAF" y ofrece talleres de especialización durante el marco de celebración del Salón Nacional de las Artes del Fuego. Así como también, ofrece cursos de especialización en otros Talleres de enseñanza en el país.

- Los alumnos del Taller participan en exposiciones privadas a nivel nacional, como por ejemplo: en el año 2005 desplegaron una exposición en el Museo de Arte Contemporáneo Lía Bermúdez en la ciudad de Maracaibo. (Conmemorando a la artista plástico Lía Bermúdez).

-La fundadora del Taller Maritza Alayón es ex alumna de la Escuela de Orfebres Alexis De la Sierra. 


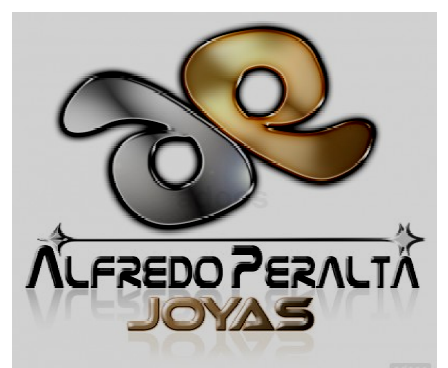

TALLER ESCUELA

ALFREDO PERALTA

VALLE ARRIBA

CARACAS, VENEZUELA

+58 416-4035922

Alfredo_peralta720@hotmail.com

Www.

FECHA DE INICIO: 1999

Fundada por el orfebre Alfredo Peralta.

PROGRAMA

\begin{tabular}{|l|l|}
\hline \multicolumn{1}{|c|}{ IMÓDULO } & $\begin{array}{l}\text { Introducción a los metales. } \\
\text { Punto de fusión de los metales. } \\
\text { Quilataje. } \\
\text { Teórico/práctico } \\
\text { Pureza de los metales. } \\
\text { Aleaciones de plata y oro. } \\
\text { Soldaduras. }\end{array}$ \\
\hline II MÓDULO & $\begin{array}{l}\text { Uso y manejo de equipos y } \\
\text { herramientas. } \\
\text { Medidas de seguridad. } \\
\text { Técnicas básicas: calado, perforado, } \\
\text { limado, lijado, martillado, pulido. } \\
\text { Decapantes. }\end{array}$ \\
\hline III MÓDULO & $\begin{array}{l}\text { Domos. } \\
\text { Anillos básicos. } \\
\text { Candelabros. }\end{array}$ \\
\hline \hline IV MóDULO & $\begin{array}{l}\text { Zarcillos básicos. } \\
\text { Engastes: alta joyería. } \\
\text { Gemología: propiedades de las piedras, } \\
\text { tasar, tallar, engastar. }\end{array}$ \\
\hline
\end{tabular}

- Desde 1998 al 2000, el orfebre Alfredo Peralta llevaba una sección de Joyería y Orfebrería en el programa "Nuestra Mañana" de un Canal Televisivo venezolano.

- El orfebre Alfredo Peralta, posee una línea comercial en alta joyería: anillos de compromiso, aros de boda, diademas y anillos de grado. 


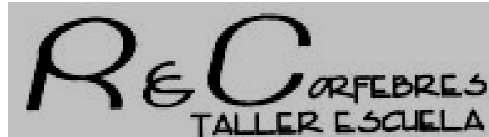

\section{$R$ \& C ORFEBRES,}

TALLER ESCUELA

CARACAS, VENEZUELA.

+ 58 212- 4218007

rcorfebres@gmail.com

www.facebook.com R\&C Orfebres, Taller-

FECHA DE INICIO: 2000

- Rosa Falena (QEPD).

- Carlos Graterol.

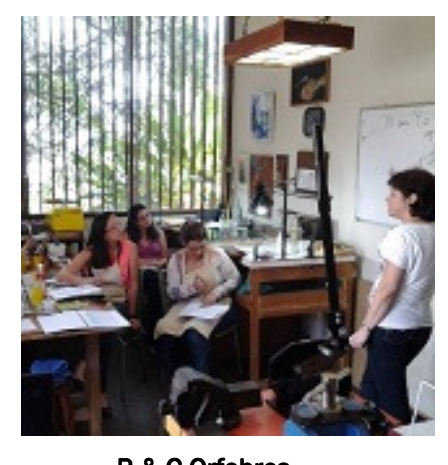

R \& C Orfebres

Taller Escuela. 2011

PROGRAMA

IMAGEN 36

\begin{tabular}{|c|c|}
\hline Cera & $\begin{array}{l}\text { - NIVELI } \\
\text { Iniciación al Modelado de Anillos en Cera. } \\
\text { Trabajo en Tacos tubos o perfiles sólidos } \\
\text { de Cera. } \\
\text { - Nivel II } \\
\text { Trabajo en láminas e hilos de cera. } \\
\text { Elaboración Artesanal de Moldes para } \\
\text { Cera. } \\
\text { Elaboración de moldes huecos y macizos. }\end{array}$ \\
\hline Mokume gané & $\begin{array}{l}\text { Introducción a la antigua técnica del } \\
\text { laminado japonés. } \\
\text { Técnicas de fusión. } \\
\text { Soldado de las láminas de cobre y plata. } \\
\text { Diseño de textura. } \\
\text { Diseño de pieza para incluir lámina de } \\
\text { Mokume gané. } \\
\text { Proceso de grabado y laminado. } \\
\text { Ejecución de pieza. }\end{array}$ \\
\hline Filigrana & $\begin{array}{l}\text { - NIVEL I } \\
\text { Introducción a la Técnica de la Filigrana } \\
\text { Plana. } \\
\text { Elaboración de los hilos para filigrana. } \\
\text { Entorchado y aplanado. } \\
\text { Preparación de la soldadura. } \\
\text { - NIVEL II } \\
\text { Diseño. } \\
\text { Proceso vestir pieza. } \\
\text { Soldado. } \\
\text { Acabados. } \\
\text { Filigrana en Volumen. }\end{array}$ \\
\hline & - NIVELI \\
\hline
\end{tabular}




\begin{tabular}{|c|c|}
\hline Esmalte sobre metal. & $\begin{array}{l}\text { Procedimientos y técnicas introductorias } \\
\text { en el esmaltado al fuego sobre metal. } \\
\text { Esténcil e Hilos Flotados. } \\
\text { - NIVEL II } \\
\text { Grabado al ácido nítrico. } \\
\text { Técnica de Basse Taillé y Champlevé. } \\
\text { - NIVEL III } \\
\text { Cloisonné y Plique a Jour. } \\
\text { - NIVEL IV } \\
\text { Esmalte pintado. } \\
\text { Técnica de los Esmaltes Vitrificables. } \\
\text { Grisalla de Ópalo y Limoges. }\end{array}$ \\
\hline Cadenas & $\begin{array}{l}\text { AVANZADAS } \\
\text { Técnica de Elaboración Artesanal de } \\
\text { Cadenas Antiguas Nivel Il a través de } \\
\text { Eslabones. } \\
\text { SOLDADAS } \\
\text { Cadena Etrusca. } \\
\text { Cadena China. }\end{array}$ \\
\hline Forja y martillado & \\
\hline
\end{tabular}

Talleres de especialización en:

Técnicas básicas, Avanzadas y Contemporáneas.

-El orfebre Carlos Graterol es miembro de la "AVAF" y ofrece talleres de especialización durante el marco de celebración del Salón Nacional de las Artes del Fuego.

- Los cursos de orfebrería de la "AVAF" al no tener una sede, se llevaban a cabo en R\&C Orfebres Taller Escuela. En la actualidad, dichos cursos son en diferentes espacios de la Galería Universitaria Braulio Salazar en Valencia, Carabobo y en su mayoría, dentro del marco de celebración del Salón Nacional de las Artes del Fuego en la ciudad de Valencia, Venezuela.

- El taller realiza permanentemente exposiciones colectivas en Galerías de arte en la ciudad de caracas.

-De los alumnos egresados de dicho taller, los siguientes orfebres han obtenido premios en el "SNAF":

- Ana Mercedes Carvallo.

- Tatiana Tischencko.

- Yolanda Sucre.

-De los alumnos egresados de dicho taller, los siguientes orfebres han obtenido premios en el "SNO":

- Tatiana Tischencko.

- Yolanda Sucre. 


\begin{tabular}{|c|c|}
\hline $\begin{array}{c}\text { CO } \\
\text { Taller Escuela de Orfebreria c.A }\end{array}$ & $\begin{array}{l}\text { TALLER ESCUELA DE } \\
\text { ORFEBRERIIA } \\
\text { JOANNA PALACIOS } \\
\text { CALLE SAN MARINO, VISTA ALEGRE, } \\
\text { CHACAO. } \\
\text { CARACAS, VENEZUELA } \\
\text { +58 212-2643256 } \\
\text { www.joannapalacios.com } \\
\text { jp.tallerescueladeorfebreria@hotmail.com } \\
\text { info@escueladeorfebreriajoannapalacios.com } \\
\text { www.facebook.com Escuela de Orfebrería } \\
\text { Joanna Palacios. } \\
\text { FECHA DE INICIO: } 2003 \\
\text { Fundada por la orfebre: } \\
\text { Joanna Palacios }\end{array}$ \\
\hline PROGRAMA & $\begin{array}{c}\text { Taller Escuela de Orfebrería } \\
\text { Joanna Palacios. } 2009 . \\
\text { IMAGEN } 37\end{array}$ \\
\hline UNIDAD I & $\begin{array}{l}\text { Conceptos básicos } \\
\text { Conocimiento del taller } \\
\text { Uso y manejo de las herramientas } \\
\text { Sistemas de medición }\end{array}$ \\
\hline UNIDAD ॥ & $\begin{array}{l}\text { Calado } \\
\text { Limado } \\
\text { Lijado manual y mecánico } \\
\text { Pulido manual y mecánico }\end{array}$ \\
\hline UNIDAD III & Soldadura \\
\hline UNIDAD IV & $\begin{array}{l}\text { Formación de superficies manual, } \\
\text { mecánica, con ácidos } \\
\text { Volúmenes } \\
\text { Embutido }\end{array}$ \\
\hline UNIDAD V & $\begin{array}{l}\text { Engastes } \\
\text { Reconstrucción de piedras }\end{array}$ \\
\hline UNIDAD VI & $\begin{array}{l}\text { Remaches } \\
\text { Articulaciones }\end{array}$ \\
\hline UNIDAD VII & Introducción a la cera perdida \\
\hline
\end{tabular}


Alambre artístico.

Art clay.

Beadmaking.

Bisutería fina con plata.

Cadenas I, II y III.

Cera perdida.

Cincelado.

Engaste fino (avanzado).

Esmalte sobre metal al fuego.

Filigrana (avanzado).

Fundición artesanal en jibia.

Grabado al ácido.

Grabado con buril.

Granulado (avanzado).

Joyería (avanzado).

Kum boo (avanzado).

Micro mecanismos (avanzado).

Mokume gané (avanzado).

Platería y utilitaria (avanzado).

Resinas y polímeros.

Tocados y accesorios para el cabello.

vitro fusión.

-El taller realiza exposición anual de las obras de sus alumnos en alguna Galería o espacio expositivo en la ciudad de Caracas.

-Los mejores alumnos son promovidos para la participación en la Feria Anual de Arte en el Ateneo de Caracas.

-El Taller Escuela realiza intercambios con otras escuelas de orfebrería y eventos relacionados a área:

- 3er. Encuentro Hispanoamericano de Plateros, Zacatecas, México. Cursos de especialización. En Patronato de plata del Perú, Perú.

- El Taller Escuela se encuentra en proceso de revisión del pensum de estudios ante el Ministerio del Poder Popular para la Educación de la República de Venezuela. 
CARACAS, VENEZUELA

+58 212- 2675217 / 7157910

riocaracas@yahoo.com

www.facebook.com Especialidades Rio Grande FECHA DE INICIO: 2004

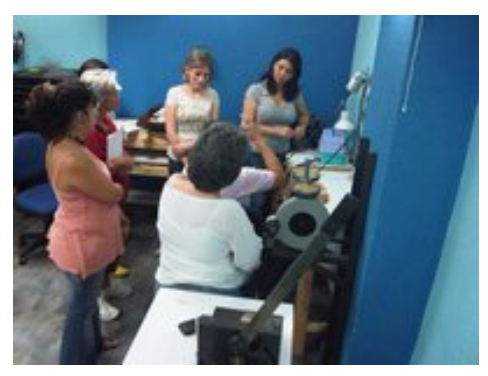

PROGRAMA

Especialidades Río Grande. 2009.

\begin{tabular}{|l|l|}
\hline I UNIDAD Nivel básico & $\begin{array}{l}\text { Corte, segueteado, aleaciones, } \\
\text { fundición, laminado, soldaduras, } \\
\text { limado, lijado, pulido. }\end{array}$ \\
\hline \multirow{2}{*}{ II UNIDAD Nivel avanzado } & Soldaduras varias en metales \\
& varios. \\
& Trabajos en construcción. \\
& Trefilado. \\
& Anillos. \\
& Cadenas. \\
& Engastes. \\
\hline
\end{tabular}

\section{Cursos de especialización}
Alambrismo.
Baños electrolíticos.
- Cera perdida.
- Diseño de Joyería.
- Engastes.
- Filigrana.
Otros Cursos Especiales.

- Especialidades Rio Grande, son los distribuidores de equipos y materiales de la marca "Rio Grande" en Venezuela.

- Los cursos son dictados por orfebres invitados tanto venezolanos como extranjeros. 


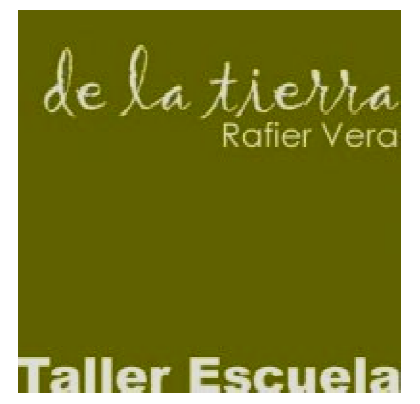

TALLER ESCUELA DE LA TIERRA

CALLE ALEGRÍA BERACASA, № 11

LOS CHORROS.

CARACAS, VENEZUELA

$+58212-3686010$

tallerdelatierra@yahoo.es

tallerdelatierra@gmail.com

www.facebook.com Taller de la tierra

FECHA DE INICIO: 2006

Fundado por el orfebre: Rafier Vera

Taller Fscuela

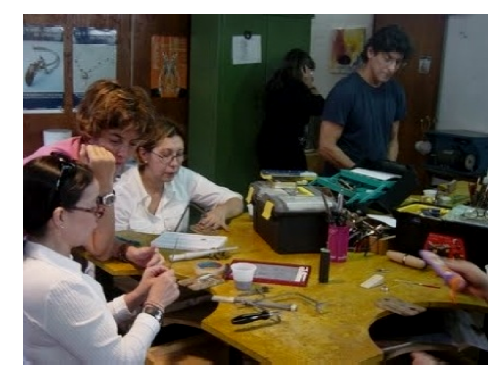

Taller Escuela de la tierra. 2009. IMAGEN 39

PROGRAMA

\begin{tabular}{|l|l|}
\hline Iniciación a la orfebrería & $\begin{array}{l}\text { Laminar, trefilar, solar, construcciones } \\
\text { con volumen, calar, pulir, acabados, } \\
\text { aplicado en anillos, pulseras, collares, } \\
\text { zarcillos y otras piezas utilitarias. }\end{array}$ \\
\hline Pequeño formato & $\begin{array}{l}\text { Inclusión de técnicas de Joyería y el } \\
\text { manejo de materiales no convencionales } \\
\text { como vidrio, acrilico, madera y otros. }\end{array}$ \\
\hline Micro fundición a la cera perdida & $\begin{array}{l}\text { Talla y modelado en diversos tipos de } \\
\text { ceras. } \\
\text { Aleaciones. } \\
\text { Vaciado en metales nobles. }\end{array}$ \\
\hline Micro mecánica & $\begin{array}{l}\text { Desarrollo de piezas con diversos tipos } \\
\text { de mecanismo para unir sus partes sin } \\
\text { soldadura, en metales nobles. }\end{array}$ \\
\hline Ensamblaje & $\begin{array}{l}\text { Bisagras, broches, eslabón maestro, } \\
\text { crucetas, poleas, rótulas, tornillos, } \\
\text { tuerca. }\end{array}$ \\
\hline Joyería libre & $\begin{array}{l}\text { Uso de técnicas de orfebrería como } \\
\text { medio de expresión artística. Desarrollar } \\
\text { objeto tridimensional } \\
\text { descontextualizando la joya como } \\
\text { ornamento. }\end{array}$ \\
\hline Esmalte sobre metal & $\begin{array}{l}\text { Champlevé, Cloisonné, sobre relieve, } \\
\text { pintado, grisaille, mosaico con vidrio. }\end{array}$ \\
\hline Experimental de forjado & $\begin{array}{l}\text { Desarrollar varias piezas con varios } \\
\text { metales. }\end{array}$ \\
\hline
\end{tabular}

- El Taller realiza permanentemente exposiciones colectivas en Galerías de arte en la ciudad de caracas. 
De los alumnos egresados del Taller de la Tierra, los siguientes orfebres han obtenido premios en el "SNAF":

$$
\begin{aligned}
& \text { Yolanda Sucre. } \\
& \text { Mary Peña. } \\
& \text { Georgina Doumat. } \\
& \text { Luis Jaspe. }
\end{aligned}
$$

- De los alumnos egresados del Taller de la Tierra, los siguientes orfebres han obtenido premios en el "SNO":

$$
\begin{aligned}
& \text { Yolanda Sucre. } \\
& \text { Gustavo Smitter. } \\
& \text { Luis Macero. }
\end{aligned}
$$


Tal y como mencionamos con anterioridad, presentaremos algunos nombres de orfebres que tienen talleres de enseñanza ya establecidos. Sin embargo, consideramos sólo mencionar el nombre del orfebre facilitador, el nombre del Taller y la ciudad donde se encuentra.

\begin{tabular}{|l|l|l|}
\hline $\begin{array}{l}\text { Nombre del } \\
\text { orfebre }\end{array}$ & $\begin{array}{l}\text { Ciudad donde } \\
\text { se encuentra }\end{array}$ \\
\hline \hline Isabel Tinoco & "Colperic" & Caracas \\
\hline José Orellanes & "J.A.O. Cristo" & Caracas \\
\hline $\begin{array}{l}\text { Ana Rita Bevini } \\
\text { Nadia Karroum } \\
\text { Carolina Perdomo }\end{array}$ & "Arigana" & Valencia \\
\hline $\begin{array}{l}\text { María Valeska } \\
\text { Quintero }\end{array}$ & "Artes de Fuego" & Caracas \\
\hline Mariela Reyes & "Taller-Escuela Mariela Reyes" & Caracas \\
\hline Maritza Alayón & "Maritza Alayón" & Caracas \\
\hline \hline Soledad Castro & "Sol Castro" & Caracas \\
\hline Lisbeth Cortéz & "Tierra Mágica" & Aragua \\
\hline \hline Lutz Podolski & "Lutz Podolski" & Mérida \\
\hline Aris Hernández & "Taller Aris Hernández" & Maracaibo \\
\hline
\end{tabular}

De igual modo, hacemos la acotación, que muchos de los orfebres que tienen talleres establecidos, son contratados por entes gubernamentales para dictar cursos de técnicas especializadas. A continuación, presentamos un recuadro en donde, aparecen los nombres de una gran cantidad de orfebres con larga trayectoria en el medio.

\begin{tabular}{|l|l|}
\hline Barquisimeto, estado Lara & Maria Isabel Mayorca \\
\hline Boconó, estado Trujillo & Edecio Barazarte \\
\hline \hline Caracas, Distrito Capital & - Abelardo Tucapel \\
& - Alberto Álvarez \\
& - Ana Alexandra Henríquez \\
& - Ana Mercedes Carvallo \\
& - Beatriz Tovar \\
& - Carola Sosa \\
& - Carlos Graterol \\
& - Clara López \\
& - Christian Gramcko \\
& - Cristina Giralt \\
& - Eleazar Molina \\
& - Elizabeth Cruz Baharez \\
& - Ernesto Guevara \\
& - Fany Bello \\
& - Fernando Silva \\
& - Francisco Porras \\
& - Gabriela Urdaneta \\
& - Isabel Gilly \\
& - Isabel Silva \\
& - Ingrid Urdaneta \\
& - Julia Ferreira \\
\hline
\end{tabular}




\begin{tabular}{|c|c|}
\hline & $\begin{array}{l}\text { - Julio Cesar Carvajal } \\
\text { - Julio Mota } \\
\text { - Leonor Austria } \\
\text { - Lourdes Silva } \\
\text { - María Valezka Quintero } \\
\text { - Mario Lacurcia } \\
\text { - Marisela Unda } \\
\text { - Maritza Alayón } \\
\text { - Maruja Herrera } \\
\text { - Nancy Bracho } \\
\text { - Orlando Sagastegui } \\
\text { - Oscar Iñatti } \\
\text { - Rafael Bello } \\
\text { - Rosalía Gudiño } \\
\text { - Sonia Parisca } \\
\text {-Tatiana Tischencko } \\
\text { - Ursicinio Galletti } \\
\text { - Vanesa Benítez } \\
\text { - Venezuela Rocca } \\
\text { - Vilma Sánchez } \\
\text { - Yolanda Sucre }\end{array}$ \\
\hline Maracay, estado Aragua & Rafael Marín \\
\hline Maracaibo, estado Zulia & $\begin{array}{l}\text { Carolina Fernández } \\
\text { Aris Hernández }\end{array}$ \\
\hline Mérida, estado Mérida & $\begin{array}{l}\text { - Antonio Medrano } \\
\text { - Duglas Pereira } \\
\text { - Jaghanat Rodríguez } \\
\text { - Henry Doncell } \\
\text { - Luis Betancourt } \\
\text { - Lutz Podolski } \\
\text { - Pablo Mejías }\end{array}$ \\
\hline \multirow[t]{2}{*}{ Miranda, Baruta } & - Marisela Hunda \\
\hline & $\begin{array}{l}\text { - Ana Rita Bevini } \\
\text { - Carolina Perdomo } \\
\text { - Gabriela Brazao } \\
\text { - Gersenda Suárez } \\
\text { - Graciela Gómez } \\
\text { - Isabel Betancourt } \\
\text { - Lucía Ramírez } \\
\text { - Nadia Karroum }\end{array}$ \\
\hline Pampatar, estado Nueva Esparta & Iván Cedeño \\
\hline
\end{tabular}

1.2.2.2 Cronología de bienales y salones de arte que incluyan la modalidad de Orfebrería.

En este apartado daremos a conocer cronológicamente los salones de arte y bienales de arte que incluyen la modalidad de orfebrería entre sus representaciones artísticas.

Década de los años 70:

1971 Salón Nacional de las Artes del Fuego. Galería Braulio Salazar. Valencia, estado Carabobo.

\section{Década de los años 90:}


1991 Bienal Nacional de Artes Plásticas de Puerto la Cruz, estado Anzoátegui. (Patrimonio Cultural desde el año 2007).

Década de los 2000:

2004 Bienal de Artes Plásticas para Estudiantes de la Universidad de los andes. Galería la Otra Banda, Mérida.

2005 I Salón Nacional de Orfebrería. Museo Cruz Diez. Caracas, Distrito Capital.

2008 I Salón Oriental de Arte. Galería Pedro Báez. Barcelona, estado Anzoátegui.

En la actualidad se llevan a cabo una gran cantidad de salones y bienales de arte. Sin embargo, al leer las bases para su participación podemos evidenciar que existe una minoría en la cual incluyen la modalidad de orfebrería. También hemos podido evidenciar que, intermitentemente desde el año 1970 en Venezuela han aparecido salones dedicados exclusivamente a la orfebrería pero lamentablemente no han tenido continuidad. Aún así, desde principios de los años noventa inicia la participación dentro del campo de la orfebrería escultórica, lo que ha generado una gran participación de escultores que por alguna razón, se encuentran de tránsito en la disciplina de la orfebrería. Con lo cual, se ha dado gran importancia a esta nueva tendencia que fusiona la escultura con la orfebrería.

Ya desde la época del dos mil, talleres de orfebrería y orfebres consagrados, se han dedicado a exposiciones colectivas con colaboración de importantes críticos de arte. Así pues, se están dando la tarea de insertar este arte a nivel de museos y galerías e incentivando a escultores reconocidos que lleven su arte al ámbito de la orfebrería.

\subsection{CONTEXTO ARTÍSTICO DE LA ESCULTURA VENEZOLANA.}

\subsubsection{APROXIMACIÓN HACIA UNA NUEVA ESCULTURA.}

Tal y como se ha comentado en los antecedentes del contexto artístico de la orfebrería venezolana; antes de la colonización española, la artesanía elaborada por los indígenas venezolanos, se ceñía a un estilo figurativo de líneas sencillas. En su mayoría, basado en el modelado de arcillas, de tipo utilitario, -como vasijas $u$ otros utensilios para la cocina de sus alimentos- como las de tipo decorativo -figurillas humanas y animales-. Así como también, se presume que hay indicios de pequeños objetos vaciados macizos- en oro con figuras de animales. Sin embargo, a partir de la presencia española en el país, esta artesanía no fue tomada en 
cuenta, substituyéndose por completo, por el estilo y material establecido por los colonizadores.

Los colonizadores de las tierras venezolanas, establecieron diversos gremios artesanales. Se constituían por excelentes maestros entre carpinteros, ebanistas, tallistas, constructores de retablos, alarifes y escultores. Con este arte, se debía adornar las Iglesias y por ende el arraigo de la evangelización. Cada gremio, debía fomentar la instrucción para su desarrollo artesanal.

Así pues, se establece el inicio de la producción del arte colonial, inspirados en el estilo Barroco imperante en Europa para ese entonces. Debido al poder simbológico de las figurillas humanas, animales $u$ otros objetos y elementos para el ornato del cuerpo, es que, la artesanía traída por los hispanos produce fascinación en los indígenas venezolanos. Pues, la carga emotiva de las imágenes de las tallas y por supuesto el estilo colmado de detalles orgánicos, encanta a los indígenas, lo que permite a los hispanos calar hondamente su estilo, substituyendo de raíz la artesanía aborigen. Durante muchas generaciones, prevaleció la técnica de la talla en madera de cedro, así como también el estilo Barroco que las instituía. Lo cual se mantuvo invariable hasta principios del siglo $\mathrm{XIX} \mathrm{X}^{43}$.

Una vez liberado el país del yugo español en el año 1824, la talla en madera centra su actividad en el mobiliario y es la pintura quien se mantiene como representación artística. Así pues, los artistas dejaron testimonio en grandes lienzos. En ellos, plasmaron las batallas más importantes de la gesta libertadora. Así como también, hechos relevantes que sucedieron del posterior dominio del territorio venezolano. Así, transcurrieron varias décadas y la pintura se mantenía en boga; hemos corroborado, que no había cabida para otro tipo de representación.

Todo este panorama cambia a partir de 1870, cuando el General Guzmán-Blanco gobierna Venezuela. De ese gobierno, se instauran ciertas ordenanzas para beneficio del país. Pues, las artes toman un nuevo impulso con la instauración del culto a los héroes de la guerra de la independencia. Esto, trasciende hacia la creación de la "Escuela de Escultura" en la ciudad de Caracas en el año 1873. Los frutos de dicha escuela se ven casi inmediatamente, puesto que es allí donde se elaboran los magníficos monumentos alegóricos a la lucha contra el yugo español. Estas obras, se emplazan en algunas zonas de la ciudad de Caracas, como en el resto de ciudades -o pueblos- donde ocurrieron esas batallas.

43 La escultura de la antigua provincia de Venezuela. Hernández, J.M. http://museosdevenezuela.org/Documentos/Revista/Conservacion2.shtm! 
El artista venezolano Eloy Palacios - recién llegado de la Escuela de Escultura de Múnich-es nombrado como Director de la Escuela de Escultura en la ciudad de Caracas. Surge un importantísimo encargo oficial del caudillo: El Altar de la Patria. Monumento a la Batalla de Carabobo" (IMAGEN 40)44.

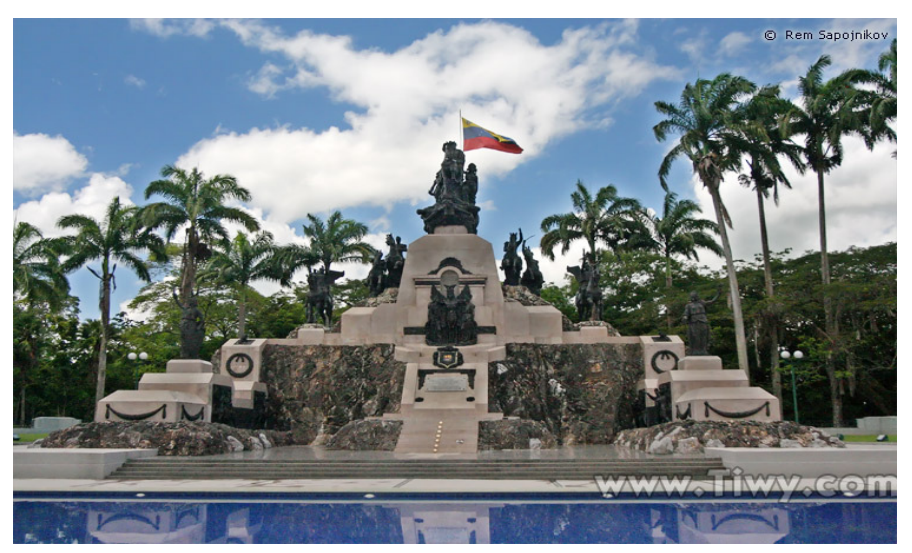

Altar a la patria. Monumento a la Batalla de Carabobo

$$
\text { IMAGEN } 40
$$

Este altar es un monumento, donde se ubica un grupo escultórico alegórico a los héroes que participaron en la Batalla de Carabobo. Le confiaron a Palacios: las numerosas y monumentales ornamentaciones escultóricas del Palacio Legislativo,-decoración escultórica del Capitolio-, el cual ya se construía para ese entonces. Allí sus pupilos tuvieron oportunidad de aplicar los conocimientos impartidos por este gran escultor. Palacios desarrolla en sus obras el tema histórico y tienen un carácter monumental, en las que se demuestra su influencia por el romanticismo y el realismo europeo. Del mismo modo, se aprecia el dominio que posee de la técnica del modelado, pues la figura humana, es fielmente representada con tal expresividad que demuestra su maestría sobre este arte. Este artista recurre a modelado en arcilla, el vaciado en yeso, la talla en madera, el vaciado en bronce e introduce por vez primera en el país la terracota.

En tal sentido, podemos afirmar que en Venezuela la escultura, surge bien entrado el siglo XIX. Aparecieron las escuelas de arte, las que sustituyeron a los viejos talleres de los imagineros, y que abogarían en adelante, por un estilo inspirado en el academicismo europeo. Guiaron su enseñanza hacia la formación de artistas individuales, que se dedicarían a la figura humana y a los temas históricos y aún así fue vista como manifestación secundaria, destinada a conseguir por medio de la copia de yesos la elaboración de obras de ornato público o de interés funerario. De allí, que sus principales empeños hayan provenido de los

44 Trayectoria del escultor Eloy Palacios hasta 1883. Resumen. Salvador, J. M. (2003). http://argos.dsm.usb.ve/archivo/38/5.pdf 
monumentos histórico/conmemorativos y funerarios, los retratos de próceres civiles/militares y su instalación en plazas públicas. Estas plazas, eran adornadas con bustos, estatuas ecuestres y relieves alegóricos a temas históricos. Es desde esta época, que este tipo de monumentos comienzan a ser colocados en plazas en territorio venezolano y en el extranjero.

Dentro de los Escultores venezolanos más destacados que realizaron importantes obras en bronce y mármol en los siglos XIX y XX se encuentran: “Eloy Palacios, quien se considera el más importante del siglo XIX, precursor de la enseñanza de escultura y pionero en difundir la estatuaria en bronce -los cuales eran vaciados en el extranjero ya que en el país no existían talleres de fundición-. Palacios se formó en Múnich desde los diez años de edad en pintura y escultura, a los quince años ingresó en la Academia de Bellas Artes muniquense, la cual frecuentó, durante cinco años, y se perfeccionó en el arte de la escultura. Por motivos familiares, regresa al país a su ciudad natal -Maturín-"45. Sin embargo, en Maturín no consiguió un sitio propicio para difundir su arte. Por influencia de su hermano mayor, quien era militante del Gobierno, Palacios es trasladado a la ciudad de Caracas y es nombrado Director de la "Escuela de Escultura".

De esa época, también tenemos al escultor Rafael de la Cova quien fue discípulo de Eloy Palacios en dicha escuela. Participó en la ejecución del monumento a Cristóbal Colón en la ciudad de Caracas. -De la Cova, Fue el primer artista que gozó del patrocinio del gobierno de Guzmán Blanco para su formación artística en Francia. Sin embargo, su obra no tuvo gran trascendencia en el País-. De igual modo, encontramos a Andrés Pérez Mujica, quién se halla dentro de la tradición francesa del desnudo femenino. Estudió dibujo, pintura y escultura en la Academia de Bellas Artes de Caracas y completó su formación en París. Pérez Mujica fue perfeccionista en el detalle y en la ejecución técnica. Representó varios temas históricos y literarios con una notable influencia del realismo Francés. Este artista demuestra el gran dominio que posee al ejecutar sus obras conservando impecable el movimiento, tal y como evidenciamos en la obra Bacante (IMAGEN 41). Obra ésta, ganadora del Gran Premio del Salón de los Artistas Franceses, realizado en París en 1921.

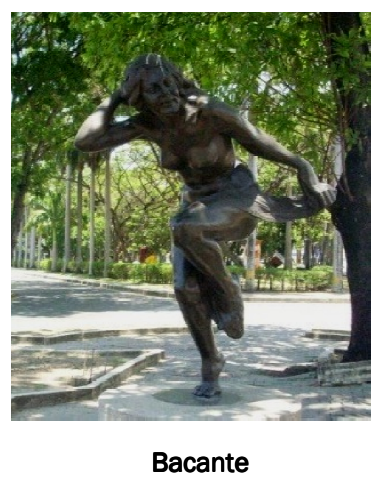

Bacante
IMAGEN 41

Una vez iniciado el proceso de enseñanza de la escultura en el país y al ver los resultados de los discípulos de Palacios, la

45 Ibid. 
pequeña “Escuela de Escultura" se transforma en el año 1877, en el "Instituto de Bellas Artes". En el instituto, suceden intercambios con profesores franceses. Así como también, con artistas criollos formados en las mejores escuelas de París. Es así, como los pocos escultores que hubo en el país desde finales del siglo XIX hasta principios del $X X$, mantuvieron los estilos predominantes en Europa: el Neoclasicismo, el Romanticismo, el Naturalismo y el Realismo.

En el año 1904 el presidente de Venezuela para ese entonces Cipriano Castro, decreta la creación de la "Academia de Bellas Artes", en sustitución del "Instituto de Bellas Artes". Sin embargo, la enseñanza no variaba, se mantenían los cánones clásicos de la escultura y la pintura, la cual no tenía más cabida que la figuración retratista y temas históricos. Es por ello, que comienza a crearse cierto inconformismo en los estudiantes de la academia. Algunos pintores, ya comenzaban a dar muestra de otro tipo de representación. Ellos, enfatizan sobre la valoración de la luz en el paisaje, a través de un manejo especial de la materia y el color. Este nuevo estilo, se alejaba del academicismo reinante en Venezuela y es gracias a ese colectivo, que se instaura el "Círculo de Bellas Artes". Esta congregación, tuvo su origen en la protesta que estalló en el año 1909 contra los métodos de enseñanza aplicados en la Academia de Bellas Artes" por Antonio Herrera Toro -su Director-. Los jóvenes artistas inconformes por el tipo de enseñanza, asomaban cierta influencia de revistas actualizadas de arte parisino que llegaban al país. Conscientes de lo que sucedía en París, solicitaban una renovación en dicha institución. Esa importante agrupación artística estuvo integrada por pintores, periodistas, escritores, poetas, músicos, y otras personas vinculadas al arte; entre los principales personajes que formaron parte de dicho grupo figuran Manuel Cabré, Leoncio Martínez Andrés Eloy Blanco, Rómulo Gallegos y Armando Reverón; siendo este último, de gran significación para la plástica nacional años más adelante.

En términos generales, dicha organización fue un punto de encuentro importante para la proyección renovadora, no sólo de las artes plásticas sino también de la literatura. En sus comienzos, el "Círculo de Bellas Artes" realizó una serie de exposiciones que contribuyeron a la re-valorización del quehacer artístico, puesto que, el arte, no era visto como un oficio serio. Aunque el "Círculo de Bellas Artes" tuvo una vida corta -5 años-, se presume que contribuyó notablemente al redimensionamiento del arte venezolano en todas sus facetas. Entre los beneficios más importantes, destacan el cambio en la "Academia de Bellas Artes de Caracas" hacia su transformación en "Escuela de Artes Plásticas", la creación del "Museo de Bellas Artes de Caracas", pero sobre todo, que de ahí surgió el pintor más importante del 
arte venezolano: Armando Reverón.

Reverón, es uno de los personajes más relevantes y complejos de las artes plásticas venezolanas desde diversos puntos de vista y es también el precursor de la modernidad estética nacional catalogación esta acuñada un siglo después de su natalicio-; pues, sus famosos objetos y muñecas construidas por el mismo fabricados por el mismo para convertirlos en los modelos para sus pinturas, siendo sus muñecas, reconocidas mucho tiempo después como esculturas blandas.

1.3.2 LA ESCULTURA MODERNA EN MANOS DE FRANCISCO NARVÁEZ.

A pesar de toda la revolución cultural-artística que aparentemente generó la creación del "Círculo de Bellas Artes", la enseñanza en la escultura estaba supeditada a los cánones de las fuentes clásicas. Puesto qué, la figuración se anteponía a cualquier otra representación. Cuando el pintor-escultor Francisco Narváez regresa a Venezuela de sus estudios en París en el año 1931, encuentra que, su propuesta artística rompe con los esquemas estéticos vigentes e inclusive, bastante criticado por los academicistas. Sin embargo, esto no le amilanó y le permitió crear por primera vez en el país un lenguaje escultórico propio. Su obra marca una nueva forma de tratar el desnudo en la escultura. La estructuración casi geométrica de la figura humana como forma única; asociada ésta, a las raíces nacionales. Narváez, exalta y valora la belleza de sus elementos étnicos, al margen de lo que para entonces era considerado arte. Tanto por la academia, como por la sociedad venezolana. Así pues, con su obra marca un hito en la escultura.

Según los datos que se indican en su biografía, su aprendizaje inicial se basa en las prácticas del taller de su padre quien era ebanista y alarife en la isla de margarita. Desde los siete años de edad, tallaba con una navaja miniaturas en madera. Estas pequeñas tallas le conducen a un acercamiento con personas importantes de buena apreciación hacia a las artes. Estas personas lo apadrinan y envían a la capital, para que estudie el oficio. Durante varios años ayudó a su padre en los trabajos de reconstrucción y restauración de imágenes de iglesias.

Desde sus inicios, demuestra un gran interés por la figura humana. Comprobamos, que Narváez es atraído por escenas de mercado de Punta Arenas, en Nueva Esparta, con sus pescadores, vendedoras y cargadoras de bultos, cuyas figuras serán recurrentes en su obra posterior.

Estudia en la "Academia de Bellas Artes de Caracas", recibe clases de dibujo, pintura, escultura, paisajes, anatomía y composición, 
finalizando sus estudios en 1928. Lo patrocinan nuevamente, pero ahora hacia Paris, donde estudia en la "Academia de Julián". Allí "establece nexos con el movimiento de Montparnasse que influyen en el léxico creativo de ese entonces: Raoul Dufy; Chaime Soutine y su violencia en las formas; Amadeo Modigliani, en la pureza lineal de sus grandes planos; Moisés Kisling, en la sensualidad de las curvas y de la materia y en la forma de trabajar el objeto para hacerlo atractivo, cálido y humano" 46 .

El estilo de su obra coincide con el contexto conceptual de lo latinoamericano: faenas de trabajo campesino, hombres que toman los frutos de la tierra, mujeres con niños en los brazos, donde el protagonismo del país se asienta en lo popular.

Esto le valió que poco a poco, su obra recibiera el reconocimiento general. Hacia 1932-33, encomendado por el Arquitecto Carlos Raúl Villanueva Director de Edificaciones y Obras de Ornato del Ministerio de Obras Públicas en Venezuela- Narváez realiza el grupo escultórico de la Fuente del Parque Carabobo (IMAGEN 42). Este grupo escultórico, vaciado en piedra artificial, fue su primera obra integrada al urbanismo. Francisco Narváez es el

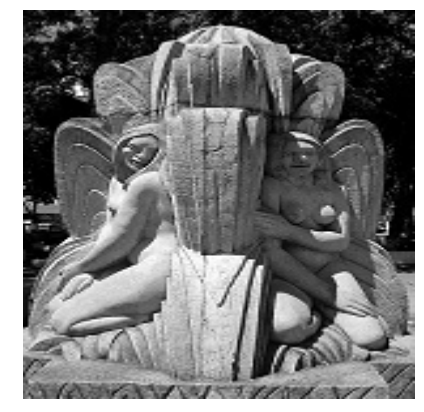

Fuente del Parque Carabobo IMAGEN 42

primer escultor en exponer individualmente en Caracas, así como también, es el pionero en la utilización de la rica variedad de maderas del país: samán, vera, apamate, pardillo, amaranto, cují, caoba, ébano, roble, cedro, guayacán y cartán. El primero también, en hacerlo a gran escala, con las piedras nativas; sobre todo con las de cumarebo y araya.

Puede considerarse que para los años treinta en Venezuela, se encuentra un panorama artístico bien establecido entre: poetas, escritores, pintores y escultores. Éstos, se reunían con frecuencia y confrontaban sus inquietudes artísticas; el taller de Narváez ocasionalmente sirve de punto de encuentro para estas reuniones. El espíritu renovador en las artes, permite que algunas ciudades del interior comiencen a prestar interés en la enseñanza de las artes plásticas y su divulgación. Así pues, se establecen algunos "Talleres Libres de Arte". En tal sentido, podemos afirmar que a partir del año 1936 intermitentemente comienza el arribo de las artes plásticas en Venezuela. Puesto que, dan inicio a la apertura de escuelas especializadas y salones de Arte. Como por ejemplo, ese año, en la ciudad de Barquisimeto se crea la "Escuela de Artes Plásticas Martín Tovar y Tovar"; así como también, la re-

46 Francisco Narváez - Venezuela Tuya www.venezuelatuya.com/.../narvaez.htm

Venezuela 
estructuración de la antigua "Escuela de Artes Plásticas de Caracas", la cual cambia a: "Escuela de Artes Plásticas y Artes Aplicadas de Caracas".

\subsubsection{DEVENIR DE LA ESCULTURA CONTEMPORÁNEA}

VENEZOLANA.

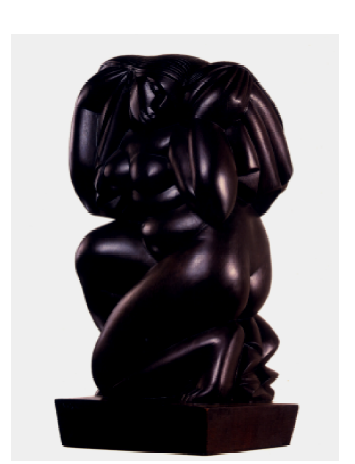

Para el año de 1940 en la ciudad de Caracas se crea el "Salón Oficial Anual de Arte Venezolano" ("SOAAV") en el Museo de Bellas Artes; una obra de la autoría de Narváez es la que obtiene el Premio Nacional de Escultura. Se trata de Figura decorativa (IMAGEN 43), obra ésta, establecida en una talla en caoba teñida, que representa la figura femenina. Se comenta, que esta obra fue muy discutida por el jurado del salón; pues, dicho desnudo, Figura decorativa se alejaba de los cánones clásicos IMAGEN 43 imperantes para ese entonces en el país. Hemos comprobado que, esta obra contribuyó al arribo de la escultura moderna venezolana.

Del mismo modo, su paso por la "Escuela de Artes Plásticas y Artes Aplicadas de Caracas", en su papel de docente y Director, contribuyó también, de manera significativa en las obras de los nuevos artistas. Tal y como afirman, muchos de los artistas formados en esta escuela, fueron los principales promotores en la difusión y promoción de las artes plásticas en Venezuela, pues, fundan nuevas escuelas y talleres de arte. Así como también, en la promoción de salones especializados en esta área, tanto en Caracas como en otras ciudades de Venezuela.

En este sentido, podemos afirmar que en el año 1943 se crea en la ciudad de Valencia "El Salón de Artes Visuales Arturo Michelena". Así como también, en esa misma ciudad dos años más tarde se crea el "Taller de Dibujo y Pintura". Ya, para el año de 1948 este taller se transforma en la "Escuela de Artes Plásticas Arturo Michelena".

Aunque se haya iniciado cierta actividad artística en el país, desde mediados de los años cuarenta el arte en Venezuela comienza a perder fuerzas. Algunos alumnos de la "Escuela de Artes Plásticas de Caracas", comienzan con protestas hacia los dirigentes de los medios expositivos; rechazan los criterios de selección para los salones, así como también, muestran rechazo ante la enseñanza en las artes. Todo este clima, crea ciertas discrepancias entre profesores y alumnos. Hemos comprobado que, existía un único acuerdo estético -exceptuando la obra de Narváez-. 
Como consecuencia de esto, en el año 1945 surge una agrupación llamada "Los Disidentes". Esta agrupación de artistas, se alzan en protesta ante la enseñanza oficial de la "Escuela de Artes Plásticas de Caracas". En las protestas, enfatizan el criterio de los dirigentes de las instituciones como el Museo de Bellas Artes y los procesos de selección de los salones de arte. "Los Disidentes" emigran a París en búsqueda de nuevas vertientes artísticas; centraron su obra en problemas netamente plásticos, donde el color, la luz, la textura, la composición, la construcción de las formas y los materiales, era lo más importante; considerándose esto, lejos del mensaje paisajista o retratista que dominaba en la pintura y escultura venezolana de ese entonces. Entre los artistas -sobre todo, pintores que figuran de esta importante agrupación, encontramos a: Pascual Navarro, Alejandro Otero, Mateo Manaure, Luis Guevara Moreno, Carlos González Bógen, Narciso Debourg, Perán Erminy, Rubén Núñez, Dora Hersen, Aimée Battistini. En París, publicaron varios números de una revista con el nombre "Los Disidentes". Esta agrupación, poco a poco va tomando fuerzas uniéndose otros artistas venezolanos, entre los que figuran: Armando Barrios, Jesús Soto, Omar Carreño, Víctor Valera, Genaro Moreno, Mario Abréu, Régulo Pérez, Mercedes Pardo, Ángel Hurtado, Oswaldo Vigas, César Henríquez, Daniel González, Hugo Baptista y Aglais Olivares. De esta manera, sus integrantes quisieron implantar el arte venezolano, a las tendencias internacionales que fueran más acordes con la época ${ }^{47}$.

Por otro lado, conseguimos que desde el año 1948, el clima político venezolano se encuentra muy tenso, hasta que finalmente en 1952 se pronuncia la Dictadura de Marcos Pérez Jiménez. El impulso en las Artes venezolanas, se ve un tanto desvanecido debido a todo ese clima conflictivo, de censura, de persecución. Sin embargo, los artistas buscan con gran ímpetu ante el público el respeto e importancia a su arte. Estos altibajos hacen eco en los salones de arte. A pesar de toda esa situación de conflictos, no impide el arribo de escultores nacidos y formados profesionalmente en Europa, los cuales de igual modo, dejan gran aporte en la escultura venezolana. Se integran algunos en la docencia, entre los que podemos citar a: Blas Campanella, Doménico Casasanta, Marcel Floris, Ernesto Maragall, Germán Cabrera, Abel Vallmitjana, José Pizzo y Hugo Daini. En su mayoría, se dedicaban a la docencia en la "Escuela de Artes Plásticas y de Artes Aplicadas de Caracas".

A pesar de que "Los Disidentes" se vincularon a las tendencias artísticas parisinas; consiguiendo con ello, grandes logros y aportaciones a sus representaciones artísticas, se mantuvieron

47 Disidentes.Todacultura.com

http://www.todacultura.com/movimientosartisticos/disidentes.htm 
como agrupación hasta el año 1950. De ellos, unos cuantos deciden seguir sus investigaciones en Europa y otros regresan a Venezuela hacia el año 1951. Estos artistas, implementan en sus representaciones esa nueva concepción; logrando con ello, asentar bases sólidas sobre sus planteamientos. De estos nuevos planteamientos, dan como resultado el inicio del movimiento abstracto en el país. Todo ello reactiva -nuevamente- el arribo a las artes, en el año 1955 se crea en la ciudad de Maturín la "Escuela Técnica de Artes Plásticas Eloy Palacios".

Tal y como se ha comentado, con el regreso al país de algunos artistas del grupo "Los Disidentes", la obra de éstos, proyecta un arte renovador; Uno de los primeros casos, es el de Víctor Varela. Cuando Varela regresa a Caracas en el año 1956, inicia las investigaciones sobre una nueva escultura en Venezuela. Según las fuentes citadas se indica que, "comenzó a experimentar en formas ópticas resueltas sobre un plano"48; y se valió del hierro para desarrollar su obra. Se convierte en el pionero en emplear este material en el campo escultórico y es con este material, que se introduce la tendencia abstracta en la escultura venezolana.

Poco a poco otros autores comienzan a darle a este material un papel protagónico ya que, por sus características se adapta a las necesidades del lenguaje abstracto vinculado a la vanguardia; asî pues, la aparición del hierro en salones de arte, trasciende en ingeniosas obras. Este material, consigue nuevos protagonistas; entre ellos, podemos citar a: Carlos González Bógen, Omar Carreño, Gego (Gertrude Goldschmidt), Pedro Briceño. Seguidamente, le suceden Narciso Debourg, Alfredo Maraver y Enrique Sardá. En el año 1957 la "Escuela de Artes Plásticas y Artes Aplicadas de Caracas" cambia de nombre a "Escuela de Artes Plásticas y Aplicadas Cristóbal Rojas".

Ya para mediados de los años cincuenta, la pintura se debatía entre los dictados del arte abstracto y cualquier otra forma de representación, -sea el paisaje o el realismo figurativo-. Sin embargo, nace otra posibilidad artística la cual denominaron como el "Realismo Mágico". Centraron en sus propuestas, la alteración de la realidad y la iluminación inhabitual. Esta representación surge, en oposición a la abstracción geométrica y a los lineamientos fieles del realismo de la figuración. En tal sentido, podemos considerar que sus autores trataron de expresar la vitalidad que representa un color o una textura, y no, lo que la figura pueda representar. Los artistas que mayor aporte dieron a esta tendencia en la pintura fueron: Mario Abréu, Oswaldo Vigas y Manuel Quintana Castillo. Es a través de esta tendencia que puede

48 Colección de Arte. Víctor Varela.

http://www.bcv.org.ve/BLANKSITE/c3/colecarte/valera_index.htm 
juzgarse como un puente que une la pintura con la escultura; puesto que, sus pigmentos necesitaban ser portadores de expresión. Por ello, los intervenían mezclando y/o yuxtaponiendo algún material o algún tipo de elemento para conseguir con ello mayor expresión.

A pesar de los cambios que se perciben en la escultura en los años cincuenta, da la impresión que sus creadores no logran concretar en sus propuestas planteamientos serios, pues, se produce un declive en estas artes. Prueba de ello, es que en el "Salón Oficial Anual de Arte Venezolano" de los años 1956, 1959 y 1960, el Premio Nacional de Escultura fue declarado desierto.

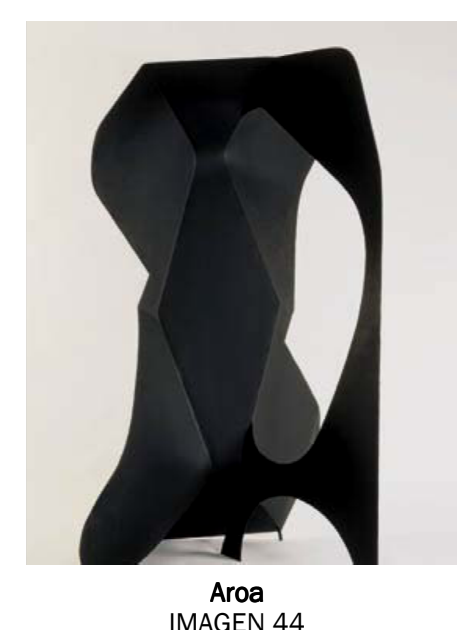

El año 1958, es de particular significación en la historia-socialcultural del país; puesto que, se derrumba la dictadura de Marcos Pérez Jiménez. A consecuencia de esto, el país comienza a respirar algunos cambios, de los cuales no escapa el ámbito artístico; pues, esta situación pudo sentirse a escasos meses en el "SOAAV" donde se encontraba una diversidad en tendencias, estilos, formatos $y$ materiales. En el "SOAAV" del año 1958, se ponía en popularidad las novedosas investigaciones en la abstracción geométrica. Prueba de ello, es Aroa (IMAGEN 44) la obra ganadora del Premio Oficial de Escultura del artista Víctor Varela cual se instituye, en una enorme estructura en hierro laqueada en color negro mate. El vacío descollante se apoya en la morfología de los recortes de esta lámina. De esta zigzagueante lámina, emergen formas en positivo y negativo que evidencian argumentos del arte abstracto. Esta ingeniosa obra, queda consagrada con el reconocimiento oficial del abstraccionismo geométrico. El escultor Valera, es el pionero en la utilización del hierro en la escultura venezolana y hoy en día es considerado el precursor del Arte Contemporáneo venezolano.

Es importante mencionar que, para ese mismo año se crean en algunas ciudades de Venezuela, centros de enseñanza de artes plásticas. Por un lado, tenemos en la Isla de Margarita la "Escuela de Artes Plásticas Armando Reverón"; en la ciudad de Yaracuy, se crea la "Escuela de Artes Plásticas y Artes Aplicadas Carmelo Fernández", y en la ciudad de Mérida, se crea los talleres libres de arte. Siendo este último, constituido en el año 1962 en "Centro Experimental de Arte". Ahora bien, puede afirmarse, que con la obra de los pintores-escultores del abstraccionismo geométrico de 
finales de los años cincuenta, es cuando arranca definitivamente el movimiento de la escultura contemporánea en Venezuela.

Pese a todo esto, aunque se haya reiniciado la actividad expositiva con el "SOAAV" el ámbito artístico venezolano tiene poca relevancia. Tan cierto es esto, que el arquitecto Carlos Raúl Villanueva, siendo Director de Edificaciones y Obras de Ornato del Ministerio de Obras Públicas y Catedrático de la Facultad de Arquitectura de la Universidad Central de Venezuela, "conmovido por esta situación, toma la decisión de hacer del Campus Universitario, un museo al aire libre, bajo el concepto, de que el arte debe cumplir una función social"49.

Según otras fuentes citadas 50 , a este proyecto se le denomina "Síntesis de las Artes Mayores, de la Ciudad Universitaria de Caracas". Para llevarlo a cabo, el arquitecto Villanueva decide incluir obras artísticas de vanguardia parisina como son las de: Antoine Pevsner, Jean (Hans) Arp, Baltazar Lobo, Alexander Calder y Henri Laurens, quienes a principio de los años 50 ya eran celebridades en el mundo del arte. Sumado a las obras de estos artistas, participan otras importantes celebridades extranjeras tales como: Víctor Vasarely, Sophie Taewber-Arp, Fernand Léger, André Bloc, Wilfredo Lam. Así como también los artistas venezolanos: Francisco Narváez, Armando Barrios, Oswaldo Vigas, Mateo Manaure, Pedro León Castro, Héctor Poléo, Pascual Navarro, Carlos González Bógen, Braulio Salazar, Alejandro Otero, Víctor Valera, Miguel Arroyo, Alirio Oramas y Omar Carreño.

En tal sentido, reseñaremos brevemente sobre algunas de las obras que formaron parte del importante proyecto.

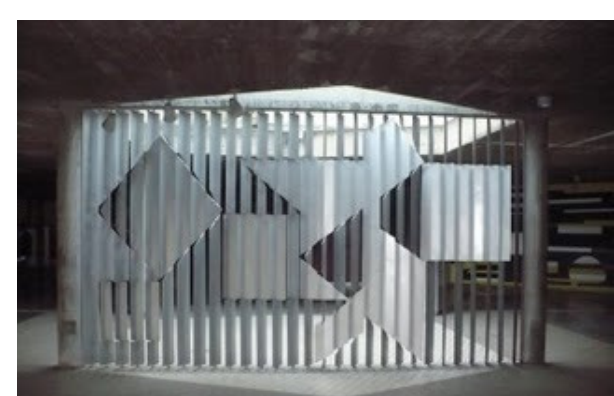

En la plaza cubierta, irrumpe un destello de luz natural a través de una abertura hexagonal del techo. En ese espacio, se integra un elemento mural en aluminio llamado: Positivo-Negativo (IMAGEN 45) del artista húngaro Positivo-Negativo

geométricos: el rombo, triángulo y cuadrado, son conseguidos por medio de láminas verticales; lo que supone, una obra de acción cinética, típica de la autoría de Vasarely.

49 Palenzuela, C. (2007). Material inédito. En prensa. p: 49.

50 Ciudad Universitaria de Caracas, su máxima obra. Colección Síntesis de las Artes. http://www.centenariovillanueva.web.ve/CUC/Sintesis Artes/Frames Sintesis Artes.htm 
La obra Maternidad (IMAGEN 46) del artista español Baltasar Lobo, pernocta sobre un pedestal hexagonal de cemento pulido. Los jardines de la ciudad universitaria - parte trasera de la sala de conciertos- se enaltecen con imponentes esculturas como esta. Lobo, personifica en este volumen curvilíneo, a una madre jugando con su hijo. El vaciado en bronce, ostenta cierto carácter arcaico recurrente en sus composiciones. El

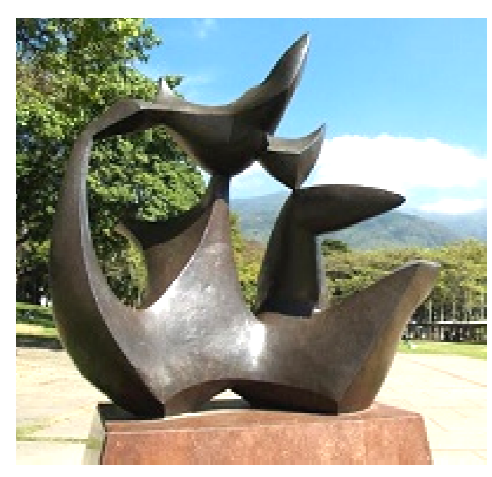

Maternidad

efusivo modelado, aparentemente muestra a la mujer con sus poses particulares, propias del gesto creador de este artista.

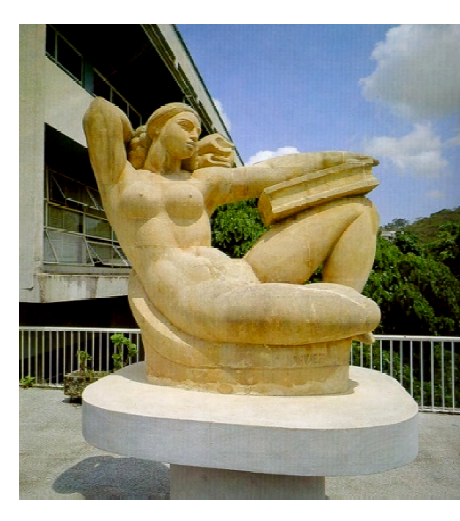

La educación

Sin duda, no podemos dejar de mostrar la escultura del venezolano Francisco Narváez. Quien, es el precursor del arte moderno

venezolano. La educación (IMAGEN 47) es una fascinante talla directa en piedra de Cumarebo, ubicada en la terraza del Instituto de Medicina Experimental. El voluminoso cuerpo femenino, yace plácidamente en una posición descanso con un libro sobre su pierna, que demuestra la destreza del autor en tallar esta materia tan particular; pues, la textura dejada en

su superficie deja en evidencia la porosidad de esta fascinante piedra. Su estilo característico, sintetiza las formas del cuerpo humano en espectaculares volúmenes con gran carga emotiva.

Entre las obras cinéticas emplazadas en la ciudad universitaria, no podía faltar Escultura Cinética (IMAGEN 48) del artista venezolano Jesús Soto. Entre el vestíbulo y uno de los jardines internos, se encuentra esta fascinante obra en hierro laqueado en azul, blanco y negro. Se trata de una obra fundamentada en la figura del cubo, elaborada en su totalidad con varillas lisas redondas de hierro, soldadas simétricamente con la intersección de varillas en otros ángulos. Su emplazamiento sobre

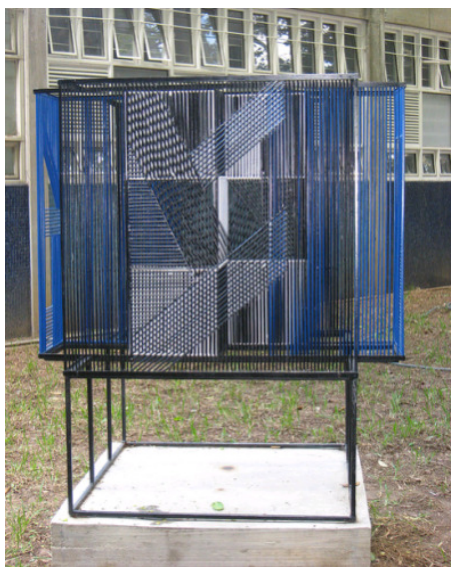

Escultura Cinética 
una estructura en varilla cuadrada de forma sencilla y abierta, permite que la obra se vea suspendida. La multiplicidad de lecturas de esta escultura cinética, tiene que ver con el movimiento del espectador alrededor de la obra. Siendo esto, indispensable para interactuar con la misma. Basándose en este aspecto fundamental y recurrente en su obra, Soto logra enormes y fascinantes estructuras lineales suspendidas emplazadas en distintos lugares tanto en el país, como fuera de Venezuela.

Finalmente,

comentaremos sobre la

gran obra Nubes

Acústicas (IMAGEN 49)

del

artista

norteamericano

Alexander Calder. Se trata

de estructuras fijas en el

techo del aula magna de

dicho recinto

universitario. Este recinto

universitario quedó

catalogado en la década

de los ochenta como una

de las cinco salas con

mejor acústica y

visibilidad de todo el

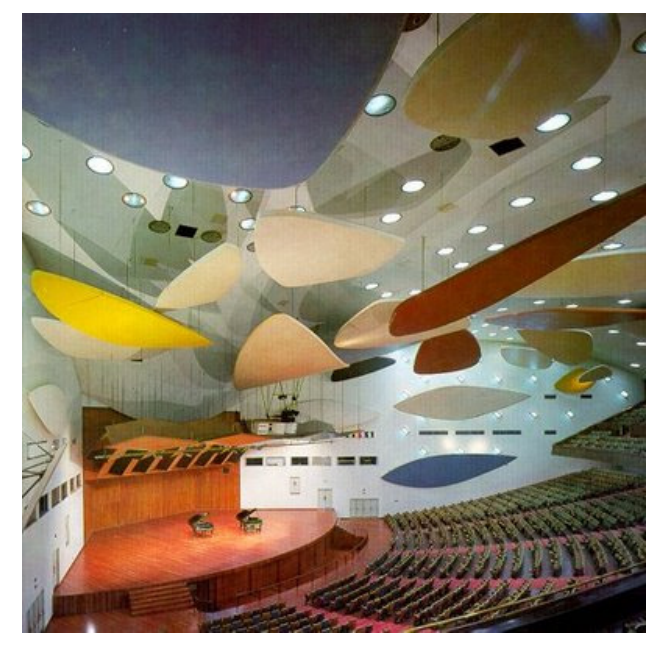

Nubes Acústicas

IMAGEN 49

mundo. Se trata de paneles reflejantes de sonido, que se instituyen en 22 planchas de madera contra-enchapada sobre armazón de acero. Las formas biomorficas dispuestas en el techo del auditorio, no sólo imprime dinamismo y color a la misma. Puesto que, la acústica impecable del recinto se debe a la disposición de las mismas y su disposición en el espacio; pues, esto permite la vibración adecuada del sonido e indudablemente, la armonía de sus colores y la adecuada luminosidad entre ellas, aporta mayor espacialidad y modernidad.

Las obras emplazadas en la Ciudad Universitaria de Caracas varían entre: cerámica-mural, ensamblajes, esculturas, estructuras tridimensionales, mobiliario arquitectónico, mosaico-mural, pintura y vitral. Así como también, las diversas tendencias de la abstracción-geométrica, constructivismo, surrealismo y figurativismo; contabilizadas en un total de 107 obras de 24 artistas -10 extranjeros y 14 nacionales-.

Otro caso particular en las artes venezolanas de finales de la década de los cincuenta, tiene que ver con Miguel Arroyo. Arroyo, quien recientemente como Director del Museo de Bellas Artes de Caracas, bajo la misma motivación que Villanueva, se impone la labor de impulsar el conocimiento y disfrute del arte en el país; 
dentro de ese contexto, se presenta una importante actividad donde exponen las obras de artistas reconocidos a nivel internacional como: Alexander Calder, Baltazar Lobo, Jesús Soto, Bárbara Hepwort, Lipchitz, Henry Moore, Armitage. De igual modo, este clima renovador en las artes, generó la apertura de otras sedes para exposiciones como la "Sala Mendoza", quien, se dio a la tarea de exhibir obras originales de artistas importantes como: Nevelson, Rodín, Zadkine, Gargallo y Marini. Así como también, la promoción de artistas nacionales. Algunas obras de estos artistas forman parte de la colección del Museo de Bellas Artes.

Puede afirmarse, que debido a esta motivación el arte en Venezuela tomó un nuevo impulso. Logrando con ello, mayor capacitación para los artistas. Así como también, la difusión y promoción de las obras de los artistas. Y lo más importante, es que con ello, se logra crear conciencia de que el arte cumple una función dentro de la sociedad.

La presencia de estos importantes artistas, en la exposición del Museo de Bellas Artes, así como también en nuevos espacios expositivos, dio lugar a la realización de talleres especializados. Tal es el caso de la técnica del vaciado en bronce. Los jóvenes artistas venezolanos se sintieron motivados por este procedimiento escultórico, ya que hasta ese entonces dicha técnica se hacia fuera del país. El "SOAAV" apoyó el lanzamiento de los artistas que se iniciaban en esta técnica. Entre ellos: Harry Abend, Maximiliano (Max) Pedemonte, Carlos Prada, Elsa Gramcko y Edgard Guinand.

El respaldo que los medios expositivos le dieron a esta técnica, ayudó a su instalación definitiva en los procedimientos más frecuentes de la escultura venezolana logrando la apertura del Taller de Fundición de Blas Campanella. Las representaciones figurativas y las abstractas con tendencias orgánicas fueron las más favorecidas por este material. Estos artistas vinieron a sumarse al grupo de maestros venezolanos 0 extranjeros residentes que empleaban constantemente el bronce en sus obras tales como: Francisco Narváez, Alejandro Colina, Ernesto Maragall, Martín Funes, Cornelis Zitman, José Pizzo, Juan Jaén, Hugo Daini, Manuel De la Fuente, Biagio Campanella y Pedro Briceño; La gran mayoría tuvieron en Blas Campanella, un apoyo importante con los servicios del mejor fundidor del país.

A fines de 1959 el abstraccionismo geométrico daba signos de cansancio y agotamiento. Podemos considerar, como poco a poco se van sumando ante el medio expositivo nuevos materiales. Sus creadores se atreven más y buscan mayor formato. Tan cierto es este planteamiento que, "en el año 1959 en el "Salón Arturo Michelena” por primera vez, son aceptadas obras en cerámica, 
esmalte y porcelana"51. Pues, las obras creadas en estos materiales, comienzan a generar vías alternativas, desvirtuando el objeto utilitario para generar un objeto escultórico.

\subsubsection{NUEVAS VERTIENTES PARA LA ESCULTURA VENEZOLANA.}

A principios de los años sesenta a través del "SOAAV", comienzan a aparecer una generación de escultores formados y egresados de los talleres, de la "Escuela de Artes Plásticas y Artes Aplicadas de Caracas"; así como también, de los talleres libres de arte de la Facultad de Arquitectura de la Universidad Central de Venezuela. Esta nueva generación, se considera que viene con una formación sólida y un proceso de investigación convincente lo cual repercute en excelentes planteamientos artísticos. Entre los máximos representantes que figuran en ese entonces podemos citar a: Harry Abend, Pedro Barreto, Edgar Guinand, Max Pedemonte, Lía Bermúdez y Jesús Soto.

Las artes venezolanas, se encuentran en un panorama fructífero y una diversidad bien representativa. Tan cierto es esto, que en el año 1961, nace el "Salón Nacional de Arte de Aragua" ("Salón Aragua") en la ciudad de Maracay, siendo en su primera edición, el ganador del Primer Premio en escultura Eduardo Gregorio. Poco a poco, se suman otros salones tales como: el "Salón D'Empire" en la ciudad de Maracaibo y el "Salón Julio T. Arze" en la ciudad de Barquisimeto; esto demuestra, que las artes venezolanas contaban con un escenario importante para la difusión y promoción de los nuevos talentos y el de los artistas ya establecidos.

En el año 1964 en la ciudad de Caracas y en la de Maracaibo, simultáneamente- se organizan nuevos grupos de artistas visuales con tendencias abstracto-expresionistas; cuya intención, era imponer un nuevo estilo. Pretendían socavar sobre la tendencia del abstraccionismo geométrico que imperaba desde hacía ya una década.

Aparentemente, estos artistas marcaron un estilo sin precedentes 52 ; ensayaron llevar la libertad de la materia y la acción creadora, al volumen. Sus representaciones, proponían demostrar la importancia de cualquier materia como medio de expresión y no estaban concebidas como un arte perdurable hecho para los museos. Lo visceral y existencial se enfrenta a lo formal y a lo bello. Para ello, integraron objetos de desecho; utilizaron

51 Palenzuela, C. (2007). Material inédito. En prensa. p: 49

52 Action Painting. Movimientos y Estilos. Más de arte.com.

http://www.masdearte.com/item_movimientos.cfm?noticiaid $=3382$ 
materiales industriales, como las lacas empleadas en el acabado automotriz. Todo ello, bajo la poética de lo arruinado -el arte pobre-. Emplearon materiales y técnicas según los métodos de la action painting norteamericana, se difundió la técnica del norteamericano Jackson Pollock -dripping-, que consistía en hacer chorrear desde cierta altura el pote de pintura industrial sobre un lienzo acostado en el piso. Con ello, se crea la técnica gestualista con el empleo de grandes lienzos/papeles como soporte53.

En ese año se crea en la ciudad de Maracaibo el "Salón Espacios Vivientes". En dicho salón, se mantiene como constante lo experimental, lo inaudito, lo espacial, las ambientaciones, las grandes escalas, la desaparición del pedestal y la participación del espectador; siendo el escultor Jesús Soto el que mayor aporte logra con su obra cinética; quien pone en evidencia su investigación sobre la fenomenología del color y sus efectos ópticos. Se percibe el interés por el movimiento real o virtual, al igual que su preocupación central que refiere al movimiento. Los artistas de esta época reducen su lenguaje a través de la abstracción y lo conceptual; comienzan a centrarse en la investigación sobre el tipo de materiales y lo que ellos pudieran transmitir. "Entre los principales artistas propulsores de esta nueva tendencia artística se encuentran: Alberto Brandt, Fernando Irazábal, Daniel González, Mercedes Pardo, Granado, Valdés, Maruja Rolando, Mary Brandt, Alcídes López Crihuela, Manuel Finol, J. M. Cruxent, Víctor Varela, Harry Abend, Elsa Gramcko, Pedro Briceño, Mario Abreu, Gabriel Morera, Carlos Contramaestre y por supuesto Jesús Soto" 54 .

Puede considerarse, que el "Salón Espacios Vivientes" dio origen al movimiento conocido con el nombre de los "Informalistas"; el cual se definió, por la expresividad de la propia materia, su rudeza, su pobreza, el óxido, la textura Un año después en la "Sala Mendoza" en Caracas, se realizó el "Salón Experimental" como respaldo a esta nueva tendencia. El movimiento duró poco más de diez años. Y hasta ahora, no se ha consumado en el país otro movimiento artístico que se haya mantenido sólido como éste.

A contracorriente de las tendencias que se llevaban a finales de los sesenta donde, se giraba en torno a las representaciones gestualistas, cinéticas y constructivistas, conseguimos un grupo de artistas que centran su arte en el valor del arte figurativo como ente representativo.

53 Informalistas y Gestualistas en el Arte venezolano de hoy. (2009) http://www.latinartmuseum.com/arte_venezolano.htm

54 Perán, E. (1981). “Primera Bienal Nacional de Escultura”. La escultura en Venezuela. Material inédito. Museo de Arte Contemporáneo Francisco Narváez. Catálogo. s/n. 


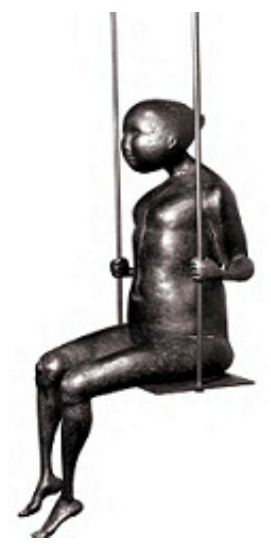

Columpio Entre éstos destaca, la obra de Cornelis Zitman.
Sus primeras obras fueron en yeso, pero rápidamente se introduce en el vaciado en bronce. En el año 1967 elabora la obra Columpio (IMAGEN 50) en bronce patinado, en esta sugestiva escultura, Zitman expresa con notoriedad que sus personajes muestren su amorfa condición, con verdadera crudeza. En ellos, se resalta la miseria, la tragedia, soledad, con lo cual añade objetos sacados de contexto, -con apariencia malograda- como por ejemplo: hamacas, camas, mesas, columpios y con ellos, crear una obra muy emotiva debido a la crudeza con que resalta tel cuerpo

Otra importante figura que surge a finales del período de los años sesenta es Gertrud Goldschmidt (Gego). Según las fuentes citadas 55 , esta artista quien procede de la arquitectura, inicia sus prácticas en el arte con fuerte evidencia de su experiencia. Su obra se fundamenta en la línea como representación. Éstas, se interceptan y generan una cuadrícula,

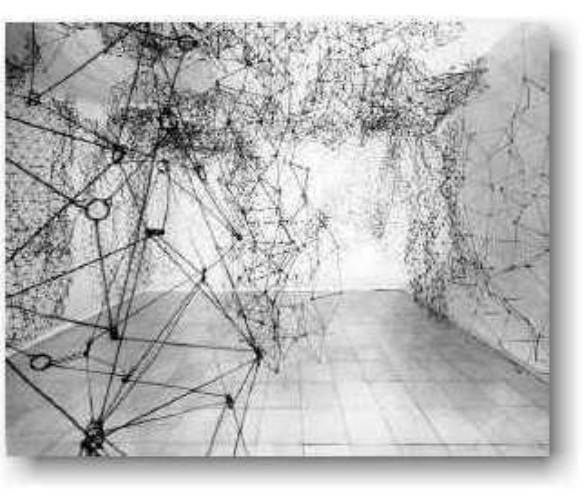
Reticulárea

utilizando como soporte la pared y suelo para integrarse en el espacio urbano. Estas cuadrículas parten de la unión del la forma del rectángulo, representan cierta cualidad, donde lo amontonado de sus líneas, la libertad en sus trazos, y la suspensión de la estructura convierten su obra en una especie de dibujo sin papel que Ilenan toda una habitación cuando se exhiben. Reticulárea (IMAGEN 51), es una clara evidencia de sus esculturas. En ella, los alambres se organizan y dan movimiento al espacio a la vez que definen y enmarcan el vacío.

Para 1969, en el "SOAAV" ingresan nuevos talentos como Doménico Casasanta, Marcel Floris, Carlos Prada, Elsa Gramcko, y Gego. Pero ocurre algo inesperado con el veredicto de la obra que obtiene el Gran Premio. Según Palenzuela56, la obra ganadora del Premio Nacional de Escultura del escultor Marcel Florís; generó muchas polémicas y fue lo que repercutió en que no hubiese

${ }^{55}$ Obra_Plastica_GEGOFundacion Gego.www.fundaciongego.com/tejeduras.html

56 Palenzuela, J. (2002). “Escultura en Venezuela 1960-2002”. p: 63. 


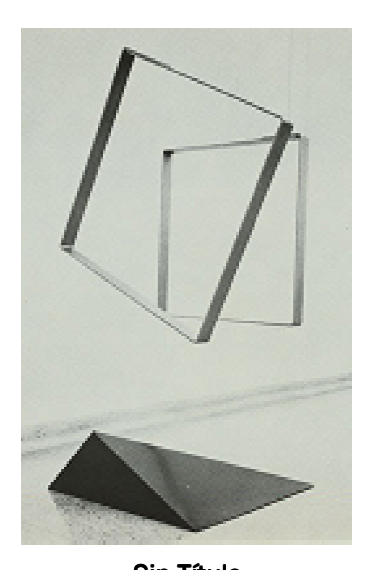

Sin Título

La obra Sin Título (IMAGEN 52) de Florís, se fundamenta en dos marcos cuadrados de mediano formato en pletina de hierro recubiertos de fórmica blanca, los cuales se encuentran suspendidos; uno de ellos, se ubica totalmente lineal con respecto al plano horizontal que lo separa del piso. El otro cuadrado, se desfasa creando una sensación de movimiento. Su base cuadrada de hierro laqueado en negro, se proyecta desde el suelo -visualmente- hacia

la forma en suspensión. Si bien es cierto que es una obra peculiar, pero desde el punto de vista plástico consideramos que es válido; puesto que, se establece bajo un concepto minimalista con bases sólidas sobre un arte conceptual.

Precisamente, a finales de la década de los sesenta, la escultura venezolana se definió por la presencia del objeto como representación del volumen. La tendencia de los ensamblajes concebidos como arte participativo en diversas tendencias como las abstractas, geométricas, cinéticas o neo - constructivistas se mantienen como constante. Se establecen las primeras esculturas minimalistas y es a Harry Abend a quien se le atribuye ser el precursor de la tendencia del minimalismo en nuestro país. Del mismo modo, conseguimos que para esa misma época se introduzca el hierro cromado como material innovador para el desarrollo escultórico.

Entre los artistas que destacan en esta nueva concepción encontramos a: Omar Carreño, Gabriel Marcos, Ramos Giugni y Rubén Márquez. Nace la década de los años setenta, y con él un destino un poco incierto para las artes, a consecuencia del colapso del "Salón Oficial Anual de Arte Venezolano". El "Salón Michelena" y el "Salón Aragua" son los únicos que se mantienen para ese entonces como entidad para la confrontación de las artes en el país. Sin embargo, este escenario resulta oportuno para un colectivo de artistas ceramistas; los propios representantes de las Artes del Fuego, tendrían que iniciar los cambios en cuanto a difusión y promoción de sus representaciones. Así pues, en el año 1971 este grupo, gestiona la realización de un Salón Nacional de Cerámica como ente autónomo. Entre Humberto Jaimes Sánchez, Julio Ferrer Gudiño, Mérida Ochoa, Mercedes González, María Oria y Alicia Benamú, presentan su proyecto ante el Instituto Nacional de Cultura y Bellas Artes. Para ese momento, el instituto contaba con el artista plástico Oswaldo Vigas, como su Director. Vigas 
quien fuera uno de los miembros de los "Disidentes", considera impostergable la necesidad de crear un salón dedicado a las representaciones de las artes del fuego. De esta manera, nace en la ciudad de Valencia el "Salón Nacional de las Artes del Fuego". Siendo el ganador del Premio Nacional de las Artes del Fuego en la tendencia de Cerámica, Colette Delozanne con la obra: Habito un lugar indeciso (Homenaje a Trudi Eberstadt) (IMAGEN 53). En ella, podemos evidenciar cómo la cerámica se desvincula de las típicas piezas del uso diario en las cocinas y manifiesta su influencia de la escultura; esta nueva

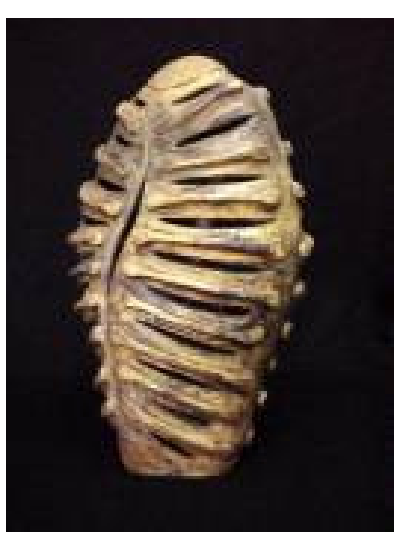

Habito un lugar indeciso (Homenaje a Trudi Eberstadt) IMAGEN 53

fisionomía en la cerámica, se introduce en el campo expositivo en grandes formatos con una tendencia innovadora.

En el año 1972, sucede otro evento importante para el desarrollo y nueva concepción del arte venezolano. Antonieta Sosa, Pedro Terán y Diego Barbosa, fueron los pioneros en utilizar otros recursos como medio expresivo; su propio cuerpo se utiliza como elemento-objeto- de arte. Estos artistas venezolanos, formados y recién llegados del extranjero, introdujeron en el campo expositivo el Arte Corporal, desde los parámetros de lo pictórico. Sin embargo, rápidamente cobra nuevos protagonistas instituyéndose finalmente en ambientaciones y performance. "La Galería de Arte Nacional y la Sala Mendoza" -ambas en la ciudad de Caracaspermitieron dar a conocer esta nueva tendencia en sus espacios. Así pues, introducen un lenguaje plástico no convencional, pues, integran al espectador en sus propuestas. En tal sentido, podemos considerar que el espectador cumple el rol de testigo/juez, donde el uso de todos los sentidos incide radicalmente en la concepción de la obra. Los nombres de: Roberto Obregón, Eugenio Espinoza, Carlos Castillo, Carlos Zerpa, Milton Becerra, Luis Villamizar, Ángel Vivas Arias, Alfredo Wenemoser, la pareja Yeni y Nan, Domingo Álvarez, Ana María Mazzei, María Zabala, Claudio Perna, Víctor Lucena y Miguel Von Dángel; todos ellos, con diferentes connotaciones mantuvieron la particularidad de hacer reaccionar al público permitiendo y consiguiendo, la participación del espectador en sus propuestas. En definitiva esta nueva práctica en el arte queda instaurada como el "Performance", siendo Carlos Zerpa su máximo representante.

Esta década, cobra en las representaciones artísticas gran diversidad de lenguajes y por ende gran cantidad de autores que las ejecutan. Alguno de ellos, irrumpen con una manera diferente de hacer el arte, las representaciones de índole conceptual toman 
gran valor. Muchos artistas se desinteresan por las galerías y los centros de arte, pues, llevan sus propuestas a la calle. Establecen un diálogo directo con el espectador, obviando el espacio físico de la habitual sala de exposición. Con ello, se pretende lograr una verdadera comunicación entre el arte y el público. Sus creadores desarrollan experiencias participativas al aire libre, con propuestas escultóricas e instalaciones que implican la participación del público. Claudio Perna, Valerie Brathwaite, Pedro Terán, María Zabala, Diego Barboza, William Stone, Víctor Lucena, Héctor Fuenmayor y Eugenio Espinoza, fueron los pioneros con estas nuevas experiencias artísticas. Dentro de esta nueva tendencia se abordan estéticas que van desde la renovación de las propuestas tradicionales, hasta las experimentaciones de índole conceptual.

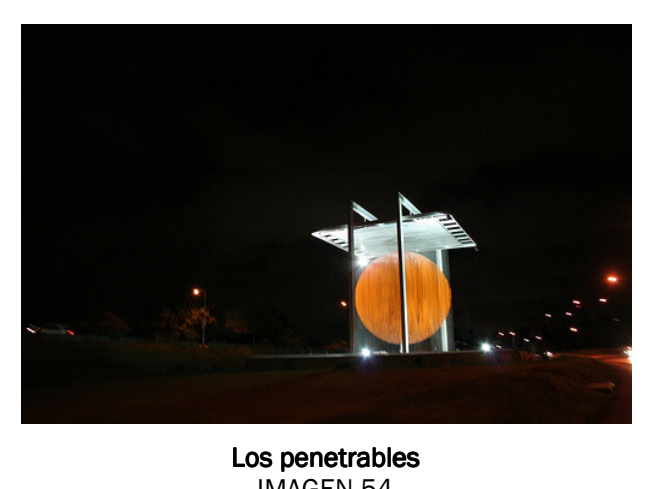

El artista Jesús Soto llegó a incorporar dentro de su arte ciertos conceptos como el tiempo, la distancia y al hombre como factor indispensable para su lenguaje plástico. La obra Los penetrables (IMAGEN 54), es uno de sus logros más rotundos; puesto que, se emplaza IMAGEN 54 primero en París (1967)

Ámsterdam (1968), y luego en Caracas (1971). En esta monumental obra, el artista utiliza un solo material y muy ligero. Las enormes y delicadas tiras de plexiglás, aparentan flotar en el espacio, entre ellas, se pronuncia una noción de infinito ${ }^{57}$.

Esta imponente obra yace imperturbable en un lado de la autopista Francisco Fajardo en la ciudad de Caracas.

Consideramos que la mejor hora para contemplarla es durante la noche, puesto que, la disposición del enorme círculo naranja colgante, se vea en levitación con un impresionante destello de luz que lo envuelve.

A partir de los años setenta, los escultores venezolanos incorporan grandes formatos, escalas monumentales y sus obras alcanzan otras latitudes. En el año 1973 se crea el "Museo de Arte Moderno Jesús Soto" y en el año 1986 se instaura la "Bienal Nacional de Arte de Guayana", siendo el ganador del Gran Premio en esa primera edición, Carlos Medina. En el año 1979 se crea en la ciudad de Caracas, la "Asociación Venezolana de las Artes del Fuego"; cuya asociación civil sin fines de lucro, se encarga de

57 Jesús Rafael Soto. Wikipedia. La enciclopedia libre.

http://es.wikipedia.org/wiki/Jes\%C3\%BAs Soto 
divulgar e impulsar el desarrollo de las disciplinas que la componen: la cerámica, el vidrio, el esmalte sobre metal y la orfebrería y su función es salvaguardar las tendencias que lo componen, incentivando, formando y especializando a los artistas sobre todo durante la celebración del "Salón Nacional de las Artes del Fuego".

Comienza la década de los años ochenta y las artes aprovechan un impulso enorme, no sólo por la fructífera economía que fluye a causa del -boom- petrolero venezolano, donde una gran cantidad de compañías trasnacionales instituyen sus empresas en el país. Esto conlleva a un intercambio social-cultura-económico que por supuesto repercute en la sociedad venezolana.

En esa década de los ochenta, encontramos a Francisco Narváez, quien se relaciona con una nueva concepción de la escultura. Se hace palpable, la síntesis de las formas en su obra y se instituye en enormes bloques tallados en piedra y muchos de ellos, posteriormente vaciados en bronce.

En la obra Gran Volumen (IMAGEN 55) la discrepancia entre texturas evidencia cómo depura su lenguaje al máximo. La contundente forma a pesar de estar abierta por su centro mantiene la fuerza del volumen macizo de la piedra. En el año 1981 se inaugura en la ciudad de Porlamar el "Museo de Arte Contemporáneo Francisco Narváez" y al año siguiente se instaura la "Bienal de Escultura

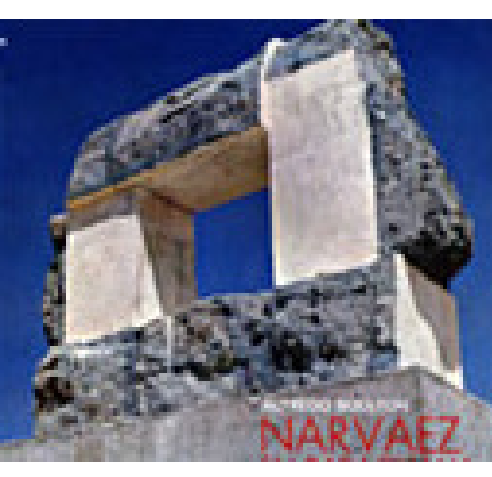
Gran Volumen
IMAGEN 55

Francisco Narváez", siendo el ganador del Gran Premio de esa primera edición, el artista Víctor Valera.

A principios de la década de los ochenta entra en boga una nueva corriente artística. Se trata del uso del cuerpo humano como objeto-arte, se le conoce oficialmente como Arte No Convencional. Desde entonces, un amplio grupo de creadores se mueve dentro de esta variante del arte; se destacaron en esta tendencia una cantidad considerable, de artistas. Entre los nombres que más se escuchaban eran el de Roberto Obregón, Antonieta Sosa, Alfred Wenemoser, Marco Antonio Ettedgui, Pedro Terán, Luis Astorga, entre otros. Sin embargo, a mediados de los años ochenta, esta nueva tendencia se interrumpe por diversas causas. Ya, este tipo de arte no tenía la misma fuerza ni la misma continuidad, excepto un pequeño grupo de artistas que se mantuvo firme a esos principios. Hemos comprobado que, Pedro Terán es el 
representante más significativo de esa tendencia. Sin embargo, encontramos a otro artista que dio mucho de qué hablar en este ámbito artístico.

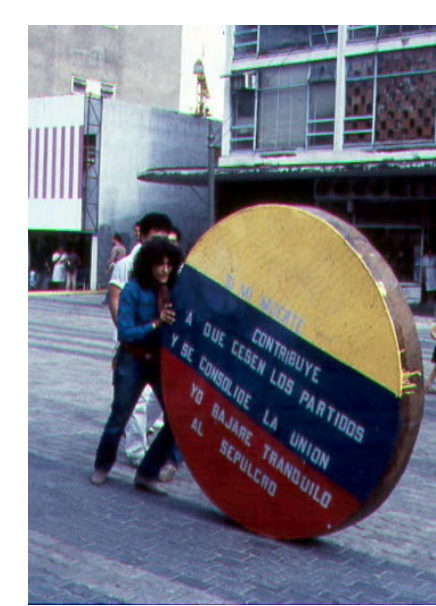

Se trata de Juan Loyola, quien se apropia de algunos espacios públicos para mostrar su arte, renunciando categóricamente a exponer en galerías, museos, en salones, así como también, a los críticos de arte, es que decide llevar su arte a la calle. Su obsesión por la bandera venezolana (como objeto de arte), transformaba su obra en permanente protesta ante la indiferencia del pueblo. Loyola protagonizó en los 80 diversos encontronazos con la policía por causa

Detalle de Loyola en plena acción del performance.

de su arte - por usar los colores patrios que para ese entonces, estaba prohibido con esos fines-. Su inclinación a la tendencia del

(performance) y el videoarte le permiten invadir las calles con sus propuestas. La (IMAGEN 56) S/T es uno de sus peculiares y memorables performances con la que obtiene el Premio Nacional, con la mención de Arte No Convencional en el "Salón Michelena" en el año 1983. Hemos comprobado que ${ }^{58}$, luego de haber rodado por las calles de Caracas una gigantesca moneda pintada con los colores patrios aludiendo al bolívar -moneda venezolana-, llena de chatarra ruidosa, que llamaba la atención del público-. Moneda está, llevaba escrito sobre sus franjas esta frase: "Si mi muerte, contribuye a que cesen los partidos y se consolide la unión, yo bajaré tranquilo al sepulcro" (Detalle de Loyola en plena acción del performance IMAGEN 56). Loyola se traslada hacia la población de la Guaira, continuando su performance e irrumpe con su arte en la inauguración del II "Salón Jóvenes artistas", encontrándose presente el Presidente de Venezuela de ese entonces, -Luis Herrera Campins- así como otros altos personeros del gobierno y las instituciones oficiales. En su actuación el artista Loyola y su agrupación, comenzaron a arrojar en el suelo, monedas venezolanas por donde rodaba la enorme moneda, a su vez, arrojaron bolsas llenas de pintura del tricolor, -aludiendo a la bandera nacional- en una de las paredes del recinto y luego Juan Loyola comenzó a escribir con espray sobre esta pared manchada, unas consignas de protesta. Obviamente, esta manifestación artística, deja perplejos a los personeros del gobierno y funcionarios, siendo apresado por la policía; éste, y muchos otros

58 El Arte de Juan Loyola. (2009) elartedejuanloyola.blogspot.com/ [Accesado en: Diciembre 13 2011]. 
performances, le privan de su libertad. Su particular manera de hacer arte, trascendió con gran significación en números salones entre Venezuela, Ecuador, Paraguay, Argentina, Puerto Rico, Brasil, Londres, Italia, Bruselas, Grecia, Francia, Alemania, obteniendo en alguno de ellos grandes premios.

Durante la misma década de los ochenta, toma un nuevo impulso el dibujo y la pintura. Los artistas vinculan sus propuestas plásticas al lenguaje Neo - Expresionista que imperaba entonces. Resaltan las formas figurativas infantiles o primitivas. Sus máximos representantes serán Oscar Pellegrini, Jorge Pizzani, Carlos Zerpa, Carlos Sosa, María E. Arria, Julio Pacheco, Francisco Quilici, Ernesto León, Edgar Sánchez, Margot Römer. En sus obras, predomina la figuración y los grandes formatos, siendo la gestualidad la característica de este período.

Hablando de los años ochenta, la tendencia del Pop-Art se introduce en el país bajo el legado de la artista plástico Marisol Escobar. El bloque de madera es la base de su obra; sobre él, dibuja y pinta sus personajes. En ellos, incorpora elementos para complementar su vestimenta un cinturón, zapatos, paraguas- con los que sugiere la ilusión tridimensional. Homenaje a Magritte (IMAGEN 57) es una de sus obras. Obra ésta, permite apreciar, cómo Escobar transfigura los macizos bloques de madera para inventar sus temas. Temas éstos, cuya significación se basa en hechos de la cultura norteamericana. Las manos, el

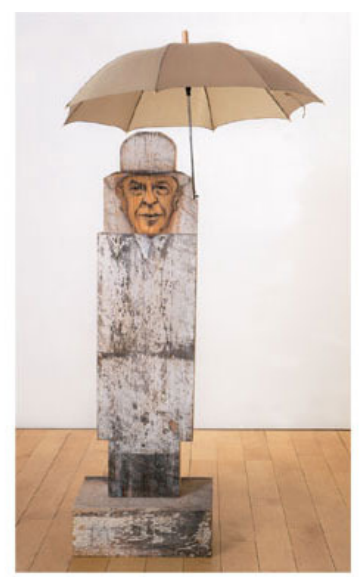

Homenaje a Magritte IMAGEN 57

rostro y los pies, son partes del cuerpo que más elabora. Su obra es una verdadera paradoja de si es escultura con tendencia bidimensional o viceversa. Esta artista obtuvo el Premio Nacional de Artes Plásticas en el año 1984.

El Premio Nacional de las Artes del Fuego en la tendencia de Orfebrería para el año 1986, se hace factible en la obra del orfebre Alexis De la Sierra. Este artista pluridisciplinario, con su vaivén entre orfebrería y escultura supone un ejemplo de la orfebrería escultórica venezolana y es el pionero de esta nueva tendencia en Venezuela.

Pectoral Ceremonial: “Le Cinquième Plaisir d' Argent” (IMAGEN 58), es uno de los cinco pectorales que conforma el conjunto ganador del Premio Nacional de las Artes del Fuego. 


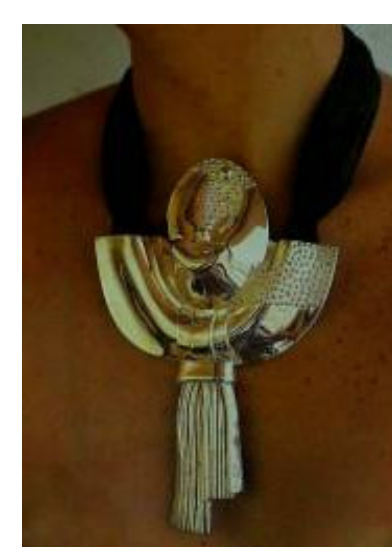

Pectoral Ceremonial: “Le IMAGEN 58

La cera perdida en mediano formato se apodera de este espectacular pectoral. Se conjugan armónicamente bajo un juego de luces, entre la plata brillantísima y el tejido del macramé color negro. La sensibilidad de De la Sierra ante los metales nobles, le permite manipular con verdadera convicción consiguiendo estupendas joyas. En este pectoral, los gránulos perfectos de plata pura se fusionan en la superficie consiguiendo un elegante contraste entre su superficie perfectamente pulida. El perfecto modelado de la cera, se transfiere con fidelidad en su vaciado, permitiendo integrar estos elementos macizos con la forma estupenda embutida.

La obra Wisidatu (Shamán) (IMAGEN 59), de la artista Kelmis Fernández demuestra en el medio expositivo cómo el vidrio es utilizado como ente representativo en su lenguaje plástico. La sutil forma femenina es magistralmente trabajada con la técnica del soplado en vidrio. El equilibrio de sus formas y el contraste de la superficie brillante/mate se exhiben de una manera emotiva y misteriosa; por lo que el jurado calificador del Salón Nacional de las Artes del Fuego, no dudó en otorgarle el Premio Nacional de las Artes del Fuego en la tendencia del Vidrio, en el año 1989.

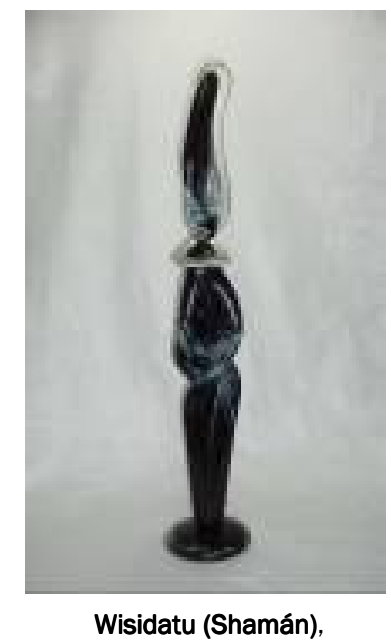

Wisidatu (Shamán)
IMAGEN 59

En la medida que se acerca la década de los noventa, el ambiente artístico se siente aventajado. Puesto que, aumentan las salas expositivas y la apertura de galerías de arte, lo que supone una mayor difusión y confrontación. Además de las típicas acciones de calle e instalaciones, que caracterizan al arte conceptual, los años noventa traen aires más vanguardistas. Sus autores, introducen al lenguaje plástico la experimentación multimedia. Así pues, los años noventa traen consigo la irrupción definitiva de las nuevas tendencias del arte cibernético y con ello, mayor impulso a la apertura de salones especializados en casi todo el territorio nacional. Como por ejemplo: en el año 1990 en la ciudad de Mérida se establece la "Bienal Nacional de Arte Moderno", y la "Bienal de Artes plásticas para Estudiantes de la Universidad de los Andes", en el año 1991 en la ciudad de Puerto la Cruz, se establece la "Bienal Nacional de Artes Plásticas de Puerto la Cruz"; 
en la ciudad de Caracas, se establece la "Feria Iberoamericana de Arte". En el año 1993 también en Caracas se establece, el "Salón Pirelli". Del mismo modo, sucede, en otras ciudades del interior como: la de Cumaná, Barquisimeto, Trujillo, Nueva Esparta, Maracaibo y Calabozo, donde establecen "Salones de Arte Municipal".

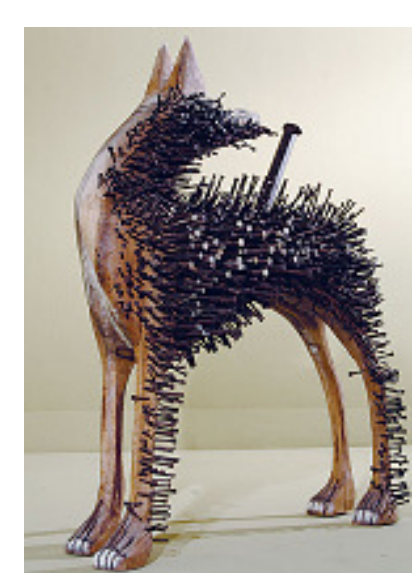

Enchávez: Perro Nagua IMAGEN 60

La artista Gaudí Esté, tras muchos años trabajando la madera consigue en los noventa el sentido real de su escultura. En un principio, sus obras se referían al hombre, la mujer o niños; éstos, aparecían casi siempre en compañía de animales. La semejanza del individuo con su mascota estableció una característica de su producción plástica. Su elaboración enfatiza con demasía el acabado de la superficie, dejando ver su veta con impecable factura en diversas maderas. Los perros, felinos y caballos serán el cent hacen visible madera deja

Integra y yuxtapone elementos a sus tallas, se hace frecuente el hierro, los clavos, las ruedas, las fibras vegetales. Así pues, combina la talla directa con el ensamblaje; pues, este método particular -talla las formas por separado y luego ensambla retocando la fisionomía de sus animales-. Toda esa madurez escultórica le hace acreed ora de dos magníficos premios: en el año 1992, obtiene el Gran Premio del "Salón Aragua" con la obra Enchávez: Perro Nagual (IMAGEN $60)$, y en el año 1995, obtiene el Gran Premio en la "Bienal Francisco Narváez" con la obra Sedicioso VI (IMAGEN 61) 59 .

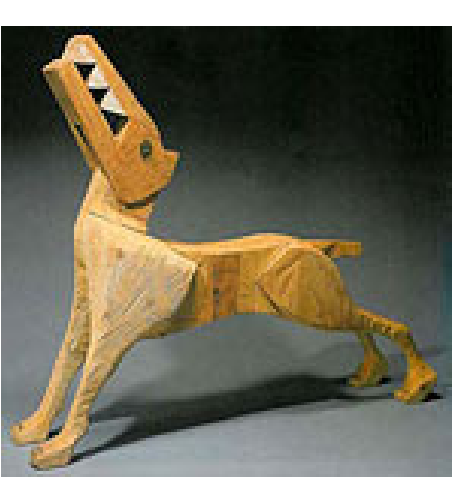

Sedicioso VI Sedicioso VI
IMAGEN 61

Pedro Barreto es uno de los artistas venezolanos quien en los años noventa tiene ya una amplia labor investigativa y fructífera. Barreto es considerado uno de los más importantes escultores venezolanos que trabajan la madera. Según hemos podido observar en su producción artística, sus trabajos se establecen

59 Gaudí Este.

http://www.gaudieste.com/ 


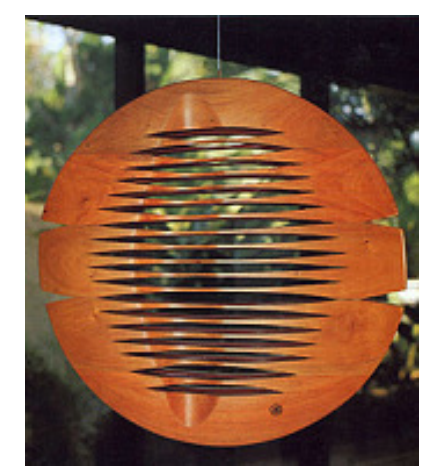

Sol
IMAGEN 62

en la talla directa. Sin embargo, se introduce en una etapa investigativa e incursiona en el vaciado en bronce y es con una obra de este material, que obtiene el Premio nacional de Escultura en el "SOAAV" del año 1967. Su pasión por la madera, hace que definitivamente se desvincule de cualquier otro material. Sol (IMAGEN 62) es una de las fascinantes obras que traduce ci nononidar da cíntosis. En ellas, ex

madera, el vuiuııı, ia sıııeura y el color que introduce en sus cavidades; el pino de Honduras, el cartán, el apamate, el cují y el palo santo, son las maderas que han sido manipuladas artesanalmente por las manos prodigiosas de este artista.

Tal y como hemos comentado, ya en la década de los noventa encontramos un abanico de posibilidades técnicas: el bronce, la plata, el cobre, el hierro, el gres, la cerámica, el mármol, el granito, las maderas, el vidrio, los polímeros, el cartón, las telas, la fotografía, el video Todo cuanto se imagine puede verse en las representaciones artísticas del arte venezolano.

\subsection{5 ÉPOCA ACTUAL. Generalidades.}

Comienza un nuevo milenio y las artes en Venezuela se engrandecen. Puesto que, "La Síntesis de las Artes Mayores", de la Ciudad Universitaria de Caracas (IMAGEN 33 al 39), es reconocida por la UNESCO como Patrimonio Mundial de la Humanidad.

"Para el año 2000 el Comité del Patrimonio Mundial de la UNESCO, reunido en la ciudad de Cairns, Australia, declaró a la Ciudad Universitaria de Caracas como Patrimonio Mundial de la Humanidad. La ciudad Universitaria de Caracas se convierte asi en una de las primeras creaciones artísticas integrales del siglo XX declarada como patrimonio mundial cultural de la humanidad, y coincide felizmente con el centenario del nacimiento de quien le diera su existencia: el Maestro Carlos Raúl Villanueva...

...El Instituto Internacional de Monumentos y sitios (ICOMOS), consideran dos criterios básicos para la inclusión de la Ciudad

Universitaria de Caracas en la Lista del Patrimonio Mundial; a saber: la misma representa la combinación de los más altos 
ideales y conceptos de la planificación urbana moderna, la arquitectura y el arte de los inicios del siglo XX. El otro criterio refiere que la Ciudad Universitaria de Caracas constituye una interpretación ingeniosa de los conceptos y espacios de tradición colonial, y un ejemplo de la arquitectura abierta y protegida, apropiada para un ambiente tropical típico"60.

El legado artístico diseminado por toda la ciudad universidad ha servido de estímulo y ejemplo a seguir en las artes nacionales e internacionales. La trascendencia de estas magníficas obras, vincula el arte con el medio arquitectónico y paisajístico, y por ende, con el individuo como ser que lo habita. La Síntesis de las Artes Mayores, ha permitido que otras Universidades, Salones de Arte y Galerías se den la tarea de incentivar a los artistas nacionales de larga trayectoria y las nuevas generaciones para que exhiban e instauren en algunos espacios urbanos sus obras. Dónde se establezca un vínculo entre el individuo con el arte en y para la ciudad.

En tal sentido, es importante destacar que en el año 2000 el Profesor Rafael Cartay, en su condición de Director de Cultura de la Universidad de Los Andes en la ciudad de Mérida, lleva a cabo el programa llamado "Alma Mater", (IMAGEN 53 al 58). Dicho programa, se encarga de emplazar esculturas de gran formato dentro de la infraestructura de sus cuatro núcleos universitarios en Venezuela (Mérida, Tovar, Táchira y Trujillo) y procura integrar lo representativo del arte contemporáneo. Este proyecto, alberga la obra de escultores de gran trayectoria nacional e internacional tales como: Rafael Barrios, Manuel de la Fuente, Oscar García, Marcel Floris, Rómulo Contreras, Rafael Martínez, José Luis Guerrero, Lajos d’ Ébneth, Jorge Zerep, Úrsula Bertram, Adela Tarnawiecki, Miguel Alonso, Jan Koblasa, Hans Gekeler, Carlos Zerpa, Enríco Armas, Fabiola Sequera, Franco Contreras, Mario Colombo, Ángel Rojas, Rafael Bartolozzi, Cruz Diez, Vera Roelm.

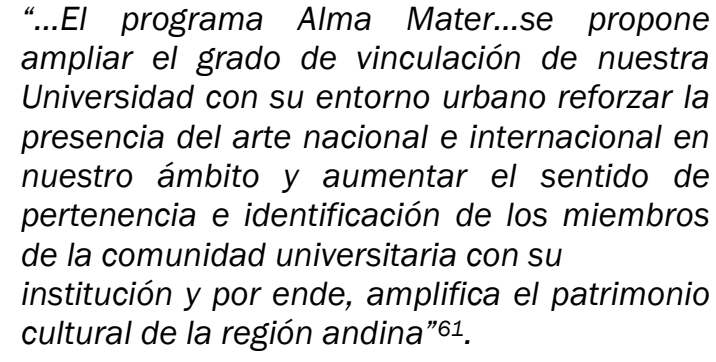

60 Síntesis de las Artes de la Ciudad Universitaria de Caracas. Obra trascendente en el arte moderno del siglo XX. Pérez, J.

http://copred.rect.ucv.ve/BD_Documentos/ip_ponencia_resumen.pdf

61 Universidad de Los Andes. (2004). “Agenda 2004. Alma Mater”. Agenda.s/n. 
Según las fuentes citadas $^{62}$, Las tendencias de los estilos de obras que se encuentran emplazadas para este proyecto, se fundamentan entre las tendencias del arte figurativo, abstracción, abstracción geométrica y constructiva. Las esculturas varían entre materiales como: acero, acero cortén, acero policromado, tubos de hierro policromado, bronce, hierro laqueado, madera, concreto revestido, mural cerámico, concreto revestido con polvo de mármol, tubería estructural, láminas y tubos de hierro laqueado y láminas de cristal laminado con pintura de esmalte.

Alma Cosmográfica (IMAGEN 63) es la obra del escultor español/venezolano Manuel de La Fuente. Se encuentra emplazada en la entrada Sur del núcleo la Líria (Facultades de Ciencias Económicas y Sociales), en una importante avenida de la ciudad. El enorme pedestal de cuerpo prismático, alberga en su interior un dispositivo electrònico. Éste permite que la obra permanentemente gire sobre un mismo eje. El emblemático rombo ondulado en bronce patinado, se erige desde esta base;

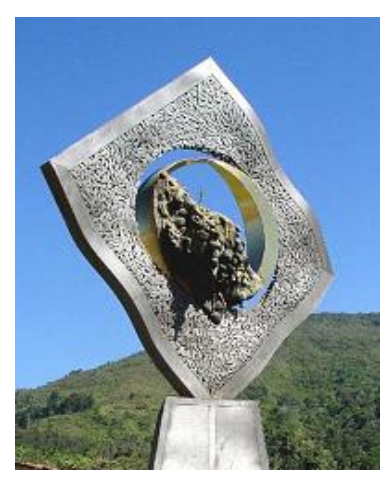

Alma Cosmográfica IMAGEN 63

tras el lento movimiento circular. Desde el centro del rombo, brotan pequeños individuos luchándo por aferrarse a ella evitando desprenderse tras el ondeante movimiento. Movimiento este, no es más que una ilusión optica que se logra desde la superficie curveada. Tema éste, recurrente en gran parte de su prolífica obra en bronce. La obra Alma Cosmográfica, constituye el emblema del proyecto Alma Mater.

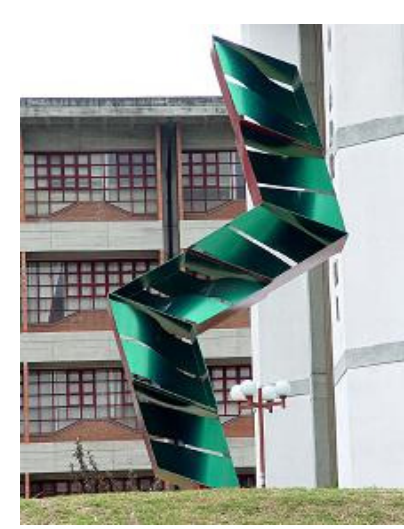

La obra Espiga del Chama (IMAGEN 64)

es de la autoría del escultor venezolano Rafael Martínez. Se encuentra situada dentro de los jardines de la Facultad de Ciencias Económicas y Sociales del recinto universitario. Carece de pedestal esta imponente espiga de acero policromado en rojo y verde. Esta fabulosa obra, se sujeta al suelo desde uno de sus vértices; lo que aporta una apariencia liviana y espacial. Las líneas quebradas conforman la estructura abstracta idealizada en metal. En su interior, serpentean simétricamente láminas onduladas; el juego de luces y Espiga del Chama
IMAGEN 64

sombras, enaltecen y degradan el tono verde que las constituye.

62 Cartay R. (2009). “Proyecto Alma Mater de la ULA”. Material inédito. Entrevista personal. 
El color enaltece el enorme corazón rojo Ilamado: Despecho (IMAGEN 65) del artista venezolano Carlos Zerpa. Un colosal rayo, lo atraviesa por su mitad, dejando ver a través de sus entrañas, el espacio vacío que resalta su forma contundente. Su forma frontal -casi plana-, y su disposición en el terreno inclinado, permite su contemplación desde muy lejos sin distorsión. El color rojo uniforme que la fundamenta, contrasta con el inmenso verdor del terreno en que habita. Sin embargo, existe cierta afinidad con la forma y su

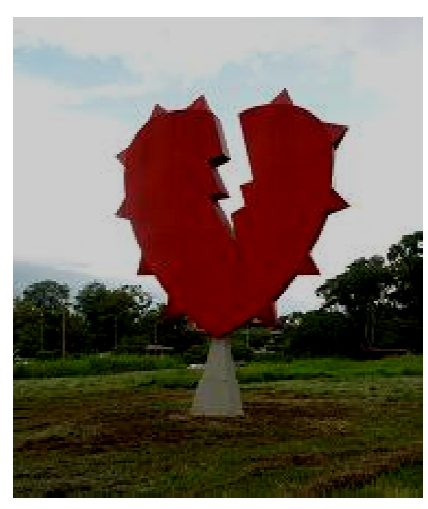

Despecho

color, lo que visualmente incita a su observación. La inclusión en el entorno, le confiere autonomía dentro del paisaje. Característica ésta recurrente en su obra, con fuerte carga emotiva, con tendencia figurativa, colores vivos y temas, -en muchos casospoco habituales.

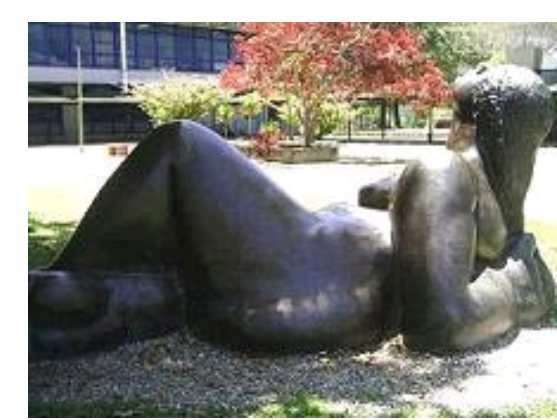

Despertares
IMAGEN 66

La figuración se hace presente en esta escultura femenina. Este vaciado en bronce patinado, se fundamenta en la figura de una mujer robusta descansando plácidamente sobre el suelo. Despertares (IMAGEN 66) del escultor venezolano Oscar García es

producto de una línea de investigación que compete a la mujer obesa en situaciones

cotidianas, empleando siempre cierto elemento que la vincula a algún contexto. En este caso, posa su cuerpo desnudo bajo la sombra de un árbol. Sin pudor alguno, en su mano se empuña una cinta que cubre sus ojos que no permite descubrir su rostro. Sin embargo, deja todo su cuerpo al descubierto en plena plaza de la Facultad de Ciencias.

Cerramos esta muestra de esculturas de gran formato del "Proyecto Alma Mater", con la obra Thinking (IMAGEN 67) de la alemana Úrsula Bertram. Como evidenciamos, es la única en la modalidad de instalación y emplazada bajo techo. Sin embargo, su ubicación cumple la misma

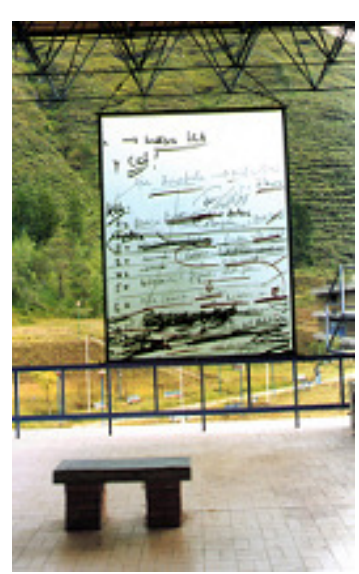

Thinking IMAGEN 67 
función que el resto, pues, se relaciona con el entorno universitario. Esta enorme lámina de vidrio laminado -ubicada frente a la Biblioteca de la Facultad de Ciencias- nos revela un prosaico cuaderno de notas, pues, las tachaduras, las anotaciones rápidas, -con pintura- propias de un cuaderno de cualquier universitario. La obra Thinking, nos resume de manera subjetiva la percepción de la autora con su obra y el entorno universitario.

Las nuevas pautas que imperan el arte actual venezolano devienen de la mezcla de culturas, técnicas, materiales y nuevos conceptos. Pareciera haber una uniformidad en donde la obra tiende a ser más subjetiva.

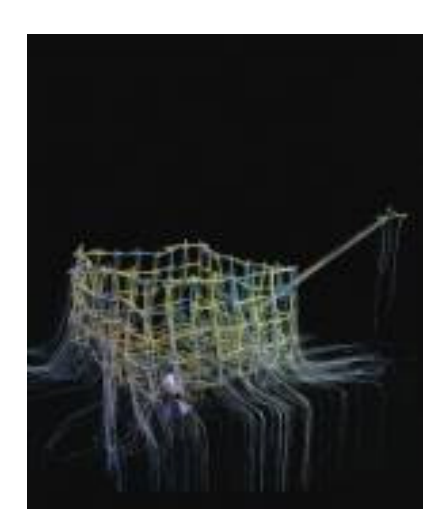

Me voy de casa, me llevo la ijama, mis juguetes. Hoy tengo memori ¿Me voy de casa? IMAGEN 68

Ramsés Larzábal desarrolla una gran parte de su lenguaje plástico con diversas artes del fuego. En la obra: Me voy de casa, me llevo la pijama, mis juguetes. Hoy tengo la memoria ¿Me juguetes. Hoy tengo la memoria ¿Me
voy de casa? (IMAGEN 68), la porcelana e hilos de nylon se entrecruzan levantando las cuatro paredes del cubo que lo constituye. El frenético desvanecimiento del cubo, deshilvana su estructura sobre una base cuadrada negra con un fondo negro. Efecto éste otorga ambigüedad entre lo terrenal y lo etéreo. Con esta instalación, Larzábal obtiene el Premio Nacional de las Artes del Fuego en el "SNAF” en el año 2002.

La obra Lecturas Reveronianas (IMAGEN 69) del artista y crítico de arte Alberto Asprino es la ganadora del "Salón Arturo Michelena" en el año 2003. El artista resume la historia de uno de los mejores pintores venezolanos -Armando Reverón- de principios del siglo $X X$.

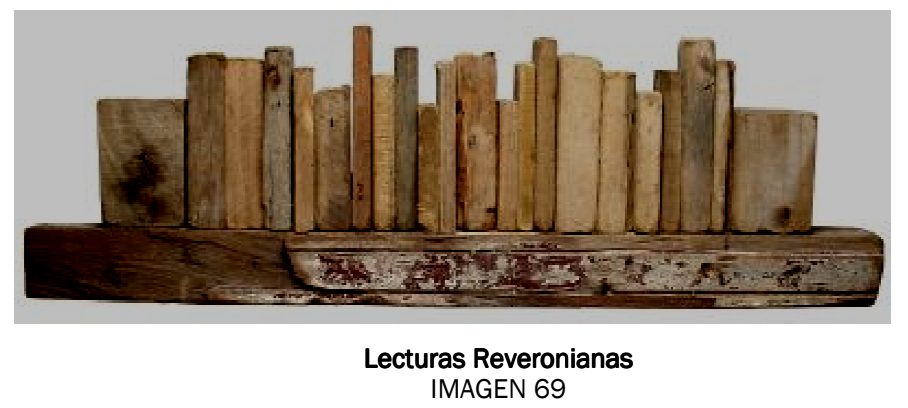

La vinculación de la obra de Reverón en este artista va más allá de una simple admiración; su condición de curador, museógrafo, arquitecto y artista plástico, le permitió descubrir la esencia de la 
obra de este insigne pintor venezolano. Acertadamente, utiliza desechos -como lo hacía Reverón-, descontextualiza y otorga otra connotación; así pues, Asprino, ensamblando retales de maderas representando una repisa de biblioteca, -como si se tratara de los magníficos modelos de Reverón de inspiración para ser reflejados en sus pinturas- para ello, utilizó trozos de maderas que yacían en la orilla de las playas de macuto y concienzudamente escogió y posteriormente transfiguró en esta sugestiva propuesta.

La escultura contemporánea actual, se encuentra en un proceso de maduración donde las nuevas técnicas van enriqueciendo el lenguaje plástico. La escultura venezolana, también se ha visto influenciada por este proceso desde comienzos del siglo XX.

El Consejo Nacional de la Cultura, conjuntamente al Ministerio de Cultura, motoriza un proyecto para las artes en el año 2003. Según las fuentes citadas hemos corroborado que ${ }^{63}$, en la importante muestra se expone del Arte Venezolano del Siglo XX, la cual Ilamaron: La Mega exposición, fue una gran exposición que se llevó a cabo en paralelo en 66 instituciones del territorio nacional. Se organizó entre los estados Amazonas, Anzoátegui, Apure, Aragua, Barinas, Bolívar, Carabobo, Cojedes, Delta Amacuro, Distrito Capital, Falcón, Guárico, Lara, Mérida, Monagas, Nueva Esparta, Portuguesa, Sucre, Táchira, Trujillo, Vargas, Yaracuy y el Zulia.

Esta importante exposición logra reunir obras dentro del contexto artístico del año 1901 al 2001, lo que permite revisar de manera exhaustiva el quehacer artístico venezolano. Esta experiencia inédita en la museología venezolana, fue un gran desafío para los museólogos, curadores, investigadores de arte y afines. A partir de las colecciones de museos, privadas e instituciones culturales, se diseñó un recorrido que enlaza la historia del arte venezolano.

Este importante proyecto albergó poco más de tres mil obras de diversos formatos, modalidades y tiempos permitió ubicar según décadas -o tiempo específico- considerando la tendencia, los artistas y obras más importantes. Este gran evento de la plástica nacional, permitió al público poder ver o conocer las obras de los mejores artistas. Así como también, ofrecer a los investigadores y público en general un material visual, del panorama del arte venezolano. De este modo, fundar bases sólidas sobre un tema que no ha sido abordado. La trascendencia de la "Mega exposición" arrojó beneficios inmediatos ya que permitió la reactivación de salones de arte que se habían visto interrumpidos por diversas causas.

63 La Mega exposición: Una aventura sin precedentes. Arte venezolano del Siglo XX. CONAC. (2003).

http://www.aporrea.org/actualidad/n11552.htm 
Después de diez años de ausencia, en el año 2005 la "Bienal de Escultura Francisco Narváez" retoma su actividad de promoción y difusión de las artes.

El Premio Nacional de Escultura lo obtiene la artista plástico Ani Villanueva con su obra: Lágrimas (IMAGEN 70); obra ésta, se fundamenta en una instalación que consta de un panel rígido pintado de blanco con trozos salientes de manguera

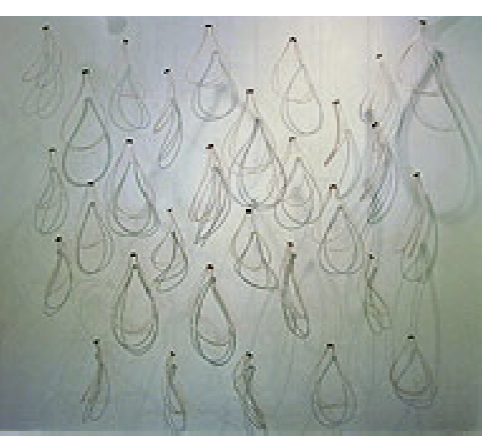

Lágrimas
IMAGEN 70

transparente con forma de gotas. La imprescindible iluminación cenital imprime un carácter especial del cual se aprovecha la artista; pues, el interior de las mangueras está ocupado por agua lo cual adiciona otro reflejo, cuyo interior traslúcido, se interrelaciona fundiéndose entre la figura y el fondo, transformándose en enormes lágrimas. Ilusoriamente, la luz refleja multitud de sombras que se unen, funden y confunden al espectador.

Ese mismo año, 2005- se desarrolla otra importante exposición de Arte venezolano del Siglo XXI, la cual llamaron: "Mega exposición II". En homenaje al artista venezolano Jesús Soto. Según la Coordinadora general de este proyecto María Eugenia Rivas ${ }^{64}$, se establece realizar una exposición que contenga las obras de los mejores artistas del país desde el año 2001 al 2005. Para ello, se eligieron las mismas 66 instituciones que colaboraron en la primera "Mega exposición" del 2003; así pues, sirviera de recepción de obras de los artistas de su región con un total de 3.819 obras inscritas por 2.258 artistas plásticos. La exposición se desarrolló entre los 7 museos de Caracas: Galería de Arte Nacional, Museo de Bellas Artes, Museo de Arte Contemporáneo Sofía Imber, Museo Alejandro Otero, Museo Jacobo Borges, Museo Cruz Diez y Museo Arturo Michelena.

64 Mega exposición II: Arte Venezolano del siglo XXI.(2005)

http://valencia.com.ve/2005/04/13megaexposicin-ii-arte-venezolano-del-siglo-xxi/ 


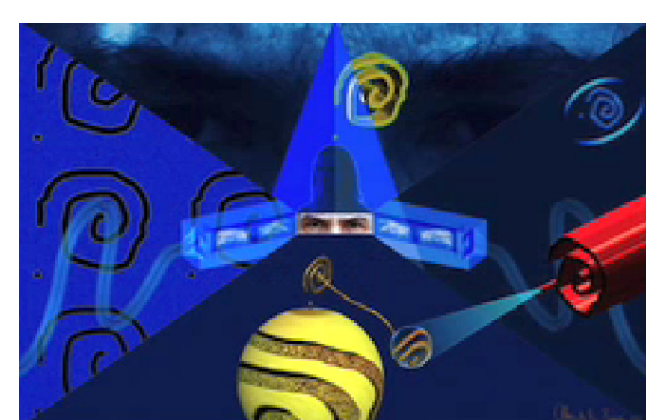

Omnia Posibilia Sunt Videnti,

En tal sentido

mencionaremos

la

pintura cibernética

Omnia Posibilia Sunt

Videnti, (IMAGEN 71)65,

del artista Alexis De la

Sierra que participó en

dicha exposición. Esta

pintura, es parte de la instalación (Soñando con los ojos abiertos)

elaborada para participar en la Bienal de Venecia

en el 2003; sin embargo, no pudo participar puesto que la obra generó polémicas entre los críticos venezolanos por lo que no fue seleccionada para ser enviada. En esta pintura, el artista De la Sierra substituye el convencional lienzo, pinceles y pigmentos, por la pantalla del computador, el teclado y el ratón y es entonces con estos nuevos materiales y medios tecnológicos que pinta esta enorme pintura. Aprovecha programas avanzados de computación, y compone la pintura enfatizando los colores patrios con un acento innovador. En el centro del enorme lienzo, delata su mirada fija, provocando la máxima atención, sentenciando la composición simétrica. Mirada ésta, se repite ampliada, en la parte superior con tonalidades del azul prusia. Su larga trayectoria en el arte, acompañado de un espíritu innovador y "libre de preconcebidos academicismos, siempre analítico, investigador y a la vez espontáneo nos sorprende con nuevas visiones y con la creación de nuevos géneros de expresión plástica"66, por eso es considerado hoy en día, un artista multidisciplinario. Ha fusionado disciplinas entre orfebrería, escultura y ciberpintura. Y su evolución artística, ha trascendido las fronteras; en el año 2001, obtiene la "Medalla de Oro Magnus Laurentis Medicis" en la III Bienal Internacional de Arte Contemporáneo en Florencia, Italia, con una Escultura/Instalación que fusiona en ella las disciplinas de orfebrería, escultura y ciberpintura.

Este evento artístico que resulta con las importantes exposiciones: “Mega exposición” y “Mega exposición II" resulta un inventario que permite detenerse en la repercusión internacional de los grandes maestros de la abstracción cinética, la renovación de la figuración, el resurgimiento del dibujo, el tratamiento expresivo de la figura humana, el nuevo paisaje, el impulso gráfico y los aportes especiales de la abstracción, el arte conceptual, las

65 Pervilhac, I. (2008). “Omnia Posibilia Sunt Videnti”. Material inédito. Correo electrónico. artmanager@delasierra.com

66 García, M. “Alexis De la Sierra Orfebrería sin límites”. 2010). Revista Arte Facto. (Edición especial) № 3. pp: 036- 039. 
intervenciones, los happening, y performance. Aunque estas dos exposiciones son un reflejo de los primeros pasos, ya significa una transformación irreversible para el arte venezolano del siglo XXI. Haciendo una reflexión- Ahora, sólo falta que todo el material visual y bibliográfico recaudado de estas dos grandes experiencias, sirva de inicio, para hilvanar la historia del arte venezolano. De este modo, los historiadores, investigadores y afines deberían publicar ese material, no sólo para las entidades museísticas del país, sino para el colectivo en general.

Ya para el año 2006 comentaremos del "Salón Aragua", el Gran Premio se le concede a una fotografía del artista Roberto Mata. Resulta un verdadero impulso a este medio artístico y mejor aun al medio fotográfico analógico, en medio de tantas propuestas innovadoras del arte actual y obviamente, un verdadero impulso para su escuela de fotografía. Su propuesta, nos deleita con una espectacular imagen en panorámica tomada en una parte del trayecto desde la estación del teleférico de Mérida (Venezuela), hacia los Nevados (pueblos del Sur de ese estado). En Autorretrato (IMAGEN 72), el fotógrafo Mata hace una metáfora del título con la imagen, donde, señala que lo intrincado del camino boscoso de la fotografía es un reflejo de lo complicado del ser humano67. El ojo y pulso de Mata, captan el ángulo, determinando, la obturación y el tiempo de exposición de la imagen. La destreza con los medios tecnológicos le permiten ampliar la imagen en gran formato por medio de un plotter, destacando las luces, dando cabida a las sombras del frio y enigmático bosque. Este fotógrafo demuestra con el Premio Nacional, la impecable trayectoria en el medio y perfecto ejemplo como docente de su propia escuela en la ciudad de Caracas. Esta fotografía, representa en el "Salón Aragua" la revalorización a los métodos convencionales en fusión con la alta tecnología, dejando claro, la importancia del objeto-arte a través de los métodos antiguos; sea cual sea la propuesta. Llámese fotografía, grabado, escultura No perder la esencia de la materia, la forma o la técnica.

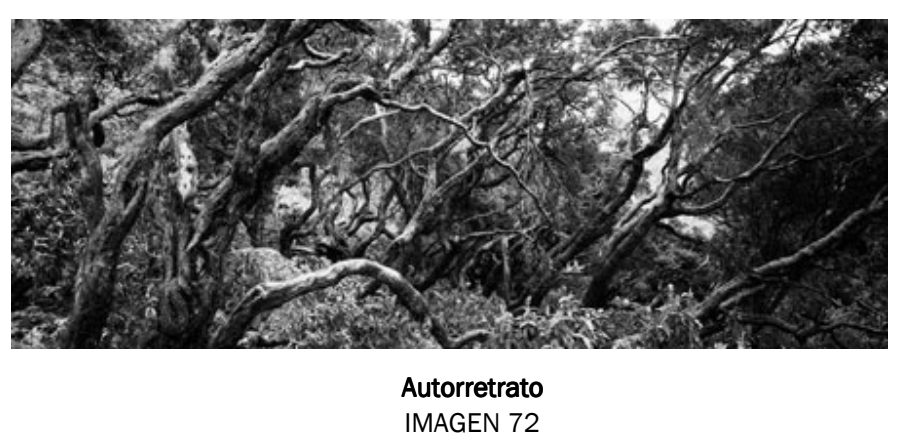

El año 2007 comienza excelentemente para las artes venezolanas;

67 El premio del Salón de Aragua me confirma que soy fotógrafo. (2006).

http://www.eluniversal.com/2006/12/13/til_art_108621.shtm! 
pues, se concreta una exposición retrospectiva del artista Armando Reverón en el Museo de Arte Moderno en Nueva York (MOMA). Evento éste, lo certifica como uno de los mejores artistas del arte venezolano del siglo XX.

La excelente retrospectiva ocupó cuatro salas del prestigioso Museo y estuvo contenida entre 100 obras inéditas, comprendidas en las tres etapas que marcaron su producción artística entre pinturas, dibujos, objetos y muñecas de trapo (Detalle de una de las muñecas de Reverón expuesta en el MOMA. 2007 IMAGEN 73). Siendo este último, muy importante para el desarrollo de la escultura en Venezuela, puesto que, hoy en día sus famosas muñecas de trapo elaboradas por él con materiales de

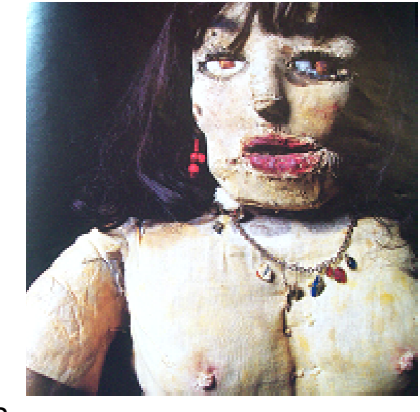

Detalle de una de las muñecas de Reverón expuesta en el MOMA. 2007.

desecho, usadas como modelos para sus pinturas- consideradas y catalogadas hoy en día, como esculturas blandas.

La "Bienal de Artes Plásticas para estudiantes de la Universidad de Los Andes" del año 2007, concede el Gran Premio al orfebreEscultor David García.

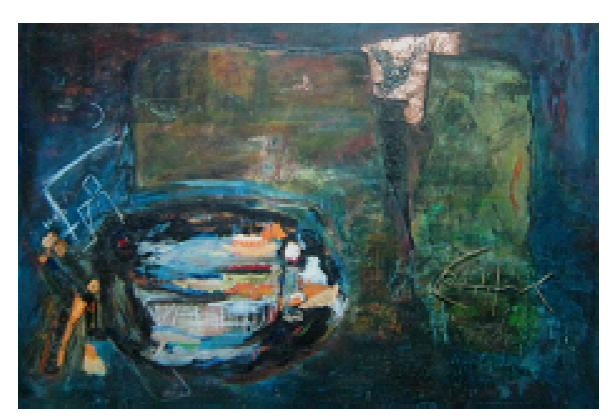
Aves, Peces, Reptiles y Cuadrúpedos
IMAGEN 74

La obra de la serie: Aves, Peces, Reptiles y Cuadrúpedos (IMAGEN

$74)^{68}$, deja en evidencia su fusión entre ambas disciplinas, pues, en dicha pintura, García yuxtapone sobre el lienzo un fragmento de una pieza elaborada en cobre, bronce y plata. En ella, se aprecia la maestría que posee con las pátinas sobre metal, cincelado y repujado. La composición, conjuga un lenguaje sugerente a las fascinantes especies marinas, explayados matices verde-azules conformando un todo. Se organiza una imagen con cuerpo matérico, donde, los trazos gestuales con suficiente pastosidad del pigmento, manifiestan el interés por la tridimensionalidad.

68 García, D. (2009). “Obra ganadora Bienal para Estudiantes de Universidad de Los Andes". Material inédito. Entrevista personal. Mérida, estado Mérida. 
El “Salón Pirelli" de la edición del año 2008, plantea como tema central de la exposición: El Relámpago del Catatumbo69. En tal sentido, podemos afirmar como la luz se convierte en un elemento ineludible en todas las propuestas. El Primer Premio, fue entregado a Bernardita Rakos por su instalación: Arráncame la vida con el último beso de amor, arráncala, toma mi corazón (IMAGEN 75).

La escultura se adentra en el campo bidimensional, pues, abarca todo el alto de la pared y habla sin palabras, del fenómeno que

ocurre con el enamoramiento. Metafóricamente, substituye el resplandor de los continuos relámpagos del Catatumbo y fusiona con el sentimiento del ser enamorado. La composición surge de manera espontánea con el brillo perpetuo del corazón. La vibración energética creada por Rakos, produce un diálogo entre

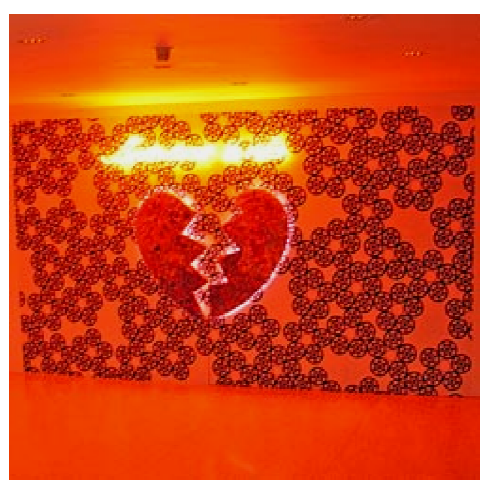

Arráncame la vida con el último beso de amor, arráncala, IMAGEN 75 el espectador y su obra.

Este nuevo impulso que se está sintiendo en las artes venezolanas hoy en día, se logra de una extensa revisión del panorama actual artístico. Para ello, los entes gubernamentales toman en cuenta una serie de factores que impiden la participación de un gran colectivo en las artes venezolanas. Huelga decir, que el arte exhibido en los museos siempre ha sido para un grupo privilegiado-, han podido establecer y engrandecer sus propuestas

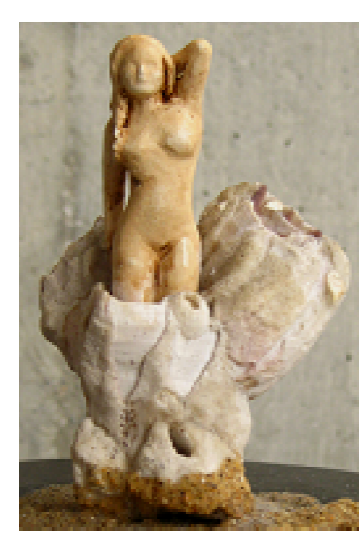

Ser
MAGEN 76 artísticas debido a la promoción que han brindado estas entidades, por lo que la actual política venezolana cree firmemente en el poder popular, pues, el arte es para todos y debe llegar a todos, con la misma medida.

En el año 2010 en la ciudad de Mérida despliegan una exposición titulada: "Salón Mujer, Arte y re-Evolución"; obviamente, se convoca en exclusiva a mujeres artistas. Para gran sorpresa, la muestra estuvo sustentada en su mayoría, con representaciones en escultura, predominando la figuración del cuerpo

69 El relámpago del Catatumbo es considerado el fenómeno natural más importante del mundo debido a su impacto protector de la capa de ozono. 
femenino. La pequeña obra Ser, (IMAGEN 76) de la artista merideña Elizabeth Quintero, se llevó el Gran Premio con la mención de Escultura. Obra ésta, curiosamente establecida en pequeño formato, pues, se trata de un esculpido en escayola, de escasos tres centímetros de alto. Mujer esta se encuentra posando dentro de una formación de coral blanco, cual diva del arte del renacimiento. El desnudo femenino, bien proporcionado y sutilmente trabajado, deja percibir la sensibilidad de su quehacer artístico y la pericia del tallado en este delicado material.

Ya para cerrar el contexto artístico de la escultura en Venezuela del año 2010, mencionamos la última confrontación acontecida con el "Salón CANTV Jóvenes con FIA", para la edición de ese cambia su nombre a "Salón Supercable Jóvenes con FIA". En este selectivo salón, se muestran propuestas artísticas bajo la perspectiva de las nuevas

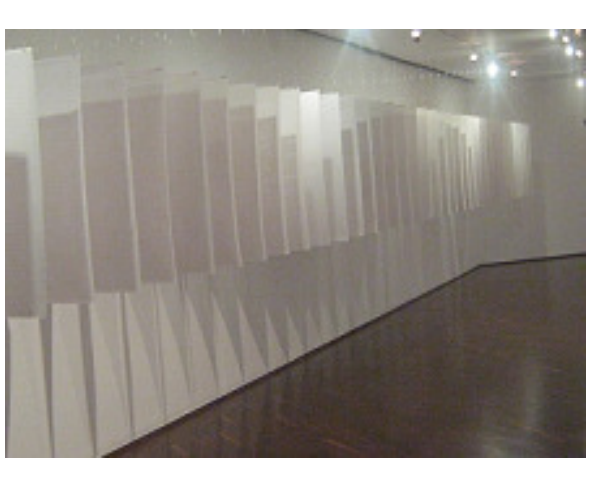

Quiero tener un bebé como tú IMAGEN 77

tendencias del arte contemporáneo. En tal sentido, dejamos en evidencia la primera mención. La obra: Quiero tener un bebé como tú (IMAGEN 77) se fundamenta en una instalación de carácter conceptual. La artista Elisa Silva, utiliza 36 reproducciones en mediano formato suspendidas diagonalmente frente a una pared; dispuestas simétricamente, una al lado de la otra -ó una frente a otra- y a través de estas nos adentra en un mundo subjetivo sobre el embarazo precoz.

La artista expresa su arte a través, del método braille, para ello, se fundamenta en una investigación de campo apoyada en encuestas a jóvenes adolescente entre 11 y 19 años de edad, siendo estos resultados, escritos en braille en un soporte ideal. Así pues, a través de un patrón codificado, los pequeños puntos en relieve, se explayan en cada folio y en cada uno muestra el resultado agobiante de la investigación El paradigma social que caracteriza las comunidades populares del país, se personifica en esta propuesta, pues, metafóricamente simula con su arte la frecuencia del caos en la adolescencia venezolana.

1.3.5.1 Centros oficiales de enseñanza de Artes Plásticas.

Dentro de este apartado, abordaremos sobre la enseñanza en artes plásticas en Venezuela. Sin embargo, lo haremos de manera general puesto que, se mencionarán los nombres de dichos centros oficiales. - llámese: universidad, escuela de artes visuales, 
escuela de artes plásticas y talleres oficiales- Así como también, las ciudades en donde están ubicadas. Es importante destacar, que existen muchos centros educativos que incluyen las artes plásticas. Sin embargo, no logramos ubicar dentro de la cronología, pues, no fue posible corroborar el año en que dieron inicio. Por lo tanto, se colocan al final de la década de los años dos mil, ya que en la actualidad, éstos, continúan formando en el área de las artes plásticas.

\section{Década de los años 30:}

1936

Escuela de Artes Plásticas y Artes Aplicadas de Caracas, Distrito Capital. (luego cambia a Escuela de Artes Visuales Cristóbal Rojas)

- Escuela de Artes Plásticas Martín Tovar y Tovar. Barquisimeto, estado Lara.

Instituto Pedagógico de Caracas. Caracas, Distrito Capital.

\section{Década de los años 50:}

1955

Escuela Técnica de Artes Plásticas Eloy Palacios. Maturín, 1958 estado Monagas.

- Escuela de Artes Plásticas Armando Reverón. Barcelona, estado Anzoátegui.

- Escuela de Artes Plásticas Armando Reverón. Margarita,

1959 estado Nueva Esparta.

- Escuela de Artes Plásticas y Artes Aplicadas Carmelo Fernández. San Felipe, estado Yaracuy.

\section{Década de los años 60:}

1962

Universidad Católica Cecilio Acosta. Facultad de Artes y Música. Licenciatura en Artes Plásticas. Maracaibo, estado Zulia.

- Universidad José María Vargas. Facultad de Arquitectura y Artes Plásticas. Escuela e Historia de las Artes plásticas. Licenciatura en Historia de las Artes Plásticas y Museología. Caracas, Distrito Capital.

Escuela de Artes Plásticas Juan Lovera. Mención Arte Puro. Apure, estado San Fernando de Apure.

Universidad de los Andes. Facultad de Arquitectura. Escuela de Artes Visuales y Diseño Grafico. Mérida, estado Mérida.

Década de los años 90: 
Instituto Universitario de Estudios Superiores de Arte Armando Reverón. (IUESAPAR). Caracas, Distrito Capital. 1993

Centro de Arte de Maracaibo Lía Bermúdez. Maracaibo, estado Zulia.

Década de los años 2000:

2005

Universidad de los Andes. Facultad de Arte y Diseño (antes era escuela que pertenecía a la Facultad de Arquitectura y se instaura como facultad en esta fecha).

2007

Fundación Universidad de Carabobo. Diplomado en Artes del Fuego. (En revisión curricular para la obtención de: Licenciatura en Artes Visuales) Valencia, estado Carabobo.

En la actualidad, sin fecha de Fundación:

- Universidad del Zulia. Facultad Experimental de Arte. Licenciatura en Artes Plásticas. Mención: Dibujo,

Grabado, Cerámica, Pintura, Escultura. Maracaibo, estado Zulia.

- Universidad Rafael Belloso Chacín. Maracaibo, estado Zulia.

- Instituto Universitario de Diseño Fundación Newman. Caracas, Distrito Capital.

- Instituto Universitario Pro-Diseño. Caracas, Distrito Capital.

Instituto de Arte Federico Brandt. Caracas, Distrito Capital. Instituto de Diseño de Caracas. Caracas, Distrito Capital.

Escuela Superior de Artes Plásticas Neptalí Rincón. Maracaibo, estado Zulia.

- Escuela de Arte Héctor Poleo. Caracas, Distrito Capital.

- Escuela de Artes Visuales Rafael Monasterios. Maracay, estado Aragua.

- Escuela Técnica Nacional de Artes Plásticas Julio Árraga. Maracaibo, estado Zulia.

- Taller Escuela Arte-Fuego Cándido Millán. Caracas, Distrito Capital.

- Taller Libre de Artes Plásticas de San Carlos. San Carlos, estado Cojedes.

1.3.5.2. Cronología de bienales y salones de arte que incluyan la modalidad de escultura.

En este apartado, se muestra a nivel cronológico las bienales y salones de arte que se llevan a cabo en el país en la época actual. Es importante destacar, que los datos que se presentan a continuación son para que el lector tenga una apreciación con respecto a la promoción de las artes en Venezuela. Puesto que, 
dentro del contexto de la escultura venezolana, sólo fueron nombrados algunos de ellos.

De igual modo, es necesario aclarar que en dicha cronología se han omitido algunos salones y bienales porque no fue posible ubicar la fecha de su fundación, ciudad donde se realizan y/o lugar donde se llevan a cabo. Así pues, en la muestra no se presentan en su totalidad.

\section{Década de los años 40:}

1943

Salón Nacional de Artes Visuales Arturo Michelena. Ateneo de Valencia. Valencia, estado Carabobo.

\section{Década de los años 60}

1961

Salón Nacional de Arte de Aragua. Museo de Arte Contemporáneo de Maracay. Maracay, estado Aragua.

1967

Salón de Arte de Paraguaná. Coro, estado Falcón.

\section{Década de los años 70 :}

1971

Salón Nacional de las Artes del fuego. Galería Braulio Salazar. Valencia, estado Carabobo.

1976

Salón Nacional de Jóvenes Artistas. Museo de Arte Contemporáneo de Caracas Sofía Imber. (MACCSI). Caracas, Distrito Capital.

\section{Década de los años 80:}

1981

Bienal Nacional de Artes Visuales. Museo de Arte Contemporáneo de Caracas Sofía Imber. Caracas, Distrito Capital.

1982

Bienal Nacional de Escultura Francisco Narváez. Museo de Arte Contemporáneo Francisco Narváez. Margarita, estado Nueva Esparta.

1982

Bienal de Artes Visuales de Churuguara. Ateneo Casa J. Riera de Churuguara. Churuguara, estado Falcón.

Salón Nacional La Nueva Naturaleza. Museo de Barquisimeto. Barquisimeto, Estado Lara. 
1984

Bienal Nacional de Artes Visuales de Maracaibo. Maracaibo, estado Zulia.

1985

Salón de Arte de la Galería Municipal de Girardot. Barquisimeto. Barquisimeto, estado Lara.

1986

Bienal Nacional de Arte de Guayana. Museo de Arte Moderno Jesús Soto. Puerto Ordáz, ciudad Bolívar.

- Bienal de Arte Alejandro Otero. Museo de Alejandro Otero. Caracas, Distrito Capital.

- Bienal de Artes Visuales de Oriente. Museo Gran Mariscal de Ayacucho. Cumaná, estado Sucre.

- Bienal Nacional de Arte de Oriente. Ateneo de Cumaná. Cumaná, estado Sucre.

- Bienal Salvador Valero de Arte Popular. Museo de Arte Popular Salvador Valero. Valera, estado Trujillo.

1987

Salón de Arte del Caribe. Museo de Arte de Coro. Coro, estado Falcón.

1988

Bienal de Artes Visuales. Museo de Bellas Artes de Caracas. Caracas, Distrito Capital.

\section{Década de los años 90:}

1991

Bienal Nacional de Artes Plásticas de Puerto la Cruz. (Patrimonio Cultural desde 2007). Galería Municipal de Arte de Puerto la Cruz. Puerto la Cruz, estado Anzoátegui.

1992

Bienal Barro de América Roberto Guevara. Centro de Arte de Maracaibo Lía Bermúdez. Maracaibo, estado Zulia.

1990

Bienal de Artes Plásticas para estudiantes de la Universidad de los Andes. Galería la Otra Banda. Mérida, estado Mérida.

1990

Salón / Bienal de Jóvenes Valores Neoespartanos. Margarita, estado Nueva Esparta. 
Bienal de Arte Popular Salvador Valero. Núcleo Rafael Rangel de la Universidad de los Andes. Museo Salvador Valero. Trujillo, estado Trujillo.

1992

Bienal Nacional de Artes Visuales. Museo de Barquisimeto. Barquisimeto, estado Lara.

1992

Salón Nacional de Artes Visuales. Museo de Artes Visuales Alejandro otero. Caracas, Distrito Capital.

1992

Salón Anual de Artes Visuales Héctor Rojas Mesa. Ateneo de Cabudare. Cabudare, estado Lara.

1993

Feria Iberoamericana del Arte (FIA). Hotel Tamanaco. Caracas, Distrito Capital.

1993

Salón de Artes Plásticas Cristóbal Rojas. Caracas, Distrito Capital.

1993

Salón Pirelli. Museo de Arte Contemporáneo de Caracas Sofía Imber (MACCSI). Caracas, Distrito Capital.

1994

Bienal de Artes Plásticas Juan Lovera. Consejo Nacional de la Cultura. Caracas, Distrito Capital.

1996

Salón Nacional de Artes Visuales Dr. Francisco Lazo Martí Casa de la Cultura de Calabozo Calabozo, estado Guárico.

1997

Salón Nacional del Vidrio. Museo de Arte Contemporáneo Sofía Imber. Caracas, Distrito Capital.

1997

Salón CANTV, de Jóvenes con FIA. Galería de Arte Nacional. Caracas, Distrito Capital.

1998

Bienal Internacional de Arte de Cumaná. Museo de Arte Contemporáneo de Cumaná, estado Sucre.

1998

Salón Anual de Artes Visuales Juan Lovera. Caracas. 
Bienal de Artes Gráficas Juan Gurruceaga. Museo Carlos Cruz Diez. Caracas, Distrito Capital.

- Bienal del Vidrio. Galería Universitaria Braulio Salazar. Valencia, estado Carabobo.

1999

Salón de Arte Ciudad de Juan Griego. Juan Griego, estado Nueva Esparta.

1999

Salón de Arte Digital. Museo de Arte Contemporáneo del Zulia. Maracaibo, estado Zulia.

1999

Salón de Arte Exxon Móbil. Museo de Bellas Artes. Caracas, Distrito Capital.

1999

Salón el Ajedrez en el Arte. Centro de Bellas Artes Maracaibo. Maracaibo, estado Zulia.

Década de los años 2000:

2000

Salón Universitario de Arte. Galería Universitaria de Arte de la Universidad Central de Venezuela. Caracas, Distrito Capital.

2003

Mega Exposición. Estados: Amazonas, Anzoátegui, Apure, Aragua, Barinas, Bolívar, Carabobo, Cojedes, Delta Amacuro, Distrito Capital, Falcón, Guárico, Lara, Mérida, Monagas, Nueva Esparta, Portuguesa, Sucre, Táchira, Trujillo, Vargas, Yaracuy ,Zulia.

Salón de Artes Visuales Dycvensa. Caracas, Distrito Capital.

2004

Bienal de Escultura Trazos. Galería de Arte Trazos. Caracas, Distrito Capital.

2005

Salón de Arte Descentral. Galería de Arte Trazos. Caracas. Mega Exposición II. Estados: Amazonas, Anzoátegui, Apure, Aragua, Barinas, Bolívar, Carabobo, Cojedes, Delta Amacuro, Distrito Capital, Falcón, Guárico, Lara, Mérida, Monagas, Nueva Esparta, Portuguesa, Sucre, Táchira, Trujillo, Vargas, Yaracuy ,Zulia. 
Bienal del Fuego. Museo de Bellas Artes de Caracas. Caracas, Distrito Capital.

2006

Bienal de Arte al Aire Libre. Caracas, Distrito Capital.

2006

- Salón de Artes Visuales Demetrio Silva. Aeropuerto Internacional Ezequiel Zamora. San Carlos, estado 2007 Cojedes.

- Bienal Salón Arturo Michelena. Centro Cultural y Deportivo Don Bosco del municipio de Naguanagua, estado Carabobo.

- Bienal de Pequeño Formato. Maracay, estado Aragua.

- Bienal Nacional de Artes Visuales Estado Barinas. Galería Universitaria de la Universidad Experimental de los Llanos Occidentales Ezequiel Zamora (UNELLEZ). Barinas, estado Barinas.

- Salón de Artes Visuales y del Espacio. Museo de Artes Visuales y del espacio. San Cristóbal, estado Táchira.

- Salón de Arte Joven Banco Caroní. Museo Alejandro Otero. Caracas, Distrito Capital.

- Salón de Artes del Fuego Sol de Cojedes. Aeropuerto Internacional Ezequiel Zamora. San Carlos, estado Cojedes.

- Festival Internacional del Fuego. Museo Carmelo Fernández. San Felipe, estado Yaracuy.

- Salón Caroní. Museo Alejandro Otero. Caracas, Distrito Capital.

I Salón Nacional "Lo uno y lo diverso. Confrontación de arte sobre papel”. Galería Universitaria Braulio Salazar de la Universidad de Carabobo. Valencia, estado Carabobo. 
Tal y como hemos mencionado anteriormente, en el campo de la orfebrería venezolana comenzó a gestarse un cambio significativo con la primera y única exposición titulada "I Salón de la Nueva Orfebrería Venezolana" el año 1976. En la cual, la intervención de escultores y otros artistas plásticos fue determinante; pues, con una visión particular, relacionaron aspectos importantes de su producción artística con técnicas, formatos y metales propios de la orfebrería.

Algunos artistas desde entonces, han continuado de manera inequívoca en esa nueva visión, y la unión paradójica de materiales y metales no convencionales en las joyas, han sentado las bases que constituyen el marco teórico argumentado en esta investigación. En tal sentido, hemos podido evidenciar que, en las ediciones del "Salón Nacional de las Artes del Fuego", del "Salón Nacional de Orfebrería" y "Bienal de Artes Plásticas para estudiantes de la Universidad de los Andes en Venezuela", esta disciplina ha venido dando pasos firmes y agigantados, ya que, obras con esta nueva tendencia de la orfebrería, han obtenido el máximo galardón.

Esto demuestra que entre formas, tendencias, formatos, y conceptos, la orfebrería escultórica se ha convertido en un verdadero lenguaje plástico capaz de adaptarse a cualquier disciplina artística del arte actual.

\section{CAPÍTULO 2}

\section{VISIÓN ACTUAL Y PERSPECTIVAS DEL ORFEBRE VENEZOLANO}

\subsection{EL ORFEBRE VENEZOLANO ACTUAL. Propuesta nacida de una} investigación de campo.

2.1.1. DATOS DE LA POBLACIÓN ENCUESTADA. Características más importantes.

Tomando en cuenta el tema de estudio del Primer Capítulo, en el contexto de la orfebrería venezolana, pudimos manifestar algunos aspectos y ciertas características, que han sido fundamentales en el desarrollo de la disciplina de la orfebrería en Venezuela. Debido a que hasta ahora, no conocemos un estudio completo sobre el tema, decidimos realizar una investigación de campo para obtener información actualizada. Para ello, decidimos aplicar un cuestionario a un grupo de orfebres, cuyas respuestas muestren de manera general y fidedigna como ha sido su formación, cuales son las tendencias que abordan, cuales son los estilos que caracteriza su obra, cuales son las técnicas más recurrentes en su 
producción, cuales materiales utilizan y que repercusión ha tenido su obra en el medio expositivo venezolano. Basándonos en esto, poder crear el perfil del orfebre venezolano actual. Tomando en cuenta los aspectos mencionados, los hemos enumerado en orden de importancia:

Inicio en la orfebrería.

Tipo de educación recibida en orfebrería.

Taller propio de orfebrería.

Metales usados en orfebrería.

Materiales usados en orfebrería.

Estilo en la orfebrería.

Técnicas usadas en orfebrería.

Convergencia entre orfebrería y escultura.

Año de convergencia entre orfebrería y escultura.

Participación en salones de arte con orfebrería.

Premios obtenidos en salones de arte con orfebrería.

Una vez clasificados estos aspectos, desglosamos de cada uno de ellos las características necesarias para precisar las preguntas; para ello, tratamos de ser lo más objetivos posible para obtener respuestas cerradas (Si ò No), pues, esto nos garantizaría de manera precisa la objetividad de la información. Finalmente, concretamos el cuestionario en once preguntas.

Con la colaboración de algunos orfebres pudimos obtener los correos electrónicos, teléfonos y domicilio de otros orfebres, para hacerles llegar el cuestionario. Concretándose en un universo de 340 orfebres a los cuales fue enviada la encuesta y 25 orfebres encuestados y entrevistados personalmente.

\subsubsection{RESULTADOS DEL CUESTIONARIO APLICADO. Muestra de Gráficos. Generalidades.}

El cuestionario se concretó en 11 preguntas y la encuesta se llevó a cabo en dos etapas: la primera en el año 2007 y la segunda en el año 2010.

Así pues, en la primera etapa -año 2007- el cuestionario desarrolló 9 preguntas y se concluyó con la participación de 30 orfebres; siendo usados ya, en el Trabajo de Investigación "Producción artística de Alexis De la Sierra en la Venezuela actual" -con el cual se obtuvo el DEA, año 2009-.

Para la segunda etapa de la encuesta, que se realizó en el año 2010, lo cual concluyó con la participación de otros 37 orfebres. Para esta ocasión, mejoramos el cuestionario agregando 2 preguntas, pues, estas nos conducirían hacia la repercusión en el medio expositivo venezolano actual. 
Ahora bien, para aprovechar los resultados de la primera investigación de campo, enviamos las dos nuevas preguntas a los treinta orfebres anteriormente encuestados.

De este modo, la muestra fue de 67 orfebres entre el 2007 al 2010 todos ellos residentes entre las ciudades de Caracas, Valencia, Boconó, Barquisimeto y Mérida.

Al procesar todas las encuestas, pudimos aseverar en primera instancia que la muestra reunida variaba entre:

- Orfebres que han sido ganadores del Premio Nacional de las Artes Fuego, en el Salón Nacional de las Artes del Fuego ("SNAF").

- Orfebres que han sido ganadores del Premio Nacional, en el Salón Nacional de Orfebrería ("SNO”).

- Orfebres que se dedican a la docencia en orfebrería, paralelamente a su producción artística.

- Orfebres que tienen otra profesión y en paralelo han conseguido a través de esta disciplina sustento económico.

- $\quad$ Orfebres que viven de su producción en orfebrería, pero no participan en salones de arte.

- Orfebres que se dedican a la orfebrería, con fines ocupacionales

A continuación, mostraremos con gráficos las respuestas de las 11 preguntas del cuestionario aplicado, que manifiesta en porcentajes los aspectos y características más relevantes de la producción de los orfebres venezolanos de la época actual.

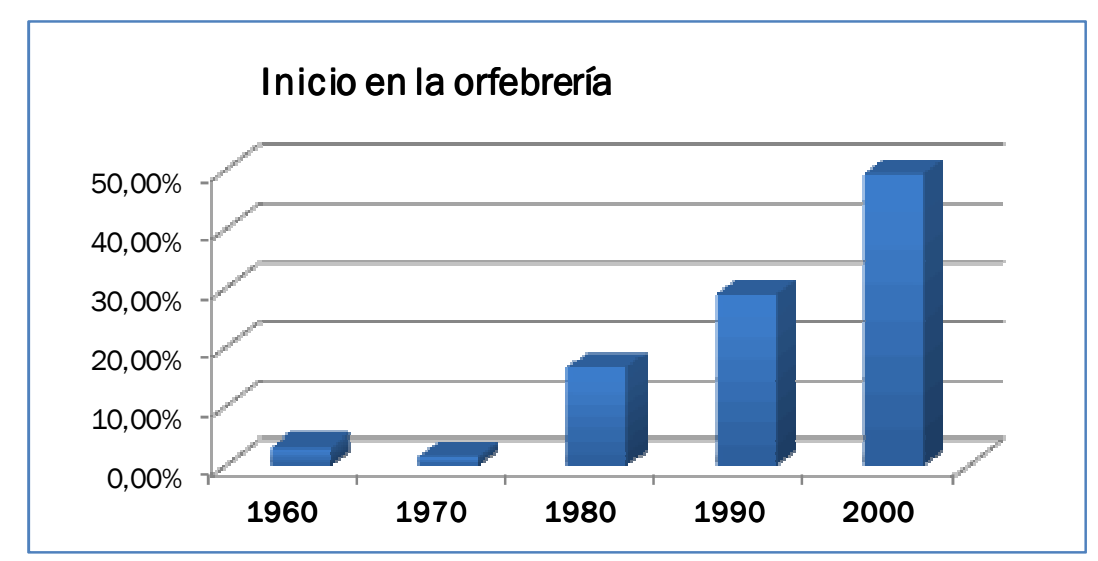

Gráfico 1. Inicio en la orfebrería por décadas.

En el Gráfico 1 se muestran las respuestas de la pregunta número 1 del cuestionario, que indica ¿Año de inicio en la orfebrería? Como se puede observar, entre la década del sesenta $(2,98 \%)$, y la 
del setenta (1,49\%) fue poco desarrollada; sin embargo, comprobamos que la del sesenta fue a través del intercambio entre artistas de otras dependencias artísticas y la del setenta ocurrió con el intercambio entre artesanos. Se aprecia una tendencia de crecimiento desde la década de los ochenta $(16,41 \%)$. Década esta, en la cual apreciamos un contundente impulso, debido al aporte del orfebre Alexis De la Sierra, pues, con esta disciplina gana el Premio Nacional de las Artes del Fuego en el importante "SNAF" en Venezuela y crea su Escuela de Orfebres, en la ciudad de Caracas; siendo éste, el primer eslabón de la cadena de Talleres que existen actualmente en el país. También, corroboramos que muchos alumnos formados por él, establecieron talleres de enseñanza tanto en Caracas como en otras ciudades del interior de Venezuela.

En la década de los noventa (29,85\%), la orfebrería crece con pasos firmes, debido a la apertura de otros talleres privados de enseñanza y la creación de la Asociación Venezolana de la Artes del Fuego ("AVAF"); capacitando a nuevos y expertos, con cursos de especialización en las disciplinas que la componen.

En la década del dos mil (49,25\%), se percibe un aumento significativo en el desarrollo de la disciplina. Para ese entonces, la popularidad de la orfebrería en Venezuela trascendió en diversos estratos, tanto por la apertura de nuevos talleres privados de enseñanza, nuevos espacios expositivos y su inclusión en los salones de arte en Venezuela.

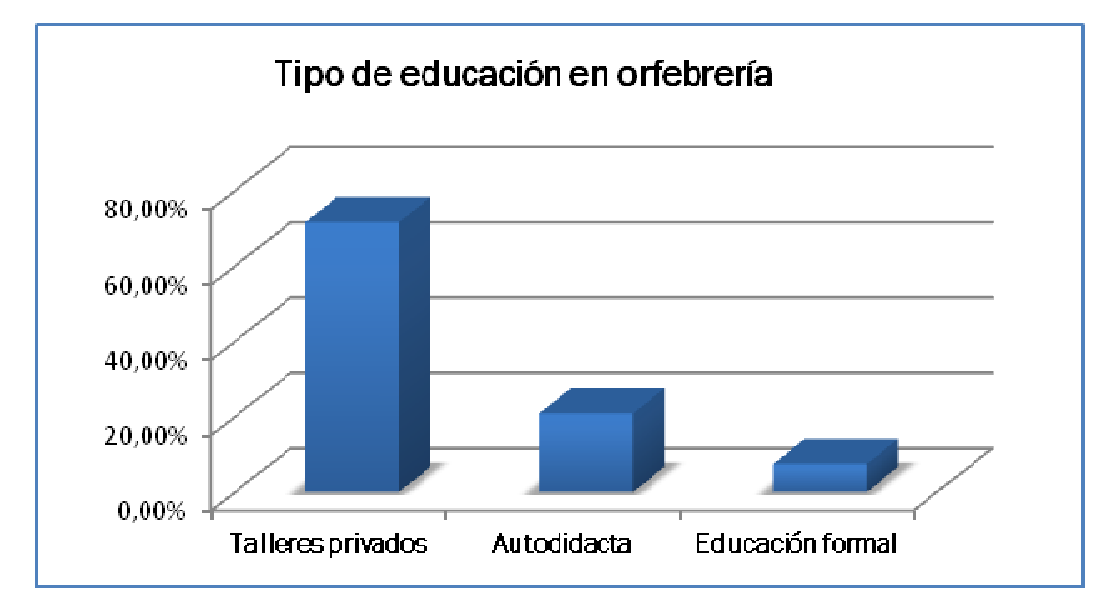

Gráfico 2. Tipo de educación recibida en orfebrería

En el Gráfico 2 se muestran las respuestas de la pregunta número 2 del cuestionario, que indica ¿Cómo aprendiste a trabajar en orfebrería? Como podemos observar, la gran mayoría de los orfebres, se han introducido en la disciplina a través de los talleres privados (71,64\%). Coincidiendo entre alguno de ellos, que la introducción ocurrió con fines ocupacionales, por la curiosidad 
debido a la popularidad en los medios así como también, por el interés en la orfebrería con fines comerciales y por la búsqueda de un lenguaje plástico.

Los orfebres cuya formación ocurre de manera autodidacta (20,89\%), se debió, al intercambio entre artesanos de diferentes tipologías, como la cerámica, la cestería, los tejidos y la orfebrería; lo cual resultó en una hibridación bien interesante. Así como también, su formación autodidacta se debió al estudio a través de bibliografía especializada y a través de internet.

El pequeño grupo de orfebres cuya formación en orfebrería se debió a la educación formal $(7,46 \%)$, ocurrió, por medio de asignaturas optativas en carreras universitarias. Así como también, en la especialización en institutos de educación superior, con titulación en técnico superior y técnico medio.

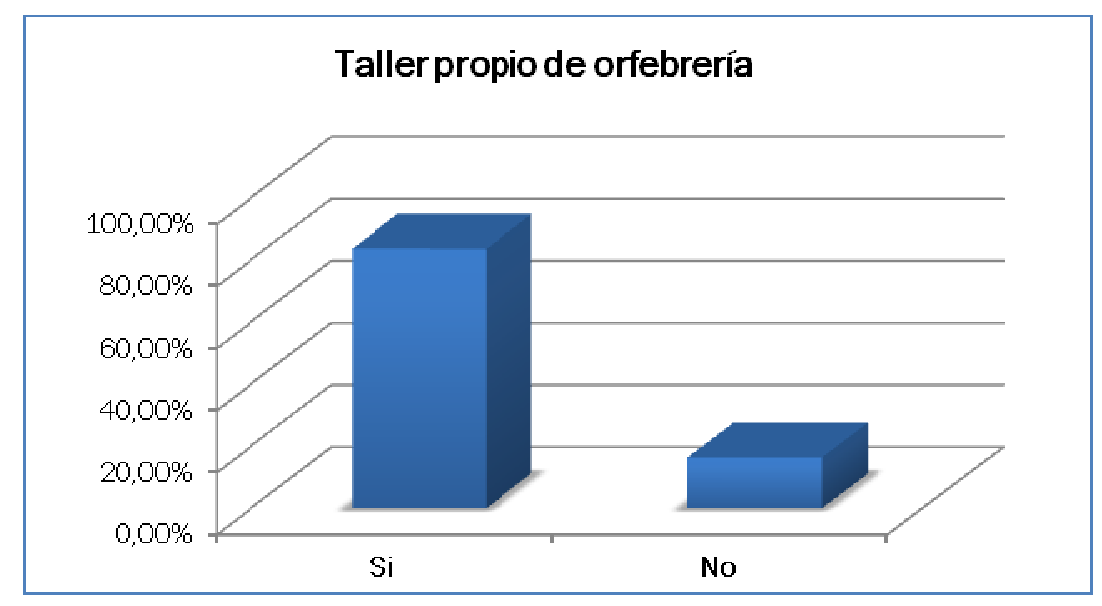

Gráfico 3. Taller propio de orfebrería.

En el Gráfico 3 se muestran las respuestas de la pregunta número 3 del cuestionario, que indica ¿Posees taller propio de orfebrería? Observamos, que la gran mayoría de los orfebres si tienen taller propio donde trabajar $(83,58 \%)$ y hemos comprobado, que muchos de estos, son talleres compartidos con otros orfebres, donde mancomunadamente adquirieron los equipos y maquinarias; donde cada quien, tiene su propio espacio de trabajo. Del grupo de orfebres que no tienen su taller propio $(16,41 \%)$, se trata de algunos que se encuentran en la fase de iniciación en la disciplina; parte de este grupo, trabajan en los talleres de enseñanza, pues, la gran mayoría, tienen horarios de uso del taller fuera de las clases. 


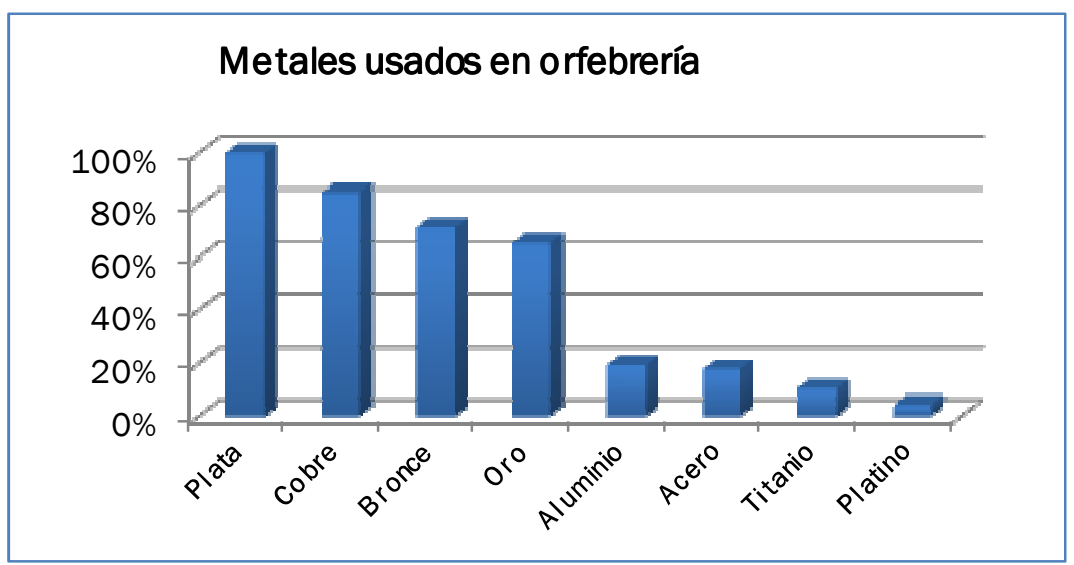

Gráfico 4. Metales usados en orfebrería.

En el Gráfico 4 se muestran las respuestas de la pregunta número 4 del cuestionario, que indica ¿Con cuál de estos metales trabajas en orfebrería? Podemos aseverar, que todos los orfebres usan la plata en la fabricación de sus obras (100\%). Seguidamente, con el mismo orden de importancia usan el cobre (80, 59\%), bronce $(71,64 \%)$ y oro $(65,67 \%)$; obviamente, que la preferencia en el uso de la plata tiene que ver con varios aspectos. Principalmente, con la facilidad en su adquisición y por supuesto por su condición en la apariencia y su maleabilidad. Los metales del aluminio $(19,40 \%)$, acero $(17,91 \%)$, titanio $(10,44 \%)$ y platino $(4,47 \%)$, demuestra que su utilización e inclusión en las obras, no ha sido tan recurrente quizá en unos, por su alto costo o también por su difícil manipulación; lo cual, requiere muchas horas de trabajo lo cual aumenta su valor y esto dificulta su comercialización.

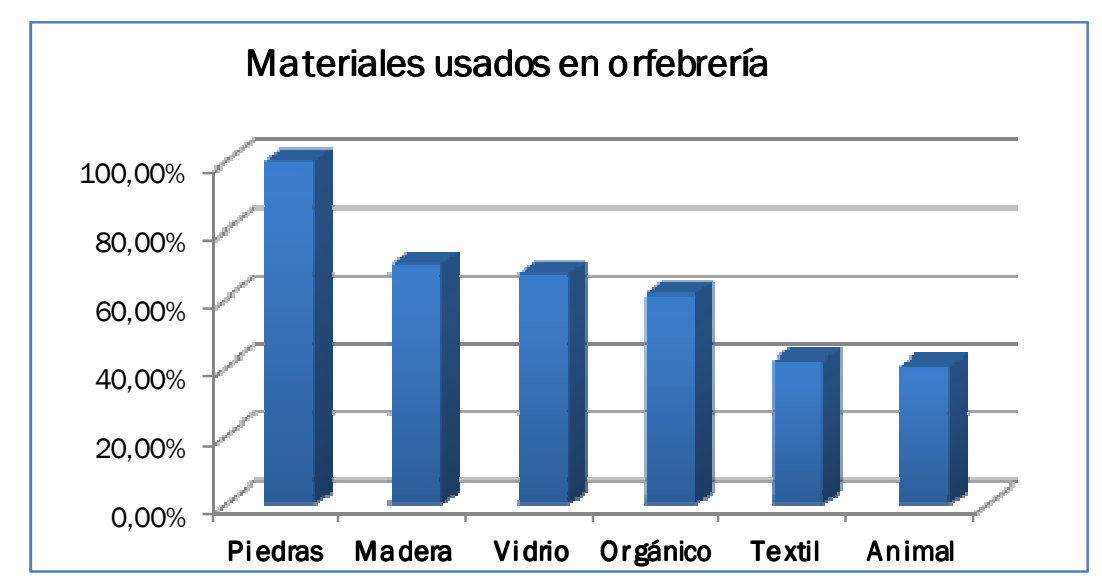

Gráfico 5. Materiales usados en orfebrería.

En el Gráfico 5 se muestran las respuestas de la pregunta número 5 del cuestionario, que indica ¿Con cuál de estos materiales trabajas en orfebrería? Se observa, que todos los orfebres usan las piedras en sus obras (100\%); indiscutiblemente, la apariencia que 
esta le aporta a la pieza, es incuestionable, pues, la magnífica variedad de piedras que existen, resulta provocativa para su inclusión. A continuación, observamos el recurrente uso de madera $(70,14)$; podemos asegurar, que se debe a la fácil manipulación y la riqueza de sus tonalidades y vetas que se complementan muy bien con el brillo de los metales. En un mismo orden de importancia, se encuentran el vidrio $(67,16 \%)$ y lo orgánico (61,19\%); quizá, la iridiscencia del vidrio explique su usanza, cuya variedad permite crear piezas atractivas entre tonos translucidos, mate o brillantes. Efectivamente, el uso de elementos orgánicos, resulta en una apariencia natural donde la heterogeneidad entre el exótico colorido de las semillas y algunos fósiles intervienen en las piezas logrando una apariencia fascinante. En cuanto a la integración de textil (41,79\%) y animal (40,29\%), consideramos, corresponde al vínculo de las fibras artesanales; donde, lo particular de la apariencia animal, entre colmillos, dientes y garras de animales salvajes y el exótico plumaje de las aves autóctonas resultan en obras muy sugestivas, que resultan en un complemento estupendo para la vestimenta.

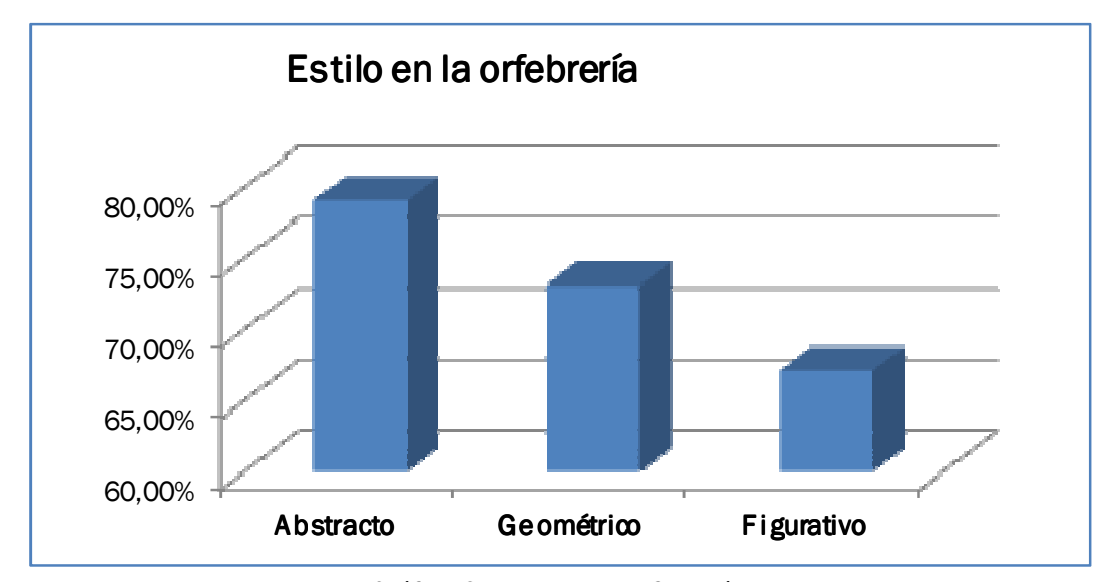

Gráfico 6. Estilo en la orfebrería.

En el Gráfico 6 se muestran las respuestas de la pregunta número 6 del cuestionario, que indica ¿Cuál de estos estilos caracterizan tu obra? Efectivamente observamos, que el estilo abstracto es el más utilizado (79,10\%); esto deviene quizás, de la inclusión de disímiles elementos, argumentados por la subjetividad del autor en una fisionomía exclusiva, que se aleja de los parámetros de la figuración. El estilo geométrico se emplea con autoridad (73,13\%); posiblemente, debido a la preferencia por un estilo moderno, donde la simplicidad, simetría y proporción, instauran un diseño limpio, de rasgos minimalistas. Por supuesto, que la figuración $(67,16 \%)$, deviene de la imperiosa necesidad del modelo figurado, donde su apariencia está supeditada a la realidad. 


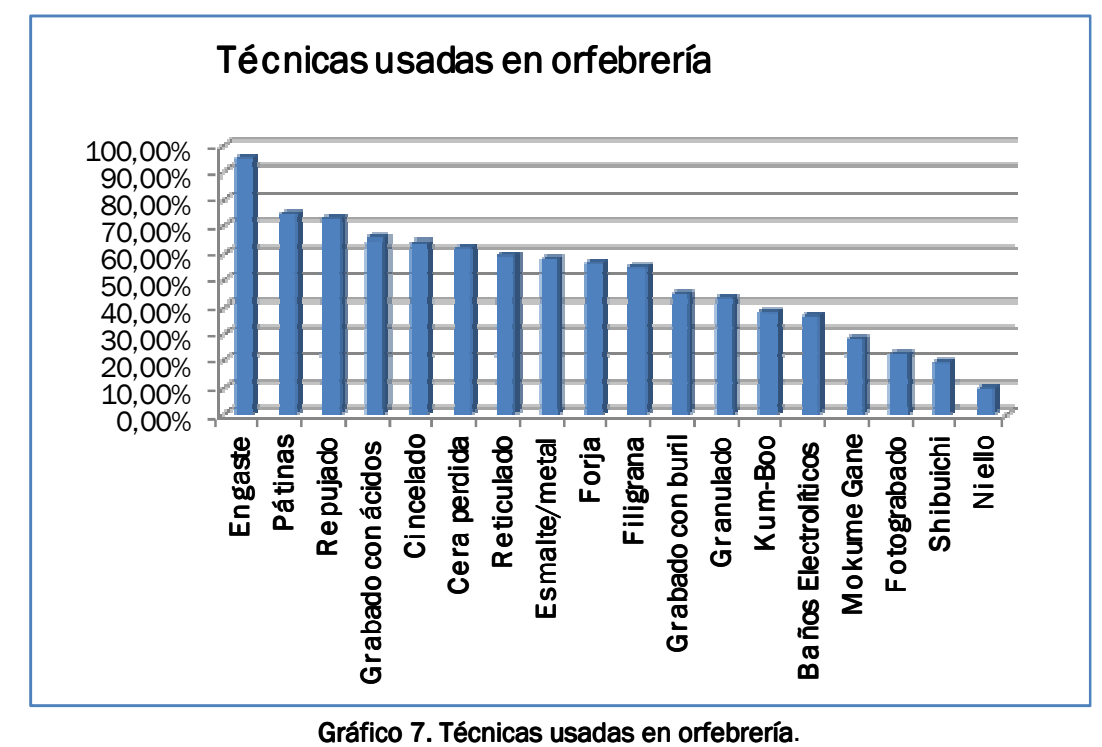

En el Gráfico 7 se muestran las respuestas de la pregunta número 7 del cuestionario, que indica ¿Cuál de estas técnicas dominas y aplicas en orfebrería? Perceptiblemente, podemos confirmar, que la formación del orfebre venezolano actual está muy bien sustentada, pues, la complejidad que tiene cada una de estas técnicas, demuestra la potestad e integridad ante su proceso creativo; en tal sentido, manifestamos con datos precisos su aplicación: Engaste (95,52\%), Pátinas (85,07\%), Repujado (73,13\%), Grabado con ácidos (65,67\%), Cincelado $(64,17 \%)$, Cera perdida (62,68\%), Reticulado (59,70\%), Esmalte sobre metal $(58,20 \%)$, Forja $(56,71 \%)$, Filigrana $(55,22 \%)$, Grabado con buril $(44,77 \%)$, Granulado $(43,28 \%)$, \%), Kum-Boo (38,80\%), Baños Electrolíticos (37,31\%), Mokume Gané (28,35\%), Fotograbado $(22,38 \%)$, Shibuichi $(19,40 \%)$, Niello $(10,44 \%)^{71}$.

Esta magnífica eventualidad, insinúa sobre la excelente labor que han realizado los distintos talleres de enseñanza en el país; pues, la insistencia, de los maestros actuales en enseñar estas complejas técnicas, permite afianzar su autonomía, permitiendo que sea abordada con devoción y convicción en el competitivo y exigente mundo de la joyería.

${ }^{71}$ Ver en el apartado de GLOSARIO DE TERMINOS el significado de cada una de las técnicas mencionadas en el Gráfico 7. 


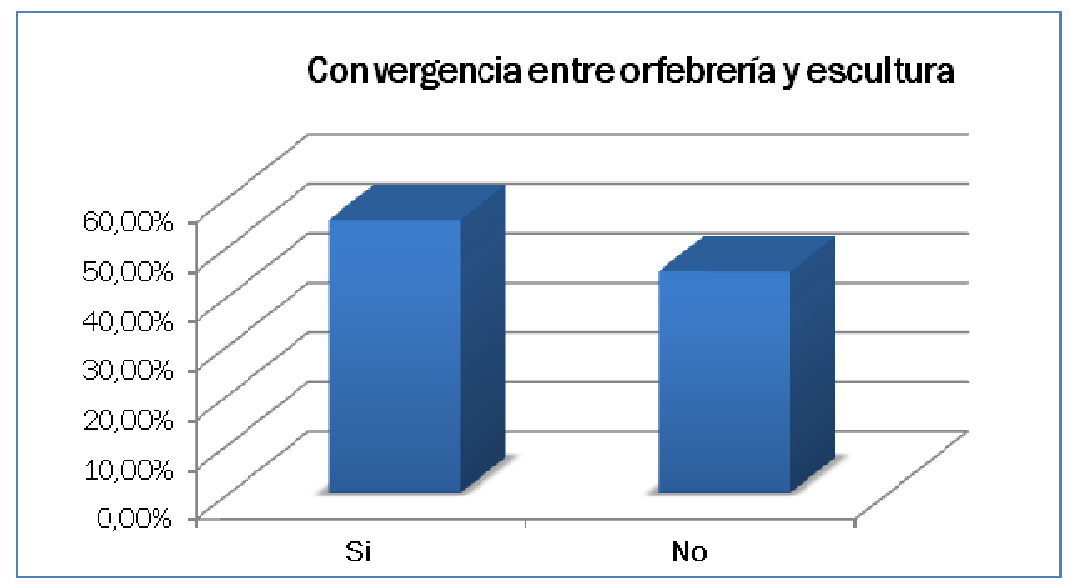

Gráfico 8. Convergencia entre orfebrería y escultura.

En el Gráfico 8 se muestran las respuestas de la pregunta número 8 del cuestionario, que indica ¿Existe convergencia entre orfebrería y escultura en tu obra? Esto afirma, que en más de la mitad $(55,22 \%)$ de los orfebres venezolanos de la época actual existe convergencia entre ambas disciplinas. Perceptiblemente, aseveramos que alcanzaron los límites de la ornamentación de una joya; donde su dimensión ceñida al cuerpo humano, exigió más espacio, por eso se adentra en otros formatos donde la joya se aproxima a una tendencia multidisciplinar sin desvirtuar su esencia. Estos datos muestran, que en la orfebrería venezolana actual, existen dos vertientes: la ornamental y la escultórica. Sin embargo, los datos del gráfico, reflejan que existe un grupo importante de orfebres que se mantienen en la orfebrería con los argumentos de una joya como ornato al cuerpo (44,78\%); lo cual no quiere decir, que sus joyas se ciñan a diseños clásicos o anticuados, pues, cada vez más, estas joyas adquieren y se apropian de un semblante más escultórico debido a la inclusión de elementos, materiales y conceptos de otras disciplinas artísticas.

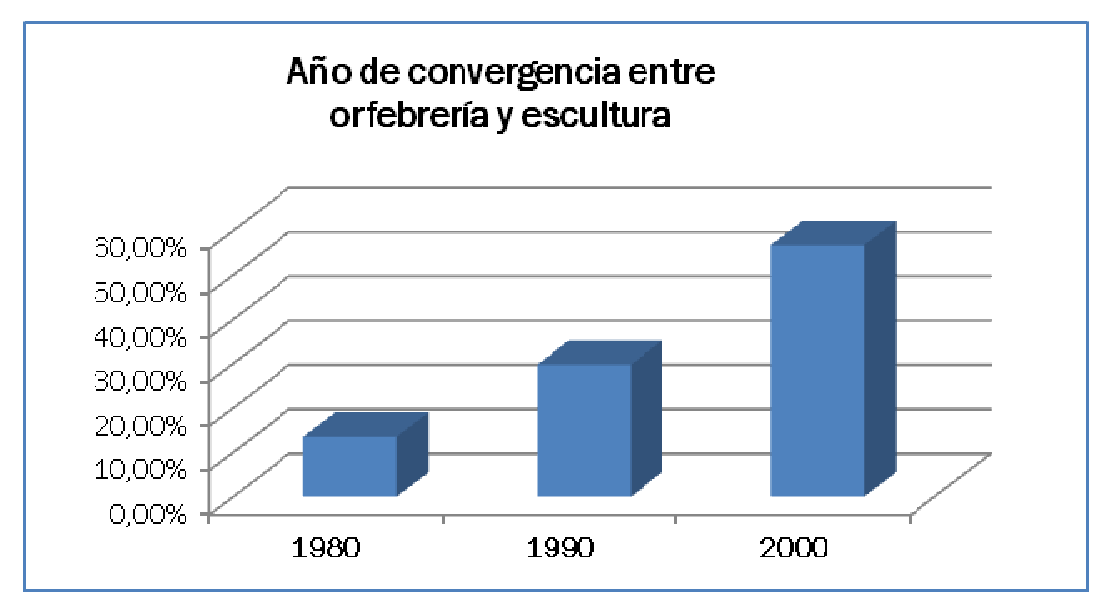

Gráfico 9. Año de convergencia entre orfebrería y escultura 
En el Gráfico 9 se muestran las respuestas de la pregunta número 9 del cuestionario, que indica ¿Desde qué año existe convergencia entre orfebrería y escultura en tu obra? Fundamentándonos en el porcentaje de orfebres que hace convergencia entre orfebrería y escultura podemos observar que esto ocurre desde la década de los ochenta $(13,51 \%)$. Ya para la década de los noventa $(29,72 \%)$ el aumento significativo de la convergencia entre la orfebrería y la escultura insinúa un beneficio para la disciplina con esta fusión. En la década del dos mil (56,75\%), como se aprecia, definitivamente la convergencia entre estas dos disciplinas ya anuncia la nueva tendencia: la orfebrería escultórica.

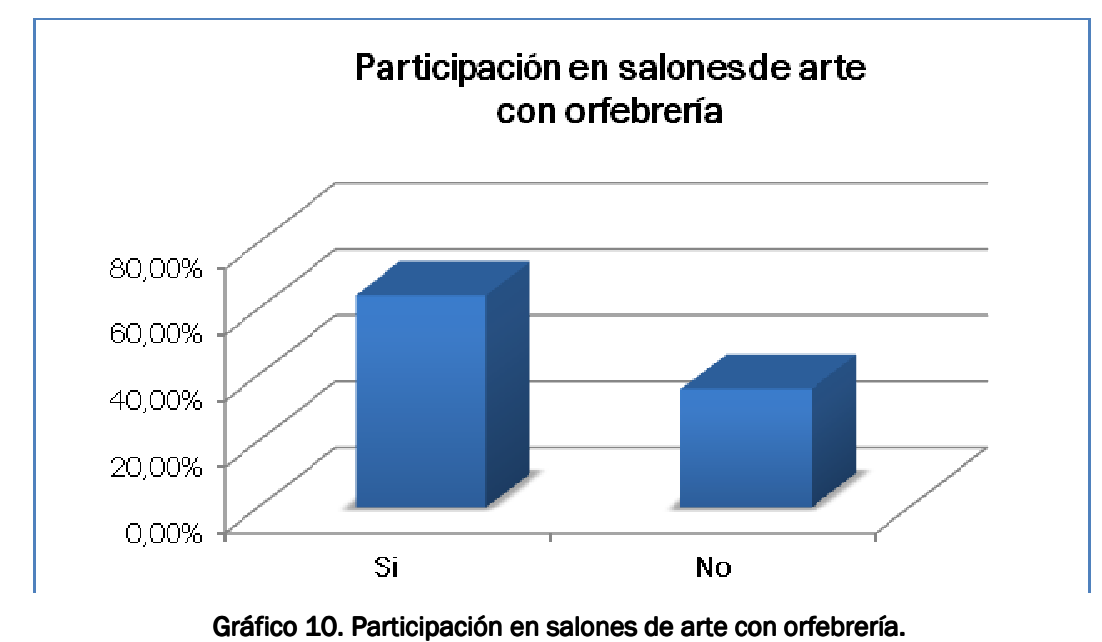

En el Gráfico 10 se muestran las respuestas de la pregunta número 10 del cuestionario, que indica ¿Participas en salones de arte con piezas de orfebrería? Como podemos observar, la mayoría de los orfebres de la época actual participan en salones de arte con piezas de orfebrería $(64,17 \%)$; esto muestra, dos vertientes importantes para la disciplina. Por un lado, que los orfebres, están invadiendo el campo artístico expositivo con la orfebrería en cualquiera de sus tendencias. $Y$ por el otro lado, que algunos salones de arte en Venezuela en la actualidad, han reconocido la autonomía de la orfebrería como una disciplina artística. Tomando en cuenta la respuesta de los orfebres que no participan en salones de arte con sus obras (35,82\%), puede explicarse en varios aspectos. De esta cantidad de orfebres, algunos abordan su obra en orfebrería con fines ocupacionales; otros, la abordan con fines comerciales y otros consideran que aún no están preparados para participar a nivel de salones de arte. 


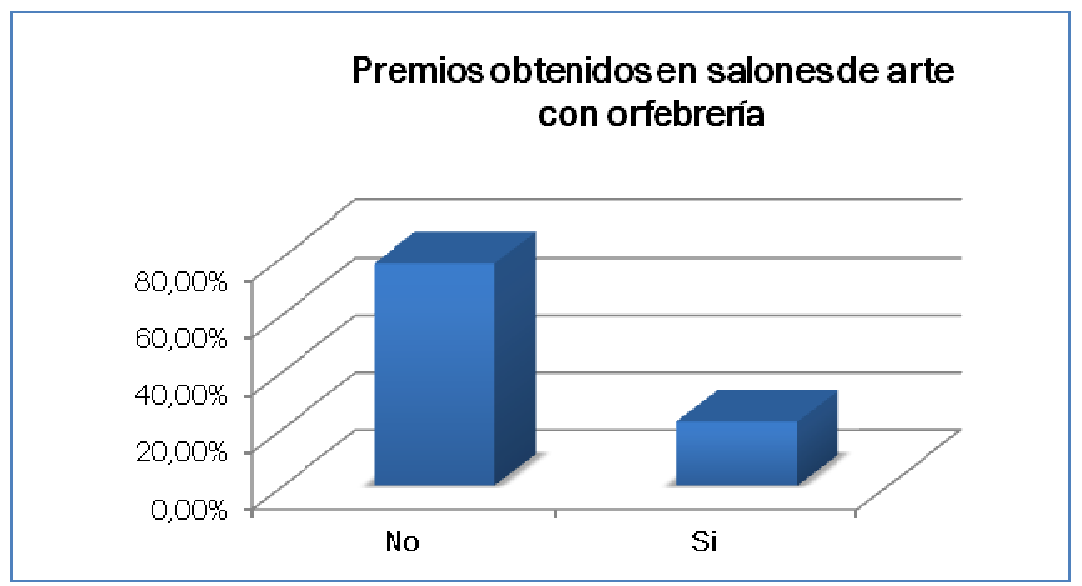

Gráfico 11. Premios obtenidos en salones de arte con orfebrería.

En el Gráfico 11 se muestran las respuestas de la pregunta número 11 del cuestionario, que indica ¿Has obtenido algún reconocimiento nacional o internacional con orfebrería? Como podemos observar, la gran mayoría de los orfebres no ha obtenido ningún reconocimiento $(77,61 \%)$. Sin embargo, la aceptación de su obra en salones de arte tiene gran significación; pues esto muestra, que sus obras se ajustan a los criterios artísticos de selección. La otra cantidad de orfebres que si han obtenido reconocimiento en salones de arte con esta disciplina, tanto en Venezuela como en el extranjero (22,29\%), representan una muestra de menor cantidad. Sin embargo, certifica por expertos en las artes, que la obra del orfebre venezolano ha conseguido un lenguaje plástico multidisciplinar; donde la destreza, genialidad, simbología, excelente factura, y la devoción hacia la disciplina, se ajusta a las tendencias artísticas actuales.

\subsubsection{PERFIL DEL ORFEBRE VENEZOLANO ACTUAL. Valoración} personal.

Tomando en cuenta los resultados del cuestionario aplicado del cual hablamos en el punto anterior, hemos elaborado un perfil del orfebre venezolano actual. Perfil este, manifiesta de manera general, los aspectos y las características más importantes de su producción artística; ahora bien, fundamentándonos en ello, comprobamos que, el orfebre formado en esta disciplina entre la década de los sesenta y setenta produce de manera fluctuante, entre talleres privados y del intercambio entre artesanos. Así como también, su praxis heterogénea se ciñe entre los cánones clásicos de la alta joyería y la tradición entre lo artesanal y lo autóctono de algunas culturas ibérico y sur-americana.

A partir de la década de los ochenta, algunas personas en la búsqueda de una terapia ocupacional -como así lo llamarontomaron cursos con el reconocido orfebre Alexis De la Sierra en su 
Escuela de Orfebres en la ciudad de Caracas, lo cual, repercutió de manera inmediata en la difusión y promoción de la disciplina; pues, la gran mayoría de los participantes en el "SNAF" en Venezuela, fueron alumnos formados por él. Esto, motivó a otras personas de su entorno, en tomar los cursos y por ende su inclusión en el medio expositivo. Del mismo modo, se sabe que algunos ex alumnos de su Escuela de Orfebres, establecieron otros talleres privados de enseñanza tanto en Caracas, como en el interior del país; formando otra gran cantidad de orfebres.

Para la década de los noventa, la popularidad del orfebre, alcanzó varios estratos, pues, la organización de exposiciones individuales y colectivas, dentro de los mismos talleres, galerías, museos, clubes, consulados y en salones de arte; motivó categóricamente la apertura de otros centros de enseñanza. La sana competitividad entre ellos, permitió que la enseñanza se especializara cada vez más. En este sentido, un grupo selecto de artistas especialistas en la cerámica, esmaltes al fuego, orfebrería y el vidrio, fundaron la "Asociación Venezolana de las Artes del Fuego" ("AVAF"); siendo su punto de encuentro anualmente, durante el marco de la celebración de la exposición del "SNAF", donde, ofrecieron talleres prácticos de capacitación a los novatos y talleres de especialización a los artistas ya formados, en las diversas tendencias que congregan esas artes. Esto, de alguna manera, originó una oleada, que abarca otras dependencias, pues, unos centros de estudio en educación superior incluyen a la orfebrería en asignaturas optativas en algunas carreras, así como también, otros centros de estudio, logran estructurar aquellas carreras que compete a las artes plásticas, consiguiendo menciones en las artes del fuego. Esto fue de gran significación para el orfebre, pues, pudieron abordar a la orfebrería con fundamentos más artísticos/escultóricos con un criterio académico importante.

Ya para la década del dos mil, el orfebre venezolano se consigue con un panorama amplio tanto para su formación, como para su desarrollo artístico; por un lado, la apertura de una gran cantidad de talleres de enseñanza, donde cada uno adjudica su autoridad, tomando en cuenta las nuevas vertientes de la joyería contemporánea, dejando honda huella en sus alumnos -y por ende en las piezas que ellos ejecutan-. La inclusión de semblantes particulares que devienen de la fusión de la orfebrería con otras profesiones, pues, esto se evidencia en repetidas ocasiones, con la obtención del Premio Nacional de las Artes del fuego en el "SNAF" por arquitectos y otros profesionales, que han establecido un estupendo lenguaje artístico a través de la orfebrería. Así como también, la motivación que se ha generado por la apertura de nuevos sitios expositivos, donde la confrontación entre sus propuestas, demuestra la integridad de su formación y revela su seña de identidad. 
Una particularidad que observamos en los orfebres de la época actual, es que la gran mayoría, poseen un taller propio para trabajar; esto de algún modo, les garantiza comodidad e intimidad en su proceso de realización. También podemos aseverar, que algunos talleres de enseñanza tienen horarios para su uso, fuera de las clases habituales, lo cual permite la constancia en la práctica de esta disciplina.

Ahora bien, basándonos en la producción del orfebre venezolano, apreciamos una fisionomía bien interesante que se bifurca en dos tendencias: la orfebrería ornamental y la orfebrería escultórica. Dentro de la orfebrería ornamental, conseguimos dos semblantes interesantes, siendo el primero, aquel orfebre que se ciñe a los cánones clásicos de la joyería; pues, de manera conservadora, se mantiene fiel con sus dimensiones y el uso de metales y piedras preciosas, donde su producción, se enfoca en joyas para el ornato al cuerpo. $Y$ en el segundo semblante, se encuentran aquellos orfebres que integran metales, materiales y conceptos de otras dependencias para la elaboración de sus joyas; obviamente, esta última combinación, les permite concebirlas con otra fisionomía, donde el semblante escultórico se apropia de ellas, pero siguen siendo joyas ornamentales.

Entre aquellos orfebres que abordan la disciplina con una tendencia escultórica, conseguimos dos grupos. Por un lado, el orfebre que se pasea entre la ornamentación y lo escultórico; manteniendo la autonomía de cada una. Y por el otro lado, conseguimos aquellos orfebres que enfocan su orfebrería solamente al campo escultórico; grupo este, encontramos que desarrollaron un lenguaje plástico, fusionando de manera explícita a la orfebrería con la escultura, donde la heterogeneidad entre todos los elementos que las componen, llámese: metales, técnicas, materiales y formatos, se reúnen armónicamente a través de una diferente apariencia que se sintetiza en una escultura. En la orfebrería escultórica, intervienen otras valoraciones, como por ejemplo: el espacio tridimensional en el que se exhibe.

En las obras del orfebre venezolano se aprecia el uso recurrente de diversos metales; considerando, que el país cuenta con algunas zonas mineras de distintos metales, principalmente el oro, le siguen, el aluminio, hierro y cobre y su comercialización es asequible. Sin embargo, este no es el punto único por lo que los utilizan, ya que su uso frecuente, refiere a las nuevas vertientes que ha conseguido la orfebrería.

Entonces, en primera instancia, apreciamos el uso recurrente de la plata, esto se debe en gran parte, porque no existe restricción para 
su adquisición, ni mucho menos por la cantidad y obviamente, por el semblante de su superficie y su maleabilidad.

La relevancia en la aplicación del cobre, bronce y oro resulta bien interesante, pues conseguimos que también sean muy usados y casi en la misma proporción; por supuesto, que la tonalidad de su superficie tiene mucho que ver, pero indudablemente, que su maleabilidad y bondad tiene gran significación, pues, estos permiten ser usados con facilidad en todas las técnicas. Sin embargo, la heterogeneidad de la orfebrería actual, ha conseguido la inclusión de otros metales como entes representativos, entre estos tenemos el aluminio, el acero y el titanio; de estos tres, el aluminio sobresale en su uso, puede ser porque puede obtenerse en diversos perfiles en grandes formatos preservando la belleza de su superficie. El uso del acero se encuentra en segundo orden de uso, quizá, por su tenacidad y rigidez y bella apariencia. Y el uso del titanio, por la exquisita coloración que adquiere su superficie al aplicarle el fuego. Con esporádica ocasión usan el platino, lógicamente, por el alto costo y su difícil manipulación.

La biodiversidad fascinante del territorio nacional, sitúa una gran cantidad de elementos que reflejan la autonomía de cada localidad. Estos materiales autóctonos, han resultado ser trascendentales en la inclusión de las piezas de los orfebres; así pues, la belleza de las piedras, la tez espectacular entre las maderas, las variopintas semillas de árboles y palmas, los delicados corales blancos, rojo y negro, las fascinantes perlas cultivadas en mar y rio, las sublimes conchas marinas, las oriundas fibras orgánicas, las exóticas plumas de aves, los enigmáticos fósiles y los contundentes cuernos, colmillos, dientes y garras de animales salvajes todas y cada una de ellas, fundamentan sus propuestas. Por eso, esta cualidad y simbología se han convertido en la esencia de sus piezas, con lo cual, se manifiesta el gentilicio del orfebre venezolano. Casualmente, la complejidad de la moda actual, repercute de manera significativa en la inclusión de alguno de estos materiales inverosímiles; con los que dichos materiales, han resultado un perfecto aderezo para sus joyas.

La variedad de estilos que revelan las propuestas del orfebre de la Venezuela actual, se congrega en tres géneros: el abstracto, el geométrico y el figurativo. El más recurrente de ellos, señala que el estilo abstracto sea la máxima representación. Esto, deviene de la intencionalidad de tipo formal y conceptual; pues suponemos que, por la singularidad de la praxis, el material y sobre todo el fundamento con los que argumentan su obra, reflejan la naturaleza del objeto idealizado bajo la subjetividad de su intelecto. 
En un segundo orden, conseguimos que el estilo geométrico sustente con demasía las obras de los orfebres. Quizá, por la convicción del predominio de la simetría, donde lo lineal domina la superficie a favor de trazos rectilíneos; desarticulando de facto, las formas curvas, pues su lectura, afianza rasgos decididos de contorno limpio y precioso y no existe la subjetividad para su apreciación.

En tercer orden de uso y no menos importante, ubicamos al estilo figurativo. Obviamente, suponemos que por su ideología a una imagen reconocible; donde la analogía de la forma con su realidad, se apropia de esta expresión, pues, transfigura en forma verosímil, idealizando o intensificando alguna de sus características. Consideramos que cada uno de estos estilos, refleja la personalidad del orfebre.

En las piezas de estilo abstracto, casi siempre, suelen ser el resultado de un trabajo espontaneo; donde lo inesperado sustenta sus propuestas. Las piezas de estilo geométrico, por lo general, suelen ser el resultado de un trabajo ordenado, sistemático, preciso y proporcionado donde no hay cabida para los errores. Y, en las piezas de estilo figurativo, generalmente son el resultado de un estudio meticuloso y detallista de una imagen reconocible; donde la similitud resulta de la elección adecuada de una técnica y la maestría que permite expresar con fidelidad esa realidad.

Tomando en cuenta sobre la producción del orfebre venezolano actual, podemos corroborar positivamente sobre el dominio y aplicación de diversas técnicas. Esto, señala de manera implícita, sobre su amplia formación y por ende, en su certeza a la hora de ejecutarlas; perceptiblemente, consideramos que esto se debe en gran parte a la insistencia de los talleres de enseñanza en preservar con verdadero juicio esta disciplina. E indudablemente, la aplicación recurrente en las obras de los orfebres, demuestra el interés en mantener su arraigo incluyéndolas en la nueva tendencia de la orfebrería.

Considerando esto, aseveramos que la hegemonía del uso del Engaste destaca entre todas las técnicas; ya que gracias a ella, en cualquiera de sus maneras, llámense: bisel, pavè, de grano o de garras, consiguen la inclusión adecuada de algún elemento en la superficie de la obra. En segunda instancia aseveramos la utilización recurrente de las Pátinas y el Repujado, pues debido a estas, acentúan con la tonalidad de las pátinas el valor de la textura.

Con la técnica del repujado, logran el volumen total o parcial en la superficie metálica; con lo cual, adquieren mayor expresión en su obra. Ahora bien, la obra del orfebre venezolano destaca con gran 
frecuencia, ciertos rasgos, que devienen de algunas texturas conseguidas a través de diversos elementos o de algunas técnicas, siendo las más utilizadas: el Grabado con ácidos, Cincelado, Reticulado y Shibuichi; pues, con su aplicación, objetan la analogía con alguna superficie que fundamenta su propuesta. Positivamente, la bondad de las técnicas de la Cera perdida y la Forja, es aprovechada con gran frecuencia en las obras del orfebre venezolano. Suponemos que esto se debe, por el hecho de conseguir resultados idealizados previamente por su instinto creador; ya que, el interactuar con el modelo deseado en la cera, logra plasmar su fuerza descargada a través del fuego que los concluye vaciado en un metal.

El constante uso de las técnicas de la Filigrana, el Grabado con buril y el Granulado, demuestra no solo su delicada y elegante apariencia sino que manifiesta su temperamento meticuloso y detallista; pues, la paciencia y maestría reflejan su temperamento, intelecto y rendición ante esta disciplina.

El reiterado uso de la técnica del Esmalte sobre metal, conjuga su atrevimiento en la intervención de la superficie; quizá, por la certeza del protagonismo que estos ejercen en la pieza, entre la estupenda variedad de colores traslúcidos, brillantes y mates, que perceptiblemente manifiestan su sello de identidad.

Indudablemente que el uso de la técnica de Baños electrolíticos se debe en gran parte, a la hermosa apariencia del oro y la plata pura; siendo esta técnica, ideal para adulterar la condición de ciertos elementos metálicos, exaltando y preservando su superficie con una finísima capa metálica sea de oro, plata, níquel u otro metal.

El uso de la técnica del kum-Boo se adentra al léxico creativo del orfebre venezolano para lograr en sus piezas un bello diseño en laminilla de oro puro sobre la superficie de la plata. $Y$ en busca de este semblante colorido metálico recurre también al uso de la técnica del Mokume gané; pues, con gran destreza y sensibilidad, aplica el mokume con bellos diseños para resaltarlos entre la variada tonalidad de su lámina entre el amarillo del latón, el rosado del cobre y el blanco de la plata.

La interacción entre la orfebrería con otros tópicos del arte, permiten que el orfebre venezolano, manipule la técnica del Fotograbado como una herramienta ideal para eternizar alguna imagen y fundamentar su propuesta artística.

La utilización de la técnica del Niello es poco habitual, sin embargo, en aquellos orfebres que si la abordan, la contundencia de sus diseños grabados en el metal, se enaltece con la 
integración del tono ennegrecido de su composición; consiguiendo con ello, un bello y laborioso diseño en alto contraste.

Un detalle importante que hemos encontrado en la obra de los orfebres de la época actual, es que en más de la mitad de ellos, existe convergencia entre la disciplina de la orfebrería y la disciplina de la escultura. Perceptiblemente, confirmamos que alcanzaron los límites de la ornamentación de una joya; donde su dimensión ceñida al cuerpo humano, exigió más espacio, por eso se adentra en otros formatos donde la joya se aproxima a alguna tendencia multidisciplinar, sin desvirtuar su esencia.

Significativamente, esto ha venido sucediendo desde la década de los ochenta, -y ya lo mencionamos anteriormente, que se debe a la influencia rectora del orfebre Alexis De la sierra-; desde entonces, se aprecia una tendencia de crecimiento; consiguiendo que en los orfebres de la época actual, más de la mitad de ellos, se han aproximado a la tendencia de la orfebrería escultórica.

Las exigencias del arte venezolano actual, han logrado que esta vertiente de la orfebrería, sea considerada como una disciplina artística más; e irrumpa y se apropie de manera categórica, en las galerías, museos y salones de arte.

\subsection{LA ORFEBRERÍA EN LA CREACIÓN ESCULTÓRICA}

VENEZOLANA. Clasificación por tendencia de los principales Orfebres. MUESTRA DE ESQUEMA. Generalidades.

Considerando la importancia y veracidad de la información de Capítulo 1, que habla sobre el contexto artístico de la orfebrería venezolana, decidimos tomar como punto de partida aquellos salones de arte que incluyen a la orfebrería como una tendencia artística; siendo alguno de éstos: "El Salón Nacional de las Artes del fuego, la Bienal de Artes Plásticas para Estudiantes de la Universidad de los Andes y el Salón Nacional de Orfebrería", comprendidos entre la década de los años 70 al 2010.

Una vez realizada la recopilación de obras expuestas en dichos salones, sintetizamos la muestra; considerando en algunos casos, aquellos orfebres que han reincidido en los salones y cuya obra, ha contribuido de manera significativa en el desarrollo de la orfebrería en la creación escultórica venezolana actual. Esta muestra finalmente concretó un total de 46 orfebres y de cada uno de ellos, expondremos de manera objetiva, sobre los aspectos técnicos, formales y conceptuales que caracterizan su producción.

Ahora bien, fundamentándonos en la heterogeneidad de las obras de estos orfebres, la muestra se divide en dos tendencias: la ornamental y la escultórica; en tal sentido, hemos elaborado un 
esquema que clasifica a los orfebres seleccionados en la tendencia donde encaja su producción. Una vez, divida la muestra, aseveramos que existían ciertas características en su semblante por lo cual sub-dividimos en grupos, según su estilo y/o característica.

Tomando en cuenta a los orfebres de la tendencia ornamental establecidos en un total de 20, se sub-dividen en tres grupos según su estilo: Abstracto, Figurativo y Geométrico.

En los orfebres de la tendencia escultórica establecidos en un total de 26, se dividen en dos grupos: los que desarrollan su producción entre la tendencia ornamental y la escultórica y los que desarrollan su producción sólo en la tendencia escultórica.

En tal sentido, elaboramos un pequeño esquema, que muestra de manera precisa, la cantidad de orfebres clasificados en cada tendencia, comentada anteriormente y los cuales serán mencionados posteriormente.

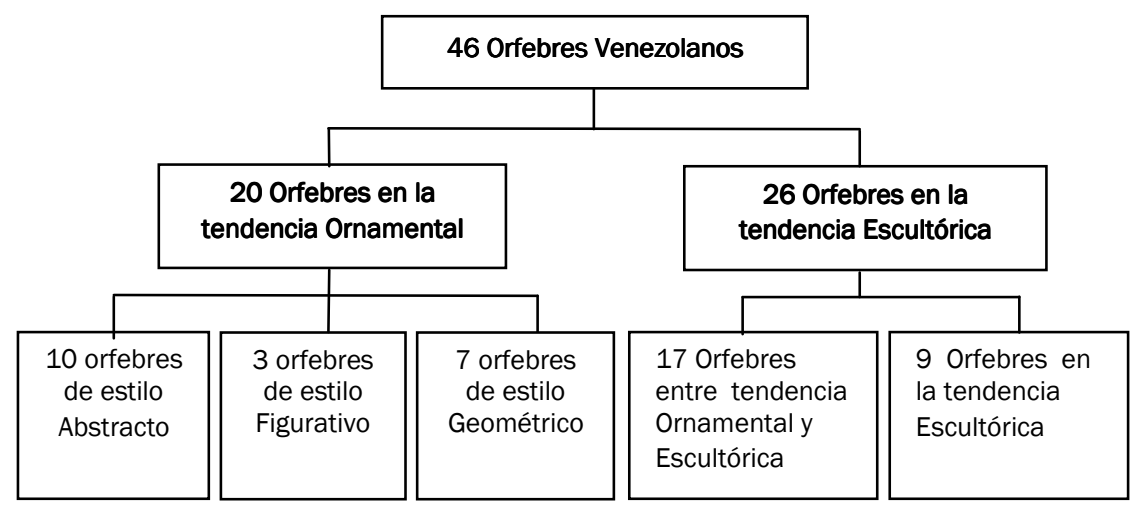

Es importante destacar sobre la veracidad e importancia de los datos que se exponen a continuación puesto que, la gran mayoría de las imágenes y fichas técnicas de los 46 orfebres venezolanos que estaremos hablando a continuación, fueron extraídas de la página web oficial del "SNAF"72, de los catálogos del I, II "SNO", Material inédito aportado por los organizadores de I, II, III "SNO", así como también, Material inédito aportado por el ganador de la "Bienal de Artes Visuales de Estudiantes de la Universidad de los Andes". Adicionalmente, pudimos establecer contacto con los orfebres, donde la información con respeto a su formación y producción resultó plausible para el desarrollo de la valoración personal que elaboramos de cada uno de ellos; hecho éste, consideramos un verdadero aporte para la orfebrería actual venezolana.

72 Galería Universitaria Braulio Salazar.

http://galeria.uc.edu.ve/ 
2.2.1 TENDENCIA ORNAMENTAL. Aspectos técnicos, formales y conceptuales. Valoración personal.

Tal y como mencionamos anteriormente, expondremos de manera objetiva, sobre los aspectos técnicos, formales y conceptuales que caracterizan la producción del orfebre venezolano en la tendencia Ornamental conformada por un grupo de 20 orfebres. Efectivamente, mantendremos el orden que se indica en el esquema anterior. De igual modo, hemos elaborado un segundo esquema, donde muestra los nombres de dichos orfebres, siendo estos, enumerados en un orden alfabético, clasificados dentro del estilo donde encaja su obra. Así pues, inicialmente hablaremos de los orfebres que sus joyas se establecen en la tendencia Ornamental cuyo estilo radica en lo Abstracto, luego de los orfebres que sus joyas radican en el estilo Figurativo, finalizando con los orfebres que sus joyas radican en el estilo Geométrico.

\begin{tabular}{|c|c|c|}
\hline & 20 Orfebres en la tendencia Ornamental & \\
\hline $\begin{array}{l}10 \text { Orfebres de estilo } \\
\text { Abstracto }\end{array}$ & $\begin{array}{l}3 \text { Orfebres de estilo } \\
\text { Figurativo }\end{array}$ & $\begin{array}{c}7 \text { Orfebres de estilo } \\
\text { Geométrico }\end{array}$ \\
\hline $\begin{array}{ll}1 \\
\end{array}$ & 1 & 1 \\
\hline Abelardo Tucapel & Julio Mota & Aris Hernández \\
\hline Duglas Pereira & Lucía Ramírez & Carlos Graterol \\
\hline Elina Peduzzi & Mary Peña & Georgina Doumat \\
\hline Lourdes Silva & & Jaghanat Rodríguez \\
\hline Luis Macero & & María Teresa Torras \\
\hline Lutz Podolski & & Ollantay Guédez \\
\hline Mario Lacurcia & & Simón Sorondo \\
\hline Patricia Benfele & & \\
\hline Rosa Falena & & \\
\hline Ursicinio Galletti & & \\
\hline
\end{tabular}


El trabajo de este genial orfebre se muestra muy emotivo, ya que sus piezas son creadas mediante procesos manuales, donde la sensibilidad y la creatividad se unen con total libertad y expresividad. En sus espectaculares joyas se destaca el uso de elementos naturales tales como: fósiles amonites, corales, azabache, piedras semipreciosas y colmillos de animales salvajes.

En sus joyas, se representan las más interesantes figuras del mundo animal y botánico; destacando, las formas de flores, insectos, animales marinos y seres microscópicos.

Con un trato minucioso y perfeccionista, elabora manualmente sus seres híbridos. Sus joyas, no son producto de una casualidad, puesto que, son diseños muy bien elaborados que nacen con frecuencia de un fósil, coral, colmillo o algún tipo de gema.

Una característica del trabajo de Abelardo Tucapel es el uso de fragmentos del mundo circundante transformados en hermosos collares ó broches.

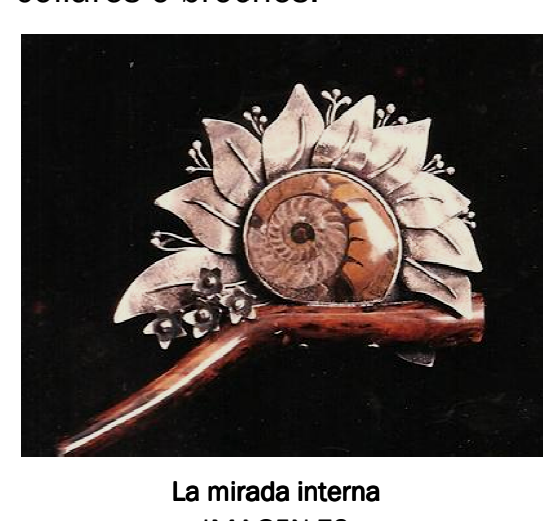

En su obra, La mirada interna (IMAGEN 78)73, de la serie: (Miradas Interiores), se aprecia un lenguaje abstractonaturalista que da origen a seres híbridos.

Puede observarse un coral vegetal marrón que a manera de caracol se adosa a un fósil amonite, ambos se fusionan de manera armónica, sus formas se mirada interna hermanan y dan vida a este hermoso ser. Un engaste a bisel, en plata, ciñe el contorno dejando ver su aspecto interior inmaculado. La forma convexa lograda tras el desbaste de los extremos da la apariencia de un fascinante ojo; de ahí, el proviene el nombre: La Mirada interna.

73 XXI Salón Nacional de las Artes del Fuego. (1994). http://galeria.uc.edu.ve/gubs.php?id $=53$ 
Puede afirmarse que Tucapel transfigura la existencia del elemento cuando realiza su obra. Esta afirmación se basa en su Metáfora del tiempo (IMAGEN 79)74; la cual, es un enorme y emblemático dije compuesto de estupendas hojas forjadas, que se presentan rodeadas de un estallido de pistilos realizados con hilos brillantes de plata. Pueden notarse dos colmillos de báquiro que destacan por su blancura en medio de matices metálicos; igualmente, un enorme jaspe se encuentra engastado en su centro y aporta una tonalidad llamativa a la joya y le transmite una luminosidad impecable al conjunto.

Estos trabajos con fósiles, fueron

merecedores de un Premio en la tendencia de Orfebrería en el importante "SNAF". En el

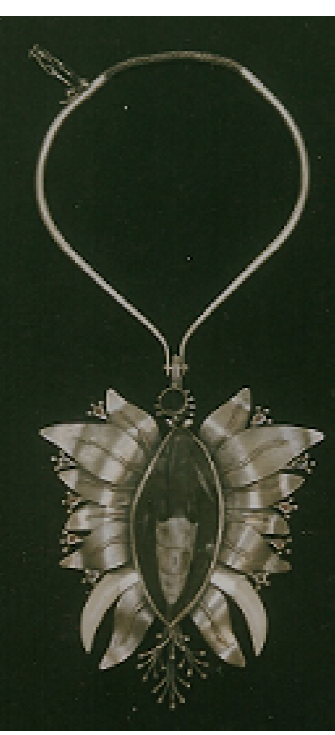

Metáfora del tiempo IMAGEN 79

año 1994 el broche Mirada interna -siendo parte del conjunto de

3 joyas-. Así como también, en el año 1998, con el collar Metáfora del tiempo; siendo ambos premios, el resultado de un esfuerzo creativo e intensa investigación en el campo de la orfebrería.

El orfebre Abelardo Tucapel, en la actualidad está dedicado a la enseñanza del oficio en la Escuela de Orfebres Joanna Palacios en la ciudad de Caracas; aunque, continúa elaborando fascinantes joyas en plata ${ }^{75}$.

\footnotetext{
${ }^{74}$ XXV Salón Nacional de las Artes del Fuego. (1998)
} http://galeria.uc.edu.ve/gubs.php?id=58

75 Tucapel, A. (2006). “Participación en SNAF”. Material inédito. Correo electrónico. abelardotucapel@gmail.com 
Tras la búsqueda de la armonía, este orfebre, compone diversos elementos manteniendo el equilibrio entre sus formas, combinando lo orgánico, animal y mineral con metales nobles. Se relaciona con la naturaleza que es su fuente de inspiración. Explora en los más recónditos lugares, reúne cuanto material le interesa, explota al máximo las cualidades del material que trabaja y los aplica de manera particular para lograr fascinantes joyas abstractas.

En una evidente búsqueda de armonía combina lo orgánico, animal y mineral con metales nobles; de este modo, compone los diversos elementos y logra mantener el equilibrio entre sus formas. Así pues, buscando esa estética que lo defina, se introduce en el estudio de técnicas, lenguaje y materiales aborígenes de diversas culturas. Su paso por los centros arqueológicos más importantes de Colombia, Ecuador, Perú, Bolivia y Chile, le ha permitido entender la importancia de estos elementos. Esto, le ha concedido convertirse en un coleccionista de objetos aborígenes de las comunidades que visita. Bajo esta perspectiva, desarrolla sus joyas en una nueva figuración, con alto grado de refinación y síntesis de manifestaciones autóctonas. De este modo, nos introduce con fascinación a su lenguaje simbólico con enorme carga emotiva- a través del cual, el orfebre Pereira concibe sus joyas como proyección hacia un mundo étnico.

En Presencia alada (IMAGEN 80) 76 se combinan armoniosamente con la plata: colmillos y dientes de animales, hueso, madera, cola de cachicamo, espinas de raya, láminas de carey, cuentas de coral blanco prehispánico y placas líticas de serpentina de los andes venezolanos. En este complejo collar, así como el resto de su producción, puede observarse la manera particular como este artista reinventa los objetos/talismán y realiza interesantes combinaciones para ornamentar y proteger al ser que lo exhibe.

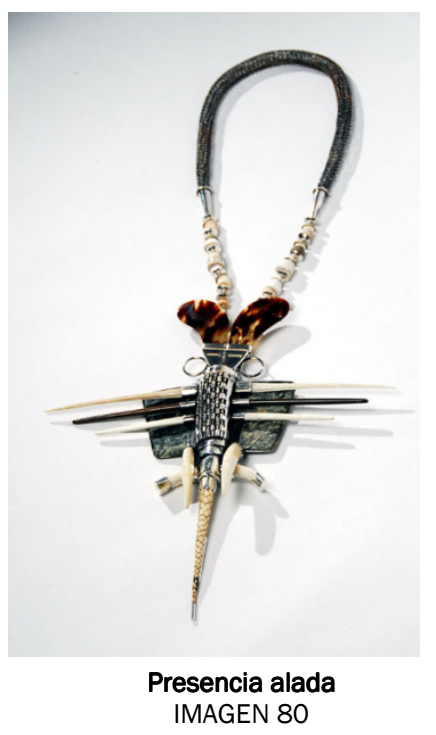

7635 Salón Nacional de las Artes del Fuego. (2008). http://galeria.uc.edu.ve/actual.php?id=79 


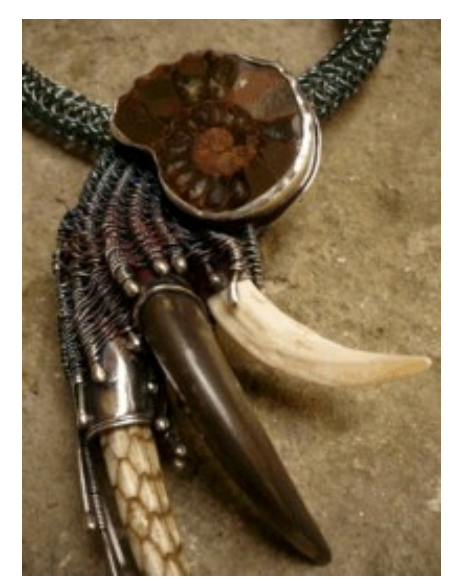

En extinción

En el pectoral En extinción (IMAGEN 81) nos enseña con libertad su gesto creador y una vez más, apreciamos la diversidad de sus orientaciones. Un enfático tejido etrusco con hilos de plata oxidada, conforma el cordón de donde emerge un dije con un imponente fósil amonite. El engaste que abraza su contorno, está realizado en plata y reproduce fielmente las formas ondulantes del fósil. De él, salen entretejidos: una enorme uña de perezoso, un colmillo blanco de báquiro y el rabo de un cachicamo, donde el orfebre demuestra la riqueza de la naturaleza animal en su estado más virgen y salvaje. Unos contundentes hilos gruesos, brotan como venas de un tejido minucioso en plata oxidada. Este sugestivo dije, colmado de detalles nos conduce a múltiples lecturas.

El orfebre Duglas Pereira se mantiene activo, tanto a nivel expositivo como en la enseñanza, en el campo de la orfebrería en Venezuela y ferias de artesanía a nivel internacional. En su transitar en el mundo de la orfebrería, ha obtenido importantes reconocimientos; como el Premio en la tendencia de Orfebrería en el "SNAF" del año 1996.

Su obra se exhibe en museos, galerías y tiendas de artesanía en Venezuela. Desde sus comienzos como artesano, ha sido un luchador por preservar y promover la orfebrería en el país. Gracias a él, se han obtenido grandes beneficios tanto para el gremio de artesanos como para el de los orfebres venezolanos. Entre estos beneficios debe destacarse: el intercambio expositivo y enseñanza del oficio con otros países, así como también, la creación del "Salón Nacional de Orfebrería"77.

77 Pereira, D. (2009). "Datos sobre su producción en Orfebrería". Entrevista Personal. Mérida, estado Mérida. 
Sistemática, detallista y ordenada, la orfebre Elina Peduzzi colma de detalles su obra, destacando el acabado y el estilo abstracto que la fundamenta. El trabajo de esta orfebre se basa principalmente en collares, los cuales elabora de una manera muy particular. Su destreza y habilidad se ven recompensadas al obtener el Segundo Premio en el "SNO", en el año 2005, con su obra América; siglo XXI (IMAGEN $82)^{78}$.

Es en América; siglo XXI, donde se combinan, la llama directa del soplete sobre la aleación de la plata y la mano

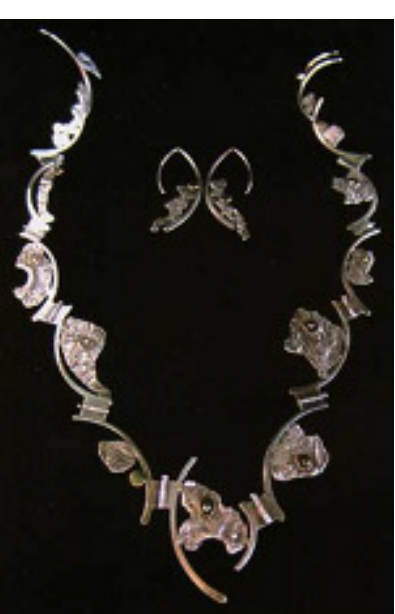

América; siglo XXI IMAGEN 82 experta del orfebre, para dejar un

excelente testimonio. En esta obra, se percibe un juego de contrastes entre las superficies lisa/rugosa, brillante/mate y las diversas tonalidades que, con perfecta armonía, conjugan oro amarillo con plata. Resaltan los espectaculares eslabones que degradan en tamaño y que están elaborados minuciosa e individualmente con la técnica del reticulado. Estos eslabones, se revelan como interesantes texturas que emergen de las gruesas láminas de plata.

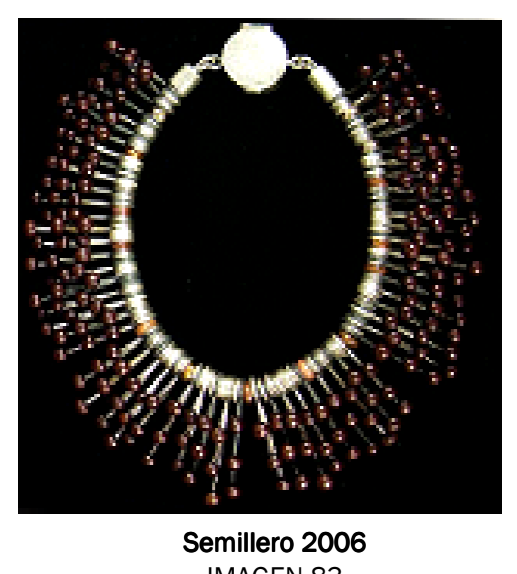

Semillero 2006

La orfebre Peduzzi logra una apariencia espectacular, donde la textura y la forma se repiten una y otra vez. La articulación del collar se realiza con imponentes hilos y tubos de plata brillantísima, que se unen por medio de una bisagra con suficiente movilidad para adaptarse a cualquier fisionomía.

En Semillero 2006 (IMAGEN $83)^{79}$, la autora nos deleita con

78 Ministerio de la Cultura y el Consejo Nacional de la cultura. (2005). "I Salón Nacional de Orfebrería". Centro de Arte la Estancia. Catálogo. s/n

79 Instituto de las Artes de la Imagen y el espacio y Mota, J. (2006). “II Salón Nacional de Orfebrería". Museo de la Estampa y del Diseño Carlos Cruz Diez. Catálogo. p: 57 
su creatividad y destreza. Este fascinante collar, es el ganador del Primer Premio en el "SNO" en el año 2006.

Bajo la temática de "Identidad Nacional" establecida en las bases del salón, Elina Peduzzi lo aborda desde la perspectiva de lo autóctono. De este modo, se vale de la sensibilidad que posee ante los materiales nativos y selecciona minuciosamente impactantes semillas de palma de color rojo vino. Con este material natural decora e introduce color entre los hilos de plata; otorga así a su obra, una connotación simbólica que deriva de las propiedades de los materiales utilizados, donde forma y color se adecuan perfectamente a su diseño, ajustándose perfectamente al criterio establecido en el salón.

El collar está compuesto por un total de sesenta y dos estilizados vástagos de plata brillantísima, de cada uno de los cuales germinan tres semillas rojas perfectamente redondas; cada vástago, se encuentra separado por gruesos eslabones de oro y cobre, exaltando sus tonalidades. Cada uno de estos elementos, cumple una función determinante en y para el diseño. Todos ellos, seleccionados en detalle y colocados minuciosamente, enaltecen la combinación de la frialdad de la plata, con la calidez del tono rojo vino de las semillas.

El broche que cierra el collar, se fundamenta en un pequeño cofre de plata que en su interior oculta un escrito, cuyo contenido revela parte del ritual de quien lo use. 
Las joyas de esta orfebre tienen un denominador común: la abstracción conseguida desde las superficies colmadas de textura y el matiz de los acabados; esta característica define su gesto creador. Por eso, en su obra no es trivial la utilización de elementos naturales. Su indiscutible labor de investigación sobre nuevos materiales aplicados a la orfebrería, nos deleita con un especial dominio que demuestra en la realización de fascinantes y espectaculares collares.

La composición de los elementos de sus collares son elegidos minuciosamente en busca de un equilibrio perfecto. Fusiona tonos cálidos y fríos con la tonalidad impoluta de la plata $u$ otros metales.

Las joyas de la orfebre Silva, se distinguen por la maravillosa manera con la cual combina diversos detalles decorativos, donde dominan las perlas, conchas marinas, piedras semipreciosas o cualquier volumen artificial. En su obra Collar III (IMAGEN 84)80 láminas de plata fueron embutidas para semejar espectaculares conchas de nácar. La composición seriada de este fascinante collar, intercala enormes cuarzos en

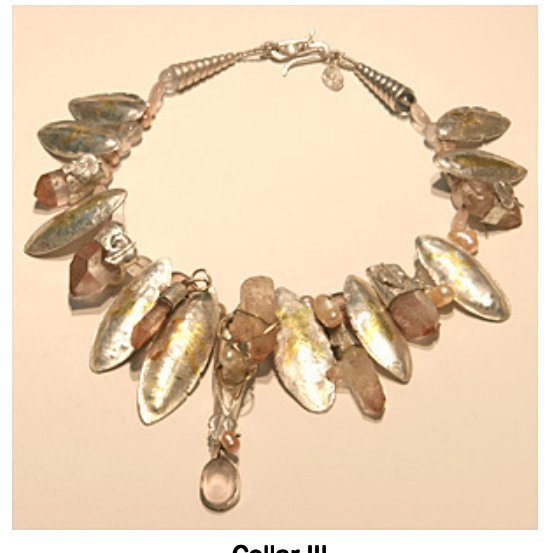
Collar III IMAGEN 84

bruto, color rosa, que estremecen hasta la mujer más elegante. Collar III es parte del conjunto -de tres collares- merecedor del Premio Nacional de las Artes del Fuego en el "SNAF" del año 1996.

En A tempo (IMAGEN 85)81, la plata mate/brillante/oxidada, se combina con titanio, niobio, perlas barrocas, aventurita y lapislázuli; elementos que se conjugan en una tendencia más moderna, bajo una estética apta para una mujer atrevida. Pese al marcado énfasis étnico de sus propuestas, esta vez utiliza el colorido espectacular que logra por calentamiento del titanio y cuyo tono, se hermana con el matiz de las perlas barrocas. Hilos de plata brillante, mate y oxidada se entrelazan y contrastan con el

80 XXIII Salón Nacional de las Artes del Fuego. (1996) http://galeria.uc.edu.ve/actual.php?id=55

8132 Salón Nacional de las Artes del Fuego. (2005). http://galeria.uc.edu.ve/actual.php?id=9 


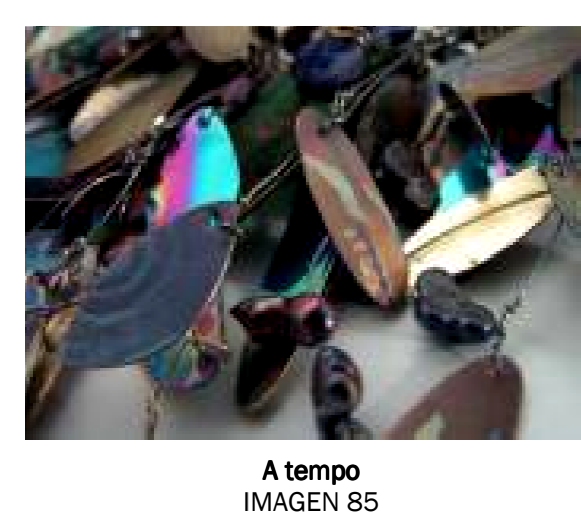

resto de los materiales. En esta atrevida propuesta, intervienen semblantes modernistas asequibles a la vestimenta de la mujer actual.

Desde principios de los años noventa Lourdes Silva se encuentra activa en el campo expositivo tanto a nive nacional como internacional. Es miembro activo de la Asociación Venezolana de las Artes del Fuego, donde ofrece cursos de capacitación de orfebrería. Según Victmary Dávila82, esta orfebre tuvo el honor de ser seleccionada para elaborar una cruz como obsequio al Papa Juan Pablo II en su primera visita a Venezuela para el acto de Beatificación de la Madre María de San José. En ella, obviamente se conjugaron los más exquisitos detalles con oro amarillo y piedras preciosas donde reluce la imagen de la Virgen de Coromoto, que dejaron testimonio de su impecable factura y la sensibilidad de su autoría. Al parecer, esta cruz actualmente se encuentra en el Vaticano.

82 Dávila, V. (2000). “Panorama de la Joyería Artística Contemporánea. Década 70, 80, 90 de Venezuela". Tesis para licenciatura. p: 58 
La influencia del reciclaje en las joyas del orfebre Luis Macero, se hace apetecible a las formas de la flora y fauna autóctona venezolana.

En sus particulares joyas se enfoca el valor del diseño, donde un material reciclado descubre otra utilidad. De este modo, el acetato transparente se convierte en el protagonista y es su mano experta quien logra hacer realidad esa imaginación.

El hábil manejo del hilo de plata, impone carácter y elegancia; donde, el entorchado sin soldadura alguna, idealiza una atractiva orquídea transparente, para engalanar el cuello de una mujer sofisticada con tendencia modernista. Así pues, hilo de plata, pinza, láminas de acetato y mano experta, se integran con convicción, para vincularse a la vestimenta de la mujer actual.

Este collar innovador Orquídea 2006 (IMAGEN 86)83, obtiene la Mención de Diseño en el II "SNO" en el año 2006. Este reconocimiento, respalda su fundamento, donde la identidad del material reciclado constituye la esencia de la joya. Pues, su reminiscencia a la naturaleza salvaje, se transmuta en la transparencia del acetato dejando ver entre alargados pétalos, el contorno del cuello de quien la exhibe.

Retazos de cuero entintado, recortes de cobre esmaltado y tiras de metacrilato, se enlazan entre eslabones de aluminio y dan

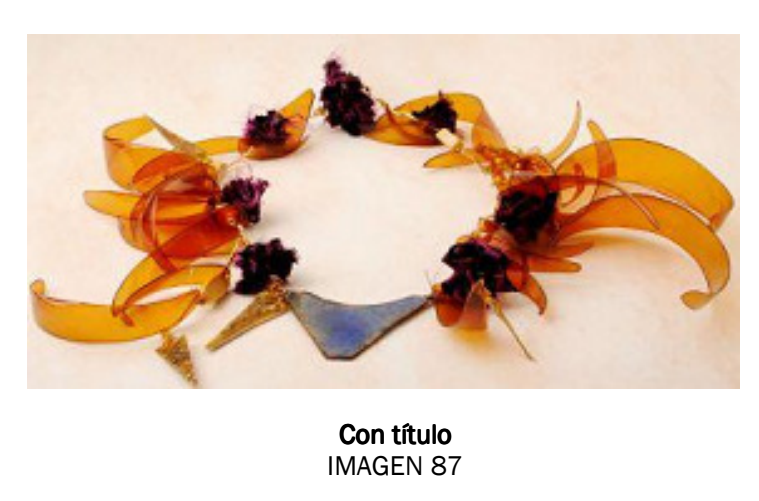

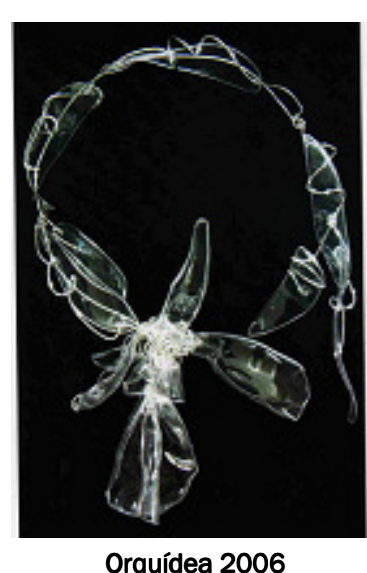

Orquídea 2006 rienda suelta a su imaginación.

El orfebre Macero, nuevamente nos encanta con un collar elaborado con materiales reciclados. Con título (IMAGEN 87) 84 se establece en un

83 Instituto de las Artes de la Imagen y el espacio y Mota, J. (2006). "II Salón Nacional de Orfebrería". Museo de la Estampa y del Diseño Carlos Cruz-Diez Catálogo. p: 112.

84 Vera, R. (2012). "Imágenes y fichas técnica de obras III Salón Nacional de Orfebrería". Material inédito. Correo electrónico. vhrafier@yahoo.com 
alegre collar, entre capullos de retazos de cuero entintado de color vino y pétalos de metacrilato color amarillo tostado, transfigurándose entre sinuosas formas, en esta elocuente propuesta. El calor de la llama del soplete, da forma contundente a los alargados pétalos de metacrilato, explayándose intercaladamente entre los eslabones de todo el collar. Un insignificante trozo de prueba de esmalte azul claro, se acopla muy bien entre los elementos, cobrando protagonismo en el collar, siendo este detalle, ideal para adaptarse a cualquier fisionomía.

Su vínculo con el mundo de las tablas, le ha permitido crear un dialogo entre el teatro y la orfebrería; pues, su imperiosa necesidad del uso de prendas extraordinarias, le ha inducido a la práctica de esta disciplina; aprovechando, el recurso del reciclaje. Argumento este, caracteriza las fascinantes joyas abstractas de su autoría. 
Este orfebre es Mecánico Industrial de profesión. Se deja seducir por el hierro desde su juventud y de su faena en la siderúrgica, inicia los primeros pasos en la orfebrería. A partir de entonces, no se ha apartado de ella.

El orfebre Podolski recrea sus fascinantes joyas, bajo criterios propios de una civilización imaginaria. Orienta su obra hacia la belleza de la forma de algún elemento, ya que ellos son el foco de irradiación de donde se origina la energía. El lenguaje abstracto altamente simbólico, a través del cual el artista concibe sus collares o pectorales, se adentra en una sensualidad que evoca en la imaginación hasta la persona más errante. La innovación que ha logrado en la técnica de la cera perdida, indudablemente es su seña de identidad; pues, una vez vaciado en plata la forma deseada, esta es intervenida con buriles, acentuando las texturas, luego las somete a un grabado con acido y finalmente las entierra por cierto tiempo en un lugar de su jardín, que contiene diferentes sales, las cuales otorgan una fascínate pátina sobre su superficie. Método este, aplicado para crear una especie de fosilización.

Tal es el caso de Gargantilla (IMAGEN $88)^{85}$, donde dos inmensos dientes de caballo sujetan un fascinante hibrido de murciélago; pues, su imaginación y destreza transfiguran a ese animal con una lámina de plata vaciada. Las texturas exageradas tras el efecto del acido nítrico, transfieren una mordida exagerada debido a su concentración. En el centro de la gargantilla, un tejido en eslabones de plata, engalanan un diente tiburón. Esta gargantilla fue merecedora de un Premio en la tendencia de Orfebrería en el año 1994.

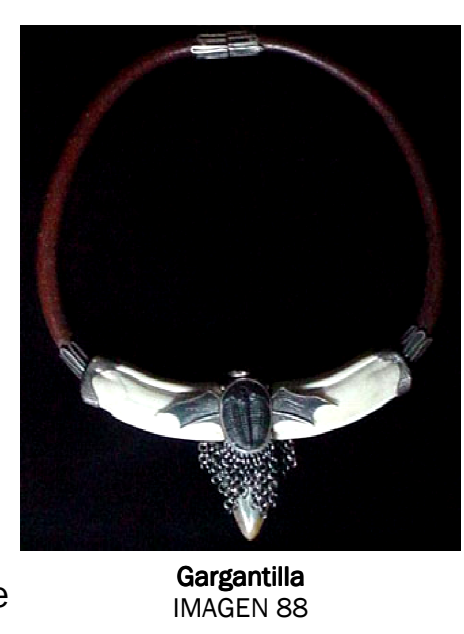

En el enigmático dije Fuego (IMAGEN 89)86, el orfebre se fundamenta en la técnica de la cera perdida. Igualmente, combina la intervención con ácidos y saca el máximo provecho a su obra, utilizando el burilado; técnica ésta, donde descarga su fuerza creadora. Aplica las pátinas con verdadera intensión de aumentar

85 XXII Salón Nacional de las Artes del Fuego. (1995). http://galeria.uc.edu.ve/actual.php?id=54

86 Podolski, L. (2007). “Fundamentos en orfebrería”. Material inédito. Correo electrónico. Lucho@lutzpodolski.com 
la expresión en los rasgos de la forma y convierte así sus joyas en objetos históricos o arqueológicos.

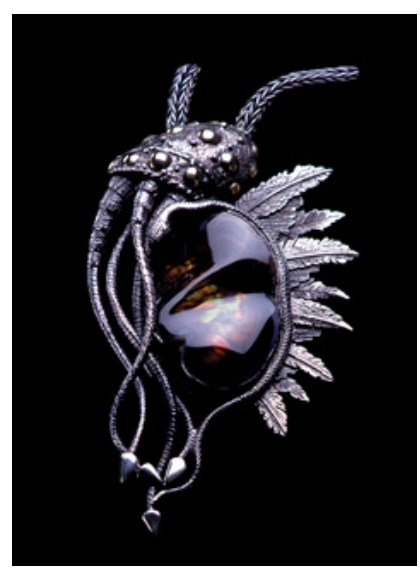

Fuego
IMAGEN 89

El trasfondo conceptual y enorme fuerza visual materializan su universo y se vale de fósiles, huesos, dientes y colmillos de animales, fusionados con la plata oxidada para formar fabulosas joyas.

Este orfebre forma parte de un grupo de artistas entre ceramistas y orfebres en rescate de esta tradición artesanal, llamado "Grupo Turgua" desde el año

1992, donde dos veces al año exponen sus obras en la localidad de Turgua estado Miranda. 
Este artista crea un proyecto de orfebrería contemporánea venezolana, con el cual pretende revalorar motivos autóctonos de la América Indígena. De este modo, sus piezas se establecen bajo un estilo abstracto con elementos expresivos de culturas aborígenes. Así pues, Orfebrería Amerindia se instaura, utilizando de manera simbólica los elementos que la componen, pero adaptados a semblantes de las joyas contemporáneas. La variedad de técnicas que utiliza este orfebre y la impecable ejecución con que las realiza, evidencian la convicción con que se enfrenta en cada joya que realiza.

El collar Hombre Pájaro (IMAGEN 90) muestra una fascinante turmalina roja87, engastada con cuatro imponentes garras de plata. Esta piedra no solo es de gran belleza por su similitud al rubí, sino por su atribución de grandes poderes mágicos. Se vale de la creencia popular que considera la turmalina como un amuleto, capaz de eliminar energías negativas y ayudar al crecimiento espiritual. Por ello, Lacurcia focaliza la atención en la piedra,

situándola en medio del pectoral como eje central del ser- de donde irradia toda la energía protectora al

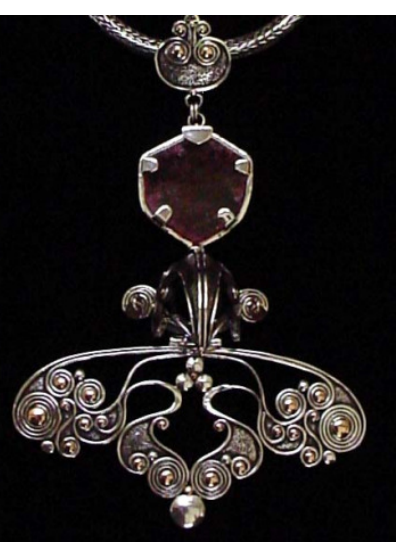

Hombre Pájaro IMAGEN 90 collar y obviamente a quien lo use. De ese eje central, pende un ala en pleno vuelo, transmutada en un tejido de plata con diminutos hilos entorchados que se ajustan en una bella filigrana. Las pequeñas esferas embutidas en oro amarillo, proporcionan un contraste delicado entre los matices plateados y dorados.

Tras un largo proceso de investigación entre técnicas, materiales y tendencias, este orfebre ha depurado su estilo. Éste ha adquirido un semblante preciosista, con un estilo singular. La abstracción preponderante se va apropiando de rasgos más definidos de contornos más simples.

87 XXX Salón Nacional de las Artes del Fuego. (2003).

http://galeria.uc.edu.ve/actual.php?id=41 


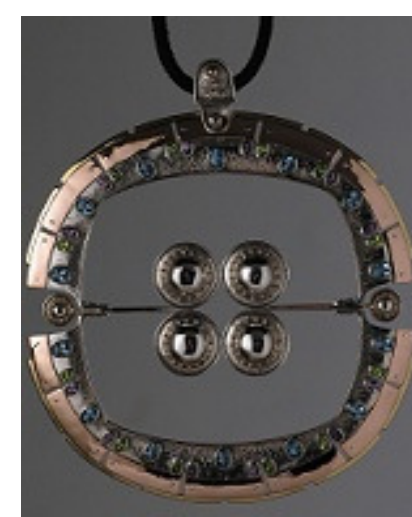

Medallón Ceremonial IMAGEN 91

En Medallón Ceremonial (IMAGEN 91)88, el cual ganó la Mención de Destreza Técnica en el III "SNO" en el año 2007, se puede observar su evolución simétrica con tendencia preciosista. Los matices entre el oro amarillo, oro rosado y la plata, revelan su exquisito brillo. En este inmenso medallón, el orfebre Mario Lacurcia nos impacta con un diseño moderno, donde la sutileza y maestría en el engaste de los topacios, amatistas y peridotos, sugieren ser el complemento de la vestimenta de sus seres fantásticos aborígenes.

88 Vera, R. (2012). "Imágenes y fichas técnica de obras III Salón Nacional de Orfebrería". Material inédito. Correo electrónico. vhrafier@yahoo.com 
PATRICIA BENFELE

Collares artesanales apuestan sus formas por la emotividad.

El haber pasado por la "Escuela de Orfebres Alexis De la Sierra" le permite hoy en día, que trabaje la plata con libertad, gran destreza y excelencia, acertada

capacitación en el vidrio y el metal se demuestran con convicción en sus joyas. Estos materiales parten del vínculo de ser trabajados a altas temperaturas y son metamorfoseados por su instinto creador, conjugándolos en un solo lenguaje. En el collar La puertita

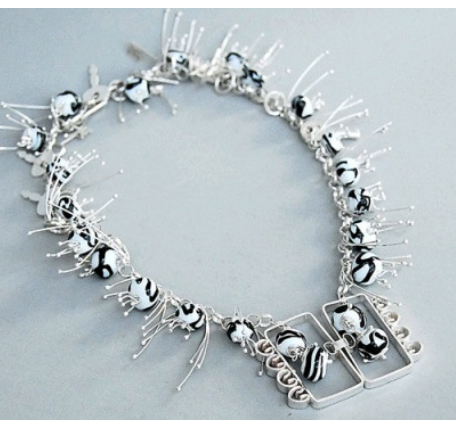

La puertita del cielo

del cielo (IMAGEN 92) ${ }^{89}$, perfectos eslabones en hilo de plata, conforman el cordón que lo fundamenta. En él, simétricamente se sujetan espectaculares cuentas de vidrio murano de color blanco y negro. Cuentas éstas, conseguidas manualmente una a una, tras la fundición con soplete. Así pues, la destreza de la orfebre se arraiga en cada una de ellas, evidenciándose entre la similitud de sus formas y tonalidades mate impecables. Destellantes hilos de plata empuñan las esferas de vidrio, sujetándolas con frenesí al collar (Detalle del collar la puertita del cielo IMAGEN 93). La técnica de la cera perdida, resultó una aliada para fundamentar el trasfondo de la pieza. El vaciado en plata de las pequeñas Ilaves resultan ser determinantes. Pues, metafóricamente el collar representa a un manojo de llaves que abrirá las puertas del cielo al ceramista Cándido Millán. El ceramista Millán, fue uno de los

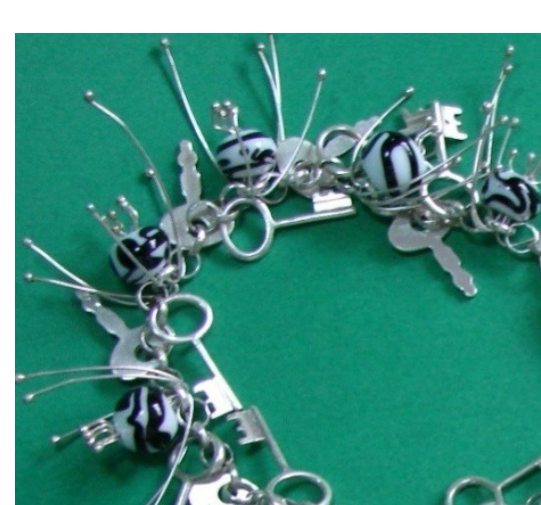
precursores de este arte en Venezuela, dejando un importantísimo legado en esta disciplina en el arte venezolano.

Para el año 2007 este collar, fue merecedor del Premio en la tendencia de Orfebrería en el prestigioso "SNAF", que rendía homenaje en esa edición, al recién fallecido Ceramista Detalle del collar la puertita del cielo venezolano Cándido Millán.

8934 Salón Nacional de las Artes del Fuego. (2007).

http://galeria.uc.edu.ve/actual.php?id=72 
No es más que un sentimiento (IMAGEN 94) es otra joya de la orfebre Benfele 90 , cuyo trasfondo tiene analogía con su título.

Una alegórica jaula que mantiene encerrada a la feliz pareja el día de su boda, pone a reflexión el tema en cuestión. Aseverar que el matrimonio encadena una pareja, con pasión y sin razón es algo incierto en cualquier

sociedad. Por eso, metafóricamente los enormes eslabones de plata, semejan las rejas que sellan y protegen las

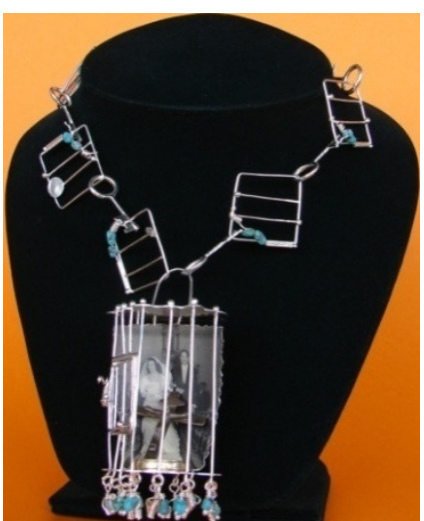

No es más que un sentimiento IMAGEN 94

ventanas de una casa. La emotividad de las llaves vaciadas en plata resultan ser la solución, pues con ellas se abre y cierra la jaula que mantiene unida en su interior a la pareja.

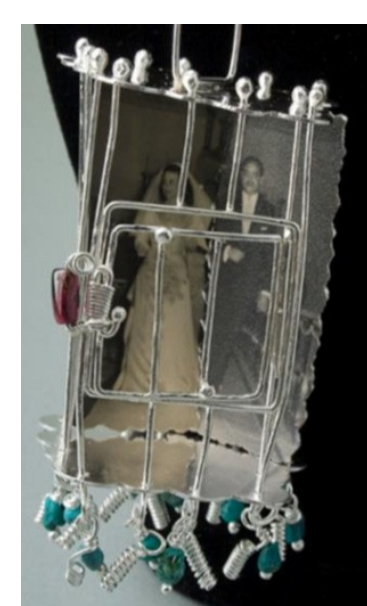

Una alianza en oro plantada en la base de la jaula, cuya pureza y poder, reafirma el común acuerdo de esa unión. La inclusión de la fotografía de los recién casados -el día de la boda-, añora el momento y testifica con un sonajero de turquesas que penden de la jaula que los enclaustra (Detalle de no es más que un sentimiento IMAGEN 95).

La persuasión de los materiales, la simbología que ellos representan, y la abstracción sutil de sus propuestas, nos acerca y vincula a una orfebrería Detalle de no es más que
un sentimiento conceptual cuya tendencia hacia lo escultórico se hace evidente.

90 Benfele, P. (2012). “Obra en salones". Material inédito. Correo electrónico. patricia benfele@yahoo.com 
Desde finales de los años sesenta, Rosa Falena se involucra en el ambicioso mundo de la orfebrería. Su vínculo con otras disciplinas de las artes del fuego, le permite pasearse con holgura entre ellas. Es por ello, que explora en las calidades de los materiales y los aplica con certeza.

Esta destacada orfebre domina cabalmente la técnica de esmalte al fuego; es por esto que, aprovechando las bondades que la técnica le ofrece, interviene con ellos sus exclusivos diseños y de este modo, obtiene el Premio en la tendencia de Esmalte sobre Metal en el "SNAF" en el año 1997.

El punto de partida de sus joyas puede provenir de cualquier campo.

Sin embargo, cabe destacar que existen ciertas características que se mantienen como constante en la apariencia de su superficie. 0 bien, a través de los tejidos con hilos de plata; los esmaltes al fuego o cualquier técnica que deje un semblante interesante. Esta característica se destaca en el fascinante collar Sinfonía del Rhapis excelsa (IMAGEN 96)91, el cual mereció el Premio en la tendencia de Orfebrería en el "SNAF" del año 2003. En esta joya un tejido etrusco,

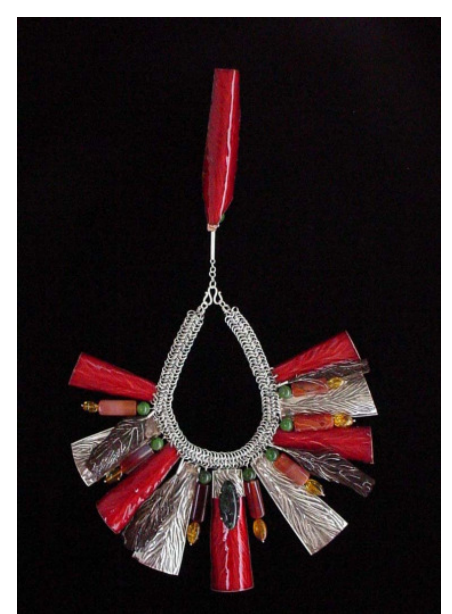

Sinfonía del Rhapis excelsa IMAGEN 96

con hilos de plata en forma de cordón, sujeta el collar. Una variedad de esmaltes de tonos cálidos brotan de fragmentos de cobre en forma cilíndrica; detalle este que evidencia su especial destreza. El tono rojo subido del esmalte utilizado, ostenta el carácter y la personalidad de su autora.

Otra característica importante de la obra de la orfebre Falena, es la unión de muchas texturas en una misma pieza. En Estropajo inn !!, (IMAGEN 97)92, los caracoles seccionados dejan ver su extraordinario interior, otorgando un juego de texturas que se entrelazan unos con otros entre impolutos aros de plata. Puede notarse como los detalles imperantes, se saturan por elementos poco usuales que son sacados de su contexto.

91 XXX Salón Nacional de las Artes del Fuego. (2003). http://galeria.uc.edu.ve/gubs. php?id=41

9232 Salón Nacional de las Artes del Fuego. (2005). http://galeria.uc.edu.ve/actual.php?id=9 


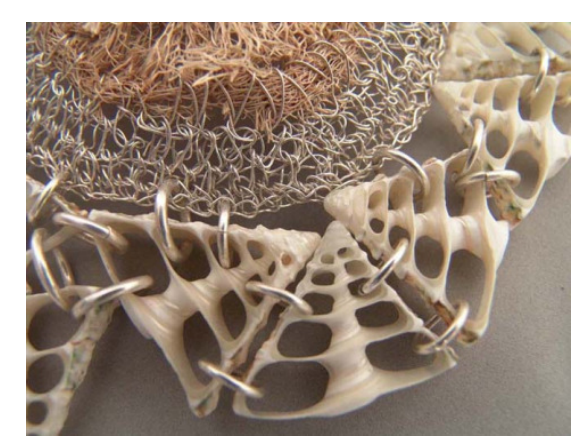

Estropajo inn!! IMAGEN 97

La uniformidad de sus contorneantes formas se entrelazan, como eslabones, con impecables hilos de plata. La paradoja del estropajo como material unificador, se entreteje con un tupido tejido en hilo de plata para filigrana.

La técnica tradicional del crochet, se hace visible a través de los brillantes y finísimos hilos de plata. La fusión de texturas entrelazadas, se degrada en exquisitas tonalidades y crea una proyección de líneas en un espacio tridimensional. A pesar de la diferencia que notamos en los materiales utilizados, existe reciprocidad en su alianza. Así pues, cuerpo y volumen se encarnan en un solo ser.

La orfebre Rosa Falena (QEPD) asumió una labor importante en el medio de la orfebrería venezolana puesto que, conjuntamente al orfebre Carlos Graterol formaron un Taller de enseñanza: "R\&C Orfebres Taller Escuela" en la ciudad de Caracas. Siendo este el primero en conseguir intercambio con maestros orfebres internacionales. Así como también, la inclusión en el medio expositivo internacional en la tendencia de esmaltes al fuego.

En repetidas ocasiones, dentro del marco de celebración del Salón Nacional de las artes del Fuego, ofrecen cursos de especialización en el ámbito de orfebrería y esmaltes al fuego. 
Las joyas del orfebre Ursicinio Galletti evocan el exótico colorido de la fauna del mundo indígena con colores de tierra, elementos orgánicos y tamaños exagerados. De este modo, transmiten a la perfección esa vivencia con el mundo aborigen.

Para entender el mundo creativo de este orfebre, es necesario abstraernos de la vida en la ciudad. Su significado radica en lo sagrado, destacando elementos del mundo animal, orgánico y mineral. Pues, éstos, son sacados de su contexto y metamorfoseados por su gesto creador. Por ello, puede afirmarse que estas joyas son estupendas narraciones de vivencias autóctonas. Las joyas de Galletti podríamos catalogarlas como orfebrería indígena puesto qué, se enmarcan dentro de un contexto natural, cuyas características nos aproximan a un mundo nativo.

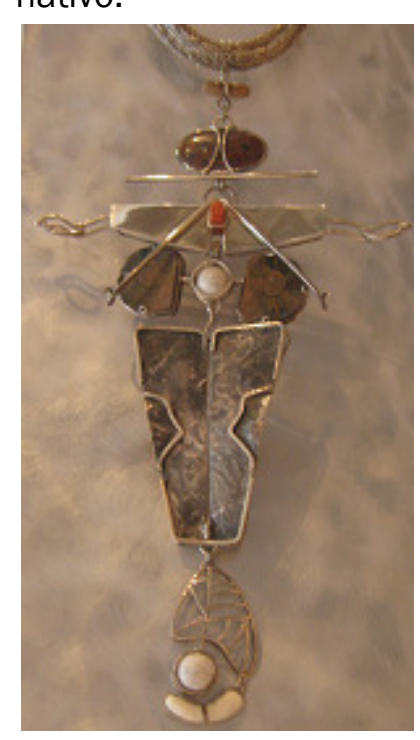

El vuelo del Shamán IMAGEN 98
El pectoral El vuelo del Shamán (IMAGEN 98 $)^{93}$, se compone de múltiples elementos del reino mineral y animal. Dónde la plata se fusiona armónicamente con la sobriedad de hermosos fósiles amonites, pepas blancas de zamuro, un fascinante colmillo de báquiro y un diminuto jaspe rojo. Todos estos elementos tienen un significado especial, puesto que, fueron sacados de su contexto para afianzar el carácter, autoridad y protección a quien lo use.

Un verdadero amuleto es esta magnífica joya, la cual posee una carga simbológica que sólo es descifrable por nativos 0 aquellos que conozcan su ideología. Sin embargo, para el público que la observa, aun sin conocer el trasfondo de los elementos que la componen, puede apreciarse como una joya abstracta de belleza demasiado extravagante para el uso cotidiano.

Excelente representación de su estilo abstracto, es el fascinante y colorido pectoral Wonken (IMAGEN 99)94, el cual reúne una serie de elementos que a simple vista resultan muy llamativos y la

93 XXVII Salón Nacional de las Artes del Fuego. (2000). http://galeria.uc.edu.ve/actual.php?id=62

9431 Salón Nacional de las Artes del Fuego. (2004). http://galeria.uc.edu.ve/gubs.php?id=27 
conjunción de todos y cada uno de éstos, otorgan vitalidad y protección al portador.

El diseño se realiza en hilos gruesos de plata; característica ésta, que constituye un aspecto recurrente en todas sus producciones. Los cuatro puntos cardinales (Detalle de Wonken IMAGEN 100) se encargan de integrar y exaltar el detalle central.

Dos impecables colmillos de báquiro bordean un fabuloso fósil, en el cual, resalta una perfecta forma circular entramada en su interior. Sobre él,

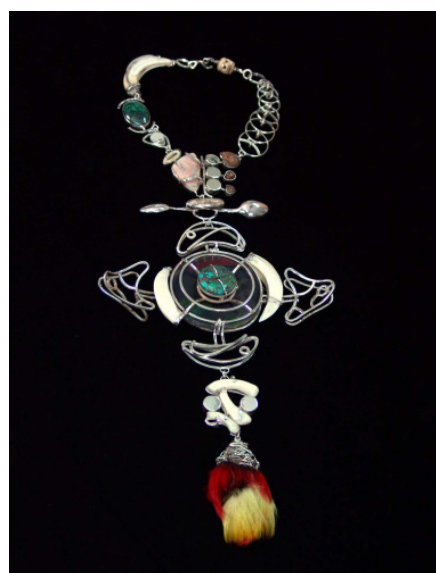

Wonken

brota con desenfado una piedra en bruto (turquesa telaraña). Este contraste, fue premeditado por su creador, respetando ciertas creencias que enfatizan que mientras menos la piedra sea modificada el poder de protección contra enfermedades será mayor. Cada uno de estos elementos de la naturaleza, utilizados

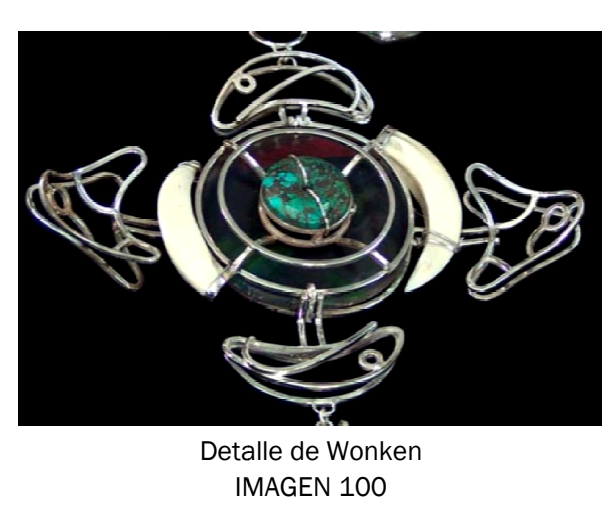
en su obra, es seleccionado bajo un profundo respeto. Como atributo a la deidad, este pectoral finaliza con un péndulo tejido, que empuña plumas de Makiritare -ave autóctona del sur de Venezuela, muy colorida-. Estas plumas son símbolo de autoridad y en su ideología, expresan el rango IMAGEN 100 jerárquico de quien la exhibe.

En definitiva, consideramos que sus pectorales son una fusión entre fantasía, recuerdos, anécdotas y misticismo. A través de ellos, el autor narra sus vivencias con los aborígenes, contexto en el que habitó por muchísimos años.

Este artista hace de la plata, un vehículo para manifestar su devoción por algunos elementos; de este modo, aplica su destreza de orfebre para enlazar estos fragmentos con detalles de joyas actuales. El trabajo de construcción con hilo cuadrado evidencia su autoría, así como también, en la manera particular de engastar las piedras; pues, tímidamente, el hilo las sujeta por su contorno, dejando al descubierto gran parte de ella. Esta característica permite verla casi completa evitando que el metal le quite protagonismo. Sus joyas, recargadas con múltiples elementos, evocan el exótico colorido de la fauna del mundo indígena. Y, por 
muchos años han dejado fiel testimonio en el prestigioso "SNAF", donde consiguió un Premio en la tendencia de orfebrería en el año 1996 y Accésit al Premio Nacional de las Artes del Fuego con la obra Wonken en el año 2004.

El orfebre Ursicinio Galletti figura con gran importancia como miembro de la "AVAF", puesto que, fue el fundador del "Taller de Orfebrería de la AVAF".

En la actualidad Galletti cuenta con una Galería Taller de Orfebrería en la ciudad de Caracas, donde permanentemente, sus alumnos exponen las mejores joyas y son vendidas al público. Así como también, frecuentemente ofrece cursos de especialización donde alumnos y foráneos pueden acceder a ellos ${ }^{95}$.

95 Galletti, U. (2010). "Producción en orfebrería”. Material inédito. Entrevista personal. Caracas, Distrito Capital. 
Joyas con acento figurativo devienen de su estupenda intuición y formación.

El legado de la escuela Cristóbal Rojas se fundamenta con convicción en la obra del orfebre Julio Mota. Su habilidad en la orfebrería y en la escultura, devela la importancia de estas, en su formación; pues, el estupendo conjunto Pulsera/Marioneta/Dije (IMAGEN 101) elaborados en plata96, expresan entre sus formas la adecuada proporción; la estupenda habilidad y el impecable acabado. El bello contraste que destaca en la marioneta, se debe a los azabaches tallados y engastados excelentemente, cuya

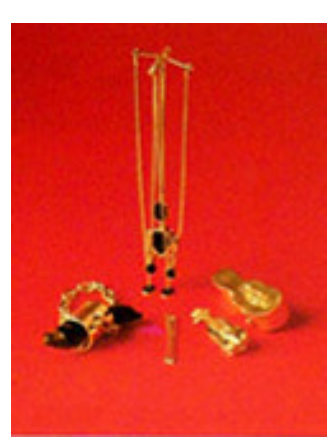

Pulsera/Marioneta/Dije Violín

dimensión se apropia del móvil cuerpecito, que pende de cuatro delicadas cadenas fijas a la cruceta que lo dirige. El espectacular

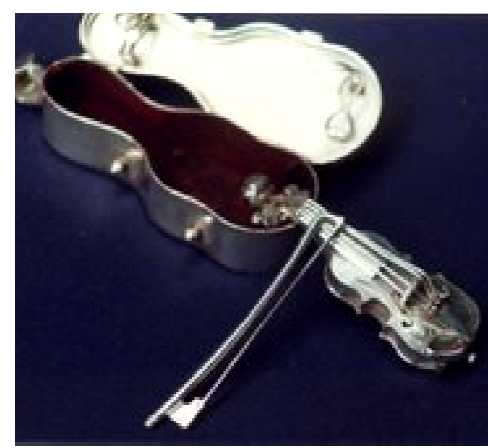

Detalle de Dije Violín IMAGEN 102 dije con forma de violín, enfatiza la belleza de su forma, manteniendo los rasgos característicos de este instrumento musical; desde su estuche perfecto con su forro de terciopelo, hasta los mínimos detalles de la curveada superficie, delicadas cuerdas y el imponente arco con su cuerda, el orfebre Mota no escatimó esfuerzo ni detalle para demostrar su agilidad e intuición de orfebre (Detalle de Dije Violín IMAGEN 102).

Su producción se constituye en magnificas joyas figurativas, donde la heterogeneidad de sus semblantes, reflejan su apropiada percepción. Sea cual sea el tema que aborda, este siempre será una excusa para dejar claro su extraordinaria manera de transformar los metales nobles en sugestivas y originales prendas.

En el conjunto de gargantilla y dos brazaletes Ajuar de la Diosa del eterno retorno (IMAGEN 103)97, el orfebre Mota se plantea una figuración idealizada en las facciones aborígenes de la cultura hispanoamericana y argumentándose en la creencia de la reencarnación, elabora este ajuar para ser usado durante el viaje

96 XXI Salón Nacional de las Artes del Fuego. (1994). http://galeria.uc.edu.ve/actual.php?id=53

97 Mota, J. (2007). “Obra actual de orfebrería”. Material inédito. Correo electrónico. julio30764@hotmail.com 
a la otra vida, por ello, Julio Mota se rige por una norma de elegancia básica y apuesta por la sencillez como forma de belleza. Simplifica la forma para que esta pueda ser apreciada con todo su candor, evitando en lo posible, la intervención de muchos elementos que desvirtúen su esencia.

Contornos limpios y decididos, estas magnificas joyas se afianzan en un semblante particular; pues, rostros achatados, ojos y labios

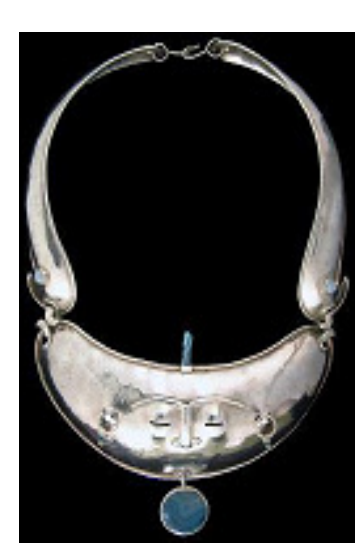
alargados, se transfiguran y se explayan en las anchas láminas de plata, tras la acción del repujado y el cincelado. Siendo esta técnica, abordada con demasía por los orfebres del pasado, el orfebre Mota rinde homenaje ejecutándola con total convicción.

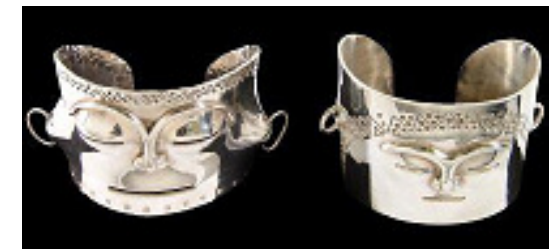

Ajuar de la Diosa del eterno retorno IMAGEN 103

La sensibilidad y pericia de este orfebre ante la temática que se plantea en sus joyas, le permite desarrollarlas estupendamente, dejando en ellas, un excelente testimonio. 
Las joyas de Lucía Ramírez poseen líneas simples pero con alto grado de refinamiento. El haber transitado por la Escuela de Orfebres Alexis de la Sierra, le ha permitido que sus joyas sean hoy en día ejemplo de un exquisito acabado. Así pues, partiendo de ese aspecto importante, Ramírez ha logrado definir una expresión que la caracteriza. Ésta, se establece en un estilo figurativo, para el cual, se vale de la construcción como técnica. El laminar, trefilar y seguetear sus propios perfiles en plata, son llevados a término a través de la yuxtaposición de planos y otros elementos, unidos por diversas soldaduras. La destreza que posee, permite que sus bocetos se transfiguren con verdadera fidelidad en el metal.

En el trío de Broches (IMAGEN 104) las piedras 98 protagonizan en los diseños. Perfectos y brillantísimos engastes de bisel, sujetan y exhiben cabuchones de ónix negro, turquesa y jaspe. Estos broches, gozan de armonía entre sus formas, color, brillo y

un delicado contraste, con el mate de la superficie de la plata.

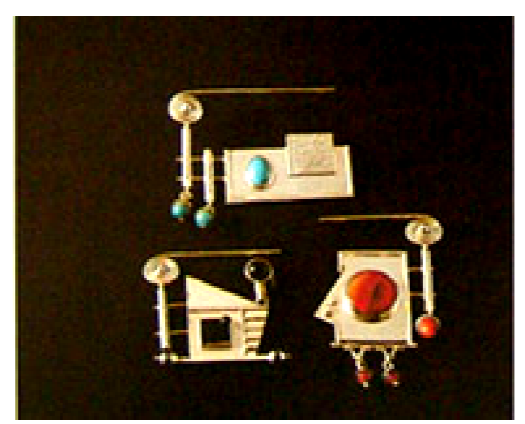

Broches

La inspiración provocada por el juego de contrastes entre los elementos que componen sus joyas, conduce a Ramírez a establecer los diseños en elementos reconocibles. La simetría define sus joyas a través de líneas contundentes en alto o bajo

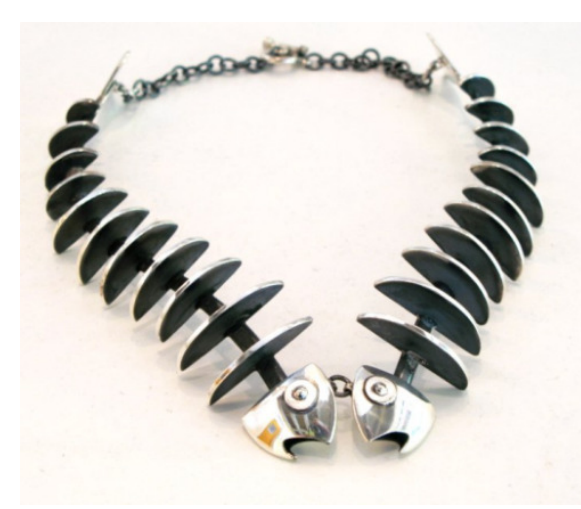

Collar relieve, de donde emergen sus diseños figurativos en plata. La Oxidación y el uso de piedras mate en cabuchón, engastadas en bisel le aportan carácter a las piezas mostrando pulcritud en sus acabados y superficie.

En Collar (IMAGEN 105) situamos en la primera mirada, su figura referente. Este particular collar, emerge de la trama de líneas que se

98 XXI Salón Nacional de las Artes del Fuego. (1994).

http://galeria.uc.edu.ve/actual.php?id=53 
hacen presentes en contundentes láminas de plata. Miradas dilatadas se entrecruzan boquiabiertas y un pequeño eslabón las une eternizando su momento. Caras embutidas, se enfrentan resplandeciendo sobre su brillantísima superficie; de ellas, emerge un enorme espinazo desvaneciendo su forma. El brillo extremo del canto de la lámina, contrasta enérgicamente con la pátina negra que cubre su reverso y anverso.

La factura impecable, la particularidad de los diseños y una importante cantidad de exposiciones, le han permitido hoy en día ser reconocida en el ámbito artístico a nivel nacional.

Durante varios años, el Gobierno del Estado Carabobo, le ha pedido elaborar el Rosario de la Virgen del Socorro -patrona de los carabobeños- para la celebración de la Feria Internacional de Valencia, -estado Carabobo-. Este hermoso y delicado Rosario es elaborado totalmente a mano en plata 925 bañada en oro 18, de gran longitud. Esta fascinante joya, se la disputan los toreros en la monumental y es otorgado como premio, al triunfador de la fiesta taurina.

La orfebre Lucía Ramírez se mantiene activa en el campo expositivo venezolano y en la docencia del oficio en su propio taller de orfebrería. 
La orfebre Mary Peña establece un discurso narrativo en cada joya que realiza. Entre sus formas, se encuentran elementos figurativos que representan una pequeña historia de la

vida cotidiana. De este modo, fusiona técnicas y materiales propios de la orfebrería con

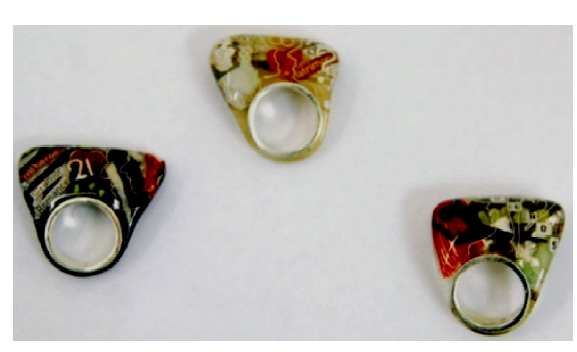

Proyección de vida de un diario abierto IMAGEN 106

elementos y materiales de otras disciplinas. El sugestivo trío de anillos Proyección de vida de un diario abierto (IMAGEN 106)99, surge de la unión paradójica entre la plata y el vaciado en resina. Así pues, estupendos aros de plata adquieren otra fisionomía con la yuxtaposición de un collage entre hilos de plata, cacho de toro, conchas de nácar, coral, papel, plástico e hilos de lana. Su composición, contiene elementos alegóricos que insinúan la similitud con su título.

En este conjunto de anillos, se manifiestan tres etapas de la vida de la mujer: la soltera, la comprometida y la casada. Así pues, en la de soltera, a través de una silueta de un rostro en hilo de plata, se exhibe sola y placida, con su cabellera suelta -de lana roja-

que armoniza entre un fondo jovial y colorido que contiene la frase "sueños". La comprometida, (Detalle

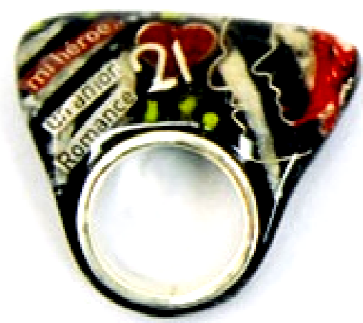

Detalle de Proyección de vida de un diario abierto

de Proyección de vida de un diario abierto IMAGEN 107) se exhibe junto a otro rostro entre frases románticas de recortes de papel que indican "mi héroe, un amor y romance", y un inmenso corazón rojo de corales. Y, la casada, se exhiben los dos rostros - uno frente al otro- entre alianzas de oro entrelazadas y una frase en papel que señala "oh, matrimonio" entre un fondo de color ámbar con sutiles fragmentos de nácar y un delicado bordado de hilo blanco.

9935 Salón Nacional de las Artes del Fuego. (2008).

http://galeria.uc.edu.ve/actual.php?id=79 


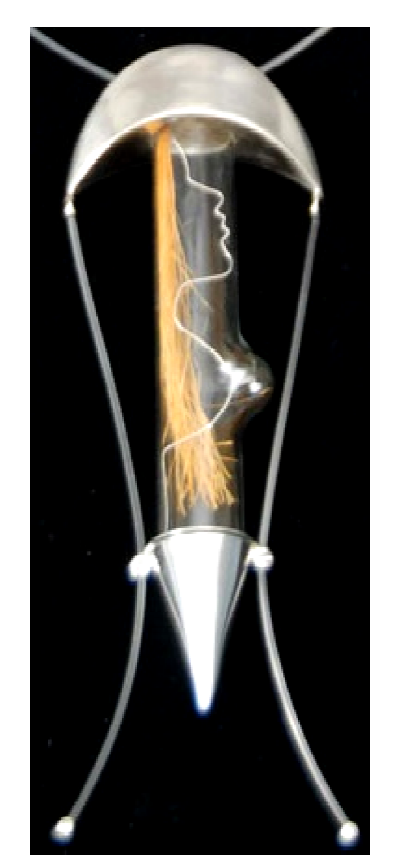

En 600 cc. Exigencias del Siglo XXI (IMAGEN 108)100, la orfebre lanza una mirada a la estética de la mujer venezolana y nos recrea con un collar que fundamenta sobre este tópico.

La aguda visión y destreza, se armonizan entre materiales y formas que realzan esta tipología. Así pues, un tubo de ensayo contiene un experimento del prototipo de la mujer actual venezolana. Pues, una larga y amarilla cabellera de hilazas de moriche, son parte de la transformación que se manifiesta en la silueta de hilo de plata. Silueta esta, representa un rostro cuya nariz perfilada, labios engrosados y aumentados pechos, manifiestan los 600

cc de dosis suministrada. Una encantadora torrecilla en plata, la protege y sujeta dentro de esa nueva coraza para evitar ser $600 \mathrm{cc}$. Exigencias del Siglo estropeada.

XXI
MAGEN 108

Su diseño particular, la sensibilidad ante la selección de los materiales usados, la creatividad con la que enfoca los detalles compositivos y la mano experta que las ejecuta, se congregaron en ambas propuestas para hacerse merecedoras del Premio en la tendencia de orfebrería en el "SNAF" con los anillos: Proyección de vida de un diario abierto en el año 2008 y el dije: 600 cc. Exigencias del Siglo XXI en el año 2009.

La orfebre Mary Peña demuestra con su arte la influencia de la enseñanza de Rafier Vera, pues, la inclusión de nuevos materiales y el fundamento de estos, como ente expresivo en sus joyas.

10036 Salón Nacional de las Artes del Fuego. (2009). http://galeria.uc.edu.ve/actual.php?id=85 
El orfebre Aris Hernández, después de su jubilación en la Industria Petrolera, se inicia en las artes a través de los vitrales. Desde su infancia se adoctrina con excelentes maestros venezolanos en las dependencias de la pintura. Sin embargo, es a partir de su jubilación, que estas secuelas le avecinan al vitral; Siendo cautivado por el entramado metálico de esta técnica, curiosamente, deriva en fascinantes tejidos. En esa etapa de experimentación, utilizó diferentes metales, consiguiendo en la plata y el oro, la bondad y particularidad que hoy en día fundamentan sus magnificas joyas.

Actualmente, éstas han trascendido a otras latitudes, pues, ha calado en un mercado altamente cautivador, al relacionarse con el mundo de las pasarelas y certámenes de belleza. Diseñadores de moda reconocidos a nivel nacional e internacional, engalanan sus desfiles con las fascinantes prendas de este orfebre.

El orfebre Hernández, es pionero en Venezuela en la elaboración de joyas tejidas en macramé con hilos metálicos. Sus sofisticados y laboriosos collares los realiza en oro y plata; donde, cada punto del macramé, se adapta a un diseño específico.

Gracias a su trayectoria como docente en el manejo de maquinarias y herramientas, adquirió una experiencia, que luego le sirvió de manera trascendental en su quehacer actual. Llegando así, a manipularlas con convicción transformándolas en sus propias maquinas; así como también, adaptar algunas herramientas, que le facilitaron la manipulación de los hilos metálicos.

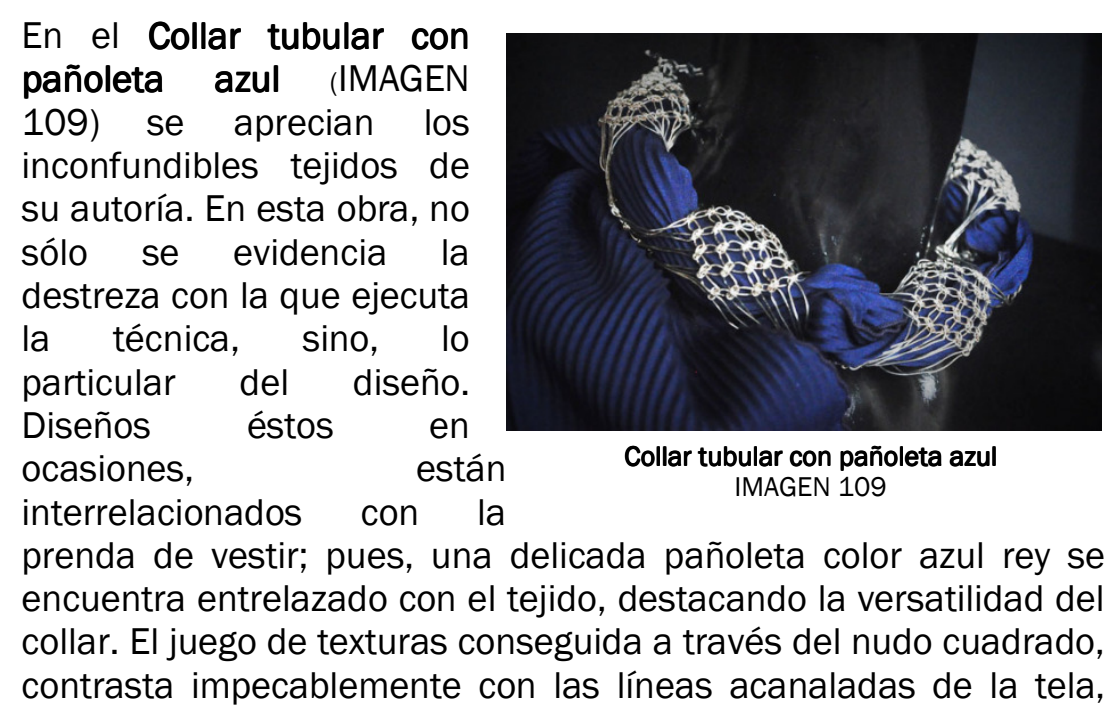


fusionándose con el entramado de delicados y brillantes hilos de plata. El resultado de esta unión, nos deleita con un diseño atrevido innovador y versátil, capaz de cautivar y engalanar a la mujer actual en cualquier rol que desempeñe.

Este orfebre, utiliza la galvanoplastia como una técnica aliada en su exitoso recorrido. De este modo, no sólo logra reducir el alto costo del oro, sino que además aporta brillo y durabilidad a los hilos metálicos.

La particularidad y ventaja de sus joyas, es que su entramada estructura de tejido en hilos metálicos, se adapta perfectamente a cualquier fisionomía, siendo esto, consecuencia de un riguroso estudio de la joya y la tenacidad adecuada de los metales para su uso y constante manipulación.

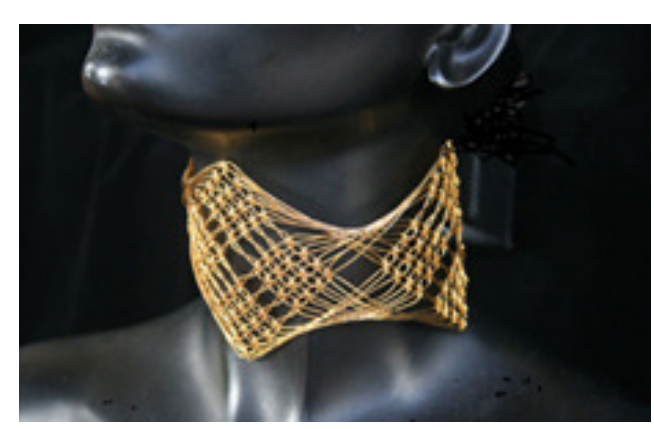

El Collar con hipérbolas de la (IMAGEN 110) está sometido a un baño electrolítico de oro $18 \mathrm{~K}$. Esta generosa capa de oro amarillo que los enaltece, se entretejen con maestría de la mano experta de Hernández; la Collar con hipérbolas IMAGEN 110 simetría impoluta de los hilos, se entretejen sugestivas cuadriculas que dejan espacios vacios para fundirse con la piel del cuerpo que lo exhibe. El impecable y generoso baño de oro cubre todo el collar, cuya superficie, es susceptible a resistir las sustancias químicas presentes en las cremas humectantes, perfumes o simplemente el $\mathrm{pH}$ de la piel.

Las joyas de estilo geométrico del orfebre Aris Hernánez que van desde impresionantes coronas, pectorales, collares, brazaletes, pendientes y anillos, son un verdadero aporte en el mundo del diseño de modas del país; y, gracias al escrutinio de su producción, se introduce con mano experta, en el medio expositivo venezolano. Tras el estimulo de una muchedumbre por sus joyas, crea su propia escuela; donde principiantes y expertos, pueden desarrollar este fascinante oficio, bajo la particularidad del tejido del macramé como técnica autónoma. 
Con lo anterior comentado, podemos aseverar, que el orfebre Aris Hernández resulta un buen ejemplo de alguien que ha logrado enlazar su profesión con una pasión101.

101 Hernández, A. (2013). “datos de formación y producción”. Material inédito. Correo electrónico. hernandezaris@yahoo.com. 
CARLOS GRATEROL

La explosión colorida de sus collares se conjuga en armonía con el brillo de la plata.

En las joyas del orfebre Carlos Graterol, se aprecia el color como elemento fundamental de todos sus diseños; donde, la explosión colorida se logra por medio de la técnica de esmalte al fuego. Desde principio de los años noventa, incursiona en esta técnica convirtiéndola en su aliada. Una característica recurrente en sus joyas son los fascinantes colores en su máximo esplendor; los cuales se unen armoniosamente con el brillo impoluto de la plata. De este modo, Graterol juega con los tonos que van desde los más vivos, entre opacos o brillantes; hasta los más sutiles, sean satinados o traslúcidos.

Titanio anodizado, plata 1000 y esmaltes al fuego se fusionan en un solo ser. Un enérgico tubo esmaltado de color rojo ladrillo, sujeta férreamente un enorme dije con esmaltes traslúcidos que degradan del violeta al turquesa. Estos elementos juntos componen el collar Contra...el vudú de mis amigos $\left(\right.$ IMAGEN 111) ${ }^{102}$.

El orfebre Graterol en este collar, asegura un buen equilibrio estético y visual capaz de engalanar cualquier vestuario que lo acompañe.

En el dije, la superficie de los perfectos círculos convexos de cobre,

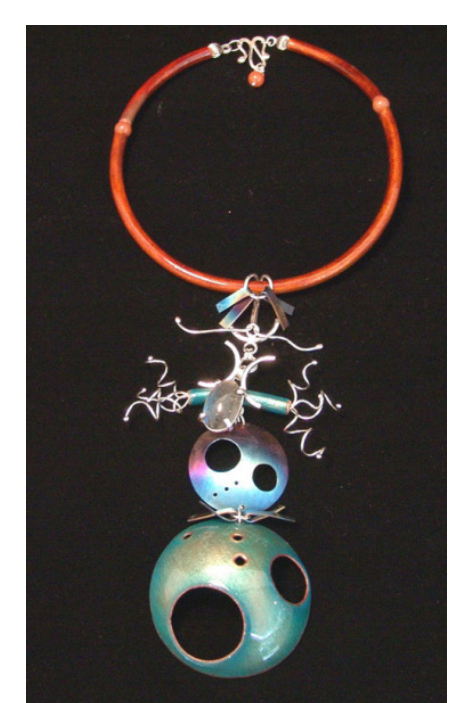

Contra...el vudú de mis amigos IMAGEN 111 se convierten en el médium para exaltar una delicada degradación traslúcida que va del turquesa al violeta. Las circunferencias caladas en su interior, permiten que la piel se fusione entre sus formas interviniendo como un ente unificador. Las dos imponentes circunferencias se sujetan entre ellas y se unen al collar, con un sistema articulado que permite su movilidad y por ende mayor comodidad. Este colosal dije está sujeto al collar por serpenteantes hilos de plata brillante.

La perseverancia por el arraigo a su técnica predilecta tiene una recompensa en el prestigioso "SNAF" en el año 2009. Puesto que,

10233 Salón Nacional de las Artes del Fuego. (2006).

http://galeria.uc.edu.ve/actual.php?id=66 


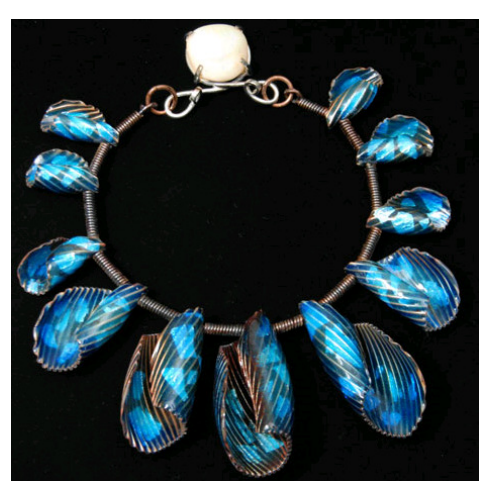

el collar de su autoría “...canción que canta en el fondo oscuro del mar, la caracola..." En memoria de Rosita Galea de Falena (IMAGEN 112)103, obtiene el Premio en la tendencia de Esmalte sobre metal.

Sin vacilar, una vez más se enfrenta ante los esmaltes con significativa intención. Por eso utiliza fascinantes formas del foil corrugado, y fusiona con hermosos

...canción que canta en el fondo oscuro mar, la caracola..." En memoria de Rosita Galea de Falena MAGEN 112

al Prusia. La esencia del fulgor que emiten los canales del metal pulido

entre las formas y tonalidades del azul, le da presencia a cada una de ellas con la similitud a una concha de nácar. Simétricamente, las conchas azules se separan con hilos de plata frenéticamente entorchados. (Detalle de...canción que canta en el fondo oscuro del mar, la caracola...en IMAGEN 113).

Las formas coloridas utilizadas refieren a ese entorno que impulsa su gesto creador, para llevarlo a término en este sugestivo collar. Los esmaltes al fuego, constituyen la mejor opción de este orfebre a la hora de ejecutar sus joyas. Con ellos, logra un exótico colorido que se hace apetecible para la vestimenta de la mujer actual.

La perfección de su obra es el Detalle de...canción que canta en el fondo resultado de un largo proceso de investigación; donde tonos

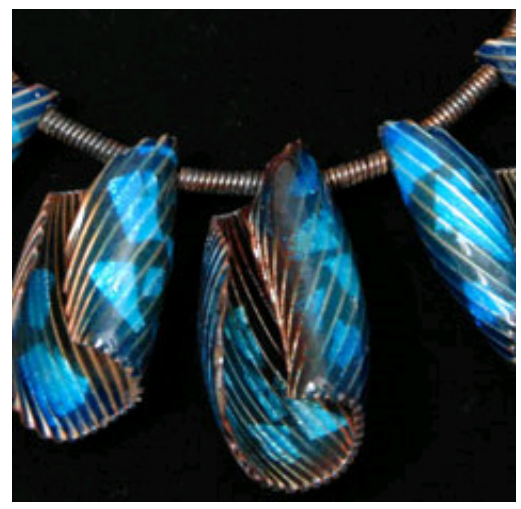
de Rosita Galea de Falena IMAGEN 113

fuertes y tamaños exagerados se

conjugan en armonía y se traducen en estupendos collares.

El orfebre Carlos Graterol, es otro eslabón importante en la cadena de talleres de enseñanza de orfebrería en Venezuela. Desde hace casi dos décadas, se dedica a la docencia en este oficio tanto en su Taller Escuela R\&C Orfebres, como en otros espacios; pues, siendo miembro de la Asociación Venezolana de las Artes de Fuego, ofrece talleres prácticos en diferentes técnicas, así como también, ha ofrecido conferencias sobre algunos tópicos de la historia de la orfebrería venezolana.

10336 Salón Nacional de las Artes del Fuego. (2009).

http://galeria.uc.edu.ve/actual.php?id=85 
Joyas que devienen de la alta costura.

El ser artista repercute en la diversidad con que se abordan distintas disciplinas. El caso de esta orfebre deviene de esa esencia; pues, su inicio es en la alta costura. Desde el conocimiento del diseño, corte y confección de prendas de vestir, parte su decisión de ampliar su punto de vista y enriquecer sus diseños con joyas elaboradas manualmente.

De este modo, la orfebre Georgina Doumat inicia su transitar en el mundo de la orfebrería de la mano experta de Carlos Graterol y Rosita Falena (QEPD) -Taller R\&C-, donde la intuición de estos orfebres y su adecuada enseñanza, permitieron a esta diseñadora de modas poder vincular su profesión con el fascinante mundo de las joyas.

En un principio, las joyas eran para complementar sus trajes. Luego, aborda la orfebrería bajo su propia perspectiva enriqueciendo así su labor como diseñadora. De este modo, se pasea entre ambas disciplinas sacándole provecho a las bondades de las telas y los metales. Al tener bien desarrollada las habilidades manuales por el dominio de ambas carreras, una disciplina nutre a la otra. Así pues, el diseño de modas y la orfebrería le otorgan una ventaja en las múltiples fases del diseño y se constituyen, en un medio para establecer su propio estilo.

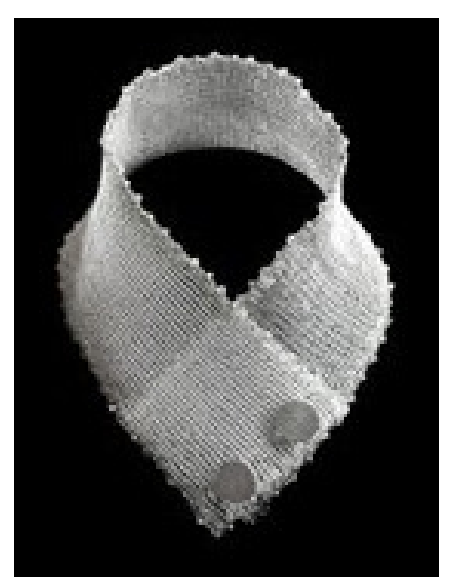

Alta costura IMAGEN 114

La afirmación anterior queda evidenciada en el collar elaborado en plata pura, que se muestra en la Alta costura (IMAGEN 114). Este acertado diseño, nos remite a un cuello de traje de etiqueta. En esta obra Doumat comparó las diversas técnicas posibles para hacer su diseño y finalmente, utilizó los procesos básicos del tejido de crochet. La elección del uso de la plata sin aleación, fue determinante para su propósito final. Considerando que, los finísimos hilos en plata pura permiten la manipulación con gran soltura, por eso, el tejido de principio a fin quedó pulcro. Finalmente, la orfebre consigue una superficie mate entre los tupidos hilos metálicos, tras la acción del arenado. Dejando el brillo impecable en los dos botones de su extremo para exaltar su 
bello contraste. El impulso creador que deviene del diseño de modas, apuntala en los diseños de sus joyas.

El ojo meticuloso de un artista ve y observa las cosas de una manera diferente. Así pues, los detalles mínimos son tomados en cuenta para desarrollar cualquier propuesta. Detalles éstos, que conducen al logro de joyas increíbles como el conjunto Sinuosidades (IMAGEN 115)104. Collar,

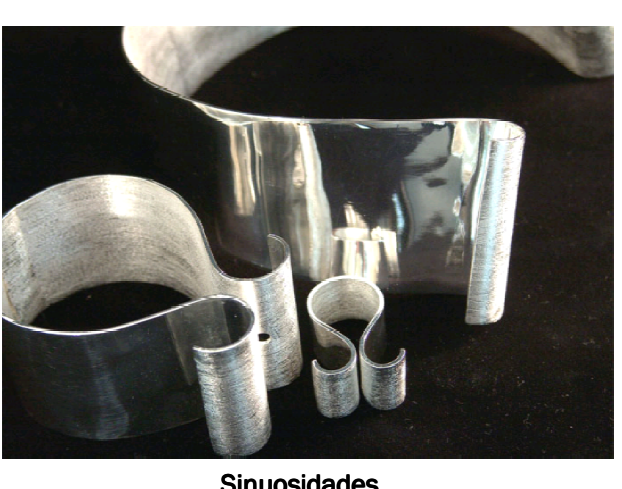

Sinuosidades

pulsera y anillo nacen de la

camisa de un frac, donde, cuello y puños almidonados se transmutan en lámina de plata. En la obra Sinuosidades, la orfebre enfatiza el ámbito del diseño de modas bajo un criterio más conceptual. Consigue de la plata pura las propiedades adecuadas para su función. Intencionalmente lo quiere así, no sólo por su maleabilidad, sino por el tono y el inmodificable brillo de la superficie. El satinado del interior de las piezas, le aporta un mayor contraste en la superficie del diseño, cuyas formas simples y resplandor impecable, refuerzan la intencionalidad de la obra.

El poder comprender la naturaleza de su inspiración e identidad de la forma, le ha permitido desarrollar las joyas con más soltura y libertad creadora. Por ello, identificó su lenguaje con piezas que se definen en formas sencillas con alto grado de delicadeza.

Al parecer, su vínculo con el mundo de la moda y las pasarelas ha rendido frutos tanto a nivel nacional como internacional, en este sentido, fundamenta sus diseños de ropa con una línea de joyería en dos vertientes, una comercial y la otra artística ${ }^{105}$.

10433 Salón Nacional de las Artes del Fuego. (2006). http://galeria.uc.edu.ve/actual.php?id=66

105 Doumat, G. (2013). “Profesión y orfebrería”. Material inédito. Entrevista online https://www.facebook.com/georgina.doumat?fref=ts 
JAGHANAT RODRÍGUEZ DE LA SIERRA

La perfección técnica se hace presente en sus collares.

El orfebre Jaghanat Rodríguez elabora los diseños con frenesí y escoge las técnicas y metales de sus obras con acertado conocimiento. Trabaja con minuciosidad cada detalle para alcanzar la perfección.

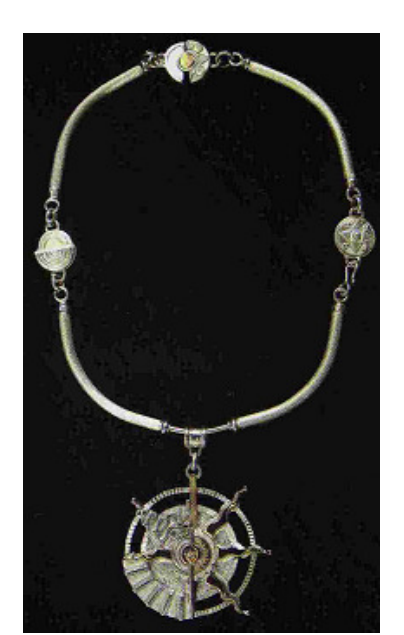

La conciliación y mimetismo de los cuatro puntos cardinales se establecen en Encuentro entre el sol y la luna, 2006 (IMAGEN 116)106. En una superficie colmada de texturas y contrastes se compenetran la pureza de la plata y el oro amarillo. Cada elemento se satura de textura lograda por diferentes técnicas y entre estas se hace evidente el cincelado. Las hendiduras de un grueso hilo de plata sostienen el halo del cual se aferran los rayos de luz del sol.

Encuentro entre el sol y la

Rayos de sol se transfiguran en una luna, 2006 delgada e imponente lámina de orc la blanquísima superficie de la plata. Cinco trozos de hilo en media caña, se fragmentan en e ocaso que deviene de la alineación entre el sol y la luna. En el centro del dije, un zigzagueante hilo de plata estremece el magnífico brillante. El cual se aferra entre su engaste, engalanando la inmaculada lámina de oro amarillo que constituye el núcleo del eclipse (Detalle de Encuentro entre el sol y la luna, 2006 IMAGEN 117).

La ambigüedad del diseño de la joya, se exalta ante la perfección de sus acabados. Este magnífico collar fue merecedor de la Mención de Destreza Técnica, en el II "SNO" del año 2006.

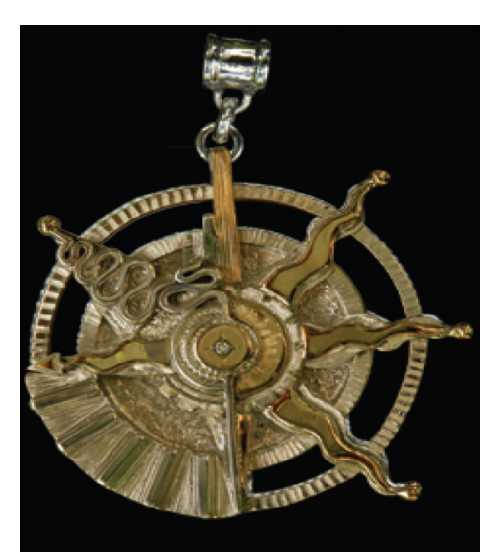

Detalle de Encuentro entre el sol y la luna, 2006 IMAGEN 117

106 Instituto de las Artes de la Imagen y el espacio y Mota, J. (2006). “I Salón Nacional de Orfebrería". Museo de la Estampa y del Diseño Carlos Cruz-Diez. Catálogo. p: 87. 
La destreza que colma las manos hacedoras de este orfebre, convierte los metales nobles en estupendas joyas. Su visión particular de la orfebrería, le amplia su instinto creador, permitiéndole alcanzar armonía en sus diseños y esmero en los detalles.

Este joven licenciado en Idiomas Modernos se ha dedicado en pleno a la disciplina de la orfebrería. Lo que comenzó como algo cotidiano en su entorno familiar, hoy en día lo mantiene profesionalmente. Aprendió este arte milenario de mano de su tío el orfebre, Alexis de la Sierra. Así pues, este excelente aprendizaje le ha descubierto su potencial y le ha permitido el sitial que hoy en día tiene en este ámbito artístico venezolano.

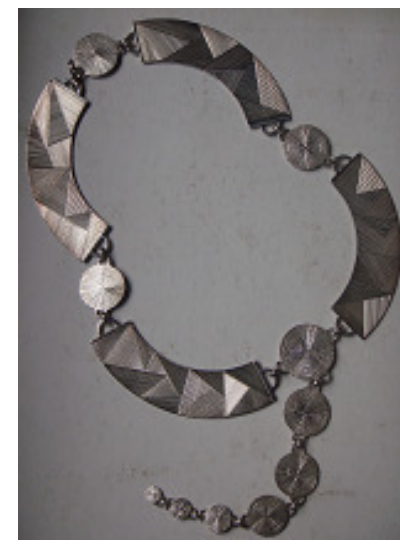

Pectoral Cinético

Pectoral Cinético
IMAGEN 118

En el collar Pectoral Cinético (IMAGEN $118)^{107}$, se pone en evidencia la manera impecable como este artista realiza sus construcciones. Cada eslabón, es una pieza única elaborada a mano tras el proceso del grabado con buril. Sin embargo, estos eslabones se relacionan manteniendo la continuidad del estupendo diseño que los establece. Con destreza en el manejo del buril sobre la lámina de plata pura, logra que el diseño lineal se repita inequívocamente (Detalle de Pectoral Cinético IMAGEN 119). El orfebre Rodríguez De la Sierra ha perfeccionado esta técnica cuyos diseños parecieran estar ejecutados mecánicamente. El metal puro le permite lograr a la perfección esta técnica puesto que, al no tener ningún tipo de aleación, resulta muy maleable y por ende apetecible ante sus diseños laboriosos.

Diseño este de, apuesta por sutiles líneas traducidas en incisiones milimétricas continuas que se cruzan entre verticales, horizontales y diagonales, creando un juego de luces discrepantes que producen fascinación. El proceso de esta técnica es lento y meticuloso, ya que no permite errores.

Cada tema que desarrolla el orfebre Jaghanat Rodríguez presenta una abundancia de posibilidades con un estilo geométrico predominante.

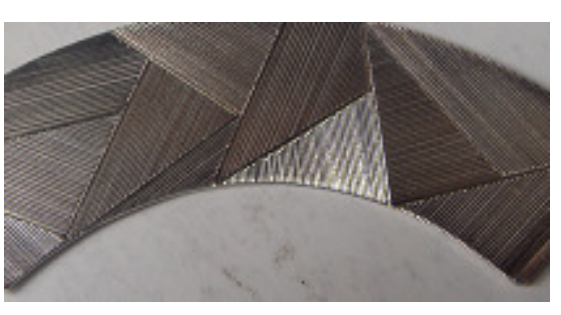

Detalle de Pectoral Cinético IMAGEN 119

107 Rodríguez De la Sierra, J. (2010). "Premios en salones de orfebrería”. Material inédito. Entrevista personal. Mérida, estado Mérida. 
Con el Pectoral Cinético, rinde homenaje al artista cinético venezolano Jesús Soto y fue merecedor de la Mención de Premio del Público en el III “SNO” año 2007. 
El caso de la artista María Teresa Torras (QEPD) es bien particular, pues, en el contexto de la escultura venezolana, se le conoce hoy en día como escultora y su prolífica obra, se ajusta a los grandes formatos. Sin embargo, su praxis deviene del arte textil, donde teje fastuosos e inmensos tapices con fibras naturales, obteniendo premios en la tendencia de Artes aplicadas en el -antiguo- Salón Anual de Arte Venezolano.

A principios de los años setenta cuando surge el "Salón Nacional de las Artes de Fuego" participa en varias ediciones de ese salón con joyas en plata. Su participación en el "SNAF" en esta disciplina, rápidamente obtiene buenos resultados; Al parecer, el particular semblante de sus joyas, se desvincula de la fisionomía de las joyas de esa época, por lo que le otorgan un Premio en la tendencia de Orfebrería en el año 1974; y, dos años más tarde sus joyas marcan un precedente importante en el contexto artístico, pues, el Premio Nacional de las Artes del Fuego en la tendencia de Orfebrería, es para un conjunto de tres bellos collares en plata de su autoría (IMAGEN 105-106)108.

En el espectacular conjunto de collares en plata de María Teresa Torra, se aprecia un marcado estilo geométrico. En ambos, utiliza el hilo plano de plata, para contornear el cuello con un magnifico cierre alargado de caja, que permite encajar con perfección los aplanados hilos; cuya curvatura forjada, se ajusta cómodamente a la fisionomía del cuello.

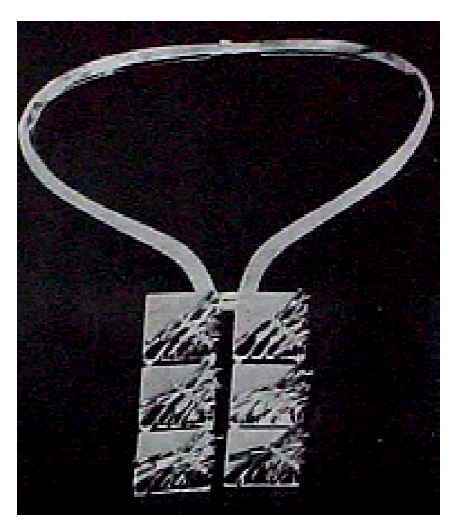

Collar

En el Collar (IMAGEN120), un bello dije rectangular dispuesto verticalmente, se apropia del semblante de un pectoral. Este bello rectángulo está elaborado con seis idénticos cuadrados de lámina de plata, donde su disposición, propone ese semblante rectangular. Cada uno de estos cuadrados, esta calado diagonalmente dejando libre su otra mitad; siendo este espacio, ocupado por un tejido de hilos laminados de plata. La disposición entre ellos, manifiesta su habilidad como tejedora de tapices e intuición de orfebre; pues, los espacios abiertos entre la lámina

108 IV Salón Nacional de las Artes del Fuego. (1976).

http://galeria.uc.edu.ve/actual.php?id=58 
pulida, dejan entrever la piel, creando un sugestivo contraste que dialoga entre la belleza del brillo de la plata y la tez de la piel de quien la use.

En el otro Collar (IMAGEN 121), interviene nuevamente con un diseño marcadamente geométrico. Un enorme dije rectangular, abarca gran parte del ancho del cuello, donde su semblante oculta una belleza extraña. El compendio de sus tapices, se transmuta entre estos simétricos hilos laminados de plata y soldados en forma de cruceta en un mismo eje. Hilos éstos, se entretejen a lo largo del marco rectangular que fundamenta el dije. La textura lograda entre intercalados salientes hilos, enfatiza su enérgica forma, que se

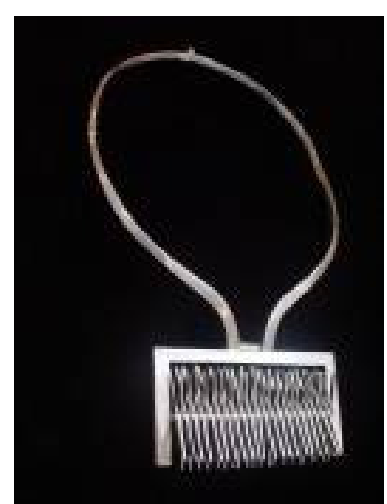

Collar

contrapone con la rigidez del marco de plata que la encierra.

Con estos magnificas collares vemos como la persuasión de los metales nobles califican su intelecto con convicción.

La artista/orfebre María Teresa Torras, dejo un importante precedente en la orfebrería venezolana; aunque su producción no tuvo continuidad, consolidó un lenguaje plástico que ha sido motivo de inspiración de las joyas de los orfebres de la época actual. 


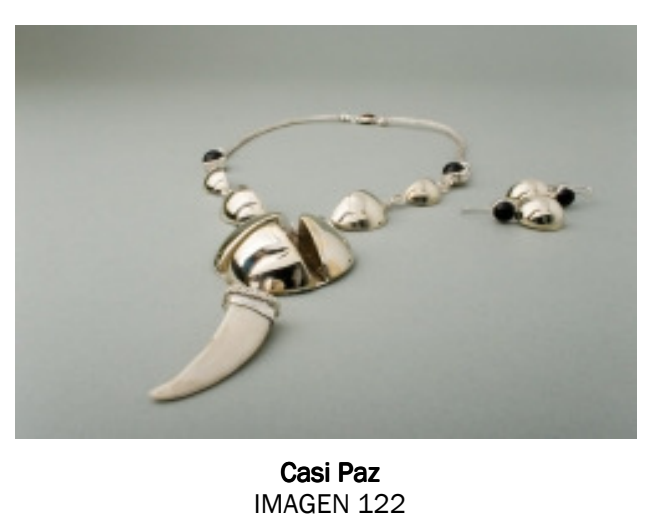

Este joven con apenas 13 años de edad demostró sus dotes de orfebre en el III “SNO" en el año 2007. Pues, el conjunto en plata Casi Paz (IMAGEN 122) 109 de su autoría, obtiene la Mención de Talento Joven.

En la joya Casi paz, conjuga la vida salvaje transforman en este enigmático amuleto. La vida y apariencia del tigrillo eternizado en el colmillo, crean una armoniosa composición, donde se connota la disparidad entre la delicadeza del brillo impoluto de la plata y lo feroz del blanquecino colmillo. Plata y alpaca se fusionan en un solo ser, para rememorar al felino entre sus semblantes.

Un pequeño ojo de tigre, se encarga de cerrar el collar con la tenacidad de la alpaca. La escogencia del ónix negro tallado en cabuchón y su idóneo engastado en bisel, nos deleita con su pericia de artesano. En tamaño ascendente, brotan de su contorno domos de plata brillantísima, que culminan en un volumen exagerado y seccionado. Con verdadera intención, su inciso deja ver el interior texturizado y oxidado simulando la tez del animal. De este domo, pende aferrado el colmillo, discrepando entre su esencia y la finura del engaste laminado que lo sujeta.

El no haber podido aprovechar el premio en el Salón Nacional de Orfebrería el cual era ser instruido en el oficio en una escuela reconocida en España, establece su taller y se centra en la práctica de las técnicas enseñadas por su padre: tejido en hilos metálicos, construcción engaste y repujado siendo ésta ultima su principal fuente de inspiración. Así pues, varios años más adelante vemos como se mantiene como constante en sus propuestas con esta técnica

Con el golpe continuo del martillo en la lámina de plata, modelos ingeniosos son concebidos tras esa acción.

109 Vera, R. (2012). "Imágenes y fichas técnica de obras III Salón Nacional de Orfebrería". Material inédito. Correo electrónico. vhrafier@yahoo.com 
Faena ruda es dominada por la mano sencilla de este joven orfebre, transformando a su antojo en caprichosos volúmenes brillantes que se han convertido en el referente de sus joyas.

Con el transitar de los años integra más elementos manteniendo como constante ciertas características que demuestran su autoría. Así pues, de un enigmático cordón tejido en cuero, pende un inconfundible dije del orfebre Ollantay. En el dije S/T de la (IMAGEN

123) apreciamos como la perseverancia ante una técnica se hace evidente; pues, el repujado, compone sus diseños

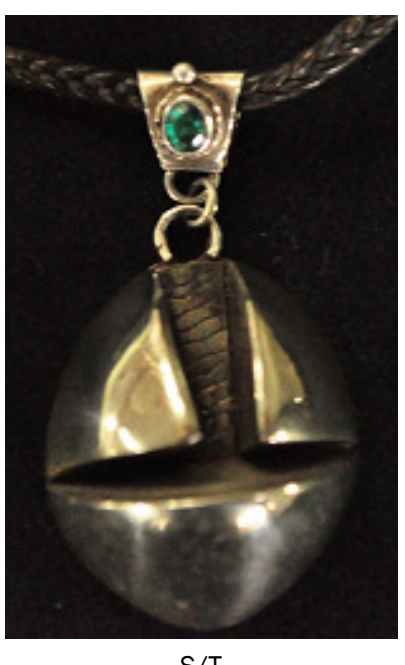

S/T

una y otra vez. Diseño éste, posee líneas simples y juega con la intersección de planos en el volumen.

Entre líneas verticales y horizontales se exterioriza esta perfecta ranura que atraviesa su parte superior, de donde emerge una textura fascinante que atrae la mirada. El brillo de la plata del domo, se hermana con caprichosas líneas hendidas y oxidadas aportando carácter y dramatismo entre sus formas. La bella esmeraldina hace fugazmente el color verde, propiciando la elegancia y delicadeza de la joya, evocando la magnífica tonalidad de la esmeralda en su estado natural.

La corta trayectoria del orfebre Ollantay Guédez nos emociona en ambos diseños donde se conjugan ciertos argumentos: la geometría que fundamenta su intelecto, la persuasión de los materiales autóctonos y la influencia de simbolismos al mundo de las joyas como ornato y las joyas talismán110.

110 Guédez, G. (2012). "Datos de la producción de su hijo Ollantay Guédez". Material inédito. Entrevista personal. Mérida, estado Mérida. 
SIMÓN SORONDO

Pequeños espacios complejos que se transforman en collares.

Recuerdos atávicos pernoctan en las fascinantes joyas del orfebre Simón Sorondo. Tras un cúmulo de historias, desarrolla una serie de pectorales y anillos en donde, se narran vivencias transfiguradas en pequeños espacios complejos entre la plata y estupendas gemas. Así pues, reminiscencias de la cultura Inca adoptan una fisionomía especial con marcado estilo geométrico, dando vida al pectoral Imperio Incaico (IMAGEN 124)111 . El estupendo diseño se establece sobre una base conceptual que radica en la energía que confieren las piedras a aquel que la usa.

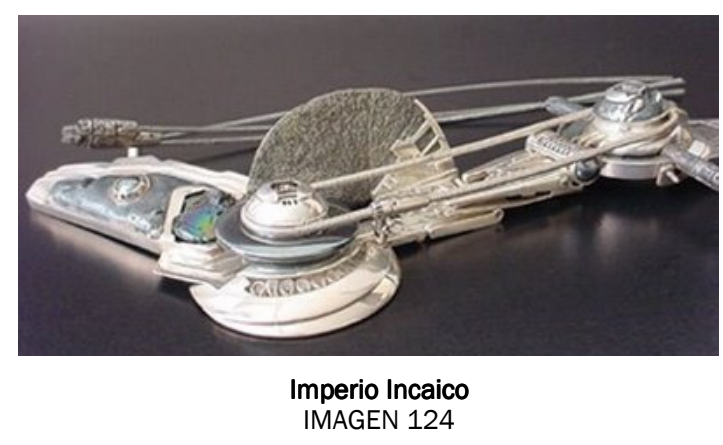

Esta joya representa en esencia, un conjunto de elementos y detalles que manifiestan el arraigo por sus ancestros $\quad \mathrm{y}$ transmiten una sensación especial; como si se tratase de un talismán salido de

las manos de aquellos indígenas, Sorondo nos recrea con este singular pectoral y demuestra su destreza ante el dominio de los metales. La leyenda del reloj solar Inca, se transfigura en la estupenda piedra que pernocta en su centro, entre plata, guaya de acero y acerinas. Todos y cada uno de estos elementos, cumplen una función en el diseño de rasgos indígenas con un aspecto moderno. De este modo, la convexidad de la circunferencia en plata es irrumpida por el tejido tupido de la filigrana. En su centro, lleva insertado un disco de acerina dentro del cual, se ajusta un pequeño domo en plata. Dentro de éste domo, se asegura una guaya de acero constituyendo un sistema de articulación mecánico, que permite ajustar su forma al cuello del portador. Al otro extremo, la guaya se asegura de un domo de inferior tamaño cuya cúspide, lleva engastado otro cabuchón de acerina.

La armonía entre el brillo y los tonos de la plata pulida y el semblante de la acerina, conjugan la belleza entre sus formas, embelesando con su impecable factura. Este magnífico pectoral obtiene un Premio en la tendencia de orfebrería en el "SNAF" del año 2000.

111 XVII Salón Nacional de las Artes del Fuego. (2000).

http://galeria.uc.edu.ve/actual.php?id=62 
Una vez más, el orfebre Simón Sorondo nos recrea con joyas de su autoría, con reminiscencias de una cultura del pasado.

Echándole un vistazo a su producción, se adivina la conexión con un estilo geométrico explícitamente futurista. En esta ocasión, trabaja en conjunto con una diseñadora de modas Argentina Laura Valenzuela en donde sus joyas se exhiben con los trajes de la colección (Desfile colección Primavera-Verano 2005-2006 de Laura Valenzuela IMAGEN 125) 112 .

Tomando en cuenta el estilo de dicha colección, aprovechó las bondades de las telas y la particularidad de los modelos de los trajes para representarlos con

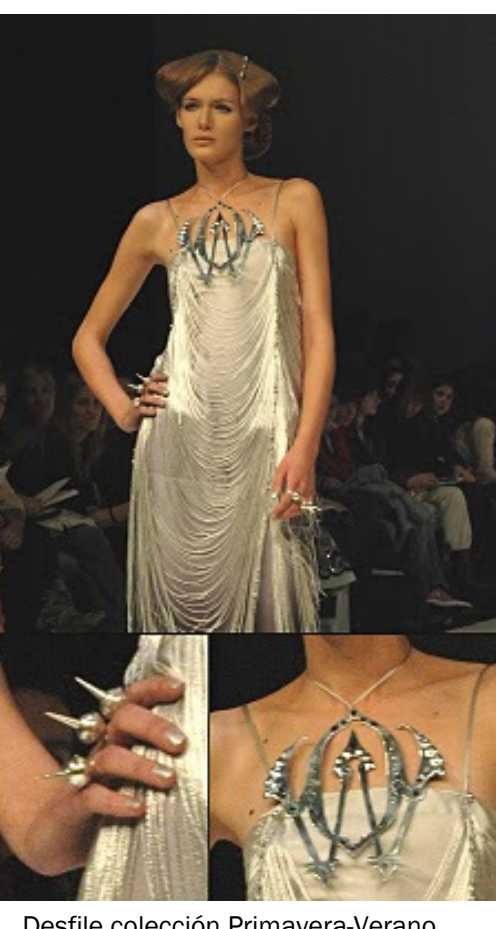

esfile colección Primavera-Verano 2005-2006 de Laura Valenzuela IMAGEN 125

sus enfáticas joyas. Así pues,

elaboró diseños entre pectorales y coronas en aluminio y anillos en plata con formas y tamaños exagerados, que parecen ser sacados de la edad media.

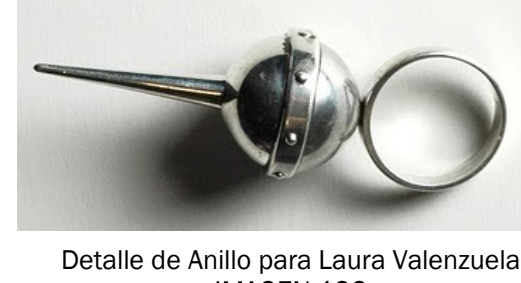

Espacios abiertos en los pectorales, lucen con armonía entre piel y metal la fusión con las telas de los hermosos trajes. El impecable calado de la silueta, muestra con gran definición los detalles de sus formas dejando IMAGEN 126 en evidencia su pericia como

orfebre. Las manos de las modelos ostentan con gran entereza, voluminosos anillos cuyos diseños discrepan con la delicadeza de los trajes. Sin embargo, esa paradoja entre la sutileza y rudeza debe cumplirse porque el orfebre lo ha dispuesto así. De este modo, el protagonismo de la vestimenta y los accesorios son independientes, pues, ninguno le quita protagonismo al otro. Así pues, estupendas esferas de donde salen imponentes formas punzantes, se ajustan en los dedos y se adaptan al vaivén de las manos al caminar (Detalle de anillo de Desfile colección PrimaveraVerano 2005-2006 de Laura Valenzuela IMAGEN 126). La solidez

112 Simón Sorondo.

www.simonsorondo.blogspot.com/ 
de sus diseños unido a una técnica depurada y detallista, son el testimonio de la experiencia en la joyería.

Su transitar en la orfebrería inicia para finales de los años ochenta logrando rápidamente la excelencia que lo caracteriza; para ese entonces, trabaja como ayudante del orfebre Alexis De la Sierra, lo cual genera ciertas expectativas estableciendo hacia finales de los noventa su propio "Taller-Escuela Metal Gema", en la década del dos mil se traslada para Argentina; siendo en la actualidad, un importante centro de enseñanza, donde el día a día, transmite a sus alumnos la sabiduría que tiene del oficio.

Sus largos años de permanencia en Venezuela dejaron honda huella, en salones de arte tanto con su obra como la de alumnos formados por él. Así como también en diversas experiencias vinculadas al proceso educativo en la disciplina de la orfebrería; ya que, estuvo como Coordinador de la carrera de Diseño de Joyas del "Instituto Superior Universitario Monseñor de Talavera, -hoy desaparecida- en la ciudad de Caracas.

Con las joyas de Simón Sorondo, concluimos con los orfebres venezolanos que desarrollan su producción artística a través de la orfebrería ornamental. Obviamente apreciamos, una estupenda diversidad donde la originalidad, de sus diseños, la habilidad con que manipulan los metales, la ideología que las origina y la impecable factura que consiguen; han fundamentado un lenguaje artístico que se apropia de la fisionomía del cuerpo, para ser lucidas como estupendos complementos de la vestimenta de la moda actual.

\subsubsection{TENDENCIA ESCULTÓRICA. Aspectos técnicos, formales y} conceptuales. Valoración personal.

Tal y como mencionamos anteriormente, expondremos de manera objetiva, sobre los aspectos técnicos, formales y conceptuales que caracterizan la producción del orfebre venezolano en la tendencia Escultórica conformada por un grupo de 26 orfebres. Efectivamente, mantendremos el orden que se indica en el primer esquema. De igual modo, hemos elaborado un tercer esquema donde muestra los nombres de dichos orfebres; siendo estos, enumerados en un orden alfabético, clasificados dentro de la tendencia donde encaja su obra. Así pues, inicialmente hablaremos de los orfebres que su producción se establece en paralelo, entre la tendencia Ornamental y la Escultórica y finalmente, hablaremos de los orfebres que su obra se establece en la tendencia Escultórica.

En este apartado hicimos la clasificación solo enfatizando las tendencias sin tomar en cuenta el estilo en que esta encaje, 
puesto que, su producción se establece en paralelo entre la Ornamental y la Escultórica; y en muchos casos, ambas producciones se fundamentan en estilos diferentes. Por ello, decidimos presentarlo de esta manera para que pueda ser valorada cada joya y obra, según su tendencia.

\begin{tabular}{|c|c|}
\hline $\begin{array}{l}26 \text { orfebres en la tendencia } \\
\text { Escultórica }\end{array}$ & encia \\
\hline $\begin{array}{l}17 \text { orfebres entre tendencia } \\
\text { Ornamental y Escultórica }\end{array}$ & $\begin{array}{l}9 \text { orfebres en tendencia } \\
\text { Escultórica }\end{array}$ \\
\hline Alexis De la Sierra & Ana Mercedes Carvallo \\
\hline Christian Gramcko & Edymar Álvarez \\
\hline Claudia Padrón & María Graciela García \\
\hline Claudo Kalán & María Njaim \\
\hline David García & Mildred Maury \\
\hline Edecio Barazarte & Natalia Santamaría \\
\hline Gustavo Smitter & Patricia Querini \\
\hline Haydee Pérez Criollo & Ricardo Laverde \\
\hline Julia Ferreira & Víctor Rodríguez \\
\hline Liliana Benítez & \\
\hline Nadia Karroum & \\
\hline Rafael Bello & \\
\hline Rafier Vera & \\
\hline Samantha Fung & \\
\hline Sonia Parisca & \\
\hline Tatiana Tischenko & \\
\hline Yolanda Sucre & \\
\hline
\end{tabular}


La praxis de su lenguaje plástico lo convierte en el pionero de la orfebrería escultórica en Venezuela.

El nombre del maestro Alexis de la Sierra significa orfebrería al más alto nivel en Venezuela. Desde sus inicios en el medio, sus joyas siempre fueron referencia tanto por el diseño como por el excelente acabado. Sus joyas persistentemente han sido cotizadas en los estratos sociales más altos, en certámenes de belleza y en el mundo del diseño de modas, por lo que la diversidad de sus diseños es inexorable ante tanta demanda.

Un conjunto de 5 collares en plata de su autoría obtiene el Premio Nacional de las Artes del Fuego en la tendencia de orfebrería en el prestigioso "SNAF" en el año 1986 Le premier plaisir d'argent (IMAGEN 127); con lo cual, deja un legado importante en el campo artístico venezolano, enarbolando la disciplina como ente expresivo en el arte. Este bello collar, elaborado en plata Britania con la técnica de la cera perdida, se fundamenta en un ovalo rodeado de una espectacular franja acanalada; y desde su centro, sale una lamina colmada de diminutos surcos lineales, que se explayan por toda su

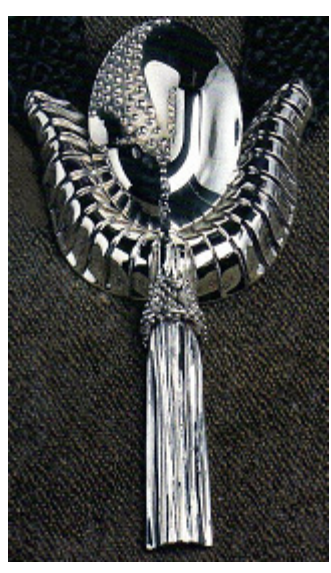

Le premier plaisir d'argent IMAGEN 127 superficie; el delicado tejido en macramé, constituye el enorme cordón que lo sujeta, otorgándole un delicado contraste entre la

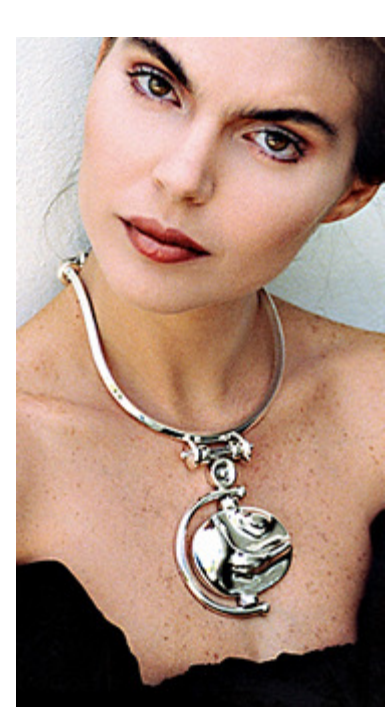

Pectoral ergonométrico II IMAGEN 128 superficie de la plata brillantísima y delicado tono sedoso del negro.

Pectoral ergonométrico II (IMAGEN 128) es una de esas fascinantes joyas que, con tanta devoción y dedicación embellecen hasta la mujer más encantadora. Pues, la ex Miss Universo Bárbara Palacios resplandece -aun mas- entre su fisionomía y tono de piel con el brillo y formas del perfecto pectoral. La cera perdida es la técnica elegida para convertir la plata pura en este interesante dije. El ovalo ondeante después de vaciado, es manipulado con el martillo para acentuar y exagerar sus curvas. El sistema de articulación mecánica usado para unir el dije al collar, permite su movilidad para adaptarse al cuello de 
quien lo exhibe. El hilo grueso que abraza el cuello y sujeta el dije central, está compuesto de plata esterlina cuya tenacidad, evita que se deforme con el uso. El enigma de lo desconocido convierte a De la Sierra en un investigador ambicioso por descubrir nuevas expresiones. Sea cual sea su vínculo con la historia más remota, su obra se recubre siempre de elementos, signos y formas que nos sugieren una nueva era de la humanidad.

La Cruz Obispal (IMAGEN 129) es una de las tantas joyas concebidas bajo la seducción de este tópico. En ella, se descubre cómo emotivamente el artista la elabora bajo la seducción de los materiales, pues, la plata pura y el oro de 24 quilates son los metales elegidos para exhibirla solemnemente y convidar al espectador a internarse entre sus sugestivas formas. Cuatro ángeles vaciados en cera perdida, dispuestos en los cuatro puntos cardinales, son quienes constituyen esta espectacular cruz; su fuerza centrípeta los une en un solo cuerpo, de donde emergen dos impactantes amatistas. La abertura horizontal que yace en su interior, crea un vacío donde

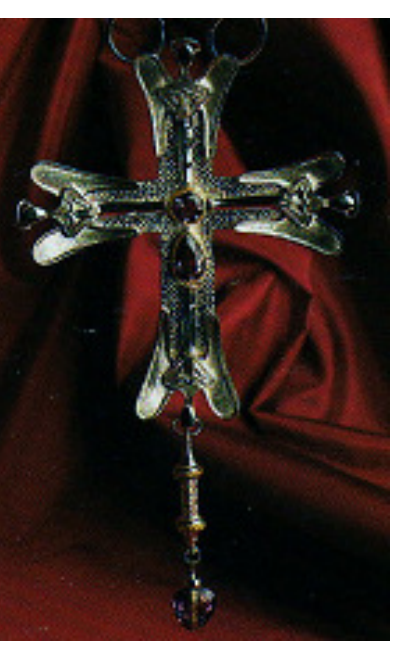

Cruz Obispal descansa la esencia del espíritu. Un sugestivo péndulo de oro y plata cuelga de la parte inferior de la cruz obispal. En él, se abraza delicadamente una amatista tallada en forma de corazón dispuesta a transmitir serenidad a través de su vaivén. Esta fastuosa cruz, fue elaborada en el año 1989, a petición del Obispo Ignacio Velazco (QEPD) para usar como complemento de su importante atuendo.

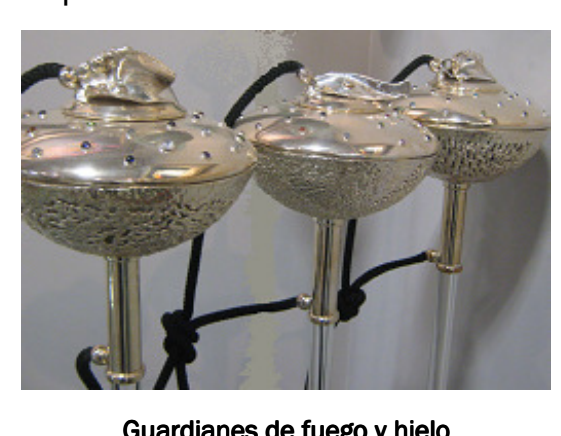

Guardianes de fuego y hielo IMAGEN 130

El perfecto dominio de técnicas en orfebrería y en escultura al servicio de su creatividad desbordante, es el aspecto determinante que le ha permitido crear un lenguaje plástico llamado Orfebrería Escultórica, donde, la perfecta unión entre orfebrería y escultura, se hacen presente en esta nueva tendencia. Bajo esta premisa, sus joyas se adentran en otro contexto, desprendiéndose del cuerpo para apoderarse del espacio tridimensional. 
Poderosas referencias antiguas, templarias y metafísicas conforman una iconografía futurista, omnipresente en su obra. En Guardianes de fuego y hielo (IMAGEN 130), la inclusión del efecto lumínico en el volumen irrumpe en el campo tridimensional. El domo de plata seccionado en dos partes,

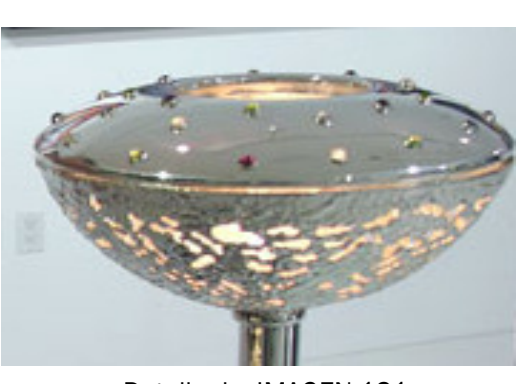

Detalle de IMAGEN 131 constituye la copa luminaria de la cual se emiten dos tipos de luces artificiales (Detalle Guardianes de fuego y hielo de IMAGEN 131). Con gran elegancia, ostentan piedras semipreciosas sobre el copón superior. Magistralmente engastadas sobre pequeños orificios, la luz se proyecta desde el interior del volumen chispeando hermosos matices sobre la superficie pulida de plata. Tras la acción del reticulado el copón inferior de plata se transforma en una superficie colmada de textura rugosa; de él, surgen diversos orificios que derrochan luces blancas en diferentes direcciones. Así pues, Guardianes de fuego y hielo se convierten en meros portadores de luminarias, que armonizan con su contraste de matices en el espacio en que habitan. La paradójica unión del fuego y el hielo, deja testimonio sobre su superficie con exquisitas texturas ${ }^{113}$.

Contando con más de cuarenta años de vida artística, este creado ha ido ampliando su propio lenguaje a través de la orfebrería, la escultura y el arte cibernético. Libre de preconcebidos academicismos, siempre analítico, investigador y a la vez espontáneo nos sorprende con nuevas visiones y con la creación de nuevos géneros de expresión plástica.

En Soplo de vida, todavía hay esperanza (IMAGEN 132)114, demuestra su maestría y el aporte de su particular obra en el arte contemporáneo. Pues, esta obra multidisciplinaria resultó ser la ganadora de la Medalla de oro Magnus Laurentis Medicis en la "Bienal Internacional de Arte Contemporáneo en Florencia", Italia en el año 2001.

La aplicación y fusión de técnicas de otras disciplinas artísticas con aquellas propias de la orfebrería se transforman en un solo lenguaje. Una instalación concebida bajo los criterios artísticos que lo caracterizan como pionero de la orfebrería escultórica en Venezuela. En ella, De la sierra minuciosamente congrega varias

113 De la Sierra, A. (2010). "Producción en orfebrería”. Material inédito. Entrevista personal. Caracas, Distrito Capital.

114 Marín, C. (2003). "Alexis De la Sierra. Más allá de sí mismo" Revista Ocean Drive. Vol 4. № 5. p: 73. 
disciplinas que conciernen y convergen con el arte de la instalación. De este modo, la pintura cibernética, medios audios visuales, la escultura y la orfebrería, se hermanan bajo una misma mirada. Donde, el espectador interactúa con la obra a través del sentido de la vista, oído y olfato.

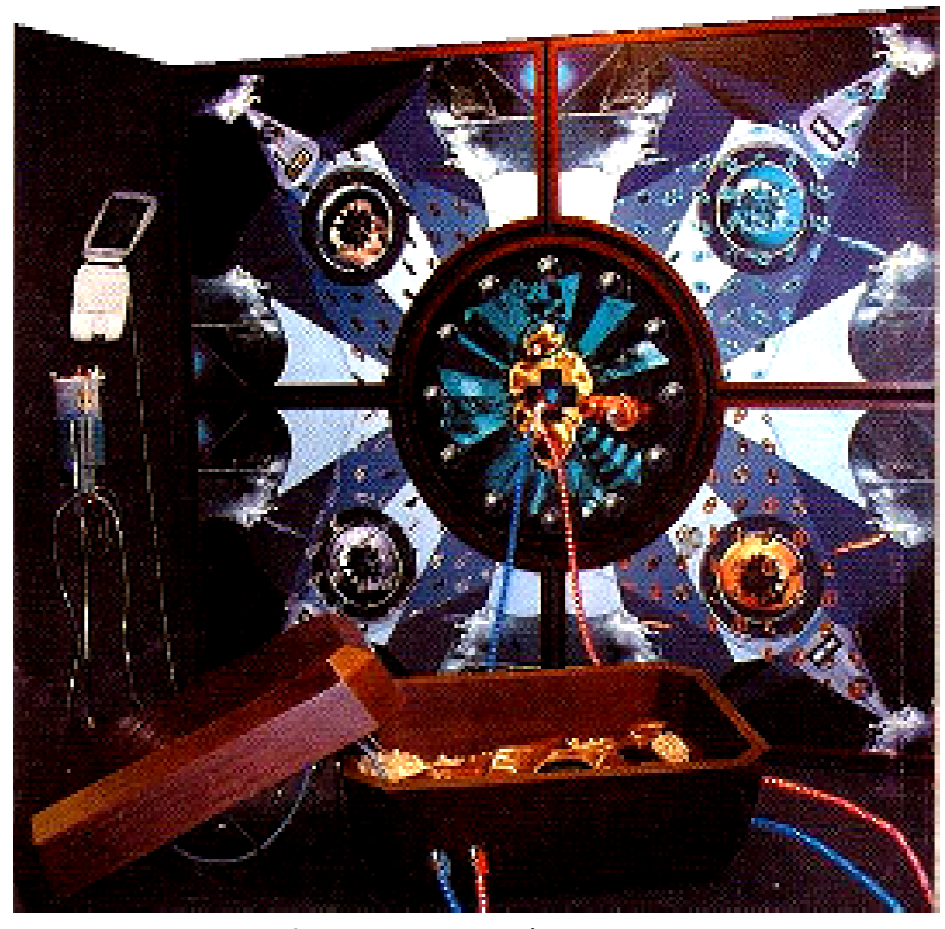

Soplo de vida, todavía hay esperanza

IMAGEN 132

Esta instalación, se constituye sobre una base de madera y dos paredes siendo una de ellas, un enorme lienzo seccionado en

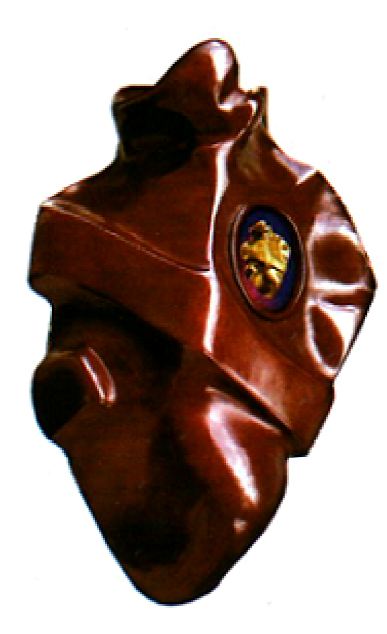

cinco partes. Esta enorme pintura, fue creada digitalmente e impresa con pigmentos y equipos de alta tecnología.

Del centro de esta pintura cibernética, siendo un corazón dorado-, salen dos mangueras con luz intermitente en su interior, una roja y otra azul; estas mangueras, se unen a un inmenso cofre de madera donde descansa un corazón de bronce patinado: Sursum Corda (IMAGEN 133). En el interior de este corazón, yace otro corazón más pequeño en oro de 24 quilates. Como una coreografía, se sincronizan la luz Sursum Corda intermitente de las mangueras, la 
música que sale del ordenador portátil y el agua del interior de la unidad de cuidados intensivos -respirador asistido por un monitor que registra las presiones en las venas principales-. Todos y cada uno de estos elementos, crean este espacio ilusorio en un ambiente emotivo de múltiples lecturas. La ilusión y subjetividad del espectador dan rienda suelta a su imaginación ante esta instalación ${ }^{115}$.

115 Pervhilac, I. (2008). “Ficha Simbológica/Conceptual. Instalación Soplo de Vida Todavía hay Esperanza por Alexis De la Sierra. Bienal Internacional del Arte Contemporáneo de Florencia (2001)". Material inédito. Correo electrónico. artmaneger@delasierra.com 
Con el paso del tiempo, comienza a ver la joya como un espacio expresivo.

A principios de la década de los noventa, el orfebre Christian Gramcko inicia su transitar en la orfebrería y es la forma de la figura humana el referente en sus joyas. Aprovechando las bondades de la técnica de la cera perdida y los esmaltes al fuego, satura de detalles cada joya entre texturas orgánicas, personajes modelados en cera y colores espectaculares en esmalte. De este modo, usa elementos de la naturaleza y los interviene para que se ajusten a la morfología de un dedo, el contorno de la muñeca o el cuello y se transformen en una joya. Así como también, modela la cera, creando estupendos personajes que se complementan entre estas estupendas formas y a su vez con los esmaltes.

En la joya Sobre el Madero (IMAGEN 134), el orfebre Gramcko convierte las ramas sinuosas del madero en un brazalete. Su interior deja acoplar el movimiento de una feliz pareja, donde sus cuerpos desnudos con esencia y presencia se aferran al entorno que los

ampara. Con premeditación, una lámina de plata esmaltada entre tonos de color azul, se ajusta perfectamente entre sus formas, involucrándose en el brazalete Sobre el madero.

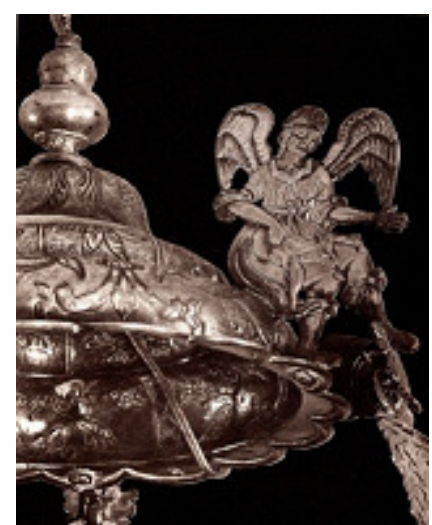

Experimenta con esta tendencia por mucho tiempo y en ese transitar, se convierte en miembro de la "AVAF". Esto, le permite la asistencia en cursos de tecnificación en esmaltes al fuego y exposiciones internacionales. Obteniendo premios en Japón, Estados Unidos, Argentina y Venezuela.

Según nos comenta el propio orfebre Gramcko116, en el año 1996, el profesor Carlos Duarte, siendo crítico de arte, bajo su condición de Director

Lámpara del Sagrario IMAGEN 135 del "Museo de Arte Colonial de

116 Gramcko, C. (2010). “Imagen de la obra restaurada en 1996”. Material inédito. Correo electrónico. christiangramcko@gmail.com 
Caracas"; le encarga a este orfebre, la restauración de la Lámpara del Sagrario, (IMAGEN 135), obra Elaborada en su totalidad en plata por un importante orfebre de mediados del siglo XVIII. Así pues, con gran maestría, Gramcko recurre a las técnicas del cincelado y repujado devolviéndole sus impecables formas orgánicas donde su intervención, mantuvo impecable su condición original.

Durante varios años, se mantuvo inmerso en la figuración, hasta que el transitar en el diseño grafico le ayudó a ver la joyería de otro modo. Poco a poco, fue encontrando la esencia de otras formas a través de los materiales y comienza a ver la joya como un espacio expresivo. Entonces, va generando una obra totalmente diferente vinculada a una nueva filosofía y fisionomía.

La nueva mirada sobre el entorno del arte actual, le permite responder a los cambios experimentados. Así pues, pequeños fragmentos de la cotidianidad se vinculan a un lenguaje del que se va apoderando hasta llegar a una orfebrería conceptual. En la obra Se despide una perla (Homenaje a Elizabeth Schönn) (IMAGEN $136)^{117}$, modifica la poesía en otra realidad.

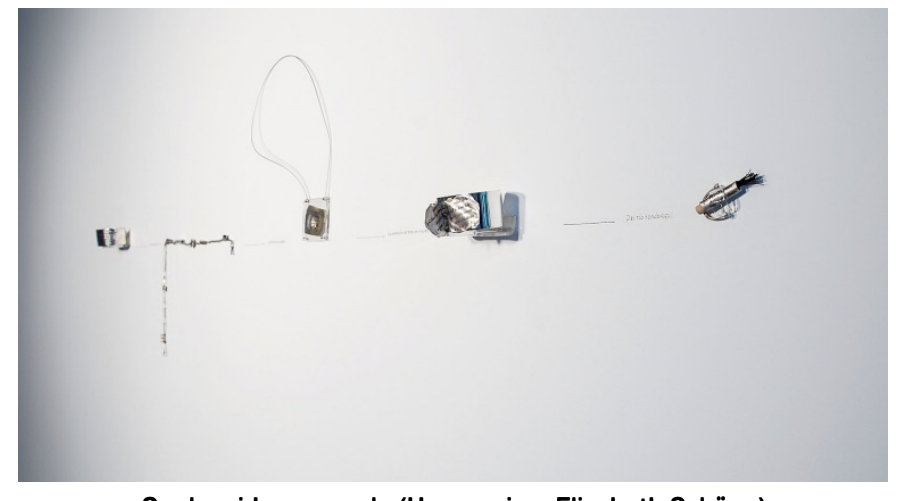

Se despide una perla (Homenaje a Elizabeth Schönn) IMAGEN 136

Esta simbiosis deriva de las fascinantes escrituras de la poetisa venezolana Elizabeth Schönn (QEPD), donde pequeños párrafos elaborados con plata, perlas y otros elementos se traducen en una fascinante lectura tridimensional (Detalle de Se despide una perla (Homenaje a Elizabeth Schönn) IMAGEN 137).

Su nueva mirada de orfebre, revela el enigma que encierran las dulces y emotivas frases del poema, con materiales que vinculan lo fugaz de una palabra a lo tangible de lo escrito. Entre la plata, el acrílico, el grafito y la superficie de la pared blanca, se explaya una

11734 Salón Nacional de las Artes del Fuego. (2007).

http://galeria.uc.edu.ve/actual.php?id=72 
escritura fluida por medio de un particular grafismo. Siendo este, un significativo testimonio de su traducción que le permitió hacerse ganador del Premio Nacional de las Artes del Fuego en la tendencia de Orfebrería en el "SNAF" del año 2007.

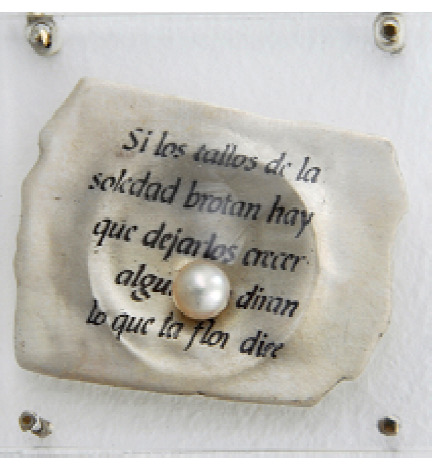

Detalle de Se despide una perla (Homenaje a Elizabeth Schönn)
IMAGEN 137 
El universo indígena es plasmado en sus propuestas a través de materiales autóctonos.

La orfebre Claudia Padrón materializa el universo indígena venezolano con este pectoral. Por eso, establecer un estilo que caracterice esa cultura a través de elementos autóctonos de la flora y fauna de su país, resulta absolutamente necesario. El advenimiento de otras culturas, no permitió la continuidad de esos orígenes que tanto se añoran en la actualidad. Por eso, Padrón selecciona exhaustivamente materiales nativos y con verdadera mesura los ubica y los dispone según su capricho.

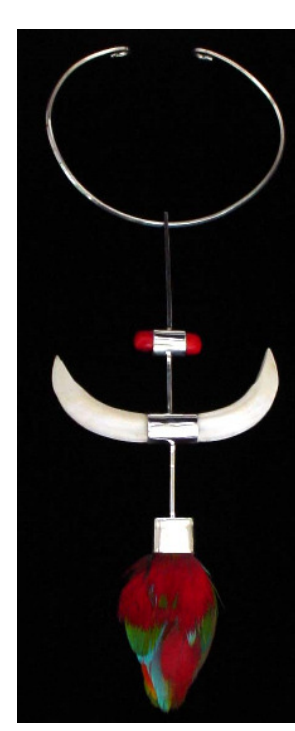

Las guacas nos Las guacas nos
siguen en la curiara...

se nos sale

el corazón...

En el pectoral Las guacas nos siguen en la curiara... se nos sale el corazón... (IMAGEN 138)118, la riqueza de la vegetación, la vida salvaje y el colorido de la fauna, coexisten entre formas reconocibles y se unen entre el misticismo y la simbología que los establece.

Fragmentos de una cultura desarraigada se relacionan en esta propuesta para testificar su presencia sin desvincularse de su simbología. Cada uno de estos elementos tiene una significación particular; las semillas de peonia, los colmillos de jabalí y las plumas de guacamaya para fundamentarse en un único espécimen.

Según hemos conocido de otras culturas a través de la historia del arte, sabemos que los pectorales han sido considerados un tributo de gran valor para quien lo usa, que aun hoy en día, muchos de los elementos que los componen son un enigma. Sin embargo, someramente podemos señalar la simbología de los tres elementos usados en este pectoral según los mitos populares. La peonia es un poderoso amuleto para unir a las parejas y su bienestar. El colmillo de jabalí para combatir el maleficio de las personas (mal de ojo) y las plumas de guacamaya determina el rango social, símbolo de dignidad, y poder de los jefes tribales. Donde, la plata como metal unificador interviene entre ellos con simplicidad sin quitarles protagonismo. Entonces, este mítico pectoral podemos traducirlo como un fantástico amuleto cuya simbología y características semejan a un híbrido de ave en pleno vuelo. $Y$, su trasfondo pasa desapercibido en la moda de la mujer actual. La sensibilidad y

118 XXX Salón Nacional de las Artes del Fuego. (2003).

http://galeria.uc.edu.ve/gubs.php?id=41 
respeto por el uso y disposición de cada uno de estos elementos, permitieron que esta joya fuese galardonada con un Premio en la tendencia de Orfebrería en el "SNAF" en el año 2003.

En la obra Pinceles llenos de tintas (IMAGEN 139)119, vemos como pasa del plano ornamental al escultórico con habilidad sin desvirtuar la esencia de la orfebrería. Donde, los elementos una vez más, cumplen el rol protagónico que las fundamenta. La paradoja entre el título y su forma se convirtió en un enigma; que nos permitió descifrar que estas pequeñas totumas dejaron su entorno y pasan a ser de un fruto de un árbol a unas espectaculares gotas negras. Cuyo interior, aun mantiene sus semillas originales. Al agitarlas, su sonido indudablemente nos remite a su estado original. El uso de la plata no es trivial, puesto que, interviene con la técnica y el perfil adecuado permitiendo constituirla sin quitarle protagonismo a los otros elementos. Por eso, estos alargados hilos de plata empuñados a las bellas totumas se transfiguran en delicadas cerdas de pinceles, que se explayan en el plano desde un mismo punto, dejando una mancha de tinta negra en ese punto de partida.

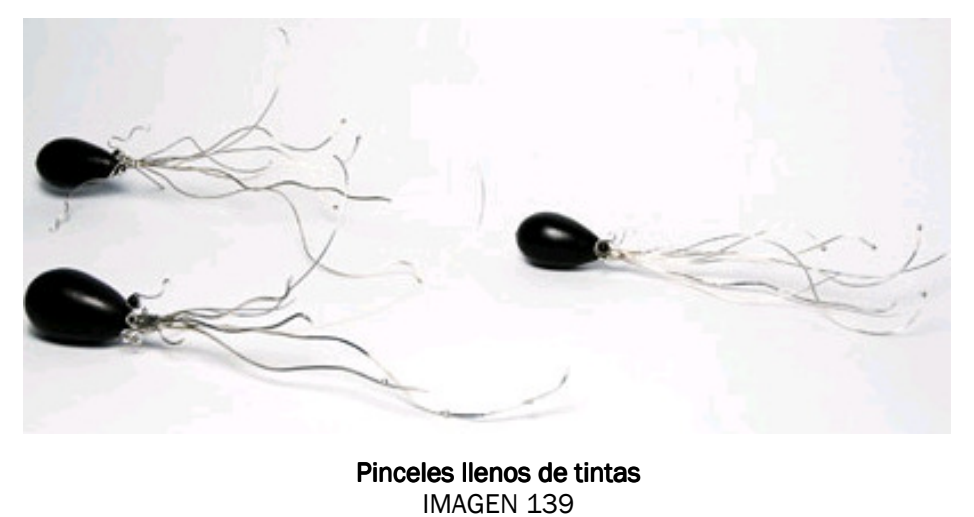

La orfebre padrón nos delita con otra propuesta de su autoría, donde la agudeza con la que aborda sus propuestas, nos enseña con demasía como su instinto, mano certera y sensibilidad son utilizados en su obra; así pues, en la emotiva obra Sin título (IMAGEN 140)120. Utiliza un pedazo de cola de marta cibelina interviniéndola para darle su original semblanza. Pues, tratando de devolver vida a este bello animalito, aferra entre sus bellos pelos detalles en plata. Claudia Padrón, fundamenta su preocupación ante el uso indiscriminado de su piel felpuda, para engalanar y abrigar a los cuerpos oligarcas de quienes pueden pagar su costoso valor.

11935 Salón Nacional de las Artes del Fuego. (2008).

http://galeria.uc.edu.ve/actual.php?id=79

120 IX Exposición Colectiva de la ACAF. (2006).

http://galeria.uc.edu.ve/actual.php?id=16 


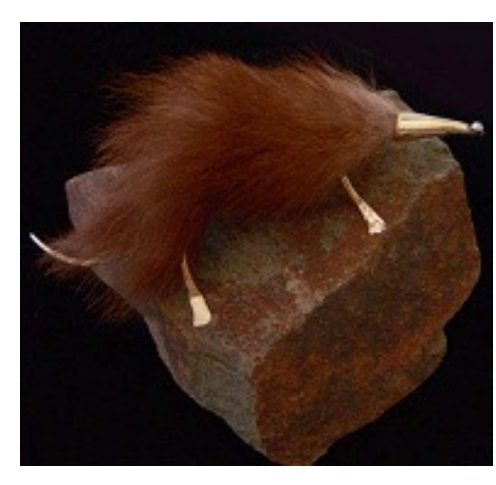

De este trozo de roca, el animal se aferra fuertemente con sus bellas paticas de plata, evitando a toda

cosa ser un complemento de

vestimenta humana.

Sin título

IMAGEN 140 
CLAUDO KALÁN

Técnicas de alta joyería imbuidas en formas excéntricas.

Claudo Kalán es un artista multidisciplinario de tendencia contemporánea, con un estilo excéntrico que lo define. Su prolífica obra, se centra en la pintura, alta costura italiana, alta joyería y orfebrería. Siendo esta última, de la que comentaremos.

Bajo la influencia de la línea como ente unificador, el orfebre Kalán recurre al tejido de punto, y al entorchado con hilos de plata. En el anillo Vida inteligente (IMAGEN 141) ${ }^{121}$, con su visión particular, apuesta por ingeniosas formas con reminiscencias orgánicas. El hilo redondo de plata, cumple un rol protagónico que fundamenta su presencia. Pues, enérgicamente enrollado a su aro, se bifurca formando una peculiar hoja.
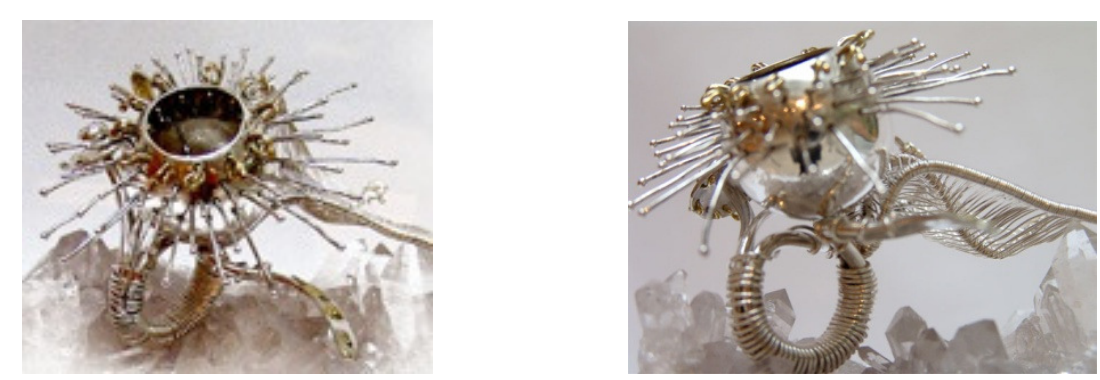

\section{Vida inteligente
MAGEN 141}

La fuerza descargada en el tejido, se refugia en sus entrañas para simbolizar el movimiento que la erige. La inserción atrevida de los hilos en la esfera, se explayan simétricamente por todo su diámetro, creando una analogía entre sus formas. Los inconfundibles hilos de oro amarillo, provocan un contraste que invita a descubrirlos y fijar la mirada en una misteriosa pieza engastada dentro de la esfera. La persuasión de los metales nobles, la extravagancia y el perfecto acabado, le permitieron hacerse acreedor de un Premio en la tendencia de Orfebrería con esta obra en el "SNAF" del año 2006.

Para el "SNAF" del siguiente año, -2007- una obra de su autoría obtiene nuevamente un Premio en la tendencia de Orfebrería.

Se trata de Animación suspendida... son mil años de viaje (IMAGEN $142)^{122}$, en donde, la alta joyería se desborda entre los detalles de la enigmática figura.

12133 Salón Nacional de las Artes del Fuego. (2006). http://galeria.uc.edu.ve/actual.php?id=66

12234 Salón Nacional de las Artes del Fuego. (2007). http://galeria.uc.edu.ve/actual.php?id=72 
Como un viaje de exploración espacial, una cruz latina en plata sujeta un desorbitado ojo que todo lo ve. La amplitud de su mirada atónita, transgrede entre los numerosos brillos de las piedras semipreciosas que lo rodean.

Deliberadamente, esta pieza deja perplejo a quien lo observa. Pues, la inclusión de un ojo de cerámica, subordina al resto de los elementos. Sin embargo, no escatima en el impecable acabado

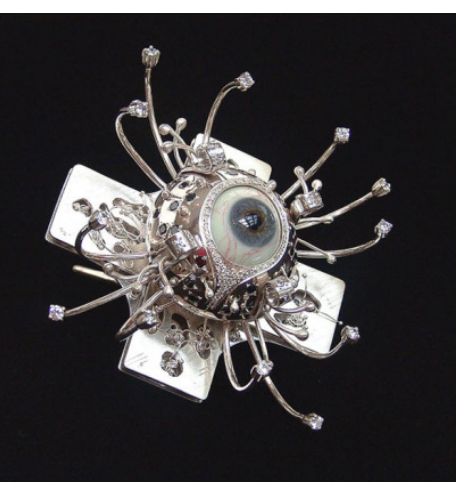

Animación suspendida... son mil años

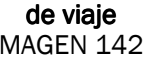

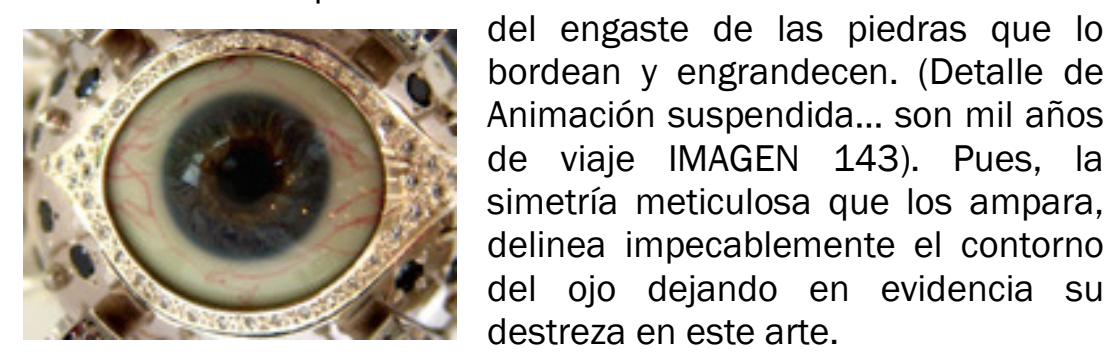

Detalle de Animación suspendida... son mil años de viaje

La obra de este orfebre, se beneficia de una creatividad particular, siempre saturada de detalles con exquisita factura y un estilo fuera de serie. Así pues, a través de la orfebrería, Claudo Kalán se permite dar rienda suelta a su imaginación; pues, con la unión paradójica de estilos y elementos, resultan en un lenguaje moderno- extravagante que lo caracteriza ${ }^{123}$.

123 Claudo Kalán

www.claudokalan.com/ 
La obra del artista David García es versátil por su trayectoria en el mundo de las artes. Su principio deviene de la orfebrería y aprovecha al máximo las bondades de algunas técnicas y la nobleza de ciertos metales. Sin apartarse de esta disciplina se introduce en el diseño grafico y posteriormente en Artes Visuales, siendo en esta ultima la que produce fascinación; pues, alcanzó fusionarla con la orfebrería. Sus joyas, expresan dicotomía entre orfebrería y escultura, ya que, las concibe bajo un mismo lenguaje. El proceso de fabricación es lento porque son realizadas artesanalmente -funde el metal, lamina, prepara sus hilos-; por ello, es tan meticuloso a la hora de ejecutarlas.

En el dije Plateada Marina (IMAGEN 144)124, se aprecia su particular manera de trabajar el metal. Pues, partiendo del estudio de las figurillas indígenas venezolanas, García evoluciona hacia una serie de dijes en plata denominada Mujeres.

A través de la incorporación de formas elaboradas con diversos perfiles en plata, crea esta figura femenina de su mundo imaginario que nos fascina y relata vivencias de ese enigmático pasado. Sin apartarse de su tipología originaria caderas anchas, extremidades inferiores gruesas e inmensa cabeza - conjuga con delicada armonía una bella aguamarina

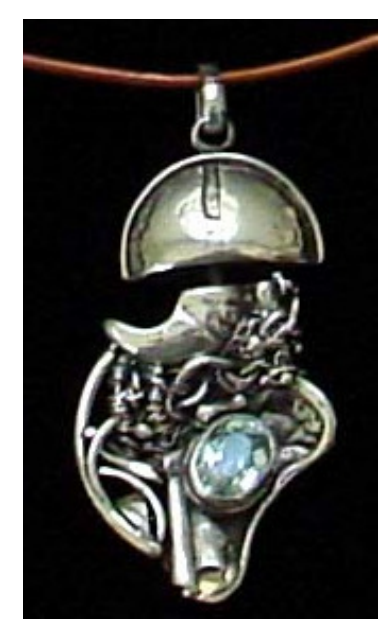

Plateada Marina Plateada Marina facetada con la plata como metal unificador. A través del repujado, los hilos entorchados, el impecable engaste de bisel y la inconfundible oxidación, se convierten en un dije que argumenta bajo su perspectiva-, parte de la historia venezolana. Este orfebre no deja escapar detalles, puesto que, el orificio del interior del engaste y la adecuada altura de la lámina de plata brillante que lo conforma, permite que el brillo del metal atraiga los destellos del azul claro de la bella agua marina y enfatice la orientación de sus tallas. Los hilos entorchados en plata conforman parte de la figura femenina y aprovechan el contraste que se produce entre sus formas con la oxidación que las enfatiza. Este bello dije fue merecedor de un Premio en la tendencia de orfebrería el "SNAF" del año 2003.

124 XXX Salón Nacional de las Artes del Fuego. (2003).

http://galeria.uc.edu.ve/gubs.php?id=41 
Su producción artística va de una escala a otra, transforma y fusiona técnicas, materiales y formatos con lo que ha logrado con cada tendencia, importantes reconocimientos. Con la obra Del Imaginario Verde Rosa (IMAGEN 145) de la serie reptiles ${ }^{125}$, el artista García nuevamente se hace acreedor de un Premio en la tendencia de Esmalte sobre Metal en el "SNAF" en el año 2007. En ella, prevalece el detalle minucioso del orfebre con la visión, dimensión y ejecución del escultor.

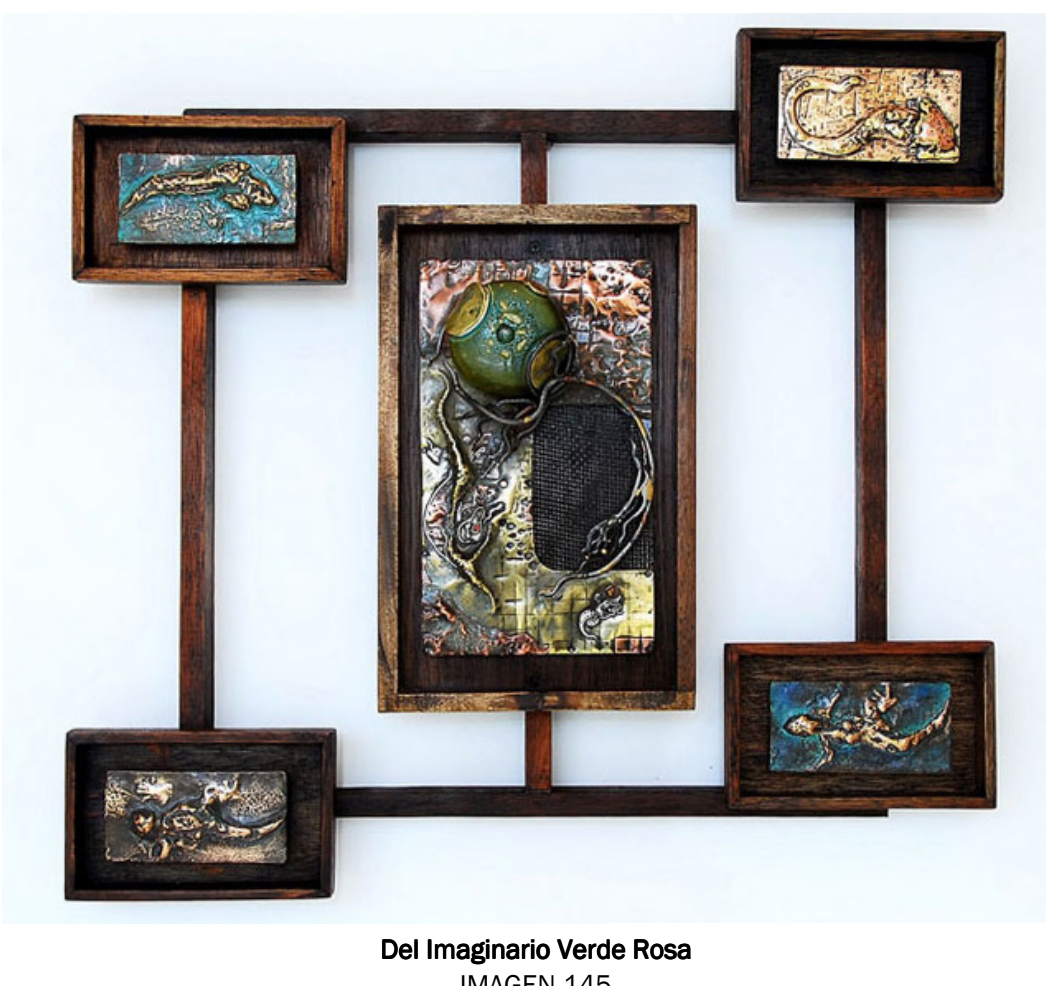

A través de la fundición en bronce, anora nos deleıta con esta emotiva y colorida obra. La disposición de cada uno de los elementos que la componen enfatiza su interesante trasfondo. Pues, como si se tratasen de yacimientos arqueológicos, cada uno de estos reptiles se destaca dentro módulos de madera, perpetuando el descubrimiento de su particular fisionomía.

Los detalles de la textura y silueta plasmados en la cera, mantienen la fidelidad de su gesto creador tras el proceso de fundición. Intencionalmente las pátinas y el lustre del metal, conservan el parecido a un hallazgo en la naturaleza de estos animales fosilizados.

Nuevamente el artista David García nos demuestra con su obra la fusión de la orfebrería con otras disciplinas artísticas. Una

12534 Salón Nacional de las Artes del Fuego. (2007).

http://galeria.uc.edu.ve/actual.php?id $=72$ 


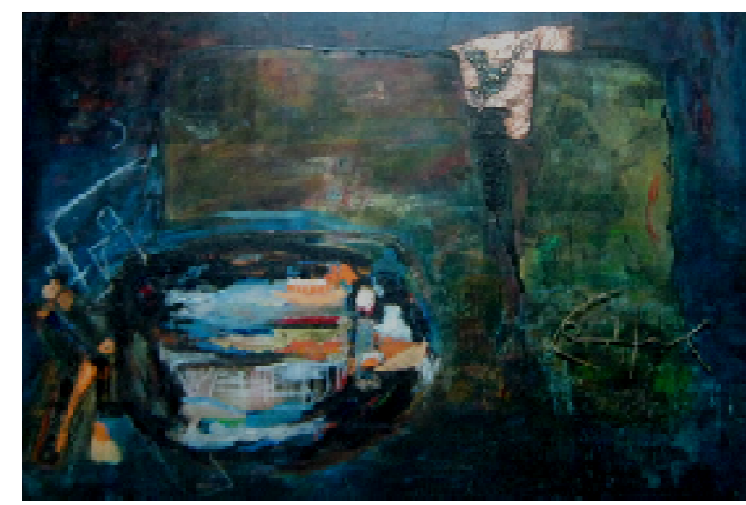

particularidad que

cuenta en su obra,

tiene que ver con el

tema y su

aplicación en otros

ámbitos. Así pues,

en Aves, peces,

reptiles

cuadrúpedos

(IMAGEN 146) de la

serie reptiles,

ahora interviene

Aves, peces, reptiles y cuadrúpedos

pintura. En este enorme óleo, los colores escogidos evocan el exótico y enigmático colorido del mundo marino. Las tonalidades que logra entre ellos, transmiten la serenidad y tranquilidad que tanto nos fascina de ese hábitat.

El destello metalizado deja entrever una lámina de cobre con una silueta cincelada de un ave emprendiendo un vuelo frustrado (Detalle de Aves, peces, reptiles y cuadrúpedos IMAGEN 147). El reticulado de plata se refunde en la lámina, completando vagamente la silueta del ave fósil.

Frente al enorme pez, un pequeño esqueleto de pescado, se hace apetecible y está a punto de ser devorado.

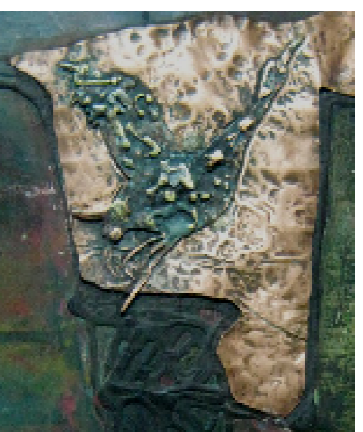

Detalle de Aves, peces, reptiles y cuadrúpedos IMAGEN 147

La sensibilidad de este artista ante cualqui artística deja evidencia en los mejores salones del país. Pues, esta obra -Aves, peces, reptiles y cuadrúpedos- fue la obra ganadora de Gran Premio en la "Bienal Nacional de Artes Visuales de Estudiantes de la Universidad de los Andes" en el año 2007126.

126 García, D. (2009). “Obra ganadora Bienal para Estudiantes de Universidad de Los Andes". Material inédito. Entrevista personal. Mérida, estado Mérida. 
EDECIO BARAZARTE

El entorno en que habitó, se convierte en su gesto creador.

Al analizar la obra del orfebre Barazarte hemos conseguido algunos aspectos recurrentes que han sido el motivo de su inspiración. Vivió su niñez y juventud formándose como artesano en un escenario natural, cuyo entono colmado de detalles entre luces, tonalidades, formas, figuras y anécdotas se transfiguran en su quehacer artístico. Pequeños fragmentos de esas experiencias, han conseguido elementos recurrentes en cada una de sus piezas: hojas de plantas, flores, tonalidades, siluetas y texturas, que se han aliado con la técnica de la filigrana, el repujado, la cera perdida y la oxidación, para ser creadas con fidelidad en sus propuestas.

Como una alegoría a la vida en solitario, este tríptico en madera policromada congrega fielmente dos disciplinas: la pintura y la orfebrería. ¡Vuela papagayo, como mis pensamientos! (IMAGEN $148)^{127}$, es una obra donde el orfebre Edecio Barazarte nos recrea con total convicción la fusión entre estas dos disciplinas. En ella, logra un lenguaje plástico interesante donde sus habilidades de pintor y orfebre se conjugan en una sola obra. De tal manera que, la policromía de la madera, acentúa su razón de unión con una pequeña escultura en plata.

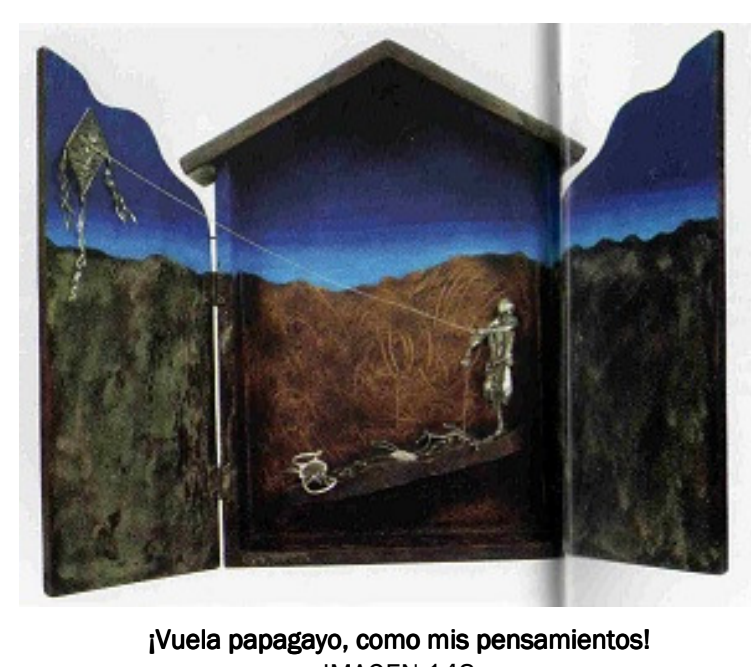

IMAGEN 148
El tríptico, conjuga una ficción de vivencia cotidiana donde la nostalgia embarga escena. Así pues, el paisaje pintado entre los matices de un cielo azulado y tonos de la textura de una montaña, se hacen participes de la escena melancólica. Solitariamente un personaje enfundado entre láminas repujadas e hilos de plata, efusivamente aferra entre sus manos el cordón entorchado que dirige el vuelo sagaz de la cometa. Y, el viento en el horizonte lo eleva con majestuosidad, resplandeciendo sobre la silueta de las

127 Instituto de las Artes de la Imagen y el espacio y Mota, J. (2006). "II Salón Nacional de Orfebrería". Museo de la Estampa y del Diseño Carlos Cruz-Diez. Catálogo. p: 52-53. 
montañas. En el papagayo, finísimos hilos de plata pura visten con delicadeza su estructura; invitándonos a internarnos entre sus formas que con maestría y pulcritud se fundamentan en una delicada filigrana.

Tiempo, retrospectiva y un secreto que me protege (IMAGEN 149) es un collar de su autoría que se llevo el Primer Premio en el III "SNO" en el año 2007128.

Una vez más, Barazarte vincula el entorno natural en su quehacer artístico, e inventa otra realidad creando sugestivas formas.

Los impecables hilos de plata, se hermanan para dar vida a un fascinante cordón tejido, que sujeta un ostentoso dije (Detalle de Tiempo, retrospectiva y un secreto que me protege IMAGEN 150). Sutiles hojas sinuosas, repujadas, oxidadas y macizos gránulos de plata brillantísima

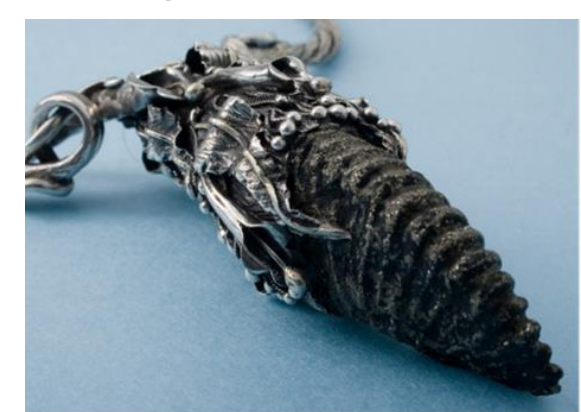

Detalle de Tiempo, retrospectiva y un secreto que me protege IMAGEN 150

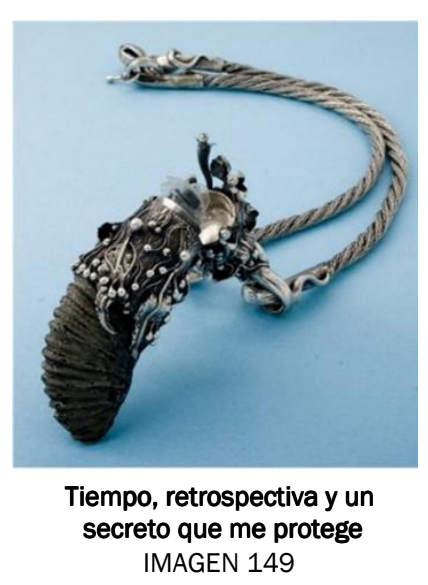

se aferran al fósil amonite, protegiéndolo del nuevo entorno en que ahora habita. Dotado de articulación mecánica, el imponente fósil contiene oculto un misterioso cofre que solo él conoce su verdad oculta.

La genialidad de sus joyas, el impecable detalle que las fundamenta y el interés en aprender esta disciplina de otras culturas, le ha permitido exponer en Colombia, Perú, México, España, Nueva Zelanda, Japón y Paris. Y, se ha hecho merecedor de importantes premios tanto en Venezuela como en estos países. 


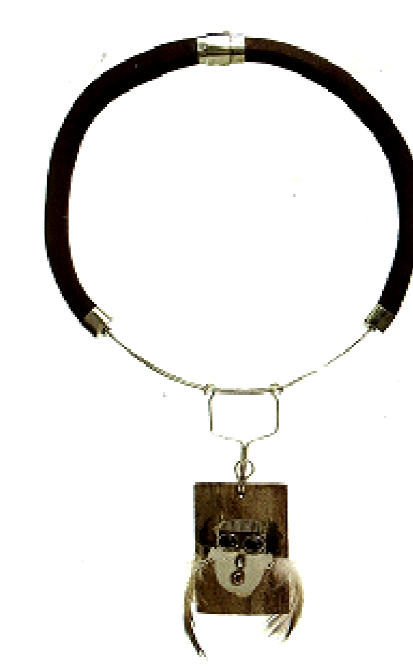

Las joyas del orfebre Gustavo Smitter devienen de una tendencia artesanal, muy sencilla, que se establece bajo el fundamento del arte pobre. Tendencia esta, que ha transgredido, revolucionado y modificado a las disciplinas artísticas del arte contemporáneo. Por ello, la inclusión de elementos varios de deshechos no es trivial y la discrepancia entre su factura es ineludible.

Una singular rama de bejuco tratada y pulida impecablemente se fundamenta en el aro del collar Raíces, 2006 (IMAGEN 151) ${ }^{129}$. Su juicio ante la conceptualización de la orfebrería actual, Raices, 2006 se evidencia entre la perfecta elaboración del broche de alpaca y la discrepancia entre lo natural y lo manufacturado. Del impecable hilo de plata pende un simpático dije (Detalle de Raices, 2006 IMAGEN 152), cuya elaboración sencilla creada con la técnica del collage, compone un enigmático rostro que desata el interés del concepto del uso de materiales de desecho en una joya. Mirada atónita de dos ónix negros simbolizan el rostro del dije. Como un rompecabezas, sobre un trozo de bambú los fragmentos de materiales se acoplan a su nueva forma. Dos sencillas plumas,

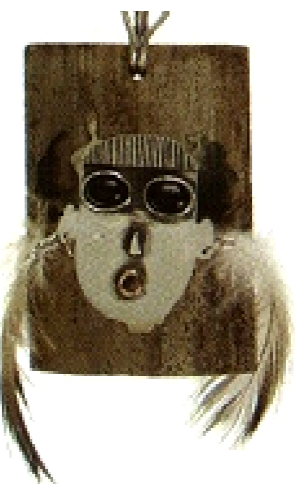

Detalle de Raices, 2006 IMAGEN 152 arrebatan la presencia del pequeño ser y convierten en un hibrido de hombre-ave.

En el "SNO" del año 2010, la obra Psiquis (IMAGEN 153) de su autoría obtiene la Mención de Orfebrería Conceptual y Alternativa130. El cambio significativo que ha dado su obra evidencia la nueva visión que ha adoptado ante la orfebrería escultórica.

129 Instituto de las Artes de la Imagen y el espacio y Mota, J. (2006). "II Salón Nacional de Orfebrería". Museo de la Estampa y del Diseño Carlos Cruz-Diez. Catálogo. p: 75.

130 Vera, R. (2012). "Imágenes y fichas técnica de obras III Salón Nacional de Orfebrería". Material inédito. Correo electrónico. vhrafier@yahoo.com 
Así pues, la esencia de la pieza-dije tiene que ver con la irreverencia hacia la orfebrería tradicional, que siempre se ha esmerado en la utilización de metales preciosos; excluyendo, metales como el cobre, el bronce o la alpaca. Pues, sin apartarse de las bondades de algunas técnicas tradicionales de la orfebrería como: la soldadura, el engaste, el calado, micro mecánica y las pátinas, utiliza el bronce y la alpaca como metal unificador. Donde, la inclusión de los cables telefónicos, el acrílico y la madera intervienen con un mismo rol protagónico. Por eso, todos y cada uno los elementos tienen importancia sin tomar en cuenta su precio ni condición.

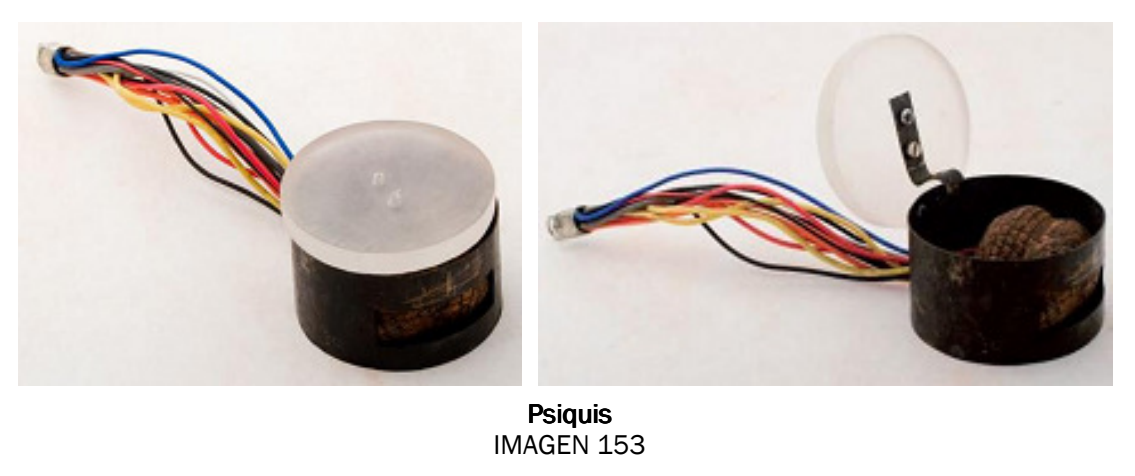

La obra Psiquis, se fundamenta en una caja redonda tipo joyero, en bronce patinado con tapa de acrílico. Un trozo de madera tallada con forma alude a un cerebro, es el centro y razón de ser de la obra. Desde su interior, salen energéticos cables telefónicos de colores vivos que se aferran de un bello engaste de alpaca.

La simbología de este dije-joyero no es más que reprimir y encerrar los pensamientos, la creatividad y la razón de libertad del artista, ante los materiales en los que decide trabajar para satisfacer a la sociedad.

Una pequeña ventana del joyero deja asomar un trozo de madera tallado con forma de cerebro. Lo cual vincula su esencia con el pensamiento, siendo esta ventana su única opción para desvincularse con el exterior. Sin embargo, le obliga a seguir otro guión de la vida, pues, se encuentra encerrado.

La formación de Gustavo Smitter como orfebre, deviene de la enseñanza del Taller de la Tierra de Rafier Vera, obviamente que es un claro ejemplo de su influencia ante el concepto y semblante de esta particular joya. 


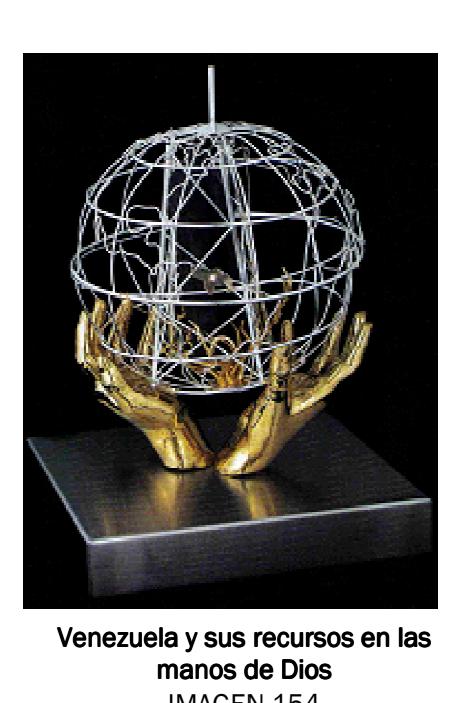

La orfebre Haydee Pérez Criollo, quienes odontólogo restauradora de profesión; ha conseguido de la orfebrería una afinidad con su entorno que la fascina, pues, la cera perdida, se convierte en su aliada para la consecución de sus alegóricas obras. Sus primeros pasos en la disciplina de la orfebrería, los da de la mano del orfebre Alexis de la Sierra. Quien inequívocamente, capta su destreza, intuición y sensibilidad; guiándola con mano firme hacia la orfebrería escultórica. Indudablemente, lo anterior comentado lo podemos aseverar en la obra: Venezuela y sus recursos en las manos de Dios (IMAGEN 154)131, donde la simbología de los elementos, la pericia en su aplicación y la temática que aborda, son un notable ejemplo de la influencia rectora de este maestro.

De este modo, las manos femeninas vaciadas en bronce, sujetan con delicadeza y ahínco un globo terráqueo tejido con hilos de plata, que muestra solo el mapa físico de Venezuela. Así pues, como una alegoría al gentilicio venezolano, la orfebre Pérez Criollo, cala en azabache la silueta del mapa de este país, del cual brota un fascinante diamante venezolano.

Del entramado globo de hilos de plata, germina de sus entrañas un cúmulo de ramas bañadas en oro, analogía ésta, nos traduce la orfebre con las minas de oro que yacen en el sur de Venezuela. Tópico este, refiere a su visión particular, sobre la incertidumbre sobre el uso o abuso de los valiosos recursos naturales del país. Con mano acertada, la orfebre decide cual tendencia abordar, pues, en la convocatoria para el II Salón Nacional de orfebrería del año 2006, pautan sobre la temática de Identidad Nacional.

131 Pervilhac, I. (2005). “Tierra, Arte y Cultura en Venezuela”. Centro de Arte la Estancia. Catálogo. s/n. 
Para ello, la orfebre Pérez Criollo se argumenta sobre el uso de materiales autóctonos en una imaginativa joya. Así pues, elabora el collar Guayana adentro (IMAGEN 155)132, con la inclusión de la plata pura y el azabache.

Basándose en la superstición del uso de este magnífico material, interviene el azabache delicadamente transformándolo en esta impactante gargantilla, cuya forma, la protege un regio tejido en hilo de plata. En su centro, se aferra un medallón de

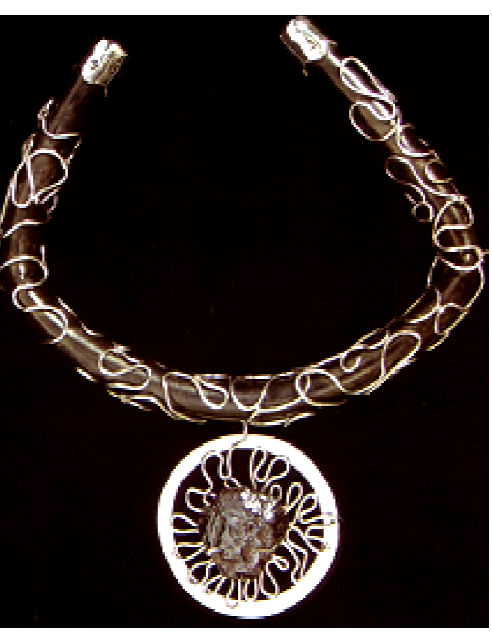
Guayana adentro
IMAGEN 155

plata pura que reproduce el tejido de la gargantilla con un trozo virgen de azabache.

El uso de ciertos elementos naturales hacia la religiosidad popular, dieron origen a la creencia en que ciertos objetos radica el poder de un talismán. Por eso, la orfebre argumenta su propuesta basándose en esta creencia, donde el azabache una y otra vez, es usado como un poderoso protector contra cualquier maleficio.

132 Instituto de las Artes de la Imagen y el espacio y Mota, J. (2006). "II Salón Nacional de Orfebrería". Museo de la Estampa y del Diseño Carlos Cruz-Diez. Catálogo. p: 66. 

protege.

El orfebre venezolano Julia Ferreira, quien es ingeniero de profesión, ha sabido sacar ventaja de la orfebrería. Desde sus inicios, con la asistencia personal del orfebre Alexis De la Sierra, se adiestra con convicción en el oficio; y desde entonces, su inclusión en el medio ha sido ineludible.

El compendio de su producción artística señala su amplia formación, y la repercusión en la formación de otros orfebres; Pues, asiduamente su obra, es aceptada en el "SNAF", así como también, alumnos formados por ella.

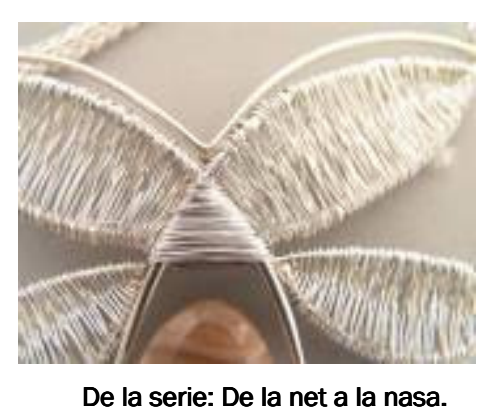

Atrapado en el Aire. Atrapado en Agua. Atrapado en Tierra

La sensibilidad de su gesto creador permiten que elabore bellas $y$ sugestivas obras, donde la praxis y el concepto, se convierten en mediadores; así pues, en el conjunto de tres collares de plata: De la serie: De la net a la nasa. Atrapado en el Aire. Atrapado en el Agua. Atrapado en Tierra (IMAGEN 156) ${ }^{133}$, se argumenta en los cuatro elementos esenciales en la existencia de vida: agua, tierra, aire

y fuego; siendo el último de ellos, quien objetivamente concreta esta propuesta. Partiendo de la hegemonía de los elementos de la naturaleza, metafóricamente elabora tres estupendos dijes desde la esencia de cada uno; un pasivo pez simboliza el agua; un brioso toro simboliza la tierra; una grácil mariposa simboliza el aire y el fuego se transfigura entre cada uno de ellos, a través del metal que los establece. Fundamentando sus tres collares en estas simbólicas figuras, un regio hilo de plata siluetea su analogía; siendo el frenesí y pericia de las manos de Ferreira quien entreteje su estructura y da vida a estos bellos seres.

Con el transitar de los años, ha incursionado en muchas dependencias y las que ha fusionado con visión experta hacia la orfebrería. Seguridad industrial, museología, gemología, joyería industrial de alto consumo y comercio exterior para el sector de la joyería, se congregan todas, en su actual proyecto de vida.

13332 Salón Nacional de las Artes del Fuego. (2005). http://galeria.uc.edu.ve/gubs.php?id=9 
El pragmatismo de su profesión y la esencia de la orfebrería, se vinculan en su léxico creativo para dar origen a esta particular joya/utilitaria Sin títulos (IMAGEN 157) 134 . Basándose en la disparidad de los cantos rodados; el cubo como principio en la construcción de una vivienda

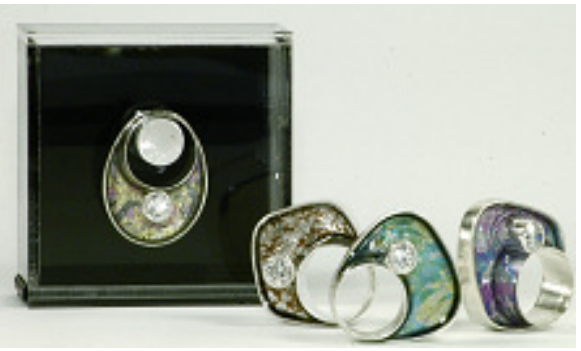

Sin títulos IMAGEN 157

y la joya como complemento en la vestimenta, la orfebre Ferreira elabora un elocuente pisa papel cuyo interior exhibe espectaculares anillos en plata. De este modo, al igual que el canto rodado, la morfología de los 20 anillos, se deforman en su

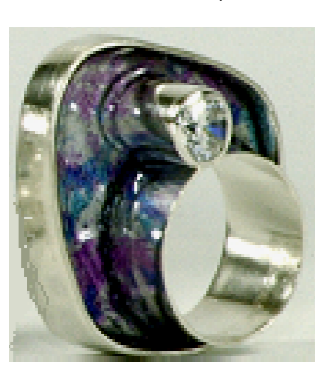
exterior, entre anchas y delgadas láminas de plata; así pues, entre bellos circones engastados idénticamente de los aros, éstos, manifiestan su disparidad a través del contorno y las tonalidades de resina de poliéster (Detalle de Sin títulos IMAGEN 158). El pisa papel cubico en metacrilato, custodia y exhibe entre su interior los disímiles anillos; IMAGEN 158
apropian del contexto que las protege.

Bajo esta misma argumentación, Julia Ferreira nuevamente nos recrea con una fascinante joya/artística, donde ésta, en desuso, se apropia de un entorno para exhibirse y ser admirada. Así pues, la obra De la serie: ¿por qué guardada? mejor compartida. Cachalote (IMAGEN 159) se basa en un bello dije en plata135, elaborado delicadamente con láminas de mokume gané y una delicada ágata. La emblemática ballena cachalote,

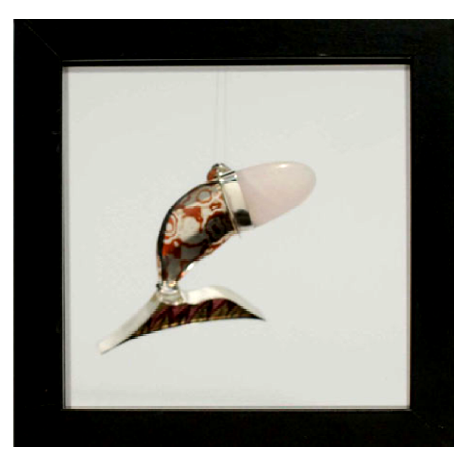
De la serie: ¿por qué guardada? mejor

transfigura a través de la maestría de la orfebre Ferreira; pues, la acertada talla de la gema, alude delicadamente parte del cuerpo de este animal y la pericia del embutido en la lámina del mokume

134 Ferreira, J. (2012). “Datos sobre su producción”. Entrevista online. https://www.facebook.com/julia.ferreiraorfebre?fref=ts

13537 Salón Nacional de las Artes del Fuego. (2010). http://galeria.uc.edu.ve/actual.php?id=89 


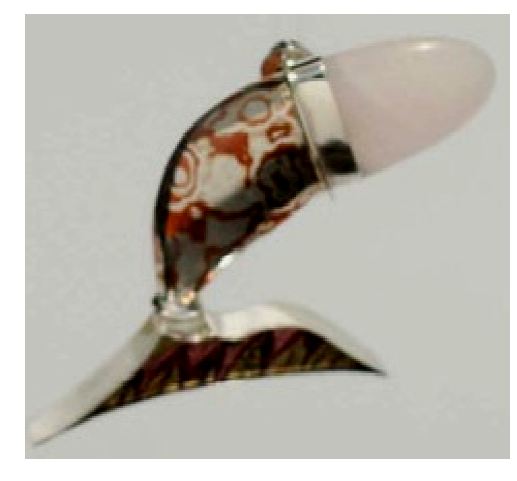

Detalle de De la serie: ¿por qué guardada? mejor compartida. Cachalote

bella obra bidimensional preservación de su especie. gané, fundamenta en pleno, su corpulenta fisionomía.

bbviamente su esencial cola elaborada con un diseño zigzagueante en mokume, cuestiona su rigidez (Detalle de De la serie: ¿por qué guardada? mejor compartida. Cachalote IMAGEN 160). La otra manera de ver o usar esta joya, se asegura con su título ¿por qué guardada? mejor compartida. Cachalote; ya que, cuando no es usada, se exhibe sobre la pared dentro de un marco, transformándose en esta que evoca subliminalmente la

La obra de la orfebre Julia Ferreira durante muchos años ha dejado en alto la importancia de una buena escuela y el buen uso de los metales nobles, tanto en Venezuela como en los países donde expone sus propuestas. Ese esfuerzo ha trascendido de manera significativa en la orfebrería, pues en paralelo entre Venezuela y México, forma parte de un grupo de especialistas en el área, que elaboran actividades para el desarrollo de la orfebrería de ambos países; enfatizando, la importancia del arraigo de la disciplina, conjuntamente a sus nuevas tendencias para su masiva producción y su exportación. 

emotivos.

Las joyas de la orfebre Liliana Benítez se basan en la imponente maestría, la cuantiosa creatividad y el perfecto acabado. Su trayectoria ha sido consumada con intuición y perseverancia, lo cual se consolida en un lenguaje artístico con una visión particular. La influencia rectora del orfebre Alexis de la sierra se hace evidente siempre entre sus propuestas, ya que la perfecta ejecución es una de las características que la define así como su mentor.

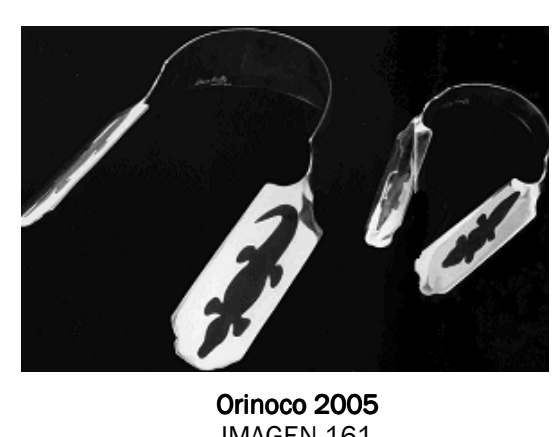

En Orinoco 2005 (IMAGEN161)

un conjunto de pectoral con brazalete en plata pura y azabache ${ }^{136}$, se establece en un diseño sobrio que exalta la belleza de ambos materiales. La orfebre Benítez decide manipular la plata con esta fascinante técnica, que le hizo merecer el Primer Premio en el "Salón de la Talla de Azabache" en el año 2002. Técnica esta, extremadamente laboriosa que permite decorar en la superficie metálica mediante la incrustación de este material fosilizado; con el diseño de este animal. Así pues, aprovecha las bondades de esta técnica y su destreza; pues, talla minuciosamente en el azabache la silueta del emblemático caimán del rio Orinoco e incrusta con perfecta maestría dentro de la lámina de plata. La superficie del collar y el brazalete, deslumbran entre el contraste que se genera en su superficie entre la impecable factura, el impoluto brillo de la plata y el fascinante color negro del azabache, con la simetría y sobriedad del diseño.

La influencia de la enseñanza del orfebre Alexis De la Sierra, se evidencia en las joyas de Liliana Benítez. Pues, tras varios años de aprendizaje y especialización en su escuela, en sus propuestas, impera el perfecto acabado capaz de recrear una atmosfera impecable.

En el espectacular brazalete Hilanderos de poesía (IMAGEN $162)^{137}$, su intuición interactúa con la plata y las cuerdas de

136 Instituto de las Artes de la Imagen y el espacio y Mota, J. (2006). “II Salón Nacional de Orfebrería". Museo de la Estampa y del Diseño Carlos Cruz-Diez Catálogo. p: 106-107.

13735 Salón Nacional de las Artes del Fuego. (2008).

http://galeria.uc.edu.ve/actual.php?id=79 
guitarra e inventa otra realidad. La cera perdida forma parte del entorno que fundamenta el brazalete. Pues, pequeños personajes vaciados en plata, se aferran de las cuerdas, creando una atmosfera paradójica donde la imaginación configura un sinfín de posibilidades. Este enigmático brazalete, resulta ganador de un Premio en el "SNAF" del año 2008.

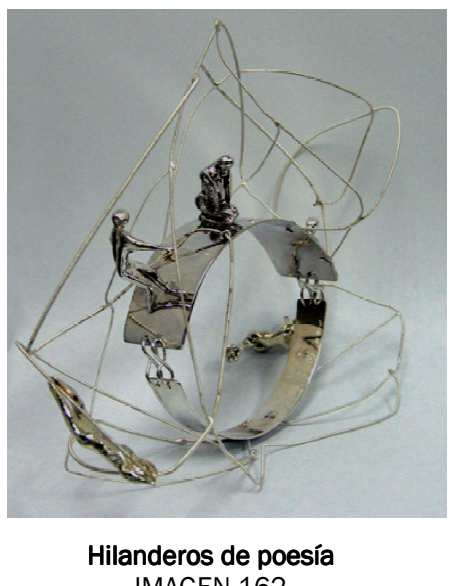

IMAGEN 162

El proceso de búsqueda de una nueva sintaxis escultórica, la diversidad de registros de sus trabajos desde cualquier ámbito ha consolidado su lenguaje artístico en la orfebrería escultórica. Tendencia esta, que le ha permitido merecer importantes premios. Pues, Caracas: ciudad portátil, mi sueño en blanco y negro (IMAGEN 163) obtiene nuevamente ${ }^{138}$, un Premio en la tendencia de Orfebrería en el "SNAF" en el año 2010.

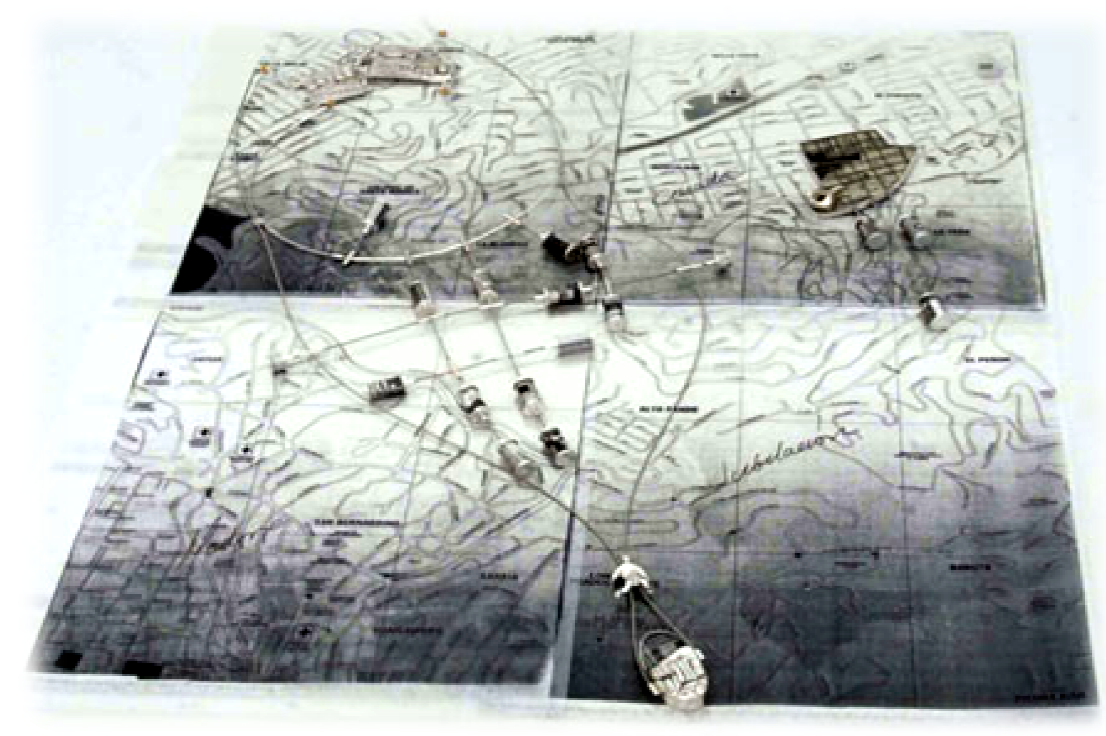
Caracas: ciudad portátil, mi sueño en blanco y negro
IMAGEN 163

En esta obra, la orfebre Benítez nos recrea con sus interesantes joyas metamorfoseadas por su instinto creador. Así pues, un simpático collar, dije y prendedor en plata, interactúan con otros elementos para transformarse en un fragmento de plano

13837 Salón Nacional de las Artes del Fuego. (2010).

http://galeria.uc.edu.ve/actual.php?id=89 
tridimensional de la ciudad de Caracas. La estructura modular del plano en blanco y negro se compone de 4 zonas en las que ha trascurrido su vida. Por ello la disposición de cada uno de los elementos sobre esas zonas, contienen reminiscencias entre sus formas, las experiencias acontecidas.

Plata, acero, fotografía y transparencias se transforman en un ambiente cotidiano que irrumpe en las nuevas tendencias de la orfebrería.

Su trabajo deriva de la necesidad de comunicación visual con el entorno vivido. Cada escenario, expone y mantiene la identidad, presencia y singularidad de su vida. Donde la etapa de estudiante, casada, madre y jubilada se reencuentra con los materiales cuyas calidades intrínsecas componen su discurso plástico.

El espacio ocupado por su intelecto es desarrollado y saturado hasta alcanzar la razón de su ser artista. Entender y encontrar la esencia del arte, ha sido el producto de su madurez creativa139.

139 Benítez. L. (2010). “Premios en orfebrería”. Material inédito. Entrevista personal. Caracas, Distrito Capital. 
NADIA KARROUM

La fascinación por elementos de la naturaleza se transforma en emblemáticas propuestas.

La sensibilidad que posee la orfebre Nadia Karroum ante los elementos de la naturaleza, permite dar rienda suelta a su instinto creador. Sea cual sea el material en el que decide operar, éste, es transformado a su antojo convirtiéndolo en imaginativas propuestas.

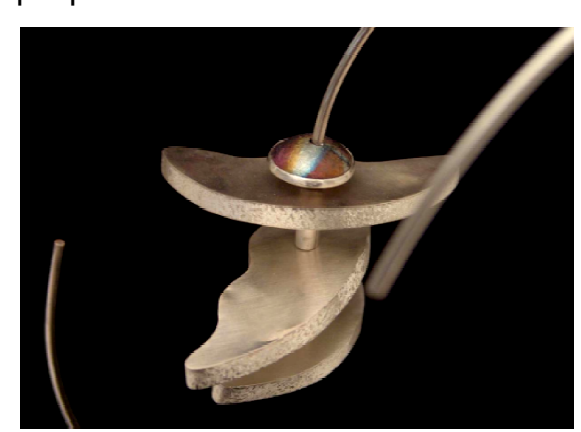

En el collar Celentéreo (IMAGEN 164)140, la plata pura, los imanes y el titanio, se acoplan en perfecta armonía para dar vida a esta hermosa e inofensiva medusa. De este modo, Karroum evoluciona su morfología y apariencia traslúcida, en contundentes Celentéreo láminas de plata pura, cuyo IMAGEN 164 interior esconde imanes que permite cierta movilidad. Pues,

deliberadamente la disposición entre ellos, permite que se repelen apenas al tocarla, simulando una analogía con su entorno. Un delicado engaste de bisel, sujeta la pequeña cúpula de titanio anodizado. Y, su cálida tonalidad irrumpe en el centro del dije, de donde sale un enorme tentáculo de plata pulida. Así pues, matices tornasol contrastan sutilmente con la frialdad de la plata, fusionándolos en un solo ser.

Con la obra En vía de extinción (IMAGEN 165) ${ }^{141}$, nuevamente la orfebre karroum nos introduce a su alegórico mundo marino. Así pues, una enorme alga se explaya sobre la pared donde, su cuerpo fragmentado entre finas láminas, se aferra entre bases circulares; pues, pequeños

discos vaciados en resina, degradan su tonalidad del transparente al negro,

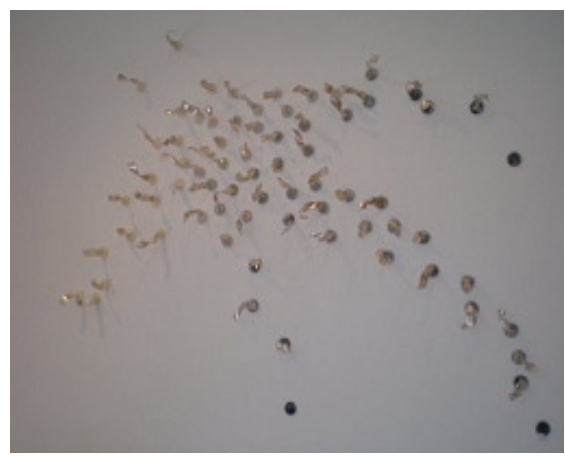

En vía de extinción IMAGEN 165

14032 Salón Nacional de las Artes del Fuego. (2005). http://galeria.uc.edu.ve/gubs.php?id=9

14136 Salón Nacional de las Artes del Fuego. (2009). http://galeria.uc.edu.ve/actual.php?id=85 


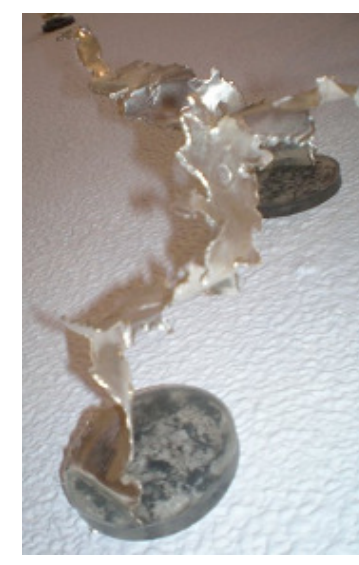

Detalle de En vía

de extinción

La mutación de esta nueva especie marina, se erige entre láminas de cobre que tras la acción del reticulado, sus formas ondulantes nos maravillan con el brillo de su superficie. Una imponente capa de plata pura las cubre totalmente pues, tras la acción del baño electrolítico, la superficie cobriza se modifica con un brillo impecable plateado. Fragmentos brillantes de forma zigzagueante, se sujetan de las bases y juntas establecen esta singular forma de la silueta de una enorme alga (Detalle En vía de extinción de IMAGEN 166). sus piezas. Así como también, le han otorgado varios premios como en la obra Celentéreo en el año 2005 y En vía de extinción en el año 2009.

Una vez más la orfebre Karroum sorprende con sus magnificas propuestas, pues, el pectoral Talismán (IMAGEN 167) obtiene la Mención de Identidad Nacional, en la III Edición del "SNO" en el año 2007142. Este magnífico pectoral, transfiere con mano experta su léxico creativo ante los elementos primitivos que lo componen.

Como un estupendo amuleto, la orfebre selecciona y dispone minuciosamente ciertos elementos para preservar la fuerza de su naturaleza y ostentar con su nueva fisionomía su soberanía. Un notable cordón negro sujeta el esplendido pectoral, cuyos elementos sintetizan su apego a lo nativo; cuya simbología, enaltece la devoción hacia su usanza. La orfebre se basa en los mitos de santería, a

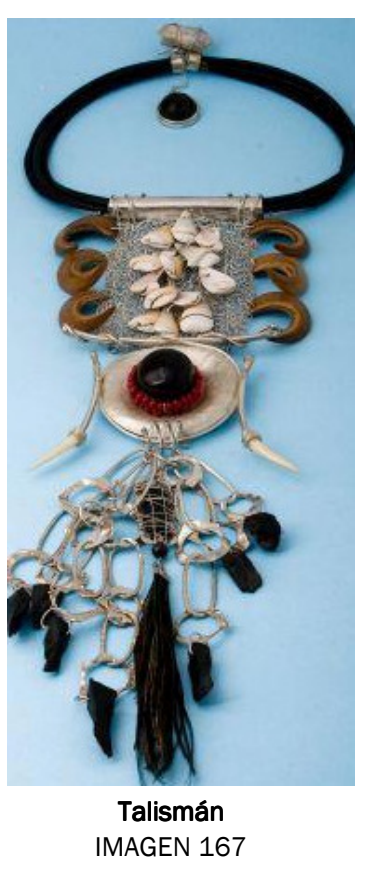
través del uso de los caracoles para interpretar el futuro de aquel que los consulte/use. Por eso, metafóricamente, la malla tejida con finísimos hilos de plata se transforma en una estera, pues, sin titubeo, la orfebre lanza los

142 Karroum, N. (2012). "Premios de orfebrería en salones". Material inédito. Entrevista online. https://www.facebook.com/nadia.karroum.3?fref=ts 
caracoles para iniciar el diálogo Como un rito, se entabla la charla desde el tambor que ensordece con su fantástica pepa de zamuro y custodiado por dos poderosos colmillos de payara, amilanando el sonajero de donde penden los azabaches.

La simetría del tejido, la pulcritud del embutido del disco, la maestría de los engastes y el frenesí de los eslabones forjados; desvelan la maleabilidad de la plata, donde la mano creadora los manipula con maestría. La composición de los elementos se reagrupa en un orden de importancia, donde el colorido, emprende un dialogo con las joyas de la moda actual. 
RAFAEL BELLO

Sus dotes de orfebre caminan a la par entre la escultura y las

joyas.

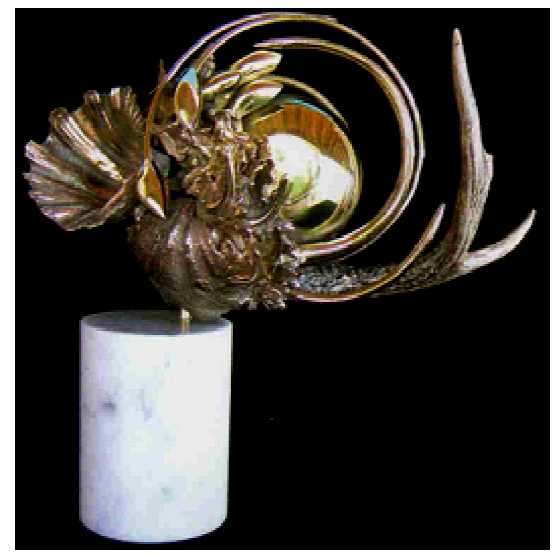

El espejo de la bruja IMAGEN 168

En ocasiones, es difícil saber cuándo una obra ha sido concebida desde la influencia de una forma, un tema o la seducción de los materiales. En El espejo de la bruja (IMAGEN $168)^{143}$, se argumentan algunas posibilidades desde su título hasta lo consumado; pues, la persuasión de las formas caprichosas de elementos del reino animal y botánico, con la

seducción de los metales, evoca una singular ficción de un cuento de hadas.

El orfebre Rafael Bello, nos recrea con una alegoría entre la naturaleza y la simbología de sus formas. El asta de venado se convierte en un elemento seductor que instituye la obra. La transfiguración del metal por medio de su instinto creador, evidencia la pericia que posee en la cera perdida. Manipular las ceras de esa manera no es cuestión de suerte ni casualidad. Pues, concienzudamente talla esas formas caprichosas y efímeras de la naturaleza, donde, exquisitamente el bronce las fundamenta de manera permanente. Una emblemática esfera repujada en latón y pulida en extremo, refleja turbadamente el anhelo de quien la observa. Detalle éste quizás, sea el que origina el argumento de la obra.

Dos lenguajes surgen de un mismo creador. Sus dotes de orfebre caminan a la par entre la escultura y las joyas.

En el collar S/T (IMAGEN 169)144, apuesta por la sobriedad de diseño recalcando la belleza del metal con su destreza técnica y el impecable acabado. Juego de brillos, matices y miradas fundamentan y complementan el diseño.

143 Ministerio de la Cultura y el Consejo Nacional de la cultura. (2005). "I Salón Nacional de Orfebrería". Centro de Arte la Estancia. Catálogo. s/n.

144 Platería Hispanoamericana Contemporánea. (2009).

http://galeria.uc.edu.ve/actual.php?id=83 
Por eso, premeditadamente, la superposición de planos es inexorable, pues, unos brillantes en extremo, otros opacos con bella textura, se fusionan con el colorido fascinante de la piedra labradorita. Este sensual juego de brillos entre la delicadeza de la plata y los matices tornasolados de la piedra, imprimen carácter y comparten protagonismo entre ellas.

Diseño fragmentado previamente, conjuga la belleza de sus formas, evadiendo la rigidez; pues, pequeñas

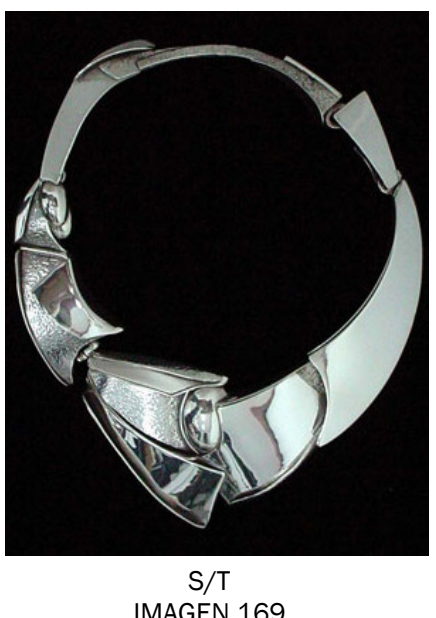

bisagras en su reverso, aportan movilidad adaptándose con soltura a la fisionomía y movimientos del portador. 
Su instinto juzga cualquier objeto cotidiano y su condición de orfebre los convierte en Joyas únicas.

Para el año 2005 organizan el Salón Nacional de Orfebrería, siendo el primero en el país dedicado exclusivamente a esta disciplina. El afortunado en ganar el Primer Premio, fue el orfebre Rafier Vera con la pieza Primoldialmente metal (IMAGEN 170)145.

El orfebre Vera deviene de las artes plásticas y el paso por la Escola Massana en Barcelona, le ayudó a encontrar la esencia de la orfebrería como ente expresivo en el arte. De este modo, esa experiencia y la tenacidad con la que ha abordado esta disciplina, le ha permitido establecer un estilo particular que lo caracteriza hoy en día.

El abordar técnicas de la orfebrería bajo el enfoque y dominio de diversas disciplinas artísticas le permitieron crear un estilo genial y particular donde la técnica de la cera perdida se convierte en su aliada. Su instinto creador juzga cualquier objeto cotidiano y su condición de orfebre los convierte en joyas únicas. Así pues, utiliza pequeños objetos cotidianos que en sus joyas adoptan otra función. Pues, un insignificante objeto, lo somete al proceso de la cera perdida re-convirtiéndolo en un elemento fundamental de sus joyas.

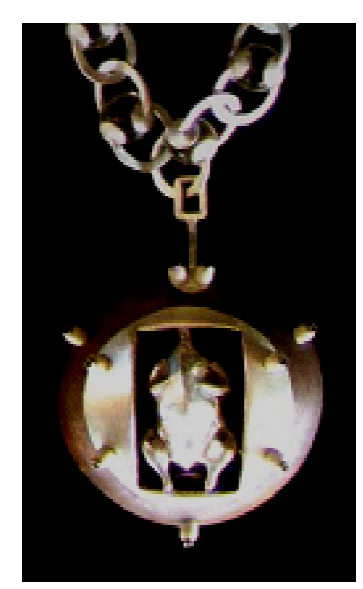

Primordialmente metal IMAGEN 170

En el collar Primordialmente metal, pequeñas esferas de vidrio se ajustan con pericia entre eslabones cóncavos de plata, formando la interesante cadena de donde pende un particular dije. La convexa superficie en madera de vera, resulta ideal para el disco que lo compone. Pues, un disco repujado en plata de menor tamaño, superpuesto a él, se ajusta de forma idónea y ambas crean entre un espacio calado, un nicho que sujeta un cuerpo de ave desplumado. Elemento éste, siendo un pequeño complemento de juego de niños, es sacado de su contexto convirtiéndose en el elemento principal del dije. Plástico/plata metamorfosis ideada por el instinto creador de Vera para recrearnos con esta pequeña historieta infantil convertido en un dije jovial algo extravagante.

145 Ministerio de la Cultura y el Consejo Nacional de la cultura. (2005). "I Salón Nacional de Orfebrería". Centro de Arte la Estancia. Catálogo. s/n. 
Según argumentos de la joyería contemporánea, que desvela nuevos caminos a través de materiales, técnicas, temas y conceptos, las joyas del orfebre Rafier son un relato que nace de la metáfora de un objeto. Para él, la relación con un pequeño elemento es esencial. Objeto este, lo inspira y persuade al proceso de transformación que permite crear un vinculo entre la

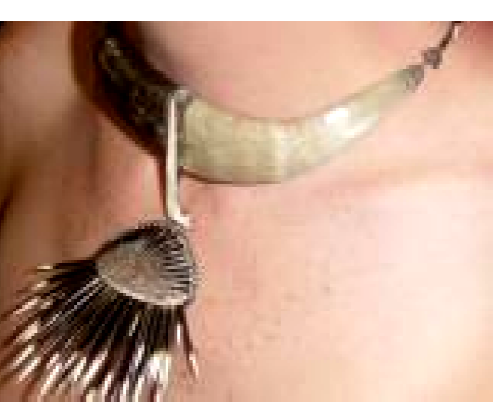

Sin Título joya y su usuario. De este modo, en Sin Título (IMAGEN 171) un puercoespín transforma su fisionomía y se apropia de un singular dije146. Sin embargo, sus púas no dejan de persuadirnos ante el peligro que ellas representan.

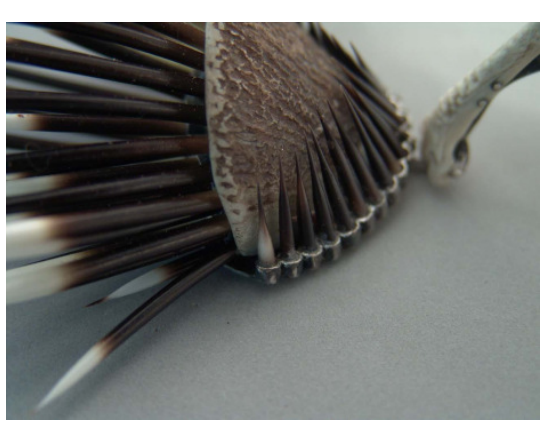

Detalle de Sin Título

El enfrentamiento entre la sutileza de una joya y lo absurdo de una anti-joya se vinculan en este collar. Pues, la maestría que desborda entre el engaste del cacho de vaca que constituye el collar, los pequeños engastes de bisel en plata del dije y la

disposición de las filosas púas entre ellos (Detalle de Sin Título IMAGEN 172), resultan una amenaza con el movimiento y roce del cuerpo. De este modo, sus joyas son ejecutadas bajo la perspectiva de los materiales como ente expresivo, donde la maestría los convierte en pequeños entes imaginarios que revelan su contexto y provocan infinidad de conceptos. Conceptos éstos, hacen reflexionar sobre la esencia de una joya y su uso. "147.

El orfebre Rafier Vera en la actualidad, cuenta con un Taller Escuela de Orfebrería propio que enseña las técnicas básicas y clásicas del oficio, enfatizando la esencia de la orfebrería contemporánea, apropiándose de otros materiales, formatos y conceptos. Siendo algunos de sus alumnos, ya recompensados en algunos salones.

14632 Salón Nacional de las Artes del Fuego. (2005). http://galeria.uc.edu.ve/actual.php?id=9

147 Vera, R. (2006). “La orfebrería como medio de expresión plástica”. II Salón Nacional de Orfebrería. Ciclo de Foros -En la Candela- 6ta. Conferencia. Museo de la Estampa y el Diseño Carlos Cruz Diez. Caracas, Material inédito. Correo electrónico. abelardotucapel@gmail.com 
La orfebre Samantha Fung crea su propia línea de joyería enmarcadas bajo un estilo muy personal. Quizá el vínculo de su profesión de arquitecto con la orfebrería, permite llevar los metales nobles a estupendas joyas, para ser usadas como ornamento o exhibirlas en un espacio como una pieza artística.

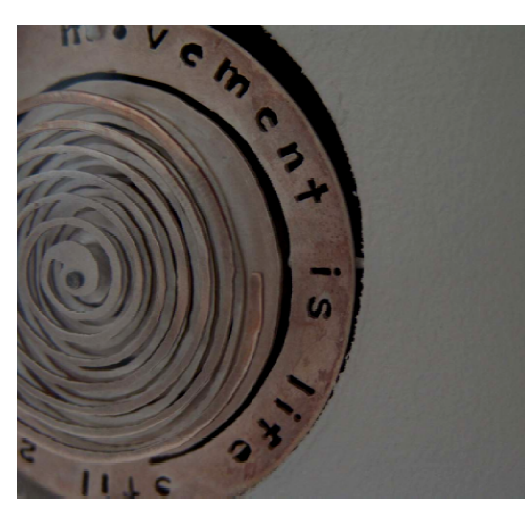
Cuatrodesiete
IMAGEN 173

Samantha Fung, se decanta por el uso de plata y oro como ente unificador. $\mathrm{Y}$, combinados con materiales cotidianos como papel, fieltro, lupas, o imanes; componiéndolos con elegancia, simetría y perfección, bajo una tendencia moderna conceptual.

La particularidad de sus diseños casi siempre convertiblespermite que el portador interactúe con ellas y las modifique a su antojo. Como por ejemplo: Cuatrodesiete (IMAGEN $173)^{148}$, esta obra en plata laminada y oxidada, es parte de una composición bidimensional compuesta de cuatro piezas. Por eso, madera, látex, plata y circón, se despojan de su contexto y se convierten en un estupendo broche. Un sugestivo mensaje calado entre sus formas, atrae la mirada curiosa de aquel que se atreva a tocarla. Destellos espectaculares emite el circón engastado en el centro del espiral, apenas con un leve movimiento. Esta obra fue merecedora de un Premio en el "SNAF" del año 2005.

Un año después, una obra de su autoría obtiene el Premio Nacional de las Artes del Fuego con la joya Deformaciones por conectividad (IMAGEN 174)149. La línea creativa de sus joyas, nuevamente sorprende al jurado del importante Salón por su estética y evidente carga conceptual.

Es un tipo de joya que ofrece originalidad inusual, donde la

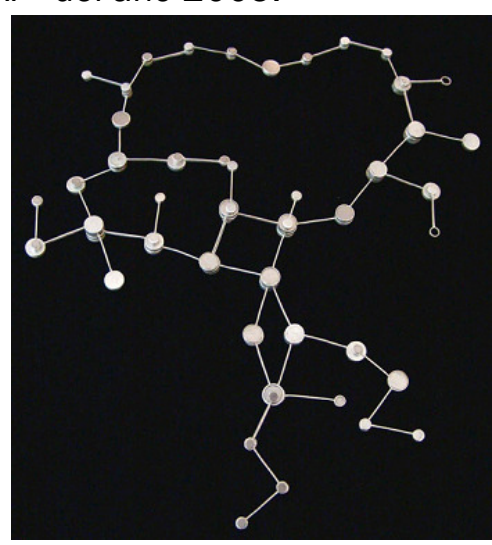

Deformaciones por conectividad IMAGEN 174

14832 Salón Nacional de las Artes del Fuego. (2005). http://galeria.uc.edu.ve/gubs.php?id=9

14933 Salón Nacional de las Artes del Fuego. (2006). http://galeria.uc.edu.ve/actual.php?id=66 
recreación y un nuevo concepto de versatilidad permiten que el usuario manipule y use total o parcialmente sus 50 piezas.

La inspiración para este diseño puede partir de cualquier aspecto. Sin embargo, aprovechando las bondades del imán y por supuesto la plata, se vale de su destreza manual y los manipula a su antojo. De este modo, engastes impecables en lámina de plata, contienen oculto un imán. Estos se unen entre sí, con idénticos hilos desarmables en plata lo que permite crear composiciones en multitud o en solitario. La ocurrencia del uso del imán se hace imprescindible, pues, con soltura y armonía se explayan sobre la vestimenta del portador.

Así pues, del gesto creador de la orfebre Fung nace la joya convertible entre plata e imanes y del portador atrevido, nace una nueva joya

(Modificación de Deformaciones por conectividad IMAGEN 175).

La mano experta de sus mentores en el oficio de la orfebrería entre Alexis De la Sierra y Ursi Galletti, asi como de otros expertos en cerámica y texti cimentaron solida formación manual siendo el paso por la Escola Massana

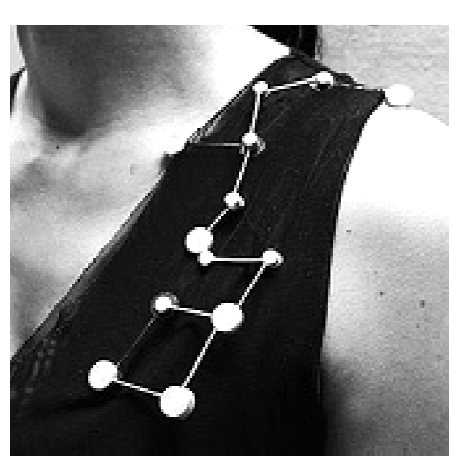

Modificación de Deformaciones por conectividad
IMAGEN 175

-Barcelona- la que concede otra nueva visión para ejecutarlas.

Con esta visión particular, la orfebre Samantha Fung, crea joyas únicas bajo una línea innovadora y vanguardista que trasciende a otras latitudes, pues, expone y vende en Venezuela, Barcelona y Holanda. 
Las joyas de la orfebre Sonia Parisca, se aproximan a una tendencia indígena con apariencia sofisticada. En ellas reúne, dos tendencias disímiles con una visión particular. Por ello, bajo la perspectiva de la estética moderna, relaciona la belleza de la plata con elementos originarios de la flora y fauna venezolana.

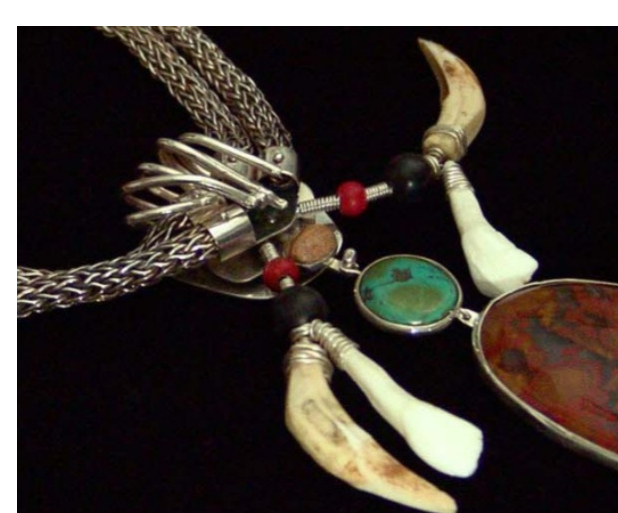

Amazona
IMAGEN 176

Amazona (IMAGEN 176)150, es un enigmático collar que fundamenta lo antes expuesto; pues, la exquisitez de la plata, se conjuga armónicamente con coloridos elementos de la naturaleza.

De este modo, la oxidación deliberada en el tupido tejido de plata, exalta sus formas dejando apreciar su impecable factura. El brillo

de la plata pura, contrasta con magníficos elementos nativos entre semillas, dientes de animales y diversas piedras. En este collar, un estupendo sistema articulable de plata entre enormes eslabones y remaches, sujetan tres elementos que componen el extraño dije. El más grande ellos, se combina entre tres piedras engastadas en plata que degradan su tamaño; así pues, un pequeño cabuchón de jaspe Morgan Hill, una mediana turquesa y un inmenso jaspe paisaje se sujetan uno del otro, por medio de delicados remaches que permiten su movilidad. Y, el dúo que las custodia, se compone de dos enormes dientes de animales salvajes: uno de jabalí y el otro de búfalo de agua. Obviamente, el bello detalle y contraste de las semillas circulares; roja y negra, sujetan enérgicamente estos dientes, con un delicado hilo de plata. Detalle este, relaciona los nativos elementos de la naturaleza con proporción y delicadeza, donde el exótico colorido entre ellos se fusiona en este imaginativo collar.

Con sabia intuición, Sonia Parisca ha sabido fusionar un lenguaje plástico desde la perspectiva de su profesión con la orfebrería,

15031 Salón Nacional de las Artes del Fuego. (2004)

http://galeria.uc.edu.ve/actual.php?id=27 
pues, siendo licenciada en Psicopedagogía y Magister en Arte, ha sabido aprovechar las bondades de cada una de ellas; donde, lo cognitivo, sensorial y espontáneo se manifiesta en sus obras con un semblante artístico particular.

Durante algunos años, estudia orfebrería con excelentes maestros, entre ellos Alexis De La Sierra, Mary Ann Scherr y Heiki Seppa donde cada uno de ellos ha dejado honda huella en su léxico creativo.

La membrecía en la "AVAF", le ha permitido exponer a nive internacional en ferias de artesanía entre Estados Unidos, Argentina y España, resaltando el valor de los elementos autóctonos venezolanos.

En la III edición del "SNO", la orfebre Sonia rinde homenaje a la cestería venezolana con una atractiva cesta metálica, Pues, un magnifico tejido en alambre e hilos de cobre patinado, fundamentan y exaltan la delicadeza de la manufactura de esta Cesta (IMAGEN 177)151.

De una base circular de madera, Sonia Parisca, fija con simetría las delicadas varillas de cobre; desde las cuales, se entretejen

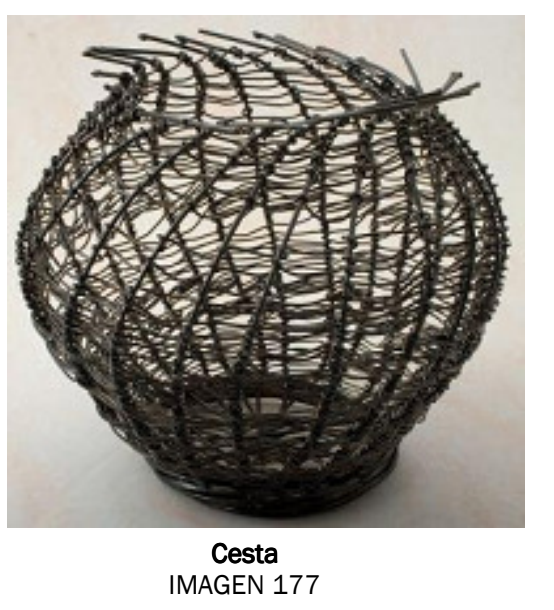
delicados hilos que forman esta bella cesta. Obviamente, la separación entre ellos, permite apreciar su tejido desde cualquier ángulo; pues, deliberadamente, su delicada retícula deja entrever su diseño fascinante y evidencia su impecable maestría. El calor de la llama del soplete, refuerza la ennegrecida pátina, donde la estupenda analogía con las fibras naturales del bejuco, se fundamentan en ella, evidenciando, su intuición y visión particular sobre la orfebrería nativa venezolana.

151 Vera, R. (2012). "Imágenes y fichas técnica de obras III Salón Nacional de Orfebrería". Material inédito. Correo electrónico. vhrafier@yahoo.com 
Tatiana Tischenko es una artista que ha abordado durante muchos años diversas disciplinas de las artes del fuego, desde la cerámica, el vidrio, los esmaltes al fuego, hasta la orfebrería. El transitar en esas áreas, le ha valido para perfeccionarse en cada una de ellas, aprovechando los materiales que los fundamentan y las diversas técnicas que los componen; pues, ha sabido fusionarlos, creando piezas geniales con las que ha merecido importantes premios.

En Agua y fuego...elementos extremos (IMAGEN 178)152, la delicadeza del perfecto acabado de una joya se evidencia entre la impecable cuenta de vidrio y la espectacular gema acoplándose en un magnifico dúo de anillos. Dos impecables alianzas de plata pura, constituyen y exhiben formas magnificas que simulan el agua y el fuego, con los que obtuvo un Premio en el "SNAF" del año 2006. Así pues, en uno de los anillos, metafóricamente,

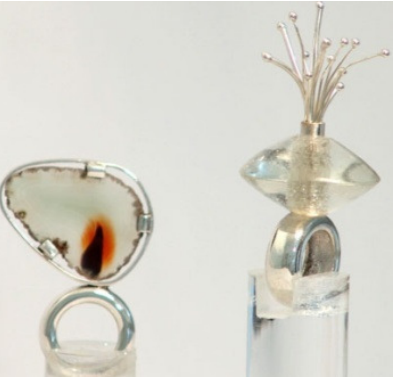

Agua y fuego...

IMAGEN 178

una llama de fuego surge de las entrañas de la fascinante ágata y con habilidad, un resplandeciente hilo de plata rodea su particular forma, sujetándola entre pequeños engastes que lo fijan a un imponente aro de plata. Del otro anillo, una enérgica fuente de agua, destellantes hilos de plata pura salen de una enorme cuenta de vidrio transparente, que se fijan con perfecto dominio del otro aro de plata; obviamente, con verdadera pericia, el vidrio y el meta son manipulados con el soplete a su antojo, convirtiéndolos por su instinto creador en dos fascinantes y sugestivos anillos.

Otra obra de su autoría, obtiene un Premio en el "SNAF" el año 2008 en la tendencia de Esmalte sobre Metal. Se trata de Caminos entrelazados, vida independiente (IMAGEN 179)153 donde la guaya de acero, los esmaltes al fuego y las plumas de guacamaya se componen en un móvil de metro y medio de alto, cuya apariencia sencilla desborda un colorido fascinante.

\footnotetext{
15233 Salón Nacional de las Artes del Fuego. (2006). http://galeria.uc.edu.ve/actual.php?id=66

15335 Salón Nacional de las Artes del Fuego. (2008) http://galeria.uc.edu.ve/actual.php?id=79
} 


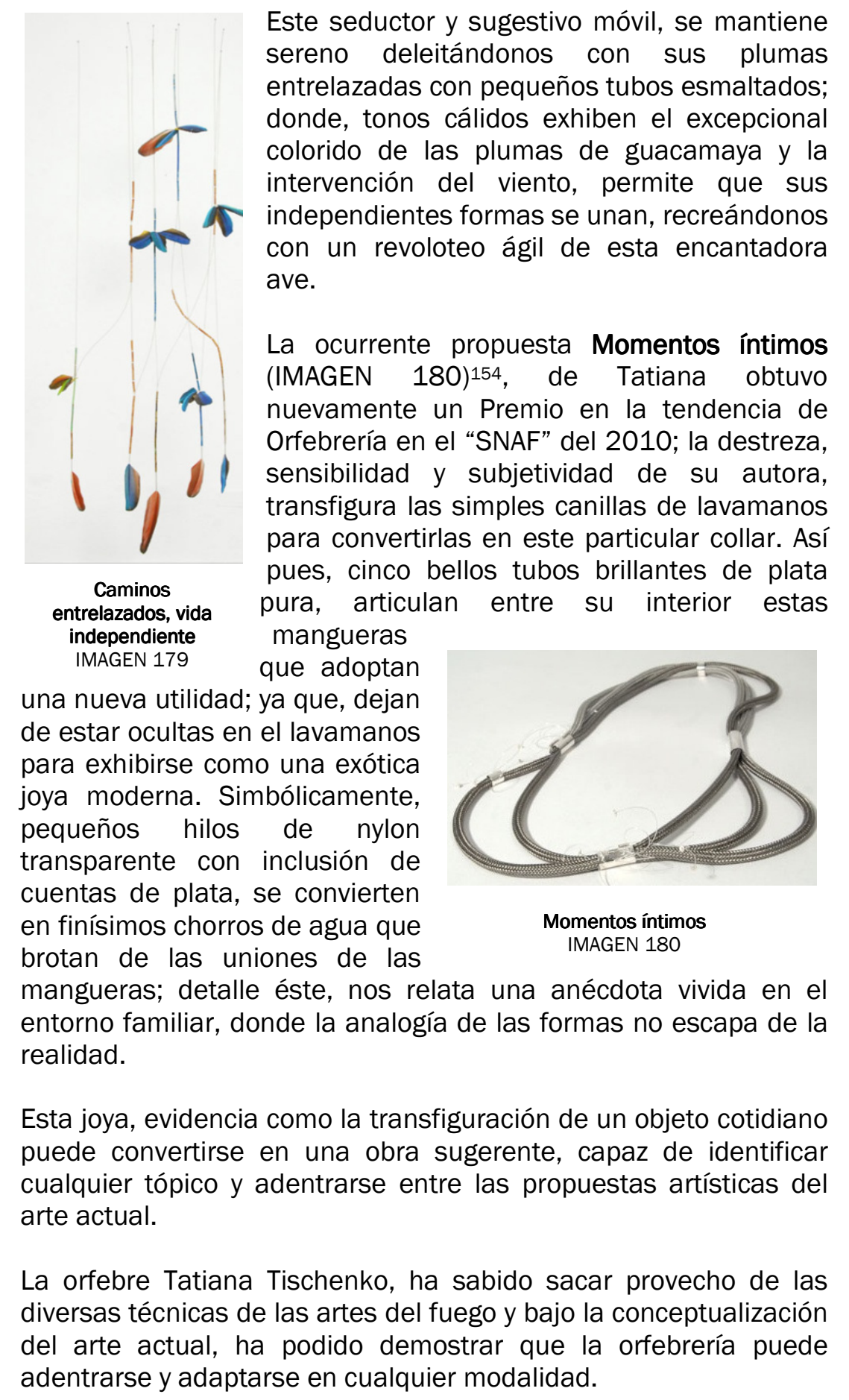

Este seductor y sugestivo móvil, se mantiene
sereno deleitándonos con sus plumas entrelazadas con pequeños tubos esmaltados; donde, tonos cálidos exhiben el excepcional colorido de las plumas de guacamaya y la intervención del viento, permite que sus ave. IMAGEN 180)154, de Tatiana obtuvo Orfebrería en "I "SNAF" del 2010; la destreza, sensibilidad y subjetividad de su autora tes de plata independiente mangueras IMAGEN 179 de estar ocultas para exhibirse como una exótica joya moderna. Simbólicamente, pequeños hilos de nylon transparente con inclusión de mangueras; detalle éste, nos relata una anécdota vivida en e entorno familiar, donde la analogía de las formas no escapa de la realidad. puede convertirse en una obra sugerente, capaz de identificar cualquier tópico y adentrarse entre las propuestas artísticas de actual. adentrarse y adaptarse en cualquier modalidad.

15437 Salón Nacional de las Artes del Fuego. (2010)

http://galeria.uc.edu.ve/actual.php?id=89 
La artista Yolanda Sucre empezó su trayectoria especializándose en los esmaltes al fuego. Aprovechando las tonalidades espectaculares y las diversas y fascinantes técnicas que lo fundamentan, ha sabido engranar su obra dejando claro sus dotes de esmaltista. El paso por la Escuela de Orfebres Alexis de la Sierra le dejo huella significativa; el hallar la importancia de la dedicación con mesura, el dominio perfecto de la técnica y el detalle impecable de sus acabados ha permitido que su obra esté muy bien sustentada. La inclusión en el medio expositivo, ha sido casi a la par de sus inicios en esta disciplina y con esa misma rapidez, su obra ha sido reconocida obteniendo importantes premios.

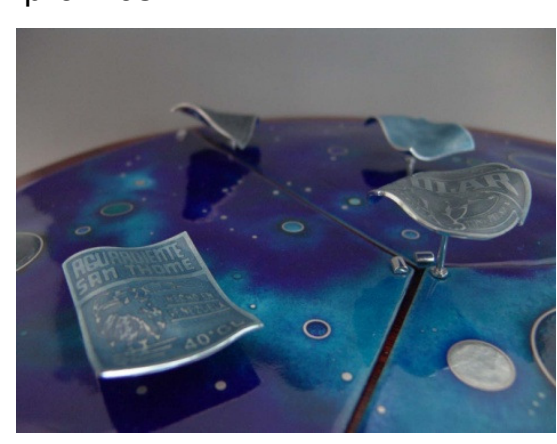

Noche de etiqueta

En Noche de etiqueta (IMAGEN 181) ${ }^{155}$, fue galardonada el año 2005 en del "SNAF" con un Premio en la tendencia de Esmaltes sobre metal; en esta obra, un enorme domo de cobre de casi medio metro de diámetro embutido manualmente, deslumbra entre los fascinantes matices de esmalte azul. Fusionados armónicamente con aros de hilo de plata y cobre, éstos, destellan impecables sobre la superficie azulada. Superficie esta, supone una imaginativa luna llena, de una noche esplendida, bajo un cielo repleto de estrellas fugaces. En donde, emblemáticas láminas de plata fotograbadas, desvelan etiquetas de licores que orbitan sobre este cielo seccionado, pues, esta simbología alude a la alegre vida nocturna. La ambigüedad del contenido de la obra, supone un interesante trasfondo que pone a reflexión sobre el tema en cuestión. Sin embargo, la manera de acercarnos a la realidad con esta obra bajo la perspectiva de la orfebrería, nos adentra hacia las nuevas tendencias del arte actual.

Nuevamente una obra de su autoría y bajo la misma temática, obtiene un Premio en la tendencia de Esmalte sobre Metal en el "SNAF" del 2006. Se trata de Viernes chiquito (IMAGEN 182)156,

15532 Salón Nacional de las Artes del Fuego. (2005). http://galeria.uc.edu.ve/gubs.php?id=9

15633 Salón Nacional de las Artes del Fuego. (2006). http://galeria.uc.edu.ve/actual.php?id=66 
en ella la artista Sucre nos deleita con su destreza y peculiar manera de enfocar un tema.

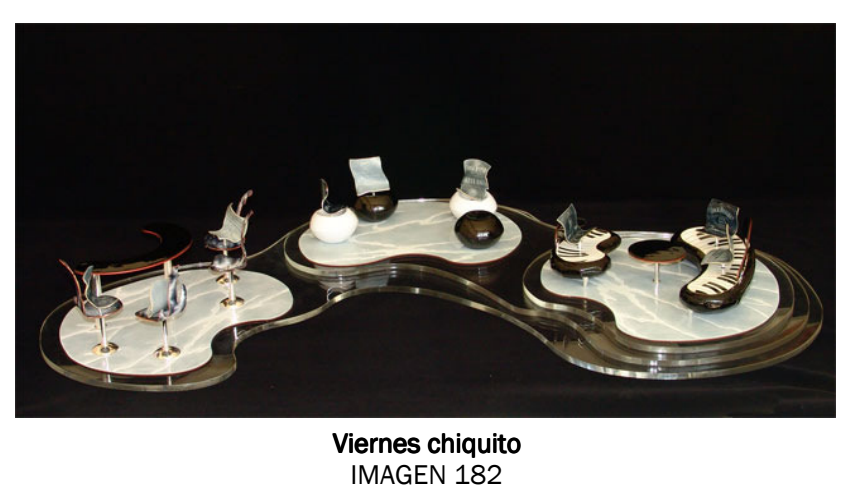

Esta propuesta figurativa, reúne las técnicas del martillado, embutido, cloisonné, fotograbado y el ensamblaje para crear un espacio ilusorio de un lujoso de esparcimiento centro nocturno. Los elementos con formas de mobiliario, se agrupan formando tres espacios diferentes de la locación. Diseños estos, se constituyen de la construcción de láminas de plata pura, del embutido y la formación de sólidos en cobre. Esmaltes duros y blandos entre mates y traslucidos se dan cita en las impecables bases, para deleitarnos con un cloisonné diferente. Pues, substituye los hilos de metal por hilos de esmalte blanco mate y a través de su entramado, funden esmaltes blanco cuyo aspecto satinado crea un sublime contraste en su superficie. Superficie esta, técnicamente difícil de elaborar que es producto de un lento y laborioso proceso que la definen como una excelente esmaltista. Obviamente, su mayor seña de identidad es el dominio que posee con los esmaltes al fuego. Su obra se enfoca en un estilo particular que declara sobre un contexto de festividad, de alegría, de compartir. En sus representaciones, la inclusión de elementos en plata son cruciales; pues, estos con habilidad, suelda directamente sobre la superficie esmaltada sin modificar su tonalidad.

Con el collar en plata A buen entendedor (IMAGEN 183)157, la mano experta y acertada de Yolanda Sucre obtiene el Premio Nacional de las Artes del Fuego en la tendencia de Orfebrería en el "SNAF" del año 2008. Este collar, se forma entre delicados tubos y cuentas en plata laminada que se sujetan entre sí, a través de minuciosos remaches. Cuya presión, permite la movilidad entre ellos y su ajuste cómodo al cuello de quien lo use.

La analogia de los tres dijes, entre formas y funcion con el título, resulta bien acertado. La primera mirada despierta algo de interés,

15735 Salón Nacional de las Artes del Fuego. (2008).

http://galeria.uc.edu.ve/actual.php?id=79 
lo que incita acercarse y observar con detenimiento para descubrir su función e interactuar con ellos. Así pues, como un pasatiempo de niños, cada dije, contiene elementos para interactuar y poner a prueba la curiosidad, concentracion, agilidad, habilidad, paciencia y competitividad típica de este tipo de juego.

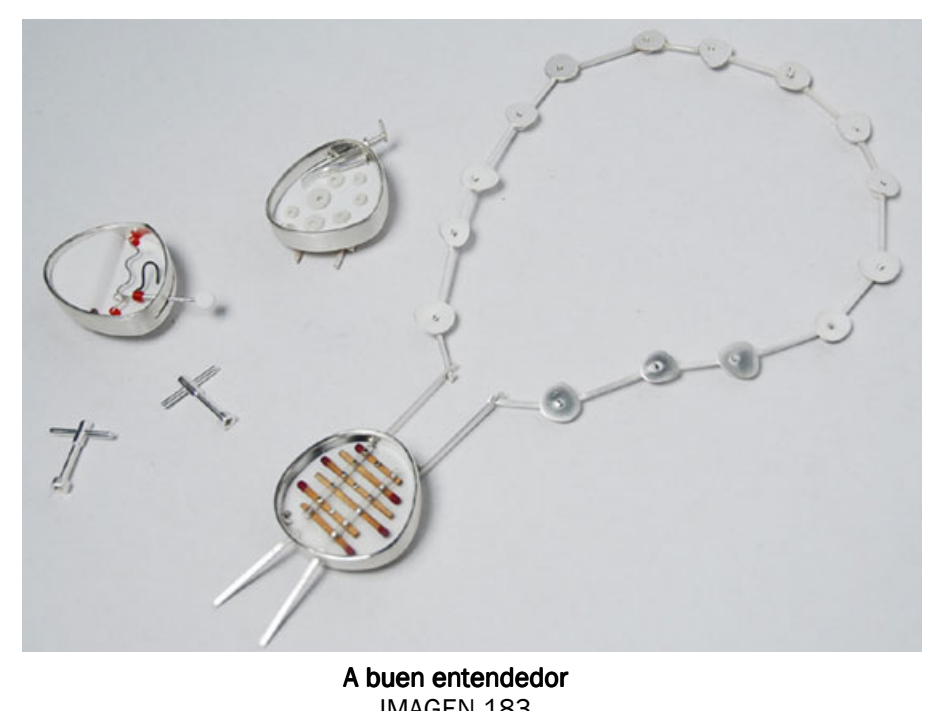

IMAGEN 183

En este divertido collar -con tres dijes-, el acrílico, el esmalte y plata, son transformados en diminutos elementos, que minuciosamente ensamblados dentro de cada dije, forman juegos con diferentes dificultades. De este modo, en el primero de ellos, dos cuentas de acrílico rojo delimitan y limitan, el ya pequeño espacio con un sinuoso hilo de plata que custodia una bolita. La palanca con punta de garfio, debe detenerla y arrastrarla con su gancho. El segundo dije, contiene en un extremo una pequeña casilla que encierra una bolita, la cual es empujada hacia adentro con un resorte a través de un delicado embolo de plata. En su interior, finas láminas de acrílico blanco con formas circulares de diversos diámetros, contienen un orificio en su centro, donde debe detenerse dicha bolita. El tercero y más grande de los dijes, intercala linealmente láminas esmaltadas de forma idéntica a unas cerillas de madera, donde una bolita de plata, debe recorrerlas de manera zigzagueante sin saltarse entre ellas.

Una vez más, la obra del orfebre Yolanda Sucre nos deleita y fascina con su maestría, donde el tema que lo fundamenta trasciende con su proceso creativo. 
La arquitecto Ana Mercedes Carvallo estudio por varios años en el "R\&C Orfebres Taller Escuela" de Carlos Graterol y a través de toda esa enseñanza ha conseguido a través de los esmaltes al fuego, una manera de interactuar con el espacio que diseña. Su necesidad de integrar elementos de la naturaleza, le ha permitido relacionar ciertas características de ese entorno, que hoy en día, son parte de un lenguaje plástico que demuestra su autoría.

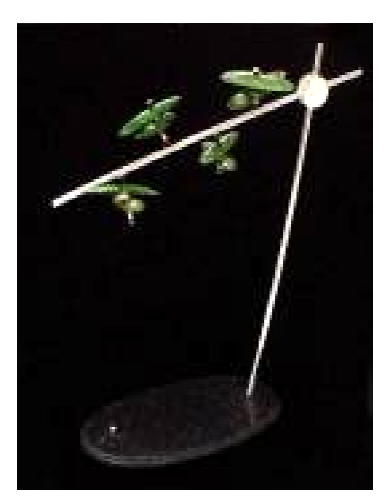

Vainitas suspendidas IMAGEN 184

Vainitas suspendidas (IMAGEN 184)158, obtuvo el Premio en la tendencia de Esmalte sobre metal en el "SNAF" del año 2003. Esta obra con acento minimalista, representa un pequeño arbusto con una rama de cuatro vainitas esmaltadas. Con simetría y perfección, la artista Ana Mercedes Carvallo simboliza este híbrido con un meticuloso proceso de fabricación.

Dos delicadas e imponentes varillas de cobre, son cubiertas elegantemente con un baño de plata pura y su truncada disposición, la erige como el pequeño arbusto que fundamenta esta propuesta. Aferradas a él, majestuosas vainitas se reproducen con elegante simetría dejando en evidencia su maduración; perpetuando su especie, con fascinantes tonalidades conseguidas con los esmaltes al fuego.

Embutidores, un tas y el martillo, son requeridos y usados con precisión para la consecución de estas significativas formas. Donde, la temperatura adecuada del esmalte exterioriza entre sus formas las tonalidades que se aferran a su analogía. En el primer plano vemos, que las redondas y abombadas semillas dejan entrever el fondo del cobre con un tamizado irregular verde claro. $Y$ en su base, las paredes del interior de la vaina, se consolidan con un esgrafiado; en ella, sobre una base gris vitrificada, su trazo lineal sobre el esmalte verde deja ver la

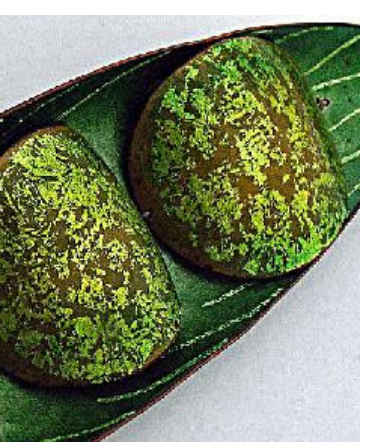

Detalle de Vainitas suspendidas

tonalidad de su interior como un tejido rasgado (Detalle de Vainitas suspendidas IMAGEN 185).

158 XXX Salón Nacional de las Artes del Fuego. (2003).

http://galeria.uc.edu.ve/gubs.php?id=41 


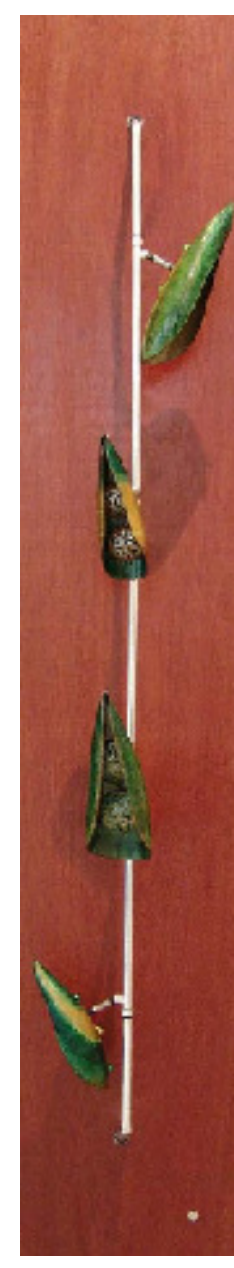

La complejidad de sus propuestas entre formas y tonalidades son parte de un proceso evolutivo y meticuloso que ha sido bien reconocido en importantes salones de arte.

La intuición y maestría van de la mano en sus sugerentes obras; donde, cualquier elemento, puede ser transfigurado a través de algunas técnicas de la orfebrería y escultura, para lograr su objetivo. Su ojo inquisidor, ha sabido descubrir la esencia del color, de las formas y de los materiales para reinventarlos y convertirlos en estupendos híbridos que asientan sus propuestas.

La artista Ana Mercedes Carvallo obtiene nuevamente un Premio en la tendencia de Esmalte sobre metal en el "SNAF" del año 2004 con la obra Vainitas transgénicas (IMAGEN 186)159.

Para perpetuar su especie, decide reinventar las (Vainitas suspendidas) galardonada en la edición anterior- y plantearla con otro enfoque; entonces, se despoja del pedestal e invade un espacio en la pared y alcanza mayor dimensión. Sobre una base de madera, germina y ahonda sus raíces esta particular planta. En la cual, un solitario y brillantísimo tallo bañado de plata, conduce la savia a las vainas en plena reproducción. El vainitas entorno natural, transforma su analogía y Transgénicas reproduce una especie concebida con sus propias IMAGEN 186 manos. La fuerza y voluntad de esta orfebre, transforman el cobre en perfectos brotes que surgen de las hojas. Transformación genética ésta, se argumenta por su instinto creador y es su mano experta la que logra su color; pues, de manera acertada, los esmaltes al fuego vinculan la forma con el contexto que la establece.

La producción de Carvallo, demuestra un sugestivo discurso plástico que se fundamenta sobre elementos reconocibles de la naturaleza y de este modo, ha creado un vínculo entre la analogía de las formas y los esmaltes al fuego.

Una estupenda cosecha de mazorcas, se componen de elementos seriados en cobre, bronce y plata. $Y$ el repujado, los esmaltes al fuego y los baños electrolíticos, constituyen el rol protagónico, para dar rienda suelta al instinto creativo de La artista Ana Mercedes

15931 Salón Nacional de las Artes del Fuego. (2004).

http://galeria.uc.edu.ve/gubs.php?id=27. 
Carvallo. La interesante propuesta Trigal de maíz transgénico (IMAGEN 187)160, fue merecedora del Premio Nacional de las Artes del fuego en el "SNAF" del año 2005.

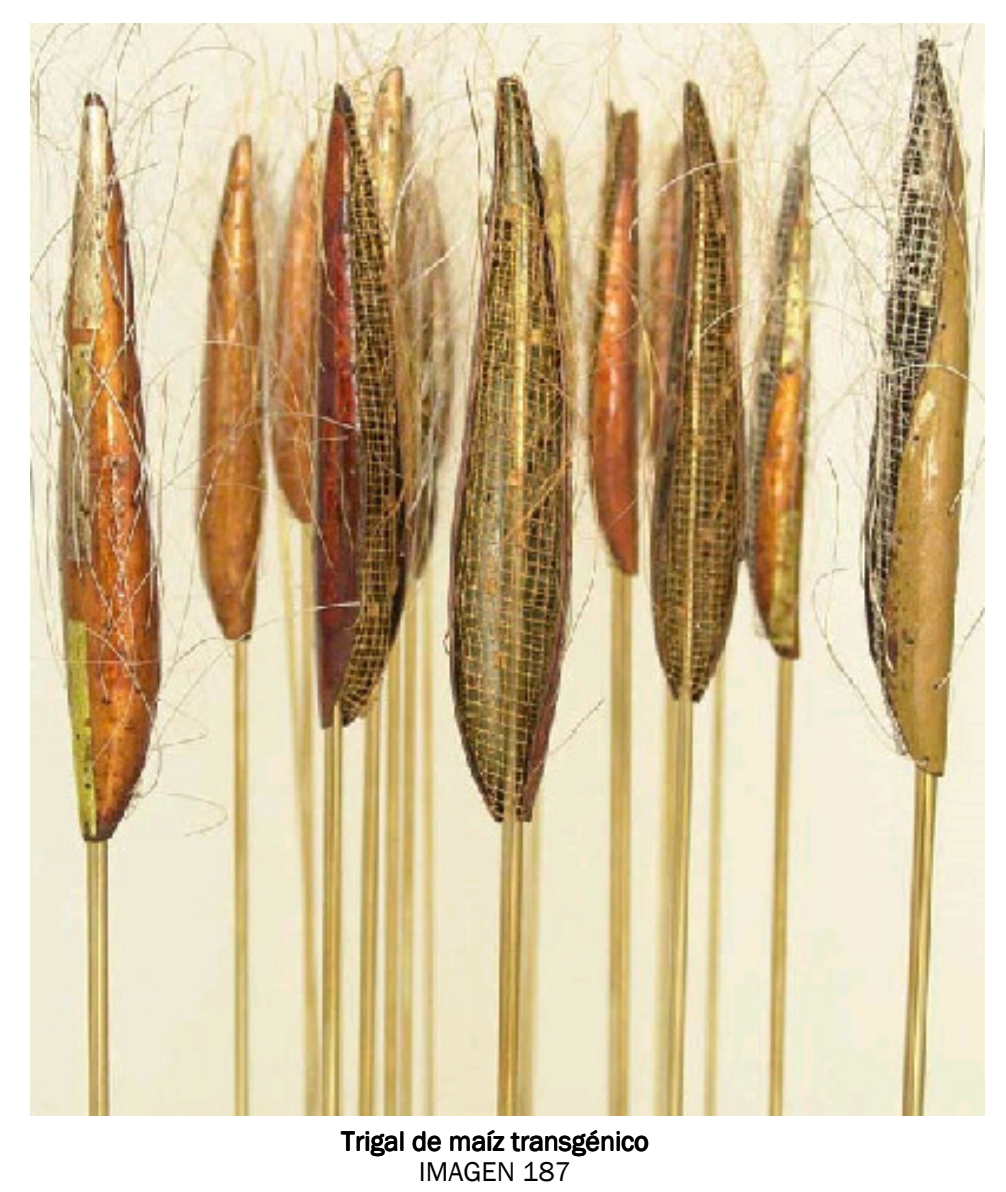

La asidua experimentación con los esmaltes y la inclusión de técnicas de la orfebrería y de la escultura, la han guiado a concebir estos elementos cotidianos en una sugestiva obra.

Formas seriadas y cortadas idénticamente, transforman su forma original con acertadas curvas que aluden a la mazorca con sus granos comestibles. La seducción de los matices metálicos de su superficie, deviene de los esmaltes traslúcidos que van del amarillo tostado al ocre. La malla metálica que pernocta en sus entrañas, protagoniza el desgrane. Mutación esta, permite que los granos se despojen de su núcleo, sin la intervención de la mano del hombre. Y el baño de plata señala la pronta maduración del maíz y de igual modo, el baño de oro, señala aquellas que ya están comestibles. La tusa de hilos de filigrana de plata que sale de cada una de ellas confirma su ciclo. La heterogeneidad de la

16032 Salón Nacional de las Artes del Fuego. (2005).

http://galeria.uc.edu.ve/gubs.php?id=9 
siembra/obra, conforman un discurso unitario, cuya simetría equilibra el conjunto donde la mínima transformación entre ellas insinúa su analogía con la realidad. Pues, como elementos propios de la naturaleza, repiten sus formas una y otra vez con natural perfección. Cuya esencia es lograda por el esfuerzo de un intenso proceso de fabricación.

La artista Ana Mercedes carvallo, es miembro activo de la "AVAF", dedicándose a la enseñanza de diversas técnicas de los esmaltes en paralelo, a su producción en orfebrería escultórica y ejecución de proyectos arquitectónicos. Así pues, maestría, sensibilidad e intuición transmite con acertada pedagogía en sus clases, donde la orfebrería y la escultura se compenetran en un solo ser. 
EDYMAR ÁLVAREZ

Alegres instalaciones fundamentan su léxico creativo a partir de la orfebrería.

La diseñadora industrial Edymar Álvarez, utiliza en su léxico creativo a la orfebrería como esencia unificadora. Su formación como orfebre deviene de los Talleres de Producción Artesanal de la Universidad de los Andes en Mérida y de la Escuela de Orfebres Alexis De la Sierra.
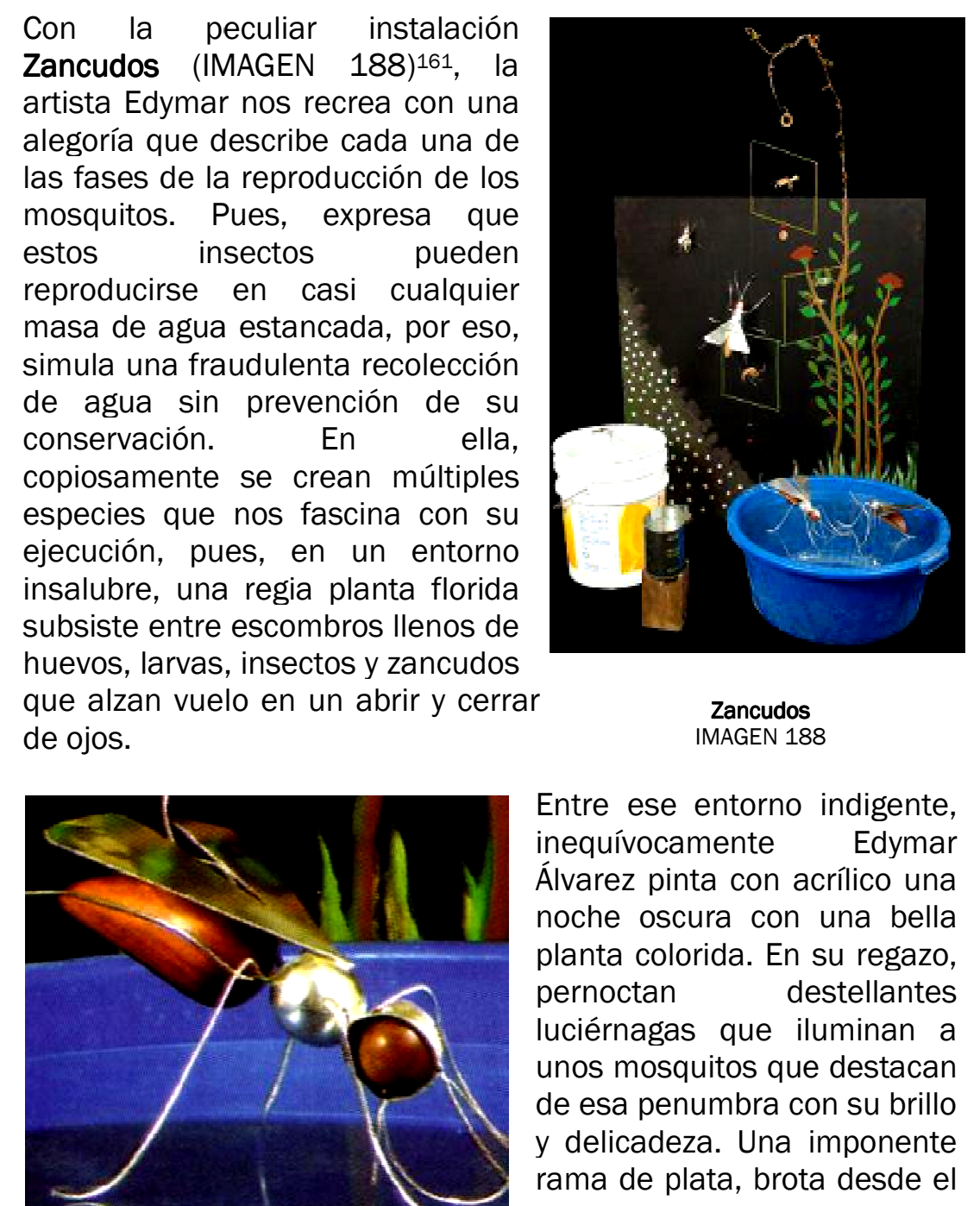

Entre ese entorno indigente, inequívocamente Edymar Álvarez pinta con acrílico una noche oscura con una bella planta colorida. En su regazo, pernoctan destellantes luciérnagas que iluminan a unos mosquitos que destacan de esa penumbra con su brillo y delicadeza. Una imponente rama de plata, brota desde el Detalle de Zancudos IMAGEN 189 interior de la planta, sujetando tres marcos de donde cuelgan estos

161 Instituto de las Artes de la Imagen y el espacio y Mota, J. (2006). “II Salón Nacional de Orfebrería". Museo de la Estampa y del Diseño Carlos Cruz-Diez Catálogo. p: 56. 
pequeños insectos. Cada uno de ellos, personifica su evolución, entre maestría técnica y diversidad de materiales. Estupendas vetas de la caoba, siluetean el enorme zancudo, cuya mesura, ensambla su cuerpo fraccionado de plata entre alargadas patas y una delicada lámina en forma de aleta (Detalle de Zancudos IMAGEN 189). Aleta esta, sujeta su torso para alzar vuelo sigilosamente en esa noche perturbadora.

Entre aleteos fascinantes de plata, cobre y latón, se compenetran en un mismo son, un bello colibrí y numerosas abejas. En esta nueva propuesta La abeja y el colibrí (IMAGEN 190) ${ }^{162}$, la orfebre Edymar Álvarez nos alecciona con un paisaje agradable y colorido sobre la integración de diversas especies; pues, en armonía, comparten su vuelo en la búsqueda de su fuente de alimento. Fascinantes alas y pico de plata, engalanan el bello colibrí de cobre; cuyo repujado magnifico, forma su delicado cuerpo, que vuela con simpatía entre las estupendas abejas. (Detalle de La abeja y el colibrí IMAGEN 191)

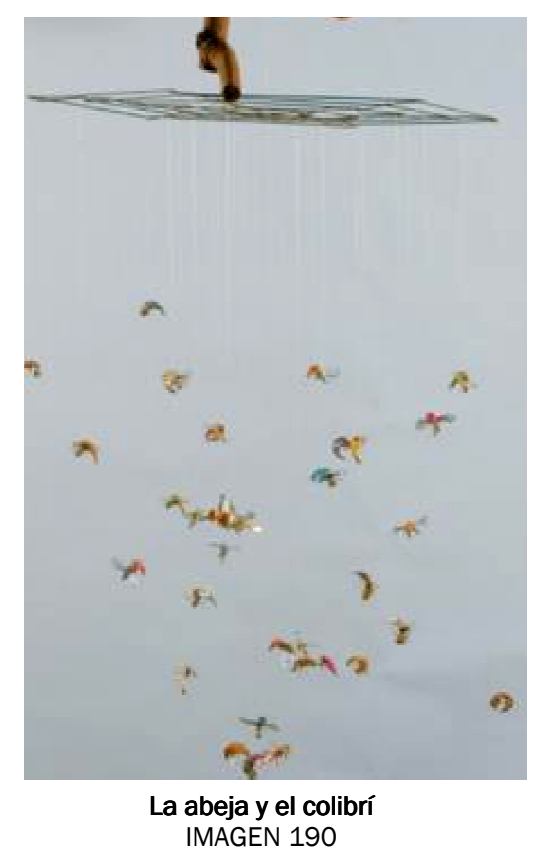

Delicadas pinceladas de color turquesa y naranja visten el colorido cuerpo de las abejas. Cuerpo este, de semilla de jabillo, concilia su curveada forma con el dócil aleteo afiligranado de plata y latón de sus alas.

Detalle de La abeja y el Colibrí
MAGEN 191

La utilización de estos tres metales no es trivial, ya que la combinación entre ellos, resulta apetecible ante su sugestiva y delicada obra. Cuyo estallido de color, aporta en cada uno de los elementos mayor luminosidad y sofisticación. Obviamente, su mayor seña de identidad es la sensibilidad con la que aborda algún tema. Por ello, esos pequeños espacios complejos evidencian con maestría, delicadeza y fidelidad, un evento cotidiano. Así pues, formas figurativas realizadas con metales nobles de un modo artesanal, definen en su contexto habitual a un zancudo, un pájaro o una abeja con un estilo particular.

162 Vera, R. (2012). "Imágenes y fichas técnica de obras III Salón Nacional de Orfebrería". Material inédito. Correo electrónico. vhrafier@yahoo.com 
MARÍA GRACIELA GARCÍA

La orfebrería y la escultura se alinean en un mismo lenguaje.

La orfebre María Graciela García elabora su obra bajo los argumentos de la orfebrería escultórica ya que, utiliza siempre técnicas tradicionales de la orfebrería y fusiona de manera sistemática con aquellas propias de la escultura. Su transitar entre ambos lenguajes, sucede en el desarrollo de su carrera en artes visuales; de este modo, la búsqueda de una diferente tendencia artística le aproxima hacia el campo de la orfebrería. Siendo cautivada por esta disciplina, comienza un estudio sistemático sobre sus técnicas vinculándolas siempre, a aquellas propias de su escolaridad: pintura, fotografía, grabado, escultura; siendo con esta última, la que justifica su inicial búsqueda, ya que, logra un lenguaje plástico multidisciplinar basado entre ambas disciplinas.

En la obra Reflejo (IMAGEN

192) intencionalmente ${ }^{163}$, la

autora exige la intervención

del espectador para su

apreciación. Puesto que,

detrás de su fachada,

contiene una pieza de menor

tamaño, cuya forma encierra

el enigma que lo vincula con

su título. De este modo, su

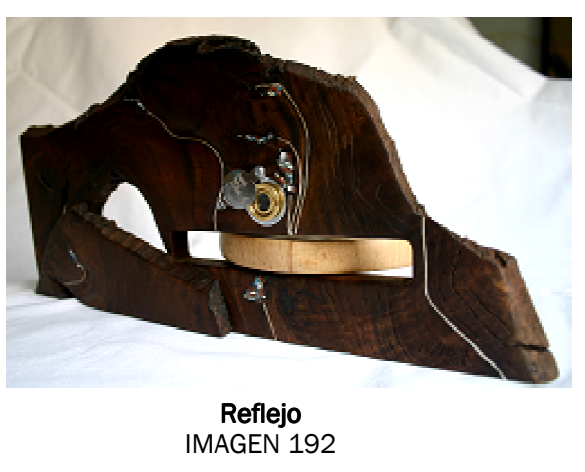

exterior se sustenta del ensamblaje de lámina de raíz de nogal, intervenida con hilos de plata y trozos de piedras semipreciosas, incrustados entre sus zigzagueantes vetas. En esta superficie, contiene una pequeña mirilla que invita al espectador descubrir su interior que oculta una pequeña pieza en plata

Detalle de la mirilla de con madera, cuya Reflejo forma desvela la IMAGEN 193 analogía con su título (Detalle de la mirilla de Reflejo IMAGEN 193). Pieza ésta, con forma de cubo (Detalle de la pieza del interior de Reflejo IMAGEN 194), se encuentra sobre una base giratoria la cual puede moverse con un dedo, desde la fachada. Así pues, Un seccionado cubo,

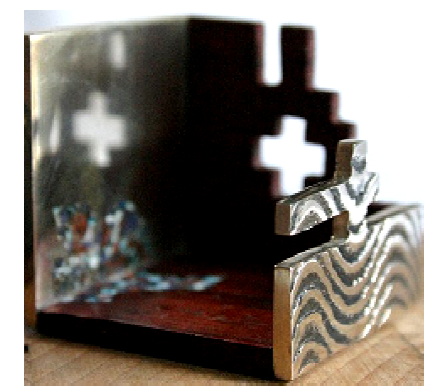

Detalle de la pieza del interior de Reflejo IMAGEN 194

163 Instituto de las Artes de la Imagen y el espacio y Mota, J. (2006). “II Salón Nacional de Orfebrería". Museo de la Estampa y del Diseño Carlos Cruz-Diez Catálogo. pp: 120-121 
ensamblado entre paredes de plata y palo rojo, refleja la superficie de sus paredes la forma de una cruz latina, entre texturas, lisas, acanaladas, brillantes y mate. Por ello, es necesaria la intervención, porque a través del movimiento, se observa cómo se consolida en una sola forma.

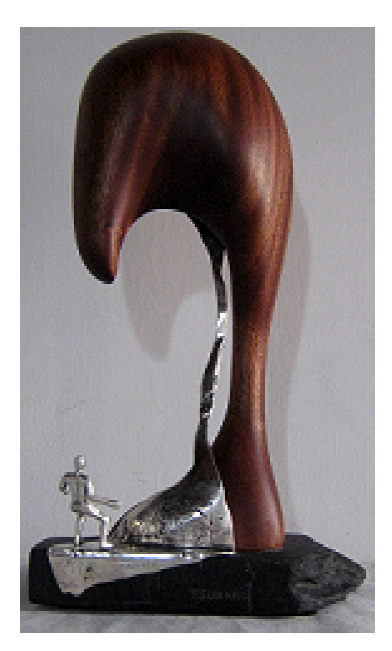

Tsunami
IMAGEN 195

La artista García, vincula su quehacer artístico a cualquier tópico, dejando en evidencia su sensibilidad y destreza técnica. Bajo su preocupación ante el cambio climático y los desastres naturales que esto origina, nos sorprende con la obra Tsunami (IMAGEN 195). En ella, una magnífica talla en madera de palo santo se hace protagonista, conjugando entre sus fascinantes vetas, las cavidades y forma de la enorme ola; a punto de ser devorado por ella, un insignificante individuo vaciado en plata, se sorprende por su magnitud, advirtiendo su trágico desenlace. Ola ésta, reproduce su forma en una forjada, reticulada y oxidada lámina de plata, dejando perenne la funesta situación. La metáfora de esta escena, delibera sobre el uso indiscriminado de los recursos naturales, donde éstos intuitivamente, se revierten por su propia fuerza.

En la obra Aférrate (IMAGEN 196) nuevamente la artista nos sorprende con su visión ante la cruel enfermedad del sida; metafóricamente, la lámina en plata y caliza que se establecen en una sola forma circular, refundida y agrietada, enfoca todas las

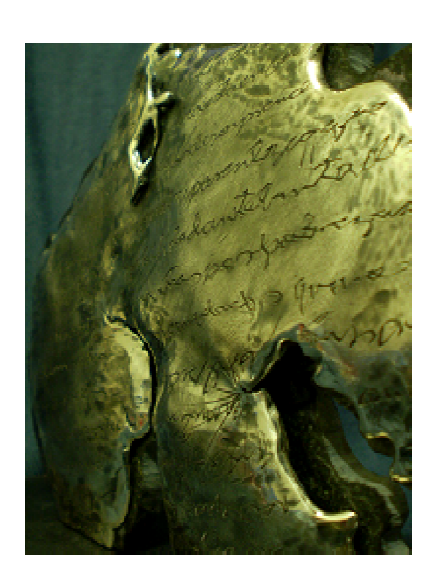

Detalle de aférrate IMAGEN 197

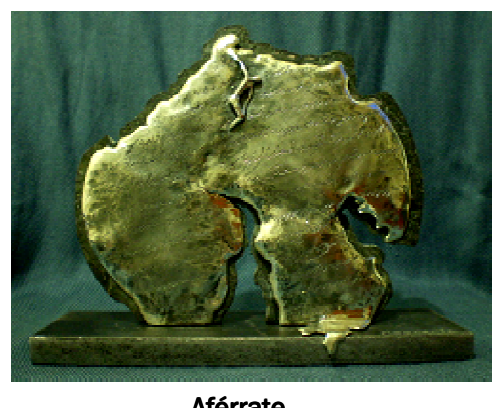

Aférrate

civilizacio nes en el mundo que han sido afectadas por este virus: donde, lo único en común, es la degradación del individuo y no les queda más que aferrarse a la fe que los mantiene con vida. Así pues, grietas caladas, refundidas y forjadas de esta emblemática en plata, es devorada lenta y acertadamente, donde un débil y agotado individuo, se aferra de ese núcleo. El grafismo indescifrable de la superficie, deja testimonio de la aflicción 
del ser que pende de ella (Detalle de Aférrate IMAGEN 197).

En esta sugestiva obra, la artista María Graciela García, nos expresa como el virus del VIH ataca sin razón y no existe condición para poseerlo. Por eso en esta obra, se transfigura la plata en el mundo entero que ha sido víctima del SIDA y como este virus se ha proliferado como una plaga sin dificultad; llevándose consigo, todo aquel individuo que encuentra.

Esta orfebre deviene de la formación como orfebre en los Talleres de Producción Artesanal de la Universidad de los Andes, Mérida. 
La obra de la orfebre María Njaim se debate entre la orfebrería conceptual y la tradicional. Con acertada convicción elabora unas piezas donde la maestría y el preciosismo de las joyas se adentran en la tipología de una escultura.

En la obra Bate que bate... (IMAGEN 198) ${ }^{164}$, la opulencia de la plata pura se apodera del entorno circundante. Un emblemático vaso de vidrio de licuadora, exonera su función para aleccionarnos con esta metáfora. Compuesto con retales de

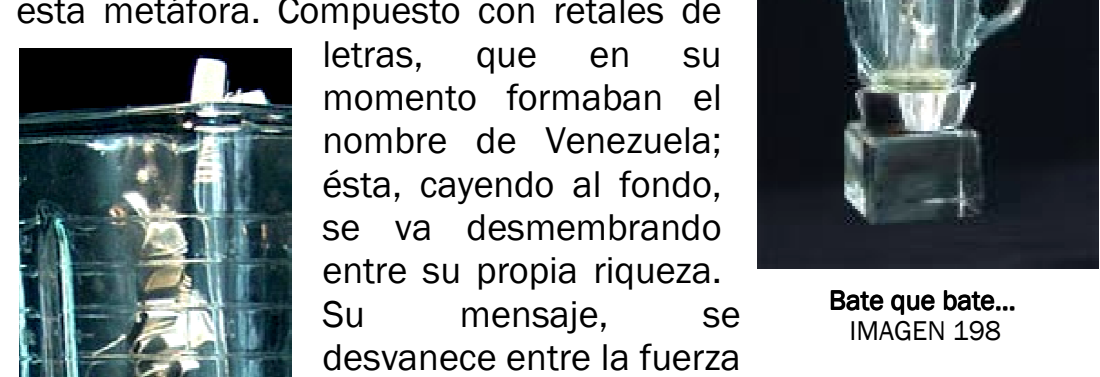

desvanece entre la fuerza

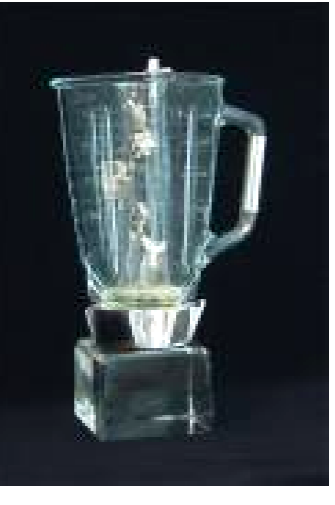

centrípeta; cuyos filos cortantes, destrozan lo que caiga en él. Así pues, de su extremo, pende arriesgadamente un enunciado, cuya expresión desorientada divulga sobre la extrema y extraña usanza de ambos elementos. Y, la mixtura de polvo de azabache que yace dentro del vaso, se refiere al petróleo y sus recursos y su analogía refiere al debate entre la confusa situación de lo hecho y lo deshecho.

La impecable factura de la construcción de los Detalle del interior de sólidos en plata, se erigen en estupendas letras Bate que bate... del abecedario, que se aferran entre hilos, para IMAGEN 199 evitar ser tocadas por las aspas y desvanezcan su palabra. La simbología de la palabra como ente comunicativo, desvanece su mensaje entre gruesos hilos de plata (Detalle de interior de Bate que bate... IMAGEN 199). Esta obra, supone ese entorno onírico, que transforma la materia prima en un ente representativo. Obviamente, la paradoja entre lo efímero del arte actual, suprime a las tendencias artísticas tradicionales; pues, elementos estos, se unen bajo un mismo concepto donde la subjetividad del artista y del espectador, fundamentan su presencia.

16433 Salón Nacional de las Artes del Fuego. (2006).

http://galeria.uc.edu.ve/actual.php?id=66 
Su concepto es acentuadamente subjetivo, donde la hibridación entre la orfebrería y la escultura se orienta bajo un lenguaje particular.

En la obra Cielo, sol y religión (IMAGEN 200)165, la orfebre Njaim expresa con su léxico creativo, su visión, sobre la humillante mano arrolladora del invasor ibérico en territorio venezolano. De este modo, declara un mestizaje entre el nuevo intelecto y su actual condición, donde la soberanía de la disciplina, se enriquece con fragmentos autóctonos.

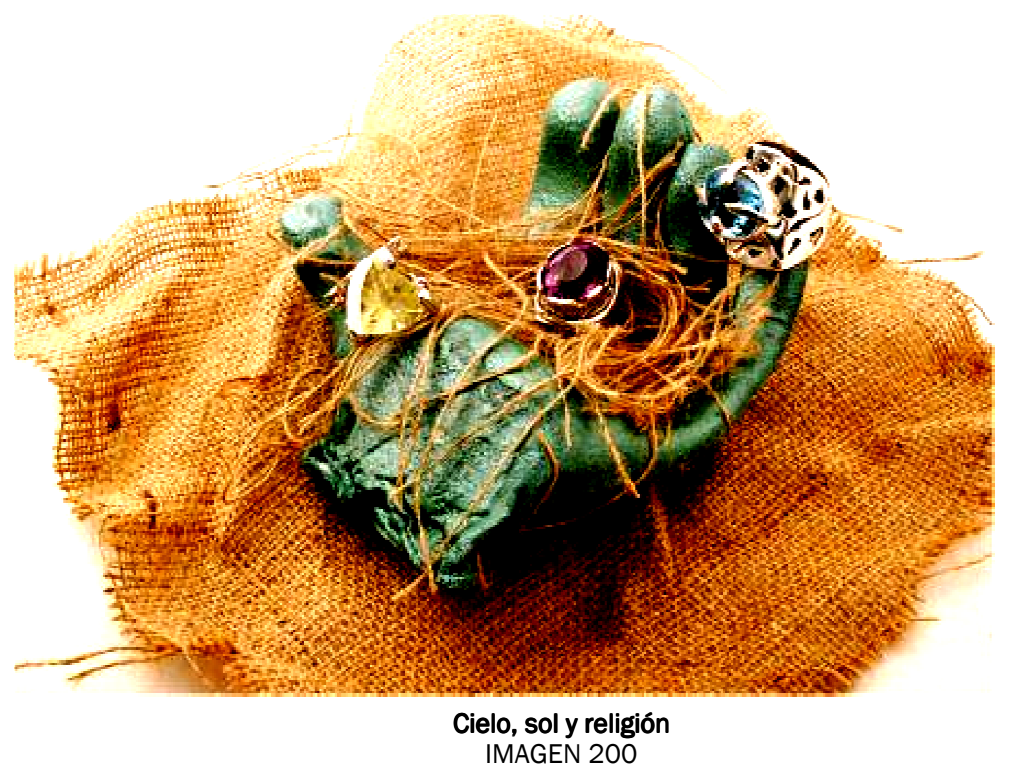

Desde ese argumento, Maria Njaim convierte en protagonista la magnitud de la joya, exquisitamente elaborada. En ellas, se decanta por la clásica talla facetada, cuyo engaste de plata, destaca el brillo que desatan un dialogo coloquial. La simbología y analogía de los colores que la componen, demuestra el linaje del orfebre venezolano actual; pues, el topacio, la aguamarina y el granate rodolita ostentan los colores patrios de la bandera nacional166.

165 Vera, R. (2012). “Imágenes y fichas técnica de obras III Salón Nacional de Orfebrería”. Material inédito. Correo electrónico. vhrafier@yahoo.com

166 Njaim, M. (2013). “Producción de orfebrería”. Material inédito. Entrevista on line. https://www.facebook.com/mariajosenjaim?fref=ts 
Las obras de Milded Maury son un buen ejemplo de la hibridación que fusiona la orfebrería con otra profesión y afición. Así pues, la heterogeneidad en su formación como antropólogo; la lealtad con el teatro y la afición por la fotografía y la literatura, permiten crear un dialogo entre ellas, alcanzando un lenguaje plástico multidisciplinar que manifiesta su autoría; por eso, toda su producción, argumenta segmentos de ese lenguaje plástico, que evidencia por encima de todo, su ingenio y destreza de orfebre.

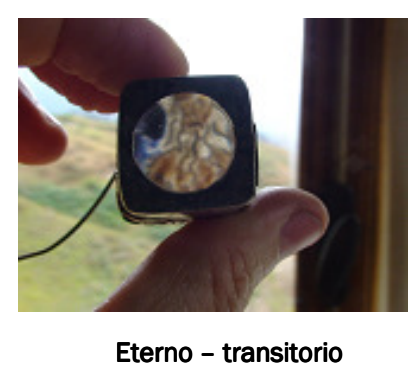

Eterno - transitorio
IMAGEN 201

Eterno - transitorio (IMAGEN 201) ${ }^{167}$ se cimienta desde las bases de la literatura, vinculándose con artificios del teatro. De este modo, la orfebre Maury, elabora una instalación que relata la Divina Comedia de Dante Alighieri, con una magnífica representación de seis piezas en plata, acompañadas de un

Cada una de estas piezas, manifiesta un acto de este estupendo poema épico, que contiene delicados vitrales de piedras semipreciosas. Éstos, pueden apreciarse a través de un visor a contraluz de diapositivas, construidos en plata, tal y como se aprecia en la (IMAGEN 201). Las seis piezas, representan con imágenes en alto y bajo relieve -cubriendo todo su contorno-, el compendio del poema; tal y como fluye la lectura del mismo, la orfebre sitúa un orden en sus representaciones: 1.Dante con las tres fieras; 2. Caronte, 3 Lujuria, 4

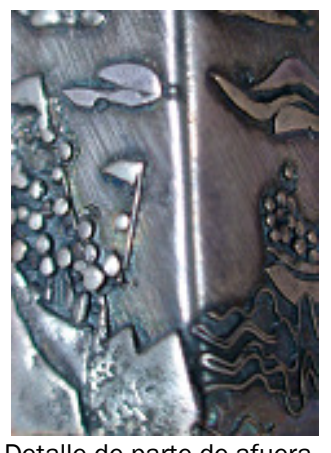
de parte de afuera del visor de Eterno-Transitorio Vergüenza, 5 Piedad de Dios, 6 Conciencia. Así pues, la pieza $N^{\circ} 2$ muestra la estupenda alegoría del barquero Caronte, navegando en las aguas del Aqueronte (Detalle de parte de afuera del visor de IMAGEN 202). En ella, trozos de formas e hilos soldados, texturizados y patinados con pericia, fingen la analogía de ese entorno, que invita al espectador a interactuar con ella.

En su interior, se mantiene oculto un pequeño diseño elaborado con hilos de cloisonné e incrustación de polvillo de piedras semipreciosas y al ser apreciado a través de la lupa del visor,

16732 Salón Nacional de las Artes del Fuego. (2005).

http://galeria.uc.edu.ve/gubs. php?id=9 
éste, pareciera ser un vitral (Detalle del interior de Eterno-Transitorio IMAGEN 203).

Esta estupenda instalación, recibió un importante Premio en la tendencia de Orfebrería en el "SNAF" del año 2005.

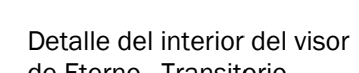
Detalle del interior del visor IMAGEN 203

La obra Unidos en la visión. Leonardo y Clara (IMAGEN 204)168, constan de dos pequeños visores elaborados en plata con vitrales en su interior. La disposición de ellos en el pedestal de madera, permite mirarlos por separado o en conjunto. Para descubrir la esencia de la obra, deben mirarse ambos visores al mismo tiempo y su manipulación permite apreciar una

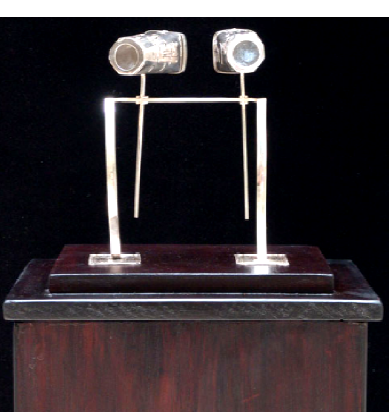

Unidos en la visión. Leonardo y Clara

nueva imagen producida por un fenómeno en el campo de visión. Por eso, titula así esta obra; pues, en un visor se encuentra la imagen de la silueta de un hombre (Leonardo) -con unos espacios

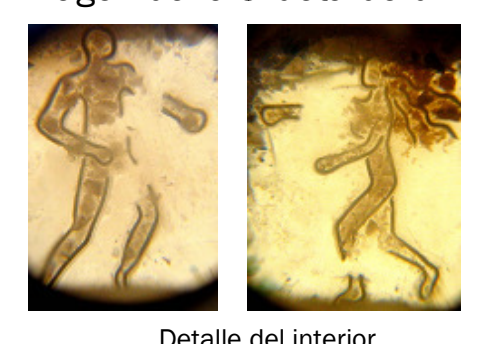
faltantes- y en el otro visor, la silueta de una mujer (clara) -también con espacios faltantes- (Detalle del interior Unidos en la visión. Leonardo y Clara IMAGEN 205) y al ser dirigidos a un mismo ángulo -al mismo tiempo-, sus siluetas se unen IMAGEN 205 y se ven abrazados, por el efecto del fenómeno de la visión binocular.

En la obra Show (IMAGEN 206)169, el inconfundible visor adopta una nueva fisionomía y se apropia de otro contexto. Esta vez, simula ser un enfático proyector de diapositiva suspendido por alargadas patas de hilo de plata.

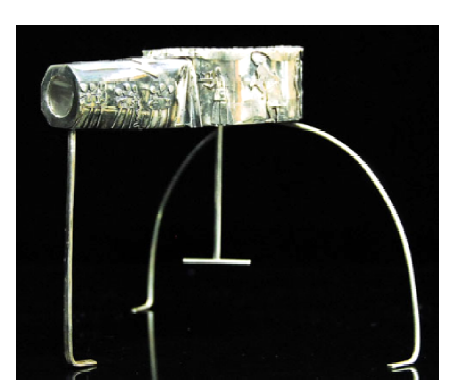

Show

16833 Salón Nacional de las Artes del Fuego. (2006). http://galeria.uc.edu.ve/actual.php?id=66

16934 Salón Nacional de las Artes del Fuego. (2007). http://galeria.uc.edu.ve/actual.php?id=72 


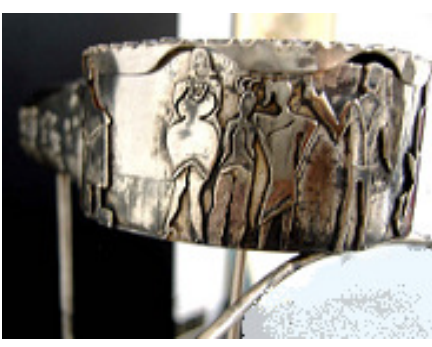

Detalle del exterior de Show

Su vínculo con los medios audiovisuales y el teatro, se plasman en esta obra con premeditación y alevosía; pues, los medios tecnológicos imperantes, han sacado de facto estos maravillosos equipos, convirtiéndolos en tan poco tiempo, en verdaderas reliquias. Por ello Maury, manifiesta entre sus formas la reconciliación con este mecanismo y el disfrute de una obra a través de él. El estupendo proyector está construido con lámina de plata, enfatizando en su exterior con una lamina calada, soldada y patinada, los personajes de una obra homónima -en la que ella participa- (Detalle de exterior de Show IMAGEN 207) que se reproduce en su interior.

En su interior, una fotografía se explaya en toda la pared circular, mostrando imágenes originales de la obra (Detalle de la fotografía del interior de Show IMAGEN 208). Estas, pueden verse en animación con una iluminación cenital, con la intervención del espectador, a través de una manivela colocada en su parte inferior, cuyo movimiento hace girar la imagen.

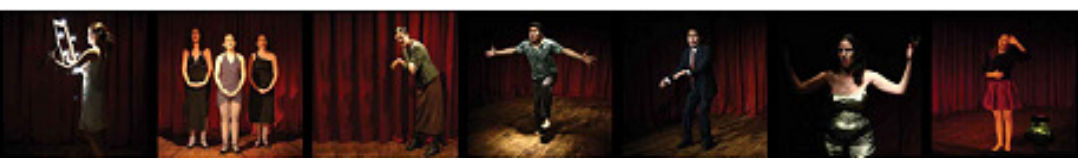
Detalle de la fotografía del interior de Show

Quizá, su profesión e ideología de antropólogo, artista en el mundo del teatro, fotógrafa por afición, literata y orfebre, le permite idealizar su fascinación a través de los metales nobles con esta pasión.

La orfebre Mildred Maury, deviene de una formación estupenda en orfebrería de la mano del orfebre Ursi Galleti, siendo ella su primera alumna y durante varios años fue su asistente. Esta experiencia le ayudo en demasía para su especialización en ciertas técnicas de las cuales saca provecho en la actualidad ${ }^{170}$.

170 Maury, M. (2013). “Datos sobre obras SNAF”. Material inédito. Correo electrónico. mildedmaury@yahoo.es 
La obra de la orfebre Natalia Santamaría, vincula ciertos aspectos que caracterizan su autoría. La aguda sensibilidad con que aborda un tópico, donde la parodia se alecciona con mano experta de orfebre y se adentra en el plano escultórico; así pues, en la obra: Amenaza (IMAGEN 209)171 se sintetizan estos argumentos; pues,

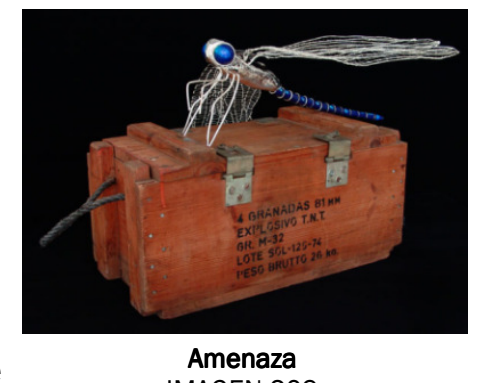
una enorme libélula, salvaguarda su nuevo hábitat de la proliferación de una epidemia. Entonces, metafóricamente la orfebre Santamaría, relaciona una particularidad de la libélula arrasar con la plaga causante de enfermedades que pueden ocasionar la muerte-y el uso de las granadas -tras su acción, causan destrucción y muerte- en esta sugestiva obra.

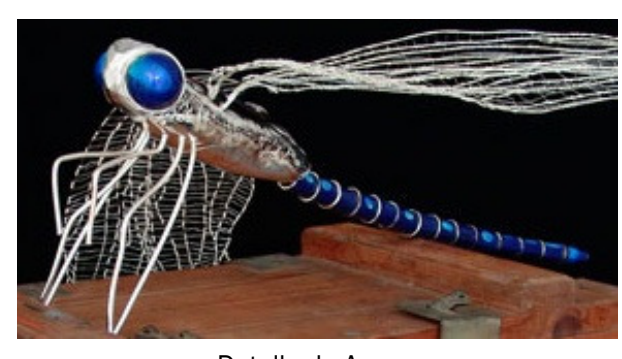

La formidable libélula elaborada totalmente en plata, se fundamenta de un fuerte y alargado cuerpo con unas poderosas alas tejidas. Su notoria cabeza, está elaborada con lámina Detalle de Amenaza embutida de plata y dos IMAGEN 210

enormes semiesféricos ojos esmaltados de azul, que invaden el rostro en su totalidad. El robusto cuerpo embutido, colmado de texturas, prolonga de su extremo una alargada cola azul; cuyos aros de plata fusionados sobre su esmalte, conjugan un exquisito contraste incrementando la curiosidad entre sus formas. Formas éstas, se glorifican con el inquietante y vigoroso aleteo, de las enigmáticas alas tejidas en delicados hilos de filigrana (Detalle de Amenaza IMAGEN 210). Sus enormes patas de hilo grueso de plata, someten con soberbia el baúl de madera que contiene ocultas las mortíferas granadas.

Entre las características de la idiosincrasia del venezolano, resaltan sus ocurrencias, aunando con sus variados dichos populares y el entusiasmo, ante cualquier adversidad. Por ello, la orfebre Natalia aprovecha su temperamento autóctono para crear una obra que desvela con su arte un tópico común.

17133 Salón Nacional de las Artes del Fuego. (2006).

http://galeria.uc.edu.ve/actual.php?id=66 
En la obra Cachicamo trabaja pa' lapa (IMAGEN 211) ${ }^{172}$, la orfebre se fundamenta en ese refrán popular, muy utilizado en los venezolanos. Con este título se refiere al hecho de que una persona trabaja muy bien algo y es otro quien se beneficia; pues, esto sucede en el reino animal; donde, el cachicamo en su labor de defensa, cava con gran

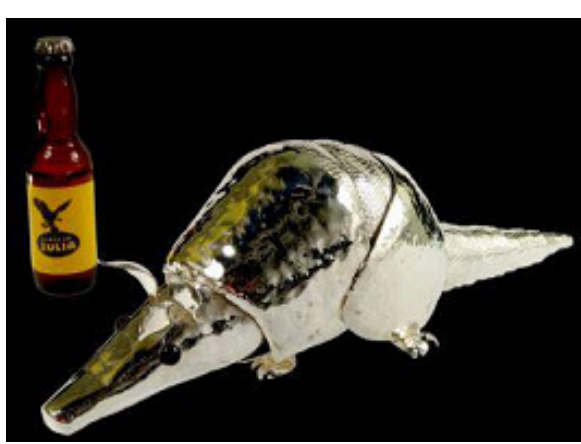
Cachicamo trabaja pa' lapa,

rapidez las cuevas donde ocultarse y las lapas, consiguen unas confortables moradas en estos escondites abandonados.

En la analogía entre el título y la obra podríamos indicar varias hipótesis. Sin embargo, no es la intención de este texto aclarar ninguna de ellas; lo que si podemos, indicar es sobre la maestría, convicción y genialidad, de la obra.

El cuerpo acorazado de este animalito es logrado tras el embutido de la lámina de plata y la aplicación apropiada de un sistema de bisagras permite la movilidad de su enorme y rígido cuerpo para que adopte un tamaño menor sin que este se desproporcione. Los diminutos y atentos ojos de ónix negro, engastados sobre rostro, revelan la mirada asustada del inocente espécimen. La semejanza de la forma, y el contexto del que se apropia, muestran la seguridad en el uso de las técnicas y la genialidad con que aborda su obra.

172 Instituto de las Artes de la Imagen y el espacio y Mota, J. (2006). "II Salón Nacional de Orfebrería". Museo de la Estampa y del Diseño Carlos Cruz-Diez Catálogo. p: 140-141. 
La obra de la orfebre Patricia Querini, desde sus inicios en la escuela de orfebres de Alexis De la Sierra, reveló el respeto hacia la nobleza de los metales, la exquisita factura con ciertas técnicas, la sensibilidad de abordar cualquier tema y no escatimar esfuerzo ni detalles a la hora de elaborar una obra. Esto consignó un nexo profesional muy importante entre ambos, pues, fundaron una galería privada en el Distrito del Diseño en la ciudad de Miami -De la Sierra, Paris \& Pervilhac-, USA, para exhibir permanentemente sus estupendas obras.

La influencia rectora del orfebre Alexis de la Sierra se hace evidente en todas sus propuestas. Pues, magníficamente éstas, revelan un estilo clásico/vanguardista donde el uso de metales nobles y piedras preciosas han marcado su acento y caracterizan su autoría.

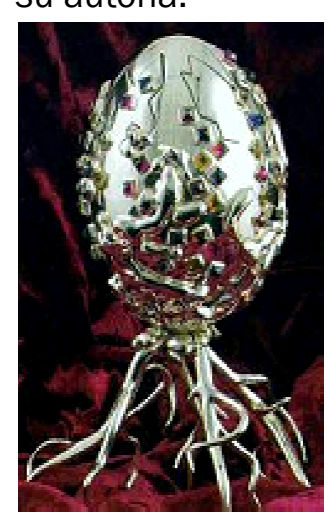

Venezuela Lux Originalis (IMAGEN 212)173, es

una obra elaborada en plata pura que remite a una tendencia escultórica conceptual. El impresionante estallido de matices sutiles en la superficie del embrión, ostentan entre su variedad, la exquisitez y la destreza de su autora.

En esta subjetiva obra, la orfebre Querin transfigura el típico huevo -como principio de vida- adornado exquisitamente con bellas piedras semipreciosas y en su base, Venezuela Lux Originalis IMAGEN 212 germinan gruesas raíces. Esta paradoja, nace de la subjetividad de la autora, basándose en los argumentos del acervo cultural del venezolano. El misticismo y simbología de las piedras, la pureza de la plata, el valor de la unión entre lo elegante con lo nativo deriva en una estirpe fuerte y atractiva por demasía, donde la pureza que lo constituye, define rasgos con autonomía.

Patricia Querini, trabaja con unos niveles de calidad muy altos, Io que permite plantear ciertos retos desde el punto de vista del diseño. Por eso, modelar en cera e incrustar en ella los fascinantes citrinos, iolitas y granates y su posterior vaciado en plata pura con tal precisión, manifiesta su paciencia, osadía y verdadera convicción sobre la manipulación de esta técnica. La fascinación

173 Pervilhac, I. (2005). “Tierra, Arte y Cultura en Venezuela”. Centro de Arte la estancia. Catálogo. $\mathrm{s} / \mathrm{n}$. 
de los metales nobles en la orfebre Patricia trascienden a la tendencia de la instalación escultórica.

En la obra Sueño al compás de las olas (IMAGEN 213)174, se afirma su querencia a este metal. Esta hamaca, exhibe un bello tejido que nace de la union de eslabones redondos de hilo de plata. En sus extremos, seis magnificas barras de vidrio, sujetan con frenesi este tejido metalico, que a su vez, éstas se aferran a una cadena magnífica de grandes eslabones. Un grueso cordon de nylon negro, tejido por ella mismalevanta y sujeta la hamaca idealizada

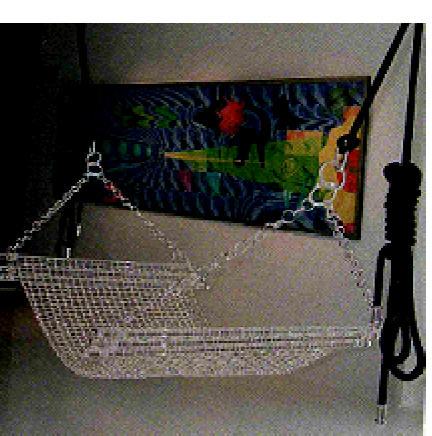

Sueño al compás de las olas IMAGEN 213 para conciliar un sueño placentero a la orilla del mar. La orfebre Patricia Querini fundamenta sus joyas como un ente expresivo, vinculadas a una nueva mirada. Por eso, invade con su arte el entorno cotidiano, explorando los cambios que acontecen en el día a día y los transfigura bajo su perspectiva de orfebre. Sus obras no se ciñen a una misma función, ni contexto, ya que, estas interactúan con cada atmosfera, revelando su nueva fisionomía. E contacto directo con el entorno, le agudiza su sentido común, estableciendo un dialogo con la realidad objetiva.

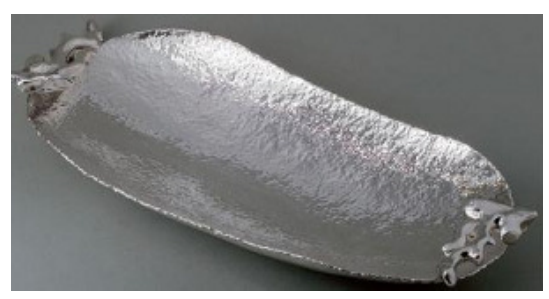

En la Bandeja margariteña (IMAGEN 214)175, apuesta por los sentidos de la vista y muy especialmente por el tacto. Su gesto creador, se encuentra con las calidades intrínsecas y la

Bandeja margariteña IMAGEN 214

sutileza de la plata, sacando de ella con la más sublime expresión, la belleza de su sencillez. Bajo la convicción del arte culinario, esta bandeja se apropia de ese entorno, para servir los manjares exquisitos con que deleitan a aquel que visita la paradisiaca Isla de Margarita en Venezuela. Esta enorme bandeja de más de medio metro de largo, fascina al jurado del III "SNO" en el año 2007 y le otorgan la Mención de Orfebrería Utilitaria. Con esta obra, La orfebre Patricia Querini, traza sutiles lazos entre la orfebrería con lo utilitario y lo culinario. Ejemplo de sobriedad y funcionalidad, potenciada con la textura impecable del embutido y el martillado, la orfebre

174 Pervilhac, I. (2005). “Tierra, Arte y Cultura en Venezuela”. Centro de arte la Estancia. Catálogo. s/n

175 Vera, R. (2012). "Imágenes y fichas técnica de obras III Salón Nacional de Orfebrería". Material inédito. Correo electrónico. vhrafier@yahoo.com 
contribuye en agregar al espacio cotidiano de la cocina con la belleza y elegancia de su arte. 
El manejo de polímeros le aproxima hacia el mundo adictivo de la orfebrería.

La producción escultórica del artista Ricardo Laverde, transita entre diversos caminos que lo llevan hacia un único lugar. Siendo arquitecto de profesión, manifiesta su intelecto en fascinantes esculturas entre polímeros y metales nobles. Su vínculo con las artes, asegura un léxico creativo con demasía, que ha repercutido en el campo de la orfebrería venezolana.

Un largo proceso de aprendizaje en su praxis heterogénea, ha sido de la mano de expertos, -siendo muy significativo el intercambio sucedido con el orfebre Simón Sorondo-; lo que hoy se ha convertido en su lenguaje plástico, deja en evidencia, que su ingenio y gesto creador superan lo enseñado.

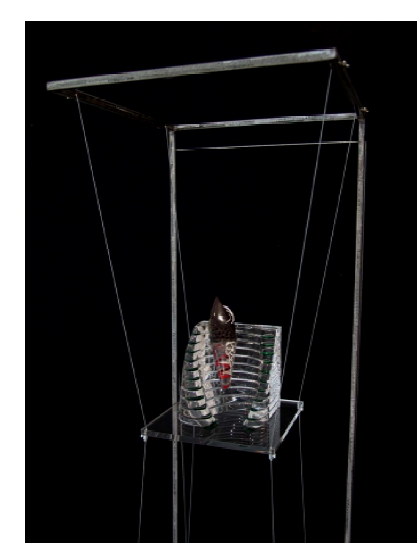

La convicción sobre el manejo de polímeros, le aproxima hacia el mundo adictivo de la orfebrería; pues, apetecibles razones, consigue para internarse entre las profundidades de esta disciplina y permanecer ahí. El Premio en la tendencia de Orfebrería en el "SNAF" del 2004 testifica su adicción con la obra Hrönir levitante (IMAGEN 215) 176 .

Hrönir levitante

A pesar de haber IMAGEN 215 iniciado orfebrería en la

ornamental -obteniendo tendencia

importantes-, su fascinación la consigue, cuando integra otros materiales. En Hrönir levitante se fundamenta su léxico creativo por lo que dedica en pleno, su magnífica experiencia. Inspirado en las Ficciones escritas por Borges, fantasea con su propio intelecto consiguiendo estupendas obras. Esta magnífica silueta con gruesas láminas de acrílico transparente, provoca internarse entre sus formas para descifrar el enigma de su estructura. Juego de líneas horizontales, articulan un movimiento que abraza un fascínate hibrido que nace de la subjetividad

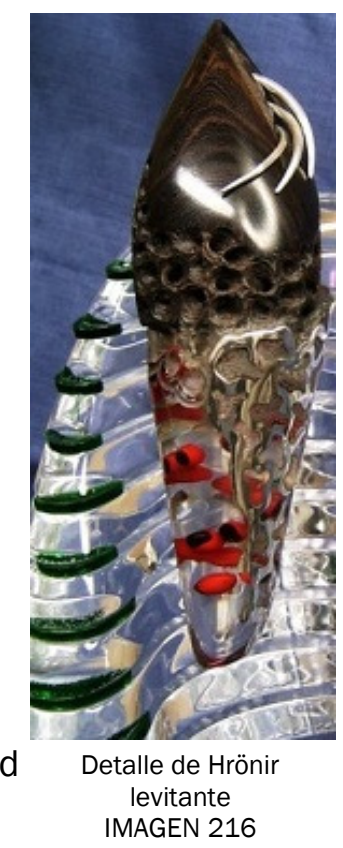

17631 Salón Nacional de las Artes del Fuego. (2004).

http://galeria.uc.edu.ve/gubs.php?id=27. 
del autor; Desde sus entrañas, salen tres garras que salvaguardan su entono. La hibridación ocurrente de Laverde, se enaltece con una sugestiva talla en ébano, armonizando entre sus formas con una lámina reticulada de plata. La calidez de las peonias en el interior de la resina, constituye la esencia de ese ser errante que puede desvanecerse solo con un cambio de mirada (Detalle de Hrönir levitante IMAGEN 216). La influencia de las ficciones de este escritor chileno, fundamentan su propio discurso narrativo que ha derivado en una estupenda producción.

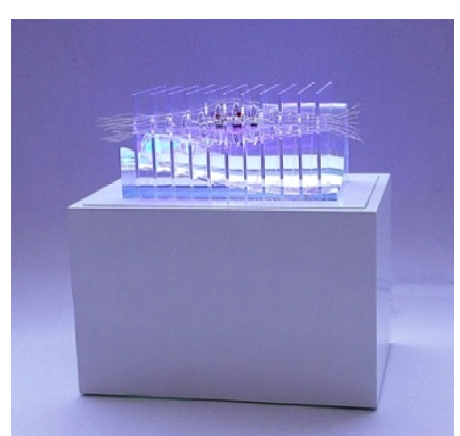

En la obra Etéreo (IMAGEN 217)177, la delicada ola de acrílico transparente, detiene entre sus formas curveadas este fascinante ser que se transfigura entre láminas que lo atraviesan. Los espacios vacíos en su interior, se apropian de un cuerpo encapsulado, para crear con sus hilos de plata pura, una espectacular silueta de un

Etéreo
IMAGEN 217
espécimen del mundo
marino. La entraña de este
ser, resalta entre la
perfección de las semillas de
parapara; peonías y los
corales rojos, quienes se
apropian de su condición
para levitar enérgicamente con la intersección de la luz natural y artificial. La luz

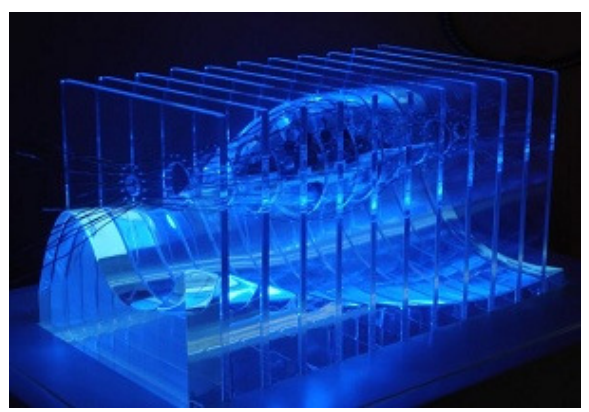

Detalle de Etéreo con luz artificial IMAGEN 218

artificial interviene con demasía en la interesante obra (Detalle de Etéreo con luz artificial IMAGEN 218).

Destellos fascinantes entre su figura fragmentada, realzan su enigmática forma y a su vez el reflejo de las luces azules, delicadamente se apropian de la pared explayando en ella, la esencia del ser etéreo.

En esta otra obra de Laverde, como un tsunami, esta fascinante ola eleva con sus límpidas aguas, a un espectacular Pez (IMAGEN 219)178. Con mirada desorbitada y boquiabierta por el contexto, se paraliza su movimiento, sin escapatoria alguna.

17734 Salón Nacional de las Artes del Fuego. (2007). http://galeria.uc.edu.ve/actual.php?id $=72$

178 Laverde, R. (2013). "Simbologia en la producción de orfebrería". Material inédito. Entrevista on line. https://www.facebook.com/ricardo.laverde.1?fref=ts 


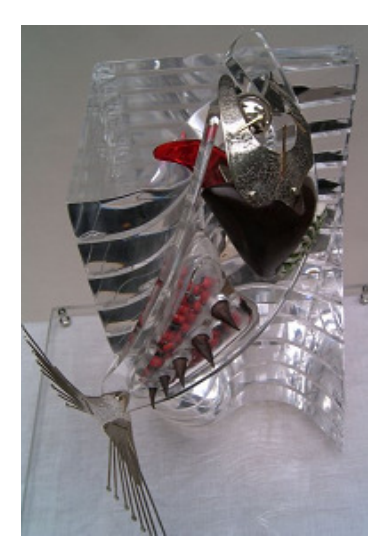

Así queda, su infalible figura en el artificio del autor, para ostentar con su destreza al sugerente pez. Un ojo desorbitado, tras la faena del embutido, se incrusta en el esqueleto de una cabeza laminada de plata. La esencia del fascinante Etéreo, cobra vida en esta propuesta y articula entre sus movimientos la energía de su encapsulado cuerpo. Cuerpo este, repleto de bellas y diminutas peonías, son custodiadas por punzantes escamas de

$$
\begin{gathered}
\text { Pez } \\
\text { IMAGEN } 219
\end{gathered}
$$

espina de jabillo (Detalle de

Pez

IMAGEN 220). Su cola fragmentada en delicados hilos de plata, impiden su recorrido entre las turbulentas aguas que lo asedian.

Sus estudios de orfebrería en la "Scuola d'Arte e Mestieri" de Vicenza, Italia, le confiere este don de manipular los metales nobles con perfecta convicción y es su agudeza de artista, quien transforma los materiales para convertirlas estas magníficas obras.

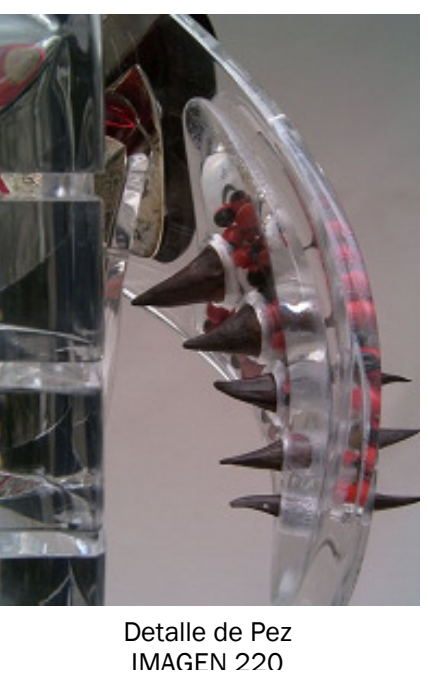


La escultura en miniatura, se convierte en su seña de identidad.

La producción artística de Víctor Rodríguez, se fundamenta desde sus inicios en la orfebrería. En su asidua participación en las primeras ediciones del "SNAF", sus estupendas joyas, demostraron su inagotable fuente de inspiración, pericia e importancia en esta disciplina con la obtención de varios Premios en la tendencia de Orfebrería. Con el paso de los años, fue adaptando su obra en otro contexto, no sólo con la inclusión de otros materiales sino llevándolas hacia el espacio tridimensional.

De manera intuitiva, sus joyas comenzaron a integrar ciertos argumentos, donde su vínculo a la tendencia escultórica fue inexorable. El interactuar con artistas de otras dependencias, le inducen apropiarse de técnicas de la escultura lo que inmediatamente transfirió sus joyas a otro plano.

Durante esa etapa de investigación y transición crea un nexo con los artistas latinoamericanos: Lam, Mata, Guayasamín, Szyslo, Tamayo y Samudio participando con ellos en exposiciones, que sirvió de trampolín para lanzar a la orfebrería venezolana en una estupenda manifestación artística. Esto obviamente, significó no sólo para su obra un verdadero impulso, sino para la disciplina en el país.

Especializado en la técnica de la cera perdida desarrolla una producción en pequeña escala, basada en la obra de algunos pintores y escultores venezolanos: como Vigas, Marcos Castillo, Guerrero y Zerpa. Transfigurando su original semblante en sugestivas esculturas en metales nobles. Esta producción, tuvo gran relevancia en su gesto creativo, puesto que, dio cabida a una nueva expresión en su obra, que le permitió obtener el Premio Nacional de las Artes del Fuego en la tendencia de Orfebrería en el "SNAF" del año 1994, con la obra: Lo que hice y donde lo hice: collar Laudan y el taller de Vulcano (IMAGEN 221)179. En ella, se aprecia, como el impecable vaciado en plata, de objetos son vinculados a un entorno que se

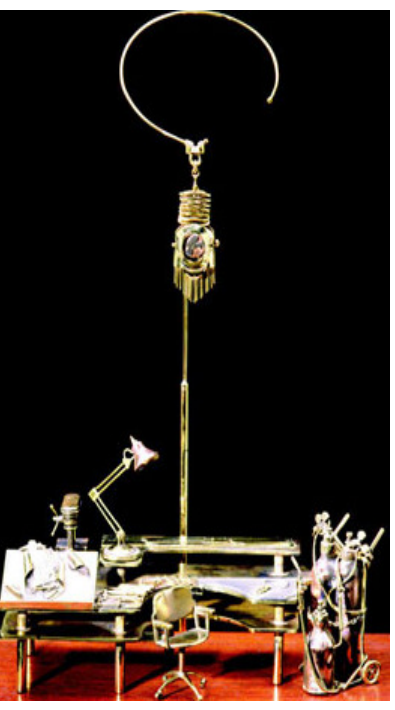
Lo que hice y donde lo hice: collar Laudan y el taller de Vulcano

transforma en un impoluto taller de orfebrería, en miniatura. $Y$ un

179 XXI Salón Nacional de las Artes del Fuego. (1994). http://galeria.uc.edu.ve/gubs.php?id=53 
estupendo collar es parte de la obra -mientras no se usa- y se apropia de otro semblante. La delicadeza de la propuesta demuestra que este orfebre no escatimó ni un detalle, para su consecución. A partir de allí, articula un sugestivo discurso multidisciplinar, que consolidaron ciertos fundamentos. Estos concluyeron, en bellas esculturas en pequeño formato, convirtiendo a la orfebrería en su aliada.

Poco a poco fue buscando en otras técnicas ciertos

retos; desarrolla

estupendas piezas con metáforas de todo tipo. Por ejemplo: en la obra Lumbreras (IMAGEN 222) ${ }^{180}$ rinde homenaje al eclipse.

Sobre una base de madera, se forman cuatro estupendos eclipses cuya

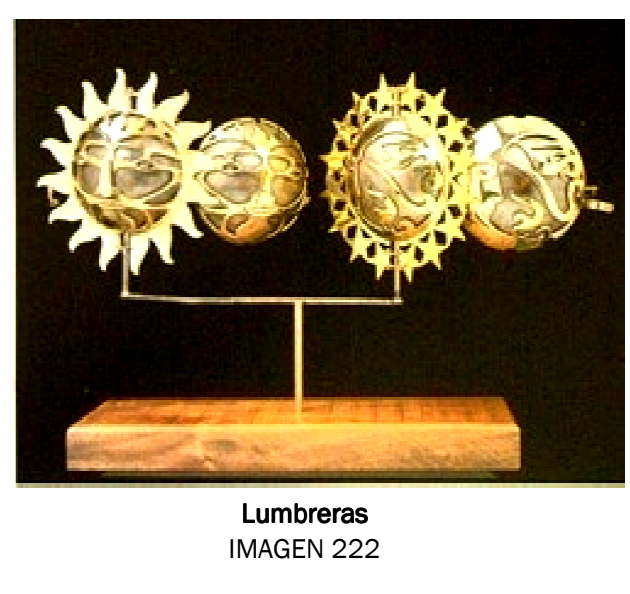
alineación en el espacio magnifica su factura. Cuatro emblemáticas lunas plateadas, establecidas en perfectas circunferencias embutidas en plata, se solapan entre estupendas formas caladas en bronce. Formas estas, trasgreden la superficie de plata con un calado impecable de formas sinuosas. Su aguda visión, aprendió a mirar y analizar las formas de manera objetiva. Por ello, dibuja con seguridad sobre la lámina y el calado minucioso y detallista concede la forma. Forma ésta, compone maravillosos detalles que suelda con precisión; demostrando el dominio que caracteriza su producción.

Con la obra del orfebre Víctor Rodríguez, concluimos con los orfebres venezolanos que desarrollan su producción artística a través de la orfebrería en la tendencia escultórica. Obviamente, hemos podido apreciar a lo largo de todo este capítulo, como el orfebre venezolano ha sabido aprovechar de esta disciplina, las bondades de los metales nobles, la conjunción de diversos materiales con una particularidad en sus semblantes. Semblantes estos, abordados con una tendencia escultórica que devienen en gran parte, por la percepción que tiene hacia los materiales que utiliza e indudablemente, el contexto en el que las elabora.

180 XXII Salón Nacional de las Artes del Fuego. (1995).

http://galeria.uc.edu.ve/actual.php?id=54 
Dentro de este capítulo, abordaremos exclusivamente sobre el orfebre venezolano Alexis De la Sierra, quien es el pionero en Venezuela sobre esta nueva concepción de la orfebrería. Considerando la importancia que tiene su obra y escuela en el país, mencionaremos ciertos aspectos que han sido fundamentales en su formación tanto en orfebrería como en escultura; así como también, mencionaremos como se fundamenta su desempeño como docente. En tal sentido, expondremos como inicia en la docencia, como se desarrolla su enseñanza y demostraremos cual es el aporte de su escuela tanto en medios expositivos, como en la apertura de otros centros de enseñanza en el país. Adicionalmente, hablaremos sobre su producción artística y como ha sido su evolución hacia la orfebrería escultórica. Para ello, hemos dividido su producción en dos partes. Por un lado, mencionaremos algunos aspectos, técnicos, formales y conceptuales sobre su producción en orfebrería, mostrando una catalogación en esa disciplina. Por otro lado, mencionaremos algunos aspectos, técnicos formales y conceptuales sobre su producción en escultura, mostrando también una catalogación. Finalmente, expondremos una cronología sobre los aspectos más importantes de su producción artística desde el año 1968, época en la que inicia sus estudios en las artes, hasta el año 2010.

3.1 VIDA Y ENTORNO.

3.1.1. Datos Biográficos.

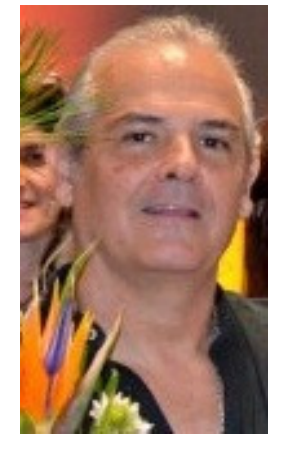

Alexis Felipe Rodríguez De la Sierra Llerandi, nace en Caracas, Venezuela el 23 de Enero de 1954. Del apellido compuesto de su padre, artísticamente adopta sólo el segundo. Es por ello que se le conoce como Alexis De la Sierra. IMAGEN 223).

Los padres de Alexis De la Sierra, ambos casualmente son refugiados de la guerra Civil Española. Sus familias huyen hacia Francia, Alexis De la Sierra. donde se conocen ! aux-Arts de IMAGEN 223 Marsella, Arnaldo Canario y Olga (Madre) de origen Asturiano.

Arnaldo (Padre) desciende de un Poeta y jurista Español, Don Luis Rodríguez de la Sierra y Figueroa, quien fuera en vida Cónsul honorario de Venezuela en Santa Cruz de Tenerife. Don Luis político y económicamente poderoso, era un representante del 
gobierno republicano con ideas de izquierda, pese a sus ideales era gran amigo de Franco. Sin embargo, cuando Franco toma el poder esas diferencias lo convierte en blanco de persecución Don Luís y su hijo mayor "Guetón", también jurista. Un día de camino a una reunión en Madrid, "lo embarcan misteriosamente de vuelta a Tenerife en el Vapor "Rio Francoli"; ya en Tenerife, lo retienen en la Logia Masónica Añaza, en la santacrucera Calle de San Lucas, donde lo torturaron y vejaron cruelmente. Al parecer, en el archivo Superior de la Policía, consta que fue dado en libertad. Su biblioteca en "Villa Loreto" fue expoliada y quemada una gran mayoría, y todo el resto de sus bienes fueron expropiados." 181 Todo esto, convence a su familia que fueron ejecutados por las fuerzas fascistas. Sin embargo, una vez que muere Franco, todos los bienes son devueltos a la familia y la calle donde estaba la casa de Don Luis, el Rey Juan Carlos puso una placa en su honor.

La familia de Don Luis, consternados por toda esa lamentable situación, huye a Francia. Arnaldo, inicia sus estudios de Pintura en donde conoce a Olga Llerandi, estudiante de dibujo, en la misma École des Beaux-Arts.

Por otro lado, Olga (Madre) y su familia salen de España escapando de las fuerzas represivas de Franco; con su madre y cuatro hermanos, huyen caminando, hacia el sur de Francia donde reciben amparo en los campos de los cuáqueros ingleses. Sus hermanos menores son situados en familias en Estados Unidos de Norte América, pero ella permanece en Francia y comienza sus estudios de arte.

Al finalizar sus estudios, Arnaldo y Olga regresan a España; se establecen en Madrid, donde se casan. Ambos se unen a la resistencia Española y son capturados junto con el hermano mayor de Olga. La pareja es puesta en libertad. Sin embargo, el lapso que permaneció en prisión deja una fuerte marca, pues la dureza de las condiciones impide que Olga lleve a término su primer embarazo. Adicionalmente, José Antonio su hermano mayor, es enjuiciado y fusilado por el ejército franquista.

Exhaustos por tanta lucha y soñando con una vida mejor, regresan a Francia donde permanecen durante 11 años. En Marsella, nace el primero de sus seis hijos, Reinaldo. Luego gracias a la gestión del Poeta Venezolano Rufino Blanco Fombona, gran amigo de Don Luis Rodríguez De la Sierra, consiguen visa de inmigrantes y es cuando se van a Venezuela. En el año de 1944 se establecen en

181 Luis rodríguez de la sierra Figueroa 1875-1936 - puerto de

lacruz .http://bernardocabo.blogspot.com.es/2010/08/lu is- rodriguez-figueroa-1.html 
Caracas, donde nacen los otros cinco hijos: Luis, Arnaldo, Alexis Felipe, Olga y José Antonio"182.

Cuando Alexis Felipe nace, su familia vivía en la urbanización Sabana Grande en un apartamento cómodo. Sus estudios de infancia hasta tercer grado de primaria transcurren en el colegio de Cervantes en la urbanización la Florida. Así como también, el resto de sus hermanos. Sus días de colegio pasan con gran placer, ya que por ser un niño extrovertido, conversador, amigable y ocurrente, lo animaban para participar en todas las actividades culturales que se celebraban.

Cuando Alexis Felipe tenía nueve años de edad se trasladan a la Isla de Cuba, en plena Revolución Cubana, a través de un familiar quien en aquel tiempo era un empresario importante en Cuba. Alexis y sus hermanos mayores estudian internos en el Colegio Santa María del Mar, el cual era para los hijos de los mártires de la revolución cubana. Ese colegio, se apoyaba en la educación de disciplina militar, inspirado en los principios psicológicos y educativos de Makarenko. Entre las actividades habituales en el colegio, eran sembrar y cortar caña, al mismo tiempo que la educación formal y cultural. A menudo, organizaban obras de teatro las cuales Alexis Felipe aprovechaba con gran entusiasmo. Su vida durante la semana de internado contrasta con los fines de semana, los cuales, acontecen con sus padres en el Hotel más prestigioso y famoso de Cuba; donde la familia aprovechaba intensamente con sus días soleados y los paseos por el malecón. Tras cinco años de vivir en la isla de Cuba regresan en el año 1968 nuevamente a la ciudad de Caracas, y se establecen en la parte alta de una confortable quinta en la urbanización Colinas de Bello Monte.

Alexis Felipe continúa sus estudios de educción secundaria en el Colegio Las Palmas; reafirmando allí su entusiasmo por el teatro. Pues, algunos de sus compañeros, estaban tomando clases en la Escuela Nacional de Teatro de Caracas y esto lo motivó para iniciar sus estudios en teatro en dicha escuela. El mundo del teatro genera en Alexis Felipe ciertas ambiciones; el deseo por comprar un carro lo aproximan a buscar un medio con el cual poder obtener ganancias, debido a que su hermano Luis vivía del arte, Alexis le pide a éste, que le enseñe a trabajar con el arte de la orfebrería.

Alexis Felipe para ese entonces, conoce mucha gente importante en el medio del teatro y la televisión, por lo que fue muy rápido dar a conocer su arte y por ende, la fácil adquisición de sus joyas. Fue

${ }^{182}$ De la Sierra, L. (2007). "Biografía y enseñanza a Alexis De la Sierra”. Material inédito. Entrevista telefónica. Diciembre 16. 
tanta la dedicación y fascinación hacia la orfebrería que se aparta del teatro y se centra en producir y vender sus joyas" 183 .

\subsection{FORMACIÓN ARTÍSTICA. Influencias.}

3.2.1 EN ORFEBRERÍA. Generalidades.

Alexis De la Sierra crece en un hogar con fuertes tendencias artísticas. Sus padres desarrollan por hobbie, el arte en el día a día. "Alexis recuerda que su casa siempre olía a óleo y aguarrás. Para él, era costumbre frecuentar con pintores, escultores y poetas. Aunque sus padres se dedicaban con frecuencia a la pintura y el dibujo, nunca les inculcaron que se introdujeran en el mundo del arte. Sin embargo, todos sus hermanos son artistas, unos dedicados profesionalmente y otros por hobbie" 184 .

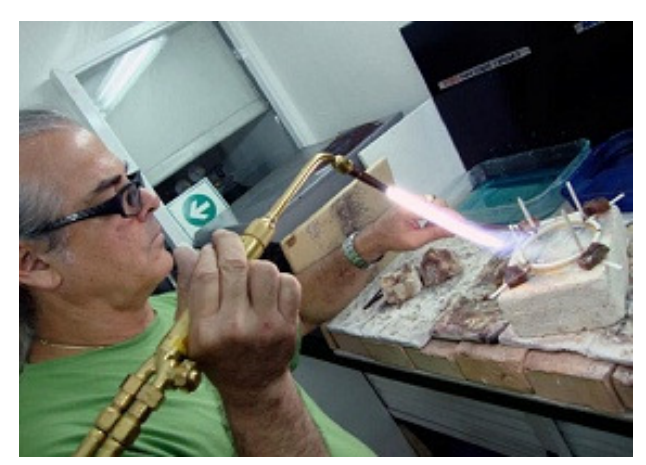

Sus tres hermanos mayores se mantienen activos dentro del ámbito artístico caraqueño. El primero de ellos, Reinaldo, trabaja con la talla en madera. El segundo, Luis, trabaja con el vidrio, la pintura y con metales al fuego en cobre y plata. $Y$

De la Sierra en el año 2009, trabajando en la El tercero, Arnaldo,

De la Sierra IMAGEN 224

trabaja con metales a gran formato. Todo este ambiente encamina hacia la ruta del arte, al precoz artista Alexis De la Sierra. La disciplina militar vivida durante cinco años, trasciende en su personalidad de una manera significativa. Los principios de la educación de Makarenko, cuyos planteamientos basados en la valoración en colectivo y la importancia del trabajo. Valores estos que le permiten adquirir ciertas actitudes con las que más adelante se convierten en pilares fundamentales para su desarrollo personal-artístico; así pues, la constancia, dedicación, esfuerzo, deseo de superación, autosuficiencia, perfección, son una de las tantas virtudes que caracterizaron a este prestigioso artista venezolano.

Para el año 1968 cuando Alexis tiene ya 14 años de edad, cursando sus estudios de bachillerato, algunos compañeros de su

183 De la Sierra, L. (2007). “Biografía y enseñanza a Alexis De la Sierra”. Material inédito. Entrevista telefónica. Diciembre 16.

184 Castillo, L. (2004). "Dar clases es lo mejor que me ha pasado como artista. Enseñar al Fuego". Revista. Todo en Domingo. № 230 pp: 23-24. 
clase motivados por conocer del teatro, se introducen en el medio. Alexis por su extrovertida personalidad y curiosidad, decide también incursionar en las artes escénicas y se inscribe en la Escuela Nacional de Teatro del Instituto Nacional de Cultura y Bellas Artes (INCIBA).

Con gran entusiasmo desarrolla ambas actividades; por un lado el estudio de asignaturas de la educación formal: literatura, matemáticas, historia y por otro lado, el estudio y práctica sobre las artes escénicas: actuación, elaboración de locaciones para el montaje teatral, tipos de iluminación. Posteriormente se dedica a la actuación profesional; con ello, vinieron las giras a nivel nacional y algunas ciudades del Sur y Centro América, colaborando como técnico de iluminación escénica.

Ya en 1970 habiendo culminado la educación secundaria, comienza a crear ciertas expectativas que iban más allá de lo experimentado; se encuentra inconforme con los medios imperantes en el teatro. Surge la necesidad de buscar un medio que pueda valerse económicamente y más perceptible, algo que fuese menos fugaz como sentía el teatro. La admiración que siente por el quehacer artístico de su hermano Luis, le aproxima hacia la orfebrería.

El léxico creativo de su hermano Luis era muy versátil, el cual se desarrolla entre confección de joyas, esmaltes al fuego sobre metal, fundición en vidrio, vitrales, entre otros. Alexis, decide incursionar en la labor con metales y para esto le pide instrucción en orfebrería y los esmaltes al fuego.

Alexis comienza sus prácticas en la orfebrería de la mano experta de su hermano Luis, quién le instruye con técnicas básicas con el cobre y la plata: el repujado, el cincelado, calado, limado, lijado, y algunas técnicas de esmaltes al fuego. Fue una corta experiencia; pues, se trató de unas pocas clases. Sin embargo, su interés le incita a aprender más y reúne algunas herramientas que no usaban sus hermanos y en un espacio de su habitación colocó una pequeña mesa semejante a las que usan los orfebres.

Con las interminables horas de práctica y su espíritu perseverante consigue un rápido aprendizaje consigue buen dominio de esas técnicas básicas; a partir de ese entonces, la orfebrería se convirtió en Alexis en una verdadera fascinación.

Realiza sus primeras joyas en las que pone en práctica una de las más laboriosas técnicas de esmaltes al fuego como lo es el cloisonné. La primera en adquirir estas fascinantes piezas, fue la Bailarina Venezolana Yolanda Moreno, fascinada con sus diseños y fascinante colorido, las compra. Se trata de tres dijes en plata 
elaborados con esmaltes al fuego. Esa primera experiencia forma parte de una gran lección de vida para él, a la que hoy en día agradece. Sobre esta experiencia Alexis recuerda, que por su casa frecuentaban muchas personas que adquirían las obras elaboradas por sus hermanos; un día Yolanda Moreno fue a comprar unos vitrales hechos por Luis, para la nueva decoración de su casa; Alexis se acerca y le comenta que él también es artista, ella sintió curiosidad y decide ver lo que hace. Al observar los tres dijes: un elefante, una tortuga y un búho, le pregunta ¿cuánto cuestan?, él responde con el precio, acotando que eran en plata y además de una laboriosa ejecución. Ella sin más, le pagó con un cheque y con entereza al despedirse le dijo, "algún día tú vas a ser famoso y conocido" 185 .

Su espíritu perseverante, de superación, innovación y perfección hicieron de ese joven entusiasta, un artista famoso y conocido tal y como lo pronosticó aquel día la famosa bailarina.

Esta dedicación rápidamente, hace que se aparte de los estudios en teatro y se dedique de lleno en la orfebrería. Puede que Alexis se apartara del mundo de las tablas pero al conocer tanta gente importante del medio, aprovecha esa situación donde inicialmente ofrece sus joyas. Al poco tiempo comienza a sentir el orgullo por el éxito que cosechaban sus joyas, así como también, por la solidez económica que esto le generaba.

Bajo este panorama, emprende un viaje con su padre a Europa y Nueva York por varios meses. La verdadera intención de su padre fue enfrentarlo directamente con las obras de importantes artistas reconocidos a nivel mundial. La constante observación, el estudio sobre sus tendencias, la valoración sobre los materiales, las técnicas, las formas, etc. le permite familiarizarse y aproximarse a nuevas tendencias.

El encuentro con obras de los clásicos del arte y los precursores del arte contemporáneo del viejo continente como en la ciudad multicultural de Nueva York, enfatiza más aún el deseo de la búsqueda de un arte innovador e incrementa su necesidad de fundamentar la orfebrería como lenguaje plástico. A partir de entonces se introduce en una etapa de experimentación entre diversos materiales con las técnicas de la orfebrería. "De la experiencia como actor, luminito y escenógrafo, descubre una fascinación por la luz"186.

185 Hernández, A. (2008). "Todos somos artistas potenciales". Diario. El Impulso. Diciembre 22 de 2008. C: 12.

186 Marín, C. (2003). “Alexis De la Sierra. Más allá de sí mismo” Revista. Ocean Drive. Vol 4 № 5. Agosto-Septiembre. pp: 72-73. 
Efectivamente la experiencia con los efectos lumínicos permite que desarrolle cierta afinidad con este elemento. La analogía entre la luz y el brillo del metal comienza a buscar esta semblanza con la pulitura en la plata, donde su exagerado brillo, se convierte en destellos que irradian una impecable luminosidad de su superficie, convirtiéndose en objetos portadores de luz. Poco a poco las formas de sus joyas van reclamando mayor luminosidad y es cuando introduce la luz artificial en el volumen. Así pues, el contraste del brillo del metal con la luz artificial le va originando más curiosidad ante este hallazgo y es entonces cuando incursiona con este nuevo semblante, con objetos de mayor formato, haciendo uso de materiales que generen mayor discrepancia entre sus formas.

Ante el abanico de posibilidades técnicas de la orfebrería, Alexis De la Sierra centra su objetivo en el estudio sistemático y posterior aplicación de algunas técnicas, por medio de bibliografía especializada y la manipulación de ciertas maquinarias. Esta etapa de aprendizaje la desarrolla entre varias técnicas: la del cloisonné, la cera perdida, el forjado, la texturización manual/mecánica, el granulado y algunos engastes, como por ejemplo el de tipo pavé; poniendo gran énfasis en el acabado final. Siendo éste, uno de los mayores aportes que su obra ha demostrado en la orfebrería venezolana.

En esa fase de experimentación decide perfeccionarse en esmaltes al fuego. Se traslada a Londres, donde realiza unos seminarios sobre "Corrientes Antiguas de Orfebrería" en el British Museum of London entre 1974-1975. Centrando interés por los esmaltes al fuego, desarrollados durante el imperio Bizantino. Estudia con gran dedicación los manuscritos del cloisonné, técnica esta que posee ya cierta experiencia, pero quiere dominar con verdadera convicción.

Ya para mediados de los años setenta, consigue un excelente nivel técnico con fascinantes resultados; Es en este momento, donde estimulado por la acogida de sus joyas, decide montar una pequeña tienda para exhibirlas y venderlas en el "Centro Comercial Plaza" con el nombre: “Alexis Pour Vous". El Centro Comercial Plaza -en la ciudad de Caracas- en ese momento, es un centro comercial muy concurrido por personas del medio artístico venezolano y personas de la alta sociedad caraqueña; la tienda es habitualmente frecuentada y las joyas de su autoría, fácilmente adquiridas.

En esa misma época De la Sierra entra en contacto con un grupo de artistas plásticos venezolanos, que expresan otra visión de la orfebrería. Estos artistas, en su mayoría, vienen formados desde los años cuarenta, de la Escuela de Artes Plásticas y Artes 
Aplicadas de Caracas. En 1976 se realiza el "Primer Salón de la Nueva Orfebrería Venezolana", celebrado en el "Museo de Ciudad Bolívar", en la ciudad de Puerto Ordáz -en Venezuela-. Alexis De la Sierra, es uno de los doce artistas invitados para participar en este significativo evento. De este modo, se introduce en el campo expositivo venezolano e inclusive desde esa primera experiencia, sus joyas han sido merecedoras de gran reconocimiento. Puesto que, algunos periódicos locales reseñaron la importancia del evento, mostrando las imágenes de joyas de su autoría; así como también, sus joyas se reseñan en el Libro "La Tierra Doctorada" por el Dr. Rafael Pineda (Armitano 1978).

En su recorrido artístico, ha aprovechado todo tipo de materiales, aunque él reconoce que en el campo de la orfebrería, tiene predilección por el oro 24 quilates y la plata 1000. No sólo por su maleabilidad que estos metales nobles ofrecen y la belleza que representan, sino por ser un material inalterable y su rendición a la pureza y belleza de estos metales. "La elección de esos metales puros, representan para él como una ofrenda a Dios, Supremo Creador y modelo perfecto a seguir; ya que Alexis siente que ha sido favorecido dotándolo con gran sensibilidad hacia las artes y el dominio de técnicas y materiales con los cuales ha podido crear su propio lenguaje plástico. Por eso no escatima y ofrece lo mejor"187.

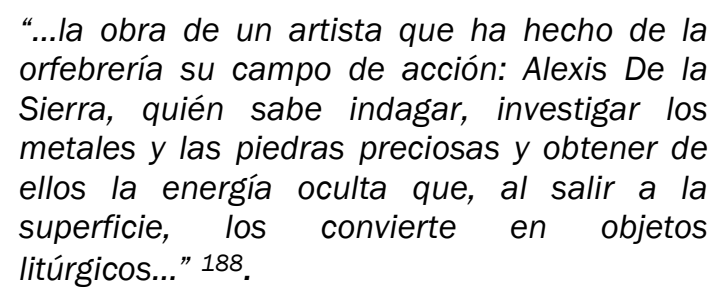

Podemos considerar que la orfebrería para este artista significa más que un simple hecho de realizar una joya. Se percibe como los metales son transformados por él, con convicción, devoción, respeto y perfección. Para él, la transformación del material representa como una especie de ritual, por ello recurre -casi siempre- a técnicas totalmente manuales y la fuerza centrípeta descargada con sus manos e instinto creador, se convierten en médium para la transformación del metal y transformar ese material en un fascinante objeto.

"Muchas de sus obras son elaboradas con complejas referencias simbólicas, religiosas, mitológicas e históricas. Se identifica con

187 Guevara, R., Asprino A., Imber, S. y Pervilhac, I. (1995). "Alexis de la Sierra. El orfebre”. Catálogo. Museo de Arte Contemporáneo de Caracas Sofía Imber. Septiembre. pp: 12-13.

188 Ibid. p: 3. 
otras culturas, pero sobre todo, con sus aspectos religiosos, ya que materializan el anhelo de alcanzar la vida eterna; cuya simbología según dice el propio artista, le atrae desde que era muy joven" 189 .

Al observar todas estas fascinantes joyas y objetos artísticos con esta carga emotiva, resulta curioso, ya que De la Sierra comenta que, en su casa no tuvieron devoción hacia alguna religión. Sin embargo, este tema se ha convertido en sujeto de estudio en muchas de sus obras en orfebrería.

La obra en orfebrería de Alexis De la Sierra es muy versátil y se divide en dos tendencias: orfebrería ornamental y orfebrería escultórica; siendo cada una de ellas abordada en diversos semblantes y tópicos. En todas ellas, logra que más que artísticas sean armoniosas, equilibradas, que deleiten los sentidos donde la inclusión de ciertos materiales y semblantes de avanzada sean valorados desde una óptica vanguardista.

\subsubsection{EN ESCULTURA. Generalidades.}

Entre 1977-1978 debido a méritos curriculares, obtiene una beca del Gobierno Venezolano, a través del Tratado Bilateral Andrés Bello del Pacto Andino, para realizar estudios en Artes Plásticas, en la Facultad de Bellas Artes de la Pontificia Universidad Católica de Chile. Obtiene el título en Artes plásticas con dos menciones: una en escultura y la otra en color. En ambas, el plan de formación se baso en la teoría sobre las representaciones en la Historia del Arte Universal.

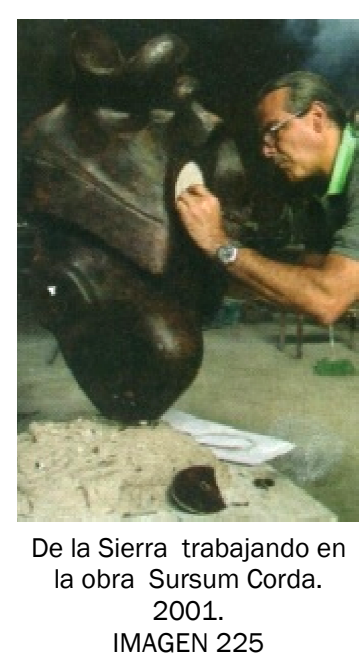

"Dos personas hicieron que me enamorara de la escultura: "Henry Moore y Bárbara Hepworth", ocurrió cuando ya llevaba 10 años como orfebre..."190.

Una vez iniciado el ciclo de la escultura, De la Sierra siente más que una motivación, un verdadero sentimiento que lo acerca a los grandes volúmenes. El estilo y percepción de las obras de Sarah Hepworth y Henry Moore, provocan un interés particular hacia la

189 Marín, C. (2003). "Alexis De la Sierra. Más allá de sí mismo" Revista Ocean Drive. Vol 4 № 5. Agosto-Septiembre. p: 73.

190 Castillo, L. (2004). "Dar clases es lo mejor que me ha pasado como artista. Enseñar al Fuego". Revista. Todo en Domingo. № 230. Febrero 29. p: 23. 
escultura, sobre todo la carga emotiva percibida por sus formas simples pero contundentes, la pureza que irradia el material macizo y la destreza ante el dominio de la materia.

En el año 1980 da comienzo su trayectoria como escultor, con la talla directa sobre madera maciza. Casualmente para esa época, el escultor venezolano Francisco Narváez, desarrolla sus espectaculares volúmenes macizos en maderas tropicales y piedras nativas, quizá, pudiera haber una conexión de la obra de Narváez con su obra.

A partir de 1981 la luz aparece de nuevo en sus representaciones, invade y ocupa el volumen, -esta vez- una simple línea de luz insinuante complementa y aporta vida al material. Desde entonces, el neón se convierte en su aliado y compañero fiel, ésta se exterioriza en la obra como si se tratase de una escenografía, y más aún, la controversia que genera en sus volúmenes entre lo macizo y lo liviano o la curiosidad entre lo palpable y lo ilusorio. En esto estamos de acuerdo con lo que afirma Marín:

"A lo largo de toda su producción artística De la Sierra ha recurrido al uso de diversos tipos de iluminación según la característica y condición de la obra. Por ello, ha utilizado la luz del neón, del xenón, la halogénica, la dicróica, la hidroxílica, la parabólica, la fibra óptica o el láser"191.

En tal sentido, podemos afirmar que dentro de la evolución investigativa en el campo de la escultura lumínica, este artista se adapta a las nuevas tecnologías de vanguardia y por ello, se le considera escultor de la luz. Al respecto, su manager Ion Pervilhac comenta que la transnacional "General Electric" y su equipo de especialistas de la firma "Proyectos Tuy Supply" han ofrecido el respaldo para fortalecer esta innovadora manera de utilizar la luz como elemento artístico.

En el año 1985 Inicia la labor como docente en su propia escuela de orfebres en la ciudad de Caracas. El largo transitar en la enseñanza, le ha aportado una formación integral, no sólo en su capacidad pedagógica ante las diversas aptitudes de sus alumnos sino en el dominio pleno de las técnicas, por lo que cada dificultad necesita una solución diferente. Así pues, ha recurrido al uso de otros métodos y nuevas tecnologías para aplicar en su quehacer artístico y por ende facilitar su enseñanza.

191 Marín, C. (2003). “Alexis De la Sierra. Más allá de sí mismo” Revista. Ocean Drive. Vol 4 № 5. Agosto-Septiembre. p: 73. 


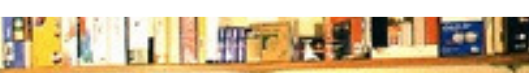

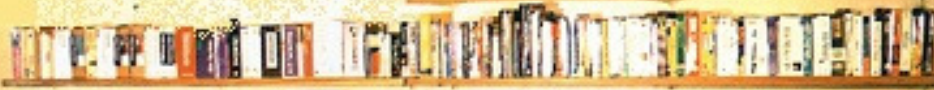

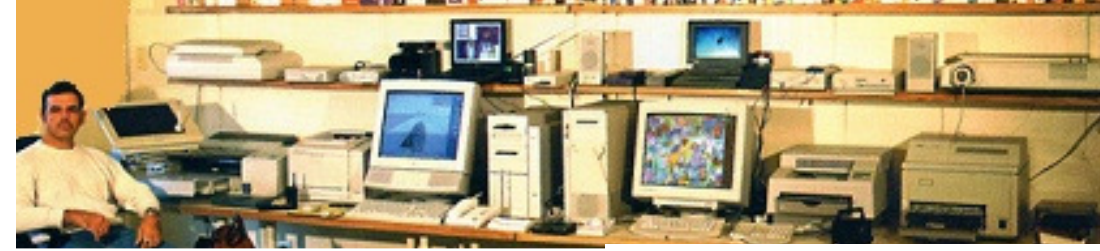

De la Sierra en su primer estudio de diseño electrónico en Caracas.1989.

IMAGEN 226

En el año 1989 integra en su léxico creativo el diseño electrónico con bibliografía especializada y equipos avanzados, aprovecha el potencial de esta herramienta tecnológica para el diseño de sus joyas y de sus proyectos escultóricos, para ello se apoya en avanzadas técnicas tridimensionales computarizadas: el fotorealismo y tecnología digital tridimensional (3-D), aplicada al manejo del volumen escultórico y al diseño electrónico.

Este nuevo sistema le permite elaborar proyectos factibles, mucho más rápida y con menor rango de error para su ejecución real. De igual modo, de manera virtual, le permite al coleccionista poder captar de manera fiel la obra en el lugar donde estará emplazada. Sin embargo, al momento de ejecutar sus obras, De la Sierra prescinde de esos estudios, y se enfrenta sin bocetos y sin vacilaciones; pues, considera, que no debe dejar influenciarse puesto que impediría su libertad ante el material que será convertido en una obra.

Con el paso de los años el diseño electrónico se convirtió en una poderosa herramienta con la cual Alexis De la Sierra, irrumpe de manera categórica en el campo bidimensional. El uso de la tecnología aplicada en sus creaciones le permite lograr mayor integración de la luces consiguiendo las transparencias que tanto admira de las pinturas de Degas.

“Este artista comenta, cómo metafóricamente substituye el caballete, los pinceles y el óleo, por la pantalla, el teclado y el ratón del ordenador. Inventa y crea filtros con los cuales convierte su arte en ciber-pinturas"192. Estas herramientas digitales para él, le hacen llegar a niveles de transparencia, de tridimensionalidad, de foto realismo, de exactitud en los matices como ningún pincel o cincel pudiera lograr.

"De la Sierra se considera un investigador innato, perseverante e inconforme, gran parte

192 Giancola, L. (2006). "Alexis De la Sierra inicia taller de Diseño Electrónico. Una actividad de nueve meses de duración". Diario. El Diario de Caracas. Junio 10. Cultura p: 18 
de su formación ha sido autodidacta, ha experimentado cuantiosas técnicas y materiales, e inclusive, su producción artística abarca, desde diminutas joyas en metales preciosos, esculturas monumentales, hasta las espectaculares ciber-pinturas"193.

A lo largo de todos los años que han transcurrido desde que se inició en las artes, este artista ha tenido sus maestros. Hubo como es obvio un proceso de aprendizaje básico. Sin embargo, ese aprendizaje fue reforzado a través de la constante experimentación e investigación con bibliografía especializada. Por ello, él se considera en parte un artista con formación autodidacta. El poder dominar algunas técnicas de la orfebrería le ha permitido desarrollar una importante producción, una gran cantidad de coleccionistas pueden dar fe de ello. De la Sierra enfatiza, que su aprendizaje en las artes no ha culminado, asiduamente comenta que en la etapa de la docencia, cada día se aprende algo de los alumnos.

La producción en escultura de Alexis De la Sierra es muy versátil, por lo que se divide en diez categorías: la escultura lumínica, en suspensión, Selfstanding, volumetrías de pared, volumetrías de techo y móviles, separaciones escultóricas de ambientes, bronces, pequeños formatos, medianos formatos y formatos monumentales.

\title{
3.3 DESEMPEÑO COMO DOCENTE.
}

3.3.1 ESCUELA. Inicio como centro de enseñanza.

\begin{abstract}
"Durante varios meses dos distinguidas y bellas damas Caraqueñas, Eugenia Meijer Werner y Tulia Soucy de González Gorrondona, venían cada quien por su lado, una vez a la semana, a pedirme que les diera clases de orfebrería, yo les instaba que para esos momentos no estaba preparado, que tenía poca edad para dedicarme a la docencia de manera formal... Les insistía que necesitaba adquirir más conocimientos y que para ello debía trabajar arduamente y por mucho tiempo. Pero todo esto no les valió de nada, así que las dos damas mencionadas son quienes literalmente me obligaron a establecer un Taller-Escuela en mi galería privada..."194.
\end{abstract}

193 Marín, C. (2003). “Alexis De la Sierra. Más allá de sí mismo" Revista. Ocean Drive. Vol 4 № 5. Agosto-Septiembre. p: 73.

194 Castillo, L. (2004). "Dar clases es lo mejor que me ha pasado como artista. Enseñar al Fuego". Revista. Todo en Domingo. № 230. Febrero 29. p: 24. 


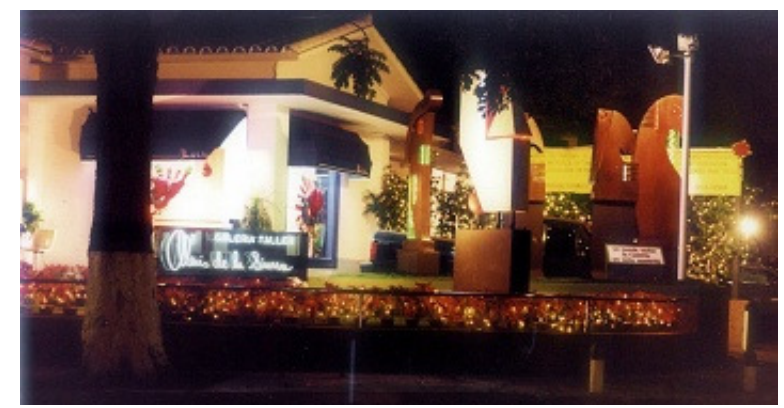

Galería/Escuela de Orfebres ADS, 1985 Urbanización las Mercedes, Caracas. IMAGEN 227

Bajo la dirección de lón Pervilhac se decide dar inicio a las actividades en la enseñanza de orfebrería. Estratégicamente se construye la escuela adosada a su galería privada -fundada en 1984-, a la vista de quien deseara observar el trabajo que realizan los alumnos.

El lunes 6 de Mayo de 1985, se inaugura, La "Escuela de Orfebres Alexis De la Sierra (Escuela de Orfebres ADS)". Para ese momento, la orfebrería en Venezuela no era una disciplina muy conocida; había un taller dirigido por el Sr. David Costa, quien personalmente daba las clases y al parecer, sus alumnos se dedicaban a la joyería tradicional.

De la Sierra comenta que para enseñar le tocó estudiar y formarse, porque se dio cuenta que le faltaba mucho por aprender. Con el devenir de los años y la demanda de la escuela hace que Pervilhac canalice la agenda de De la Sierra. Compaginar la producción y la docencia ha sido una tarea, que se ha podido cumplir gracias a la planificación, constancia y dedicación.

La Escuela de Orfebres ADS, cuenta en la actualidad con una excelente reputación. El reconocimiento de su obra como orfebre, escultor y ciber-pintor, los coleccionistas y la nueva sede de la escuela, en un centro comercial muy concurrido en la ciudad de Caracas, permiten que su labor como docente tenga gran importancia en el país. De su escuela han salido numerosos orfebres e inclusive, entre los mejores, así lo dejan claro, en las múltiples exposiciones y salones de arte, tanto en Venezuela como en el extranjero.

La Escuela de Orfebres ADS, es un lugar para la iniciación de oficio, especialización y expresión artística por medio de los metales nobles y las piedras preciosas. Por casi tres décadas formando orfebres en su propia escuela, De la Sierra ha logrado este reconocimiento con mucha constancia, dedicación, esfuerzo, voluntad y sin ninguna ayuda de entes gubernamentales. Poco a 
poco, ha ido ampliando su actividad docente, no sólo en conocimientos, sino en equipos y maquinarias necesarias para el aprendizaje y ejecución de esta disciplina. La necesidad de compartir sus conocimientos le permite incorporar la experiencia, como Maestro, como algo fundamental en su producción artística.

3.3.2 ENSEÑANZA. Desarrollo de las actividades.

Para poder ingresar a esta escuela, no es necesaria una experiencia previa; la edad tampoco es obstáculo, pues ha tenido alumnos, cuyas edades oscilan entre 9 y 70 años. El promedio fluctúa alrededor de los 26 años. Cada grupo de clases está integrado por 12 personas. Las actividades docentes las dirige personalmente, sus clases se fundamentan en la práctica. El desarrollo de cada alumno, por lo general, va con el ritmo de aprendizaje, esta primera fase, De la Sierra considera que es una de las más importantes. "Impulsar a sus alumnos en el difícil camino de hacer emerger y desarrollar la creatividad, favoreciendo la combinación simultánea entre los aspectos técnicos y plásticos"195.

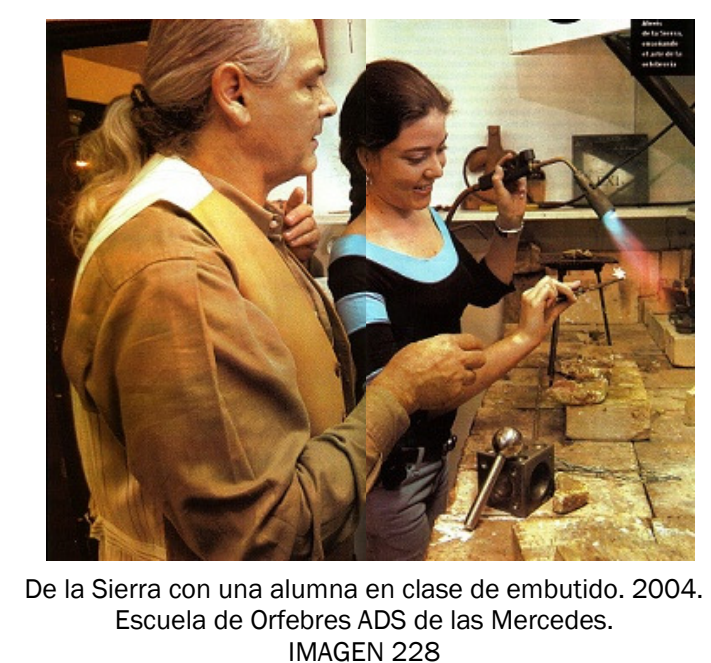

Al inicio de sus actividades, con alumnos nuevos, tiene la costumbre de recibirlos con una excelente presentación en computadora, donde les muestra las obras de algunos estudiantes, que han sido formados en la escuela; les indica cómo es el desarrollo del nivel de iniciación, técnicas, materiales y enfatiza su gran exigencia: la constancia, el esfuerzo, la impecable factura de las obras, el acabado, sin soldaduras visibles y la pulitura extrema, cuya característica ya es reconocida en las obras de sus alumnos, en importantes salones y/o exposiciones. En línea general, estos detalles han sido una de las grandes aportaciones enseñadas y asimiladas por sus alumnos.

195 Moreno, E. (2005). “Alexis De la Sierra 20 años formando orfebres". Diario El Mundo. Diario de la Tarde. Febrero 17. C: 17. p: 17. 
Asisten a su escuela personas con oficios diversos: profesionales de otras especialidades, estudiantes de pregrado, amas de casa. Unos buscan catarsis, otros, terapias así como también, otros aprender de este arte para proyectarse. Todos tendrán el chance de exponer sus primeros trabajos, en una estantería para principiantes, que tiene su lugar en el taller y los más avanzados en los espacios de la galería.

De la Sierra dicta personalmente clases de orfebrería, dos veces a la semana de 3 horas, y el resto de las clases las coordina entre sus ocho asistentes, los cuales son ex alumnos destacados, altamente capacitados. Además coordina la rutina de ejercicios prácticos para realizar en casa. Sus alumnos, por lo general, tardan entre cuatro y seis meses para lograr obras técnicamente aceptables. Una vez adquirida la soltura técnica, comienza a lucir y definirse el estilo del alumno. El esquema general de la progresión didáctica de sus alumnos es entre ocho o nueve meses, a partir de allí, estarán cubiertos los aspectos básicos de esta disciplina artística.

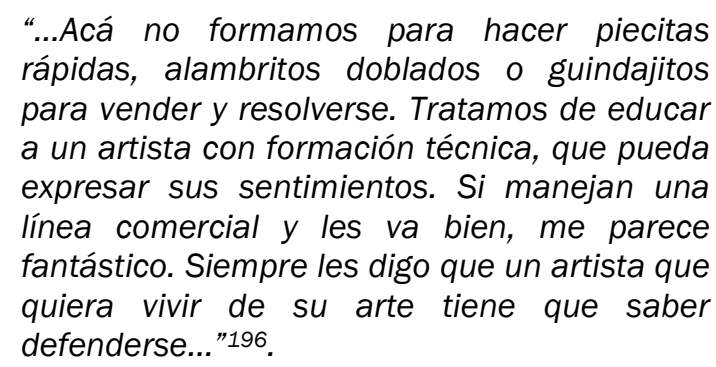

De la Sierra siempre ha dejado claro, que en su escuela, es muy importante aprender bien el oficio del orfebre. Por eso en las clases de aprendizaje, personaliza su atención en velar y constatar su asimilación, ya que una buena práctica garantiza, una obra sin complicaciones y un acabado impecable.

El taller dispone de diversas áreas de trabajo según su dependencia. Cada alumno cuenta con una mesa de trabajo con motor de percusión, compartiendo las áreas en común. Las áreas en común se dividen según se amerite:

Área de soldadura y fundición:

Sopletes de fuelle.

- Sopletes de gas.

- $\quad$ Sopletes de acetileno.

- Chaponeras y lingoteras.

196 Castillo, L. (2004). “Dar clases es lo mejor que me ha pasado como artista. Enseñar al Fuego". Revista Todo en Domingo. № 230. Febrero 29. p: 22. 
- Prensas de hierro para elaborar planchas de mokume gané.

- Laminador de capa.

Laminador de hilos.

- Trefiladoras para hilo y tubo de diversos perfiles: redondo, media caña, cuadrado, triangular.

Área de texturización:

Yunque de acero.

Yunque de plomo.

Yunque de madera.

Soporte de lacre.

Soporte de caucho.

Soporte de nylon.

Dados para embutir en metal y madera.

Embutidores en metal y madera.

Cinceles en metal y madera.

- Martillos diversos.

Área de cera perdida y esmalte:

- Horno para esmaltes, y rejillas con luz para secado de esmaltes.

Horno para descere.

Máquina de inyectar cera.

Vulcanizadora.

Centrífuga.

Área de limpieza y acabados:

- Motor para lijar y esmerilar.

Máquina de arenado.

- Ultrasonido.

- Motor de pulir.

- Tómbola.

Para los alumnos del I Nivel, la inscripción incluye el material fungible, hasta la tercera clase, luego cada alumno adquiere las herramientas de uso personal y material, correspondientes a cada técnica según el nivel que esté realizando.

Después del aprendizaje básico, es cuando los alumnos iniciados deciden, si ya terminaron su incursión en el campo de la orfebrería o si desean continuar para profundizar en esta disciplina. El 75\% de los alumnos siguen después de los nueve meses y son muchos los que cursan dos y más años, e inclusive han iniciado clases alumnos que son hijos de ex alumnos.

La enseñanza de la orfebrería se lleva a cabo por medio de un programa, cuya estructura abarca desde las técnicas básicas, donde progresivamente el alumno va adquiriendo destrezas. "La 
evolución del aprendizaje se divide en cuatro niveles, quedan desglosados de la siguiente manera:

El Nivel l: Joyería Plana. Conocimiento de las herramientas básicas, reporte de dibujos sencillos al metal, calado, repujado embutido, formación y soldadura de un domo y cubo. (Bronce y cobre).

El Nivel II: Joyería en Relieve. Esferas y domos, trabajos con hilos de plata. Cincelado, repujado y texturización con ácidos. ensamblaje/construcción de piezas multi-elementos, engastes sencillos de piedras. Técnicas opcionales \#1. (Plata)

El Nivel III: Joyería Fundida. Diseño y técnicas de modelado en cera, confección de moldes y fundición en cera perdida. Técnicas opcionales \#2.

EI Nivel IV: Introducción a la Alta Orfebrería. Engaste de piedras preciosas, introducción al electroforming, esmalte al fuego sobre oro y plata, logística de exhibición para eventos expositivos.

“Las técnicas opcionales \#1 y \#2 son las que dictan para ampliar los conocimientos, paralelamente a las clases habituales. Estas son impartidas por el mismo Alexis De La Sierra, o personas especializadas que dominan un tema o una técnica, estas clases tienen un costo adicional"197. El desarrollo de estas actividades no es el mismo, según las necesidades del alumno. Si se trata de un grupo el cual ha cumplido todo el plan de estudios, sus necesidades serán aún más específicas y de mayor complejidad; entre las técnicas opcionales podemos mencionar algunas de las ochenta y cinco clases especiales patrimonio de la escuela:

- Construcción de tubos (charnelas) de diferentes diámetros, en plata y en oro. Aplicación de métodos manuales y mecánicos.

- Tallado y fundición en sepia (Jibia). Aplicación con y sin modelo.

- Engaste con martillo eléctrico.

- Técnicas de esmaltes al fuego. Aplicación en oro, plata y cobre. Sobre piezas macizas o en construcción con soldaduras.

- Confección de cadenas bizantinas. Aplicación del trefilado manual y mecánico.

- Soldaduras para tipos diversos de cadenas.

- Fabricación de tornillos y tuercas con metales preciosos. Utilización de tarrajas con rosca fina y gruesa.

- 197 Benítez, L. (2007). "Estructura del curso de orfebrería del año 1997". Material inédito. Correo electrónico. cuarzo53@hotmail.com 
- Construcción de moldes con yeso para piezas huecas o macizas.

Instrumentos de medición aplicables en el campo de la orfebrería.

- Tipos de soldadura para cada metal y su aplicación en orfebrería, utilización de diferentes tipos de sopletes y métodos diversos para soldar.

- Reconstitución de piedra y diversos tipos de aplicaciones a una joya.

Forja de metales preciosos.

- Ensarte de cuentas para la realización de collares y brazaletes.

- Sellos de ley.

- Cera perdida: utilización de diversos tipos de cera para modelar o tallar.

- Gemología.

- Talla en azabache. En preparación para la participación al 1er. Salón Venezolano de la Talla del Azabache.

- "Clase especial vidrio". Demostración de técnicas básicas de vidrio plano dirigida a orfebres. En preparación para la participación al Salón VITRUM (Owens illinois)

Etching (diseños impresos sobre superficie metálica).

Combinación de metales.

Cadenas tejidas.

Encapsulados en resina de colores.

Texturizados.

Y así un gran número de técnicas y conocimientos aplicables al campo de la orfebrería, por lo general se dictan en una locación diferente o dentro de los espacios de la misma escuela, fuera de los horarios de estudio, salvo los que se consideren indispensables, invaden los horarios regulares de clases, recuperando el alumno en otras horas las clases perdidas.

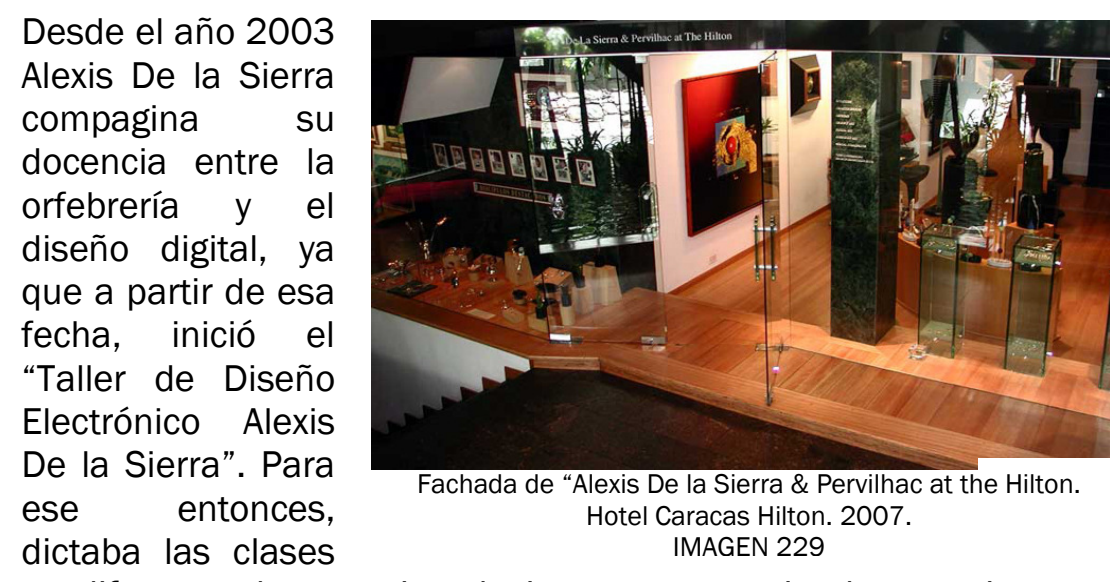

en diferentes lugares: instalaciones -compartiendo espacios con el Hotel Tamanaco y el Centro Comercial Paseo las Mercedes del 
2006 al 2007, asi como también en su escuela en la urbanización las Mercedes, en la ciudad de Caracas; ya para ese entonces tenía una sucursal de su Galería/Escuela "Alexis De la Sierra \& Pervilhac at the Hilton" desde al año 1998 hasta 2007, en un local comercial dentro del Hotel Caracas Hilton, también en la ciudad de Caracas.

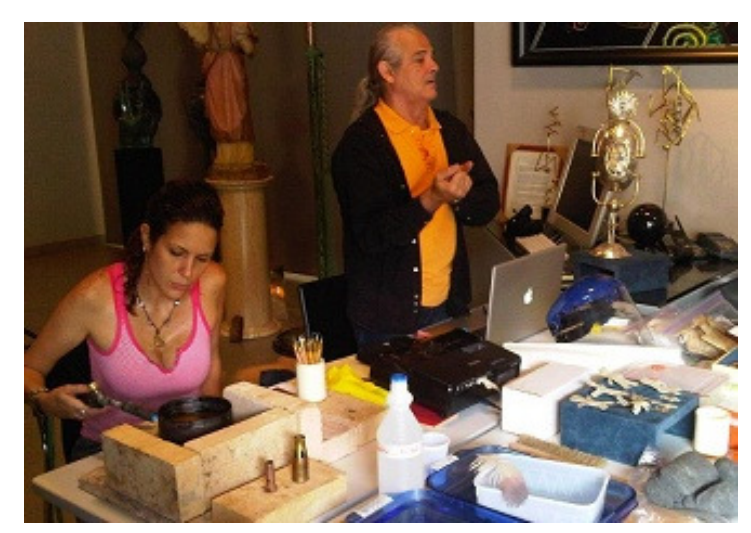

En la actualidad, todos esos cursos se congregaron dentro los espacios del nuevo taller ubicado con su Galería "Portafolio" en la planta baja del Centro Comercial Terras Plaza en la urbanización

Clase teórica de orfebrería de técnicas especiales: Etching, con una de sus asistentes. Galería Portafolio, Caracas. 2009.
IMAGEN 230

El Maestro enseña a principiantes $y$ expertos el gran potencial que encierra herramienta

tecnológica para el diseño de joyas, el diseño gráfico, las artes plásticas y las artes visuales. La actividad dura 9 meses basada en

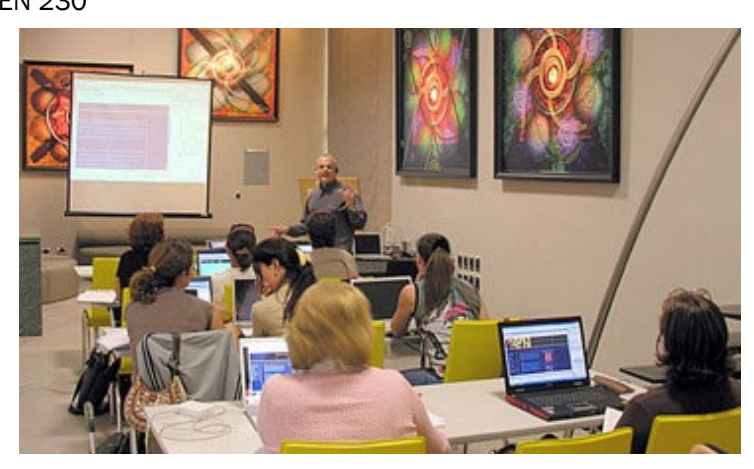
Alexis De la Sierra dictando una clase de Diseño Electrónico en los espacios de su Galería Portafolio 2007. una clase semanal en jornadas de 4 u 8 horas; según la necesidad y conveniencia del alumno198. El taller de Diseño Digital Multimedia Alexis De la Sierra, centra su desarrollo en actividades específicas tales como:

Dibujo electrónico.

Manipulación digital de imágenes.

Diagramación electrónica.

198 Conferencias y Talleres. Taller de Diseño Electrónico Alexis De La Sierra. Lunes 20 de Agosto de 2007. analítica.com.

http://www.analitica.com/va/arte/actualidad/cyt/7458692.asp 
Creación de archivos multiplataforma.

Animación digital.

Edición electrónica de video.

- Diseño de páginas web.

Aprendizaje sobre el uso de herramientas de dibujo, ilustración, diseño, pintura digital, maquetación animación video y diseño, desarrollo y creaciones de pagina web y su puesta en el aire. Todo ello con una orientación netamente artística.

Profundiza en el estudio sistemático de programas educativos de las herramientas de nueva tecnología aplicadas al arte mediante la experiencia personal y profesional en el campo digital multimedia del maestro De la Sierra en los últimos 25 años.

Un aspecto importante del desarrollo de la Escuela de Orfebres ADS, es la participación del alumno en actividades expositivas de alto nivel, así como también, la participación en seminarios sobre el mundo del arte contemporáneo, donde se hace énfasis en saber responder de manera equilibrada y responsable a presiones y a la vez diversificar la búsqueda sin perjudicar la continuidad investigativa y la calidad creativa de su obra199. Así se hace constar en los medios, dentro del marco de celebración de los XX años de fundada la escuela. En tal sentido podemos confirmar, cómo da inicio este tipo de actividades. Uno de los aportes que se le atribuyen a su escuela de orfebres, ha sido la inserción de sus alumnos al medio expositivo en Museos. Esa iniciativa nació en el año 1987, a los dos años de su fundación. Los directivos del Museo de Arte Contemporáneo Francisco Narváez, quienes se encargaban de la exposición individual de Alexis De la Sierra "100 horas, 100 obras", consideraron de suma importancia y sugieren al artista realizar en paralelo una muestra de las obras de sus alumnos. Esa muestra fue titulada: "Obras selectas de los alumnos de Alexis De la Sierra", para ese entonces la escuela contaba ya, con cincuenta y cinco alumnos, los cuales tuvieron la oportunidad de participar en ese importante evento.

Los alumnos elaboraron sus joyas en plata donde la alta calidad quedó en manifiesto, entre los espectaculares pendientes, dijes y brazaletes allí expuestos. Pero el hecho que dio a conocer formalmente la escuela fue la exposición itinerante de De la Sierra en la ciudad de Caracas/Valencia titulada, "El taller de Alexis De la Sierra, Crisol de la Nueva Generación de Orfebres Venezolanos". Los organizadores del Salón Nacional de las Artes del Fuego, tuvieron esa iniciativa para destacar la labor docente de este excelente artista venezolano. Las palabras del crítico de arte

199 Moreno, E. (2005). "Alexis De la Sierra 20 años formando orfebres". Diario. El Mundo. Diario de la Tarde.17 de febrero de 2005. C 17. p: 17 
Rafael Pineda fueron muy acertadas cuando destacó que esta escuela era la revitalización de la orfebrería en el país y el nacimiento de una nueva generación de orfebres venezolanos. Esa experiencia fue fructífera tanto para Alexis como artista-docente, como para la escuela ya que para esos momentos la orfebrería en Venezuela estaba en manos de unos pocos dedicados a la joyería tradicional.

A partir del año 1988, la escuela se propone como uno de los objetivos a cumplir las exposiciones anuales con las mejores obras de cada alumno. Independientemente de su nivel, los alumnos podrán aplicar sus conocimientos en el desarrollo de algún tema específico. Este objetivo, además de beneficiar el impulso creativo de cada alumno, permite a De la Sierra formalizar la presentación del esfuerzo de su docencia ante el público.

Debido a esta importante labor, a continuación presentamos cronológicamente sobre las exposiciones anuales de los alumnos de dicha escuela. Se revelan los nombres de las exposiciones realizadas por la Escuela de Orfebres ADS, con un punto negro ( ) y Las que presentan un guión (-) son exposiciones colectivas e individuales de los alumnos de la escuela, en otras instituciones, dentro y fuera del país.

1986

"XIII Salón Nacional de las Artes del Fuego". Valencia, estado Carabobo.

1987

- "Obras selectas de los alumnos de Alexis De la Sierra". Porlamar, estado Nueva Esparta.

- "El taller de Alexis De la Sierra, Crisol de la Nueva Generación de Orfebres Venezolanos". Valencia, estado Carabobo.

- "XIV Salón Nacional de las Artes del Fuego". Valencia, estado Carabobo.

1988

- "Taller de Orfebrería". Caracas, Distrito Capital.

"XV Salón Nacional de las Artes del Fuego". Valencia, estado Carabobo.

1989

- "Didáctica en Plata esterlina”. Caracas, Distrito Capital.

"Vestirarte". Caracas, Distrito Capital.

"Joya Mágica". Valencia, estado Carabobo.

"Arte/Facto". Caracas, Distrito Capital.

"AG 9 Visiones Contemporáneas de un Arte Antiguo I".

Caracas, Distrito Capital. 
“Joyas Escultóricas”. Caracas, Distrito Capital.

“Xilo Argentum”. Caracas, Distrito Capital.

"Zwei Kunstlehrinen”. Basel, Suiza.

"Joya Mágica”. Valencia, estado Carabobo.

"XVI Salón Nacional de las Artes del Fuego". Valencia, estado Carabobo.

1990

- "Orfebrería Utilitaria 1990". Caracas/Valencia.

"AG 9 Visiones Contemporáneas de un Arte Antiguo II".

Caracas, Distrito Capital.

"Orfebrería". Caracas, Distrito Capital.

"Ornamentos de Plata". Caracas, Distrito Capital.

"Fortunoff Jewelers". New York City, USA.

"XVII Salón Nacional de las Artes del Fuego". Valencia, estado Carabobo

1991

“Luces y Devociones". Caracas, Distrito Capital.

"Cinco del Crisol" Valencia, estado Carabobo.

"Orfebrería". Caracas, Distrito Capital.

"Divertimenti". Maracaibo, estado Zulia.

“Nacidos de Plata y Fuego". Caracas, Distrito Capital.

"Pasión y Emoción". Barakat, Panamá.

"XVIII Salón Nacional de las Artes del Fuego". Valencia, estado Carabobo.

1992

“34 Orfebres 1992". Caracas, Distrito Capital.

"Luces y Cruces". Caracas, Distrito Capital.

"Mineralita et Argenta". Valencia, estado Carabobo.

"The Americas Collection Gallery". Miami, Florida. USA.

"TazArte". Caracas, Distrito Capital.

"XIX Salón Nacional de las Artes del Fuego". Valencia, estado Carabobo.

1993

- "Objets Demodès I". Caracas, Distrito Capital /New York City, USA.

"A la Zaga del Fuego". Valencia, estado Carabobo.

"Auri Faber". Caracas, Distrito Capital.

"XX Salón Nacional de las Artes del Fuego". Valencia, estado Carabobo.

- "Objects Demodès II". Caracas, Venezuela/New York City, USA.

- "XXI Salón Nacional de las Artes del Fuego". Valencia, estado Carabobo. 
"Alexis De la Sierra: El Orfebre". Caracas, Distrito Capital. "XXII Salón Nacional de las Artes del Fuego". Valencia, estado Carabobo.

1996

- “El Tiempo en la Orfebrería I". Caracas, Venezuela.

"XXIII Salón Nacional de las Artes del Fuego". Valencia, estado Carabobo.

1997

- “El Tiempo en la Orfebrería II". Caracas, Venezuela.

"XXIV Salón Nacional de las Artes del Fuego". Valencia, estado Carabobo.

1998/1999 EXPOSICIONES SUSPENDIDAS

"XXV y XXVI Salón Nacional de las Artes del Fuego". Valencia, estado Carabobo.

2000

"Il Salón Nacional del vidrio VITRUM II, Owen Illinois". Caracas, Distrito Capital.

"ANAPACE 2000". Caracas, Distrito Capital.

"XXVII Salón Nacional de las Artes del Fuego". Valencia, estado Carabobo.

Flores de Primavera. Caracas, Distrito Capital.

2001

"Flores de Plata: Tributo a la Madre". Caracas, Distrito Capital.

"Orfebrería Primaveral. Tributo a la Juventud". Caracas, Distrito Capital.

"XXVIII Salón Nacional de las Artes del Fuego". Valencia, estado Carabobo.

2002

"Homenaje a la Eterna Juventud". Caracas, Distrito Capital. "Il Festival de la Eterna Juventud". Caracas, Distrito Capital.

- " "III Salón Nacional del vidrio VITRUM en Pequeño Formato, Owen Illinois". Caracas, Distrito Capital.

"1er. Salón Venezolano de la talla del azabache". Puerto Ordáz, Ciudad Bolívar.

- "XXIX Salón Nacional de las Artes del Fuego". Valencia, estado Carabobo.

2003

“Salón de Otoño". Caracas, Distrito Capital. 
- "A ritmo de Martillo, Segueta y Soplete". Caracas, Distrito Capital.

- "XXX Salón Nacional de las Artes del Fuego". Valencia, estado Carabobo.

- "Escuela de Orfebres Alexis De la Sierra 2003". Caracas, Distrito Capital.

2004

- "La Docencia Artística Aplicada al campo de la Orfebrería: Un testimonio de la Escuela de Orfebres Alexis De la Sierra". Valencia, estado Carabobo.

"School of Silver". Miami, Florida, USA.

- "Joyas cobran vida en oro y plata". Caracas, Distrito Capital.

- "31 Salón Nacional de las Artes del Fuego". Valencia, estado Carabobo.

2005

“Tierra Arte y Cultura en Venezuela". Caracas, Distrito Capital.

"Obras en plata para Itinerar". Caracas, Distrito Capital.

"I Salón Nacional de Orfebrería". Caracas, Distrito Capital.

"32 Salón Nacional de las Artes del Fuego". Valencia, estado Carabobo.

2006

Actividades suspendidas temporalmente por la construcción de la nueva sede de la escuela.

"II Salón Nacional de Orfebrería". Caracas, Distrito Capital.

"33 Salón Nacional de las Artes del Fuego". Valencia, estado Carabobo.

2007

"Laboratorios Roche". Caracas, Distrito Capital.

"III Salón Nacional de Orfebrería". Caracas, Distrito Capital.

"34 Salón Nacional de las Artes del Fuego". Valencia, estado Carabobo.

2008

"Yo me hago mis propias joyas, y Tù?". Caracas, Distrito Capital.

2009

"Cajas que ayudan". Caracas, Distrito Capital.

2010

“PI. 3.416 en Orfebrería”. Caracas, Distrito Capital.

3.3.3 APORTE DE LA ESCUELA DE ORFEBRES ALEXIS DE LA 
SIERRA. Repercusión en medios expositivos y en otros centros de enseñanza.

La Escuela de Orfebres ADS, repercute significativamente en el desarrollo de la disciplina en el país desde el año 1986. Con apenas un año de haber iniciado esta escuela, se comienzan a ver los resultados de su excelente labor docente, aumentando considerablemente la participación -por sus alumnos- en el "SNAF". A continuación, presentamos los resultados de los orfebres seleccionados en las ediciones del "SNAF" desde 1986 hasta el año 2010 en donde se aprecia gran participación por parte de sus alumnos 200 .

\begin{tabular}{|c|c|c|c|c|}
\hline $\begin{array}{l}\text { Ediciones } \\
\text { "SNAF" }\end{array}$ & Año & $\begin{array}{l}\text { Seleccionados } \\
\text { en tendencia } \\
\text { de orfebrería }\end{array}$ & $\begin{array}{l}\text { Alumnos de } \\
\text { Escuela de } \\
\text { Orfebres ADS }\end{array}$ & $\begin{array}{c}\text { Valoración } \\
\text { en } \\
\text { porcentaje }\end{array}$ \\
\hline XIII & 1986 & 10 & 7 & $70 \%$ \\
\hline XIV & 1987 & 10 & 7 & $70 \%$ \\
\hline$X V$ & 1988 & 9 & 7 & $77,7 \%$ \\
\hline $\mathrm{XVI}$ & 1989 & 15 & 14 & $93,3 \%$ \\
\hline XVII & 1990 & 12 & 12 & $100 \%$ \\
\hline XVIII & 1991 & 35 & 31 & $88,5 \%$ \\
\hline XIX & 1992 & 8 & 6 & $75 \%$ \\
\hline$X X$ & 1993 & 5 & 1 & $20 \%$ \\
\hline$X X I$ & 1994 & 11 & 4 & $36,3 \%$ \\
\hline XXII & 1995 & $\mathrm{~S} / \mathrm{N}$ & $\mathrm{S} / \mathrm{N}$ & $\mathrm{S} / \mathrm{N}$ \\
\hline XXIII & 1996 & 8 & 2 & $25 \%$ \\
\hline XXIV & 1997 & 23 & 11 & $47,8 \%$ \\
\hline$X X V$ & 1998 & 26 & 8 & $30,7 \%$ \\
\hline XXVI & 1999 & 31 & 6 & $19,3 \%$ \\
\hline XXVII & 2000 & 19 & 5 & $26,3 \%$ \\
\hline XXVIII & 2001 & 35 & 18 & $51,4 \%$ \\
\hline XXIX & 2002 & 17 & 6 & $35,2 \%$ \\
\hline$X X X$ & 2003 & 17 & 9 & $52,9 \%$ \\
\hline 31 & 2004 & 12 & 3 & $25 \%$ \\
\hline 32 & 2005 & 30 & 12 & $40 \%$ \\
\hline 33 & 2006 & 24 & 8 & $33,3 \%$ \\
\hline 34 & 2007 & 22 & 6 & $27,2 \%$ \\
\hline 35 & 2008 & 21 & 5 & $23,8 \%$ \\
\hline 36 & 2009 & 8 & 1 & $12,5 \%$ \\
\hline 37 & 2010 & 9 & 3 & $33,3 \%$ \\
\hline
\end{tabular}

"Pervilhac comenta, que desde el año 2000 la Escuela de Orfebres ADS, intermitentemente ha dejado de estimular a sus alumnos a

200 Los nombres de los alumnos de la Escuela de orfebres ADS seleccionados en las ediciones del "SNAF" desde el año 1986 hasta el año 1992, fueron extraidos del Catálogo página Web del "SNAF", confirmados luego por lon Pervilhac, manager de Alexis De la painra. 
participar, en el único salón especializado en la artes del fuego en Venezuela "SNAF", a manera de protesta por no estar de acuerdo con los lineamientos, criterios de organización y desempeño de estos eventos, entre los que destacan la imposición de jurados no especializados y ajenos a la disciplina de la orfebrería, entre otros factores que han influido para ello"201. Quedando de manifiesto que la participación de alumnos de Escuela de Orfebres ADS, ha sido en su mayoría espontánea. A pesar de la actitud neutral por parte de la escuela, la presencia de los alumnos sigue representando un alto porcentaje de los participantes en todos los eventos relacionados a este arte y la calidad formativa de ellos se puede apreciar en los premios que frecuentemente obtienen; en tal sentido podemos afirmar que los años 2005 y 2008 los ganadores del Premio Nacional de las Artes del Fuego en la tendencia de Orfebrería han sido alumnos de Alexis De la Sierra 2005 Samantha Fung y 2008 Yolanda Sucre-.

Este aporte significativo, no sólo se observa en los dos casos mencionados del "SNAF" sino en el Salón Nacional de Orfebrería "SNO". Este salón creado en el año 2005 está dedicado a la orfebrería de amplia convocatoria; al observar la participación en los catálogos, puede apreciarse la participación de los alumnos de la escuela de Alexis De la Sierra.

\begin{tabular}{|c|c|c|c|c|}
\hline $\begin{array}{c}\text { Ediciones } \\
\text { "SNO" }\end{array}$ & Año & $\begin{array}{c}\text { Orfebres } \\
\text { participantes }\end{array}$ & $\begin{array}{c}\text { Alumnos de la } \\
\text { Escuela de } \\
\text { Orfebres ADS }\end{array}$ & $\begin{array}{c}\text { Valoración } \\
\text { en } \\
\text { porcentaje }\end{array}$ \\
\hline I & 2005 & 55 & 3 & $5,4 \%$ \\
\hline II & 2006 & 139 & 37 & $26,6 \%$ \\
\hline III & 2007 & 126 & 31 & $24,6 \%$ \\
\hline
\end{tabular}

Es muy interesante este tipo de exposición -Salón Nacional de Orfebrería- donde la participación es libre dando como resultado una muestra versátil. Resulta curioso el porcentaje tan bajo de participación de alumnos de Alexis De la Sierra. Sin embargo, las obras ganadoras de menciones en las tres ediciones destacan algunos nombres de alumnos de la Escuela de Orfebres ADS.

La difusión y promoción de la disciplina se ha fortalecido de tal manera que muchos de sus alumnos en la actualidad viven de los frutos arrojados por el aprendizaje de esta disciplina. Han sido numerosos los casos de independización por parte de sus alumnos, con apertura de galerías, joyerías, talleres de moda, tiendas de arte e inclusive, otros trabajan para importantes casas en el extranjero. Según datos aportados por el propio Artista, se mencionan algunos de estos casos, los cuales se encuentran especificados en una tabla que se presenta a continuación.

201 Pervilhac, I. (2008). "Participación de alumnos de Escuela de orfebres ADS en "SNAF" y “SNO”". Material Inédito. Correo electrónico. artmanager@delasierra.com 
"Muchos de los que fueron sus discípulos llevan una vida artística y comercial activa. En varias instancias, se extiende hasta Estados Unidos, Italia, España o Suiza entre otros. Un caso reciente lo constituye el documental sobre la Escuela realizado por Fernando Jáuregui, para CNN World Report, transmitido en Noviembre de 2004" 202 .

Muchos de sus alumnos han realizado exposiciones individuales y han participado en colectivas, en entidades culturales y galerías importantes en Venezuela, entre las ciudades de Caracas, Valencia, Maracay, Puerto La Cruz, Ciudad Bolívar, Barquisimeto, Mérida y Maracaibo. Así como también fuera del país como en Miami, New York City, Panamá, Japón, Suiza, y España. En tal sentido podemos considerar cómo la excelente labor docente de Alexis De la Sierra es reconocida por un gran colectivo tanto en el país como en el extranjero.

A continuación mencionaremos algunos alumnos egresados de Escuela de Orfebres ADS, que desde finales de los años ochenta se han ido integrando a la vida comercial con la orfebrería.

\begin{tabular}{|c|c|}
\hline Alcira Fernández Núñez & $\begin{array}{l}\text {-Actual asistente ESOVASCA. } \\
\text {-Línea de accesorios propia. } \\
\text {-Vida comercial y artística a nivel } \\
\text { nacional. } \\
\text { alcira1970@yahoo.com }\end{array}$ \\
\hline Ana Alexandra Henríquez & $\begin{array}{l}\text {-Posee una tienda de orfebrería en las } \\
\text { Mercedes. Caracas, Distrito Capital. } \\
\text {-Línea de accesorios propia. } \\
\text {-Vida comercial y artística a nivel } \\
\text { nacional e internacional, “Alegna } \\
\text { Designs Joyería". USA. } \\
\text { anaalex2000@gmail.com }\end{array}$ \\
\hline Angela de Sousa & $\begin{array}{l}\text {-Línea de accesorios propia. } \\
\text {-Vida comercial y artística a nivel } \\
\text { nacional e internacional. } \\
\text { www.bealegna.com } \\
\text { alegnadesigns@yahoo.com }\end{array}$ \\
\hline Duglas Pereira & $\begin{array}{l}\text {-Línea de accesorios propia. } \\
\text {-Vida comercial y artística a nivel } \\
\text { nacional. } \\
\text { www.Venaventours.com/duglaspereira } \\
\text { duglaspereira609@hotmail.com }\end{array}$ \\
\hline Edymar Âlvarez & $\begin{array}{l}\text {-Línea de accesorios propia. } \\
\text {-Vida comercial y artística a nivel } \\
\text { nacional. } \\
\text { abejaycolibri@gmail.com }\end{array}$ \\
\hline Gabriela Urdaneta & $\begin{array}{l}\text {-Línea de accesorios propia. } \\
\text {-Vida comercial y artística a nivel } \\
\text { internacional. } \\
\text { gabyurdaneta@yahoo.com }\end{array}$ \\
\hline Isabel Ausin de Del Cid & $\begin{array}{l}\text {-Posee dos tiendas de orfebrería. } \\
\text { 1-Centro Ciudad Comercial } \\
\text { Tamanaco (CCCT). Caracas, Distrito }\end{array}$ \\
\hline
\end{tabular}

202 Moreno, E. (2005). “Alexis De la Sierra 20 años formando orfebres”. El Mundo. Diario de la Tarde.17 de febrero de 2005. C 17. p: 17. 


\begin{tabular}{|c|c|}
\hline & $\begin{array}{l}\text { Capital. } \\
\text { 2-Centro Comercial Sambil Caracas, } \\
\text { Distrito Capital. } \\
\text { isabelaprimera@cantv.net }\end{array}$ \\
\hline Isabel Tinoco & $\begin{array}{l}\text {-Posee dos tiendas de orfebrería. } \\
\text {-Centro Ciudad Comercial Tamanaco } \\
\text { (CCCT). Caracas, Distrito Capital. } \\
\text {-Centro Comercial Sambil. Caracas, } \\
\text { Distrito Capital. } \\
\text { intinoco@cantv.net }\end{array}$ \\
\hline Julia Ferreira & $\begin{array}{l}\text {-Línea de accesorios propia. } \\
\text {-Vida comercial en varias ciudades en } \\
\text { USA y México. } \\
\text { www.juliaferreira.com }\end{array}$ \\
\hline Leonor Austria & $\begin{array}{l}\text {-Línea de accesorios propia. } \\
\text {-Vida comercial en varias ciudades en } \\
\text { USA. }\end{array}$ \\
\hline Liliana Benítez & $\begin{array}{l}\text {-Línea de accesorios propia. } \\
\text {-Vida comercial y artística a nivel } \\
\text { nacional. } \\
\text { www.Lilianabenitez.com }\end{array}$ \\
\hline Samantha Fung & $\begin{array}{l}\text {-Línea de accesorios propia. } \\
\text {-Vida comercial y artística a nivel } \\
\text { nacional e internacional. } \\
\text { www.samanthafung.com }\end{array}$ \\
\hline María Elena Cano & $\begin{array}{l}\text {-Línea de accesorios propia. } \\
\text {-Vida comercial en varias ciudades en } \\
\text { USA. }\end{array}$ \\
\hline Nené Herrera & $\begin{array}{l}\text {-Línea de accesorios propia. } \\
\text {-Vida comercial en varias ciudades en } \\
\text { USA. }\end{array}$ \\
\hline Silvia Fassardi & $\begin{array}{l}\text {-Línea de accesorios propia. } \\
\text {-Vida comercial en varias ciudades en } \\
\text { USA. }\end{array}$ \\
\hline María Beatriz Hernández & $\begin{array}{l}\text {-Posee una joyería en la ciudad de } \\
\text { Maracay, estado Aragua. } \\
\text {-Línea de accesorios propia las cuales } \\
\text { exhibe permanente en pasarelas, ya que } \\
\text { es Modelo Profesional. }\end{array}$ \\
\hline María de los Ângeles Flames & $\begin{array}{l}\text {-Posee una tienda en el Centro Comercial } \\
\text { La Tapias en la ciudad de Mérida, } \\
\text { Venezuela "Pathos Joyas, C.A". } \\
\text {-Línea de accesorios propia. } \\
\text { metta888ve@yahoo.es }\end{array}$ \\
\hline María Francia Malavé & $\begin{array}{l}\text {-Posee dos tiendas en la ciudad de } \\
\text { Cumaná, Venezuela. } \\
\text {-Línea de accesorios propia, con } \\
\text { materiales regionales, específicamente } \\
\text { el coral negro. } \\
\text { mfrancia@cantv.net }\end{array}$ \\
\hline Isabella Rey & $\begin{array}{l}\text {-Línea de accesorios propia. } \\
\text { Isabella-rey-blogspot.com }\end{array}$ \\
\hline
\end{tabular}

Como se hemos mencionado en el Capítulo 1 dentro del Contexto Artístico de la orfebrería Venezolana, la enseñanza de la disciplina de la Orfebrería en Venezuela sucede por iniciativa privada. Es así como alumnos egresados de la Escuela de Orfebres ADS desde el año 1989 han creado talleres de enseñanza en esta disciplina. La popularidad que ha ganado este oficio -sobre todo en la ciudad de 
Caracas- ha sido una de las primeras motivaciones para estas personas. Alexis De la Sierra comenta que de su escuela, han surgido más de 19 talleres -fundados por los propios egresadosEn la actualidad son diecisiete los que se encuentran activos en Venezuela y dos en el extranjero".

Pudo confirmarse que existen algunos casos de orfebres que han sido formados en talleres de ex alumnos de la Escuela De Orfebres ADS y actualmente se encuentran en el medio comercial a nivel nacional e internacional con gran popularidad, por lo que se considera significativo mencionar por lo menos un nombre. Con ello, poder constatar el aporte de la escuela y por ende en el desarrollo de la disciplina en el país.

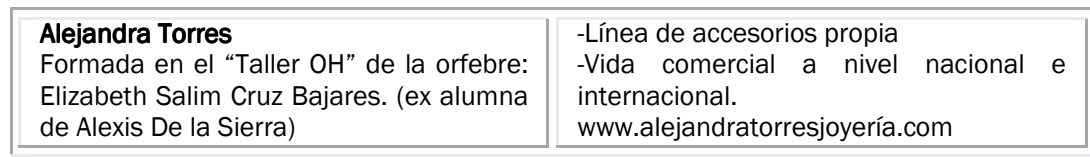

Para reforzar este comentario hemos decidido agregar en este apartado del trabajo de investigación los nombres de estos alumnos y las ciudades en donde tienen sus talleres de enseñanza:

\begin{tabular}{|l|l|}
\hline $\begin{array}{l}\text { Alumnos de la Escuela de Orfebres ADS } \\
\text { que se dedican a la docencia en } \\
\text { orfebrería }\end{array}$ & $\begin{array}{l}\text { Ciudad donde se encuentra el taller de } \\
\text { enseñanza. }\end{array}$ \\
\hline Ana Alexandra Henríquez & Caracas, Distrito Capital. \\
\hline Ana Esther Fuchs de Soued & $\begin{array}{l}\text {-Jefa del Departamento de Metales de la } \\
\text { Ciudad de Hollywood. } \\
\text {-Docente en Miami Internacional } \\
\text { University } \\
\text { of Arts and Design. USA. }\end{array}$ \\
\hline Ana Gabriela Viso & $\begin{array}{l}\text { Desarrolla su actividad docente en } \\
\text { orfebrería en el Parson Institute. Nueva } \\
\text { York. USA. }\end{array}$ \\
\hline Cristina Giralt & Caracas, Distrito Capital. \\
\hline Elizabeth Salim Cruz Bajares & Caracas, Distrito Capital. \\
\hline Edymar Älvarez & Caracas, Distrito Capital. \\
\hline Gabriela Urdaneta & Caracas, Distrito capital. \\
\hline Gersenda Suárez & Valencia, estado Carabobo. \\
\hline Isabel Tinoco & Caracas, Distrito Capital. \\
\hline Julia Ferreira & $\begin{array}{l}\text { Caracas, Distrito Capital y México DF, } \\
\text { México. }\end{array}$ \\
\hline Leonor Austria & Caracas, Distrito Capital. \\
\hline Lucía Ramírez & Valencia, estado Carabobo. \\
\hline María de los Ângeles Flames & $\begin{array}{l}\text { En la actualidad ofrece Diplomado en } \\
\text { Diseño de joyas. Mérida, estado Mérida. }\end{array}$ \\
\hline María Isabel Mayorca & Barquisimeto, estado Lara. \\
\hline María ValezKa Quintero & Caracas, Distrito Capital \\
\hline Maritza Alayón & $\begin{array}{l}\text { Caracas, Distrito Capital. } \\
\text {-Desarrolla la actividad docente en los } \\
\text { cursos ofrecidos por la “AVAF", durante la }\end{array}$ \\
\hline
\end{tabular}




\begin{tabular}{|l|l|}
\hline & $\begin{array}{l}\text { celebración del “SNAF" en la ciudad de } \\
\text { valencia, estado Carabobo. }\end{array}$ \\
\hline Simón Sorondo & Argentina. \\
\hline Soledad Castro & Caracas, Distrito Capital. \\
\hline Sonia Parisca & Caracas, Distrito Capital \\
\hline Venezuela Rocca & Caracas, Distrito Capital. \\
\hline
\end{tabular}

Como se puede comprobar, una cantidad considerable de orfebres formados por Alexis De la Sierra, se dedican a la enseñanza de la disciplina ${ }^{203}$. Estos datos ponen en evidencia cómo la enseñanza de orfebrería en el país resulta bastante lucrativa.

Aunque resulte una disciplina bastante costosa, cada vez son más los venezolanos que se interesan por este arte milenario y su formación repercute en ingeniosas obras. En muchos casos se aprecia cómo han sustituido algunos metales nobles por materiales más asequibles sin que las joyas pierdan su función ornamental; aunque existe, el caso opuesto en que los metales nobles son utilizados como un elemento escultórico, ya que por sus características pierden la función de joyas.

\subsection{PRODUCCIÓN ARTÍSTICA. Evolución hacia la orfebrería escultórica. Generalidades.}

En este apartado del trabajo de investigación se muestra cómo ha sido la evolución en su producción artística tanto en Orfebrería como en Escultura. Para ello, se toman en cuenta una serie de factores que han influido de manera significativa por lo que se considera necesario explicar a continuación.

Del estudio minucioso de la obra del artista Alexis De la Sierra, hemos podido evidenciar una serie de aspectos que han condicionado su producción artística. Estos aspectos tienen que ver con el material al cual recurre, a las técnicas que aplica, al diseño que establece, al tema que lo inspira, al formato en el cual decide operar, pero sobre todo al énfasis sobre el detalle en el acabado de cada pieza. En tal sentido, es importante destacar dichos aspectos ya que a través de éstos, ha podido establecer un lenguaje plástico que lo caracteriza como un excelente orfebreescultor; así pues, para poder analizar cómo ha sido su evolución artística, fue necesario agrupar las obras tanto en orfebrería como en escultura tomando en cuenta los aspectos mencionados puesto que en muchos casos una disciplina condiciona y nutre a la otra.

Este artista estableció un proceso metódico con el cual lleva a cabo todas sus obras. Este proceso, tiene que ver con la evolución

203 Pervilhac, I. (2008). "Dirección de contactos alumnos Escuela de Orfebres ADS".

Material inédito. Correo electrónico. artmanager@delasierra.com 
de cada una de ellas; esta evolución, no es más que las variaciones derivadas de un modelo determinado. En tal sentido podemos afirmar, que estas variaciones han resultado trascendentales en toda su producción y el artista las ha denominado "Familia de Obras" (F/O). Estas familias, dan origen a otra; inclusive, se da el caso en que una F/O en orfebrería origina una $\mathrm{F} / \mathrm{O}$ en escultura o viceversa; esta versatilidad, se debe a que es orfebre y escultor y por ello, tiene la facilidad de cambiar de un formato al otro sin que se pierda su condición. De igual importancia, recalcamos que las variaciones de una $F / O$ no necesariamente transcurren en un mismo lapso de tiempo; pues, se dan casos, que han surgido variaciones de una F/O mucho tiempo después de las primeras.

Resulta Interesante conocer estas F/O tal cual fueron concebidas ya que, en algunos casos aparentemente no existe conexión entre una familia y otra. Con esto no queremos decir que hay que conocer como ha sido su evolución para poder entender su producción. Sin embargo, consideramos importante conocer dichas variaciones para apreciar con convicción sobre su fisionomía.

Es de igual importancia destacar que en la producción artística de Alexis De la Sierra, no existe un diseño específico con el cual se identifique su autoría, ya que su obra es muy variada y no se encasilla en un sólo estilo, técnica, material o formato. Sin embargo, existen rasgos que se mantienen como constante en su producción, por ejemplo en la orfebrería conseguimos el uso recurrente de la plata pura, la simetría entre sus formas, la luminosidad de su superficie por medio de la pulitura extrema y el impecable acabado en su semblante. Sin embargo, mas adelante mostraremos gran parte de su producción agrupada cronológicamente según su condición: ornamental, utilitaria o escultórica.

3.4.1 PRODUCCIÓN EN ORFEBRERÍA. Aspectos técnicos, formales y conceptuales. Valoración personal.

Tal y como comentamos acerca del proceso de cómo ha conseguido las variaciones y generado otras familias de obras, a continuación hablaremos brevemente sobre los aspectos más importantes de las técnicas a las que recurre según el material que utiliza y el semblante del cual se apropia; sobre las formas y los formatos utilizados; así como también, la temática y el concepto con el cual fundamenta sus propuestas, tomando en cuenta su cronología por lo que a continuación mencionaremos los años de su ejecución. 


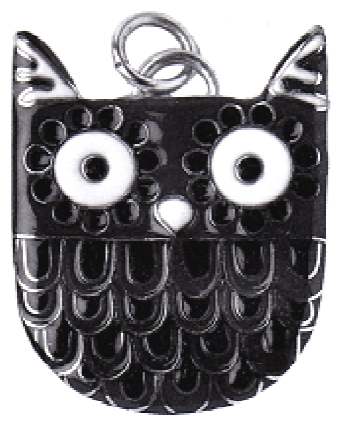

Alexis De la Sierra se introduce en el campo de la orfebrería en el año 1970 con apenas catorce años de edad. Para ese entonces realiza una serie de joyas donde pone en práctica los esmaltes al fuego.

Este dije del Búho (IMAGEN 233) confeccionado en su totalidad con esmaltes al fuego sobre plata pura, expresa la

Búho destreza del orfebre; ya que, el diseño figurativo escogido resulta técnicamente laborioso. El artista escogió para este diseño tres tonos de esmaltes, consiguiendo con dos de ellos cierto degrade tonal que conforma la totalidad de la figura; los finísimos hilos de plata laminada -especiales para el cloisonné- , colocados simétricamente uno al lado del otro, permiten que en su interior se fundan los esmaltes sin producir oxidación en sus bordes, consiguiendo con ello, un diseño de bello contraste, resaltando la plata brillantísima sobre su superficie. Este diseño es uno de los pocos figurativos elaborados por De la Sierra.

En el año 1976 se introduce en el campo expositivo venezolano; participa con ocho piezas en plata 1000 entre brazaletes y collares en el "Primer Salón de la Nueva Orfebrería Venezolana", celebrado en el Museo de Ciudad Bolívar, en la ciudad de Puerto Ordáz. Esta exposición resultó un verdadero impulso para el joven De la Sierra, pues, de los 12 participantes solo él, es orfebre ya que el resto del grupo, se trata de artistas plásticos con cierta trayectoria en las artes venezolanas de ese entonces que se encontraban de paso en la disciplina de la orfebrería; obviamente, hecho este, fue beneficioso para ambas partes; para Alexis de gran significación pues, a partir de ese momento comienza a mostrar interés en la escultura, lo que poco tiempo después fusiona con su orfebrería.

Brazalete (IMAGEN 234), es una de esas hermosas piezas con las que Alexis De la Sierra participa; en ella, se observa cómo el artista recurre a la técnica del laminado, la formación a martillo, y el engaste. La inclusión de los cuatro alargados trozos de marfil tallados idénticamente, constituye el diseño simétrico donde contrasta sutilmente la tonalidad opaca del marfil

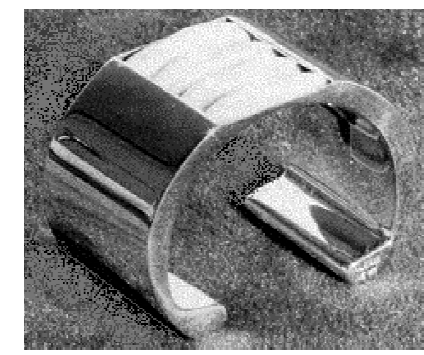

Brazalete con la superficie lisa de plata extremadamente pulida. La formación a martillo del brazalete demuestra la pericia en esta técnica, ya que la impecable factura, no muestra indicios de maltrato ante la amplia superficie pulida. 
Por meritos curriculares Alexis De la Sierra obtiene una beca de estudio de parte del gobierno venezolano y se traslada a Chile a la Pontificia Universidad Católica de Chile para estudiar Artes plásticas en las menciones de Escultura y Color. A partir de ese entonces, De la Sierra es orfebre y escultor; cada una de estas disciplinas enriquece y nutre a la otra. Tomando en cuenta ambos criterios, el artista se deleita en estudiar y aplicar innumerables permutaciones matéricas, volumétricas, donde desarrolla en paralelo joyas y esculturas y obviamente joyas con semblante escultórico.

Para el año de 1978 entra en una etapa de transición desde la orfebrería a la escultura, pero no es sino un año después que presenta sus primeros trabajos desarrollados bajo este concepto.

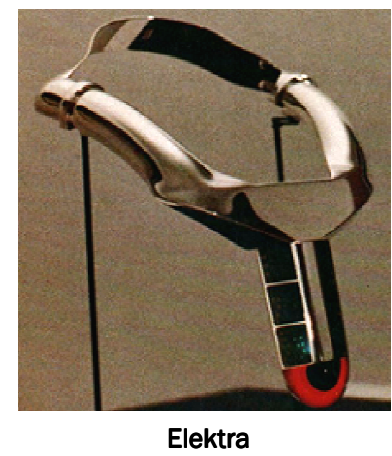

IMAGEN 235

Ya en el año 1979, se aprecia cómo sus joyas adquieren otro carácter debido a la integración de materiales y elementos poco usados en ellas. Elektra (IMAGEN 235), es una joya elaborada en lámina de plata esterlina formada a martillo, con circuitos (led) de luces alternas que se fundamentan en el centro del pectoral. Esta joya consta de siete pantallas lumínicas elaboradas con resinas de poliuretano pigmentado, donde se encuentran ensamblados los circuitos electrónicos; el dominio técnico se hace apetecible ante la impecable factura. Esta joya electrónica novedosa, presenta un diseño vanguardista, donde la substitución de las piedras por elementos lumínicos, le aporta un semblante extraordinario de formas armónicas, sin descontextualizar la joya en sí. Elektra pone de manifiesto como su creador fusiona orfebrería y escultura gracias al estudio de la integración de la luz en el objeto. A partir de ese momento su producción artística se basa en la convergencia de técnicas y metales de la orfebrería con técnicas y materiales propios de la escultura; esta fusión, es la que caracteriza su particular (Orfebrería Escultórica).

En el año 1980, retoma la investigación del cloisonné centrándose en arte bizantino y elabora un conjunto de collares; los cuales demandaron más de un mes y medio de trabajo. De la Sierra destaca la riqueza y sinuosidad de los mosaicos de este bello estilo, en fascinantes tonalidades verdes, cuyo diseño se traslada al arte de la

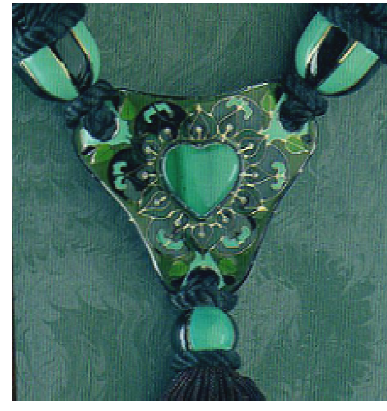

Amazonia 
orfebrería. El collar Amazonia (IMAGEN 236), lleva en su centro engastado con oro, un corazón de malaquita. A su alrededor, en puntos equidistantes, están fusionados dentro del esmalte doce chispas de brillantes; los óxidos vítreos de tonalidades verdes, se encuentran fusionados sobre toda la pieza de plata esterlina, encasillados entre finísimos hilos de cloisonné de oro de 24 quilates; sus formas orgánicas, contrastan con el formato triangular que lo compone. Esta pieza constituye el enorme dije de un collar, elaborado con cordones de seda de color negro; cordones éstos, tejidos en macramé por el propio artista. A partir de ese momento, el macramé se verá como constante en su producción.

Centrado en la investigación sobre la fusión de la orfebrería con la escultura, elabora un conjunto de cinco obras en mediano formato titulados Proyectos escultóricos (IMAGEN 237). Entre bronce y cobre se despliega una sustancial trasformación por medio de la cera perdida, engastes, formación a martillo, esmaltes al fuego y baños electrolíticos en oro. Su variada tipología surge de la simetría entre el círculo, el cilindro y el cuadrado. La mano experta de De la Sierra, modifica su estructura para lograr estas interesantes obras. Cada una de ellas, exhibe detalles perfectos entre cúpulas, cavidades, pliegues y superficies planas con una fascinante capa de oro amarillo que las cubre en su totalidad; exceptuando obviamente, las figuras esmaltadas. Esmaltes éstos entre el blanco, negro, turquesa, azul rey, amarillo y rojo, se exaltan con elegancia entre el impoluto oro amarillo del resto de la superficie. Bellos bloques macizos de caoba exhiben cada una de las obras.

Este fascinante conjunto de obras, resultaron ganadoras del Premio en la tendencia de Orfebrería del "SNAF" en el año 1980.

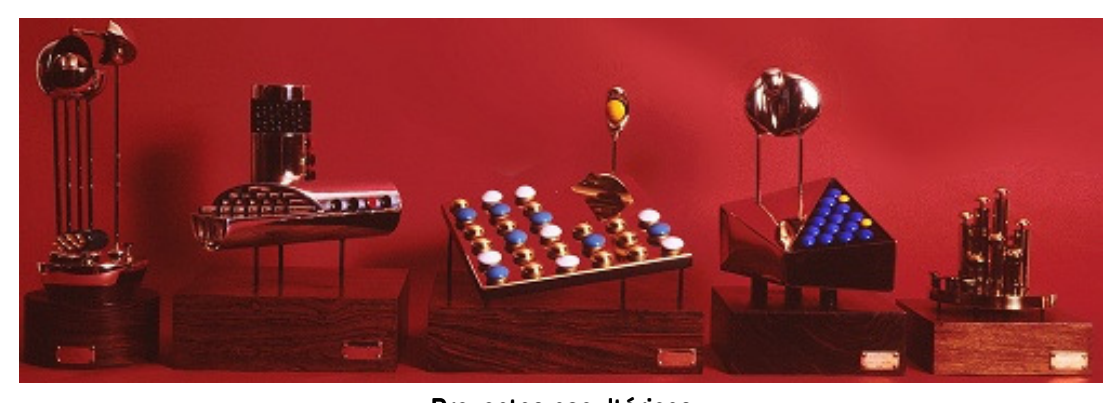

Proyectos escultóricos
IMAGEN 237

En el año 1981 centra una parte de su producción a la elaboración de un conjunto de collares. En esta oportunidad se siente influenciado por una actriz del comic, Bianca Castafiore; cuya superficialidad y respeto por las joyas, confiere en él cierta afinidad hacia el ámbito de la ornamentación. 


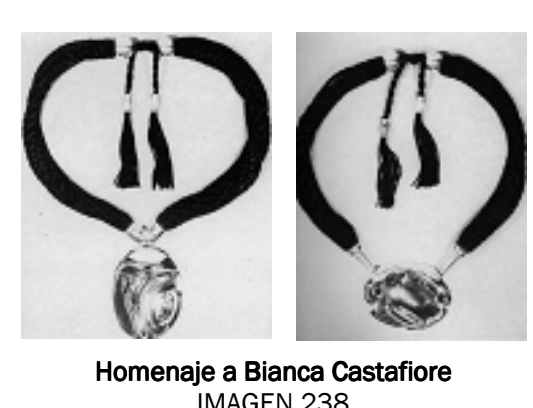

IMAGEN 238

Al parecer, a Bianca le produce placer lucir joyas y a De la Sierra, elaborarlas; de ahí nace la idea y bajo este contexto ilusorio, realiza dos collares que titula: Homenaje a Bianca Castafiore (IMAGEN 238); realizados en plata 1000.

Para ello recurre a la técnica del modelado en ceras blandas, pues material este, le permite alcanzar formas ondeantes que al ser vaciadas en plata se aprecien con la misma naturalidad. Con premeditación, la altura de la superficie ondulada permite emplear un sistema de articulación de donde se aferra el imponente cordón en macramé de color negro. Este conjunto de dos collares exquisitamente trabajado, se convierte en la obra ganadora del Premio en la tendencia de Orfebrería en el "SNAF" del año 1981.

Hacia 1983 toma como referencia el collar Elektra y realiza un conjunto de cuatro pectorales; la escogencia del aluminio y estaño como material de base no es trivial, puesto que en esta ocasión sus pectorales adquieren mayor formato y el peso del metal es determinante. Alexis de la Sierra, sin darse cuenta, con esta serie comienza un proceso metódico con el que obtenía variaciones de un diseño de este modo, nacen las Familias de obras (F/O), las cuales se revelan en toda su producción artística. En tal sentido, la $\mathrm{F} / \mathrm{O}$ de los pectorales de aluminio, se presentan en diseños particulares, con una tendencia -tipo canesú- tal y como usaban los faraones egipcios pero con un estilo futurista; unos pectorales cubren el cuello completo, en cambio en otros, el cuello queda al descubierto.

En el Pectoral de aluminio I (IMAGEN 239) se conjuga el proceso manual de la formación a martillo; dos enormes solapas idénticas de aluminio, se unen a un ovalo seccionado por medio

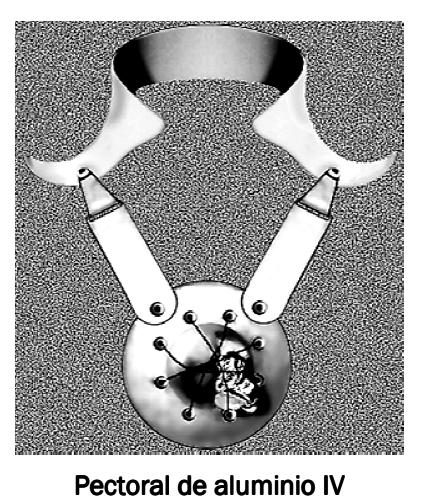

Pectoral de aluminio IV IMAGEN 240 de diez

bellos remaches.

Detalle este, permite adaptar las caprichosas y grandes formas al cuello y torso de quien lo use.

En el Pectoral de aluminio IV (IMAGEN 240), que forma parte de este conjunto, el diseño se adapta al contorno del

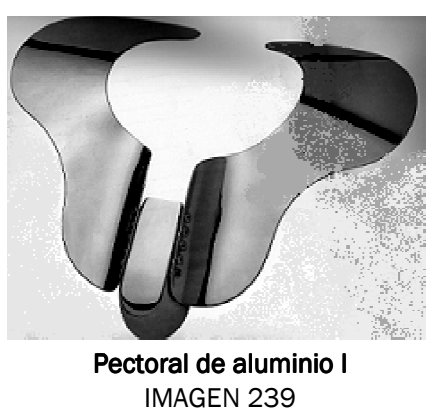

IMAGEN 239 
cuello y torso sin dejar espacios abiertos. El sistema de unión entre sus partes, contiene remaches desmontables para su apertura/cierre y movilidad, para adaptarse cómodamente al cuello. Este diseño formado a martillo, esta fraccionado entre cuatro piezas; el primero de ellos, ostenta principalmente un cuello de traje de etiqueta el cual se sujeta una pieza circular embutida y satinada a través de dos anchas láminas. El equilibrio entre el brillo exagerado de la superficie metálica, contrasta sutilmente con detalles satinados logrados por la acción del arenado. Este conjunto versátil de pectorales con semblante futurista y reminiscencias antiguas, fueron merecedores de un Premio en la tendencia de Orfebrería en el "SNAF" en el año 1983.

"Sea cual sea su vinculo con la historia más remota, su obra se recubre de elementos, signos y formas que nos sugieren una nueva era de la humanidad. Poderosas referencias antiguas, templarias y metafísicas conforman una iconografía futurista, omnipresente en su obra. La aplicación y técnicas de otras disciplinas artísticas con aquellas propias de la orfebrería constituyen la esencia de su obra"204.

Aprovechando, el entusiasmo del premio en el "SNAF" y el proceso metódico de las $\mathrm{F} / \mathrm{O}$ aprovecha para realizar variaciones de los collares que realizo en homenaje a Bianca Castaffiore. Recurre a la plata esterlina para el collar y plata 1000 para del dije, obviamente el uso de la plata pura en el bello ovalo, determina el uso de las técnicas de extrusión; pues, las bondades del metal sin aleación resultan apetecibles para la consecución

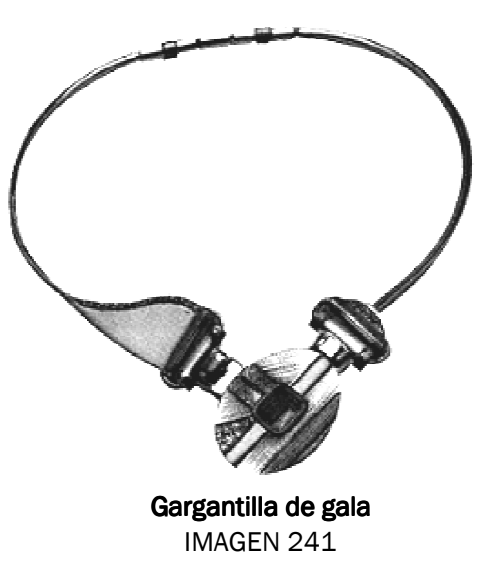
de texturas extraordinarias.

De este modo, el artista realiza bajo un estilo geométrico con fuerte presencia minimalista, la Gargantilla de gala (IMAGEN 241) cuyo diseño de vanguardia se impone ante el empleo de fragmentos de texturas lineales obtenidas mediante la extrusión mecánica. La rigidez de la parte central de este dije, está resuelta por medio de un sistema de bisagras, el cual aporta movilidad apropiada para su ajuste en el cuello de quien la use.

204 García, M. (2010). “Alexis De la Sierra Orfebrería sin límites”. Revista. Arte facto (Edición Especial). № 3. p: 036. 
De la Sierra recurre a la inclusión de chispas de brillantes engastadas minuciosamente en la superficie de la lámina y el imponente topacio facetado de talla rectangular dispuesto en el centro del ovalo, se aferra tenazmente entre las paredes del engaste de bisel. Ovalo este, demuestra la perfección técnica ante la simetría impoluta que lo establece.

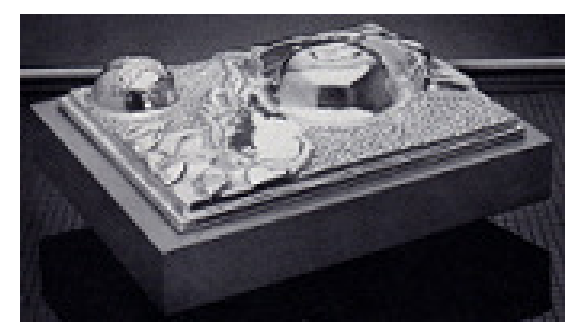

Le Jardín des délices IMAGEN 242

En 1984 reincide sobre la orfebrería escultórica y somete al metal con ciertas técnicas para alcanzar un semblante más artístico, en la obra le Jardín des délices (IMAGEN

242), recurre a una base de madera sólida de donde surge una superficie colmada de texturas. Texturas éstas, emergen de una gruesa lámina de plata. Para este proceso de experimentación, resultan como aliadas las técnicas del martillado, el embutido y el reticulado.

En el año 1985 motivado por las variaciones que dan origen a las F/O decide dar inicio a una familia de brazaletes. Para ello, se fundamenta en el brazalete elaborado en el año 1976 -(IMAGEN 181)-, procede con convicción ante este nuevo semblante.

El bello Brazalete (IMAGEN 243), en plata pura cuyo aspecto demuestra la delicadeza y elegancia entre el diseño, las piedras preciosas y el contraste entre el brillo de la plata y el oro amarillo. Mantiene como constante, la superficie plana de plata formada delicadamente a martillo; cuyo brillo extremo, contrasta con la franja en bajo relieve satinada de plata que la atraviesa diagonalmente. Detalle este

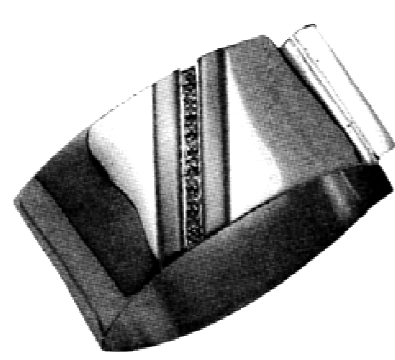

Brazalete

premeditado, es usado para explayar en su mitad una bella lámina de oro amarillo, en la que se aferran dieciocho espectaculares brillantes. El detalle minucioso y preciosista alcanzado con la inclusión de estos brillantes engatados al ras de la superficie dorada, enfatizan el carácter preciosista de este diseño elegante con un toque de vanguardia.

En el año 1986 en paralelo a otras creaciones, se introduce ante el estudio de las formas de los cuatro elementos del universo: agua, fuego, aire y tierra. 


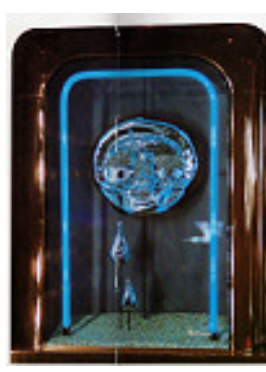

La búsqueda de la tridimensionalidad no cesa, se sumerge en una fase de experimentación e introduce nuevamente en su léxico creativo la luz artificial. Un delicado tubo de neón azul, hace alarde en un nicho construido en acrílico y madera a una subjetiva mascara de plata. Como una pequeña escenografía la obra Monumento a la soledad (IMAGEN 244), se fundamenta desde

el sentimiento de la tristeza, por eso las Monumento facciones del rostro expresan entre sus formas
un semblante tosco, sin embargo las lágrimas a la soledad que corren de su rostro se convierten en gotas de plata con fascinantes halos de luz de amatistas que yacen en su interior. Amatistas estas talladas en forma de lágrimas exaltan su belleza entre el reflejo del azul de la luz del neón.

El efecto lumínico es imprescindible, pues, al incidir sobre el rostro embutido y la superficie de las piedras, exalta más aún los detalles y matices generando discrepancia entre lo ilusorio y lo real.

En la segunda representación titulada Desencarnación y sublimación (IMAGEN 245), se fundamenta en la alegoría sobre la vida después de la muerte. Se hace evidente en los dos rostros moldeados con tesón y cadencia del martillo, como se desvanecen sus facciones en su actitud de levitación; el arco lumínico azul dispuesto en frente del nicho, los encierra y delimita dentro de ese pequeño recinto, como si se tratase del portal que da entrada a lo etéreo. Las cruces ubicadas en la parte inferior nos sugieren lo terrenal, donde yacen sus restos.

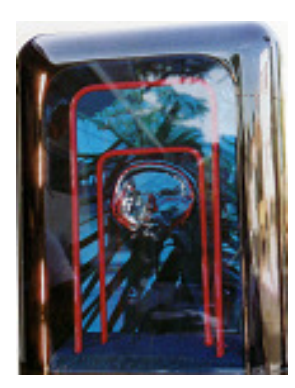

Un año después el artista retoma estas obras para que se fundamenten en una F/O de tres representaciones. En oposición al concepto original, de tristeza o sublimación, realiza en homenaje al Cuarto del Infierno de Dante Alighieri y representa esta alegoría con el título de El portal del infierno (IMAGEN 246). Subordina la escena, con dos arcos de luz de neón de color rojo y desde su centro, emerge un

El portal del infierno rostro en levitación, su forma embutida, cas redonda, sugiere la analogía del punto de fusión del metal: pues en éste momento, el metal en estado líquido se recoge en una bola. Por ello, De la sierra aporta esta apariencia en el rostro que yace en medio del fuego del infierno y expresa con su semblante, como su rostro va poco a 
poco desvaneciéndose entre el sofocante calor. Este nicho tiene la particularidad de estar hueco; su fondo en transparencia, permite que el rostro en levitación dentro de él, cree la ilusión del caos.

Ya hacia finales de los años ochenta, su léxico creativo transita en paralelo y conjuntamente entre orfebrería y escultura; ambas tendencias, se nutren y complementan fundamentándose en un mismo lenguaje que toma cuerpo y volumen entre metales nobles, mármol, cristal, madera y luz; pues, la integración de estos materiales, caracteriza su autoría y por ello se le considera como escultor de la plata y escultor de la luz. Su praxis heterogénea emotiva y de carácter preciosista, es reconocida por críticos de arte, museos y grandes coleccionistas; sin embargo, en una ocasión una de sus obras causó revuelo en el "Salón Michelena". Se trata de la obra Arco de los Cinco Sentidos (IMAGEN 247) presentada en dicho salón en 1989 -la obra fue rechazada por el reto a los

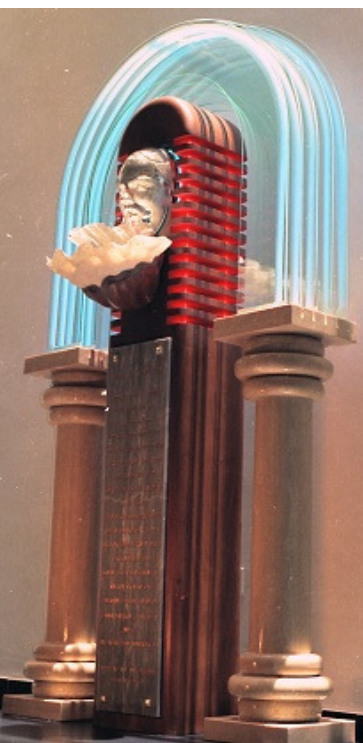

Arco de los cinco sentidos IMAGEN 247

"Rectores del Arte" que constituye el texto grabado en la placa de mármol-, ubicada en frente, que dice así:

\title{
Rectores del Arte
}

\author{
...Venid a purificaros en mi fuente \\ despojaos de todo perjuicio \\ dejad que la luz emanada \\ por los cinco arcos de los sentidos \\ ilumine los vuestros \\ acercad vuestros secos labios \\ a mi cristalina agua \\ y calmad vuestra sed \\ os devolveré la inocencia del niño \\ os acariciarán las alas de los ángeles \\ y seréis agraciados \\ con el perdón del artista...205.
}

Quizá su manera astuta de reprochar los procesos de selección en los salones de arte -en Venezuela- caló hondamente entre los jurados.

205 Pervilhac, I. (2010). "Arco de los 5 sentidos/4 imágenes X WB". Material inédito. Correo electrónico. delasierra@cantv.net 
Esta obra se fundamenta en gran formato y reúne varias disciplinas, entre ellas la orfebrería; siendo esta, el elemento central de la obra. Su rostro vaciado en estaño y cubierto por una capa de plata pura expulsa agua de sus labios que cae dentro de una fascinante concha marina de plata, cincelada y repujada; tiene un sistema de bombeo y reciclaje que expulsa el agua y hace que circule nuevamente. Debajo de esta, se encuentra una enorme concha de mar -natural- con arena blanca que constituye la simbología de la pureza. Detalle central este se encuentra en medio un enorme bloque de mármol gris tallado con profundos cortes lineales en sus lados, en la parte superior de donde sale una luz roja y en la parte de abajo se encuentra la plata con la inscripción del texto Rectores del Arte grabada y laqueada en su superficie. Dos bellas columnas de mármol travertino pulido, se ubican a los lados de la obra central y un bello arco lumínico de cinco cristales con la inclusión de luz neón azul claro, custodian e iluminan toda la obra.

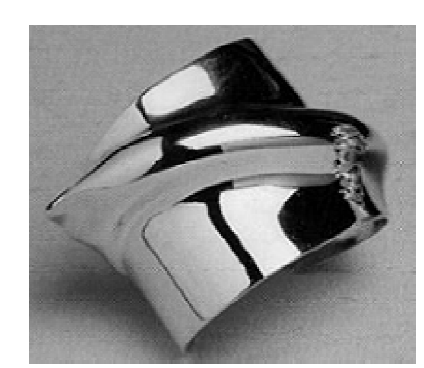

Brazalete escultórico IMAGEN 248

Para Alexis De la Sierra no importa el tiempo que transcurra entre las variaciones de sus $\mathrm{F} / \mathrm{O}$, por ello va $\mathrm{y}$ viene con total libertad, aprovecha de cada época lo que le interesa. Así sucede con la familia de los brazaletes, pues, continúa sus variaciones considerando el movimiento del agua, por eso a partir del Brazalete escultórico (IMAGEN 248) incluye un detalle convexo en contraposición a la totalidad plana del diseño inicial. Recurre al modelado en cera y su posterior vaciado en plata, para que adopte esa nueva forma con mayor libertad. Esta F/O sobrepasa las cuarenta variaciones y cada uno de ellos, va exhibiendo un detalle diferente en su semblante. En este brazalete, resalta el detalle de un entramado de hilos que se adhieren a la forma abultada que surge de la planicie brillante de plata, simulando una burda sutura que aporta cierto sincretismo entre lo delicado y lo rudimentario.

En este otro Brazalete escultórico (IMAGEN 249), surge la yuxtaposición de una lámina sinuosa que sobresale por toda su mitad; la superficie mate de esta, consigue toda la atención en su seductora forma para atraer la mirada aun más, en el impoluto brillo de su canto. Contraste este, amilana la rigidez de la base del brazalete.

El volumen es inevitable en sus

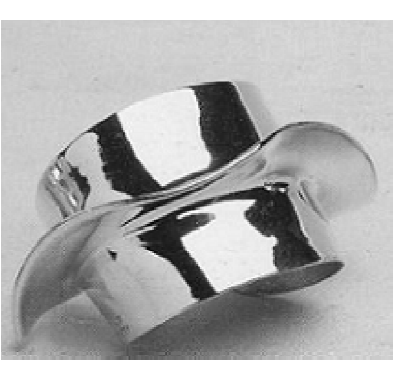

Brazalete escultórico IMAGEN 249 
propuestas, por eso Alexis De la sierra persuade los metales nobles con su gesto creador sometiendo a su antojo las caprichosas formas.

Las ondas abrazan por completo la planicie de la plata; tras la formación del volumen por medio de las ceras, consigue que poco a poco, sus formas vaciadas alcancen otra fisionomía centrándose siempre, en el estudio del movimiento del agua.

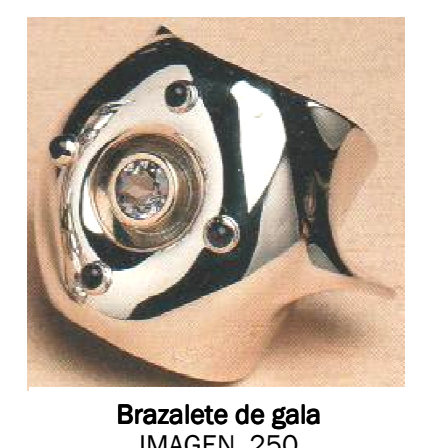
Brazalete de gala

Por ello, la sinuosidad de esta abultada forma se convierte en una espectacular joya, Esta nueva apariencia transmite en el Brazalete de gala (IMAGEN 250) una variación particular. En él, la cera modelada con el calor de sus manos, manifiesta su sensibilidad ante este dúctil material y su destreza de orfebre irrumpe en su superficie para engalanarla con estas bellas piedras. Nuevamente, la simetría impera en sus diseños; en su centro, pernocta una amatista redonda facetada cuyo engaste en oro puro trasciende sobre la superficie abultada; pues, el canal de su contorno, se introduce en el brazalete con tal pericia que permite apreciarla fácilmente desde cualquier ángulo. Cuatro bellos granates tallados en forma de bellota, custodian cautelosamente la hermosa amatista. El bello contraste entre las tonalidades de color lila de la amatista y la tonalidad del rojo vino de los granates, con el oro y la plata, realzan la estética tendenciosa del brazalete de gala.

De esta gran $F / O$ finalmente mencionaremos otro Brazalete de gala (IMAGEN 251); en él, vemos como las ondas salientes desde la superficie, se ajustan en toda la forma. Forma esta, se apropia de mayor dimensión, consiguiendo una fisionomía cómoda que se adapta a cualquier muñeca. La idónea manera de moldear la delicada lámina de cera, permite que entre sus formas se simule el ondeante movimiento del vaivén de las olas.

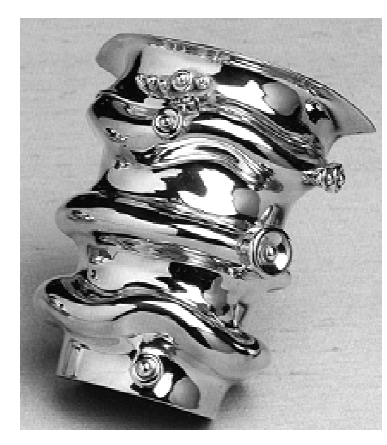

Brazalete de gala
IMAGEN 251

Una vez vaciado en plata el bello brazalete, sobre su superficie, se explayan cuentas de plata circulares y diminutos gránulos; logrando con ello, una alegoría sobre la lluvia en el mar. Pues, detalles éstos, parecieran inmortalizar el momento, de una gota de lluvia al caer sobre la superficie de las olas. La dimensión 
exagerada no es casualidad; ya que por convicción, se adentra cada vez más al formato escultórico.

Volviendo al desarrollo de los pectorales, parte de la plata pura como ente expresivo; por ello recurre a la técnica de la cera perdida, pues la maestría que posee en el modelado y talla de ceras le permite alcanzar detalles impecables, por eso no escatima tiempo ni esfuerzo en el proceso, ya que esto le garantiza un semblante perfecto al ser vaciado en plata. Esta nueva $\mathrm{F} / \mathrm{O}$ de cinco pectorales, nace de la alegoría a la diva Castafiori; motivo por el cual, ya había realizado dos collares en el año 1981.

En el pectoral Le premier plaisir d'argent (IMAGEN 252) retoma el diseño central del ovalo donde diminutos gránulos lo cubren en gran parte; logrando con ello, una apariencia delicada que contrasta con la base lisa y pulida. Los canales de plata simétricamente alineados, bordean y constituyen el todo con premeditación; de sus extremos, salen dos bellos tejidos en seda negra formando el bello collar. Este conjunto se hace acreedor del Premio Nacional de las Artes del

Le premier plaisir Fuego en la edición del año 1986.

d'argent

Como tributo a la mujer; esta vez, se inspira en dos grandes damas de otra época: "Madame de Pompadour", sabia consejera y ferviente amiga de Luis XIV y "Madame de Récamier", actríz de gran encanto en los salones parisinos, sinónimo de picardía, elegancia y gracia femenina. Continúa la $\mathrm{F} / \mathrm{O}$ hasta alcanzar los diez pectorales. En Le dixième plaisir d'argent (IMAGEN 253) se percibe cómo el detalle de los gránulos se apropian de toda la superficie; obviamente que la cera perdida es su mejor opción, puesto que, la facilidad de adherir los

gránulos al diseño previamente en la cera ya modelada, conviene con demasía para alcanzar el lustre impecable de su superficie sin que

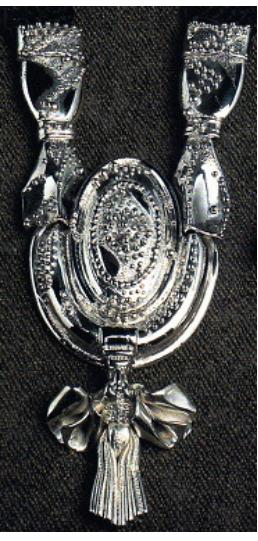

Le dixième plaisir d'argent
IMAGEN 253 estos se suelten.

Centra su producción en el estudio del origen de la vida, se interesa por el simbolismo de los elementos que tienen que ver con la creación de la vida. Incorpora en su léxico creativo una nueva fisionomía basada en formas reconocibles de este contexto. Bajo esta premisa, inicia un ciclo en el que realiza una $F / O$ donde sugiere con pequeños volúmenes de plata pura formas 
biomórficas que se fundamentan entre broches, pendientes y hebillas de cinturón.

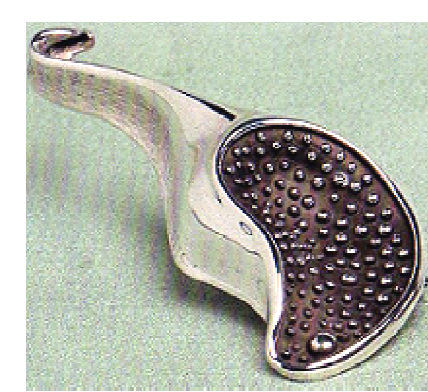

Broche- pendentif escultórico IMAGEN 254

En el Broche-pendentif escultórico (IMAGEN 254), se aprecia cómo en su interior brotan bellos gránulos, que se convierten en células portadoras de vida. En esta familia de obras cada forma, cada pieza, cada gránulo, inicia un mundo de posibilidades. El recurso técnico del granulado sobre su superficie ennegrecida deliberadamente genera un estremecedor contraste, que los resalta como si estuvieran dispuestos a fecundarse. Esta serie, es una de las pocas joyas en plata que De la Sierra interviene con pátinas para ennegrecer su superficie ya que asiduamente busca con sus joyas la luminosidad del brillo del metal.

Del proceso del modelado en ceras blandas, nace otra posibilidad. El doblez intencional percibe el gesto descargado de la mano del artista; transformando su superficie con arrebato y gran seguridad. Así nace la F/O de dieciocho hebillas. La Hebilla escultórica (IMAGEN 255) es una de estas interesantes propuestas como complemento de la vestimenta. Cuyo diseño representa la evolución de la célula, ya engendrada, invadiendo lo que toca; la fecundidad en su máximo

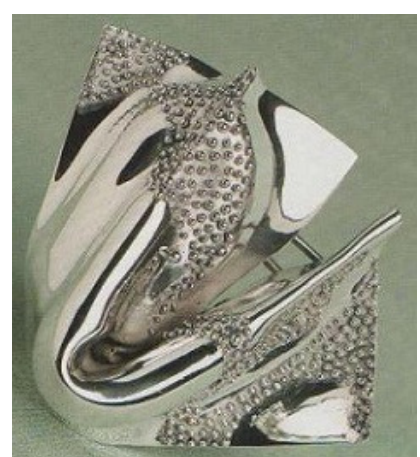

Hebilla escultórica IMAGEN 255 esplendor.

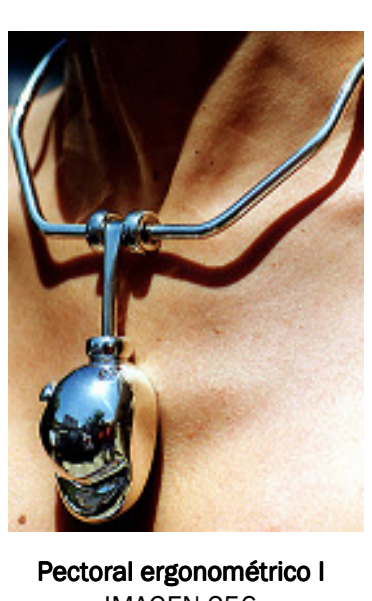

IMAGEN 256

En el largo transitar de la vida artística de De la Sierra, sus obras evocan diversos temas; la magia y la religión son uno de ellos ya que para él representan una fascinación desde que era muy joven, pero no es sino hasta 1989 cuando decide involucrarse en este tópico.

Dentro de la $\mathrm{F} / \mathrm{O}$ de pectorales se encuentra esta nueva serie ergonométrica cuyo diseño se proyecta hacia las joyas de una mujer interplanetaria. En el Pectoral ergonométrico I (IMAGEN 256) observamos como depura los rasgos del 
aro, dejando que la sobriedad del hilo redondo protagonice la tendencia futurista. Este nuevo diseño integra el collar en hilo de plata substituyendo el tejido del macramé. El brillo exagerado de su superficie, define esta sugestiva serie con volúmenes exagerados que mezcla elegancia con modernidad.

El estudio sistemático del óvalo se depura hacia la transformación en una sutil línea. Rasgos minimalistas se apropian del Pectoral micro esferas (IMAGEN 257) donde la sobriedad del diseño no deja concesión para otro elemento; pues, un único dialogo entre el delicado hilo que abraza el cuello y la sutileza de su estructura del dije aferrada a él, sugiere un sensual juego entre delicadeza y rotundidad. Las tres líneas salientes centran la mirada en sus perfectas pequeñas esferas que son el plato fuerte de esta

propuesta; los detalles satinados de su superficie, contrastan elegantemente delegando en su semblante un aire de vanguardista.

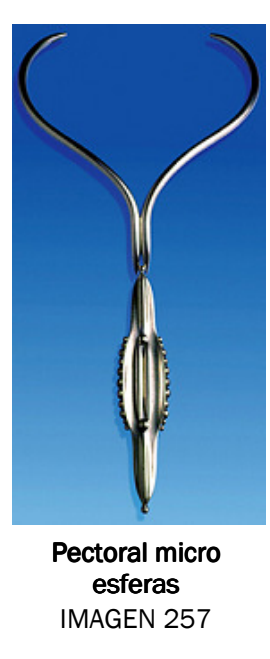

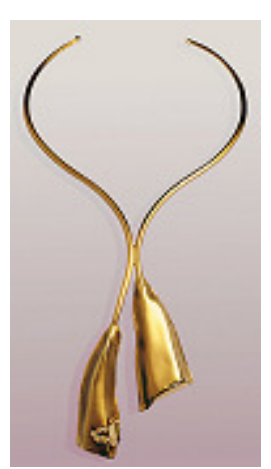
Lirios y gianduia

Las variaciones siguen rindiendo frutos en su producción, esta nueva concepción del pectoral plantea la belleza y sutileza con la sencillez del detalle. Lirios y gianduia (IMAGEN 258) elaborado con un semblante preciosista y exquisito destaca las formas de la naturaleza entre dos finísimos y largos pecíolos en oro 22 quilates. Pecíolos estos, desmayan sobre el cuello de una dama y un pequeño roce entre ambos, obliga el punto de bifurcación entre

estos dos hermosos lirios. Como una enorme gota de rocío, destella un fascinante brillante engastado en pavè sobre la superficie de oro.

La disposición de los dos lirios orientada hacia abajo, representa el inicio de su descomposición; ese momento ineludible, es representado por De la Sierra con estupenda semejanza y perfección en su semblante.

Surge un encargo magistral para obsequiar la cruz al Cardenal Arzobispo Ignacio Velasco (QEPD) para usar como símbolo distintivo de su título. La Cruz Arzobispal (IMAGEN 259) es una de las primeras joyas concebidas bajo la fascinación de esta temática. En ella, se

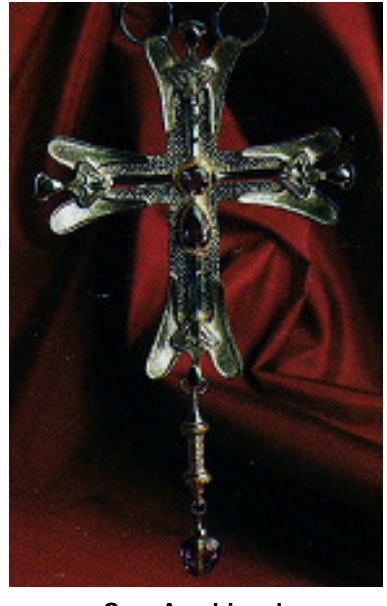

Cruz Arzobispal 
descubre cómo emotivamente el artista la elabora bajo la persuasión de la plata pura y el oro de 24 quilates. Siendo estos dos hermosos metales una unión solemne que fascina y convida a internarse en sus formas.

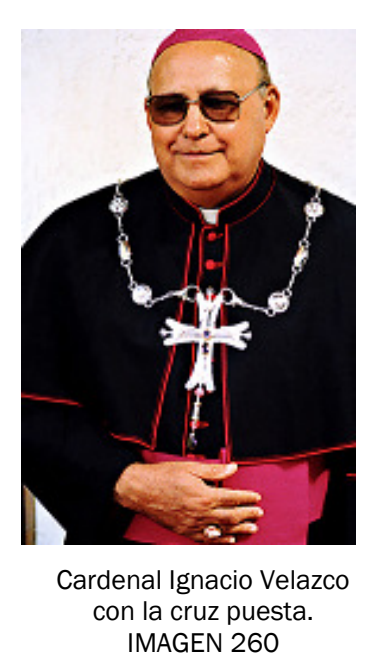

Cuatro ángeles vaciados en cera perdida, dispuestos en los cuatro puntos cardinales, son quienes constituyen esta cruz; cuya fuerza centrípeta, los une en un solo cuerpo de donde se aferran dos bellas amatistas. La abertura horizontal crea un vacío donde reposa la esencia del espíritu que pernocta en sus entrañas y el péndulo de oro que cuelga de su parte inferior, abraza delicadamente una amatista tallada en forma de corazón, dispuesta a transmitir serenidad a través de su vaivén.

$$
\text { IMAGEN } 260
$$

Las poderosas referencias antiguas, presentan una iconografía futurista en sus representaciones ya que sus diseños siempre han tenido esa tendencia innovadora Esta referencia nace espontáneamente de algún tópico y surge directamente del corazón al metal. Al parecer, surge una inspiración divina que alcanza sesiones de trabajo intenso que puede durar de 3 a 4 días y noches; sin interrupciones, sin dibujos, sin bocetos y por sobre-todo sin vacilaciones.

El enigma de lo desconocido convierte a De la Sierra en un investigador ambicioso por descubrir nuevas expresiones. De ahí nace la metáfora de objetos sacros para el encuentro con el Dios supremo entre, cruces, escapularios, incensarios, cálices, pectoral pago de promesas, péndulos; siguiendo así, en una variedad exquisita donde la orfebrería convencional ornamental se apropia de semblantes atípicos debido al argumento con el que son elaboradas. Por ello, el artista las llama orfebrería ornamental mágico religiosa.

El imponente escapulario La mansión de los elegidos (IMAGEN 261) se idealiza con esta singular fisionomía entre dos cordones tejidos en seda, de los cuales penden dos discos de plata pura. Discos éstos, perfectamente embutidos, ostentan con pulcritud una impresionante piedra de Eliat, formada y tallada en cabuchón y un fastuoso disco de cristal que encapsula tierra sagrada de Jerusalén. La bella piedra de Eliat

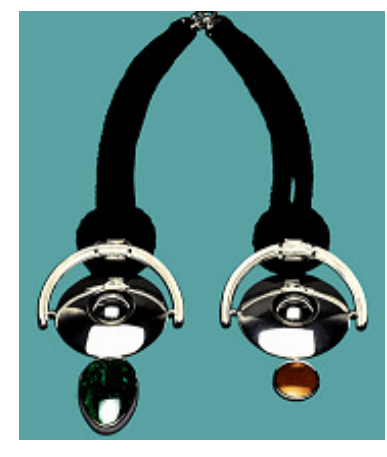

La mansión de los elegidos 
formada por artesanos israelíes, exhibe con excelencia los trozos de turquesa, malaquita y crisocola que emiten destellos de luz verde con solo girar la mirada. La pureza de la tierra sagrada hipnotiza con su sigiloso movimiento que soporta el vigor físico y mental para dar inicio al fluir energético para el encuentro con el soberano.

La multiplicidad de temas en la disciplina de la orfebrería, reúne insólitas formas que abordan todas sus producciones. Sin embargo, existe otro discurso que constituye un rol importante. Esa alteración tiene que ver con la escala donde decide manipular; por ejemplo: la escala Ilevada al plano utilitario, la cual repercute en la locación donde vaya a interactuar cuyo uso determina las formas, los materiales, la dimensión o las técnicas que amerite. De este modo, desde principios de 1990, la frialdad de la plata pura se apropia de una colección cargada de sensaciones y sentimientos sobre orfebrería utilitaria ceremonial; cuya simbología intrínseca conmemora una ceremonia nupcial. Bajo esta premisa, el artista nos deleita con una fascinante $F / O$ compuesta por siete sugerentes obras entre una bandeja porta anillos, un cetro imperial, un báculo, candelabro, así como también, tipos de luminarias.

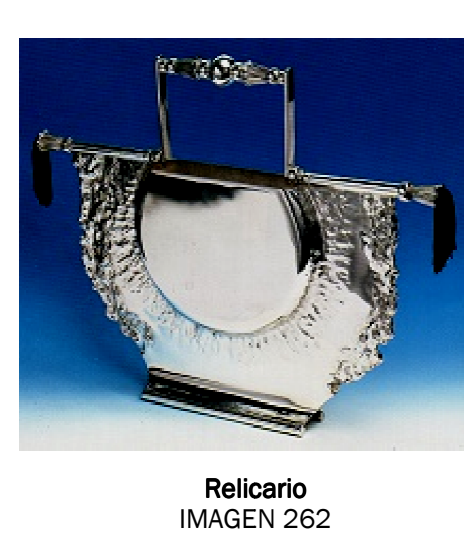

La obra Relicario (IMAGEN 262) es una de las obras de esta familia; en ella, advertimos como el orfebre De la Sierra selecciona el uso de plata como esencia sublime de todas ellas. Para esta imaginaria y fastuosa ceremonia, nos deleita con estupendos objetos colmados de detalles entre formas y texturas creadas a través de la formación a martillo y el reticulado.

IMAGEN 262

Otro ejemplar

de ese contexto tan ingeniosamente abordado, encontramos el Báculo Ceremonial de Alexis para Merlín (IMAGEN 263). Esta fascinante alegoría, nos traslada al pasado con indicios contemporáneos palpables. Pues, la teatralidad invade y se personifica en este báculo con ese osado topacio, personificado como el ojo que todo lo ve; por eso, a través de él, transfiere y dirige el poder de su energía que pernocta dentro del tubo de plata brillantísima. La fuerza de la llama del acetileno perfora y refunde la plata, dejando indicios en

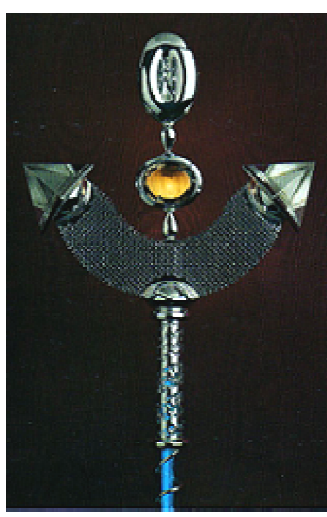

Báculo Ceremonial de Alexis para Merlín 
delgados hilos que se aferran al báculo; torneándose sobre el neón azul. Metafóricamente, el choque térmico entre la imperturbable luz y la plata fundida, se solidifica transformándose en dos pirámides de cuarzo que custodian celosamente el topacio y el bello ovalo de plata pura.

En el año 1995 el Museo de Arte Contemporáneo de Caracas Sofía Imber (MACCSI), le ofrece una exposición individual considerando que en Venezuela, su aporte ha sido trascendental para el impulso de la disciplina de la orfebrería. Así como también, la gran responsabilidad que cae sobre sus hombros por haber revivido este arte de la orfebrería, no sólo con su obra sino por haber formado en su escuela los mejores orfebres del país. En esta exposición, el artista revela claramente las etapas evolutivas por las que ha pasado durante esos veinticinco años de producción artística y reunió una variada muestra de más de 140 obras en alta joyería, que abarcan desde diminutas joyas, hasta las de orfebrería en grandes formatos que superan los dos metros de altura. Para esta celebración, De la Sierra realiza una F/O que aproveche de antesala a toda su producción, la cual fundamenta en veinticinco luminarias ceremoniales entre candelabros y candeleros.

Desde el primer momento en que el espectador se introduce en la sala, se convierte en parte de la obra ambientada teatralmente en medio de un relajante y melodioso fondo musical. La luz que sus velas encendidas emiten, iluminan tenuemente el camino, creando un espacio escenográfico muy emotivo e inclusive; indican al espectador, el camino que deben seguir para internarse en el mundo de su producción. Obviamente podemos aseverar, que estos matices histriónicos, son consecuencia de su

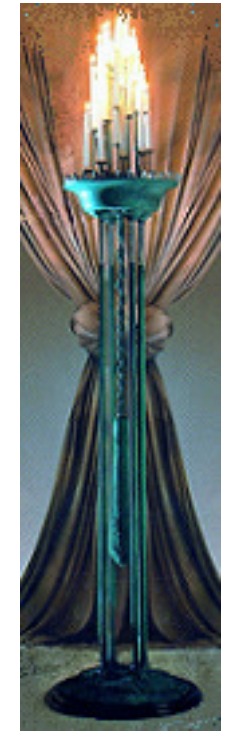

Fiat lux: XXV Aniversario contacto con el mundo de las tablas, donde la ficción y teatralidad son su mejor opción.

El proceso de la fundición donde el artista funde y forja el metal con sus manos, simboliza en ellas su fuerza descargada, dejando huella de su serhombre, de su ser-artista. La elección de estas iluminarias como antesala a su producción simboliza al fuego como portador de luz; esa luz que guía y conduce su léxico creativo. Esa luz representa la alegría, intuición, sabiduría y creación; sin este mágico elemento, no tendría sentido esa espectacular exposición. Esa familia de candelabros y candeleros tiene uno de especial significado, por ello se establece en solitario con especial particularidad. Fiat lux: XXV Aniversario (IMAGEN 264), fue realizado como emblema alusivo a esta retrospectiva, se erige I de 25 velas, 
representando cada una, los años cumplidos ininterrumpidamente de su vida artística. Las velas blancas encendidas, le confiere el rol del pebetero donde arde la llama del fuego durante esa celebración.

Sobre una base redonda de mármol negro, posa el espectacular candelabro que supera los dos metros y medio de altura206. Su ejecución llevada a cabo en bronce patinado de color verde, se constituye desde su plataforma con una textura lograda a través un refundido -similar a la que deja una vela consumida-; de esa base, salen cuatro elegantes varas vaciadas en bronce, excepto su extremo superior que finaliza en plata pura. Su disposición en puntos equidistantes, soportan la firme copa del candelabro. Desde esta copa, brotan tubos de plata que irradian la cálida luz de veinticinco velas encendidas.

De esa gran familia se elevan diez delicados candelabros, donde la plata, el cristal y el bronce patinado y la seda, crean una común unión con apariencia innovadora y exquisita. En Nautilus II (IMAGEN 265) se fusionan cualidades estéticas dispares. En su base de bronce, el proceso del refundido y su posterior pátina verde, muestra un aspecto arcaico donde la superficie rugosa, carente de brillos, contrasta con la apariencia pulcra y brillante de la plata que se destaca en su otro extremo. La superficie blanda del tejido manual del macramé que sale desde su base, se antepone ante la rigidez y belleza de los cristales, dando entrada a la copa del

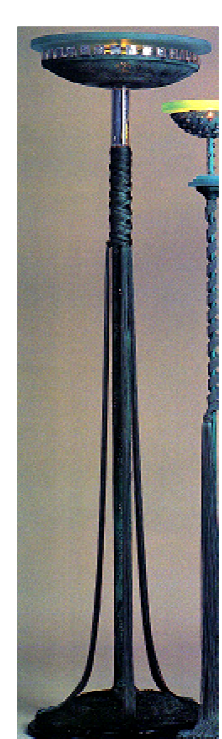
candelabro que representa la forma más sublime y preciosista; la transparencia de la simbólica bola de cristal que pernocta en su centro, ofrece morada a las luminarias que reflejan el brillo de la plata que abraza las delicadas velas.

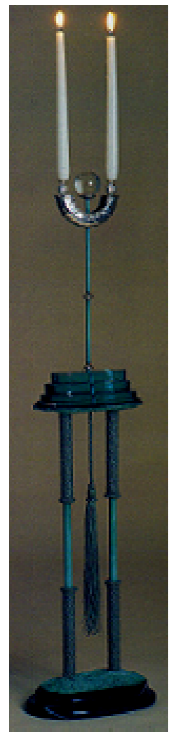

Nautilus II

Continuando sobre esta gran familia, conseguimos un segundo grupo conformado por doce estilizados candeleros, elaborados todos en bronce patinado, con cristal, plata pura y seda, donde la luz de las gruesas velas ocupan el interior de sus copas. El candelero Plinius I (IMAGEN 266) es uno de ellos. En él, la inclusión del bronce, la plata, el cristal y el macramé se reconcilian y engendran esta nueva especie portadora de luz difusa. Los hilos de seda Plinius I abrazan fuertemente la extremidad del candelero, IMAGEN 266

206 La dimensión de los candelabros y candeleros no incluye la altura de las velas. 
desde donde caen libremente sobre la base de mármol que lo sostiene. Con tenacidad, mesura y pericia, el orfebre somete al metal para transformarlo en este amplio copón que se apropia de la luminosidad que yace en su interior; y la aureola de cristal arenado sobre él, atesora el brillo entre su tenue transparencia. La melancólica luz difusa que irradia desde su interior, encierra misteriosamente el alma de la obra.

Finalmente esta exposición cierra con un par de máscaras transfiguradas en enormes candelabros. La añoranza que reflejan sus rostros vaciados en estaño, expresan la mutación que surge del contacto divino entre la materia y el ser que las ejecuta.

Para la ejecución de los candelabros de El sol y La luna, (IMAGEN 267) el artista recurre a la impresión de su rostro para perpetuar con convicción entre luces y penumbras, De la Sierra con esta representación, se enfrenta al resultado de su propia inspiración a través de volúmenes de cera, transformados en sugerentes luminarias vaciadas en estaño. La apariencia oscura de este metal en su semblante, crea una atmosfera entre lo espiritual y lo oculto; donde las sombras se aproximan a lo tangible dando cabida al calor y luminosidad de los velones encendidos. Las perfectas bolas de mármol negro, centran su atención en la perfección de su forma; transfigurándose en ese entorno como parte de su ser. Inquieto ante el enigma de lo desconocido, se sumerge en

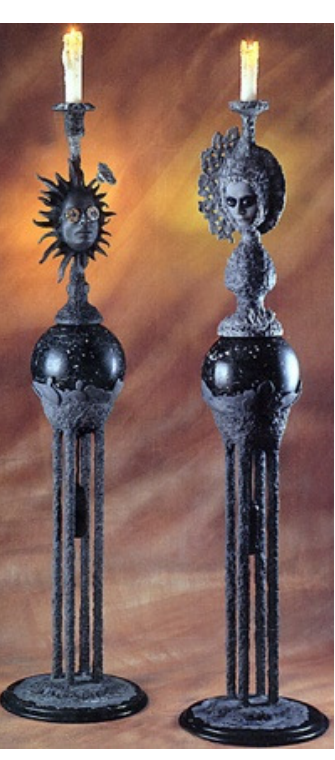
El sol y la luna
IMAGEN 267 esta insólita creación tras la búsqueda de fronteras poco exploradas y recluye sus emociones en los enormes candelabros.

En el año 2004 Alexis De la Sierra decide evolucionar un poco más sobre la $\mathrm{F} / 0$ de los candeleros. En esta nueva concepción, se exhibe la presencia del cristal con la plata pura y piedras preciosas y la inclusión del efecto lumínico artificial dentro del volumen. Los candeleros Guardianes de fuego y hielo (IMAGEN 268) ostentan con gran elegancia piedras semipreciosas sobre el copón removible que los establece. Tras el laminado se produce la formación convexa con el proceso manual del repujado y las piedras facetadas pernoctan engastadas sobre ese copón. Piedras estas, se encuentran magistralmente encajadas y engastadas dentro de pequeños orificios de la superficie impoluta de plata. 


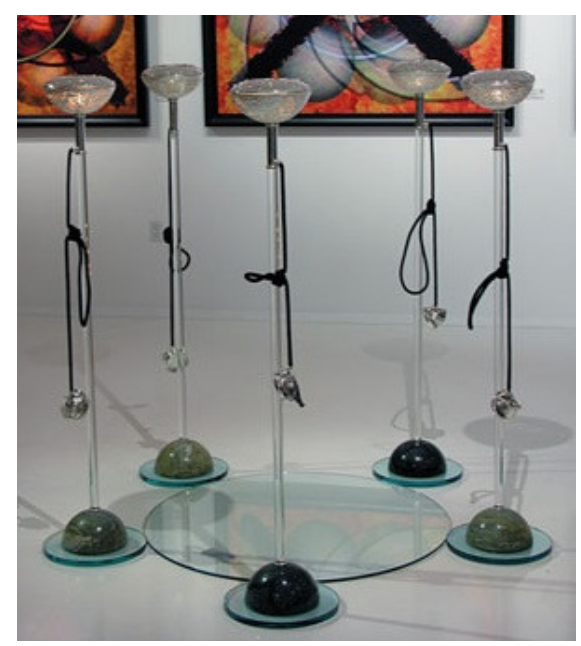

Guardianes de fuego y hielo IMAGEN 268

Los candeleros emiten dos tipos de luz. En la parte superior ostentan brillos exagerados de colores sutiles que salen a través de las piedras engastadas; y en la parte inferior, se bifurcan destellos de luz blanca que salen de orificios premeditados en esa superficie. La paradójica unión del fuego y el hielo se fusionan en armonía, en esta fascinante familia de candeleros. Alexis De la Sierra se compromete con demasía en la enseñanza apartándose con justa proporción de su producción. Sin embargo, anualmente participa con sus alumnos en las exposiciones de la Escuela de Orfebres ADS y en obras benéficas.

Para el año 2009 la Escuela de Orfebres ADS participa en una obra benéfica para una fundación que trabaja para la Cruz Roja Internacional, donde la fundación estableció unas pautas de participación con obras de cualquier índole centrándose en una "Caja". Para ello, la Escuela de Orfebres ADS determina que su exposición anual se titulará "Cajas que ayudan" y la venta será donada a la fundación.

De la sierra centra su idea en una hermosa caja musical Visiones en púrpura: Homenaje a San Gabriel Arcángel (IMAGEN 269) fundamentándose en la orfebrería suntuaria, donde la excelencia técnica se desborda entre destellos de amatistas, el brillo de la plata y la belleza del oro amarillo.

Esta hermosa caja musical elaborada con ingenio, destreza y

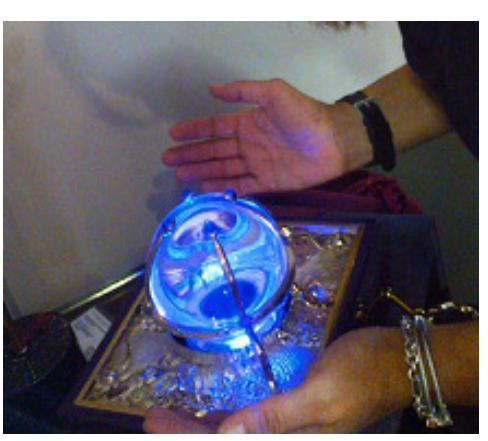

Visiones en púrpura: Homenaje a San Gabriel Arcánge

delicadeza, ostenta entre sus formas, la habilidad con que ejecuta la superficie texturizada entre fragmentos de lámina e hilos de media caña; el impecable refundido entre éstos, desvela la bella apariencia entre sus formas y brillos. El interior de la caja de madera, contiene un mecanismo mecánico conjuntamente a un dispositivo electrónico que se acciona halando con un cordón que 
sobresale de su fachada. Dispositivo este, activa un sistema sonoro/lumínico del cual sale una delicada tonada, emitiendo a su vez, bellos colores que se reflejan a través de la contundente esfera de cristal al compás de la canción. Esta esfera, se mantiene aferrada a la caja por medio de un aro de plata, que lo sujetan cuatro largas garras de hilo en media caña de plata pura. En las uniones y extremos de estas garras, se fijan delicados engastes de caja, con amatistas de talla cuadrada. Así como también, en su base, se sujetan hermosas tallas de amatista en forma de corazón con delicados engastes de bisel en oro de 22 quilates. La bella y cautivadora obra, encierra un enigma en su interior que cada usuario descubre al interactuar con ella.

\subsubsection{CATALOGACIÓN DEMOSTRATIVA SOBRE LA EVOLUCIÓN EN ORFEBRERÍA}

En este apartado del trabajo de investigación se muestran imágenes de la producción en orfebrería del artista Alexis De la Sierra desde sus inicios en el año 1970 en esta disciplina, hasta el año 2010. Es necesario destacar, que esta catalogación no se presenta a nivel cronológico sino, de manera evolutiva, tomando en cuenta sobre-todo a nivel técnico y formal. En tal sentido, tomaremos en cuenta los siguientes aspectos clasificándolos según su condición. Así pues, la siguiente catalogación demostrativa sobre la evolución en orfebrería se presenta según su condición: la Ornamental, la Ornamental Mágico Religiosa, la Utilitaria Ceremonial, la Luminaria y la Escultórica. 

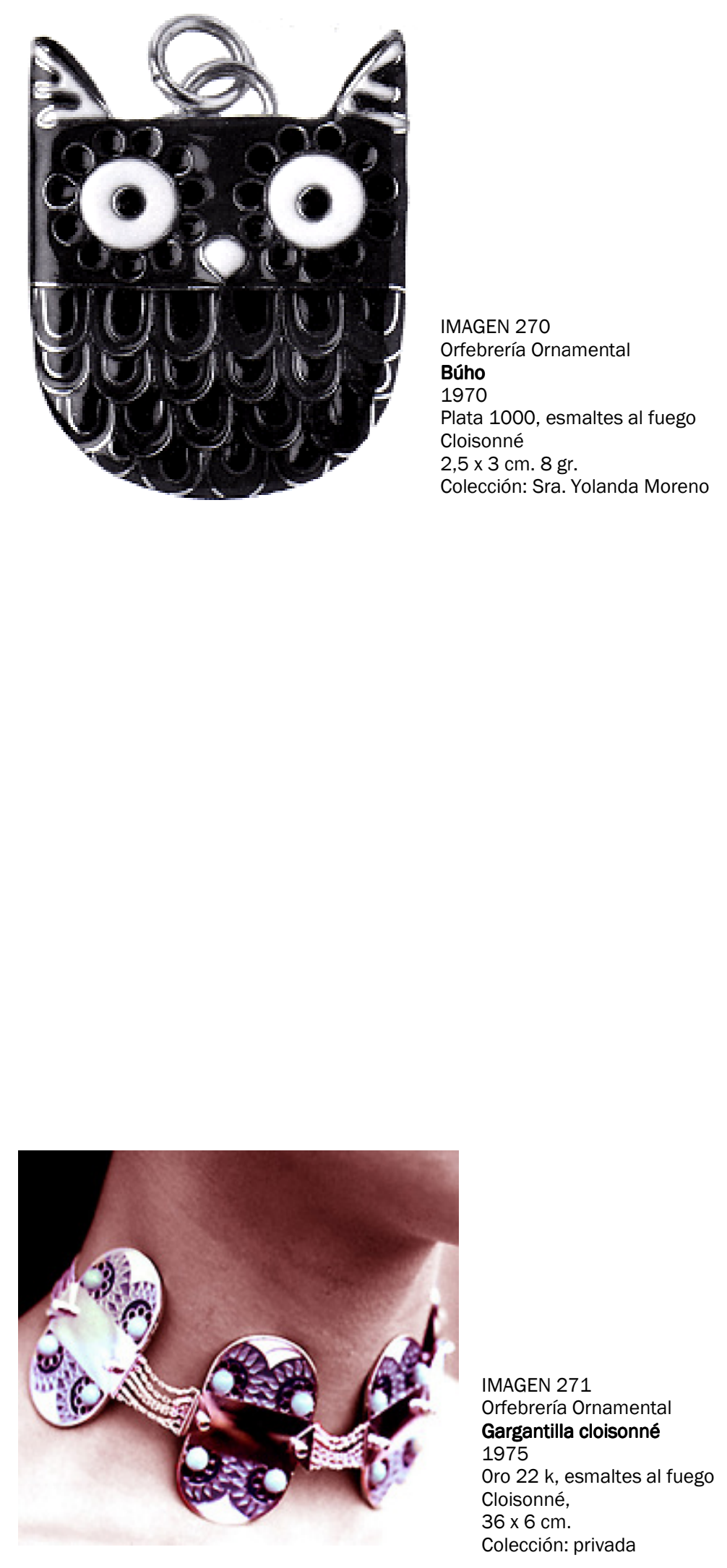


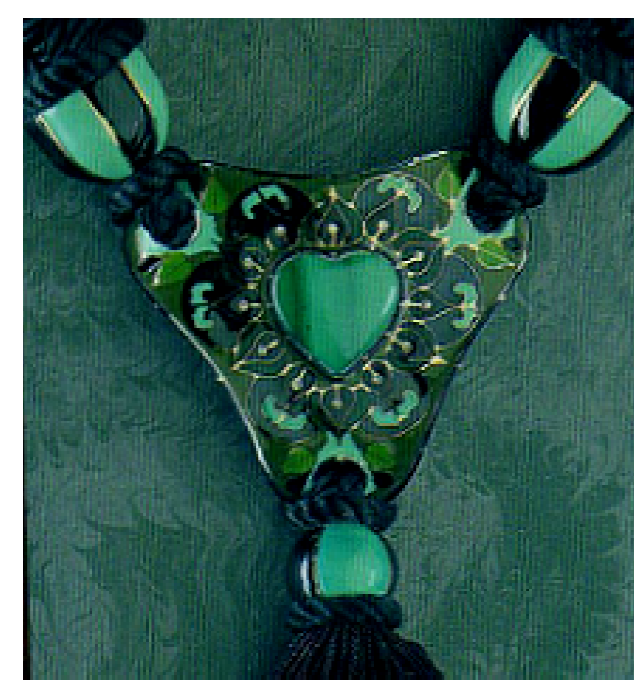

IMAGEN 272

Orfebrería Ornamenta

Pectoral Amazonia

Plata 1000 , oro 24 k, corazón de

malaquita, 12 brillantes, esmaltes

al fuego, textil

cloisonne, laminación, formación a

martillo, macramé, ensamblaj

$46 \times 14 \mathrm{~cm}, 215 \mathrm{gr}$

Orfebrería Ornamental

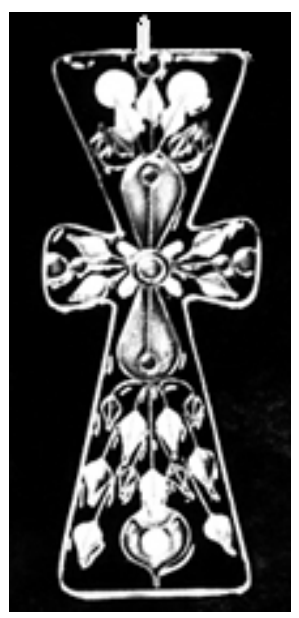

IMAGEN 273

Orfebrería Ornamental

Cruz Cloisonné

Oro $22 \mathrm{k}$, esmaltes al fuego.

$8 \times 3,5 \mathrm{~cm}$.

Colección: privada 


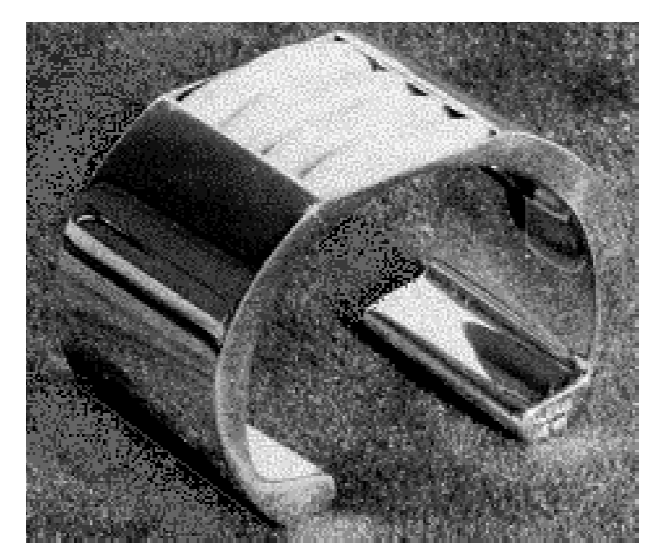

IMAGEN 274

Orfebrería Ornamental

Brazalete

1976

Plata 1000, marfil

Laminación, formación a martillo,

engaste

$6 \times 5 \times 5 \mathrm{~cm}$.

Colección: privada

Comentario: forma parte de 8 joyas

con las que participa en el "1er.Salón

de la Nueva Orfebrería Venezolana"

año 1976

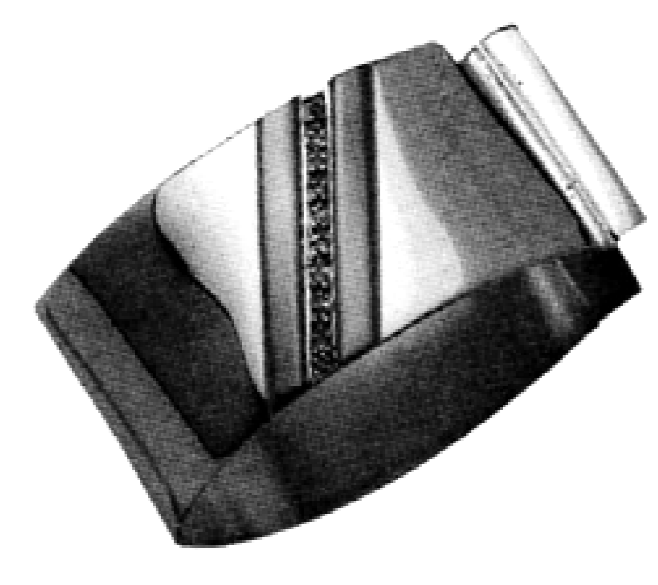

IMAGEN 275

Orfebrería Ornamental

Brazalete
1985

Plata 1000 , oro 24 k., 18

brillantes

Cera perdida, laminación,

formación a martillo, engaste

pavé

$16,5 \times 5,7 \mathrm{~cm}, 77 \mathrm{~g}$

Colección: Jahn de González 


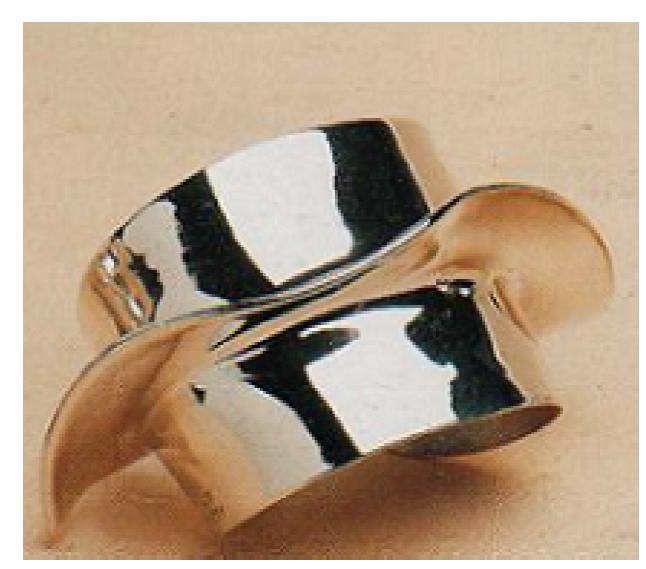

IMAGEN 276

Orfebrería Ornamental

Brazalete escultórico

1987

Plata esterlina

Cera perdida

$8 \times 8 \mathrm{~cm}, 104 \mathrm{gr}$
Colección: Sra. María Eugenia Bigott

Consalvi (QEPD)

Comentario: forma parte de la $\mathrm{F} / \mathrm{O}$

Brazaletes escultóricos

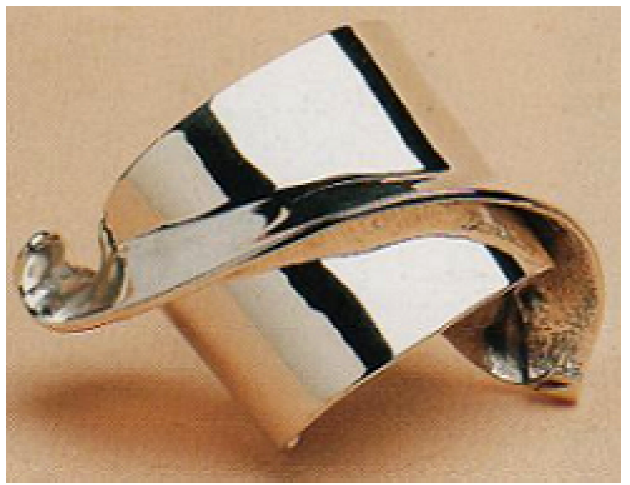

IMAGEN 277

Orfebrería Ornamental

Brazalete escultórico

1987

Plata esterlina

Cera perdida, texturización

$9,5 \times 6,5 \mathrm{~cm}, 97 \mathrm{~g}$

Colección: Arq. Adriana Simón de

Guevara

Comentario: F/O de Brazaletes

scultóricos

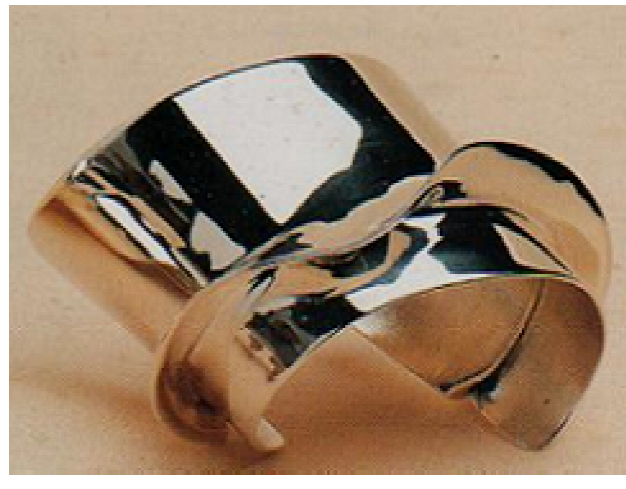

IMAGEN 278

Orfebrería Ornamenta

Brazalete escultórico

1990

Plata esterlina

Plata esterlina
Cera perdida

$9 \times 4,8 \mathrm{~cm}, 109 \mathrm{gr}$

Colección: Sra. Arian Chacón de

Salvatierra
Comentario: F/O de Brazaletes

escultóricos 


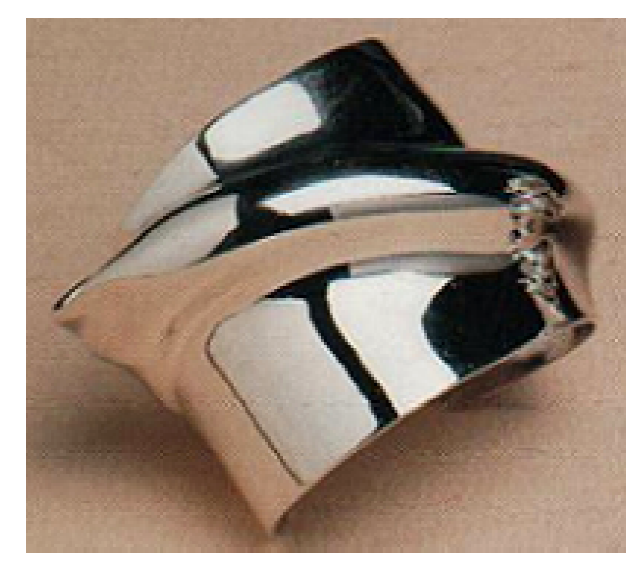

IMAGEN 279

Orfebrería Ornamental

Brazalete escultórico

1986

Plata esterlina

$9 \times 5,6 \mathrm{~cm}, 115 \mathrm{~g}$

Colección: Sra. Nelly Peña de Font

Comentario: F/O de Brazaletes

Escultóricos

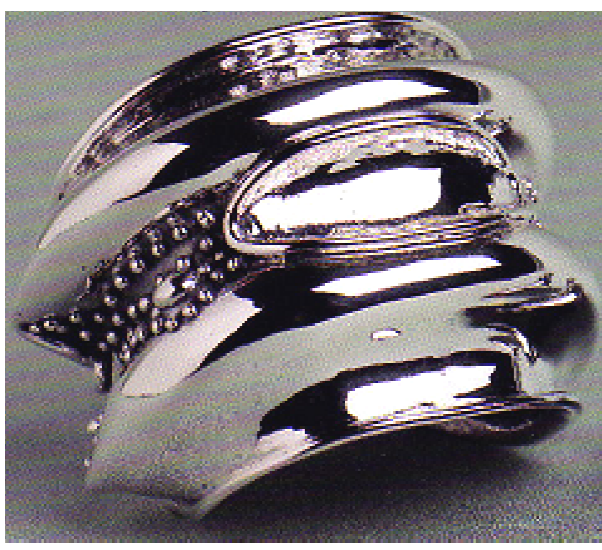

IMAGEN 280

Orfebrería Ornamenta

Brazalete de gala

1987

Cera perdida, granulado, oxidación

$8,2 \times 6,2 \mathrm{~cm}, 139 \mathrm{gr}$

Colección: privada

Comentario:F/O de Brazaletes de

gala 


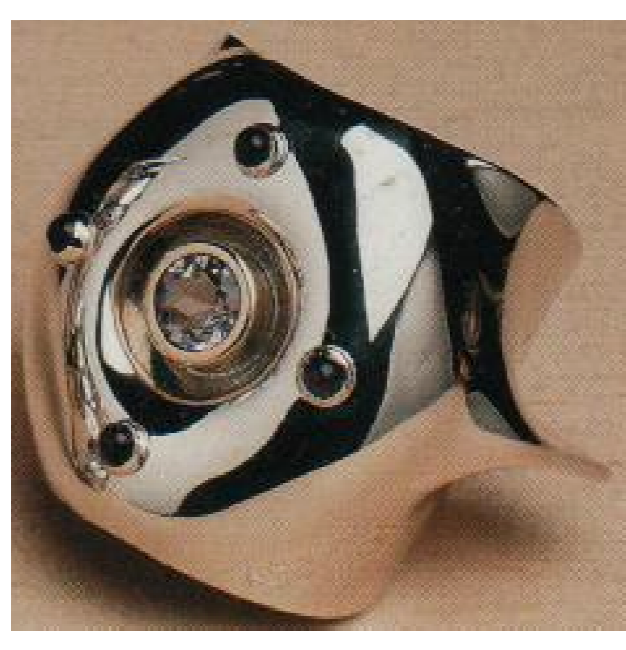

IMAGEN 281

Orfebrería Ornamenta

Brazalete de gala

1988

Plata pura, oro 24 quilates,

amatistas

Cera perdida, engaste

$7,6 \times 6,5,119 \mathrm{gr}$

Comentario: F/O de Brazaletes de

gala

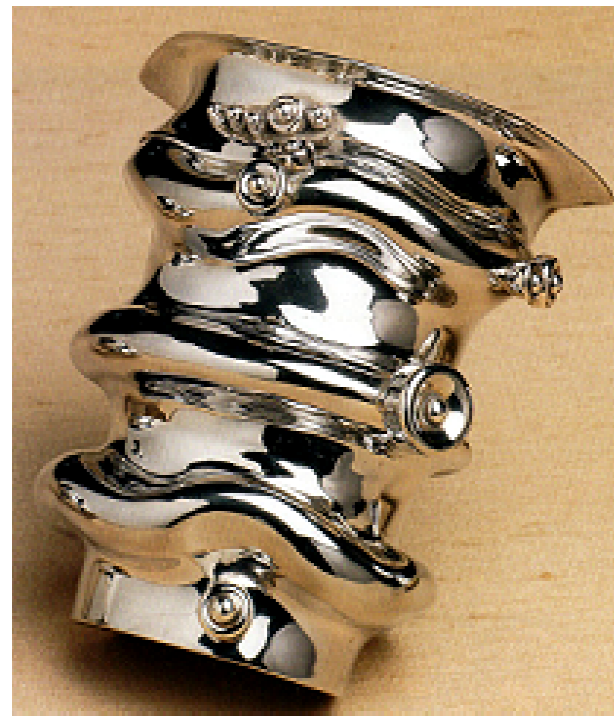

IMAGEN 282

Orfebrería Ornamental

Brazalete de gala

Plata 1000, plata esterlina

Cera perdida

$10,7 \times 9 \mathrm{~cm}, 187 \mathrm{gr}$

Comentario: F/O de Brazaletes de gala 


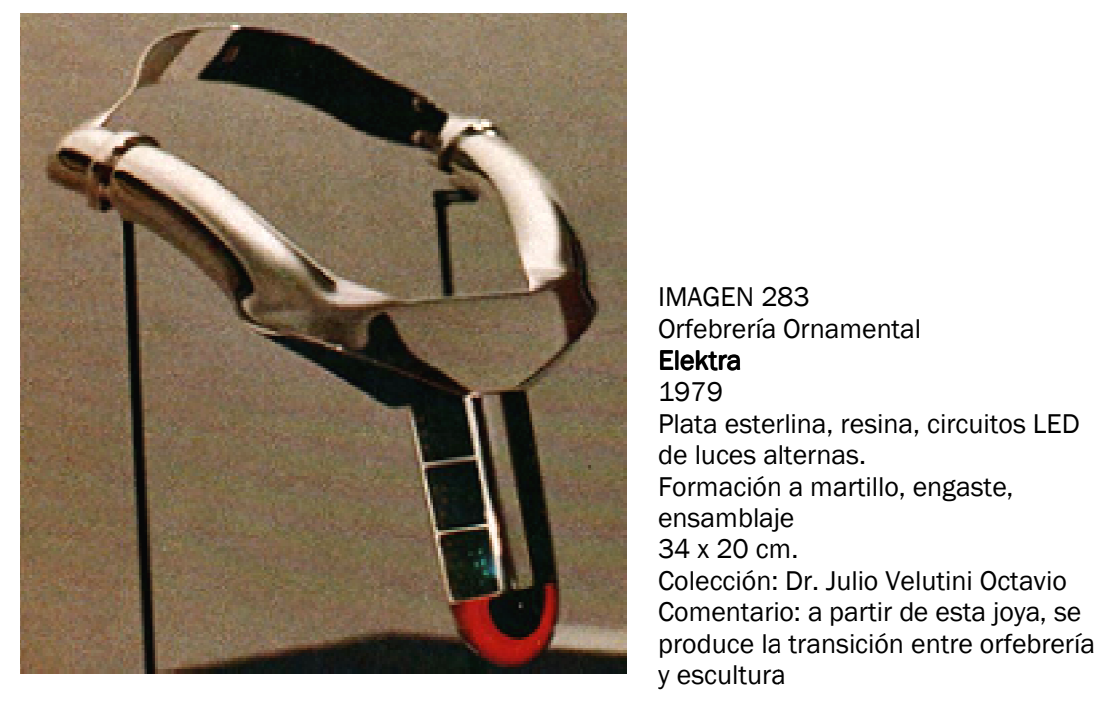




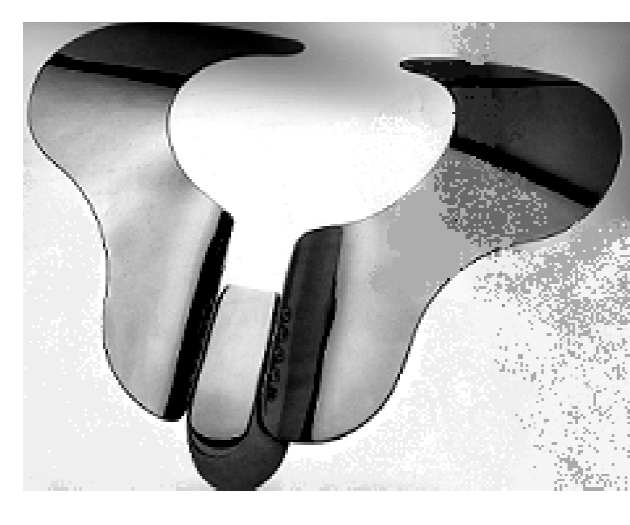

IMAGEN 284

Orfebrería Ornamental

Pectoral de aluminio

Aluminio, estaño

Laminación, corte, formación,

fundición, satinado, ensamblaje

$32 \times 25 \mathrm{~cm}, 320 \mathrm{gr}$

Coleccion: del artista

Comentario: conjunto ganador del

Premio en la tendencia de Orfebrería

en el "SNAF" del año 1983.

F/O de Pectorales de Aluminio

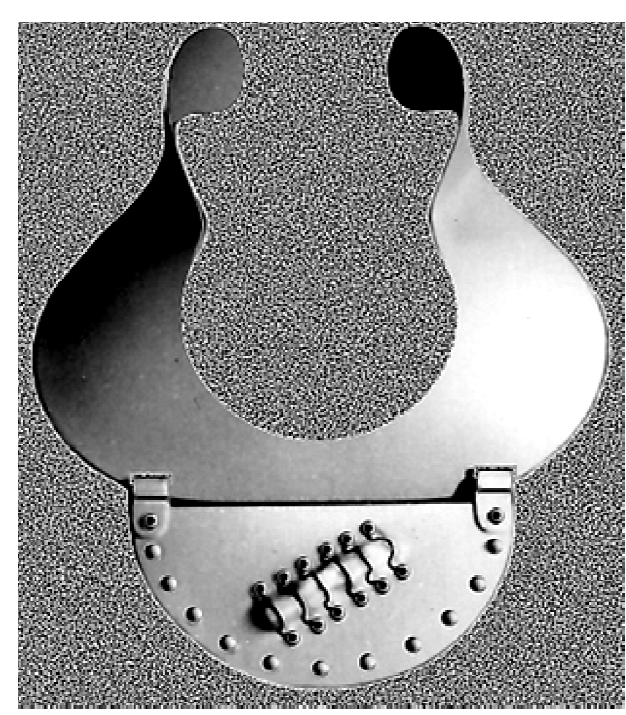

IMAGEN 285

Orfebrería Ornamental

Pectoral de aluminio II

1983

Aluminio, estaño

fundición, satinado, ensamblaje

$36 \times 20 \mathrm{~cm}, 340 \mathrm{gr}$

Colección: del artista

Premio en la tendencia de Orfebrería

F/O de Pectorales de 1983. 


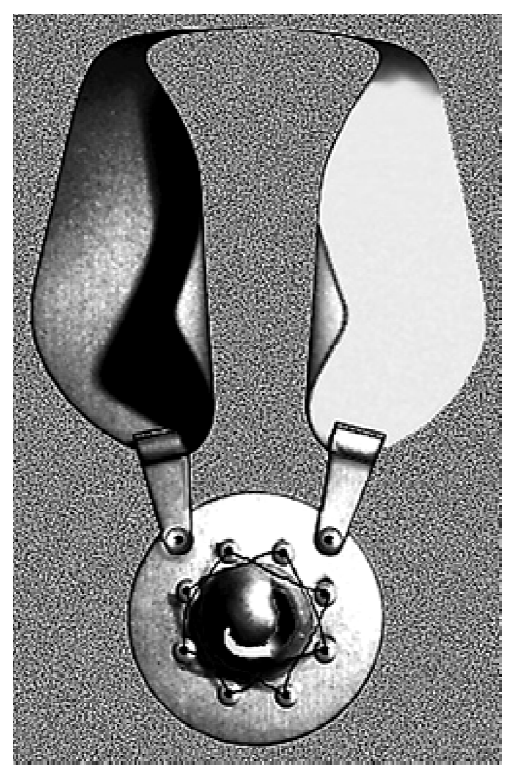

Orfebrería Ornamental

1983

Laminación, corte, formación, fundición

satinado, ensamblaje

$31 \times 28 \mathrm{~cm}, 150 \mathrm{gr}$

Colección: del artista

Comentario: conjunto ganador del Premio en la

tendencia de Orfebrería en el "SNAF" del año

1983.

F/O de Pectorales de Aluminio

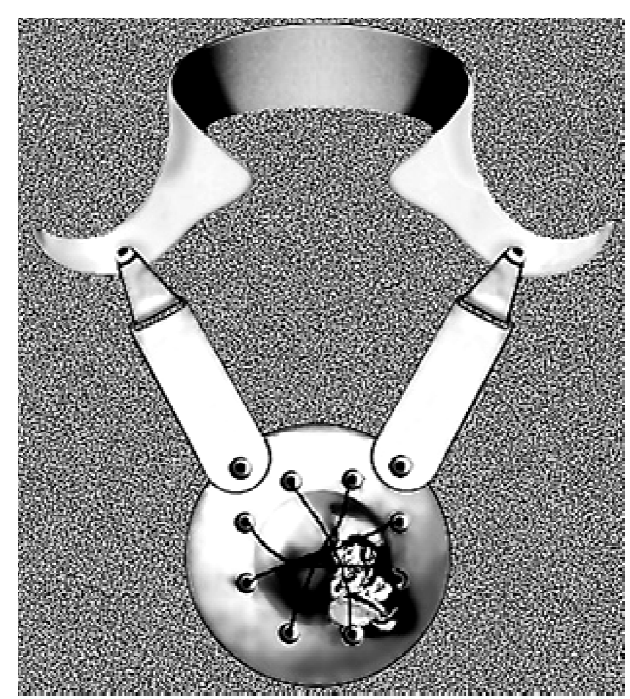

MAGEN 287

Orfebrería Ornamental

1983

Aluminio, estaño

Laminación, corte, formación,

fundición, satinado, ensamblaje

$33 \times 27 \mathrm{~cm}, 350 \mathrm{gr}$

Colección: del artista

Premio en la tendencia de Orfebrerí

en el "SNAF" del año 1983.

F/O de Pectorales de Aluminio 

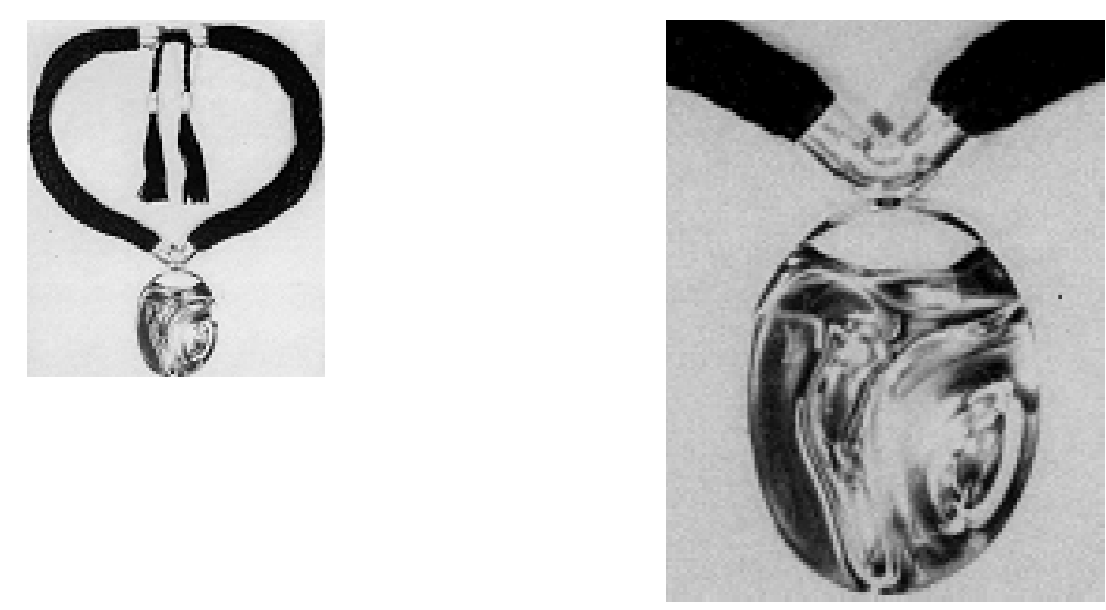

Detalle Homenaje a Bianca

Castafiore
IMAGEN 289

IMAGEN 288

Homenaje a Bianca Castafiore

Plata 1000 , texti

位

Colección: Sr. Oscar Ascaño

Comentario: Conjunto de dos collares ganadores del Premio en la tendencia de Orfebrería

en el "SNAF" del año 1980
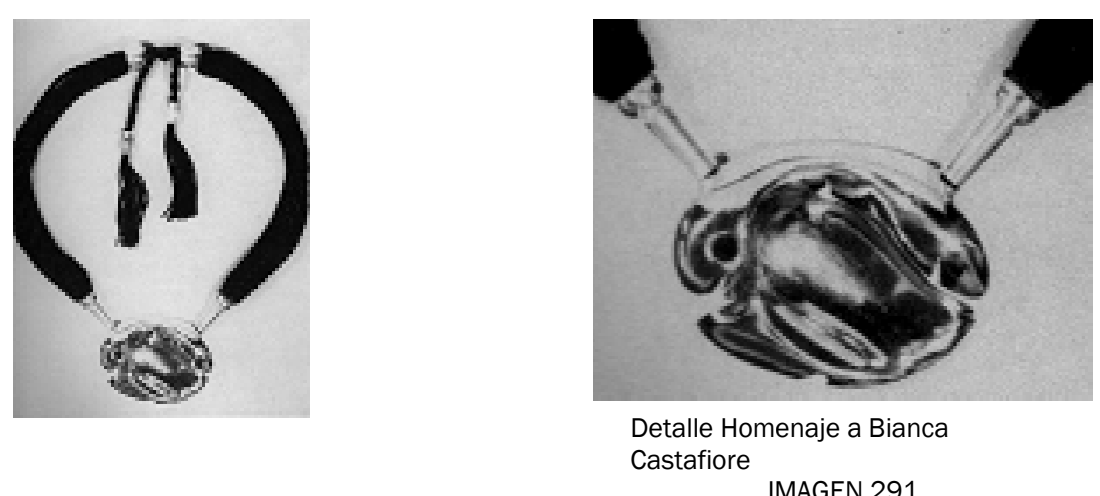

IMAGEN 290

Orfebrería Ornamental

Homenaje a Bianca Castafiore

1981

Plata 1000 , textil

Cera perdida, formación a martillo. Articulación mecánica, macramé, ensamblaje

Colección: Sr. Luis Fernández y Sra.

Comentario: Conjunto de dos collares ganadores del Premio en la tendencia de Orfebrería en el "SNAF" del año 1980 


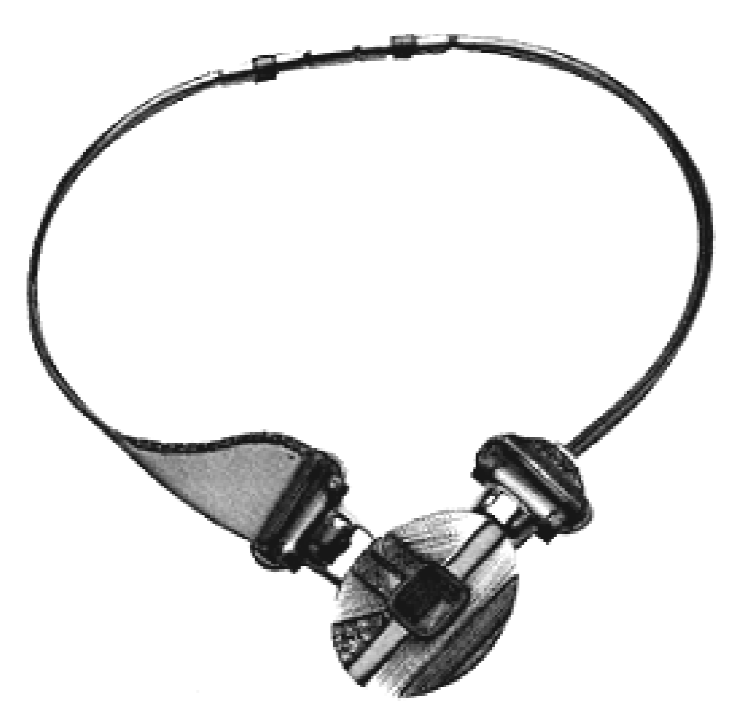

IMAGEN 292

Orfebrería Ornamental

Gargantilla de gala

1984

Plata 1000 y esterlina, brillantes, topacio

Laminación, extrusión, formación a martillo, engaste de caja y pavé, articulación mecánica,

ensamblaje

$17 \times 14 \mathrm{~cm}, 110 \mathrm{gr}$

Colección: privada 

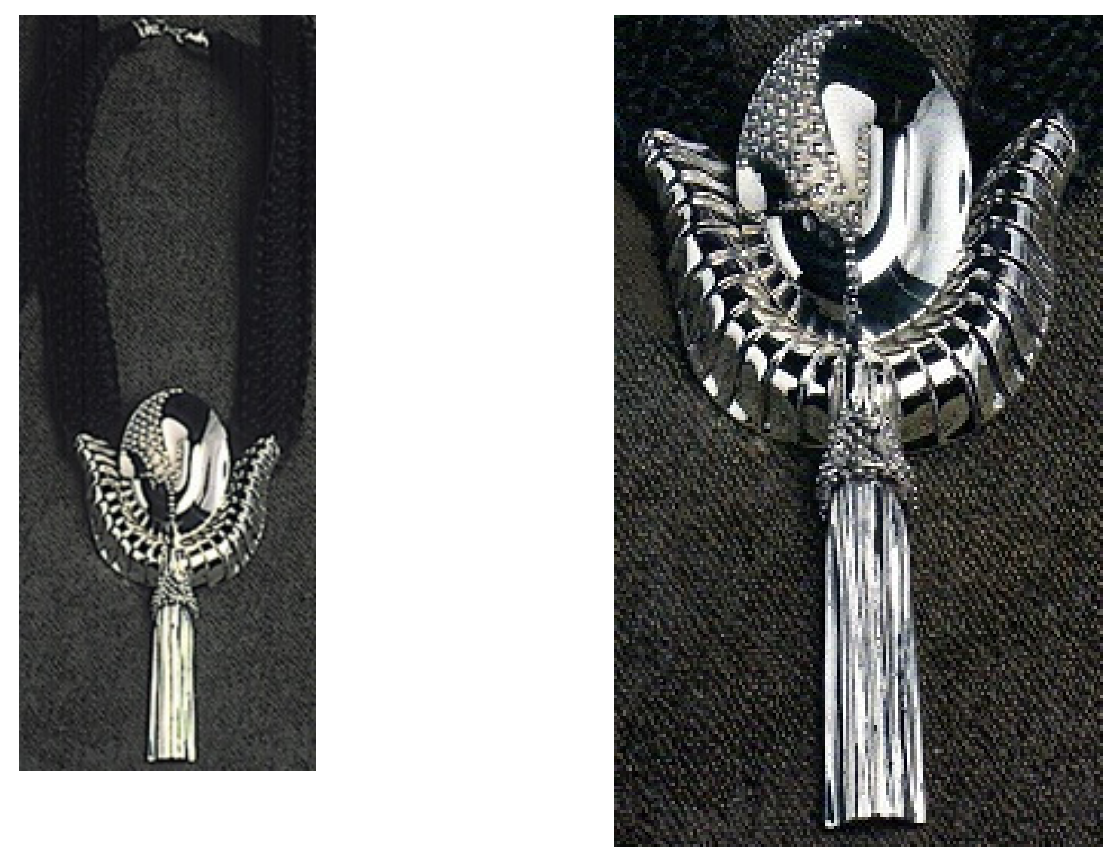

Detalle Le premier plaisir d'argent

IMAGEN 293

Orfebrería Ornamental

Le premier plaisir d'argent

Plata Britania, textil

Cera perdida, texturización mecánica, macramé, ensamblaje

$17,5 \times 10 \mathrm{~cm}, 301$

$17,5 \times 10$ cm,

Comentario: Conjunto de cinco obras ganadoras del Premio Nacional de las Artes del Fuego

en el "SNAF" de 1986.

F/O de Pectorales Ceremoniales 

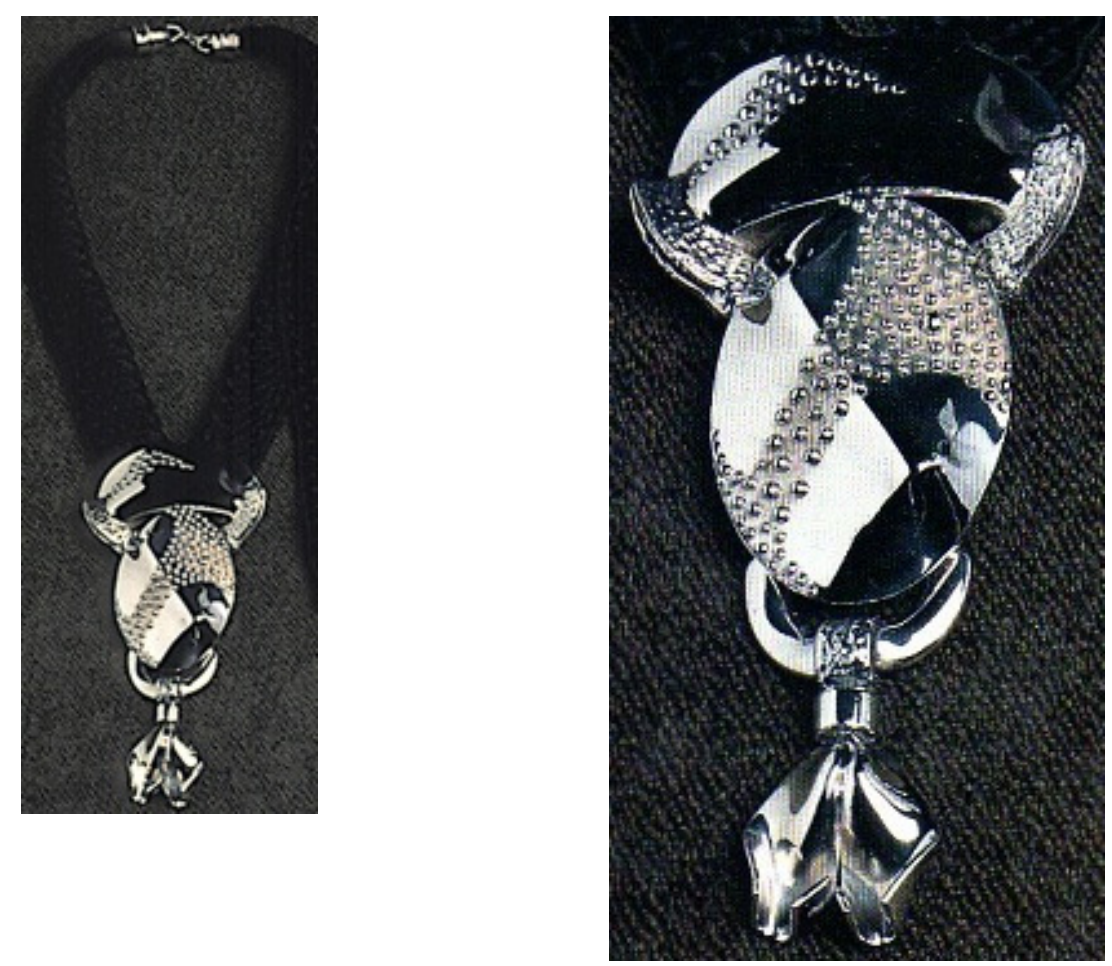

Detalle Le deuxième plaisir
d'argent IMAGEN 296

IMAGEN 295

Orfebrería Ornamental

Le deuxième plaisir d'argent

1986 Plata Britania, textil

Plata Britania, textil

Cera perdida, texturizac
$17 \times 8 \mathrm{~cm}, 225 \mathrm{gr}$

Colección: Ion Pervilhac

Comentario: Conjunto de cinco obras ganadoras del Premio Nacional de las Artes del Fuego

en el "SNAF" de 1986.

F/O de Pectorales Ceremoniales 
Detalle Le troisième plaisir d' argent

IMAGEN 298

IMAGEN 297

Orfebrería Ornamental

Le troisième plaisir $d^{\prime}$ argent

1986

Plata Britania, textil

Cera perdida, texturización mecánica, macramé, ensamblaje

$7 \times 17 \mathrm{~cm}, 250 \mathrm{gr}$

Colección: Ion Pervilhac

Comentario: Conjunto de cinco obras ganadoras del Premio Nacional de las Artes del Fuego

en el "SNAF" de 1986.

F/O de Pectorales Ceremoniales 

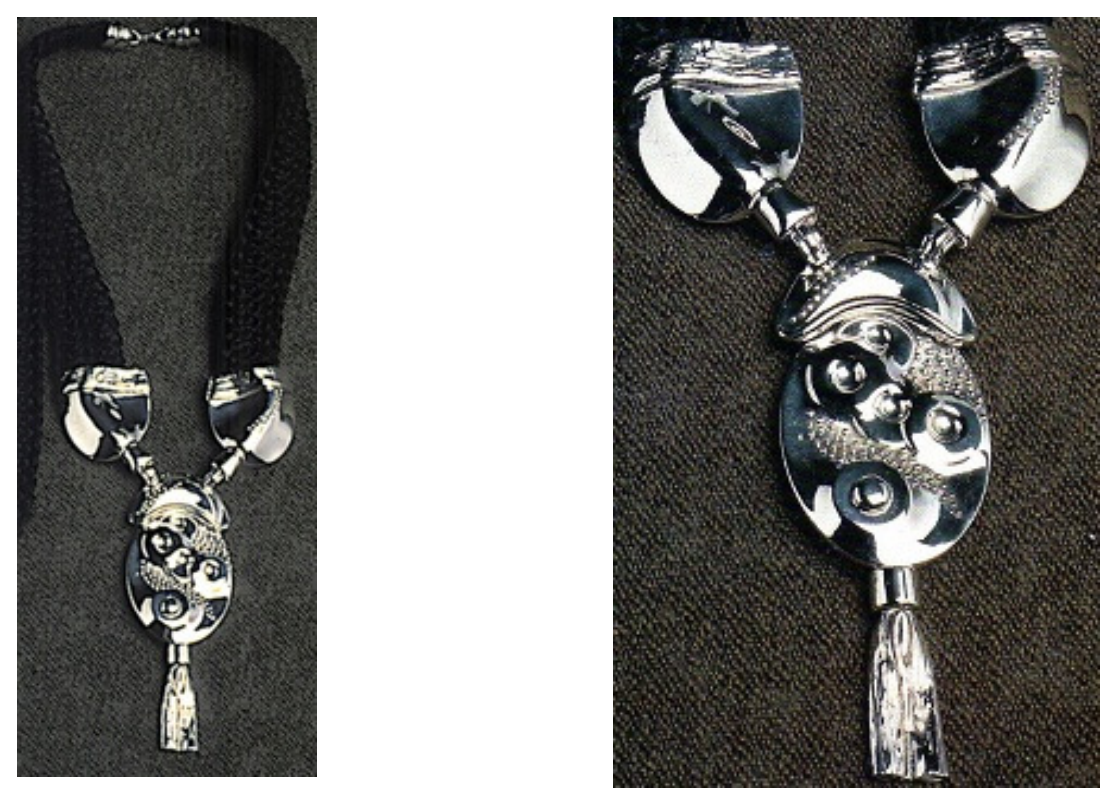

Detalle Le quatriéme plaisir IMAGEN 300

IMAGEN 299

Orfebrería Ornamental

Le quatriéme plaisir d'argent

Plata Britania, textil

Cera perdida, texturizacion mecánica, macramé, ensamblaje

$20 \times 12 \mathrm{~cm}, 300$ gr

$20 \times 12 \mathrm{~cm}, 300 \mathrm{gr}$
Colección: Ion Pervilhac

Comentario: Conjunto de cinco obras ganadoras del Premio Nacional de las Artes del Fuego

en el "SNAF" de 1986.

F/O de Pectorales Ceremoniales 

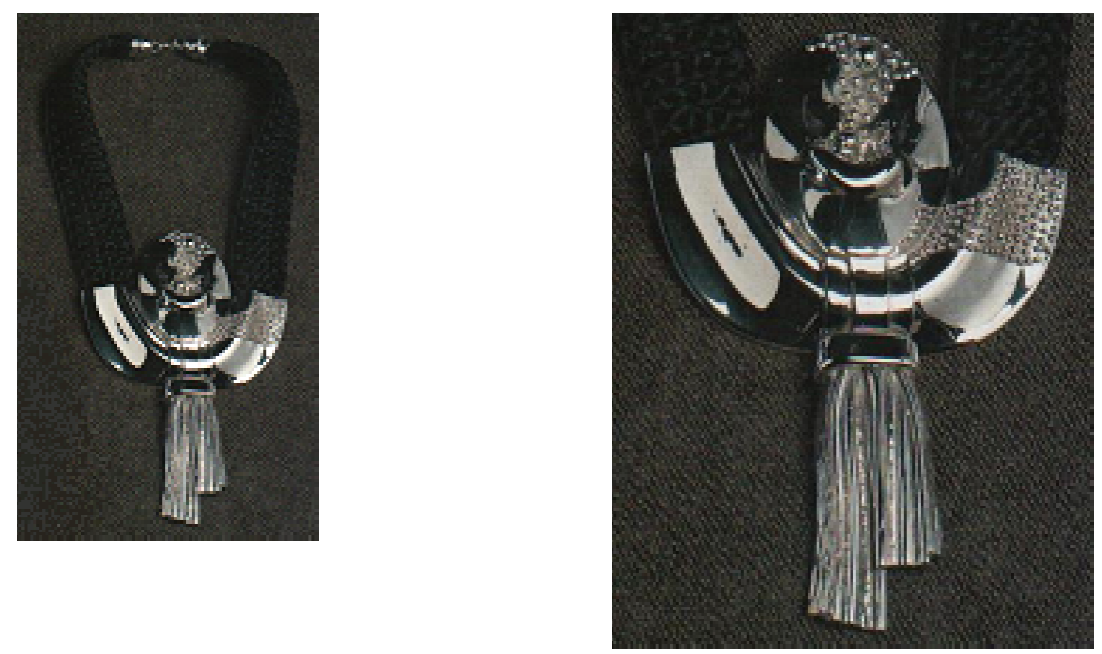

Detalle Le cinquiéme plaisir

d' argent

IMAGEN 301
Orfebrería Ornamental

Le cinquiéme plaisir $d^{\prime}$ argent

IMAGEN 302

1986 .

Cera perdida, texturización mecánica, macramé, ensamblaje

$18 \times 12 \mathrm{~cm}, 350 \mathrm{gr}$

Colección: Ion Pervilhac

Comentario: Conjunto de cinco obras ganadoras del Premio Nacional de las Artes del Fuego

en el "SNAF" de 1986.

F/O de Pectorales Ceremoniales 

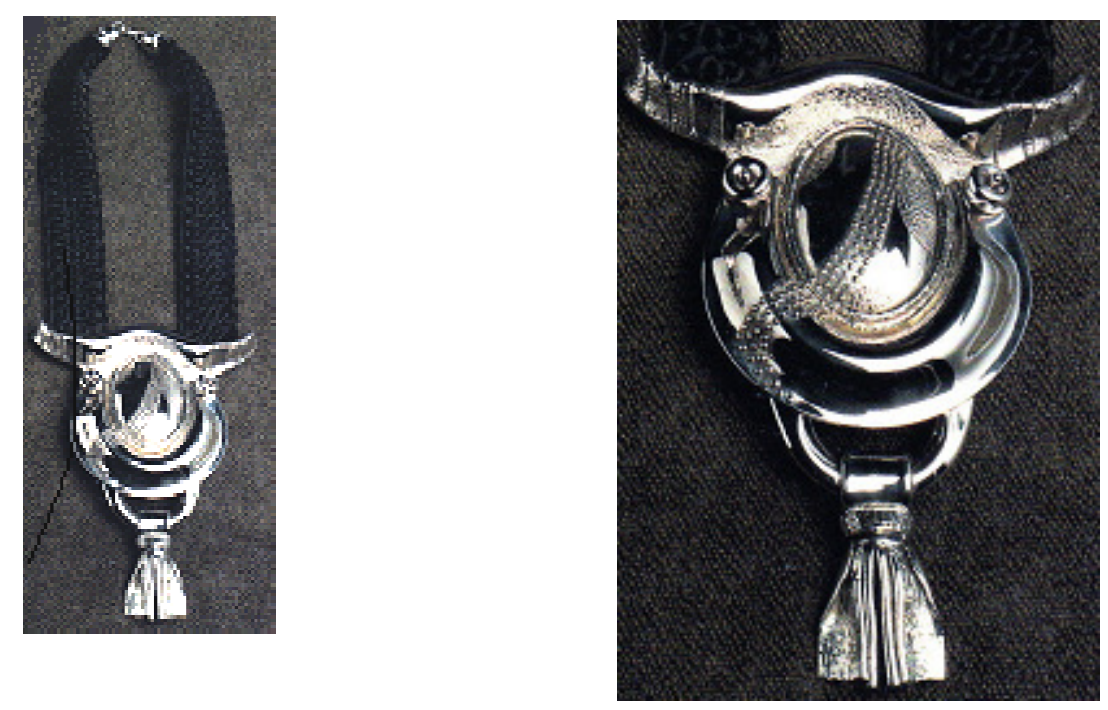

Detalle Le sixième plaisir d argent
IMAGEN 304

IMAGEN 303

Orfebreria Ornamental

Le sixième plaisir $\mathrm{d}^{\prime}$ argent

1988

Plata Britania, textil

Cera perdida, texturización mecánica, macramé, ensamblaje

$17 \times 13 \mathrm{~cm}, 344 \mathrm{gr}$

Comentario: F/O de Pectorales Ceremoniales 


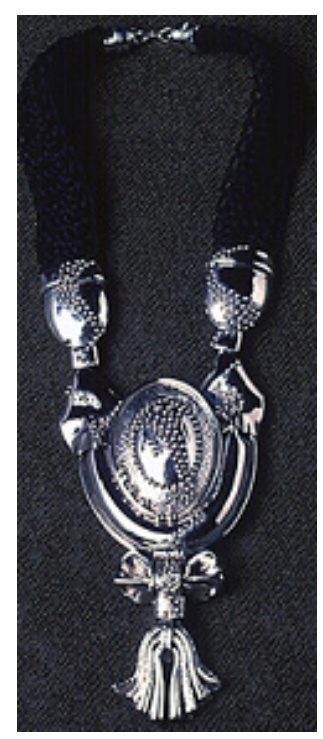

Orfebrería Ornamental

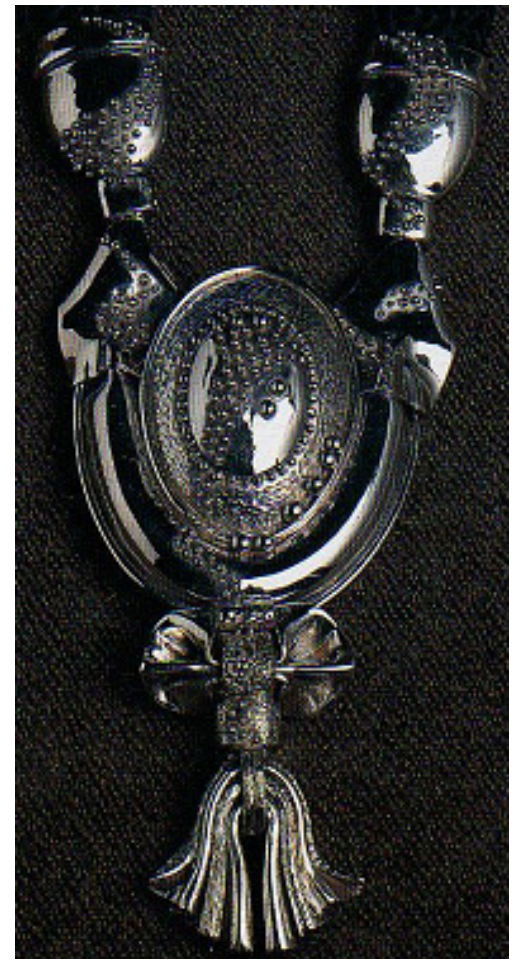

Le huitième plaisir $\mathrm{d}^{\prime}$ argent

Plata Britania, textil

Cera perdida, texturización mecánica, macramé, ensamblaje

$22 \times 10 \mathrm{~cm}, 347 \mathrm{gr}$

Colección: Sra. Isis Álvarez Renta (Santo Domingo)

Comentario: F/O de Pectorales Ceremoniales

Detalle Le huitième plaisir

d'argent
IMAGEN 306 

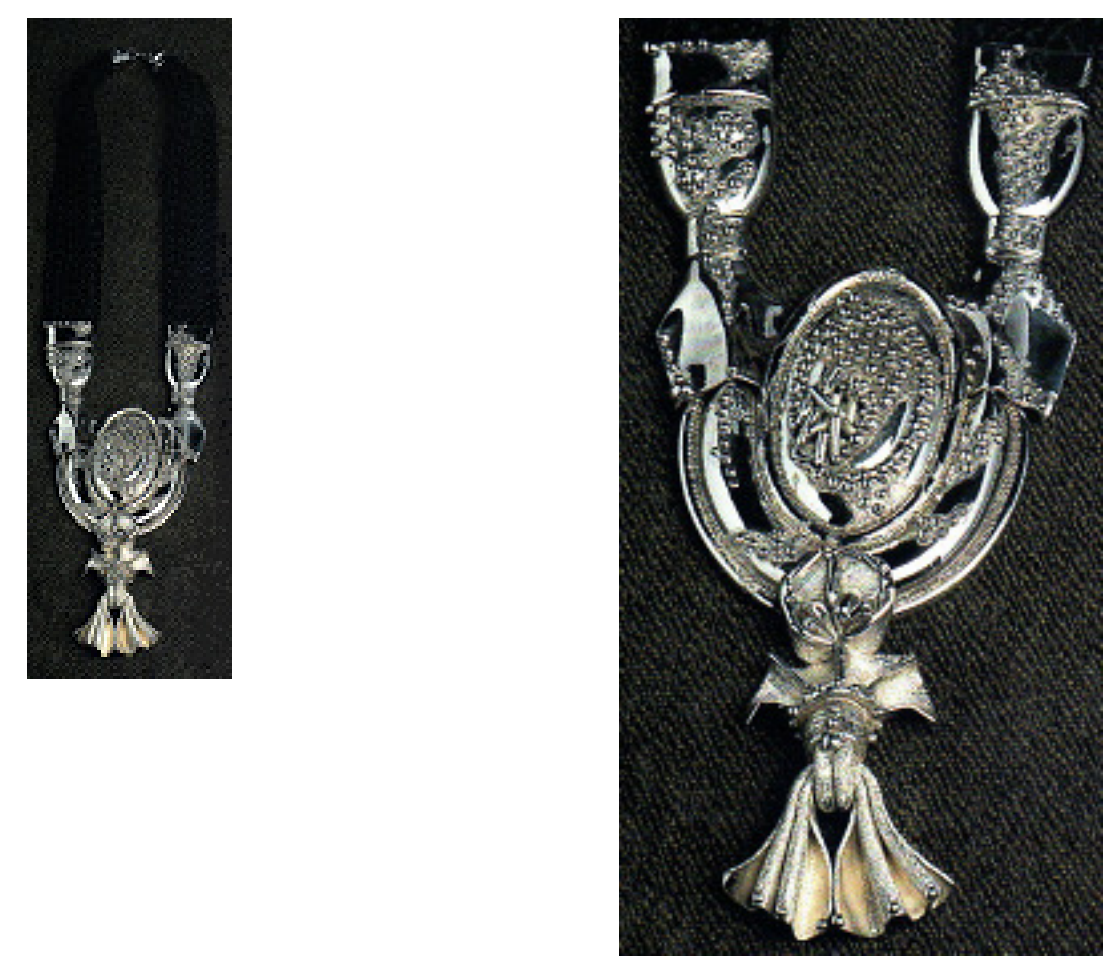

IMAGEN 307

Detalle Le neuviëme plaisir

Orfebrería Ornamental

d'argent
IMAGEN 308

Le neuviëme plaisir d'argent

1995

Plata Britania, textil

ción mecánica, macramé, ensamblaje

$20 \times 10 \mathrm{~cm}, 345 \mathrm{gr}$

Comentario: F/O de Pectorales Ceremoniales 

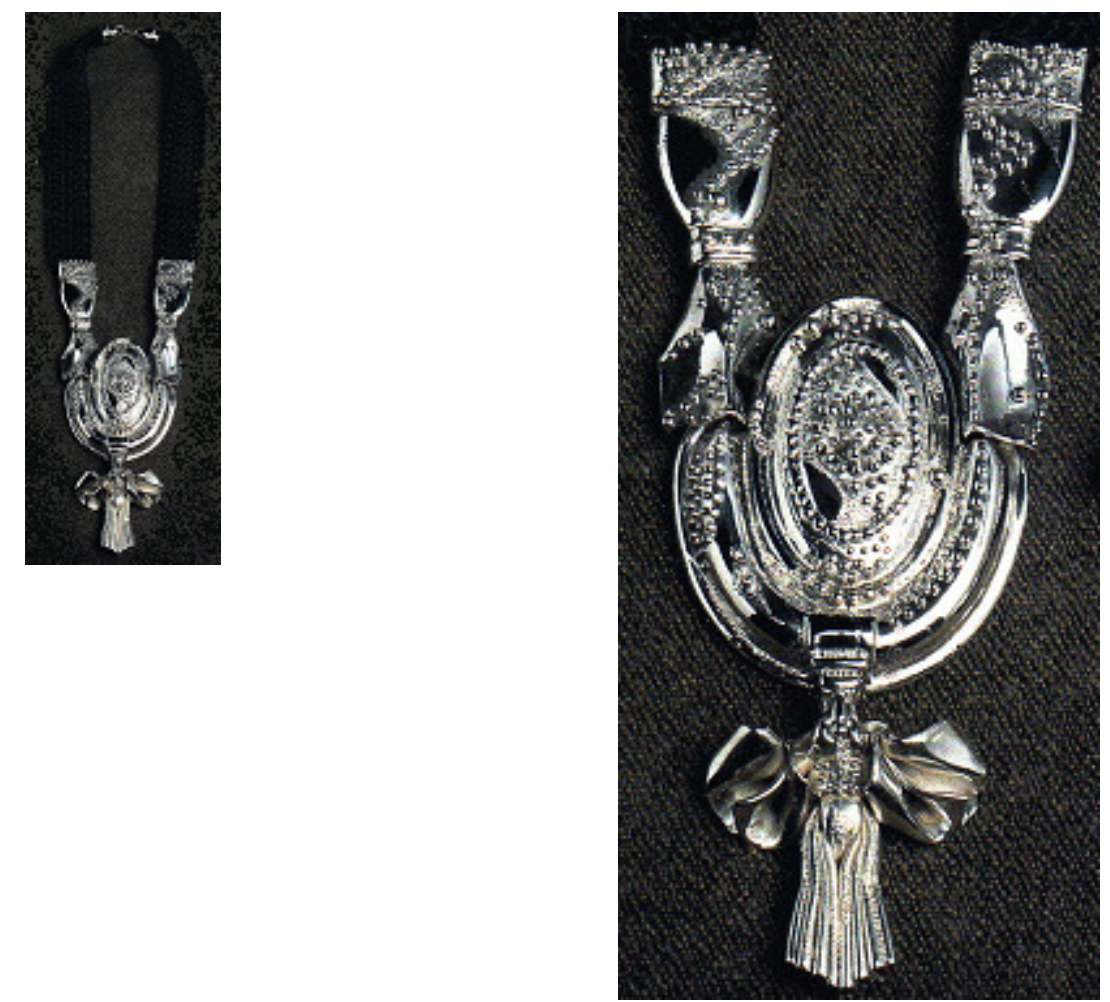

Detalle Le dixième plaisir d`argen

IMAGEN 310

IMAGEN 309

Orfebrería Ornamental

Le dixième plaisir $d$ 'argent

199

Plata Britania, textil

Cera perdida, texturización mecánica, macramé, ensamblaje

$22 \times 10 \mathrm{~cm}, 345 \mathrm{gr}$

Colección: Sra. Martha Hoefle Fa

Comentario: $F / O$ de Pectorales Ceremoniales 


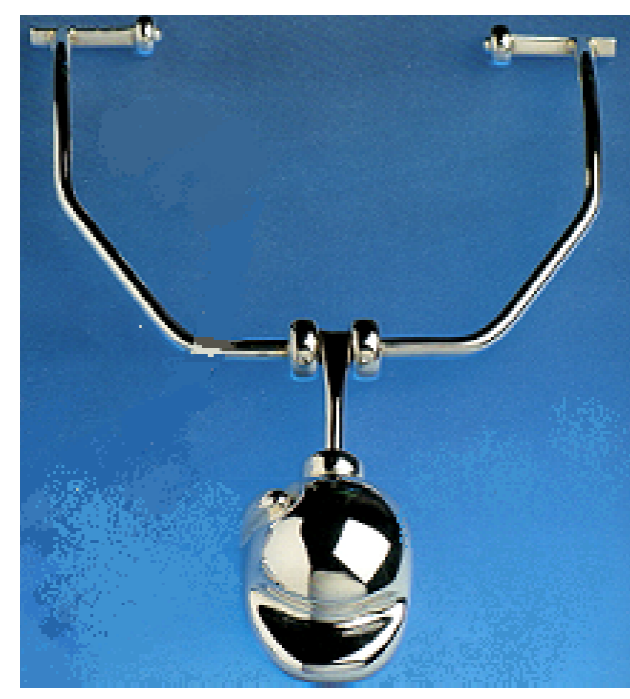

IMAGEN 31

Orfebrería Ornamental

Pectoral Ergonométrico I

Plata 1000, plata esterlina

Cera perdida, extrusión, formación a

martillo, articulación mecánica,

ensamblaje

$15 \times 12 \mathrm{~cm}, 225 \mathrm{gr}$

Colecciôn: del artista

Comentario. F/O de Pectorales

onométricos

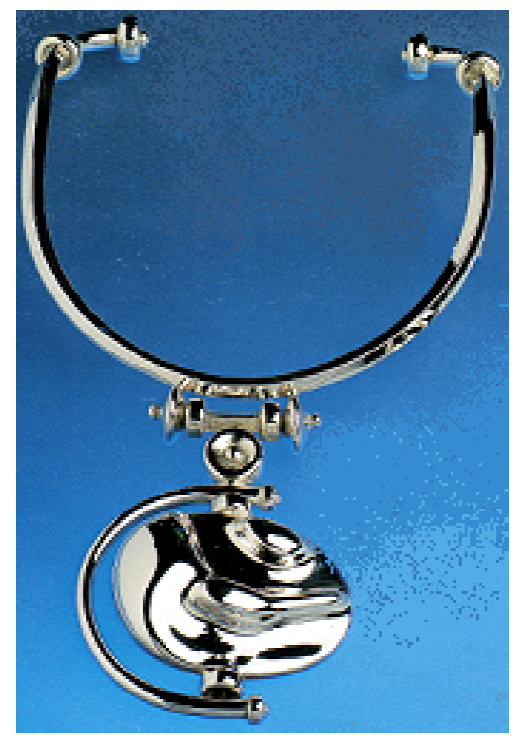

MAGEN 312

Orfebrería Ornamental

Pectoral Ergonométrico II

Pes

Plata 1000, plata esterlina
Cera perdida, extrusión, formación a martillo,

Cera perdída, extrusión, formación

$28,5 \times 14,2 \mathrm{~cm}, 248 \mathrm{gr}$

Colección: privada 


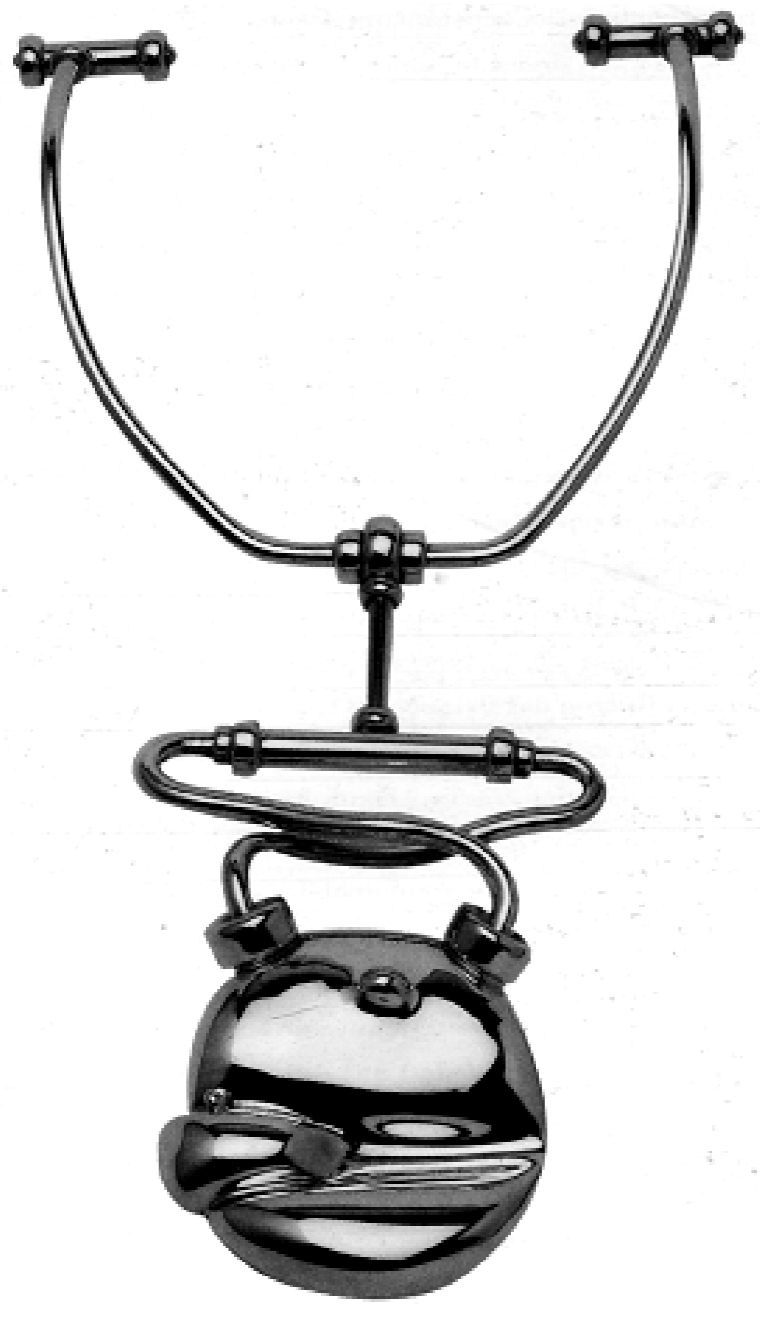

IMAGEN 313

Orfebrería Ornamental

Pectoral Ergonométrico III

Plata 1000 , plata esterlina

Cera perdida, extrusión, formación a martillo, articulación mecánica, ensamblaje $28,5 \times 14,2 \mathrm{~cm}, 346 \mathrm{gr}$

Comentario: F/O de Pectorales Ergonométricos 


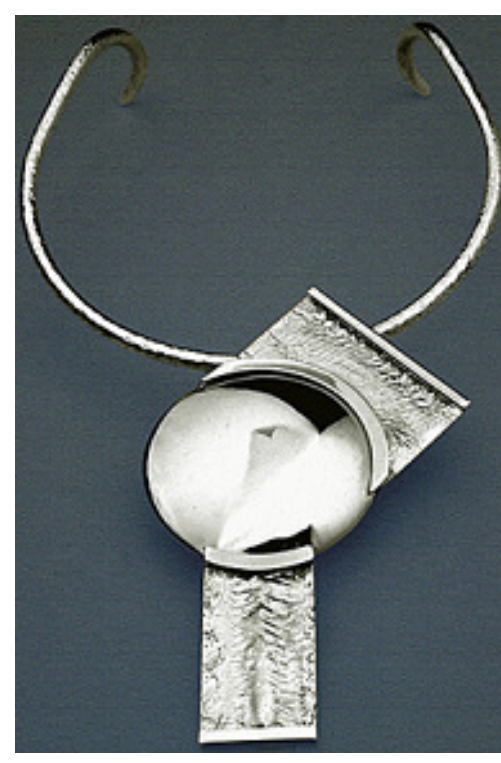

IMAGEN 314

Ofebrería Ornamenta

Pectoral Ergonométrico Reticulado

Plata 1000, plata esterlina

Cera perdida, extrusión, formación a martillo,

reticulado, articulación mecánica, ensamblaje

$29,3 \times 14, \mathrm{~cm}, 296 \mathrm{gr}$

Colección: privada

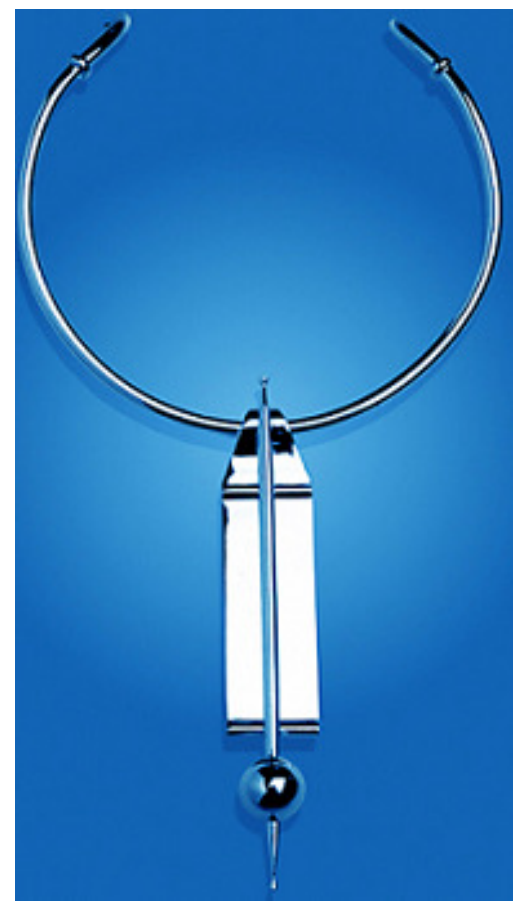

IMAGEN 315

Orfebrería Ornamental

Pectoral Ergonométrico Smith

1989

Plata 1000, plata esterlina

Cera perdida, extrusión, formación a martillo,

aminación articulación mecánica, ensamblaje

$29,8 \times 14,2 \mathrm{~cm}, 274 \mathrm{gr}$

Colección: privada

Comentario: F/O de Pectorales Ergonométricos 


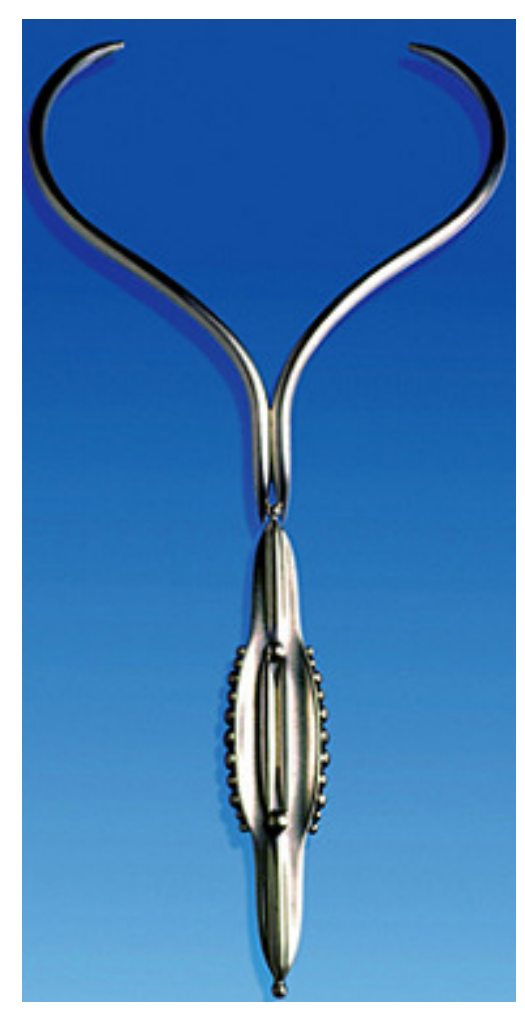

IMAGEN 316

Orfebrería Ornamental

Pectoral Micro esferas

1996

Plata 999

Cera perdida, articulación mecánica

$30 \times 14 \mathrm{~cm}$

Colección: privada

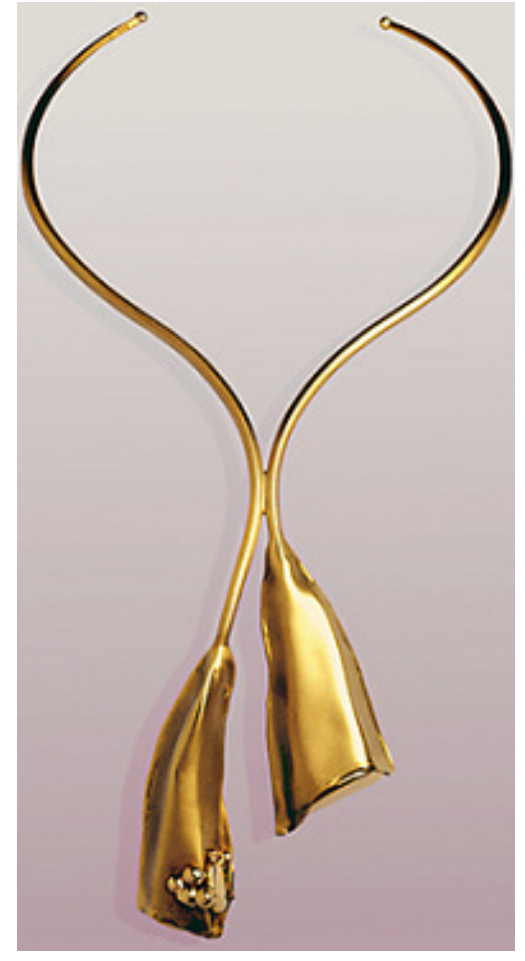

IMAGEN 317

Orfebrería Ornamental

Pectoral Lirios y gianduia

1997

Oro 22 quilates, 1 brillante

Cera perdida, engaste pave

$30 \times 14 \mathrm{~cm}$

Colección: privada 


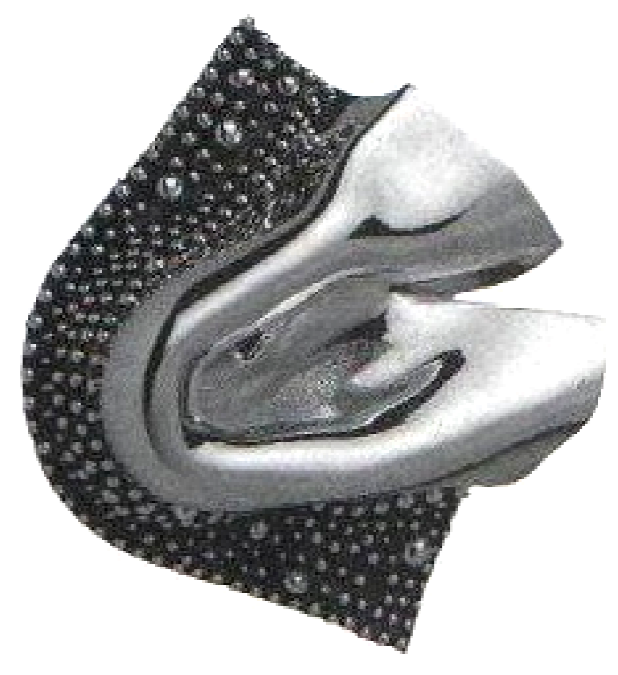

IMAGEN 318

Orfebreria Ornamental

Hebilla Escultórica

1987

Plata esterlina

Cera perdida, formación a martillo,

granulado, oxidación

$11 \times 9 \mathrm{~cm}, 174 \mathrm{gr}$

Colección: del artista

Comentario:
Escultóricas

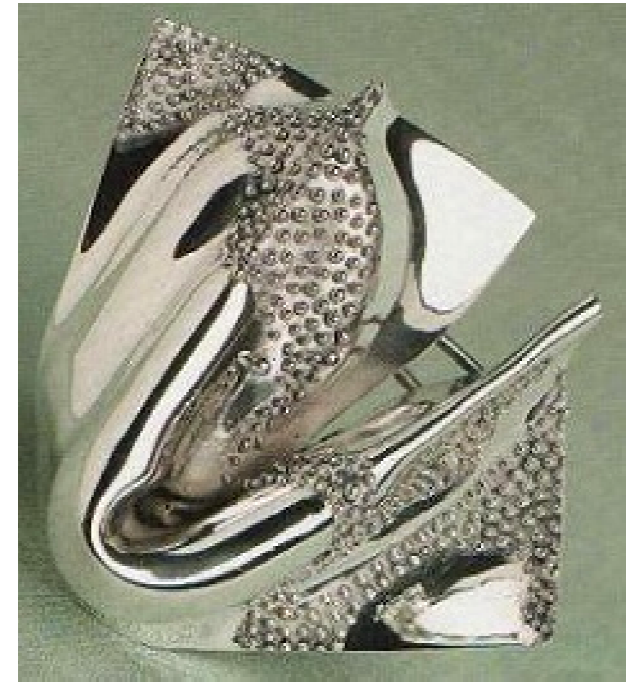

IMAGEN 319

Orfebrería Ornamental

Hebilla Escultórica

1987

Plata esterlina

Laminado, formación a martillo,

Colección: Sra. Ariana Chacón de

Salvatierra

Comentario: 


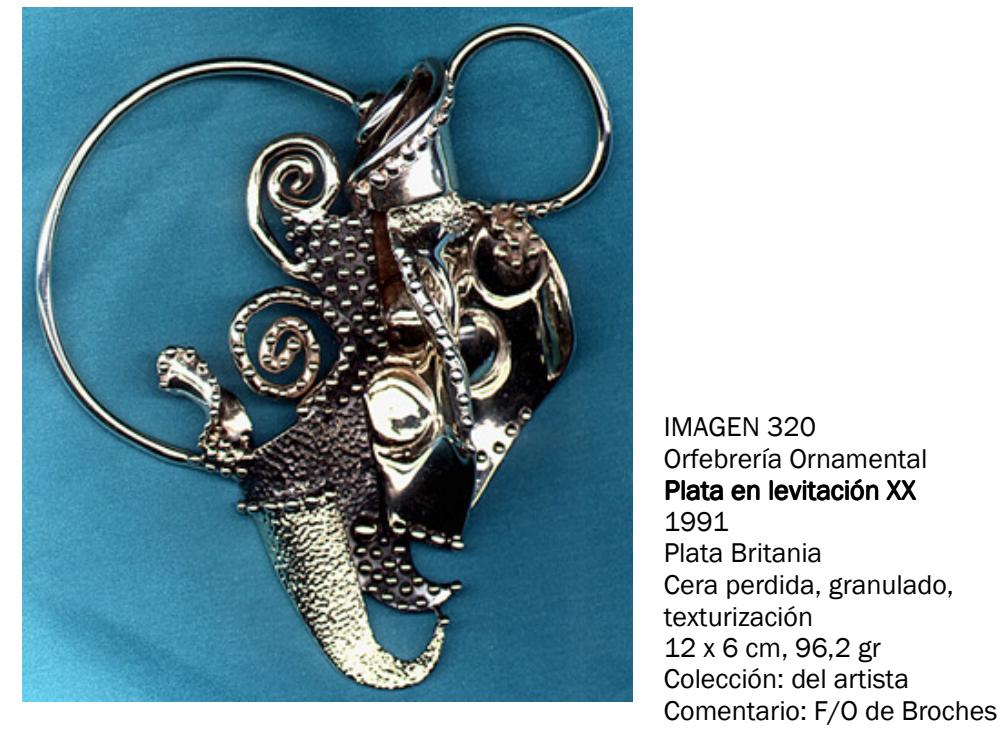




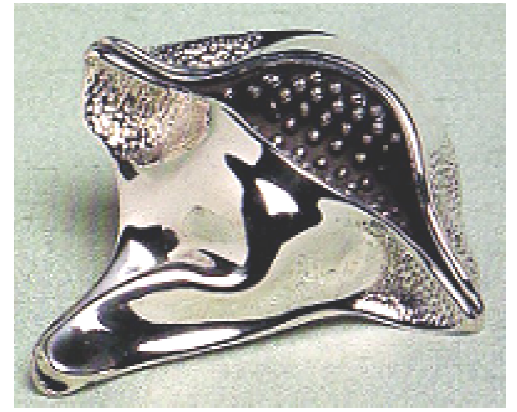

IMAGEN 321

febrería Ornamental

Broche-Pendentif Escultórico

1987

Plata esterlina

Cera perdida, granulado, texturización,

oxidación

10,7 x 5,8 cm, 62 gr
Colección: Arq. Adriana Simón de Guevara

Colección: Arq. Adriana Simón

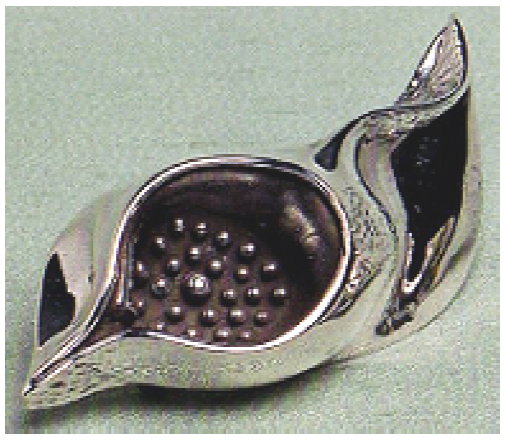

IMAGEN 322

Orfebrería Ornamental

Broche-Pendentif Escultörico

1987

Plata esterlina

Cera perdida, granulado, texturización

oxidación

$9,8 \times 4,8 \mathrm{~cm}, 74 \mathrm{gr}$

Comentario: F/O de Broches

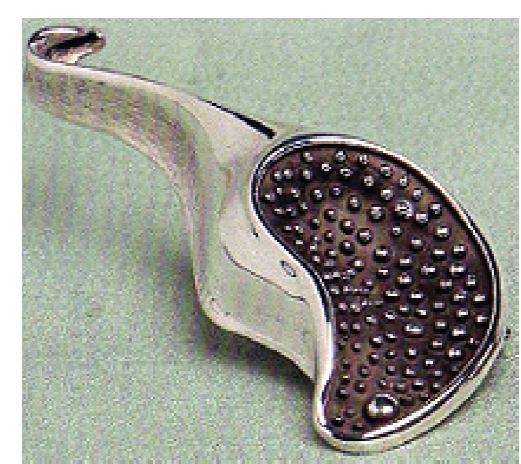

IMAGEN 323

Orfebrería Ornamental

Broche-Pendentif Escultórico

1987

Plata esterlina

Cera perdida, granulado, texturización,

oxidación

$10,7 \times 5 \mathrm{~cm}, 53 \mathrm{gr}$

Colección: del artista

Comentario: F/O de Broches 


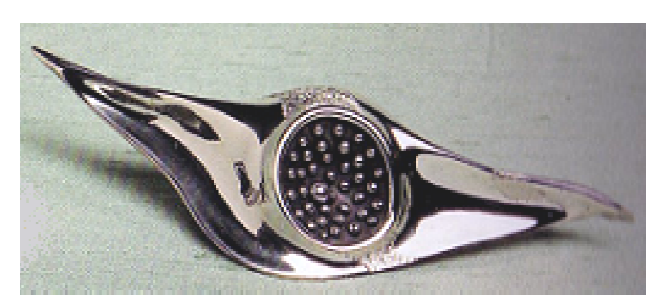

MAGEN 324

Orfebrería Ornamental

Broche-Pendentif Escultórico

1987

Plata esterlina
Cera perdida, granulado,

texturización, oxidación

$11,5 \times 5,5 \mathrm{~cm}, 51 \mathrm{~g}$

Colección: Sra. Nora Ghetea de

Jaegerman

Comentario: F/O de Broches

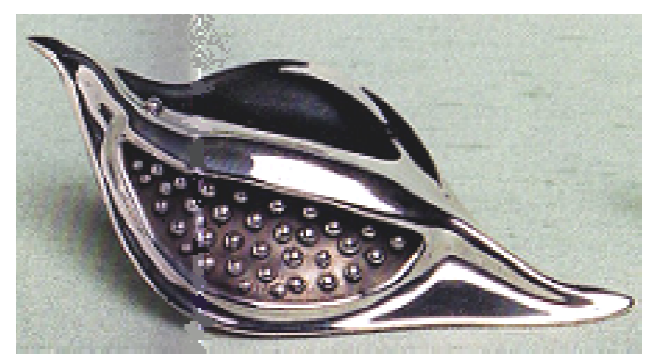

MAGEN 325

Orfebrería Ornamental

Broche-Pendentif Escultórico

Plata esterlina

Cera perdida, granulado,

texturización, oxidación

$11.5 \times 4,7 \mathrm{~cm}, 40 \mathrm{~g}$

Colección: Sr. Christophe Velay

Comentario: F/O de Broches

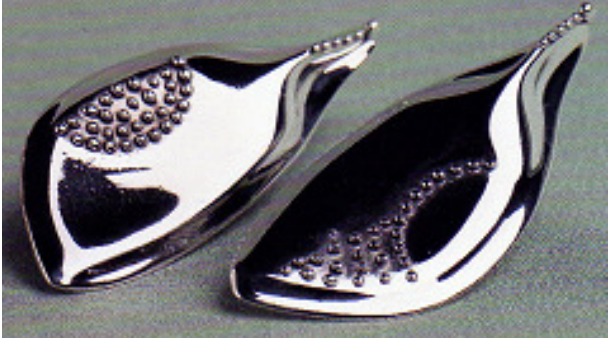

MAGEN 326

Orfebrería Ornamental

Zarcillos Escultóricos

1988

1988
Plata esterlina

Cera perdida, granulado

$9,6 \times 4 \mathrm{~cm}, 63 \mathrm{gr}$

Comentario: F/O de Zarcillos

Escultóricos

IMAGEN 327

Orfebrería Ornamental

Zarcillos Escultóricos

1988

Plata esterlina

Cera perdida, granulado,

texturización, oxidación

$5,1 \times 2,5 \mathrm{~cm}, 24 \mathrm{gr}$

Colección: Sra. Nora Ghetea de

Jaegerman

Comentario: F/O de Zarcillos

Escultóricos 

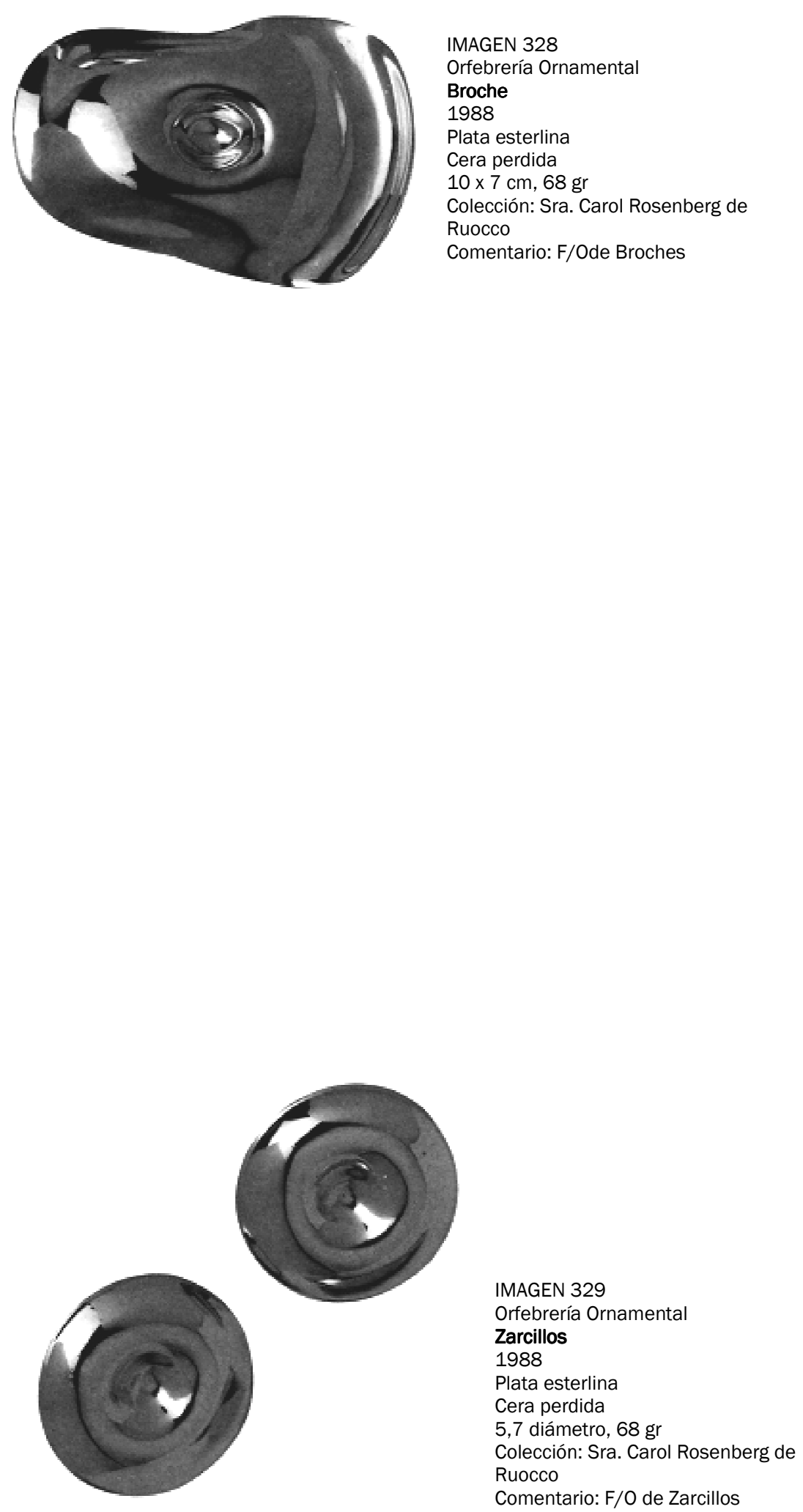


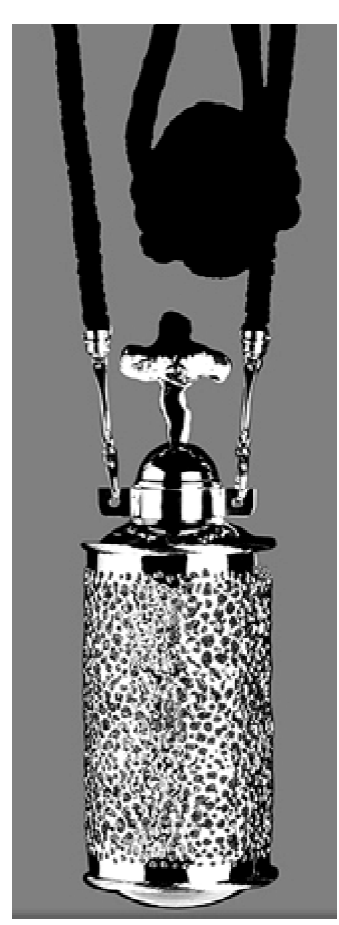

IMAGEN 330

Orfebrería Ornamental

Incensario Ad ànimas pecatorum

1995

Plata 1000, plata esterlina, oro 18 quilates, textil

Laminación, extrusión, formación a martillo, reticulación

por oxi-acetileno, macramé, ensamblaje

$36 \times 12 \mathrm{~cm}, 1600 \mathrm{gr}$

Colección: del artista

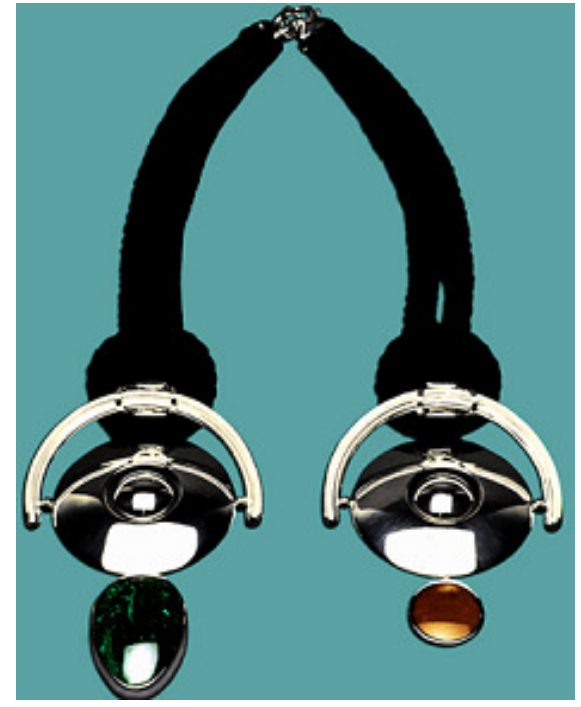

IMAGEN 331

Escapulario La mansión de los elegidos

1994

Plata 1000, plata esterlina, tierra sagrada

de Jerusalén, piedra de Eliat, textil.

Laminado, formación a martillo, engaste,

Colección: del artista

Comentario: F/O de Objetos Mágico

Religioso 


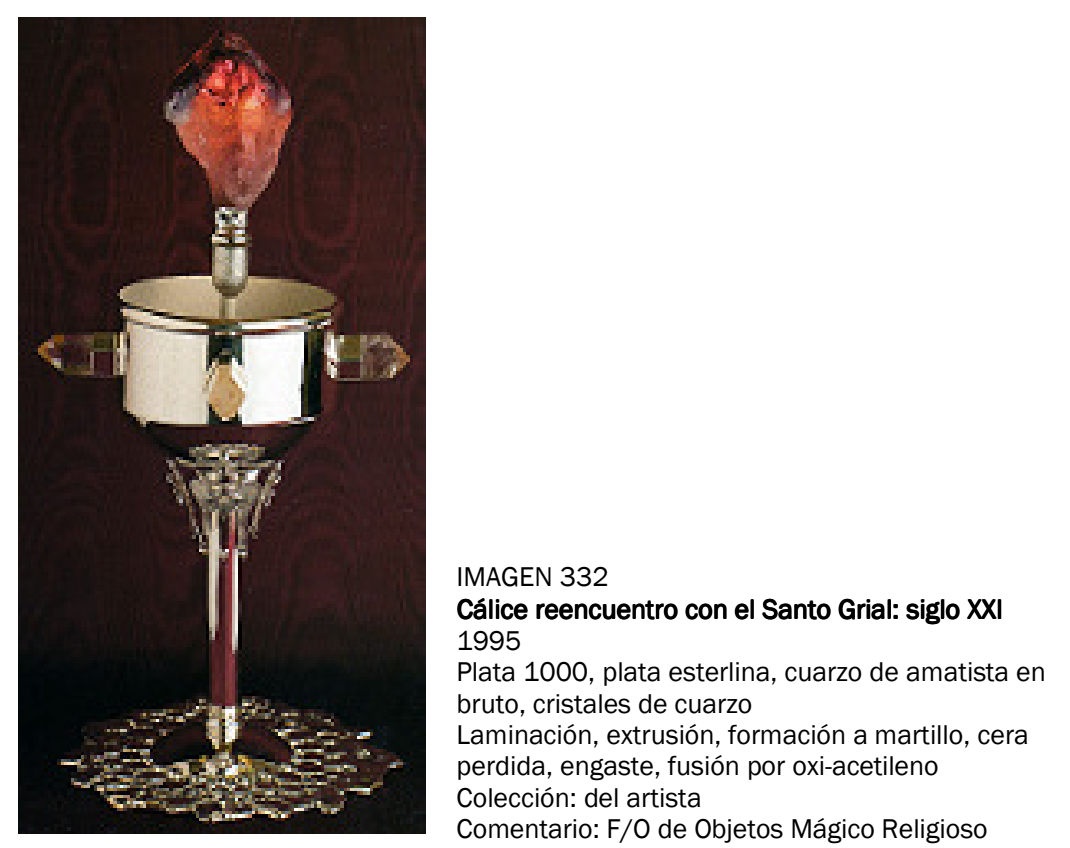



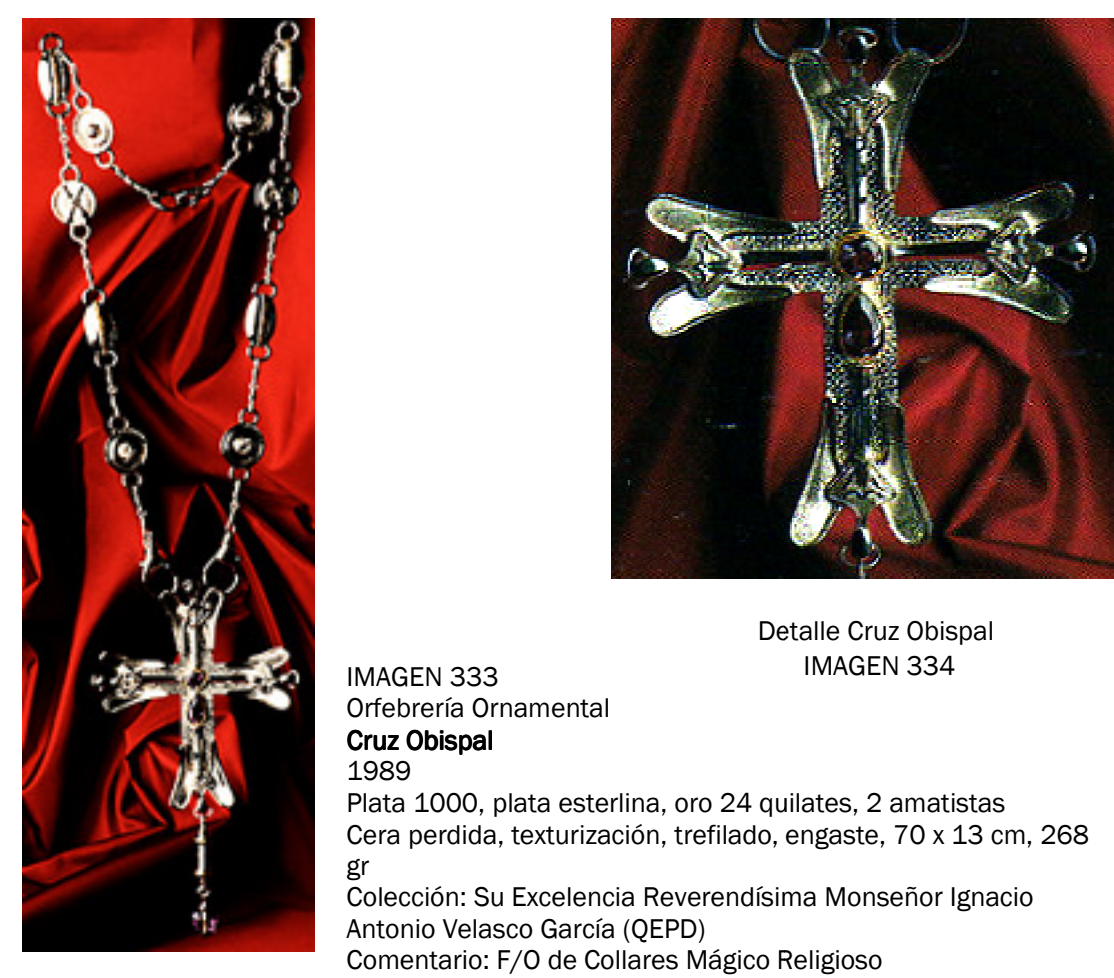

IMAGEN 333

Orfebrería Ornamental

Cruz Obispal

Plata 1000, plata esterlina, oro 24 quilates, 2 amatistas

Cera perdida, texturización, trefilado, engaste, 70 × $13 \mathrm{~cm}, 268$

gr

Antonio Velasco García (QEPD)

Comentario: F/O de Collares Mágico Religioso

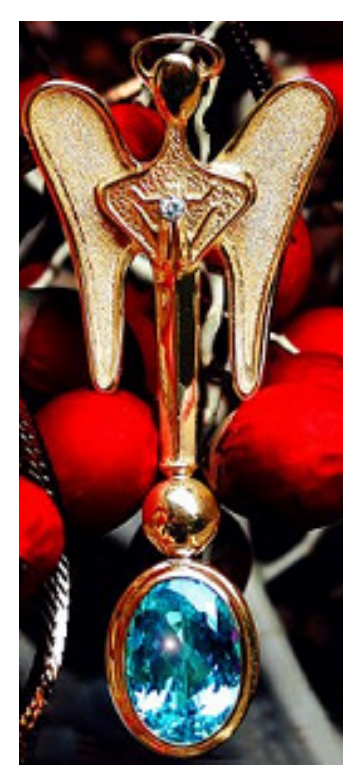

IMAGEN 335

Orfebrería Ornamental

Ángel Custodio

Oro $22 \mathrm{k}$, topacio azul de corte ovalado facetado, brillante

Cera perdida, engaste.

$60 \times 8 \mathrm{~cm}$

Colección: del artista

Comentario: F/O de Collares Mágico Religioso 


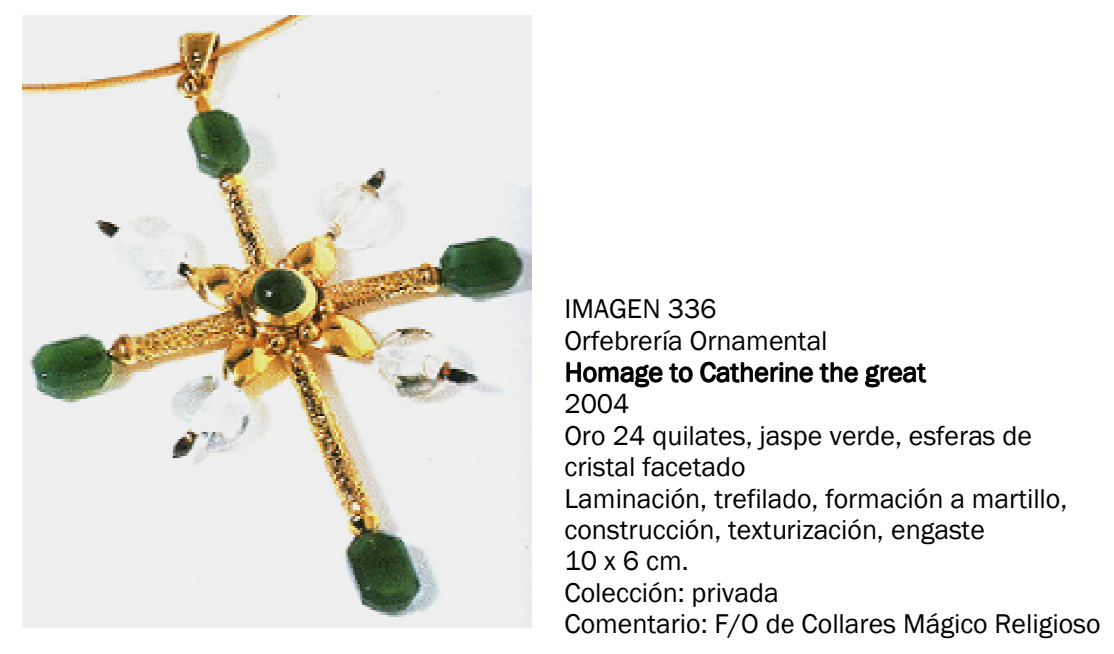




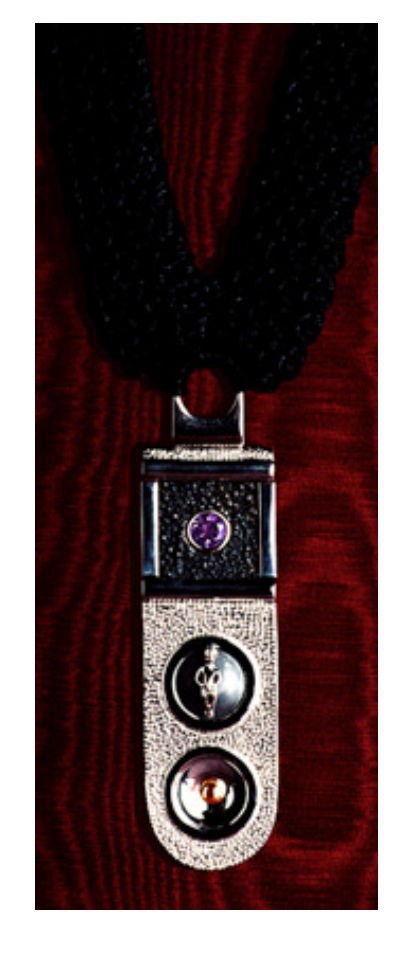

IMAGEN 337

Orfebrería Ornamental

Pectoral para pago de promesas

Plata 1000, plata esterlina, amatista, oro 18 quilates

Cera perdida, extrusión, laminación, formación a martillo,

Fundición en arcilla, engaste, ensamblaje

$25 \times 21 \mathrm{~cm}, 1200 \mathrm{gr}$

Colección: del artista

Comentario: F/O de Utilitaria Ceremonial

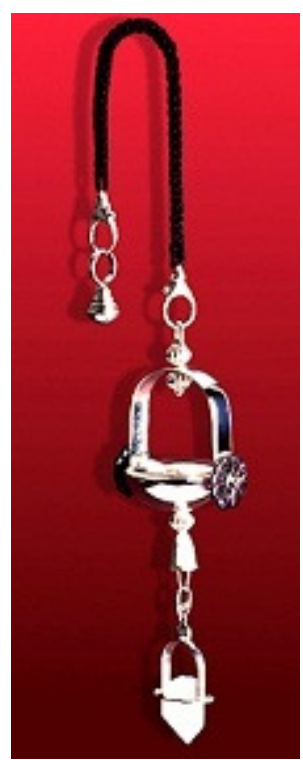

MAGEN 338

Orfebrería Ornamental

Mi Péndulo y Yo, en busca del nuevo edén

995

Plata 1000, plata esterlina, cuarzo, rosetones antiguos de

amatista, textil.

Laminación, extrusión, formación a martillo, engaste, tejido de

macramé, ensamblaje

$29 \times 9 \mathrm{~cm}, 350 \mathrm{gr}$

Colección: del artista

Comentario: F/O de Utilitaria Ceremonial 


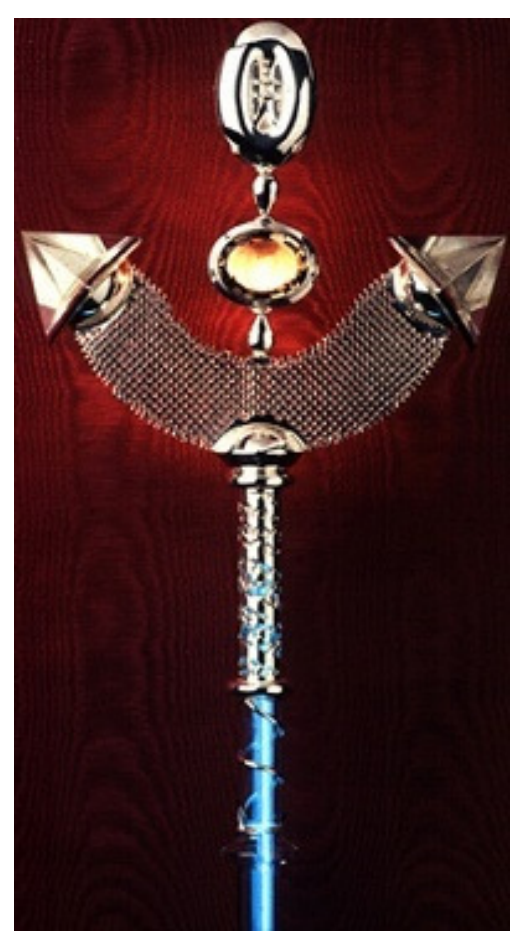

IMAGEN 339

Orfebrería Escultórica

Báculo ceremonial

de Alexis para Merlín

Plata 1000, plata esterlina, cristal, luz de neón

azul, topacio fumé, cuarzo

Laminación, extrusión, cera perdida, grabado al

ácido, granulado, engaste, ensamblaje

$1: 67 \times 24 \times 8 \mathrm{~cm}, 1320 \mathrm{gr}$

Comentario: F/O de Utilitaria Ceremonial

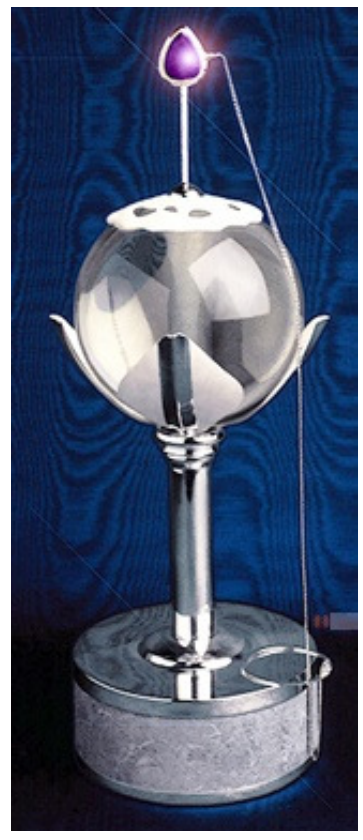

MAGEN 340

Orfebrería Escultórica

de greatest stars

discover themselves in the looking glass

1995

Plata 1000 , plata esterlina

Fundición, extrusión, laminación, formación a martillo,

repujado, reticulación por oxi-acetileno, engaste,

ensamblaje

$37 \times 12 \mathrm{~cm}, 1800 \mathrm{gr}$

Comentario: F/O de Utilitaria Ceremonial 
IMAGEN 341

ería Escultórica

Cetro Imperial el Rey de los Cruzados

1995

Plata 1000, plata esterlina, oro 24 quilates, perla, jade negro.

Talla en piedra (jade), formación a martillo, engastes,

granulado en oro y plata, ensamblaje

$49 \times 6 \mathrm{~cm}, 1200 \mathrm{gr}$

Comentario: F/O de Utilitaria Ceremonia

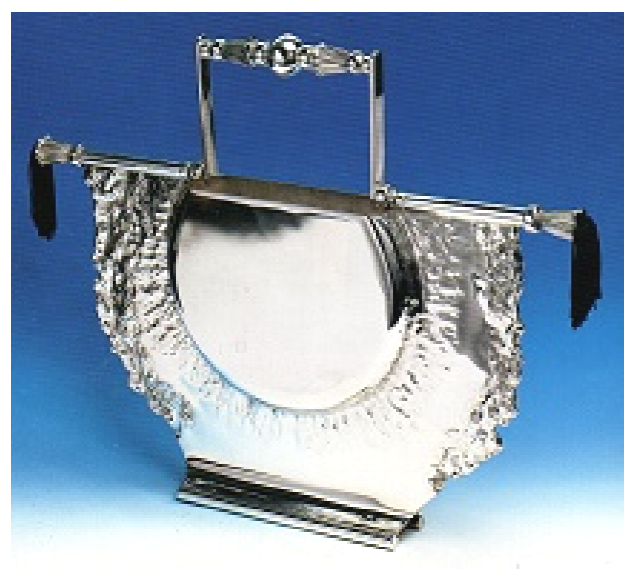

IMAGEN 342

Orfebrería Escultórica

Relicario

1990

Plata 1000, plata esterlina, textil

Laminación, extrusión, formación a

martillo, texturización por oxi-

acetileno, macramé, ensamblaje

$229 \times 37 \mathrm{~cm}, 1450 \mathrm{gr}$

Colección: del artista

Comentario: $F / O$ de Utilitaria
Ceremonial 


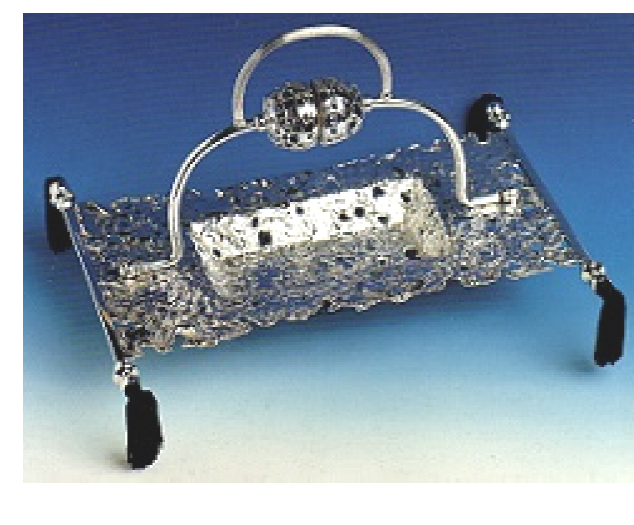

IMAGEN 343

Orfebrería Escultórica

Bandeja Porta-anillos Présentoir

1990

Plata 1000, plata esterlina, textil

Laminación, extrusión, formación a

martillo, texturización por oxi-

acetileno, macramé, ensamblaje

$31 \times 22 \mathrm{~cm}, 996 \mathrm{gr}$

Colecciôn: del ar

Comentario: F/O de Utilitaria

Ceremonial

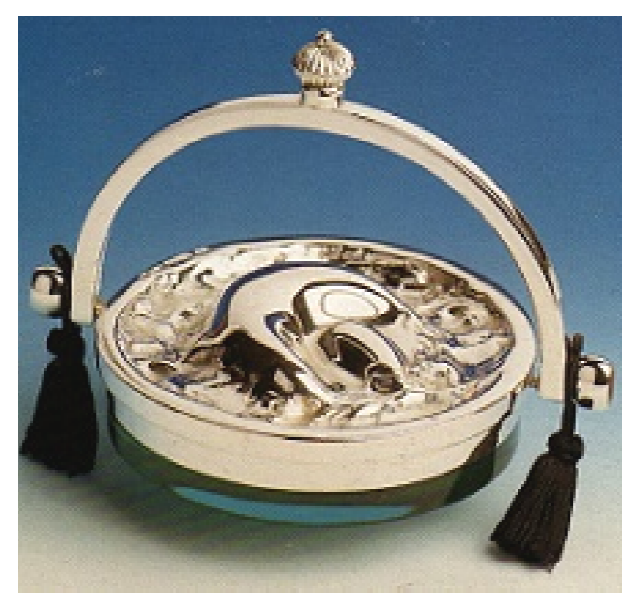

IMAGEN 344

Orfebrería Escultóric

Poids d'argent I

1990

Plata 1000, plata esterlina, cristal,

textil

Laminación, extrusión, fundición,

macramé, ensamblaje

$14 \times 11 \mathrm{~cm}, 848 \mathrm{gr}$

Colección: Dr. Roberto Pocaterra

Comentario: F/O de Utilitaria

Ceremonial 


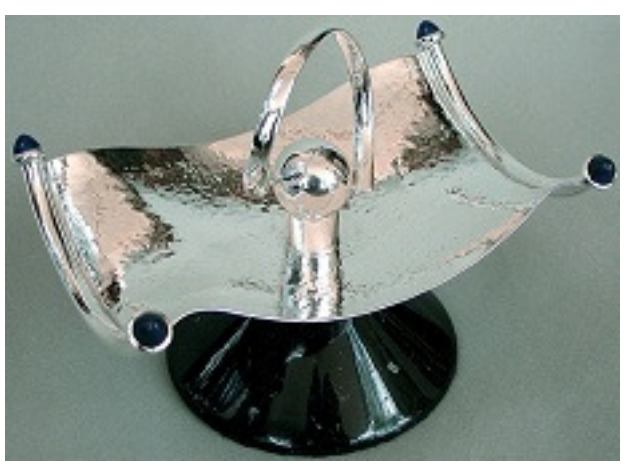

IMAGEN 345

Orfebrería Escultórica

Présentor

Plata 1000, lapislázuli, mármol,

aminación, extrusión, engeste,

formación a martillo, texturización

ensamblaje

Colección: del artista

Comentario: F/O de Utilitaria

Ceremonial

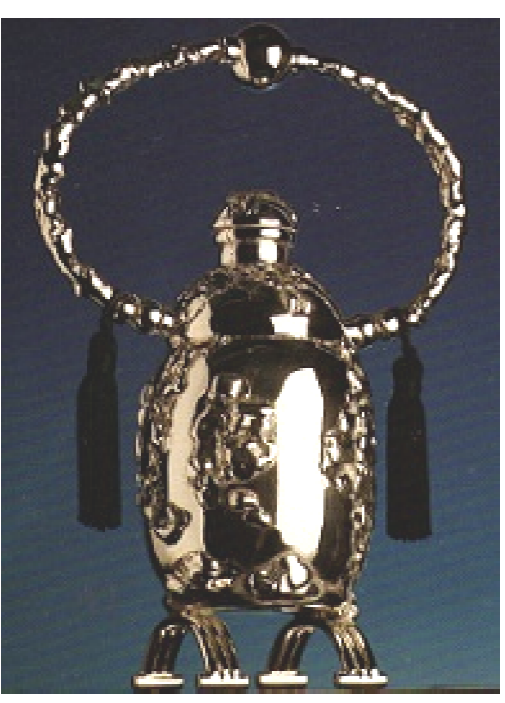

IMAGEN 346

Orfebrería Escultórica

Plata 1000, plata esterlina, texti

Laminación, extrusión, formación a martillo,

texturización por oxi-acetileno, macramé,

ensamblaje

$23,8 \times 16,2 \mathrm{~cm}, 800 \mathrm{gr}$

Colección: del artista

Comentario: F/O de Utilitaria Ceremonial

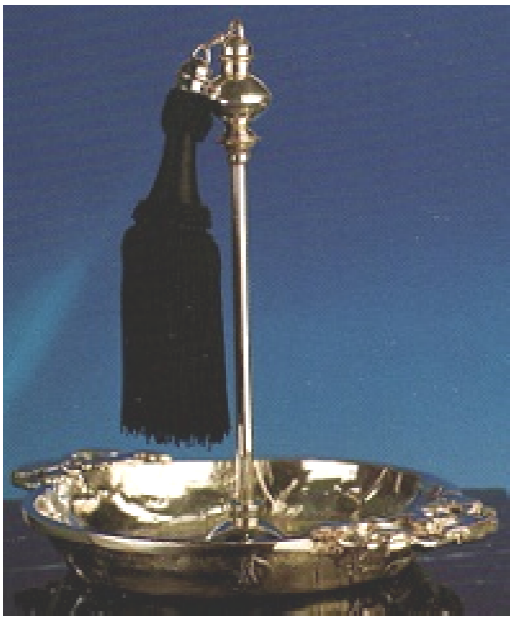

IMAGEN 347

Orfebrería Escultórica

Porta-pétalos

Plata 1000 , plata esterlina, textil

texturización por oxi-acetileno, macramé,

ensamblaje

$26 \times 21 \mathrm{~cm}, 752 \mathrm{gr}$

Colección:

Comentario: F/O de Utilitaria Ceremonial 


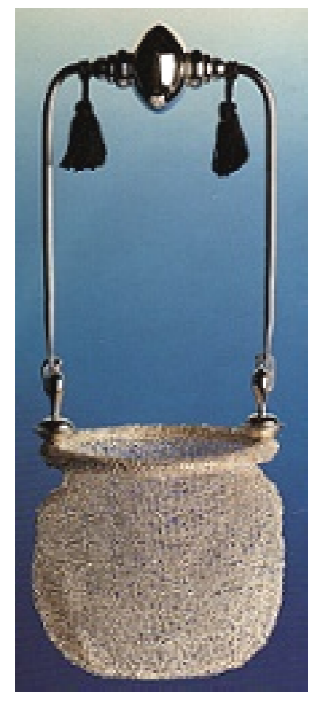

IMAGEN 348

Orfebrería Escultórica

Bolso Porta-arras

1992

Laminación, extrusión, tejido a mano, formación a martillo,

ensamblaje

$31 \times 12 \mathrm{~cm}, 280 \mathrm{gr}$
Colección: del artista

Comentario: F/O de Utilitaria Ceremonial

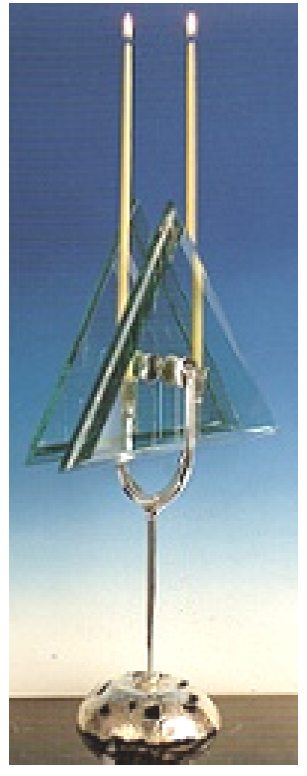

IMAGEN 349

Orfebrería Escultórica Luminaria

Candelabro

Candelabro

Plata 1000 , plata esterlina, crista

Extrusión, fundición en arcilla, texturización por oxi-acetileno,

ensamblaje

co $25 \mathrm{~cm}, 2500 \mathrm{gr}$

Comentario: F/O de Utilitaria Ceremonial 


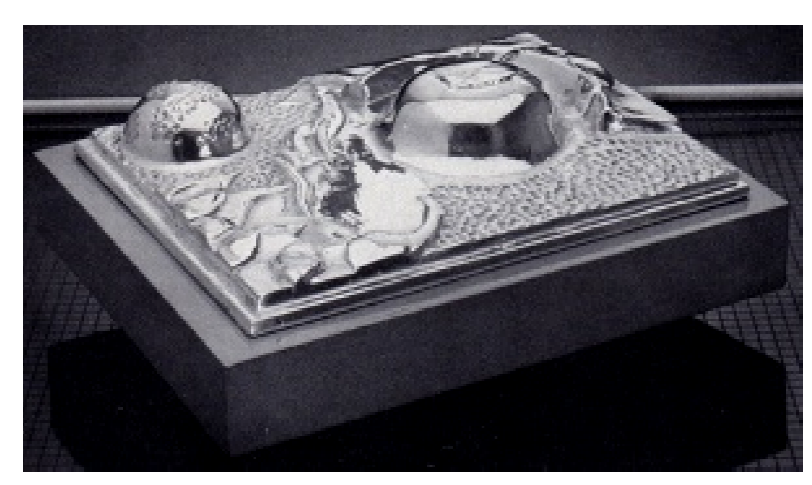

IMAGEN 350

Orfebrería Escultórica

Le jardín des délices

198

Plata esterlina, mármo

Laminación, texturización mecánica, formación a martillı

$32 \times 24 \mathrm{~cm}$.

Colecciôn: Sra. Sara Almosny

Comentario: F/O de Proyectos en Surgimient

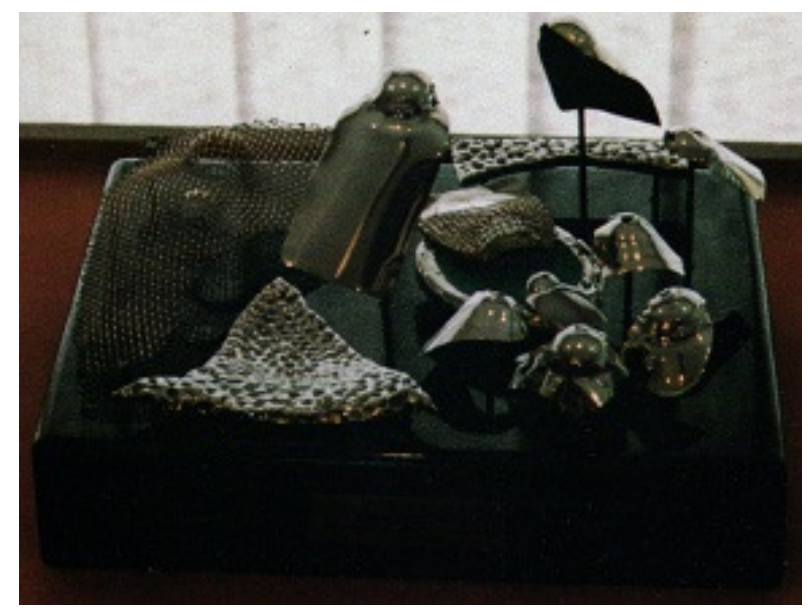

IMAGEN 351

Orfebrería Escultórica

Ritual

Ritual

Plata esterlina, malla de plata, mármol

Laminación, texturización mecánica, formación a martillo

$30 \times 24 \mathrm{~cm}$.

Comentario: F/O de Proyectos en Surgimiento 


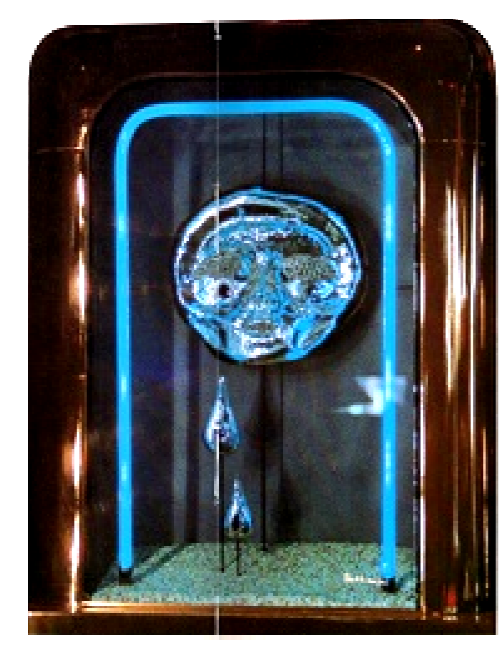

IMAGEN 352

Orfebrería Escultórica Lumínica

Monumento a la soledad

1985

Plata 1000, luz de neón azul, 3 amatistas

(totalizando 71 quilates)

Laminación, texturización mecánica, formación

a martillo, engaste, ensamblaje lumínico.

$60 \times 40 \times 20 \mathrm{~cm}$.

Colección: privada

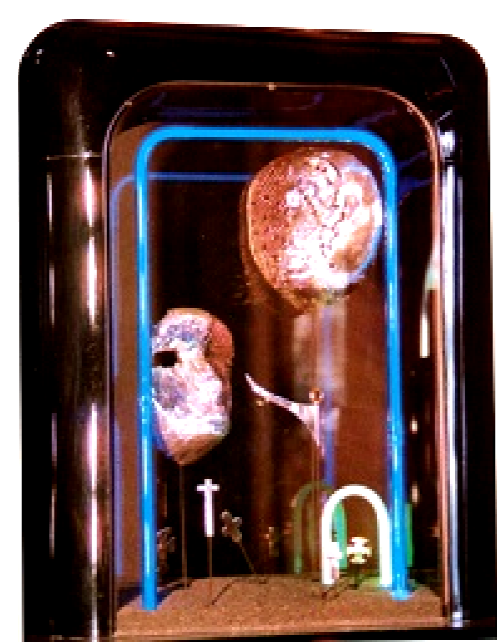

IMAGEN 353

Orfebrería Escultórica Luminica

Desencarnación y sublimación

1986

Plata 1000, luz de neón azul y blanco, topacio,

Laminación, texturización mecánica, formación

a martillo, engaste, ensamblaje lumínico.

$60 \times 40 \times 20 \mathrm{~cm}$.

Colección: Sr. Manuel Arcaya y Sra.

Comentario: F/O de Arco Lumínico

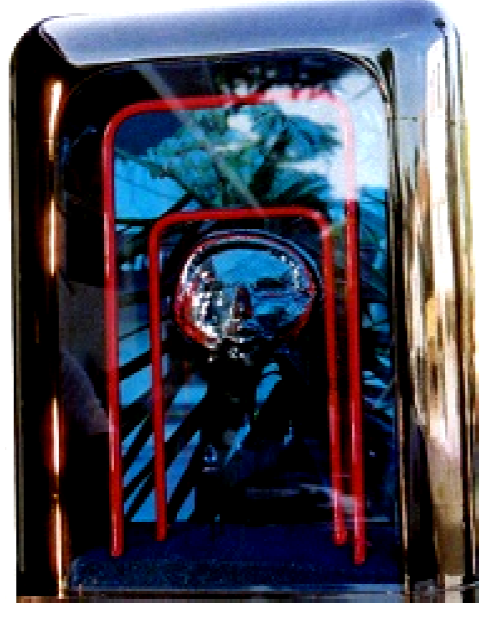

IMAGEN 354

Orfebrería Escultórica Lumínica

El Portal del infierno

1986

Plata 1000, luz de neón rojo, cristal

Laminación, texturización mecánica, formación a

martillo, engaste, ensamblaje lumínico.

$60 \times 40 \times 20 \mathrm{~cm}$

Colección: del artista 


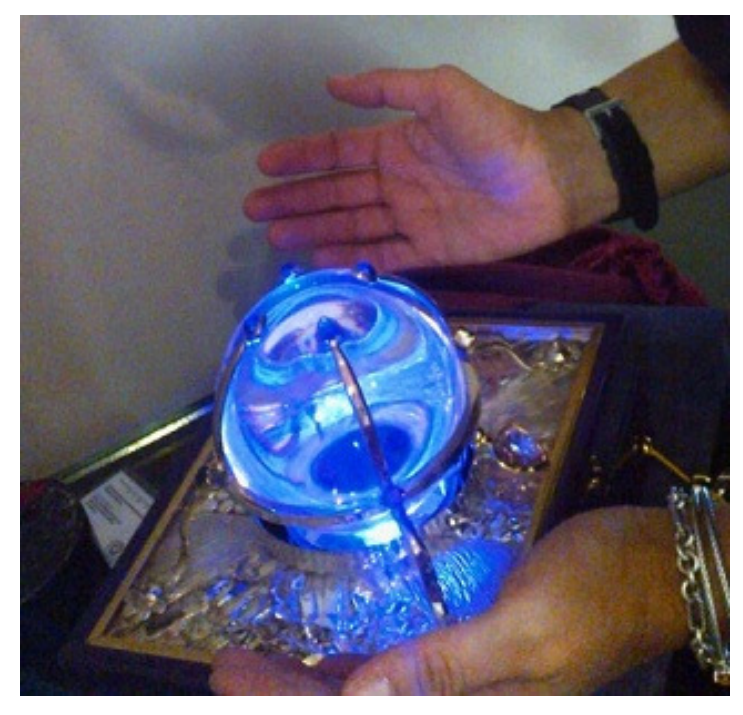

IMAGEN 355

Orfebrería Escultórica Lumínica

Caja musical Visiones en Púrpura: Homenaje a San Gabriel Arcángel

Plata 1000, plata Britania, plata esterlina, oro 24 K, amatistas facetadas en corte "carré" y en corte "cabuchon", corazón de cristal de roca rosado facetado y engastado en oro $24 \mathrm{~K}$, esfera de cristal de cuarzo 4" $\varnothing$, perlas barrocas.

a la cera perdida, formación a martillo, soldadura al propano y al oxiacetileno, engastes, texturización, desbastado y laqueado, construcción e instalación de elementos mecánicos, lumínicos y musicales. $22 \times 19 \times 18 \mathrm{~cm}$.

Colección: del artist

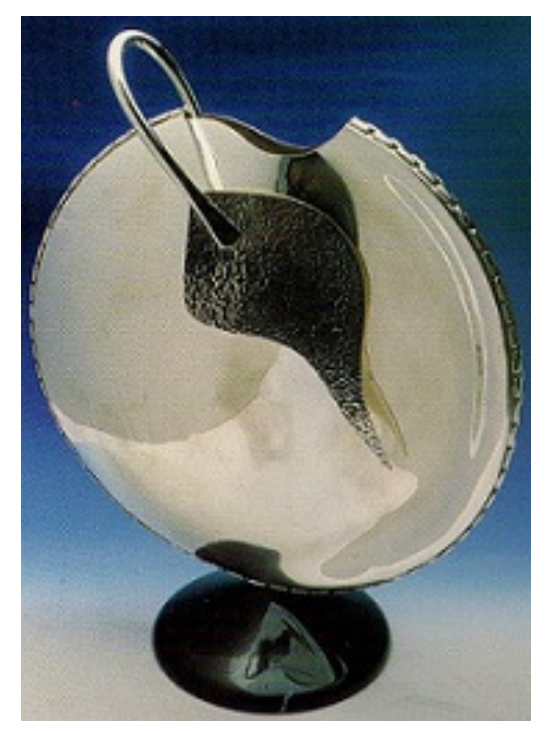

MAGEN 356

Orfebrería Escultórica

Néctar negro

1998

Plata 1000 maciza, pedestal lumínico negro

mate

ánfora: $45 \times 35 \times 25 \mathrm{~cm} /$ pedestal: $20,6 \times 30$

$\times 30 \mathrm{~cm}$

Colección: del artista 


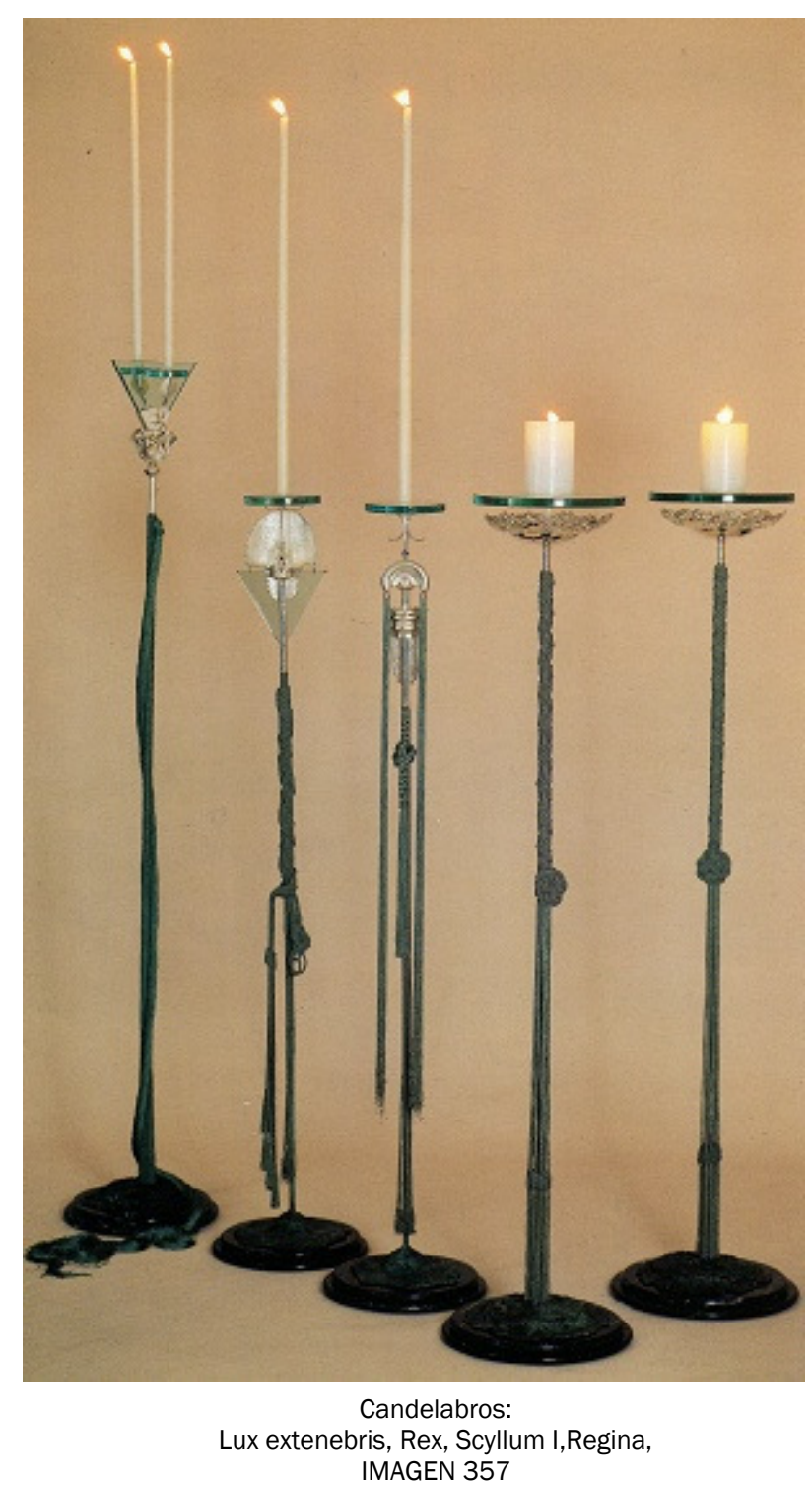




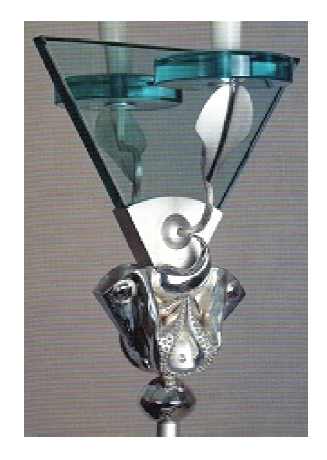

IMAGEN 358

Orfebrería Escultórica Luminaria

Lux extenebris

1994

Plata 1000, plata esterlina, cristal, bronce, textil

Laminación, extrusión, formación a martillo, cera perdida,

Sandblasting, fundición aditiva, pátina, macrame, ensamblaje

$205 \times 29 \mathrm{~cm}$

Coleccion: del artista

Comentario: F/O de Candelabros de plata

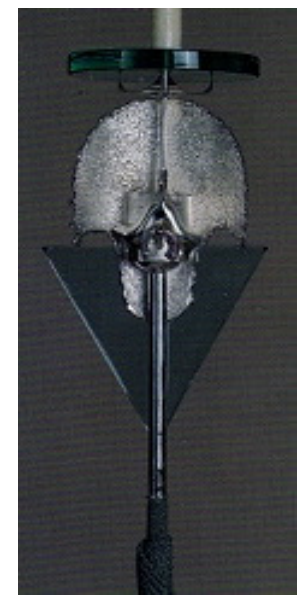

IMAGEN 359

Orfebrería Escultórica Luminaria

Rex

Plata 1000, plata esterlina, cristal, bronce, textil

Laminación, extrusión, formación a martillo, cera perdida

Sandblasting, fundición aditiva, pátina, macramé, ensamblaje

$175 \times 28 \mathrm{~cm}$

Colección: del artista

Comentario: F/O de Candelabros de plata

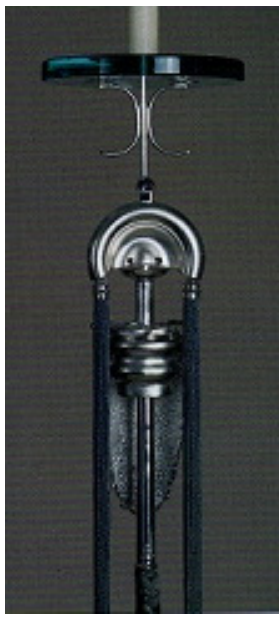

IMAGEN 360

Orfebrería Escultórica Luminaria

Regina

Regina

Plata 1000, plata esterlina, amatistas, cristal, bronce, textil.

Laminación, extrusión, formación a martillo, cera perdida,

Sandblasting, fundición aditiva, pátina, macramé, ensamblaje

$174 \times 28 \mathrm{~cm}$

Colección: del artista.

Comentario: $F / O$ de Candelabros de plata 


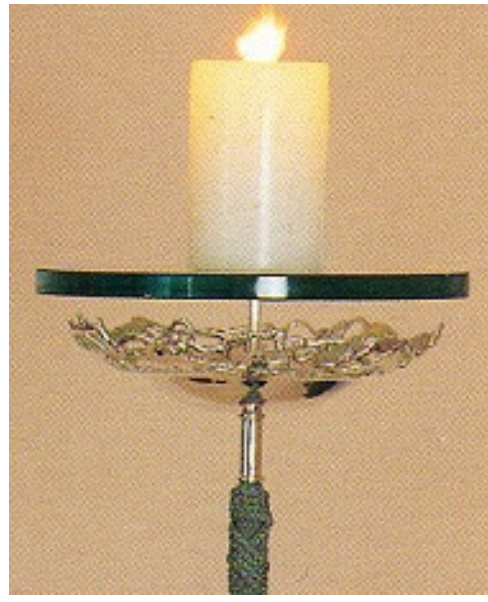

IMAGEN 361

Orfebrería Escultórica Luminaria

Scyllum I

1994

Plata 1000, plata esterlina, cristal, bronce, textil

Laminación, extrusión, formación a martillo, cera

perdida, fundición aditiva, pátina, macramé,

ensamblaje

$176 \times 32 \mathrm{~cm}$.

Comentario: F/O de Candelabros de plata 


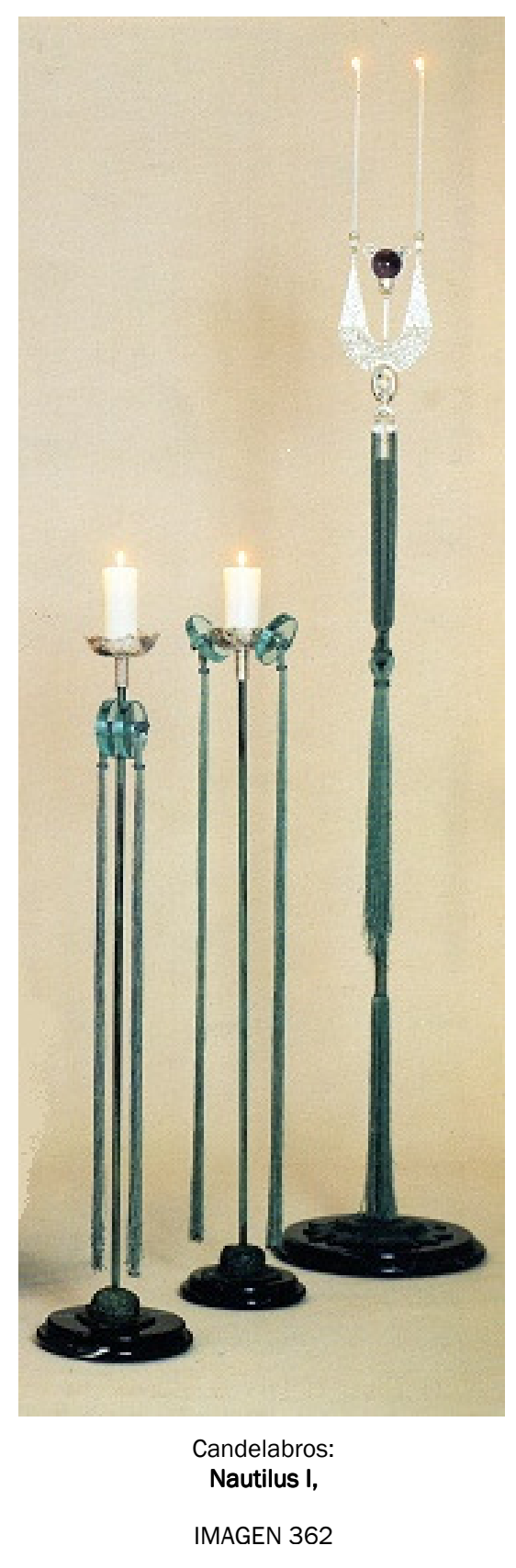


MAGEN 363

Orfebrería Escultórica Luminaria

Nautilus I

1995

Plata Britania, esfera de cuarzo, cristal, bronce, textil

Cera perdida, fundición aditiva, patinado, Sandblasting

macramé, ensamblaje

$99 \times 25 \mathrm{~cm}$

Nautilus II del artista /
Nautilus I Sr. Yves Uzán. Belle Mead, Island. Miami, USA

Comentario: F/O de Candelabros de plata

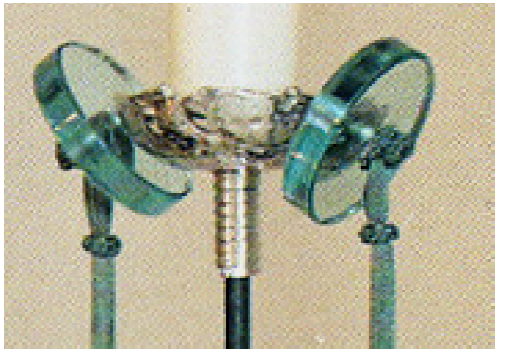

Orfebrería Escultórica Luminaria

Lux centuriae II

1995

Plata 1000, cristal, bronce, textil

Fundición en arcilla, fundición aditiva, extrusión,

pátina, macramé, ensamblaje

$115 \times 17 \mathrm{~cm}$

Colección: del artista

Comentario: F/O de Candelabros de plata

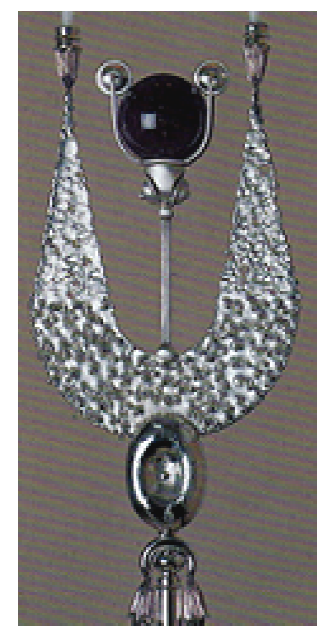

IMAGEN 365

Orfebrería Escultórica Luminaria

Lux centuriae I

1995

Plata 1000 , cristal, bronce, textil

Fundición en arcilla, fundición aditiva extrusión, pátina,

macramé, ensamblaje

$115 \times 18 \mathrm{~cm}$

Colección: del artista.

Comentario: F/O de Candelabros de plata 


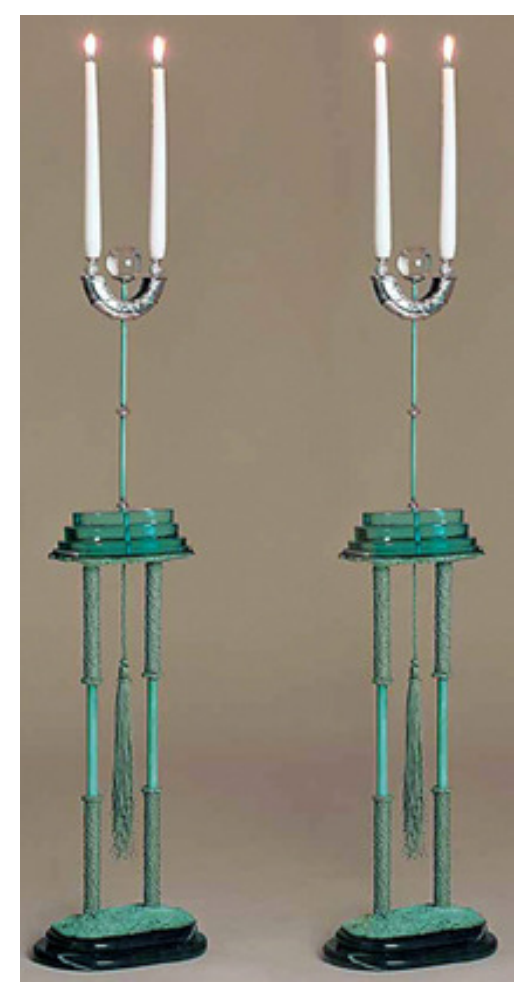

IMAGEN 366

Orfebrería Escultórica Luminaria

Imperium

1994

Plata 1000, plata esterlina, esfera de cuarzo de amatista, bronce, texti

Laminación, extrusión, cera perdida, texturización por oxi-acetileno fundición aditiva,

patinado, Sandblasting macramé, ensamblaje

$185 \times 28 \mathrm{~cm}$

Colección: del artista

Comentario: F/O de Candelabros de plata 


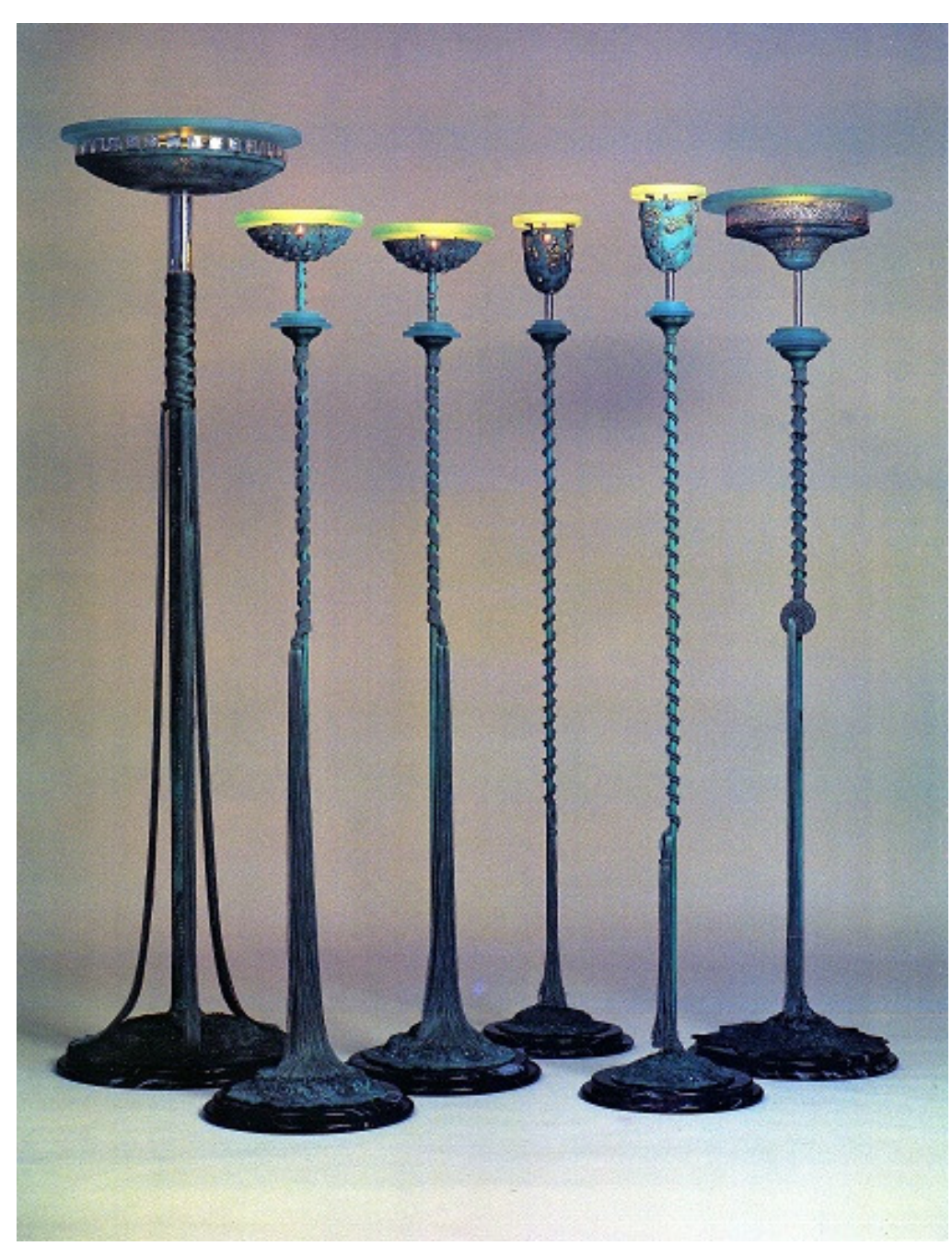

Candeleros:

ustinus I, II, Plinius I, II, Aristóteles

Alba legionari I, Augustinus I, II, Plin
IMAGEN 367 


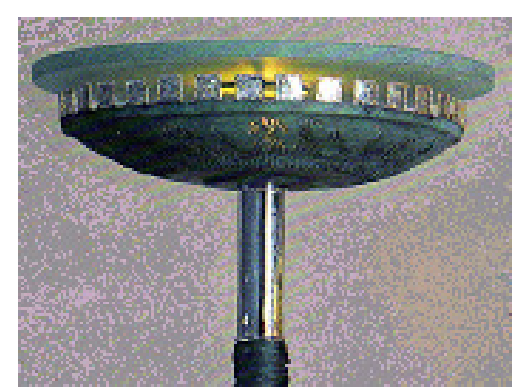

MAGEN 368

Escultórica Luminaria

Alba legionari I

Plata 1000, cristal, bronce, textil

Laminación, extrusión, formación, reticulación,

fundición aditiva, patinado, sandblasting,

macramé, ensamblaje

$194 \times 50 \mathrm{~cm}$

Colección: del artista

Comentario: F/O de Candeleros

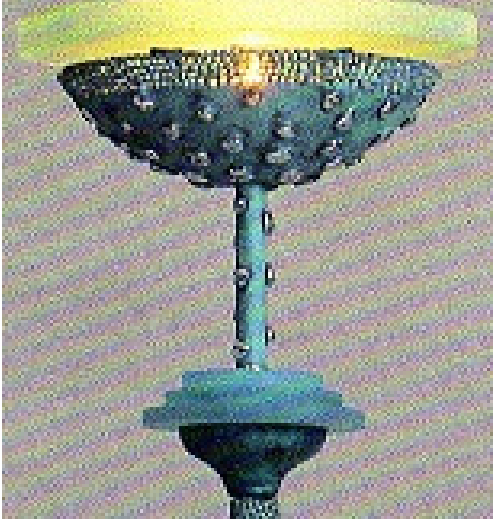

IMAGEN 369

Orfebrería Escultórica Luminaria

Augustinus

Plata 1000, cristal, bronce, textil

Laminación, extrusión, formación, reticulación,

fundición aditiva, patinado, sandblasting,

macramé, ensamblaje

$173 \times 32 \mathrm{~cm}$

Comentario: $\mathrm{F} / \mathrm{O}$ de Candeleros

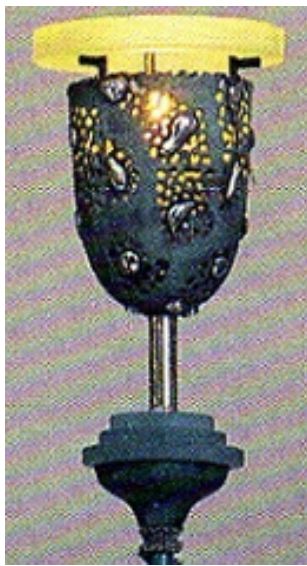

IMAGEN 370

Orfebrería Escultórica Luminaria

Plinius

Plata 1000 , cristal, bronce, text

Laminación, extrusión, formaciôn, reticulación, fundición

aditiva, patinado, sandblasting, macramé, ensamblaje

$179 \times 26 \mathrm{~cm}$

Colecciôn: del artista

Comentario: F/O de Candeleros

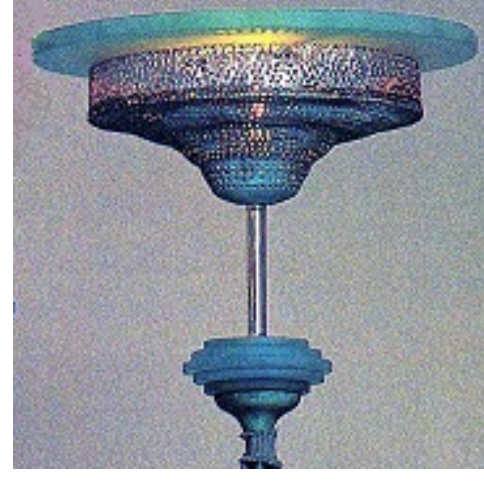

IMAGEN 371

Orfebrería Escultó

Aristóteles

Plata 1000, cristal, bronce, textil

Laminación, extrusión, formación Y reticulación,

por oxi-acetileno, fundición aditiva, patinado,

sandblasting,
$183 \times 44 \mathrm{~cm}$

$183 \times 44 \mathrm{~cm}$
Colección: CAVENDES

Comentario: $F / O$ de Candeleros 


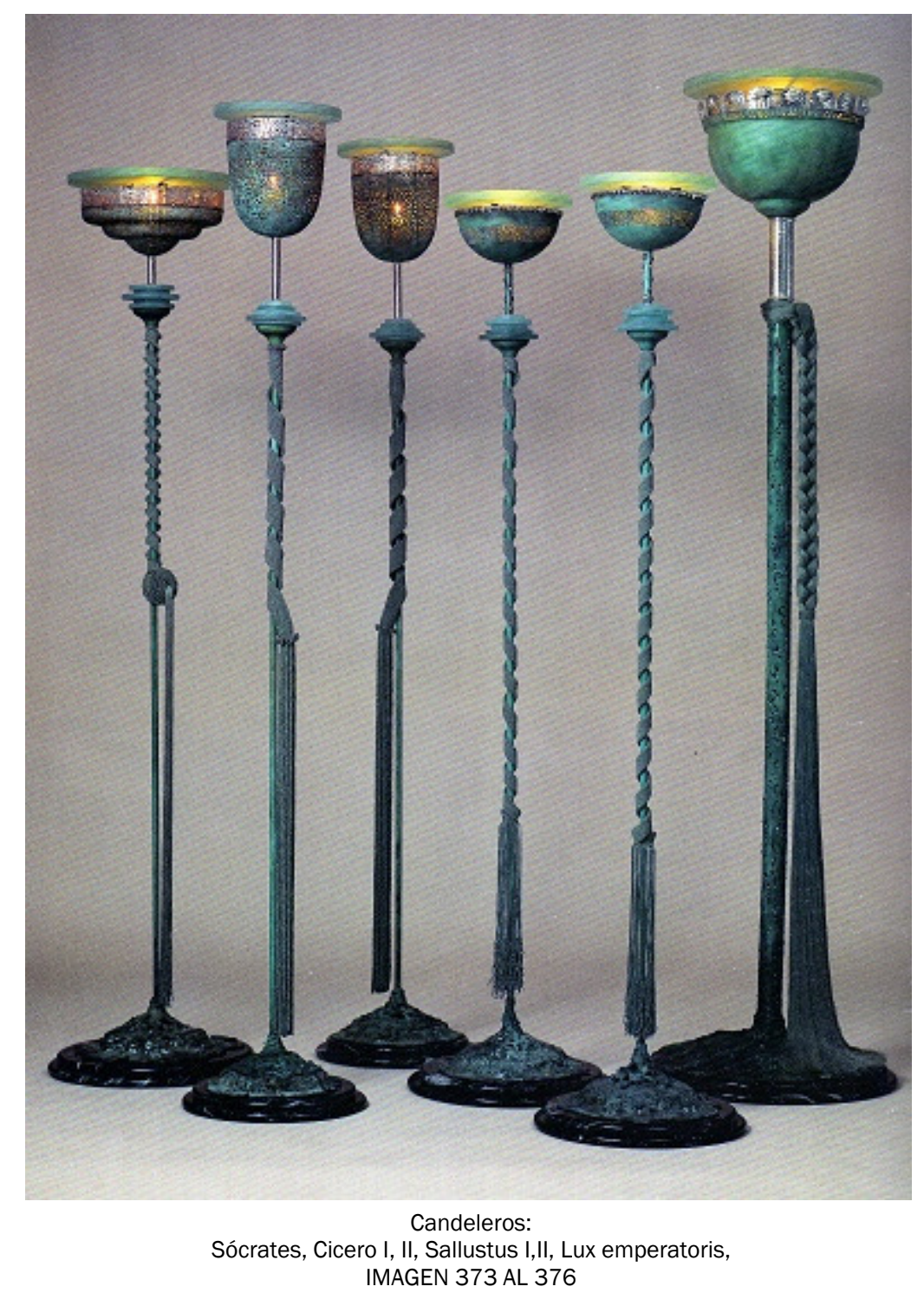




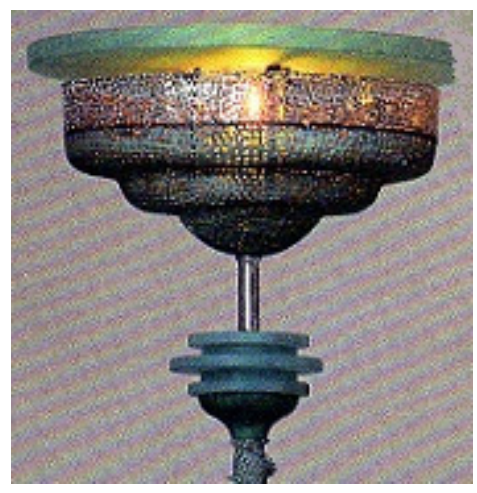

IMAGEN 373

Orfebrería Escultórica Luminaria

Sócrates

Plata 1000 , cristal, bronce, textil

Laminación, extrusión, formación a martillo,

reticulación, fundición aditiva, patinado.

Sandblasting macramé, ensamblaje

$183 \times 36 \mathrm{~cm}$

Colección: del artista

Comentario: F/O de Candeleros

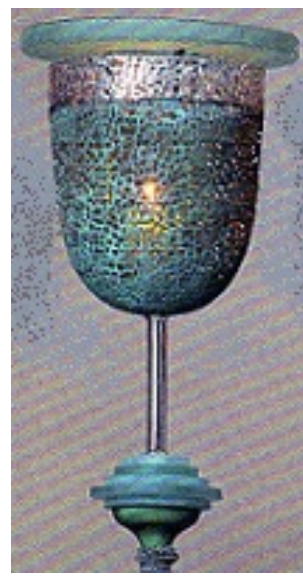

MAGEN 374

Orfebrería Escultórica Luminaria

Cicero I, II

1995
Plata 1000, cristal, bronce, texti

Laminación, extrusión, formación a martillo, reticulación,

fundición aditiva, patinado, sandblasting, macramé,

ensamblaje

$193 \times 28 \mathrm{~cm}$
Colección: del artista

Colección: del artista 


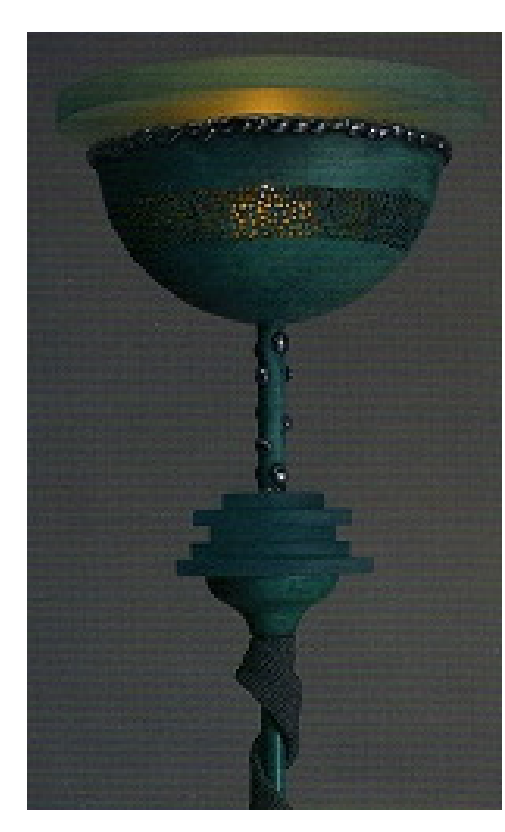

MAGEN 375

Orebrería Escultórica Luminaria

Sallustus $1, \mathrm{ll}$

Plata 1000, cristal, bronce, textil

Laminación, extrusión, formación a martillo,

reticulación, fundición aditiva, sandblasting

macramé, ensamblaje

$177 \times 33 \mathrm{~cm}$

Colección: del artista

Comentario: F/O de Candeleros

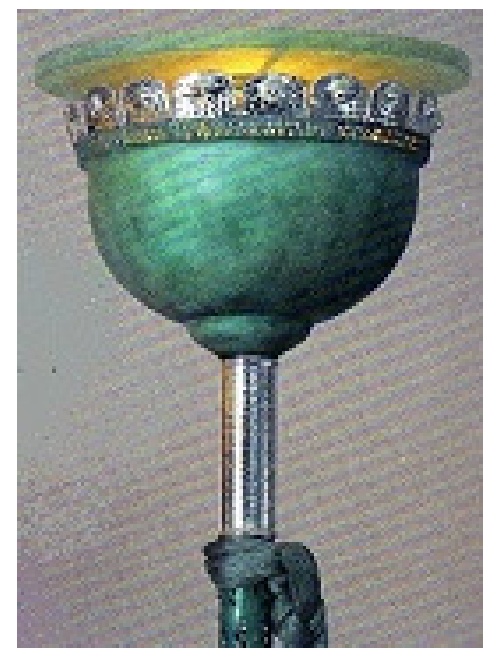

MAGEN 376

Orfebrería Escultórica Luminaria

Lux emperatoris

1995

Plata 1000, cristal, bronce, textil

Laminación, extrusión, formación a martillo,

reticulación, fundición aditiva, sandblasting,

macrame, ensamblaje

$203 \times 50 \mathrm{~cm}$

Colección: del artista
Comentario: F/O de Candeleros 


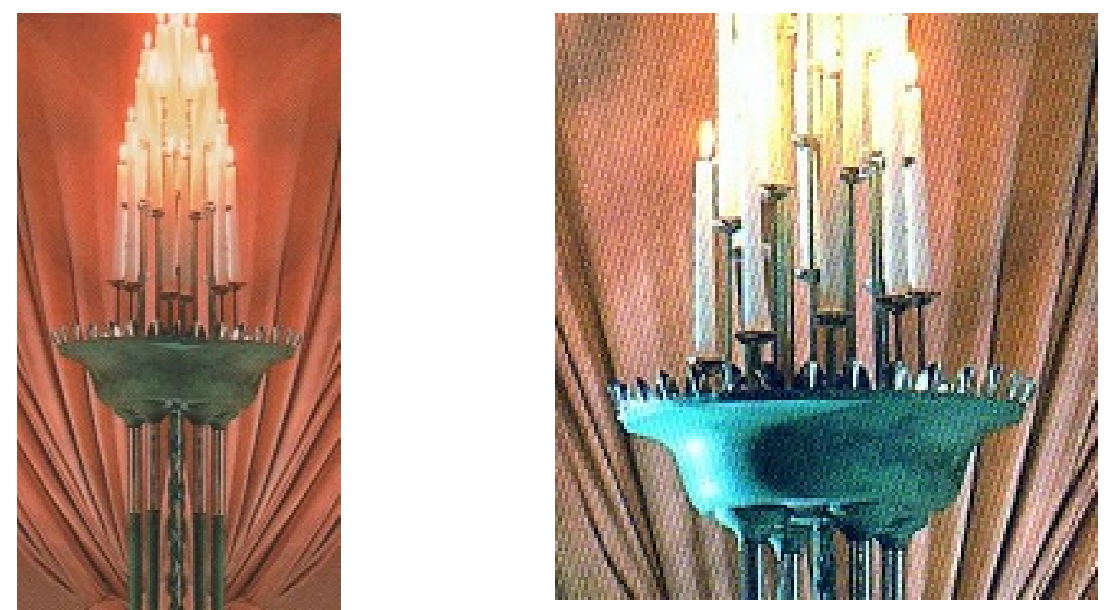

Detalle de Fiat lux: XXV Aniversario

IMAGEN 378

\section{IMAGEN 377}

Orfebrería Escultórica Luminaria

Fiat lux: XXV Aniversario

Plata 1000, cristal, bronce, text

teción a martillo, reticulación por oxi acetileno, fundición aditiva,

pátina, sand blasting, macramé, ensamblaje

$252 \times 50 \mathrm{~cm}$
Colección: del artista

Comentario: F/O de Candelabros y Candeleros 


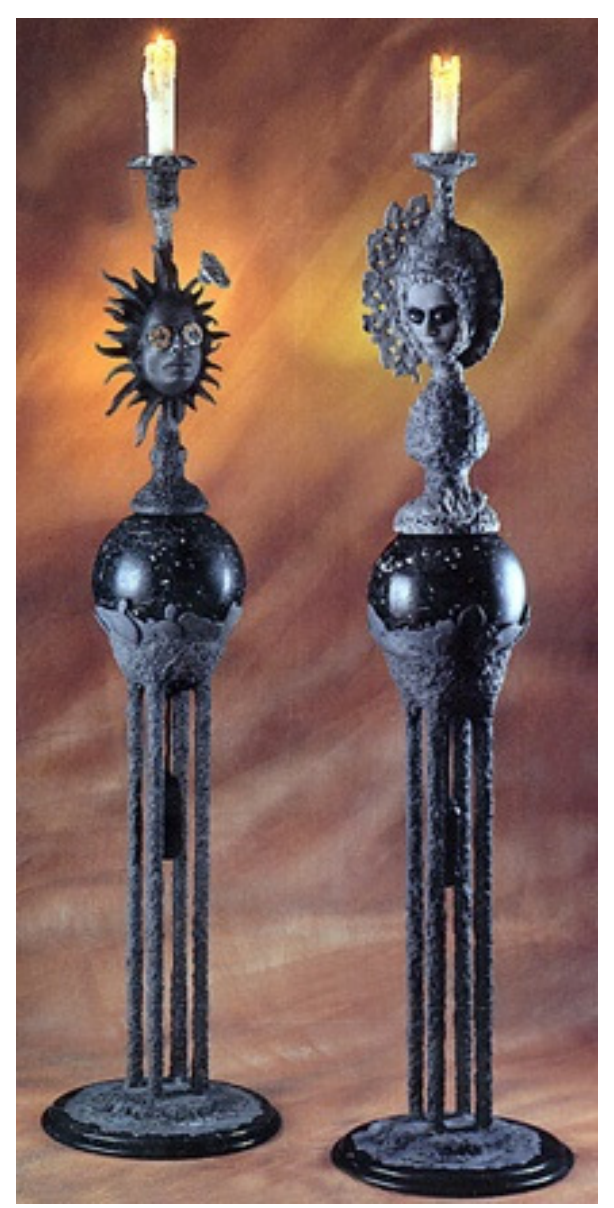

IMAGEN 378

Orín Escultórica Luminaria

-El sol

1995

Estaño, mármol negro, acero, rosetones de jaspe marmolado

Modelado, fundición aditiva, texturización por oxi-acetileno, impresión directa, lapidación, sandblasting, ensamblaje

$215 \times 46 \mathrm{~cm}$

Colección: del artista

Comentario: $\mathrm{F} / \mathrm{O}$ de Candelabros

\section{-La luna}

Estaño, mármol negro, acero, rosetones de jaspe marmolado

Modelado, fundición aditiva, texturización por oxi-acetileno, impresión directa, lapidación sandblasting, ensamblaje

$215 \times 46 \mathrm{~cm}$

Colección: del artista

Comentario: F/O de Candelabros 


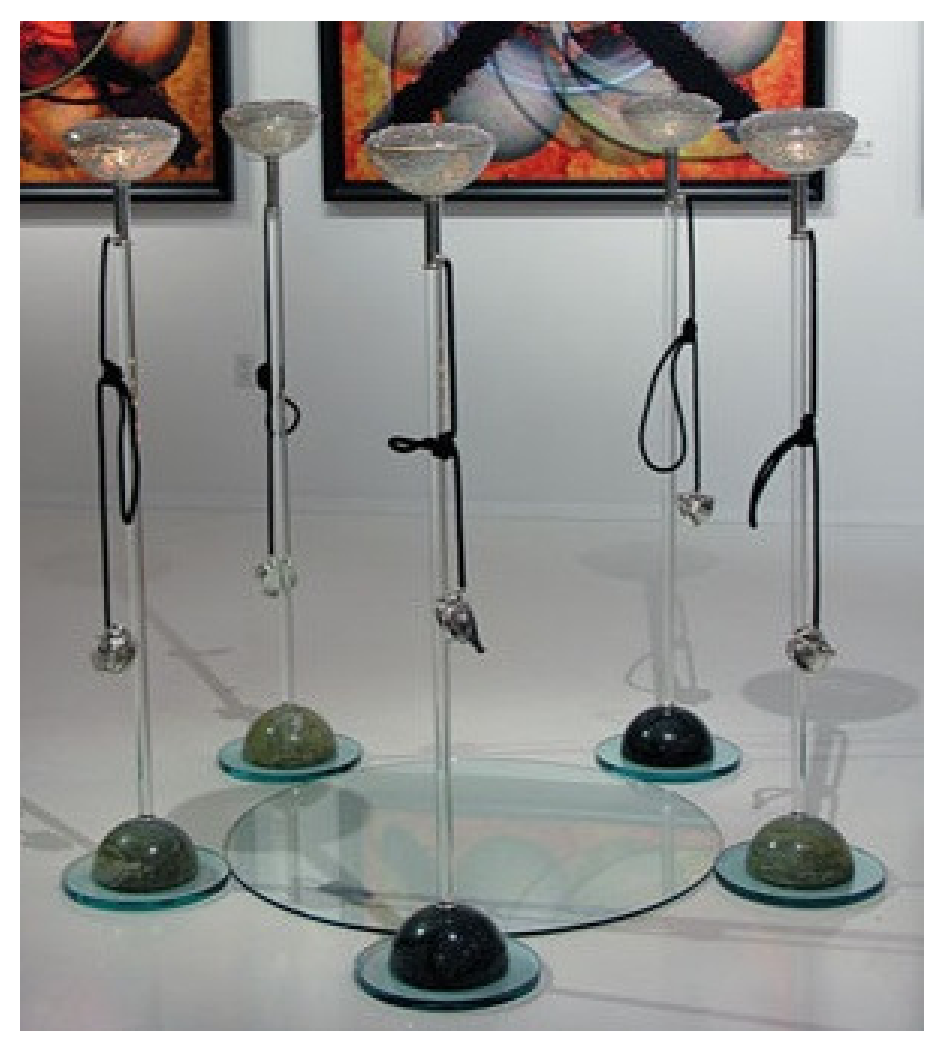

IMAGEN 379

Orfebrería Escultórica Luminaria

Guardianes de fuego y hielo I, II,III, IV, V

Plata 1000, 25 piedras semipreciosas, textil, mármol, cristal, luz dicroica

Laminado, 2 naste, formación a martillo, reticulado, ensamblaje lumínico

Colección: del

Comentario: $F / O$ de Guardianes de fuego y hielo

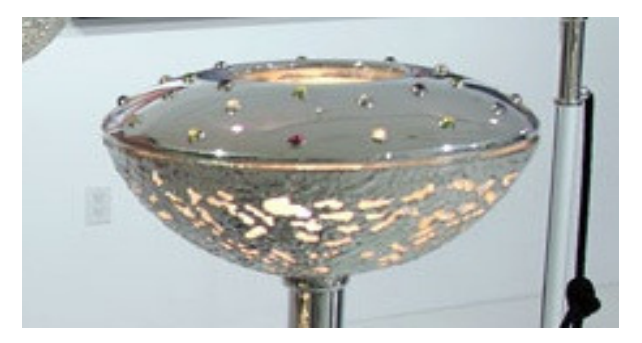

Detalle de Guardianes de fuego y hielo I,

IMAGEN 380 


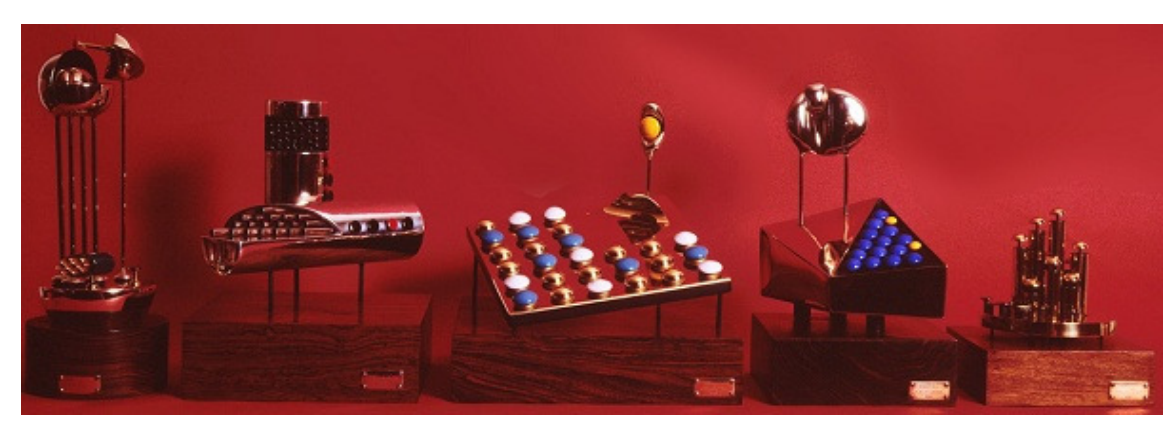

IMAGEN 381

Orfebrería Escultórica

Proyectos Escultóricos

1980

(a) fuego, oro 24 quilates

Laminación, extrusión, esmaltado, cera perdida, baños electrolíticos en oro 24 quilates. $40 \times 12 \times 12 \mathrm{~cm}, 30 \times 25 \times 25 \mathrm{~cm}, 30 \times 30 \times 30 \mathrm{~cm}, 35 \times 25 \times 25 \mathrm{~cm}, 20 \times 20 \times 20 \mathrm{~cm}$.

Colección: Privada

Comentario: Conjunto ganador del Premio en la tendencia de orfebrería en el "SNAF" del año 1980

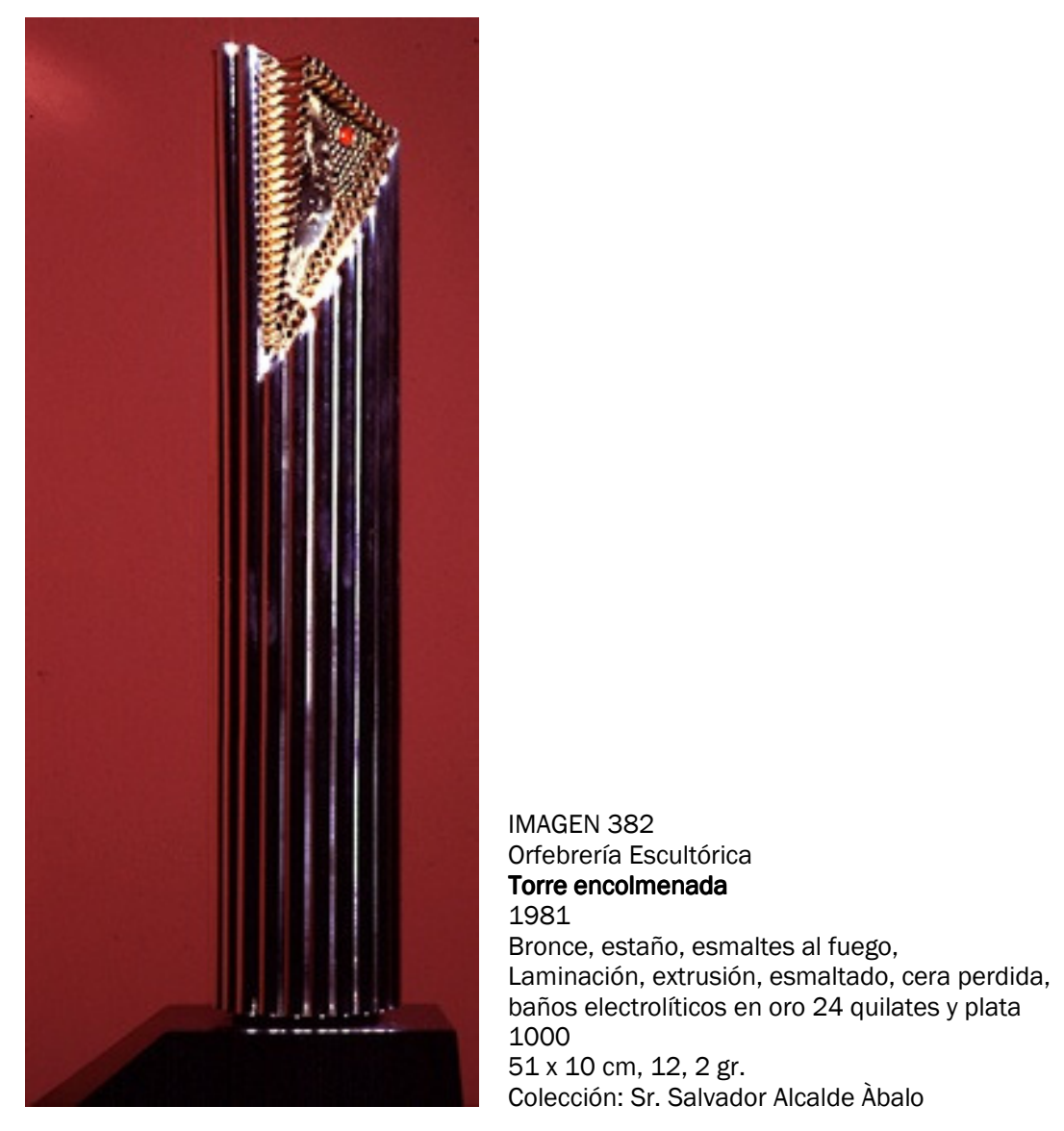




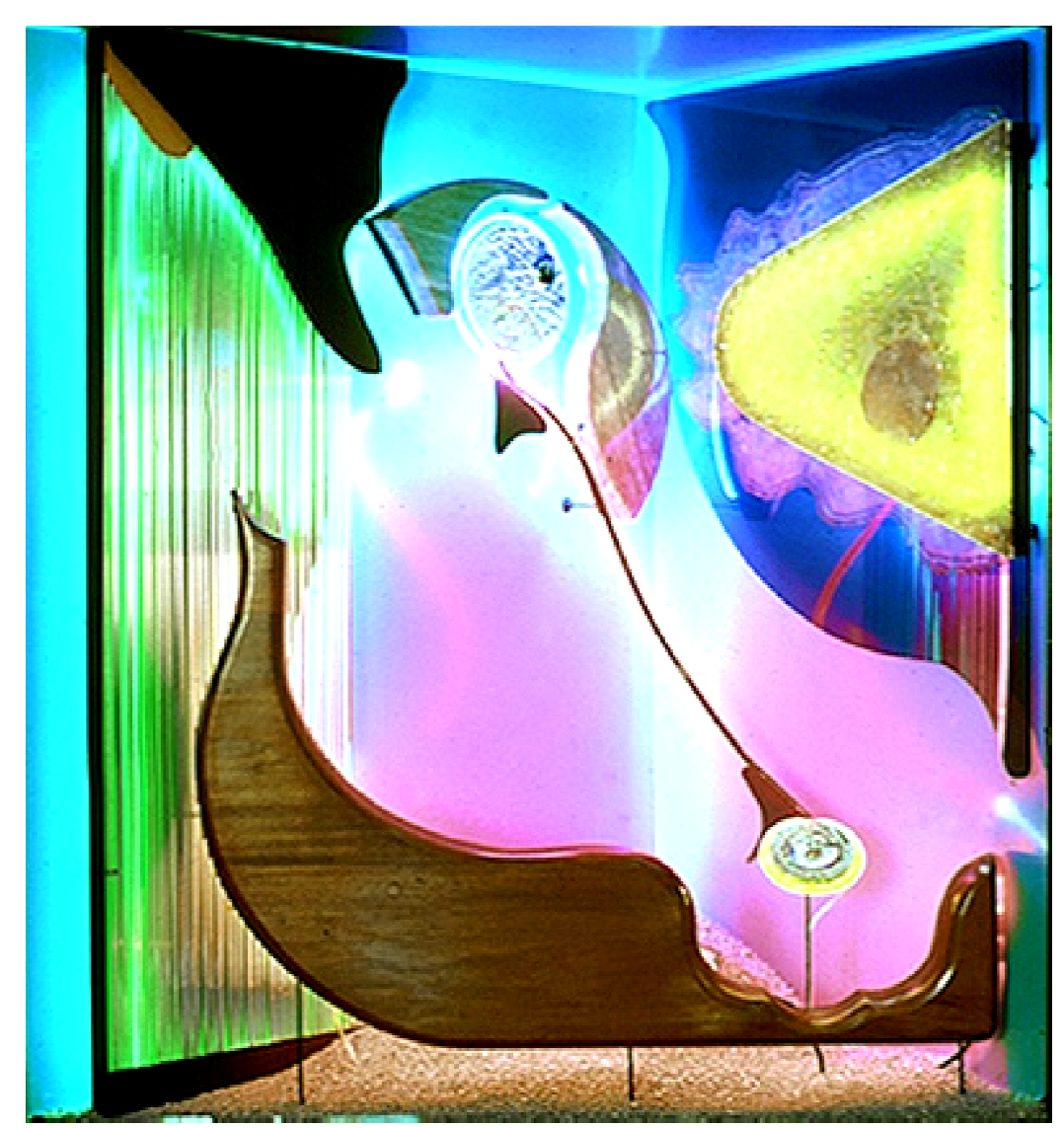

IMAGEN 383

Orfebrería Escultórica

El Sol se despide de la Luna

1986

列, latón, aluminio, vidrio de

bussols por maltes al fuego, lacas

Talla en madera y mármol, extrusión, laqueado en madera, esmaltado, martilladlo,

granulado, oxidación, ensamblaje de elemento luminico

Colección: Blanca Bottaro de Stanzione. 


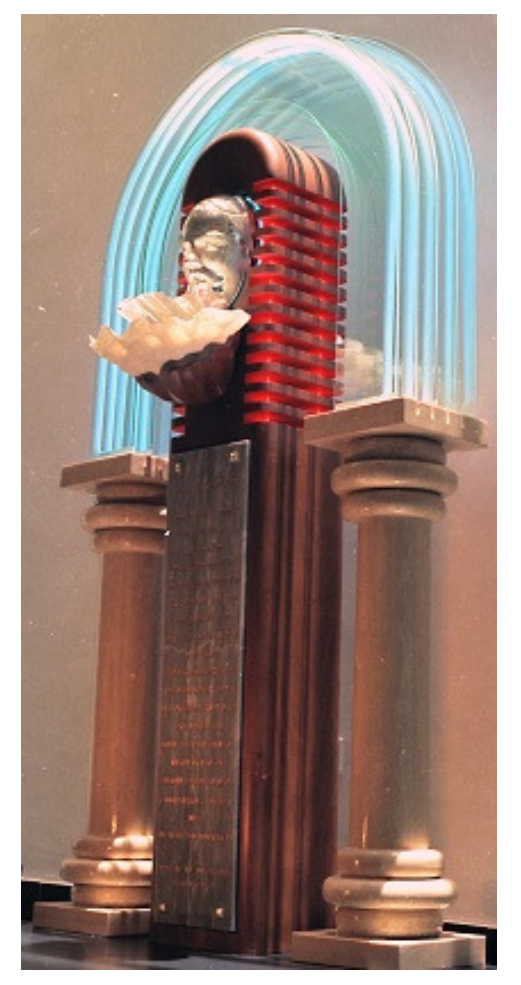

Rectores del Arte

Venid a purificaros en mi fuente despojáos de todo perjuicio dejad que la luz emanada por los cinco arcos de los sentidos ilumine los vuestros acercad vuestros secos labios a mi cristalina agua

y calmad vuestra sed

os devolveré la inocencia del niño os acariciarán las alas de los ángeles y seréis agraciados

con el perdón del artista.

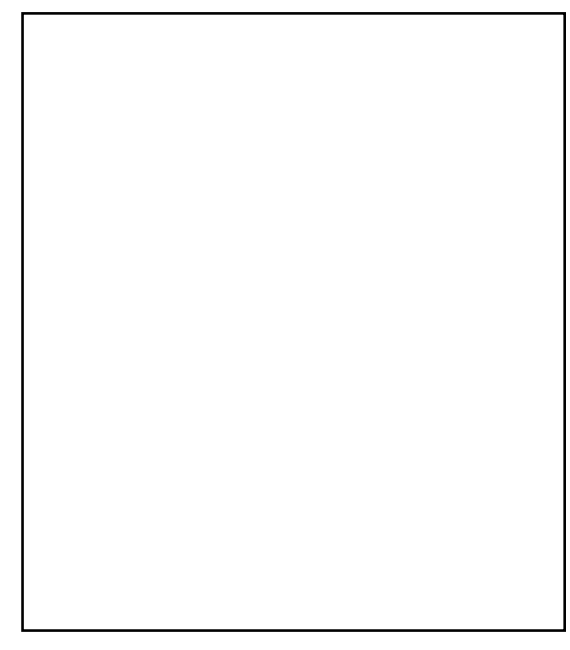

Texto grabado en la placa frontal

IMAGEN 384

Orfebrería Escultórica

El Arco de los Cinco sentidos

1986

Plata Esterlina, plata 1000, concha del Pacífico,

arena blanca de mar, agua, madera de caoba,

cristal, sistema de bombeo, mármol travertino y de

Sicilia, lacas, luz de neón, transformador de 15,000

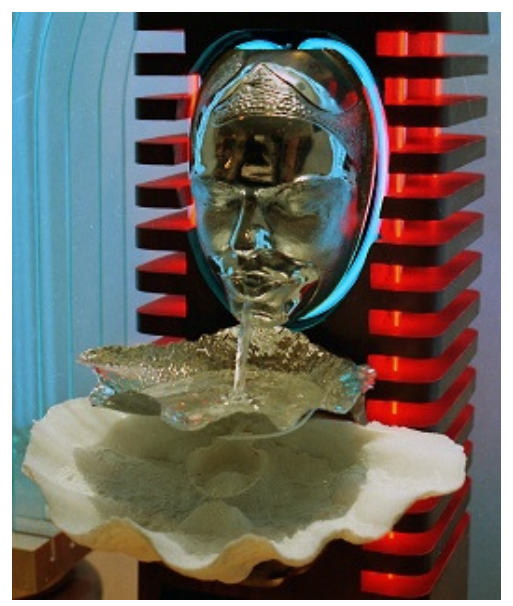

Detalle de El Arco de los Cinco sentidos

Talla de mármol, laqueado de madera, soplado de vidrio, formación a martillo, impresión directa, vaciado de estaño, baños electrolíticos de plata 1000, grabado con buril, torno, lapidación, sistema de bombeo,

Torno, lapidación de mármol, grabado, fotograbado, laqueado, ensamblaje. $1: 92 \times 1: 00 \times 40 \mathrm{~cm}$

Colección: Museo de Arte Contemporáneo de Caracas Sofia Imber. Caracas. 
3.4.3 PRODUCCIÓNEN ESCULTURA. Aspectos técnicos, formales y conceptuales. Valoración personal.

Tal y como mencionamos anteriormente, hacia mediados de los años setenta Alexis De la Sierra, se encuentra con una madurez creativa y un buen nivel técnico en el campo de la orfebrería y por méritos curriculares, obtiene una beca del gobierno venezolano, para un plan de formación en el extranjero. Obtiene el título en Artes Plásticas con mención en Escultura y en Color en la Pontificia Universidad Católica de Chile.

De este modo, hacia finales del año 1977, De la Sierra regresa al país, con gran ímpetu y un sin fin de posibilidades; surge, la imperiosa necesidad de centrarse en la investigación y aplicación de técnicas y materiales propios de la orfebrería con formatos poco usuales. Así pues, la dimensión de sus joyas se traslada al campo de la escultura, logrando más adelante una fusión entre estos métodos con el que crea un lenguaje plástico personal. Es así, como para 1978 entra en una verdadera etapa de transición desde la orfebrería a la escultura. La tridimensionalidad, se hace presente en una espectacular talla en caoba.

De la Sierra es orfebre y escultor, cada una de estas disciplinas enriquece y nutre a la otra, por eso, le interesa del orfebre, el detalle minucioso en el acabado y su preciosidad y le interesa del escultor, el volumen, equilibrio, el dominio técnico y el espacio que ocupa la obra. Tomando en cuenta ambos criterios el artista se deleita en estudiar y aplicar innumerables permutaciones

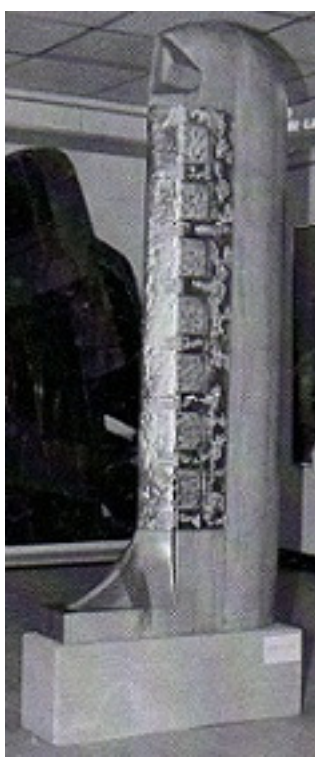
matéricas y volumétricas.

Con diez años de trayectoria en el campo de la orfebrería inicia los primeros estudios que llevan los objetos del plano de la orfebrería hacia la escultura. Desde 1979 irrumpe definitivamente en el campo tridimensional y realiza obras de gran formato pero todavía con una fuerte presencia de la estética y técnicas propias de la orfebrería. En 1981 se introduce en el campo expositivo de las artes plásticas en Venezuela con su obra Magna Colmena Martia (IMAGEN 386). En esta obra De la Sierra recurre a la talla directa sobre madera en gran formato, dejando su apariencia al natural. En el macizo volumen de la caoba, incorpora elementos metálicos de formas cilíndricas; esos pequeños cilindros de plata y otros de cobre, aportan

Magna Colmena Martia una textura atractiva sobre la superficie de la madera. Varían su apariencia entre esmaltes 
traslúcidos, dejando ver su superficie deliberadamente texturizada y otras texturas, con piedras semipreciosas engastadas en bisel; así como también, otros cilindros, dejan visible la apariencia de la plata y el cobre totalmente pulido, creando un delicado contraste entre sus semblantes con el tono de la madera. Esta obra muestra la presencia de la fusión entre la orfebrería y la escultura y este período es llamado por el propio artista (proyectos encolmenados) ya que, sus diseños, contienen compartimientos que semejan las colmenas de las abejas.

En el año 1982 continúa la exploración en la escultura pero llevadas a cabo con técnicas y materiales de orfebrería. Proyectos en Surgimiento (IMAGEN 387) se establece en una F/O de seis obras de mediano formato en plata esterlina y latón, donde el artista recurre a diversas técnicas como el embutido, el martillado,

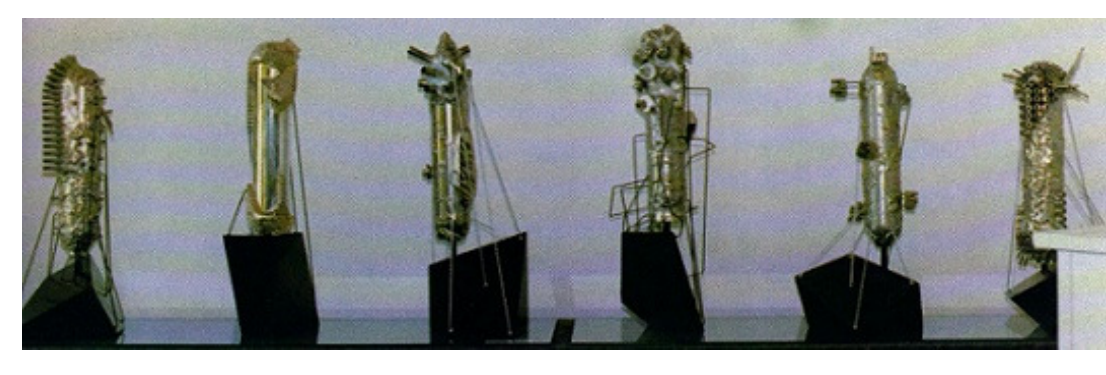

Proyectos en Surgimiento

el grabado y el granulado. La figura central de todas, es martillada hasta alcanzar la forma del cilindro, presentan variaciones tras la yuxtaposición de pequeños fragmentos de tubo redondo en plata y bronce. Estos tubos, se encuentran cortados en ángulos diferentes por lo que al soldarse sobre la figura central varía su forma, consiguiendo diversidad entre ellas. La analogía con las colmenas de las abejas se hace recurrente en sus superficies. El lustre de las seis obras, le confiere un brillo especial; esta luminosidad, lo conduce a la búsqueda de otros planteamientos.

En esa nueva búsqueda estética realiza Magna Colmena Luminis (IMAGEN 388); a partir de este momento, De la Sierra incursiona con el campo lumínico lo cual se evidencia en esta obra, para la cual recurre al uso de un pedestal un tanto peculiar. Se establece, en una base cuadrada de cristal y sobre él, posa una base de madera rectangular laqueada de color negro. Sobre esa base, se acopla una talla en caoba cuya superficie lijada impecablemente deja ver sus vetas. Sobre ella, se ajusta una

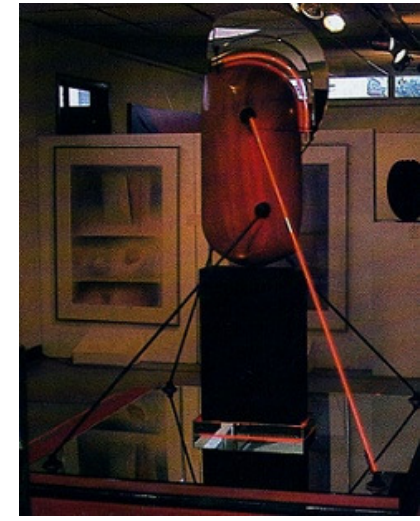

Magna Colmena Luminis IMAGEN 388 
cresta de aluminio con un delicado neón de color rojo. Efecto lumínico este, que sale también desde el interior de la talla de madera y se proyecta hacia la enorme base de donde se fija toda la obra. La luz que irradia desde su base, le otorga espacialidad en contraposición del volumen macizo que sostiene. Los tubos finísimos de neón de color rojo y negro, simbolizan rayos de luz que salen desde su interior; éstos, alegóricamente expresan la inmovilización de la madera que se halla en levitación. La unión de diversos materiales entre el aluminio, el vidrio, la madera y la luz del neón, exaltan la armonía entre sus matices. Con esta obra el artista participa en el "Salón Michelena" en el año 1982.

Desde este momento Alexis De la Sierra, desafía su proceso artístico y productivo, de forma metódica y precisa, comienza por interesarse en un tema específico, al que le va dando cuerpo tanto desde un punto de vista material como desde el conceptual. Bajo esta perspectiva desarrolla variaciones sobre algún aspecto específico ya sea, un tema, una forma, una técnica o un concepto y con ello, cada una de las obras expresa de forma diversa la misma idea. Estas variaciones, suelen realizarse entre 15 y 30 obras, surgidas de un tronco común las cuales denomina Familia de Obras. Estas familias no están sujetas a un mismo formato, material, ni dentro de un mismo tiempo ya que, pueden transcurrir hasta quince años de una variación a la otra. El artista logra entre 2 y 3 familias de obras en cada año.

La luz se convierte en un recurso formal con la cual complementa el universo de la obra. Este nuevo elemento se convierte en su guía durante los siguientes años de su producción.

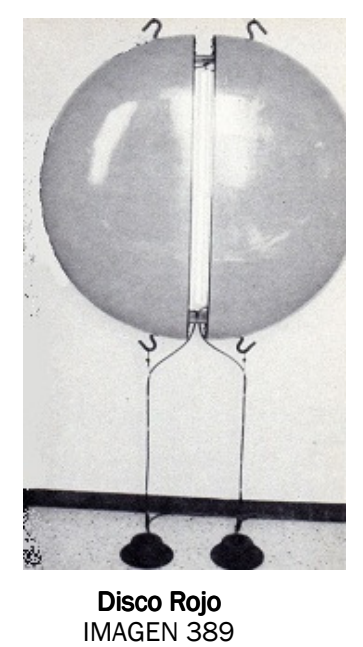

En el año 1983 con F/O de los Discos Lumínicos, resuelve el problema del pedestal; el artista sitúa la obra con propiedad suspendiéndola en el espacio. El Disco Rojo (IMAGEN 389) es una de las obras de esta familia, la cual está elaborada en caoba maciza con integración de la luz del neón. La superficie de la caoba se encuentra laqueada de color rojo, permitiendo con ello un diálogo entre la forma contundente del disco y la luz que sale desde su centro fragmentado en dos.

IMAGEN 389

El vasto conocimiento de las técnicas, la sensibilidad ante las posibilidades que ofrece el uso de la luz y la firme búsqueda de combinación de nuevos materiales, son las características principales en la obra de este artista. La luz cumple un elemento fundamental en toda su producción artística. En la escultura, este elemento lumínico complementa el volumen escultórico, ya sea en 
piedra, madera, metal. Para ello, se vale de la luz dicroica, halogénica, parabólica, cuarzo hidroxílico, xenón, fibra óptica, y láser. La versatilidad creadora le ha sido reconocida en el mundo de la plástica con el nombre de "Escultor de plata, Escultor de la Luz".

Del estudio sistemático de la figura del disco, produce varias Familias de Obras. En el año 1986 retoma esta figura y genera otra familia. En Armagedón I (IMAGEN 390), consigue una apariencia más liviana, substituye parte de su volumen matérico por la integración de un contorno lumínico superpuesto en un cristal ahumado.

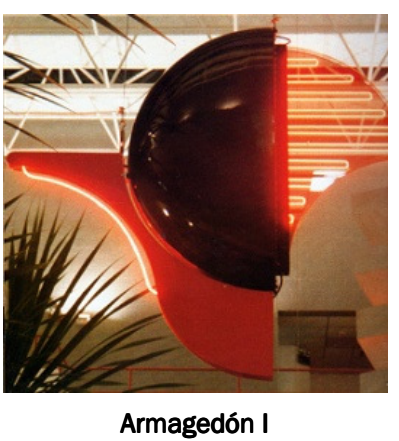

Para De la Sierra la luz tiene un valor

Armagedón

expresivo; simbólicamente ilumina el alma de la obra. Otro detalle importante que se aprecia en esta familia, es que en ellas, aplica un segundo color sobre la superficie logrando con ello, una obra mucho más armónica.

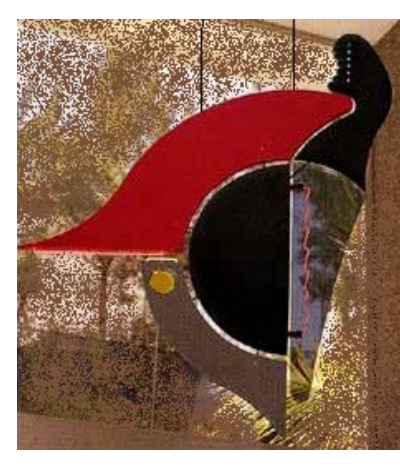

Cuatro años más tarde retoma la $\mathrm{F} / \mathrm{O}$

Armagedon y elabora la obra Nautilius (IMAGEN 391). En ella, las formas se establecen bajo una tendencia de vanguardia e integra nuevos elementos como el cristal y el mármol, creando una paradoja entre la firmeza y el peso de mármol y liviandad y claridad del cristal.

Nautilius

La luz del neón posa sutilmente sobre el cristal ahumado, en rivalidad con las IMAGEN 391 maderas laqueadas que sólo exhiben su contorno. Los colores cálidos de su superficie, discrepan con la frialdad que reposa sobre el mármol gris. Sin embargo, la inclusión de un elemento circular de color amarillo en el mármol, se instaura como punto focal imprimiendo su integración armónica en el total de la obra.

La producción artística del artista Alexis De la Sierra comprende en la actualidad, más de 500 esculturas de gran formato realizadas y emplazadas en diversas partes del mundo. Unificar su lenguaje plástico en un solo estilo resulta imposible: cada una, expresa algo diferente. Poder conocer la evolución de sus obras nos acerca al mundo interior del artista; sin embargo, hay elementos recurrentes como lo es la luz, que se transparenta a través de cortes o incorporada en la misma materia que son una de las características de su autoría. 
Cada F/O de esculturas puede ser muy diferente; mientras unas son geométricas, las otras en cambio son totalmente geomórficas. La exploración de fuentes lumínicas en su obra, las hace salir de la tradicional escultura del volumen macizo del mármol, madera, cristal o del hierro y la lanza hacia los dominios de la escultura espacial.

A partir de los Discos Lumínicos, surge la variación de sus formas hasta conseguir una silueta más alargada de apariencia cilíndrica. Realiza una nueva F/O, las cuales llama Cápsulas, una de ellas es Aurora Borrealis (IMAGEN 392). En esta obra, recurre a la talla directa en madera. El amarillo de su superficie Interviene sobre el volumen como un baño de luz. El nombre de la obra incide directamente en ella como una metáfora de la luz que precede a la salida del sol, por ello, ensambla en su interior delgados tubos de luz de neón

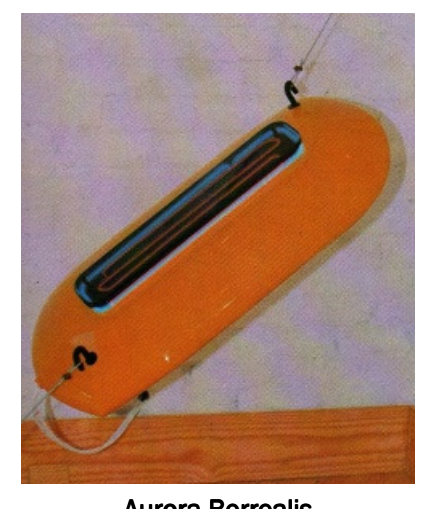

Aurora Borrealis IMAGEN 392 azul y rojo para que proyecten una luz difusa.

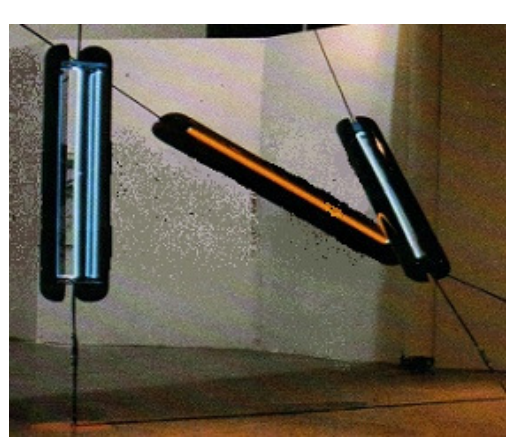

Cápsulas

IMAGEN 393

Vemos cómo las Cápsulas (IMAGEN 393) realizadas en el mismo año, suprime al máximo su forma inicial. El referente inicial del cilindro se desvanece hasta proyectarse en líneas fugaces. A pesar de ser realizadas en madera maciza su forma alargada produce la sensación de estar huecas. Esta instalación presentada compuesta por tres cilindros, muestra tres fases de su evolución: el cilindro suspendido verticalmente, se

encuentra dividido en dos partes iguales donde la luz azul ocupa el espacio abierto entre ambas caras, proyectándose sobre ellas. EI cilindro que se aloja en la mitad de la instalación, se encuentra dividido en dos partes iguales; sin embargo, entre ambas mitades, se presiona la luz de neón de color naranja, simulando la fusión entre ambos cuerpos matéricos y el tercer cilindro, se encuentra dividido también, en dos partes iguales; pero éstas, se encuentran desfasadas dejando ver en la ranura que las separa, un hilo de luz de color azul más tenue; intencionalmente, colocadas delante de un espejo reflejan fragmentos de líneas. Con esta instalación de obras lumínicas Alexis De la Sierra participa en el año 1984 en el importante "Salón Nacional de arte de Aragua" en Venezuela. 


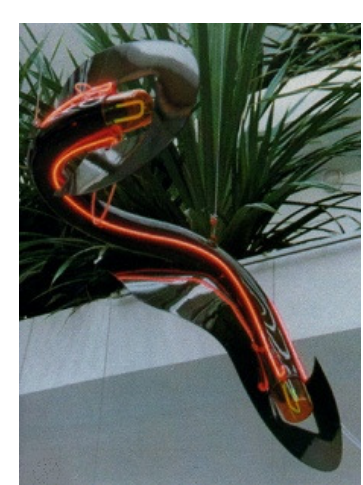

Spiritus Ubi Vuit Spirat

IMAGEN 394

Del reflejo, aparece la distorsión y con ella Spiritus Ubi Vuit Spirat. (IMAGEN 394). La inserción de la luz en el cilindro de madera, produce en su interior tal agitación que su forma se disipa ante el movimiento zigzagueante, el aluminio entra de moderador y detiene el desgaste matérico, aferrándose al delgado cuerpo para que resista. Alegóricamente lo que sobrevive de la forma del cilindro lumínico suspendido, es el reflejo de sus luces tras la rotación sobre su mismo eje. Lumínicas (IMAGEN 395). Esta complementa un grupo de cinco esculturas lumínicas elaboradas in situ, durante su exposición individual 100 Horas, 100 Obras, realizada en el Museo Francisco Narváez, en Porlamar en el año 1987. Una base insignificante de hierro sujeta levemente un bello cilindro laqueado de color rojo y sobre él se empuña un ensortijado neón rojo incandescente. Amorfas láminas de cristal, someten delicados destellos de neón rojo, que sobresalen enérgicamente del interior del

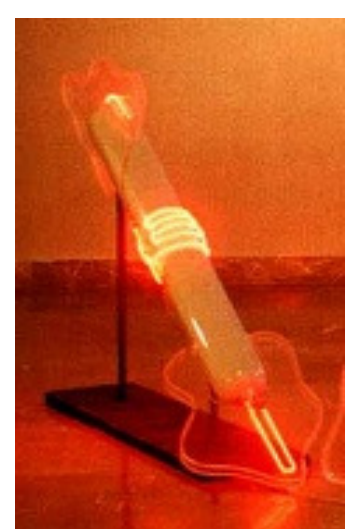
Cápsulas Lumínicas
IMAGEN 395

cilindro. La disposición de la cápsula sobre el pedestal, insinúa su intensión; pues, su expresión indica que está a punto de ser lanzada.

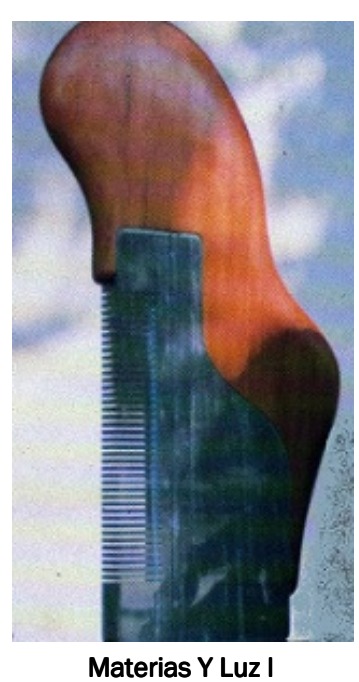

El efecto lumínico se transfigura en un halo que abraza sus contornos y de sus extremos, brotan trozos de cristal con destellos de luz. Dos delgadas varillas de hierro elevan cada cápsula para evitar su contacto con lo terrenal.

Del estudio de la integración de la luz al volumen, surge un abanico de posibilidades para crear luminosidad dentro de sus formas. Materias y Luz I (IMAGEN 396), es el nombre que da a su nueva $\mathrm{F} / \mathrm{O}$, constituida por diez obras; a su vez, cada una de ellas tiene tres variaciones, por lo que finalmente se constituye en 30 variaciones. La dureza de la caoba se hace 
dúctil ante el adverso mármol; por ello, sus formas curveadas posan plácidamente sobre él. Los cortes paralelos en el volumen del mármol, permiten proyectar la luz que subsiste en su interior, dejando asomar el alma de la obra; proceso éste, técnicamente meticuloso, ya que un punto de bifurcación no sólo interrumpe la secuencia lineal que los separa, sino que fractura el material. Las vetas de la madera y del mármol, se consolidan en esta bella obra; pese a la desigualdad de su material y tonalidad, estas, revelan una continuidad agradable en las líneas que las establece.

En la obra Materias y Luz V (IMAGEN 397), la madera toma cuerpo e invade al volumen del mármol, ambos luchan por la armonía entre sus formas, organizándose en común acuerdo en esta interesante obra. La elegancia del negro resplandeciente que cubre la talla de madera, con la delicada tonalidad del mármol, se consagran en una espectacular escultura. El bello ovalo azul, que irrumpe en el interior de la cúspide de color negro, se consagra como el gran protector; protegiendo en

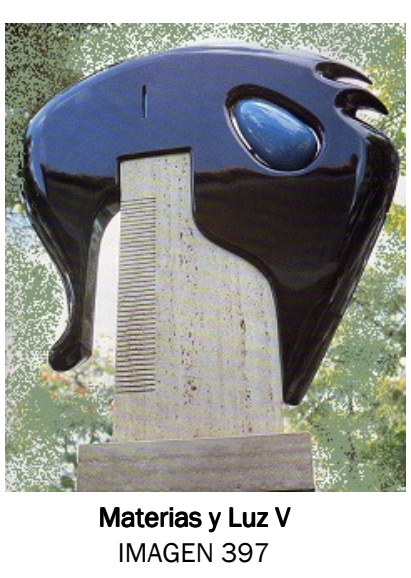
su regazo, las delicadas luces que pernoctan en el interior de los cortes del mármol.

En el campo de la escultura, De la Sierra es un pionero reconocido a nivel internacional, con su aporte sostenido en la investigación sistemática de la integración de la luz dentro del volumen escultórico; sin excluir la utilización de materiales convencionales como el bronce. Su prolífica obra, fundamentada en armonía y equilibrio, es sorprendentemente versátil en cuanto a materiales, volúmenes y técnicas. El artista se expresa en los formatos pequeños, medianos, grandes y monumentales; en todos esos formatos, traza con mano experta sus propios caminos creativos.

La luz se presenta como elemento fundamental en el léxico creativo de este artista. Suponemos esto es una herencia de las tablas en las cuales este artista, practicó el arte histriónico cuando estudiante; fascinándose por los efectos lumino-técnicos en la escenografía. Por ello, la luz se ha convertido en un elemento ineludible en su producción escultórica ya que a través de ella, instaura un argumento propio. E inclusive, sin la luz, la obra perdería su sentido existencial.

Nace otra F/O con la cual invierte la disposición de los materiales. En la obra El diálogo de los cíclopes (IMAGEN 398), utiliza la madera como plataforma desde donde erige la figura de los 


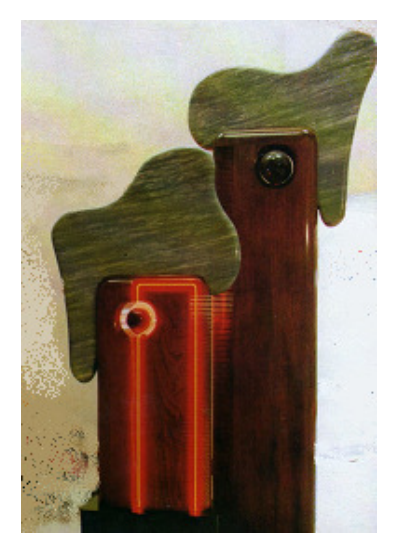

El diálogo de los cíclopes IMAGEN 398

cíclopes. En ellas, introduce un efecto lumínico de forma circular que simula ser su único ojo. La cresta de mármol gris encaja transversalmente sobre su extremo superior. La discrepancia entre el mármol y la madera se hace apetecible; no solo por las características físicas que representan cada una, sino por la disposición de sus vetas, ya que, la veta de la madera maciza se halla verticalmente sobre su alargado cuerpo y la veta del mármol se explaya horizontalmente sobre la curveada cresta. Ambos materiales se fusionan armónicamente instaurando este simpático dúo. La audacia del autor, crea un diálogo matérico que las establece como unidad.

El volumen se manifiesta en Steropes: el tercer cíclope, forjador de los relámpagos de Zeus (IMAGEN 399). El conflicto matérico se resuelve cuando la madera irrevocablemente aumenta su volumen. Dos bellas tallas de caoba se yuxtaponen para crear este enigmático tótem; en la primera de ellas, la simetría y profundidad de los cortes en su superficie reflejan provocadoramente, la luz roja ardiente que pernocta en su interior. El sinuoso trozo de mármol gris brota de ese fogoso volumen, conformando el enorme ojo. Un delicado aro de neón de color rojo, protege ardientemente el corazón latente del cíclope, cuya luz candente mantiene viva la esperanza de su ser.

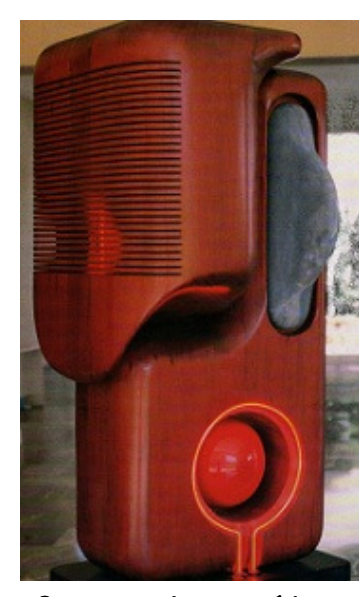

Steropes: el tercer cíclope, forjador de los relámpagos de Zeus IMAGEN 399 


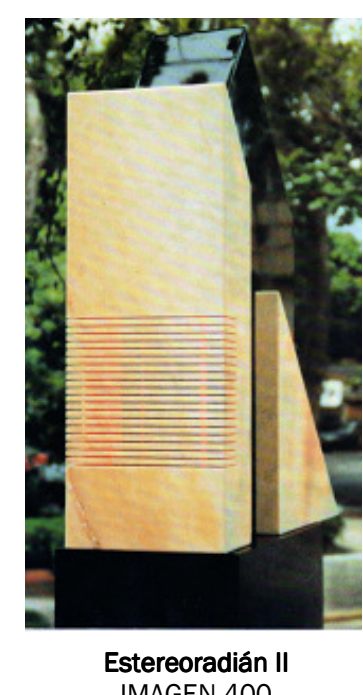

A partir de ese entonces, De la Sierra trabaja los volúmenes geométricos macizos, destacando la belleza que por sí, logra ofrecer cada forma. La desnuda pero contundente figura del rectángulo en mármol, se viste de cortes para engalanar su nueva vestidura. Hábilmente, el artista realiza cortes en diagonal sobre esta forma, transfigurándola en independientes trozos. Así pues, nace la particular F/O Estereoradián. En la obra Estereoradián II (IMAGEN 400), la figura se desarma como un juego de lego. El artista lo arma y desarma dejado espacios sin volumen; estos espacios insinúan la continuidad de Estereoradián su forma original. El estupendo laqueado negro, viste elegantemente el macizo

bloque de madera, evitando el conflicto entre las vetas de su superficie, con el solemne mármol lumínico que lo acaricia.

Las permutaciones matéricas y volumétricas de la F/O Estereoradián, le permite continuar su evolución. Centra su investigación ahora en la figura del triángulo, por eso, en la obra Opus I (MAGEN 401) se establece como unidad en un contundente mármol Bardiglio di Cappela color gris. Las fascinantes vetas de su superficie, armonizan y se integran con el paisaje natural; las aberturas horizontales de este triángulo, asoman un destellante azul turquesa que emana desde su interior. Una delicada lámina laqueada del mismo azul, relaciona su tonalidad con la luminosidad del neón imprimiendo en la obra la alianza con su entorno.

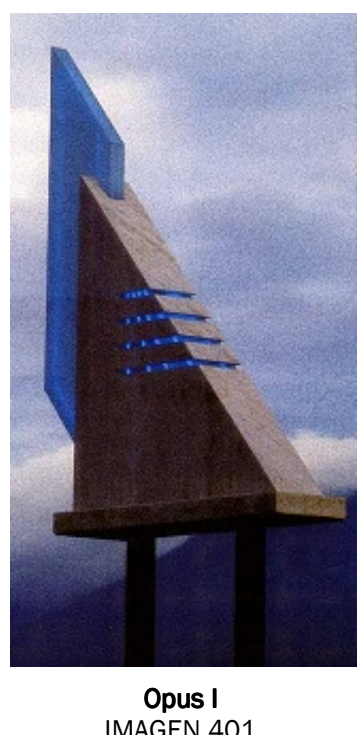

Opus I

La mano experta que conduce su creación, lo dirige hacia experimentaciones sobre técnicas y materiales que le permiten desarrollar interesantes obras. Esa experimentación, se establece en obras que van desde formas macizas y recargadas hasta lo más sencillo y minimalista; estas características pueden establecerse dentro de la evolución de una misma figura. El más claro ejemplo lo tenemos con la evolución del triángulo. En la obra La furia del silencio (IMAGEN 402), tuvo sus inicios con la F/O Estereoradián y en ella, se observa como poco a poco, sus formas se van sintetizando hasta que se convierte en un sugerente destello de cristal. 


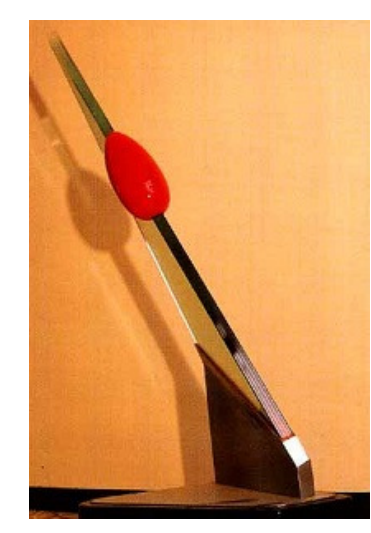

La furia del silencio

IMAGEN 402

De la Sierra experimenta en la combinación del cristal con el acero, uniendo en un solo cuerpo la frialdad de su apariencia, con la pasión de la luz del rojo del neón. Así pues, del acero que establece su base, se proyecta la luz roja por el denso filo del cristal; su intensidad lumínica, se detiene por un instante y se transforma en este ovoide resplandeciente. Fundamentándose en el estudio del movimiento del agua, desarrolla una producción en la disciplina de la orfebrería, tras la búsqueda de esa analogía en la superficie del metal belleza- decide sacar provecho de este nuevo elemento en la escultura; por ello, integra el agua en el volumen con ingenio y destreza. Así pues, la comunión del efecto lumínico sumergido en líquidos en movimiento, resultan un hallazgo del que saca provecho.

En Gaeiocchos (IMAGEN 403), la luz blanca y el agua en movimiento, generan la energía que corre por el interior de la bella escultura en hierro calibrado; del otro extremo de la obra, perforada hasta el tuétano, surge a contraposición una incandescente luz roja. Sin embargo, permanecen inalterables dejando fe de su concordancia. En la cúspide, pernocta una circunferencia seccionada, cuyo interior, aprisiona un destello de luz blanca que sugiere ser el aire; por eso, los cuatro elementos de la naturaleza se exaltan en esta sugestiva obra. Obra esta, instaurada en un ambiente al aire libre junto al mar, cobra dinamismo entre el espacio que habita y la luz natural que la ilumina. Asi pues, este magnífico tótem en medio de un hábitat natural, exalta sus contornos lineales, enfatizando su bello colorido con el estupendo mar azul de fondo.

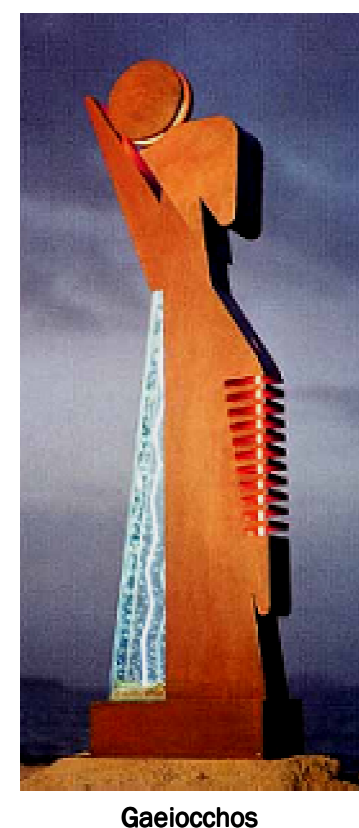

IMAGEN 403

Sea cual sea el tema que Alexis De la Sierra decida enfocar, su sensibilidad y aguda visión de artista, es abordada con misticismo, concordancia y belleza. La necesidad de interactuar con el material al cual da forma y volumen, le aproximan al modelado en barro con entidad y mesura. 


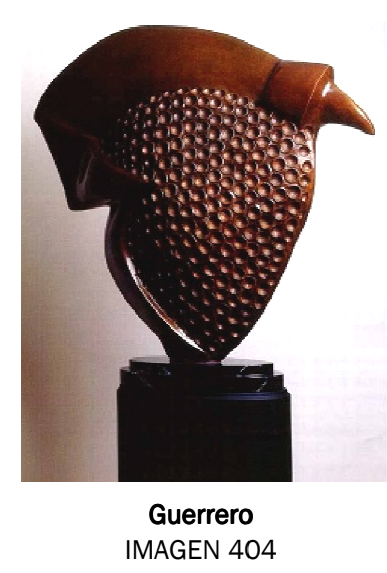

La espontaneidad de su gesto creador, genera una estupenda $\mathrm{F} / \mathrm{O}$ en bronce Ilamada Significados en Bronce. En todas ellas, renace su influencia de las obras de Henry Moore, donde la expresión de los semblantes de sus obras, dan motivo suficiente a De la Sierra para interactuar con el modelado en barro. Así, pues, la espontaneidad de su gesto en la materia, se aferra con estos fantásticos bronces, donde el color de sus pátinas imprime importancia con demasía. Lo primitivo, se arraiga en la F/O Significados en Bronce, que lo convidan a enfrentarse al barro, transformándolo en emblemáticos volúmenes. El Guerrero (IMAGEN 404) alude a la transformación de un enorme corazón, en una coraza protectora. La analogía del color de su superficie, nos aproxima hacia una superficial existencia que roe y malversa lo que toca. Por eso, Las huellas táctiles en su fachada indica que no logran penetrarlo y su espíritu guerrero lo mantiene en pié sobre el bello pedestal de mármol negro.

El impulso creador de Alexis De la Sierra, se estimula muchas veces por la petición de un coleccionista. Él, se integra con la obra de tal manera, que personalmente se encarga de interactuar con el espacio en el cual se pretende ubicar; por ello, toma en cuenta una serie de condiciones que darán inicio a su proceso creativo. Así pues, fotografía el lugar en todos los ángulos posibles, -si el caso lo amerita- hace un estudio del lugar -si es para ubicar en espacios interiores o exteriores-. Partiendo de esta referencia, determina el tipo de material más conveniente y si necesita ubicarse sobre alguna superficie o irá suspendida; observa el tipo de luz que iluminará la obra -sea natural o artificial-, determina cual tipo de luz contendrá y si ésta, se introduce en el volumen, o se ubicara fuera de ella. Analiza el tipo de personas que compartirán con la obra, para determinar los elementos que la integrarán, puesto que, permanecerá en contacto con ella por lo que deben sentirse agradados con su presencia. Para De la Sierra, este protocolo es necesario ya que, los resultados de ese contexto estimulan su creatividad y de forma convincente sabe, que puede cumplir satisfactoriamente con la demanda del coleccionista.

El sol se despide de la luna (IMAGEN 405), es una de las obras que fue concebida bajo los aspectos que se han comentado. En ella, el artista utiliza una cantidad enorme de técnicas y materiales que se organizan dentro de un espacio de gran extensión, sin iluminación natural. Por ello, recurre al uso de luces frías de tonalidades claras dispuestas en varios planos. 
La alegoría del ocaso, se establece por el espíritu ambientalista del coleccionista. La alargada caoba se ubica en el primer plano, representando el tiempo y el espacio que habitamos -la tierra- . El lateral izquierdo, se establece en alargadas varillas de aluminio que representa la torrencial lluvia dejando ver a través de ella la silueta de las montañas. El lateral derecho, se establece en un enorme sol radiante que surge después de la lluvia y se

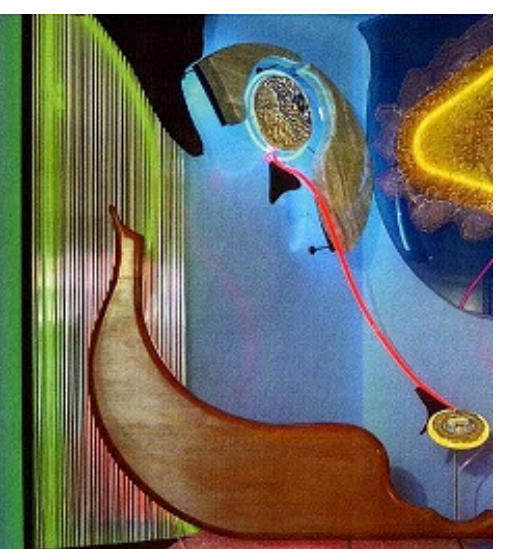

El sol se despide de la luna$$
\text { IMAGEN } 405
$$

instaura en una malla de bronce yuxtapuesta sobre una bella lámina un latón martillado, éste a su vez, se encuentra iluminando el vidrio azul que representan el firmamento. Y por último en el centro de la instalación, se determina el ocaso, donde el mármol Bardiglio di Cappela baña con su brillo de luna, el fraccionado círculo que ostenta sobre la plata martillada, que se encuentra unido con una finísima franja roja de neón, al círculo de plata esmaltada que representa el último destello de luz del día.

Así como esta alegoría, surgen muchas más, que se organizan dentro de espacios habitables. En base a esta tendencia de integración arquitectónica, desarrolla una serie de $\mathrm{F} / \mathrm{O}$ de diferentes categorías: volumetrías de pared, volumetrías de techo, volumetrías anti gravitacionales, separadores escultóricos de ambiente, y mesas escultóricas lumínicas.

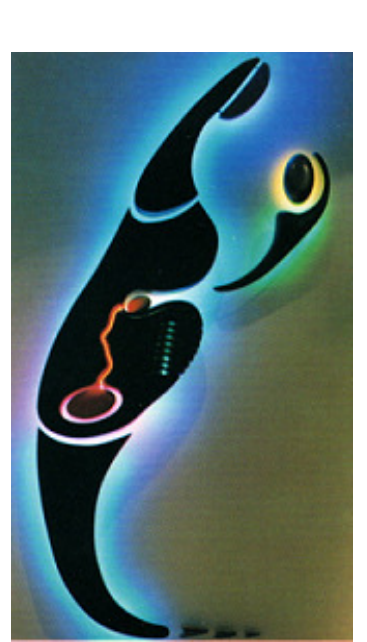

Maternidad IMAGEN 406

La prolífica obra de este artista, varía entre materiales, técnicas, formatos y conceptos que nacen desde la concepción de una joya o viceversa. Por esta razón sus obras, no requieren contener un mensaje explícito, ni se encasillan dentro de un mismo estilo. Sin embargo, nos encontramos con fascinantes alegorías, que expresan momentos colmados de realidad, donde la luz y la perfección en sus acabados siempre están presentes.

La obra Maternidad (IMAGEN 406), es un mural tridimensional que se asienta en el tópico de la fecundación, la gestación y la ofrenda del niño a la vida. Esta silueta tallada en caoba y seccionada como un rompecabezas, se arma sobre la pared 
sobre luces de colores que unifican y dan vida a su forma. Esta contundente y encantadora obra, De la Sierra interpreta bajo los dominios del arte contemporáneo una imagen mariana, que resalta el valor de la procreación y el amor que este merece.

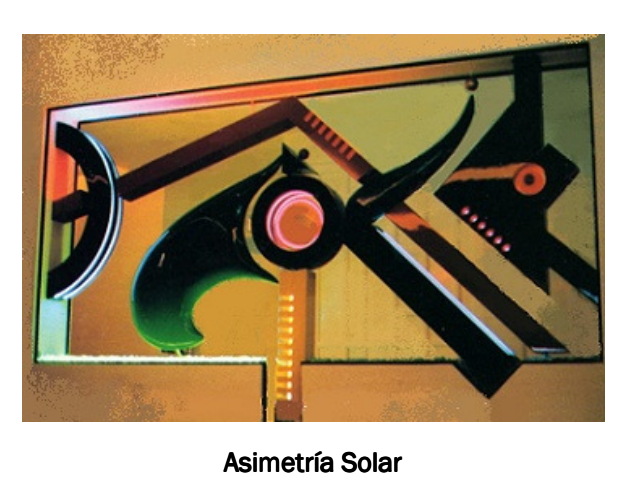

Asimetría Solar (IMAGEN 407), se establece en un representativo separador de ambiente, cuya transparencia, dialoga armónicamente entre formas y colores alegres con la integración de la luz artificial con la natural.

Sus esculturas se transforman en objetos utilitarios, dando origen a

una gran $\mathrm{F} / \mathrm{O}$ de imaginativas y amplias mesas; con más de 30 variaciones, todas ellas, se instituyen en inmensas superficies gruesas de cristal donde las bases varían entre bronces patinados, tallas de madera al natural y laqueadas y macizas tallas de mármol, de diversos colores; obviamente todas ellas, con la integración de efectos lumínicos.

En la Mesa-lumínica XXX (IMAGEN 408), un bello mármol negro tallado en forma de $(\mathrm{V})$ desvela en un lado de su interior, fogosas ranuras que derrochan

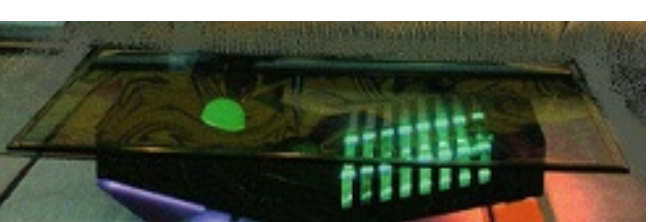
Mesa-lumínica XXX IMAGEN 408

luz verde; 'éstas,

armonizan con una circunferencia de color verde intenso del otro lado. Por su reverso, emana una tenue luz naranja que contrasta jovialmente, con el rayo de luz violeta del lado contario. La impecable transparencia del cristal, deja apreciar con atención, sus formas y colores armónicos, transformando a su entorno en un espacio moderno y jovial.

Su portafolio en la actualidad, incluye más de cuarenta corporaciones e instituciones que recurren a su talento para desarrollar proyectos exclusivos con ediciones especiales conmemorativas, de esculturas para todo tipo de locaciones, en diversos formatos y género; entre esculturas, mesas escultóricas, separadores de ambientes, móviles, murales tridimensionales, entre otros. Así como también, en la orfebrería, con acuñación de monedas, trofeos, medallas y botones. $Y$ en el arte digital, con la creación o modernización de su imagen corporativa o simplemente 
aportar a la empresa aires futuristas con sus espectaculares pinturas digitales en inmensos formatos.

La obra de Alexis De La Sierra es cotizada no sólo por coleccionistas de arte, sino también por arquitectos y diseñadores que recurren a sus obras, para aportar elementos artísticos y crear un entorno armónico, moderno y jovial a sus lugares de trabajo, así como también, enriquecer sus proyectos. Para ello, parte del estudio previo que determinará sobre la obra final. De este modo, elabora una multiplicidad de bocetos digitales en tridimensional, que luego gracias al foto realismo generado por computadora modela en 3D la obra ocupando el espacio real.

Imágenes Ascendentes I (IMAGEN 410) es la obra que fue seleccionada de las propuestas presentadas por De la Sierra al

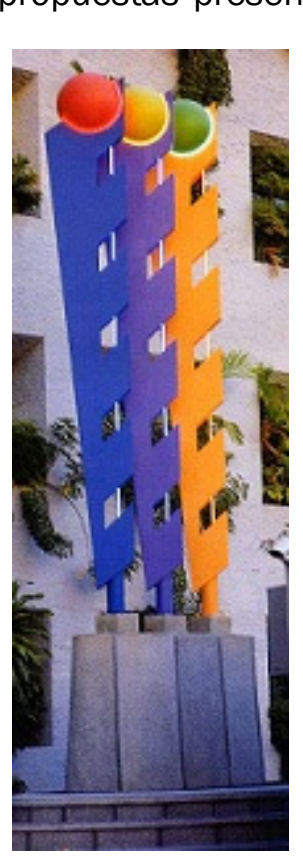
Grupo Imagen

Publicidad en Caracas. Decidieron esta obra para emplazarse frente

a su edificio sede, por la fuerza que emanan sus tres volúmenes Ascendentes I
IMAGEN 409

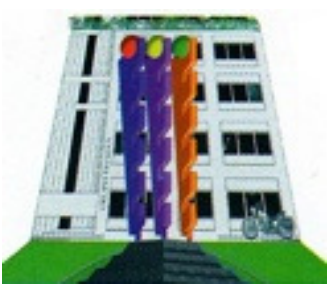
Primera fase del boceto digital tridimensional, de la obra Imágenes ascendente; la alegre combinación de colores secundarios, como elemento integrable con el diseño arquitectónico sobrio y por su carga emotiva. Ya que, se sitúa en medio de una fuente de agua que le abrazan 16 chorros de agua pulsada de donde nace un enfático arco iris.

Aunque desde el año 1994 De la Sierra se encuentra en la investigación y aplicación al medio bidimensional, a través de la ciberpintura, ha realizado cuatro $\mathrm{F} / \mathrm{O}$ donde Imágenes vuelve sobre los planteamientos iniciales, que Ascendentes I
IMAGEN 410 es la orfebrería trasladada a la escultura.

En el año 2001, Alexis De la Sierra sorprende al jurado de la Bienal Internacional de Arte contemporáneo en Florencia, Italia, con su Instalación Multimatérica Soplo de vida: todavía hay esperanza (IMAGEN 411). Pues, su obra resultó ser la merecedora del máximo galardón y le otorgan la Medalla de Oro Magnus Laurentis Medicis. Este artista venezolano, demostró en esa importante confrontación artística, la maestría, versatilidad y sensibilidad que posee ante los medios; en ella, el artista fusionó las tres disciplinas que desarrolla: la orfebrería, la escultura y la ciberpintura. Todas ellas, se enfrentan y convergen, entre técnicas 
antiguas, como la cera perdida, la talla en madera y las últimas tendencias de la cibernética aplicada al arte; fusionando escenográfico,

artesanal con lo tecnológico.

La

instalación

cargada de

simbolismos

referentes a la

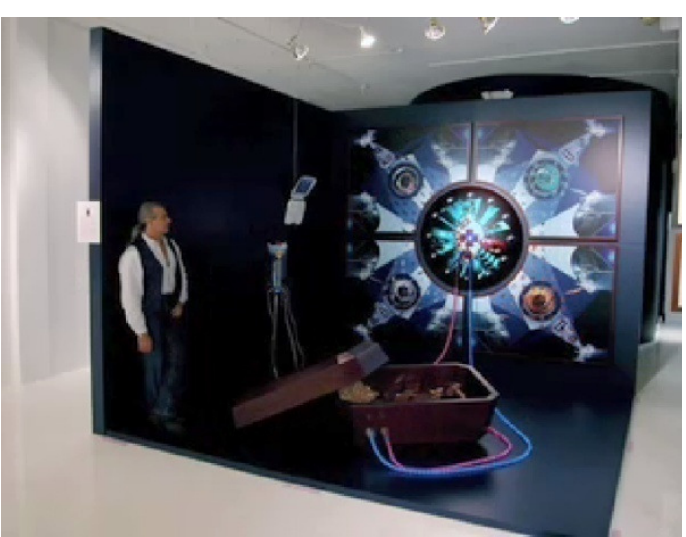

Soplo de vida: todavía hay esperanza IMAGEN 411

búsqueda de la sabiduría, la espiritualidad y la armonía universal se compone en dos partes: el pentatíptico de pintura cibernética, Quinta esencia -imagen al fondo- y La escultura Sursum Corda (Bronce dentro del cofre de madera). Concepto General de la Instalación Soplo de Vida: Todavía hay Esperanza:

“El soplo Divino, Quinta esencia de la vida material y espiritual, está en "Cuidados

Intensivos" en este otro momento histórico de la lucha entre el Bien y el Mal.

El Pentatíptico de Pintura Cibernética "Ouinta esencia" Centrado en la espiritualidad y la metafísica, rodeado de los cuatro elementos primigenios: Agua, Tierra, Fuego y Aire. Apología de los cuatro elementos generadores de vida, negación de la degradación del ecosistema. En cada extremo, una silueta del rostro del artista, le insufla energía a través de mágicos soplos, mientras su mirada se cuela en cada esquina. El elemento central, circular, reúne los elementos simbológicos referentes a la espiritualidad, a la divinidad, el Quinto elemento, atentada por el mal (icono por las explosiones del 11 de Septiembre). Este elemento central es un reflejo bi-dimensional del montaje escultórico "Sursum Corda" al cual el pentatíptico está conectado por medio de cordones umbilicales lumínicos.

La Escultura "Sursum Corda" Corazón de bronce que a su vez contiene otro corazón de oro amarillo pulido, el cual refleja la nobleza, los ideales, la paz y la Armonía Universal, en negación a la descripción del hombre. La escultura reposa sobre un lecho de aserrín de cedro del Líbano, desentrañando olores 
místicos. Es un corazón que puede dejar de latir por el caos que vive la humanidad, a menos que luchemos para no dejarlo morir, con ayuda de electroshocks y luces estroboscópicas incandescentes, que intentan energetizarlo y revivirlo. Todavía hay esperanza..." 207.

El pentatíptico de arte cibernético. Quinta esencia (imagen al fondo de la instalación) se establece en su centro, con un círculo como eje focal; desde donde, se divide en una retícula de cuatro partes iguales. Cada una de ellas, contiene en tres de sus extremos el perfil del rostro del artista, dispuestos todos ellos, en dirección hacia el centro. Esta disposición, se repite idéntica en el resto de los cuadrantes. Sin embargo, existe una tonalidad diferente en la diagonal que se dilata hacia el centro, ya que, alude a los cuatro elementos fundamentales para la vida -agua, fuego, tierra, aire-. El cuadrante superior izquierdo, el tono terracota que lo establece simboliza a la tierra; el cuadrante superior derecho, el tono turquesa que lo establece simboliza al agua; el cuadrante inferior izquierdo el tono gris que lo establece simboliza al aire y el cuadrante inferior derecho, el tono naranja que lo establece simboliza al fuego.

La pintura que se constituye sobre un lienzo circular, se encuentra ubicada en el centro del pentatíptico; doce medias esferas situadas en puntos equidistantes bordean su contorno -bien pudiera representar los doce meses del año o la división horaria-. Ambas, aluden al factor tiempo, el ahora, el presente La simetría que impera el diseño, se interrumpe con la imagen de la réplica del Sursum Corda. (Bronce dentro del cofre de madera); sin embargo, al tener perforado en su centro una cruz latina; ésta le confiere el equilibrio y espacialidad al pentatíptico.

El cofre de madera pernocta en medio de la instalación, cuya factura evidencia elegantemente las vetas y su color original; en su interior, reposa un espectacular corazón macizo en bronce patinado de color terracota, que contiene un nicho, donde reposa el mismo corazón en menor escala. Corazón éste, también vaciado en bronce, lo cubre una capa de oro amarillo de 24 quilates aportando luminosidad y exquisito contraste.

Alexis De la Sierra participa como artista invitado en la Mega exposición II celebrada en el año 2005 en Venezuela. Una exposición que se realizó en paralelo por todo el territorio nacional en los espacios de los museos más importantes de cada ciudad,

207 Pervhilac, I. (2007). “Ficha Simbológica/Conceptual”. Instalación Soplo de Vida Todavía hay Esperanza por Alexis De la Sierra. Bienal Internacional del Arte Contemporáneo de Florencia (2001). Material inédito. Correo electrónico artmanager@delasierra.com 
con la finalidad de mostrar un panorama del Arte Venezolano del año 2000 al 2005.

Los espacios de la Galería de Arte Nacional en la ciudad de Caracas, dieron cabida a la enorme pintura en arte digital Omnia posibilia sunt videnti (IMAGEN 339) que al parecer, forma parte del proyecto de la instalación multimatérica Soñando con los ojos abiertos, elaborado para la participación de la 50 edición de la Bienal de Venecia, que convergen cuatro propuestas. Cada una de éstas, debía ocupar una sala completa, estableciéndose en un gran espacio del Pabellón Venezuela de la Bienal. Las cuatro propuestas se establecen en:

1- Materia y Energía

2- Espíritu y fuerza

3- La sala de las realidades y conflictos y la sala de los sueños"; hasta que finalmente todas ellas quedan de manifiesto en la pintura en arte digital:

4- Omnia posibilia sunt videnti (IMAGEN 413)

En tal sentido, esta enorme pintura cuya traducción significa "todo es posible para quienes tienen los ojos abiertos", reúne temas utópicos y metafísicos; la presencia del ojo como ente protagonista, se fundamenta como un todo avizor. Su simbología alude al ojo, como la esencia iconográfica del ser humano pensante; aquel que sabe unir los sentidos y el espíritu en uno solo, tras el ideal de la sabiduría.

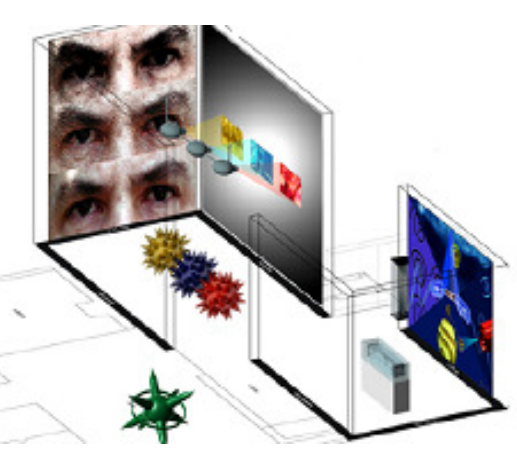

Proyecto digitalizado de la Instalación Multimatérica Soñando con los ojos abiertos IMAGEN 412

Compuesta por los tres colores

primarios del espectro cromático, son la síntesis de la simbología de los colores de la bandera nacional venezolana: el color amarillo,

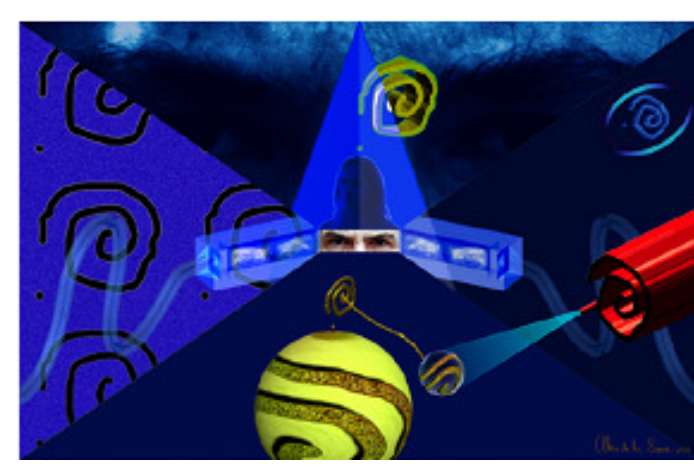

Omnia posibilia sunt videnti IMAGEN 413 tiene que ver con las riquezas del suelo venezolano

(abundancia en oro), el color azul, tiene que ver con los mares y cielo (alude a la libertad) y el color rojo, tiene que ver con la sangre derramada en conflicto, para que se hicieran realidad los 
sueños de esa patria (liberación del yugo español). Tomando en cuenta esto, podemos apreciar que la pintura cibernética se instaura básicamente en la simbología de la libertad, por eso gran parte de esta pintura se aprecia el color azul. Esa añoranza, se manifiesta en una seccionada historia que desborda entre la mirada avizora. El uso repetido de la espiral ostenta con su forma el nacimiento-muerte-renacimiento cuya simbología se exterioriza en la pintura como el proceso de crecimiento y evolución del ser humano.

\subsubsection{CATALOGACIÓN DEMOSTRATIVA SOBRE LA EVOLUCIÓN EN ESCULTURA.}

En este apartado del trabajo de investigación se muestran imágenes de la producción en escultura del artista Alexis De la Sierra desde sus inicios en el año 1980, hasta el año 2005 que es la última fecha en la cual participa en el campo expositivo. Es necesario destacar, que esta catalogación no se presenta a nivel cronológico sino, de manera evolutiva, tomando en cuenta sobretodo el nivel técnico y formal. En tal sentido, hemos clasificado su producción según su condición; considerando, que su obra es muy versátil y se divide en varias categorías: escultura de integración de orfebrería a gran formato, integración de orfebrería en mediano formato, lumínica, lumínica en suspensión, volumetrías de pared, volumetrías de techo, volumetrías antigravitacionales, separadores escultóricos de ambiente, mesas escultóricas lumínicas, bronces, formatos monumentales e instalación multi-matérica. 


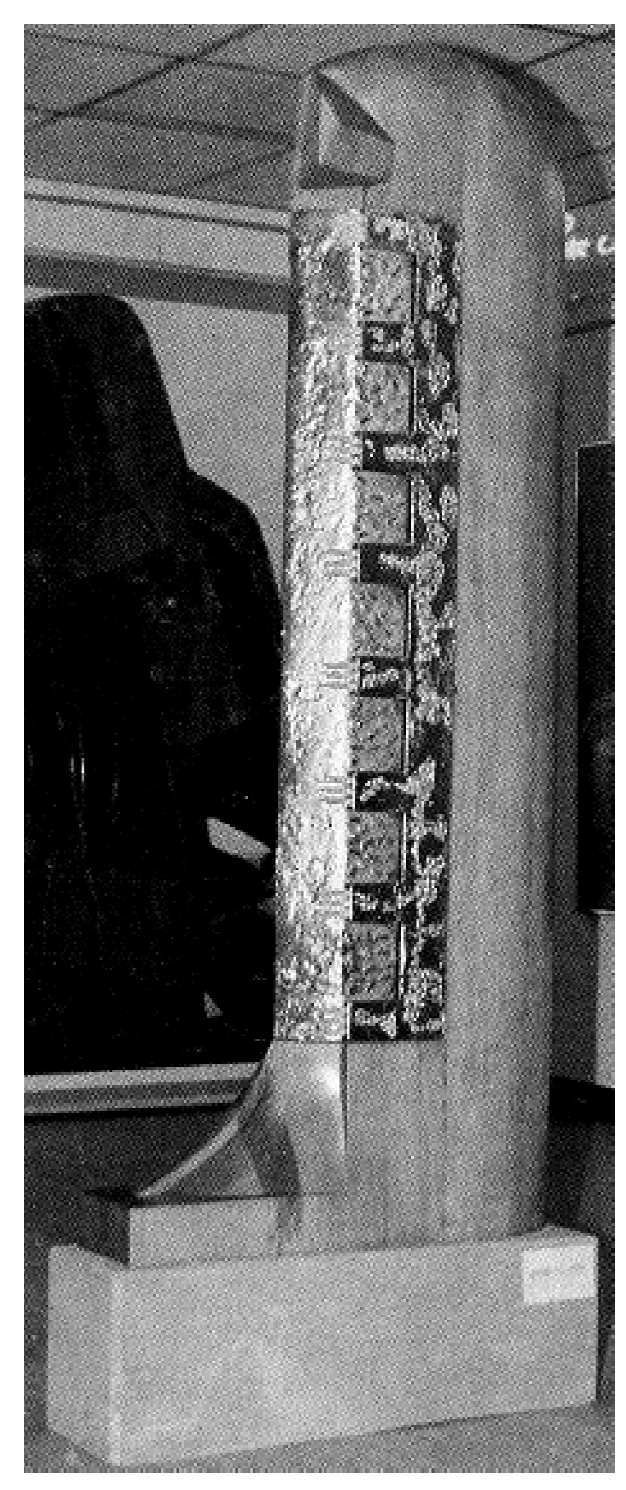

IMAGEN 414

Escultura en la categoría de integración de orfebrería a gran formato Magna Colmena Martia

1981

Caoba, cobre, piedras semipreciosas, esmaltes, mármol

Talla en madera, esmaltado, engaste, ensamblaje de elementos metálicos

$\mathrm{S} / \mathrm{D}$

Colección: Sra. Thais Murdoch. Miami, USA.

Comentario:

Con esta obra se introduce en el campo expositivo de la plástica venezolana. Salón Nacional de Artes Visuales Arturo Michelena en el año 1981. 

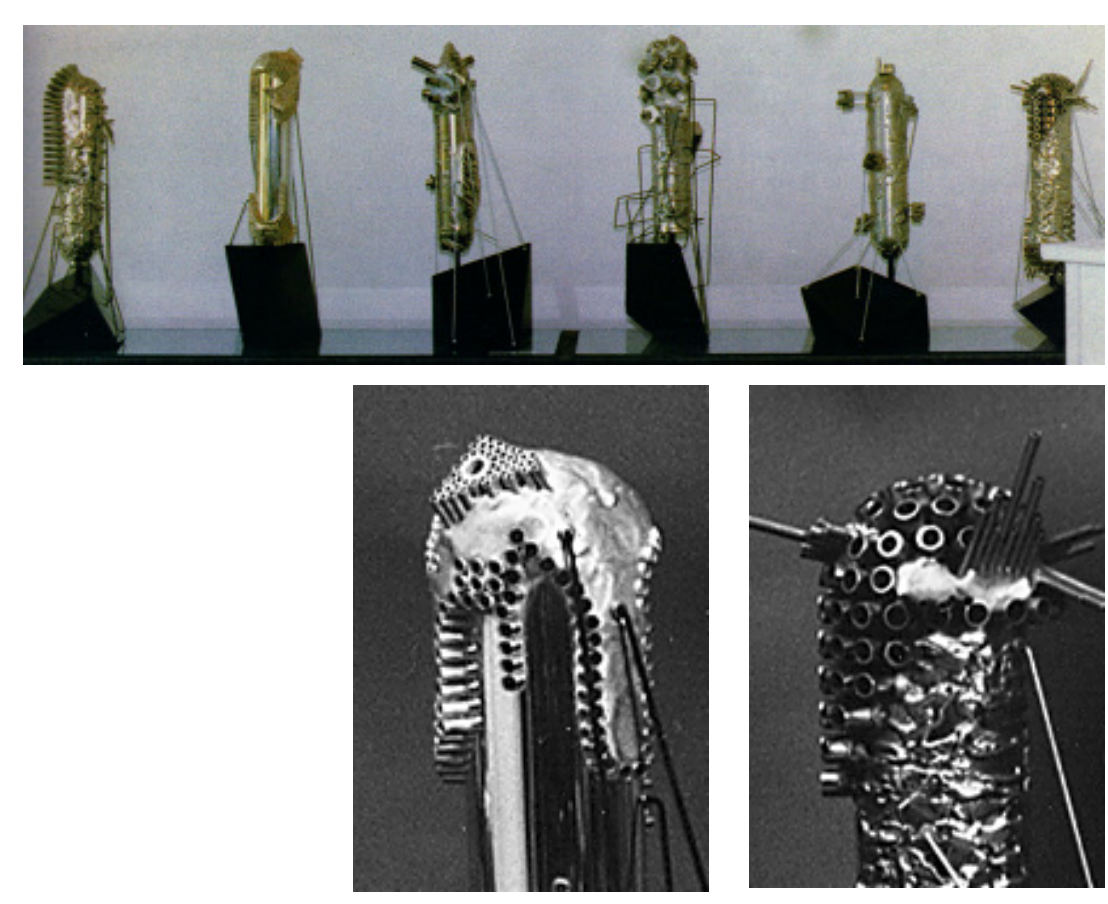

Detalles de Proyectos en Surgimiento

IMAGEN 416

IMAGEN 415

Escultura en la categoría de integración de orfebrería en mediano formato Proyectos en Surgimiento

Proyectos

Plata esterlina, latón, bronce, mármol negro.

Laminado, formación a martillo, texturización mecánica, grabado al ácido, granulado, talla

en mármol

Colección: Sr. Franklin Burke. Houston, USA

Comentario:

Forma parte de las 50 esculturas presentadas en su 2da. Exposición individual “Alexis De la Sierra At The Gallery At Grove Isle. 1982. Miami, Florida. USA. 


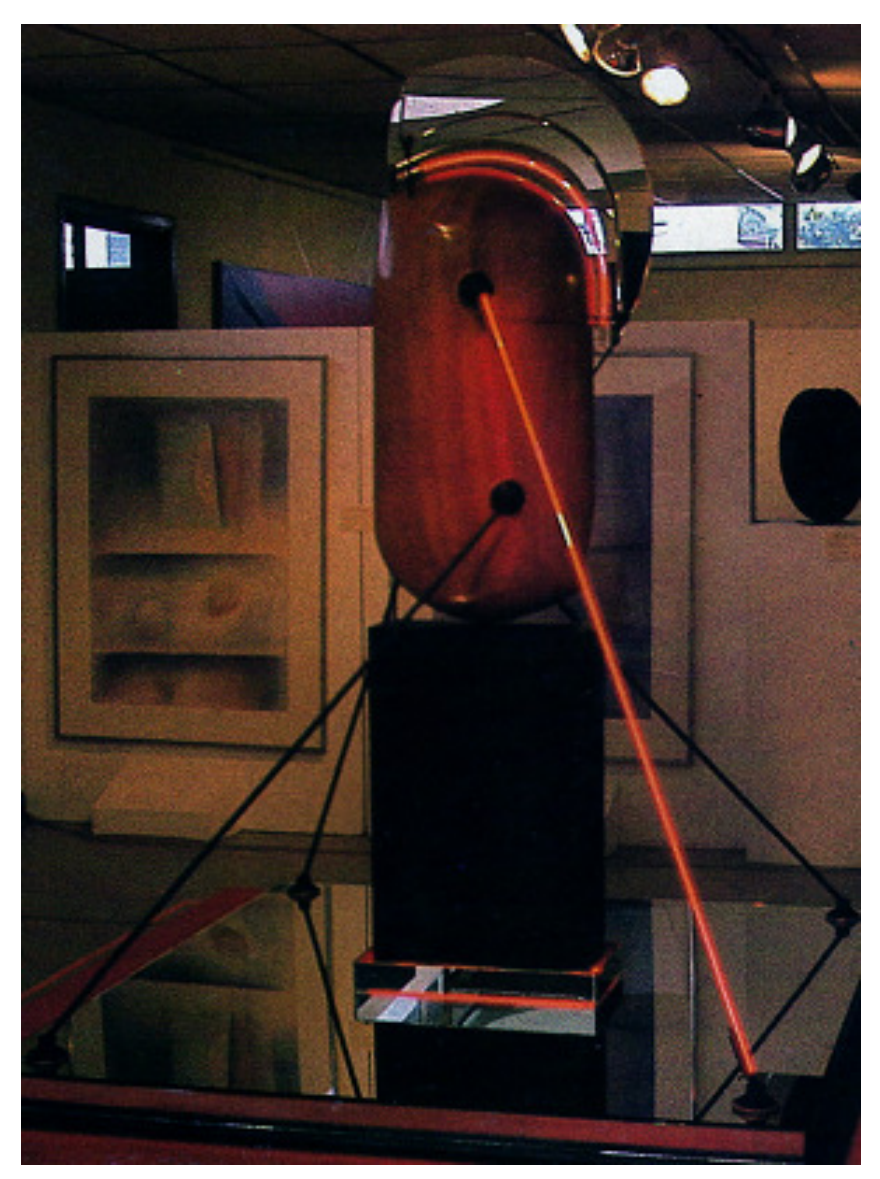

IMAGEN 417

Escultura en la categoría de lumínica

Magna Colmena Luminis

1982

Caoba, cristal, luces de neón color rojo y negro, lacas, anclajes

Talla en madera, formación a martillo, laqueado en madera, ensamblaje de elemento

lumínico

Colección: privad

Comentario:

Primera incursión en el campo lumínico a nivel de gran formato.

Salón Nacional de Artes Visuales Arturo Michelena en el año 1981 


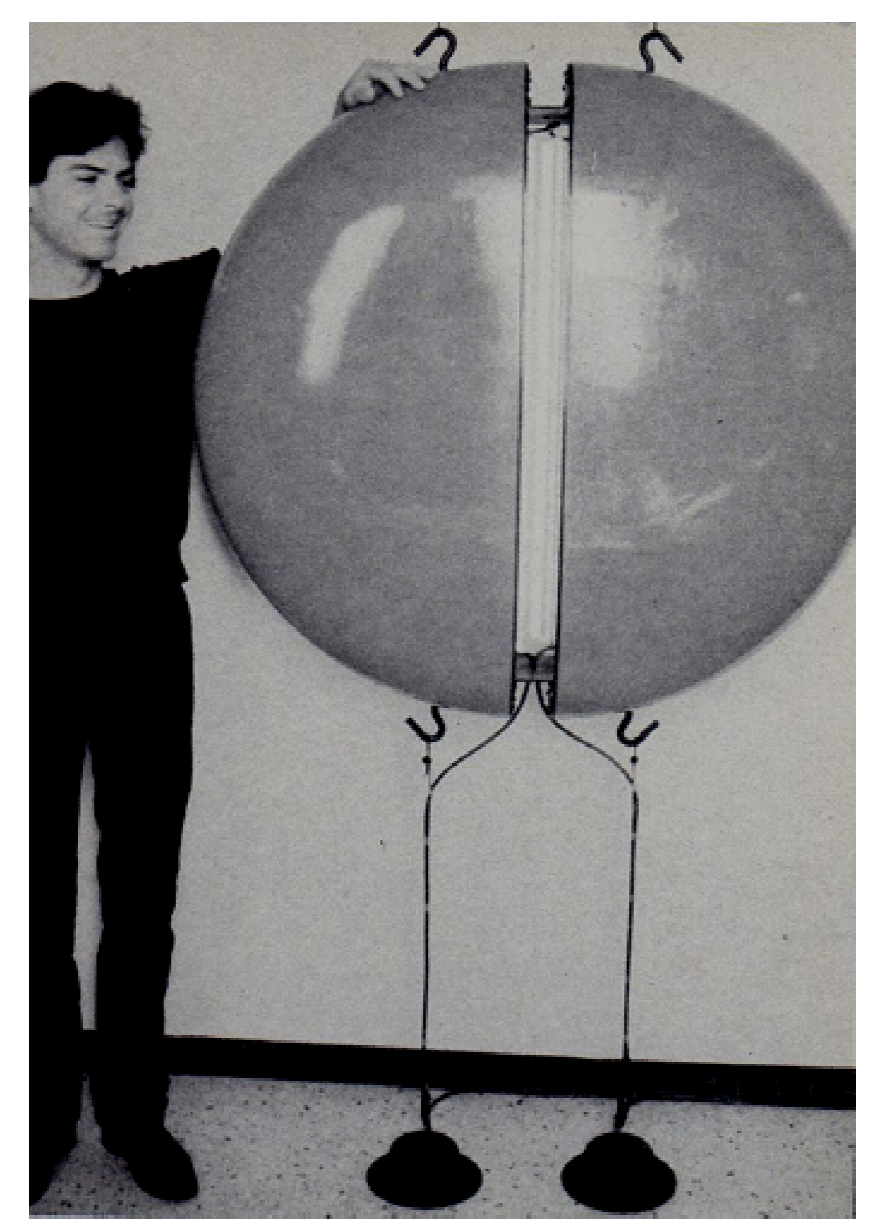

IMAGEN 418

Escultura en la categoría de lumínica

Disco rojo

1983

Caoba, luz de neón rojo, lacas, anclajes metálicos

Talla y torno en madera, laqueado en madera, ensamblaje de elemento lumínico 


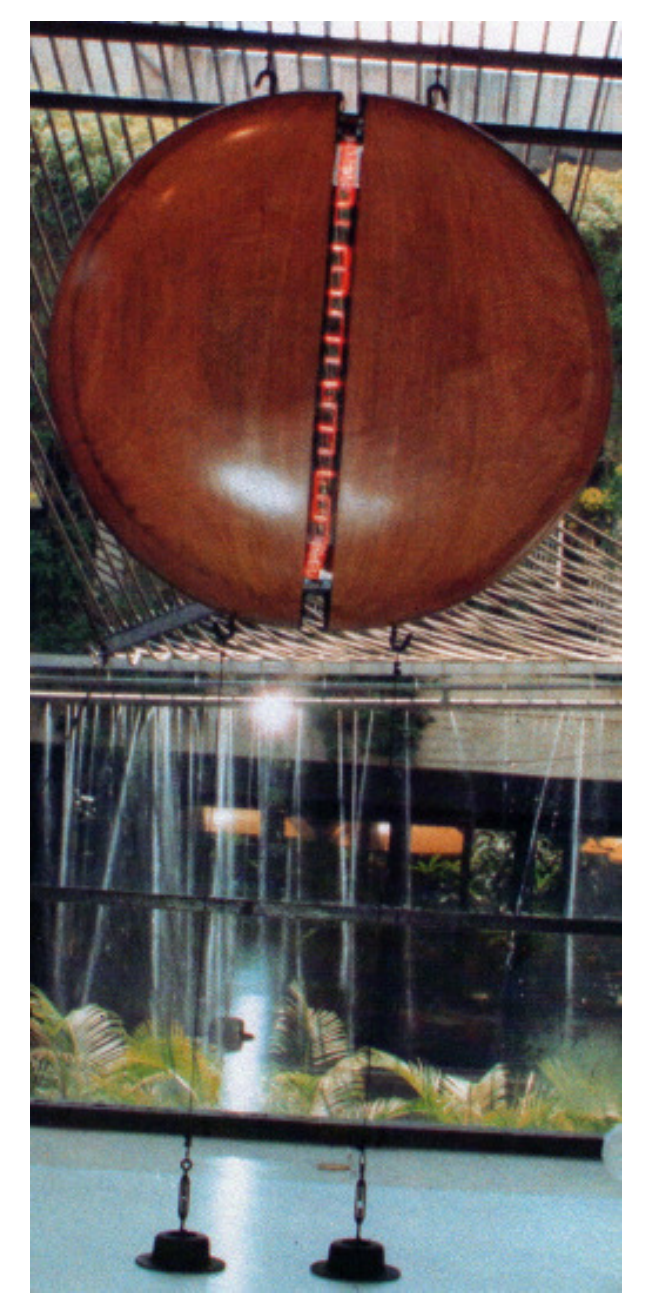

IMAGEN 419

Escultura en la categoría de lumínica

Disco IV
1983

1983 Caoba, luz de neón rojo, anclajes de metal

Talla y torno en madera, ensamblaje de elemento lumínico

$\mathrm{S} / \mathrm{D}$

Colección: privada

Comentario: F/O de Discos Lumínicos,

Expuesta en la II Bienal de Artes Visuales en el año 1983, en Caracas 


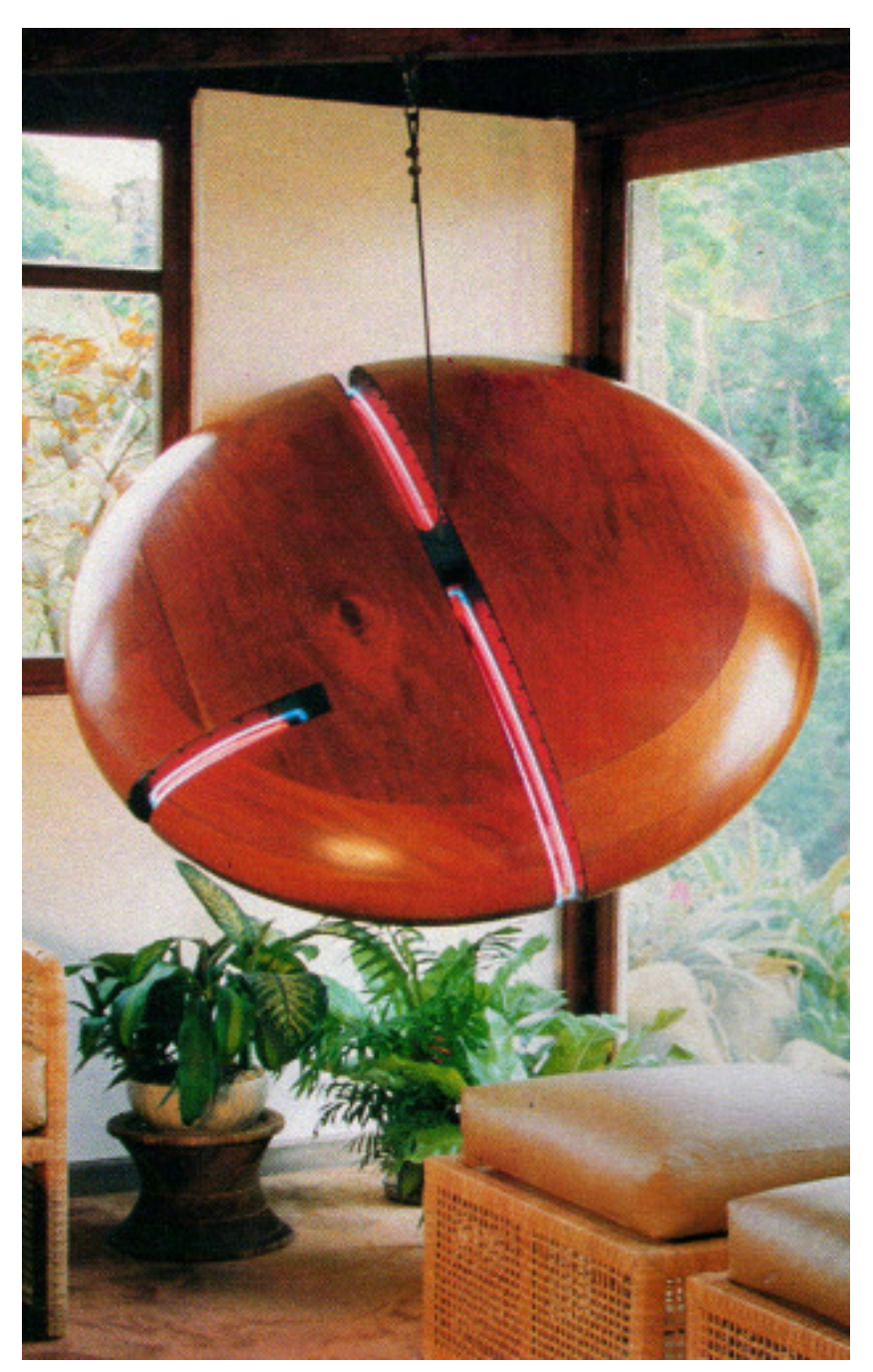

Escultura en la categoría de lumínica en suspensión

Homenaje a Discóbolo de Mirón

1983

Caoba maciza de 260 kg, luz de neón rojo, anclaje metálico

Talla y torno en madera, ensamblaje de elemento lumínico

S/D

Colección: Sr. Leonardo Ron Pedrique y Amalia Heller Comentario: F/O de Discos Lumínicos 


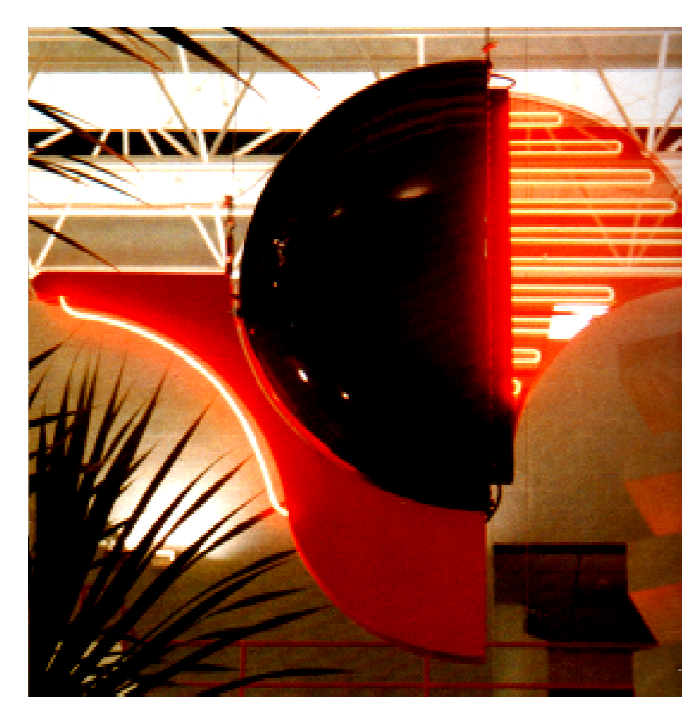

Escultura en la categoría de

umínica en suspensión

Armagedon I

1986

Cedro, luz de neón rojo, cristal de

Boussois polarizante, lacas,

anclajes metálicos

Talla en madera, laqueado en

madera, ensamblaje de

elemento lumínico

S/D

Colección: Sr. Y Sra. Díaz Mesa.

Comentario: F/O de Armagedón

Exposición Individual "Levitantes

Lumínicos y Demás Volúmenes"

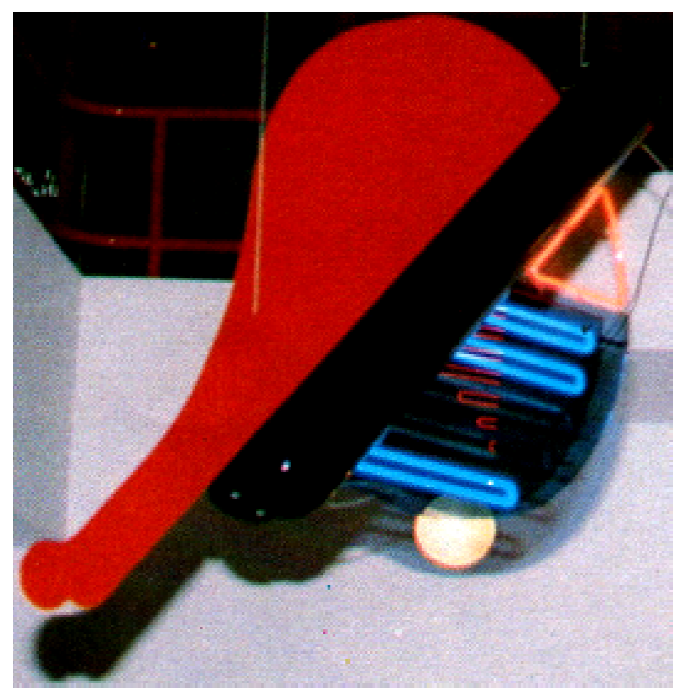

IMAGEN 422

Escultura en la categoría de

umínica en suspensión

Armageddon II

Cedro, luz de neón rojo y azul,

cristal de Boussois polarizante,

lacas, anclajes metálicos

Talla en madera, laqueado en

madera, ensamblaje lumínico

S/D

Colección: privada

Comentario: F/O de Armagedón. Exposición Individual "Levitantes 


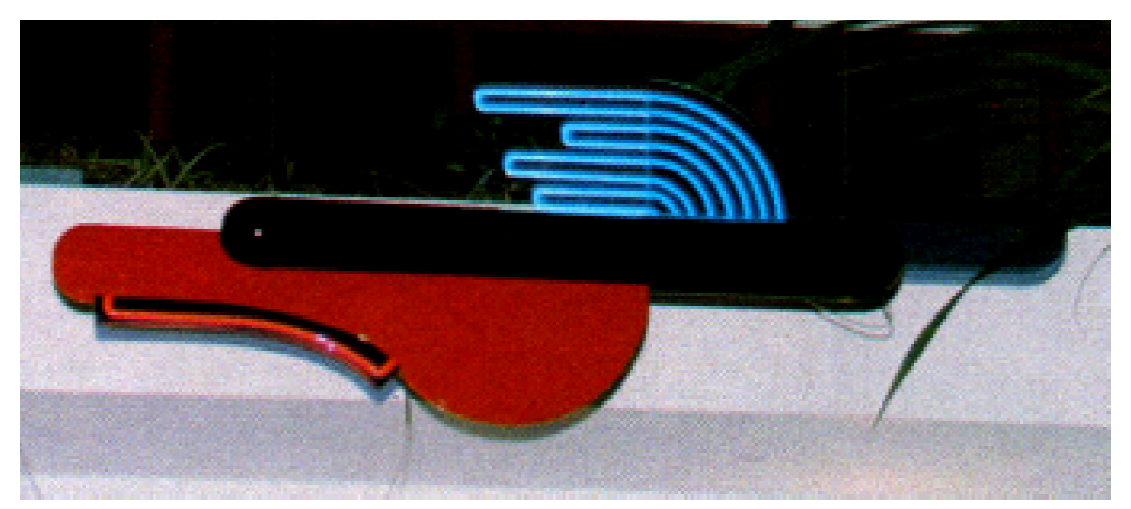

IMAGEN 423

Escultura en la categoría de lumínica en suspensión Armagedon III

1986

Cedro, luz de neón rojo y azul, cristal de Boussois polarizante, lacas, anclajes metálicos Talla en madera, laqueado en madera, ensamblaje de elemento lumínico

S/D

Coleccion: Sr. Jacques Kamhaz

Comentario: F/O deArmagedón.

Exposición Individual “Levitantes Lumínicos y Demás Volúmenes”

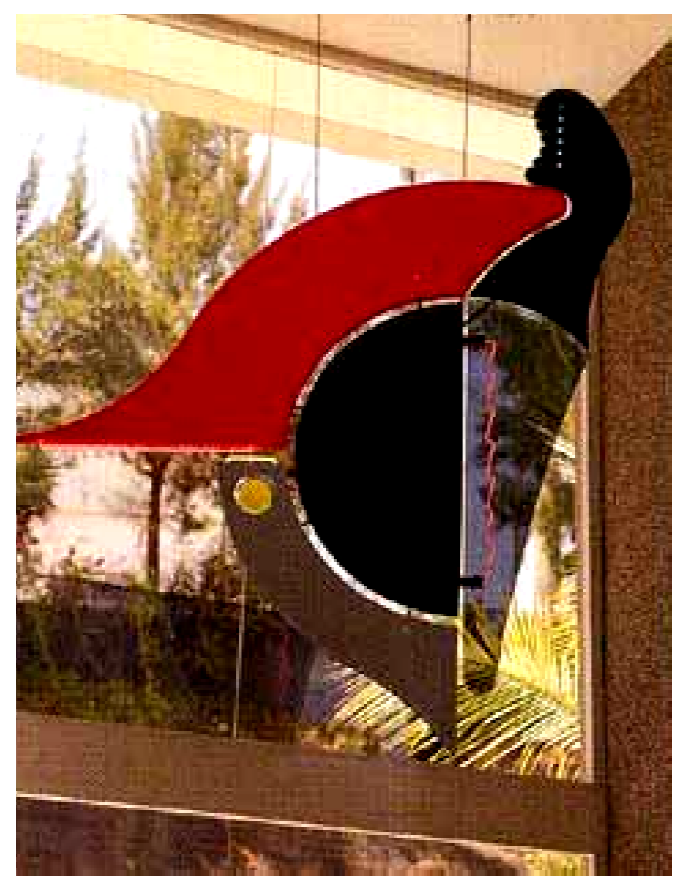

IMAGEN 424

Escultura en la categoría de

lumínica en suspensión

Nautilus

Cedro, mármol, luz de neón rojo y

azul, cristal de Boussois

anclajes metálicos

Talla en madera y mármol,

soplado en vidrio, laqueado en

madera, ensamblaje de

elemento lumínico

elemento lumínico

Colección: del Artista

Comentario: F/O de Armagedón 


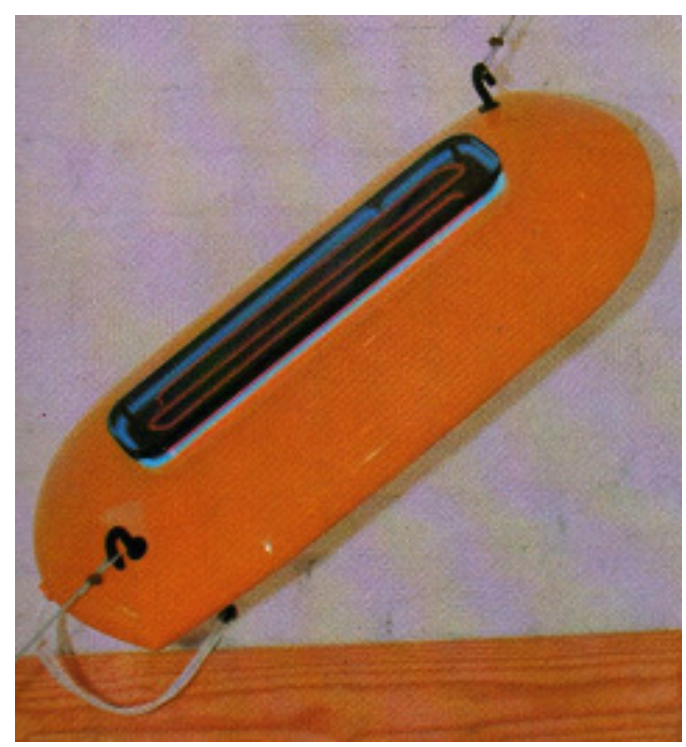

IMAGEN 425

Escultura en la categoría de

lumínica en suspensión

Aurora borealis

1984

Caoba, luces de neón rojo y azul,

lacas, anclajes metálicos

Talla en madera, laqueado en

madera, ensamblaje de

elemento lumínico

S/D

Colección: del Artista

Comentario: F/O de Cápsulas

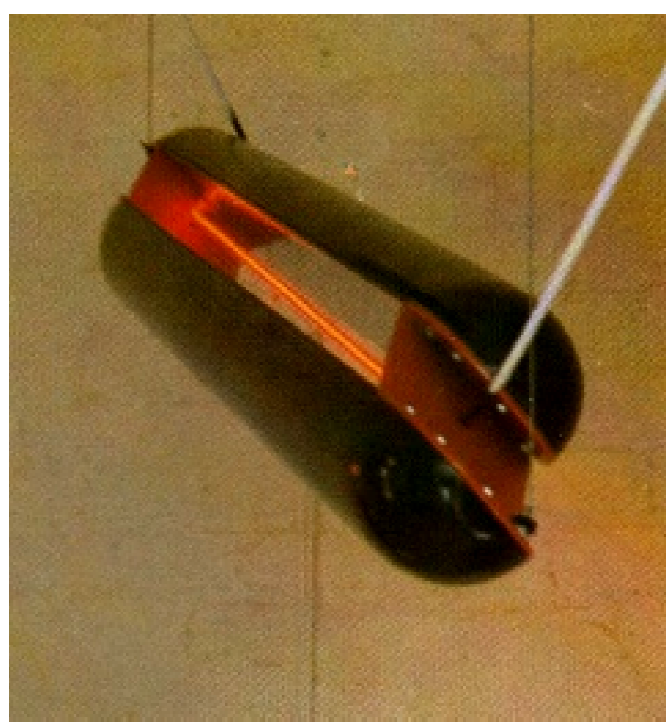

IMAGEN 426

Escultura en la categoría de

lumínica en suspensión

Cápsula: Torpedos espaciales

1984

Cedro, hierro, luz de neón rojo,

lacas, anclajes metálicos

Talla y torno en madera,

aqueado en madera y hierro,

ensamblaje de elemento

lumínico

Colección: Sr. G. Cuntrera

Colección: Sr. G. Cuntrera 


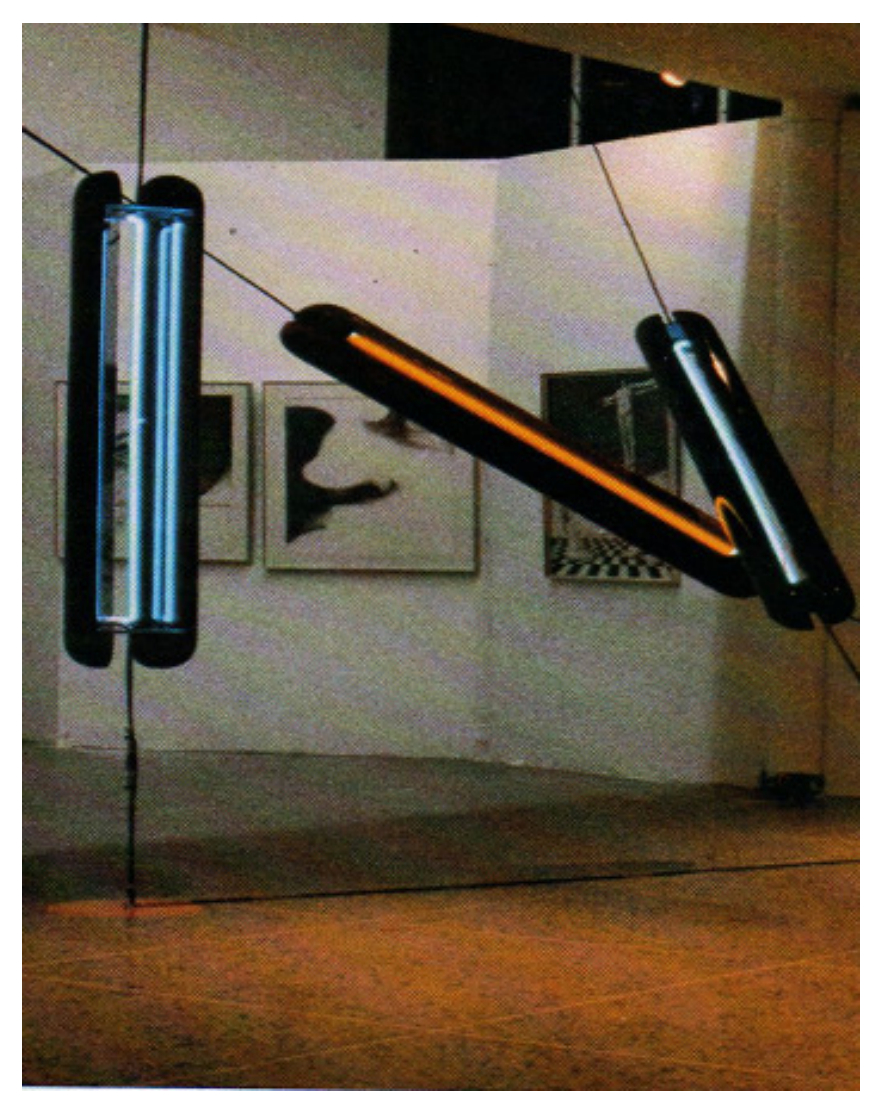

IMAGEN 427

Escultura en la categoría de lumínica en suspensión

Cápsulas
1984

Cedro, luces de neón blanca, azul y naranja, lacas, anclajes metálicos

Talla y torno en madera, laqueado en madera, ensamblaje de elemento lumínico

$\mathrm{S} / \mathrm{D}$

Colección: Sr. José Sánchez Nariño. New York, USA

Comentario: F/O de Cápsulas,

Expuestas en el Salón Nacional de Arte de Aragua en el año 1984 


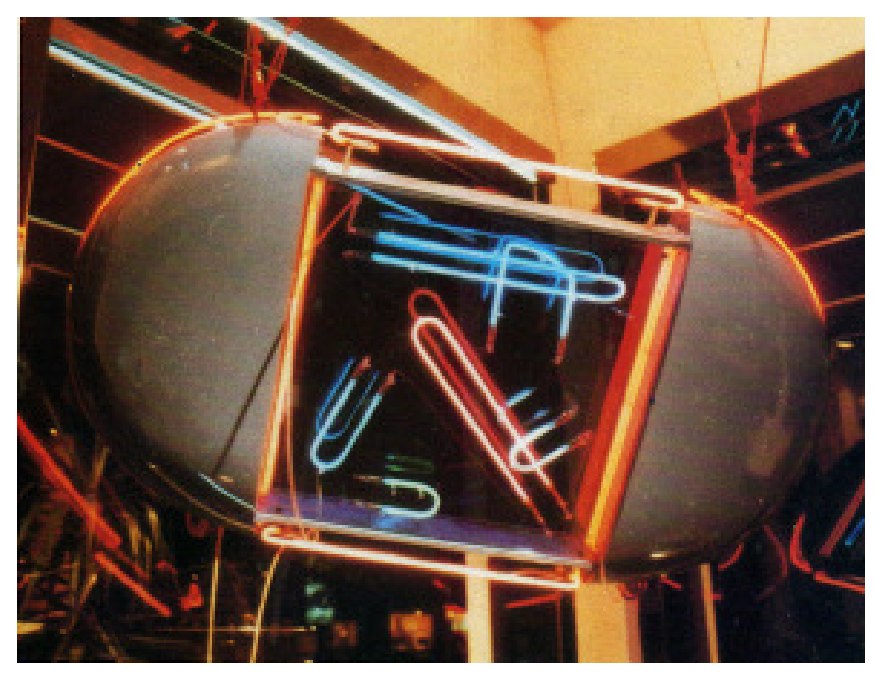

IMAGEN 428

Escultura en la categoría de lumínica en suspensión

Hommage a Magritte: la fenètre bleue

1985

Cedro, luces de neôn rojo, blanco, amarillo, naranja y azul, cristal de Boussois polarizante,

lacas, anclajes metálicos

Talla y torno en madera, laqueado en madera, ensamblaje de elemento lumínico

S/D

Colección: privada

Comentario: F/O de Cápsulas

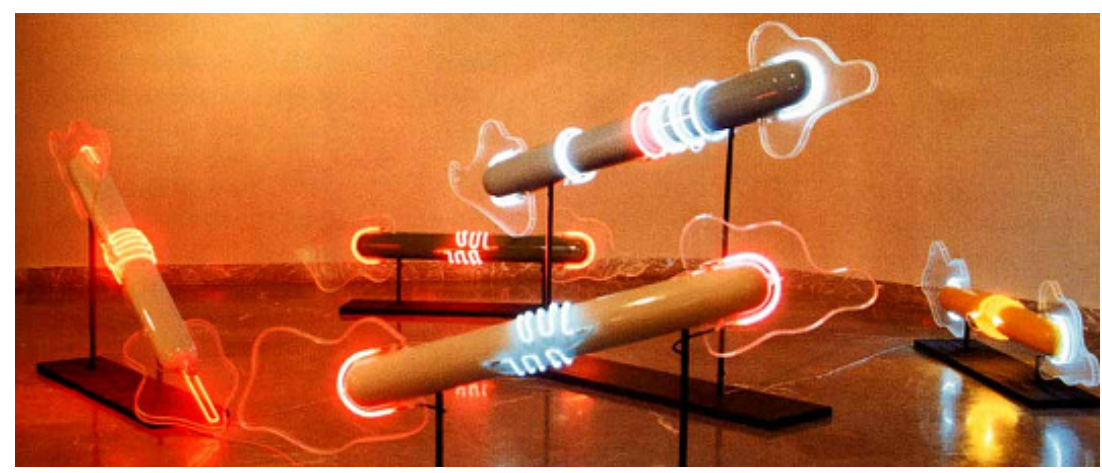

IMAGEN 429

Escultura en la categoría de lumínica en suspensión

Cápsulas lumínicas

1987

Cedro, hierro, luces de neón blanco, amarillo, azul, naranja y rojo, cristal, lacas

Talla y torno en madera, laqueado en madera, ensamblaje de elemento lumínico

S/D

Colección: privada

Comentario: $F / O$

Obras elaboradas in situ en la Exposición individual “100 Horas, 100 Obras” en el año 1987 en Venezuela. 


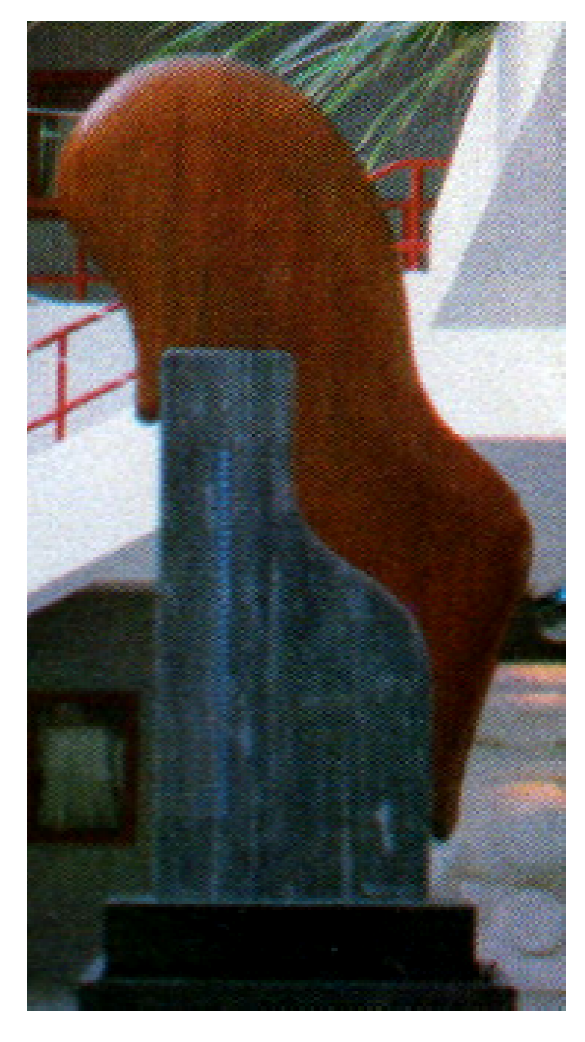

IMAGEN 430

Escultura en la categoría de lumínica

Materias y luz I

1986

Caoba, mármol Bardiglio di Cappela, luz de

neón azul,

Talla en madera y mármo

S/D

Colección:

1/3 del Artista

2/3 Sr. Mario
$3 / 3$ privada

Comentario: F/O de Materias y Luz

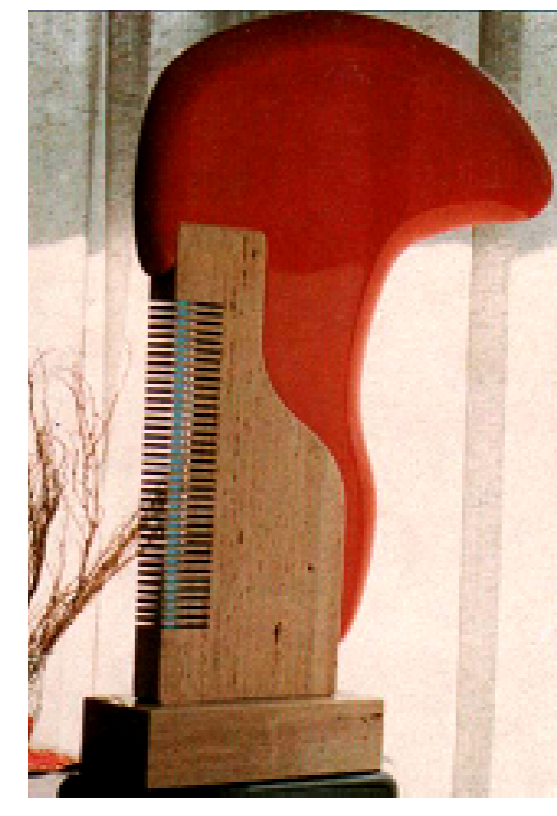

IMAGEN 431

Escultura en la categoría de lumínica

Materias y luz II

Caoba, mármol, luz de neón azul

Talla en madera y mármol

$1 / 3$ del Artista

2/3 privada

$3 / 3$ privada

Comentario: F/O de Materias y Luz 


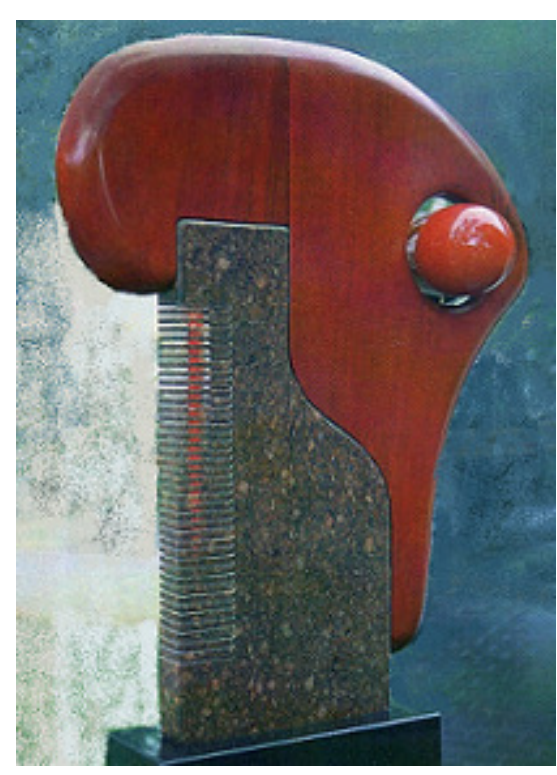

IMAGEN 432

Escultura en la categoría de lumínica

Materias y luz II

1986

Caoba, granito rosado de Guayana, vidrio

rojo, luz de neón rojo

Talla en madera y granito, soplado en

vidrio, ensamblaje de elemento lumínico

S/D

Colección:

2/3 Sra. María Eugenia Jahn de Rodríguez

2/3 Sra. Maria

$3 / 3$ privada

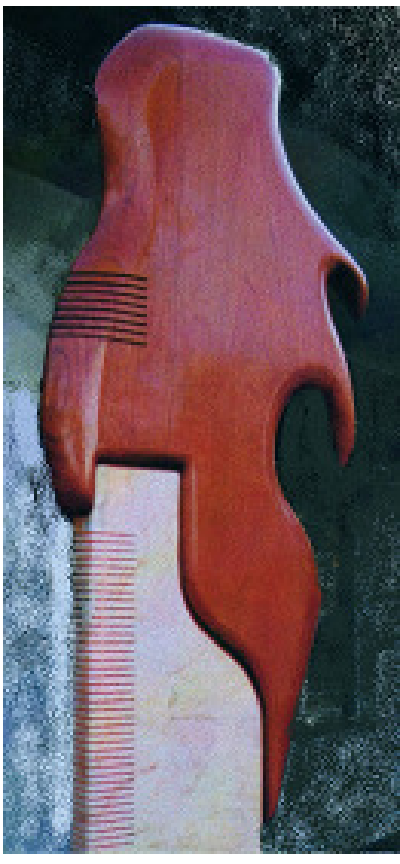

IMAGEN 433

Escultura en la categoría de lumínica

Materias y luz IV

1986

Caoba, mármol, luz de neón rojo,

Talla en madera y mármol, ensamblaje de elemento

lumínico

$\mathrm{S} / \mathrm{D}$

Colección:

$1 / 3$ del Artista

$2 / 3$ privada

Comentario: F/O de Materias y Luz 


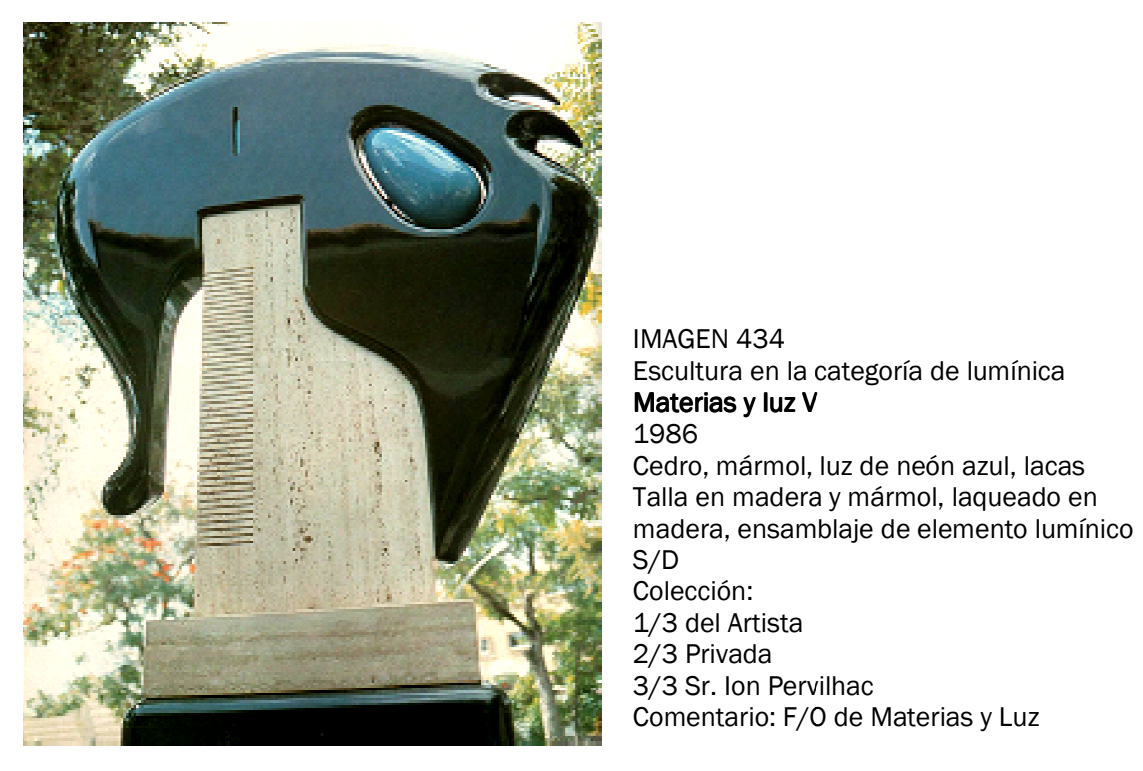

\section{MAGEN 435}

Escultura en la categoría de lumínica

Materias y luz VI "Arlequín"

1986

Cedro, mármol Bardiglio di Cappela, luz de neón rojo,

Talla en madera y mármol, ensamblaje de elemento

lumínico

S/D

Comentario: F/O de Materias y Luz 


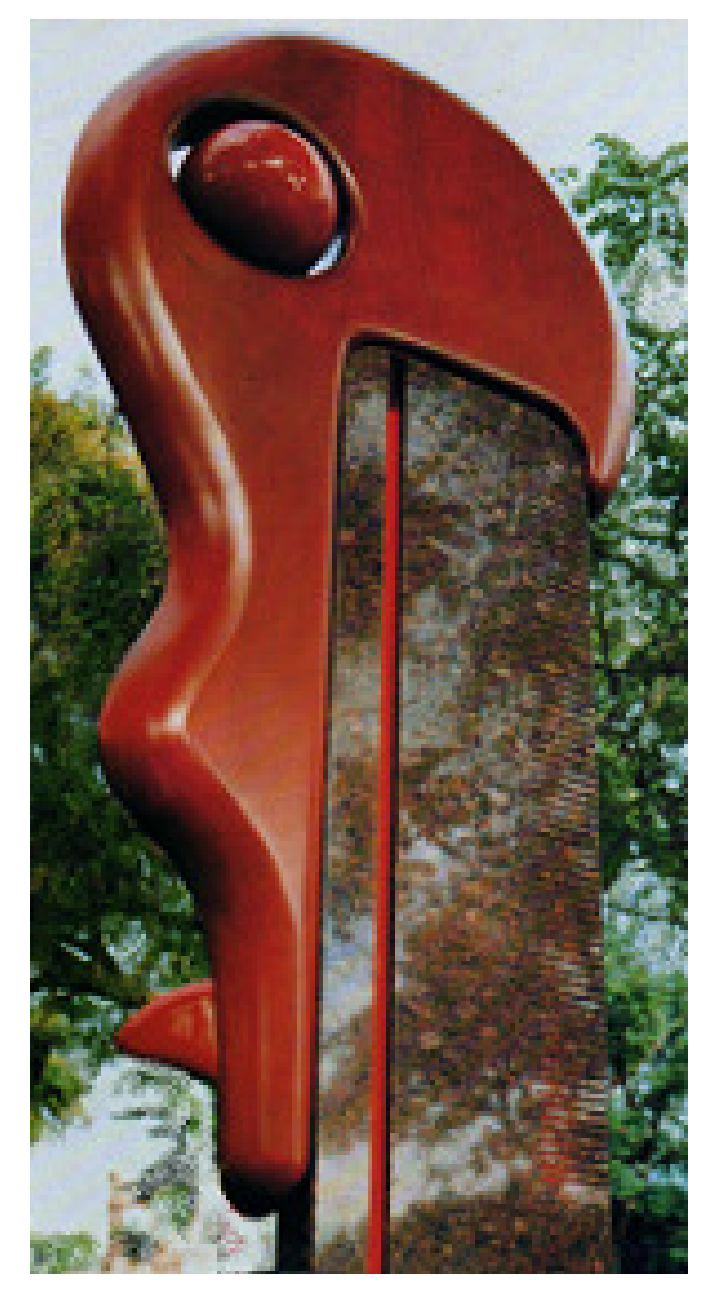

IMAGEN 436

Escultura en la categoría de lumínica

Materias y luz VII

1986

Cedro, granito rosado de Guayana, vidrio rojo, luz de neón rojo

Colección:

$1 / 3$ del Artista

$2 / 3$ privada
$3 / 3$ privada

Comentario: F/O de Materias y Luz 


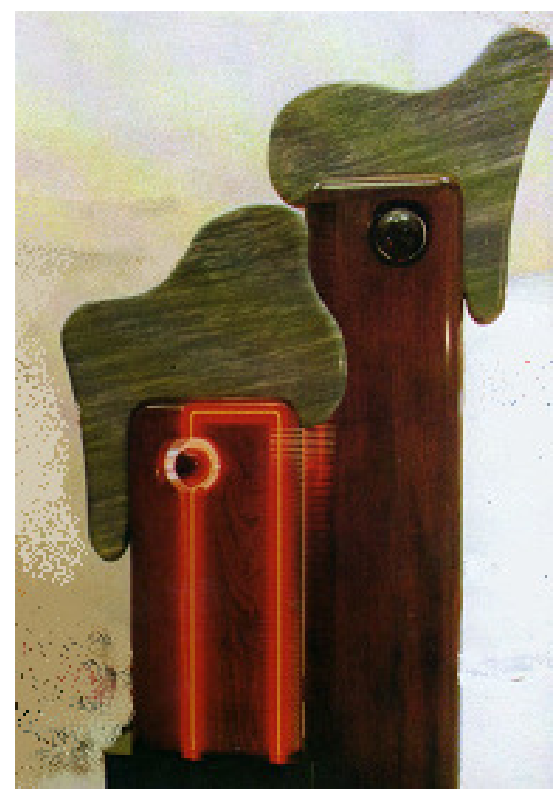

IMAGEN 437

Escultura en la categoría de lumínica

El diálogo de los cíclopes

Cedro, mármol Bardiglio di Cappela, vidrio

rojo, luz de neón rojo

alla de madera y mármol, soplado en

vidrio, ensamblaje de elemento lumínico

S/D

Colección: privada

Comentario: F/O de Ciclopes,

Expuesta en el Salón Nacional de Artes

Visuales Arturo Michelena en el año 1986

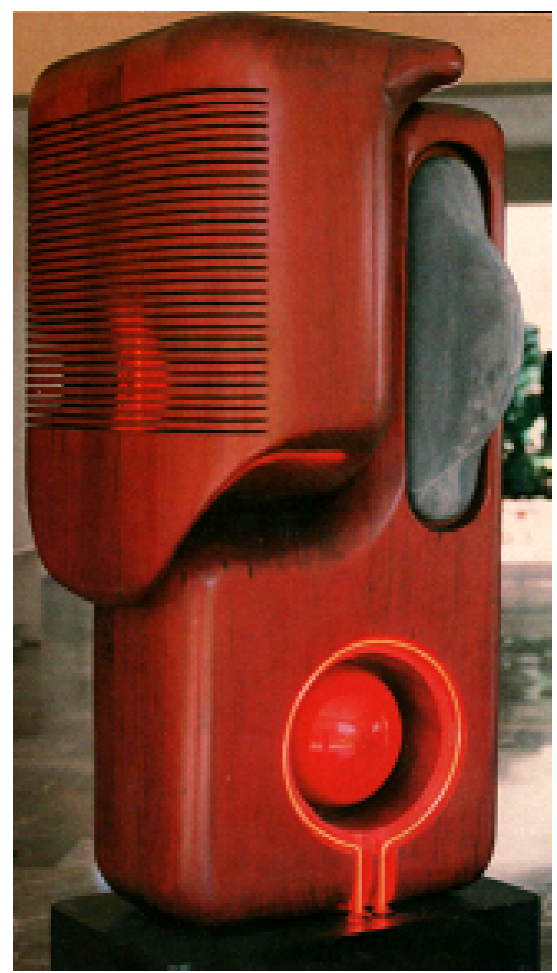

IMAGEN 438

en la categoría de lumínica

Steropes: el tercer cíclope, forjador de los

relámpagos de Zeus

1986

Cedro, mármol, vidrio rojo, luz de neón rojo

y naranja

Talla en madera y mármol, soplado en

vidrio, ensamblaje de elemento lumínico

$\mathrm{S} / \mathrm{D}$

Colección: privada

Comentario: F/O de Cíclopes,

Expuesta en el Salón Nacional de Artes

Visuales Arturo Michelena en el año 1986 


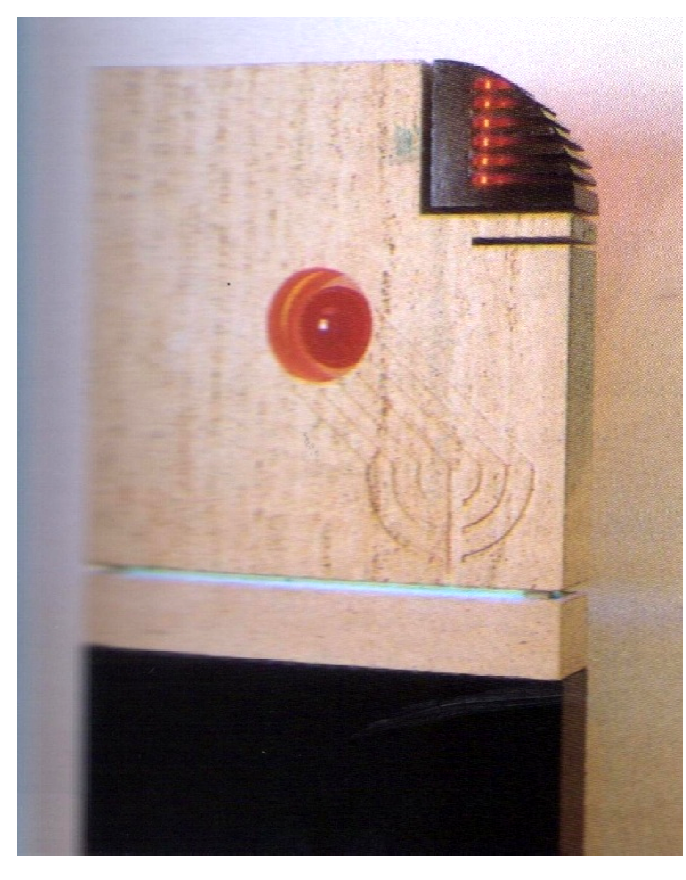

IMAGEN 439

Escultura en la categoría de

Esculura

"Érica de la vida “Menorah"

Mármol, vidrio rojo, hierro,

cedro, luz de nejn rojo y azul,

dera y mármol,

oplado en vidrio, laqueado en

madera, ensamblaje de

elemento lumínico

$56 \times 13 \mathrm{c} / \mathrm{p} 1: 76 \mathrm{~cm}$

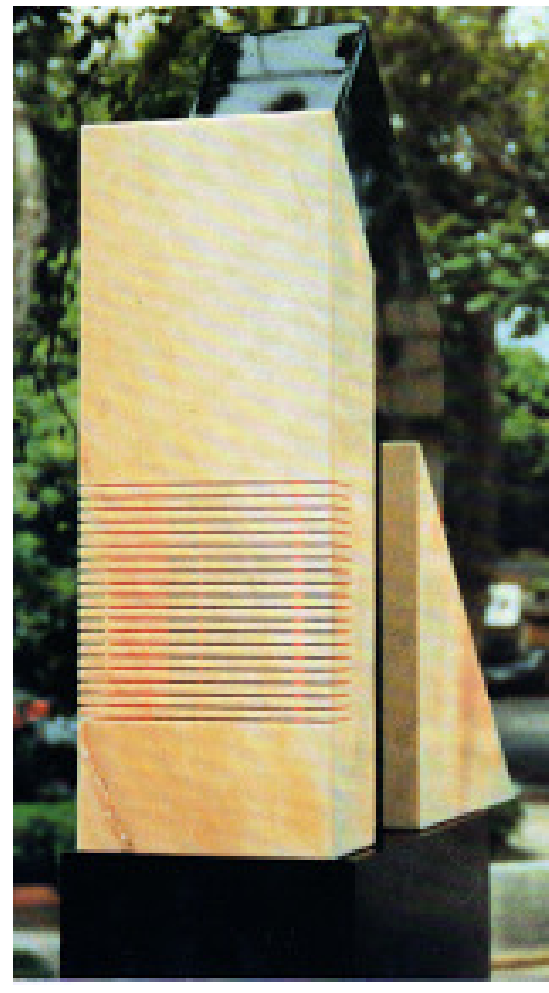

IMAGEN 440

Escultura en la categoría de lumínica

Estereoradián II

1987

Mármol, luz de neón rojo

Talla en mármol, ensamblaje de elemento

lumínico

$1 / 3$ del Artista

2/3 Sra. Nuria Tapies

$3 / 3$ privada

S/D

Comentario: F/O de Estereoradián,

Obras elaboradas para la exposiciôn

individual "100 Horas, 100 Obras" 


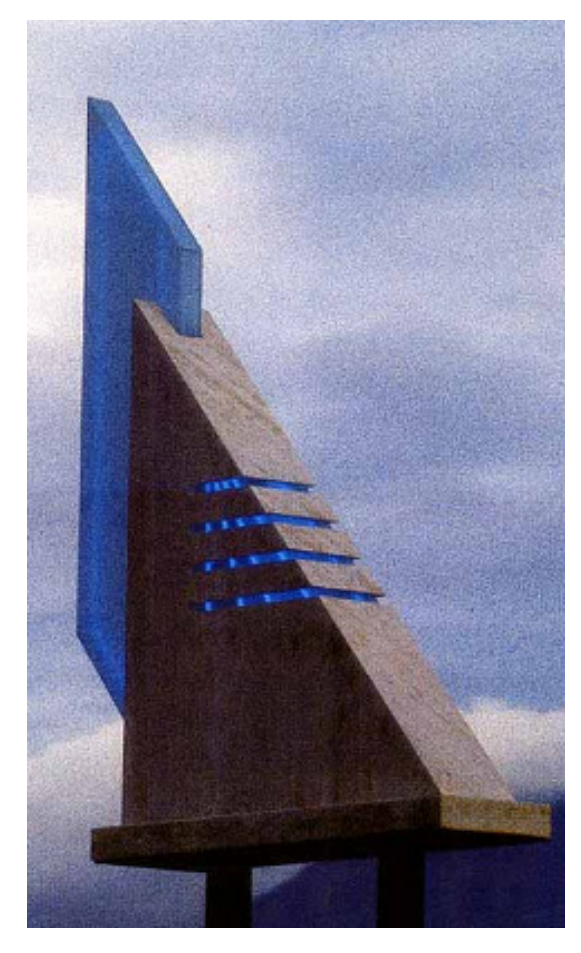

IMAGEN 441

Escultura en la categoría de lumínica

Opus I

Mármol Bardiglio di Cappela, metacrilato,

hierro, luz de neón azul

Talla en mármol, ensambro

nsamblaje de elemento

lumínico

Colección: $\times 56 \mathrm{~cm}$

Colección: privada

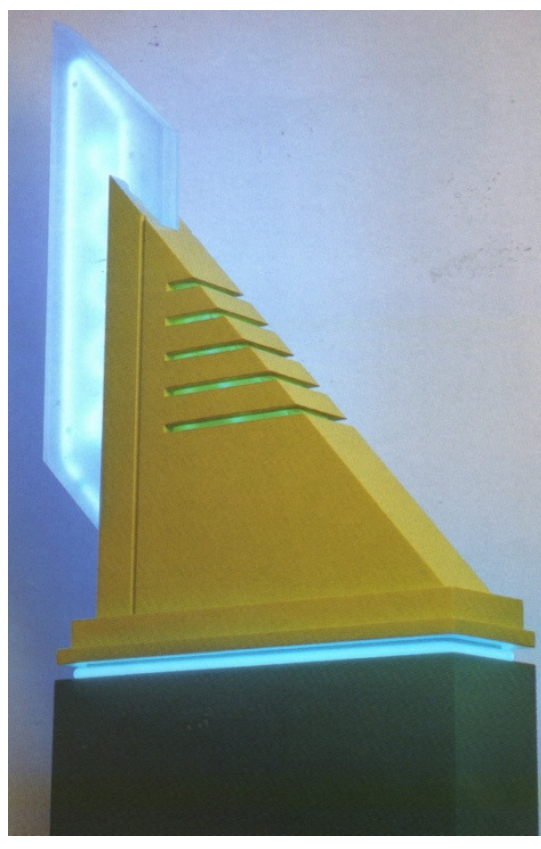

IMAGEN 442

Escultura en la categoría de lumínica

Opus I en amarillo

Opus I

Cedro, metacrilato, luz de neón azul,

lacas. Mármol

Talla en madera y mármol, laqueado en

madera, ensamblaje de elemento lumínico

$89 \times 67 \times 17 \mathrm{~cm} \mathrm{c} / \mathrm{p} 1: 93 \mathrm{~cm}$

Colección: privada

Comentario: F/O de Opus Humus 


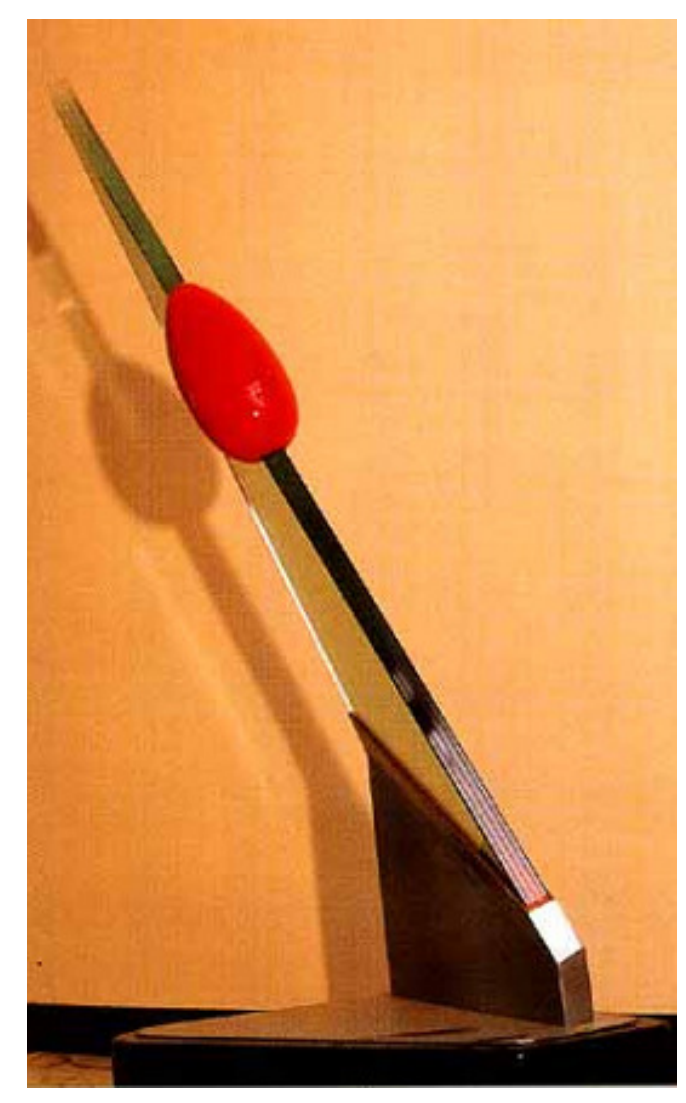

IMAGEN 443

Escultura en la categoría de lumínica

La furia del silencio

1987

Cristal, acero, vidrio rojo, luz dicróica

Soldadura eléctrica, soplado en vidrio, ensamblaje de elemento lumínico

$143 \times 57 \times 46 \mathrm{~cm}$

Comentario: $F / O$ de La furia del Silencio 


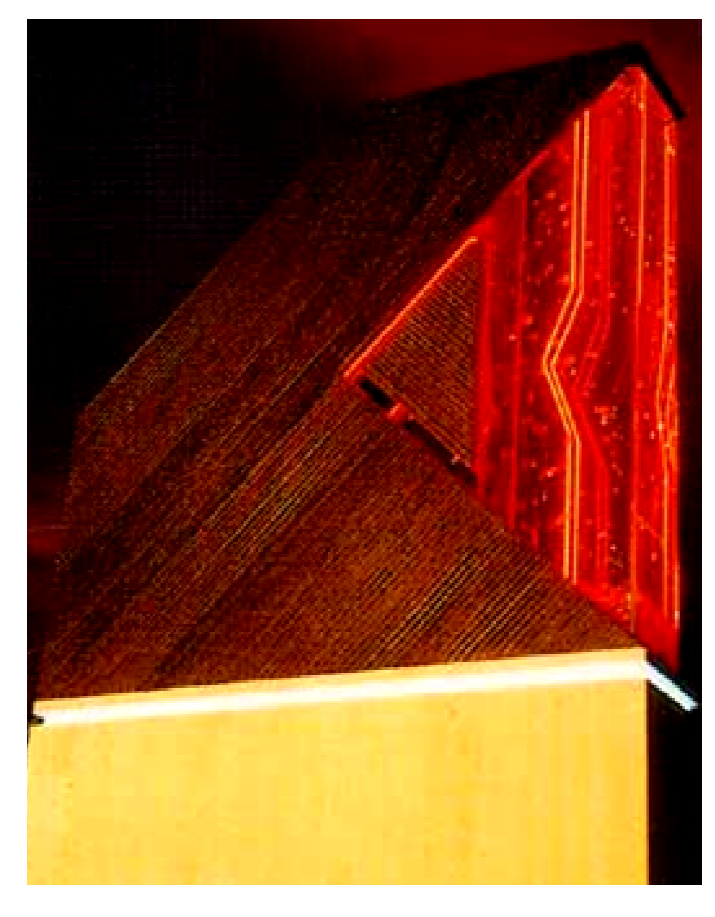

IMAGEN 444

Escultura en la categoría de

lumínica con agua en

movimiento

Roraima IV

Granito, cristal, luz de neón

rojo y blanco, cuarzo

hidroxilico, mecanismo

hidráulico, agua

Talla en granito, ensamblaje de

ele

$90 \times 90 \times 19 \mathrm{c} / \mathrm{p} 1.90 \mathrm{~cm}$

Colección: priva $1.90 \mathrm{~cm}$

Colección: privada

Comentario: $\mathrm{F} / \mathrm{O}$ con agua en
movimiento. Roraima

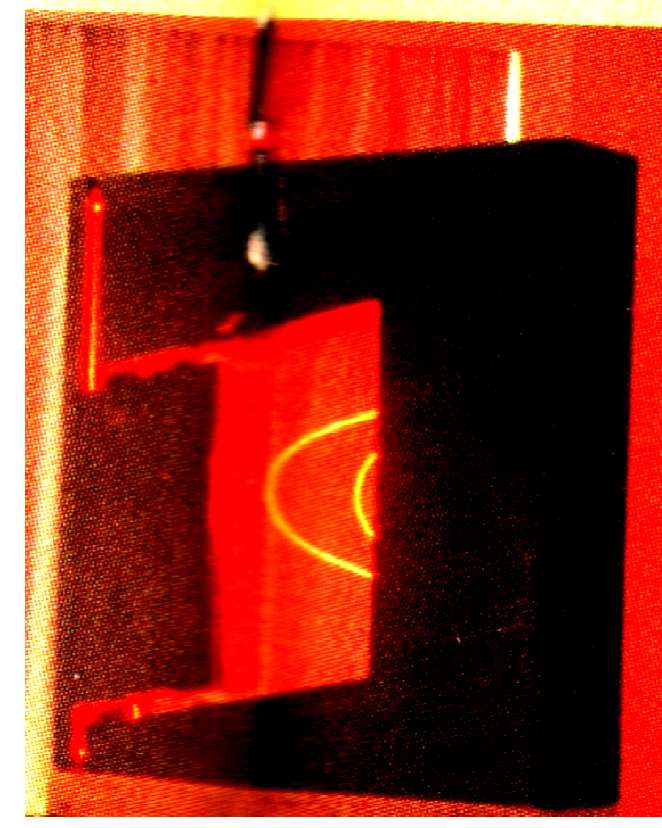

IMAGEN 445

Escultura en la categoría de

lumínica con agua en

movimiento

1989

Cedro, cristal, luz de neón rojo,

cuarzo hidroxílico, mecanismo

hidráulico, agua, lacas, anclaje

metálico

Talla en madera, laqueado en

madera, ensamblaje de

emento lumínico, metálico y de

mecanismo hidráulico

$90 \times 90 \times 19 \mathrm{~cm}$

Coleccion: privada

Comentario: F/O con agua en

movimiento. Roraima 


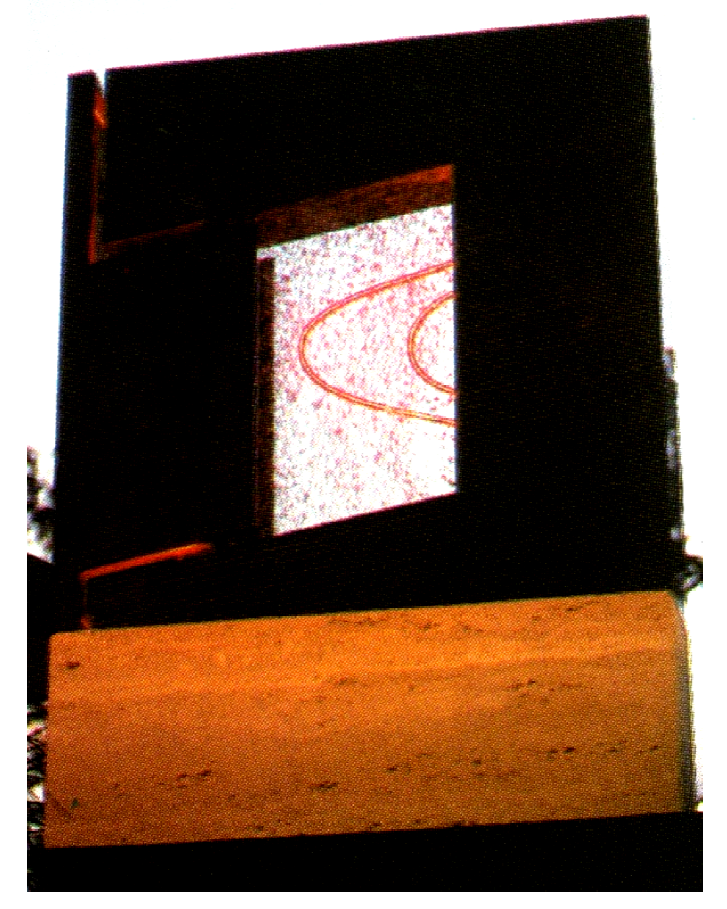

IMAGEN 446

Escultura en la categoría de lumínica con agua en movimiento Roraima XIV

1989

Cedro, cristal, luz de neón rojo, cuarzo hidroxílico, mecanismo hidráulico, agua, mármol,

lacas

Talla en madera y mármol, laqueado en madera, ensamblaje de elemento lumínico,

ensamblaje de mecanismo hidráulico

$90 \times 90 \times 19 \mathrm{c} / \mathrm{p} 1.90 \mathrm{~cm}$

Colección: Ing. Máximo Montin

Comentario: $\mathrm{F} / \mathrm{O}$ con agua en movimiento. Roraima 


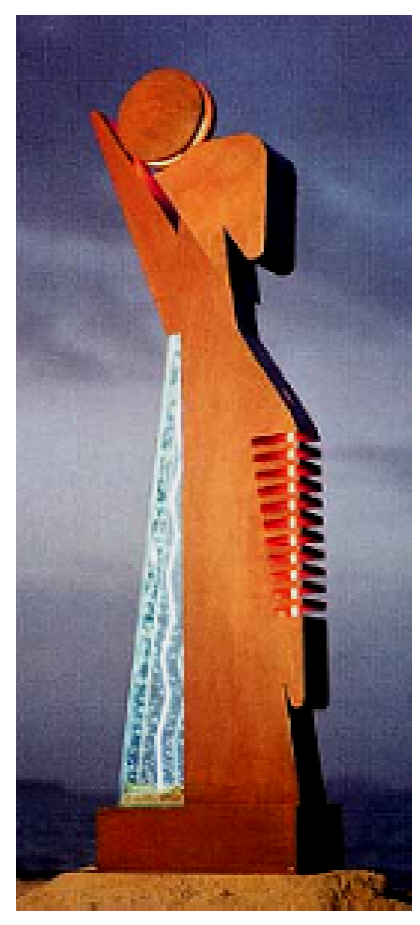

IMAGEN 447

Escultura en la categoría de lumínica con agua en

movimiento

1990

Cristal, hierro calibrado, luz de neón blanca y roja,

cuarzo hidroxilico, mecanismo hidráulico agua

Corte a laser, ensamblaje de elemento lumínico y de

mecanismo hidráulico

$200 \times 62 \times 32 \mathrm{~cm}$

Colección: Edmundo Gugliota. Miami, Usa.

Comentario: F/O con agua en movimiento. Los Hijos de

Poseidón

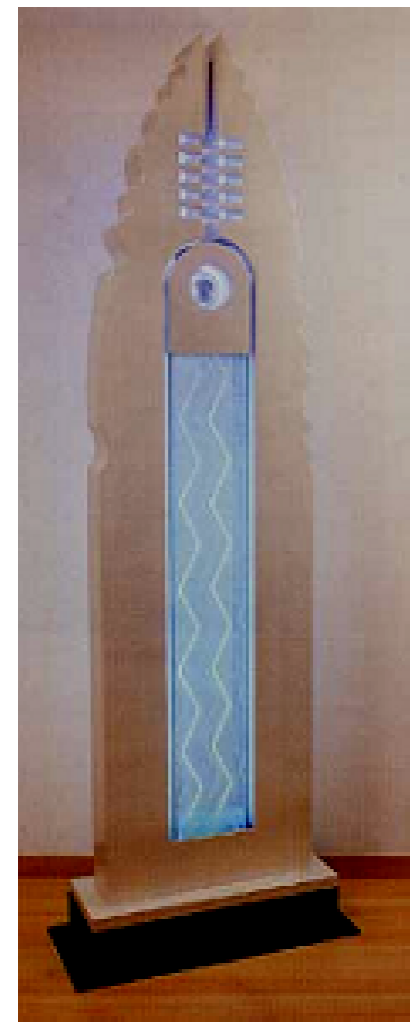

IMAGEN 448

Escultura en la categoría de lumínica con agua en

movimiento

Oración

991

Cristal, mármol, cuarzo hidroxílico, luz de neón blanca,

mecanismo hidráulico, agua

Talla en mármol, ensamblaje de elemento lumínico y

mecanismo hidráulico

$223 \times 69 \times 25 \mathrm{~cm}$

Colección: privad

Comentario: F/O con agua en movimiento. Los Hijos de

Poseidón 


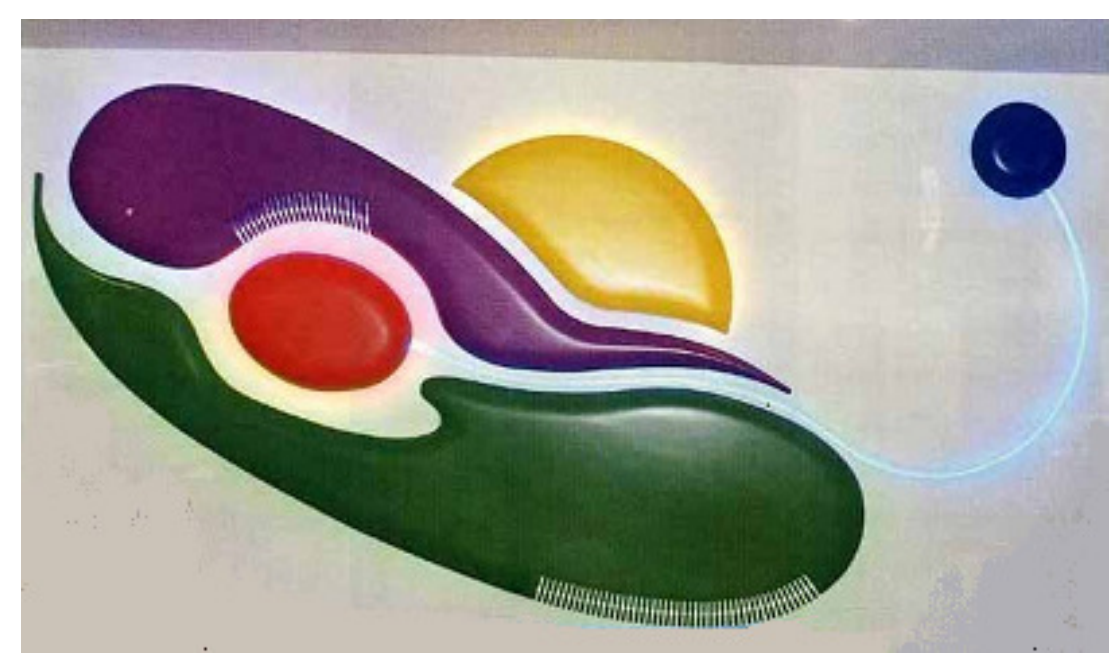

IMAGEN 449

Escultura en la categoría de volumetrías de pared

Simbiosis

Cedro, lacas, luces de neón amarillo, violeta, rojo, verde y azul

$328 \times 160 \times 13 \mathrm{~cm}$

Colección: Grupo Imagen Publicidad (Consolidación de Vepaco y Cablevisión) Caracas

Comentario: F/O de Policromía Volumétrica Antigravitacional 


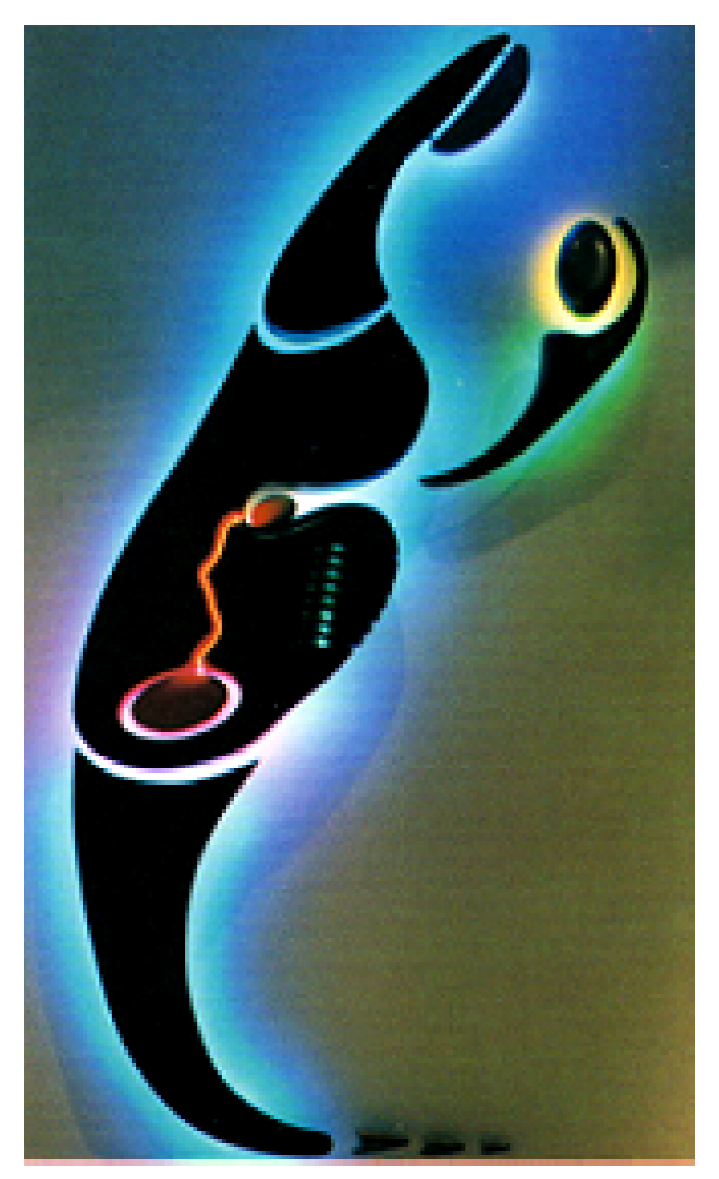

IMAGEN 450

Escultura en la categoría de volumetrías de pared

Maternidad

1991

Cedro, luces de neón azul, amarillo, verde, rojo, naranja, blanco, lacas,

Talla, torno y laqueado en madera, ensamblaje de elemento lumínico

S/D

Comentario: F/O de Policromía Volumétrica Antigravitacional 


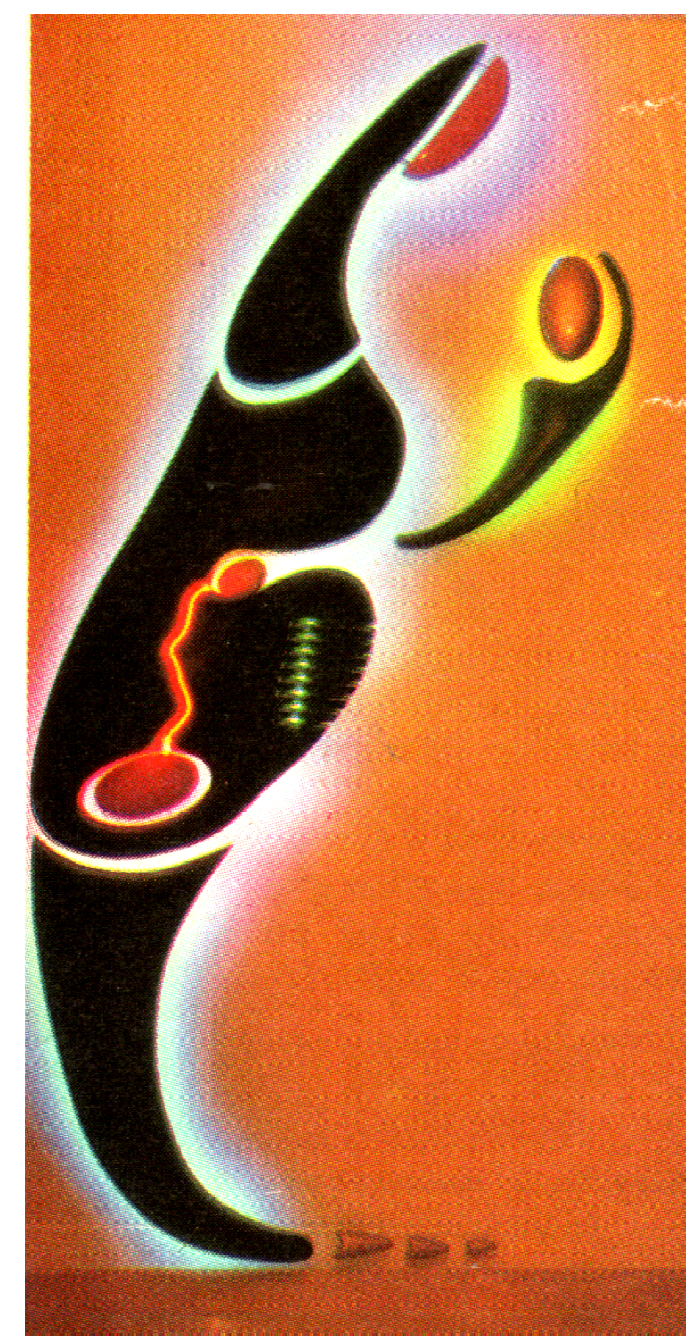

IMAGEN 451

Escultura en la categoría de volumetrías de pared Maternidad

1991

Cedro, luces de neón azul, amarillo, verde, rojo, naranja, blanco, lacas, Talla, torno y laqueado en madera, ensamblaje de elemento lumínico

Colección: privada

Comentario: F/O de Policromía Volumétrica Antigravitacional 


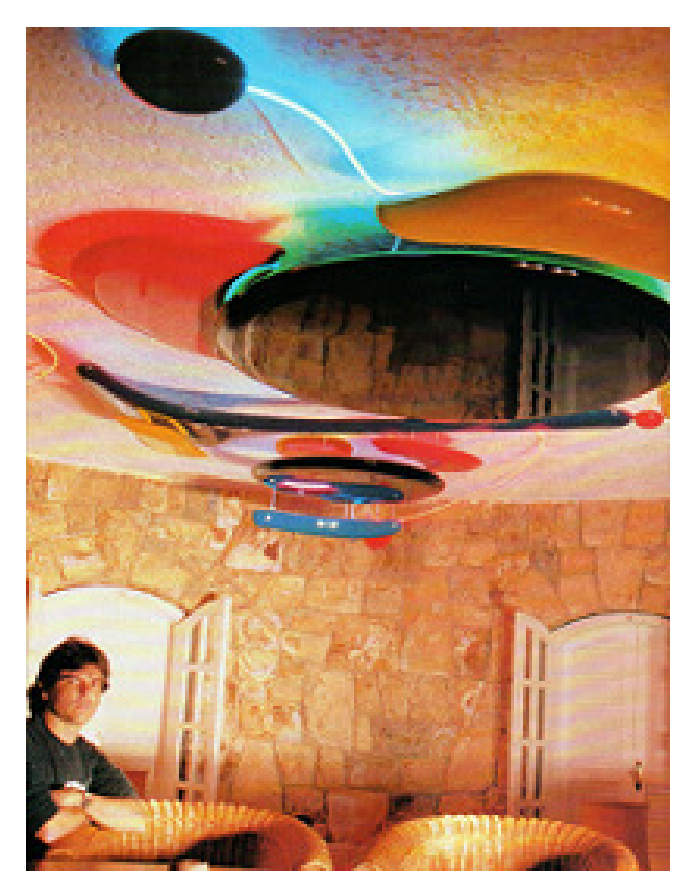

IMAGEN 452

en la categoría de volumetrías de techo

1987

Cedro, luces de neón azul, verde, amarillo, naranja y rojo, lacas

Talla, torno y laqueado en madera, ensamblaje de elemento lumínico

Colección: Sr. Miguel Cantor y Sra.

S/D

Colección: privada

Comentario: F/O de Policromía Volumétrica Antigravitacional 


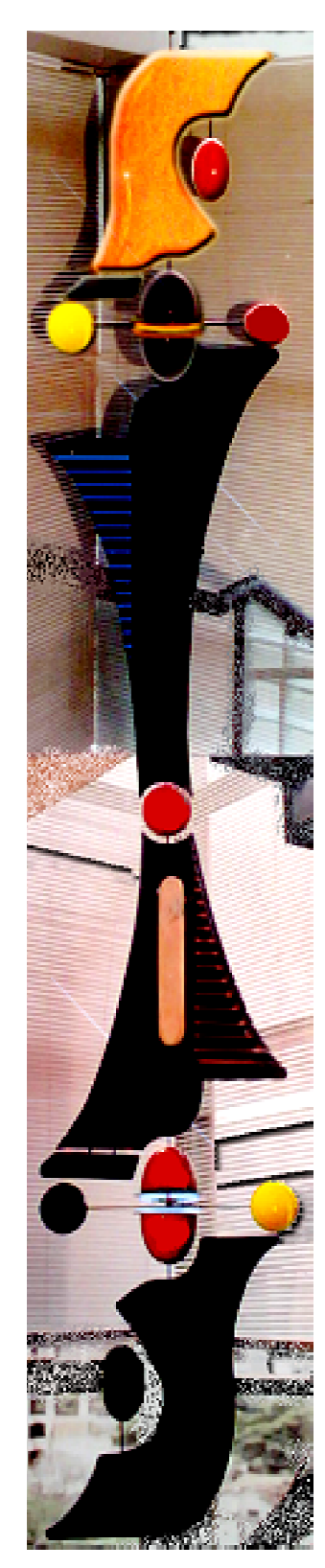

IMAGEN 453

Escultura en la categoría de volumetría antigravitacional de gran fromato Volumetría policrómica en suspensión vertical I

1988

Cedro, mármol rosado portugués, vidrio, lacas, luces de neón naranja, rojo, azul, anclajes

Talla en madera y mármol, torneado en madera, lapidación, laqueado en madera, soplado $517 \times 00 \times 20$ maje de elemento lumínico

Con $\times 20 \mathrm{~cm}, 80 \mathrm{~kg}$

Comentario: F/O de Policromía Volumétrica Antigravitacional 


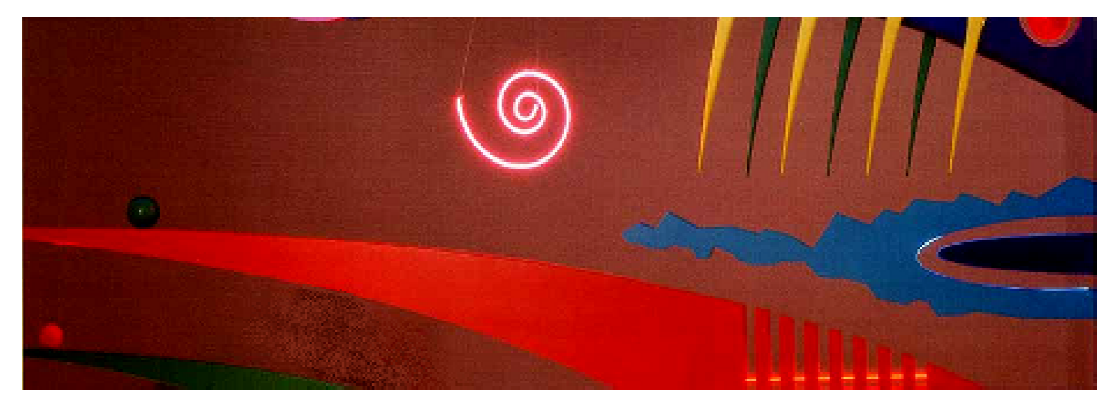

IMAGEN 454

Escultura en la categoría de separadores escultóricos de ambiente Vamos a la fiesta

Caoba, cristal de Boussois polarizante, luces de neón azul, rojo y naranja, lacas

Talla, torno y laqueado en madera, ensamblaje de elemento luminico

$286 \times 134 \times 12 \mathrm{~cm}$

Comentario: F/O de Composiciones lumínicas en transparencia

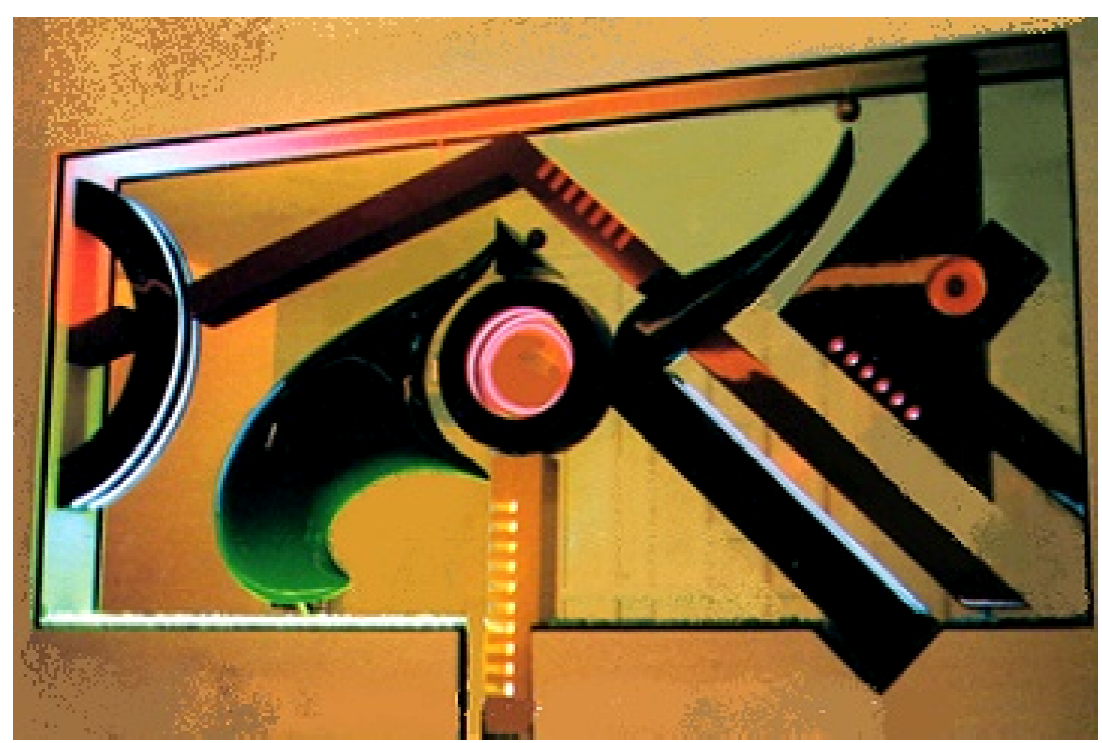

IMAGEN 455

Escultura en la categoría de separadores escultóricos de ambiente

Asimetría solar

1999

Madera,

, vidrio rojo, luces de neón blanco, azul, verde, rojo, amarillo, cristal, mármo

Talla en madera y mármol, torneado en madera, soplado en vidrio, laqueado en madera, ensamblaje de elemento lumínico

$\mathrm{S} / \mathrm{D}$

n: privada

Comentario: F/O de Composiciones lumínicas en transparencia 


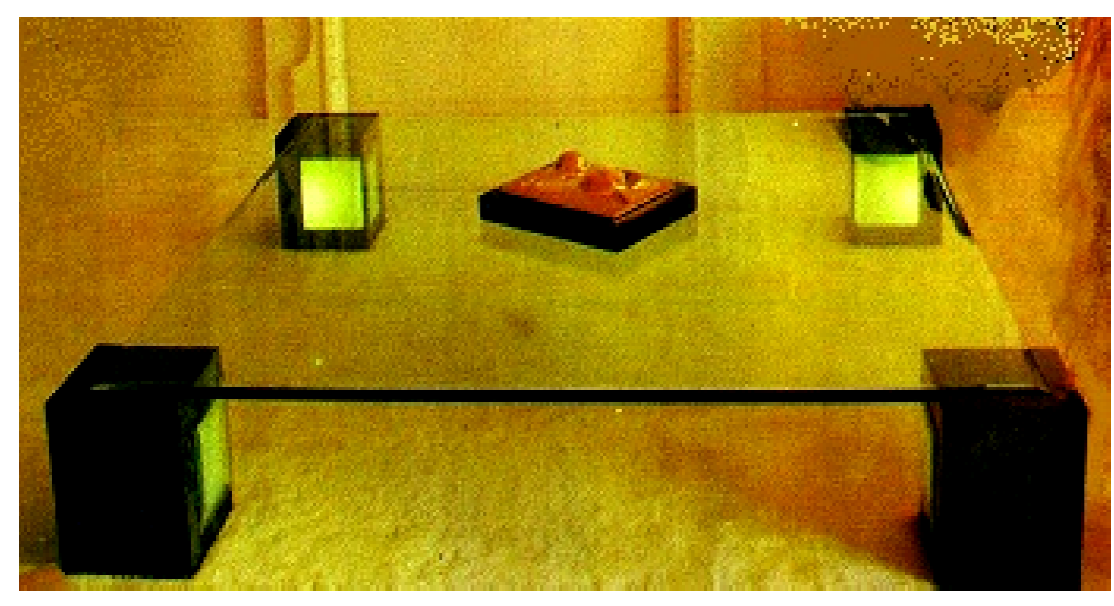

IMAGEN 456

Escultura en la categoría de mesas escultóricas lumínicas Mesa lumínica $X Y$

1996

istal, mármol, luz halogénica, vidrio verde

Lapidación, sand blasted en vidrio, soplado en vidrio, ensamblaje de elemento lumínico

Colección: Sra. Sara Almosny

Comentario: F/O de Mesas Escultóricas

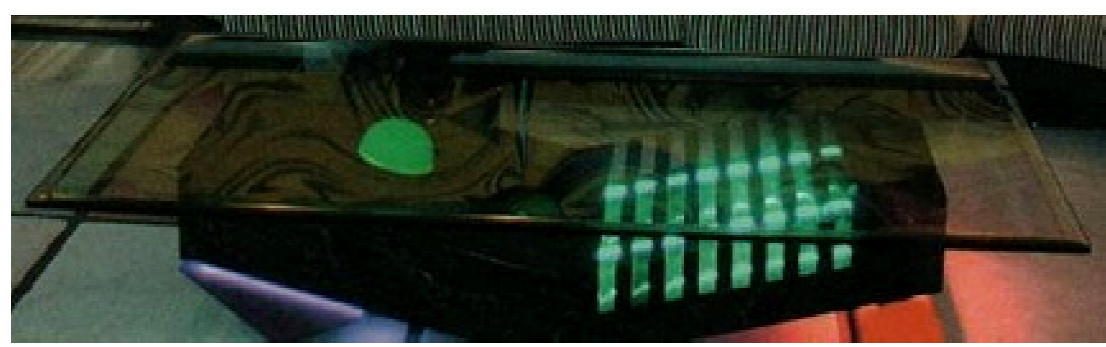

IMAGEN 457

Escultura en la categoría de mesas escultóricas lumínicas

Mesa lumínica XXX

Mármol cristal, vidrio, luces de neón roja verde y violeta

Talla en mármol, soplado en vidrio, ensamblaje de elemento lumínico

S/D

Colección: del artista

Comentario: F/O de Mesas Escultóricas 


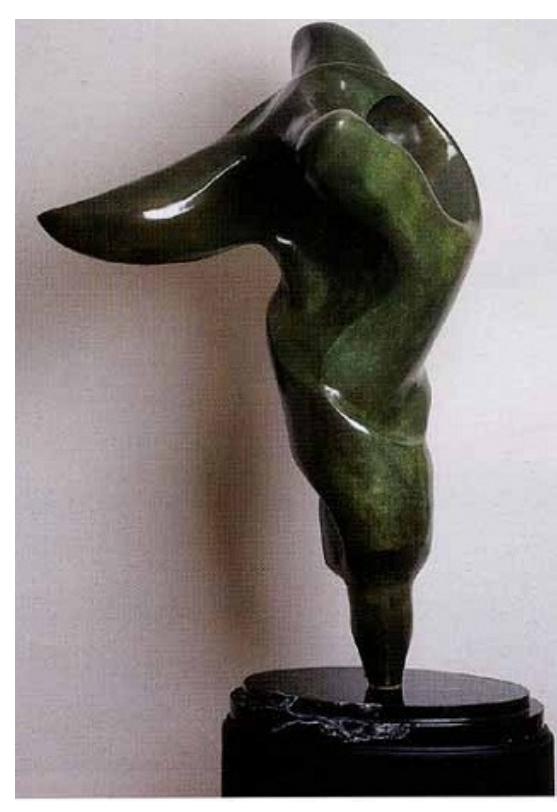

IMAGEN 458

Escultura en la categoría de bronces

El toro

1999

Bronce

Diseño y modelado en barro, fundición a la

cera perdida, patina

$102 \times 69 \times 66 \mathrm{~cm}$

Colección: del artista

Comentario: $F / O$ de Significados en

Bronce

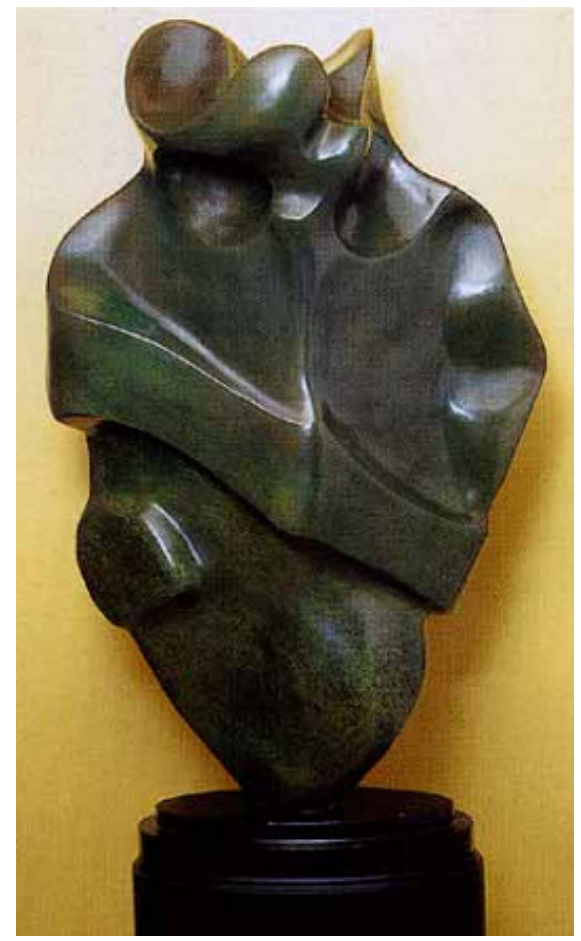

IMAGEN 459

Escultura en la categoría de bronces Corazón bravío

Corazón
1998
Bronce

Diseño y modelado en barro, fundición a

la cera perdida, pátina

$85 \times 55 \times 30 \mathrm{~cm}$

Colección: del Artista

Comentario: F/O de Significados en

Bronce 


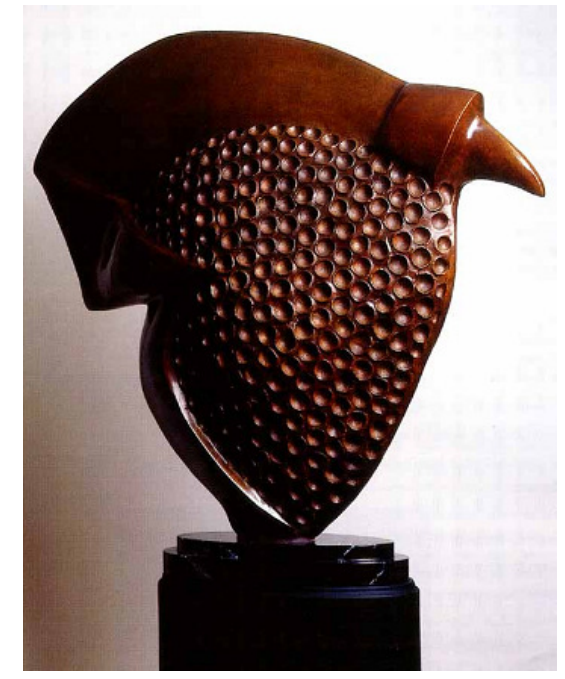

IMAGEN 460

Escultura en la categoría de bronces

Guerrero

1999

Diseño y modelado en barro Fundición a la

cera perdida, pátina, pulitura

$80 \times 76 \times 23 \mathrm{~cm}$

Comentario: $F / O$ de Significados en Bronce

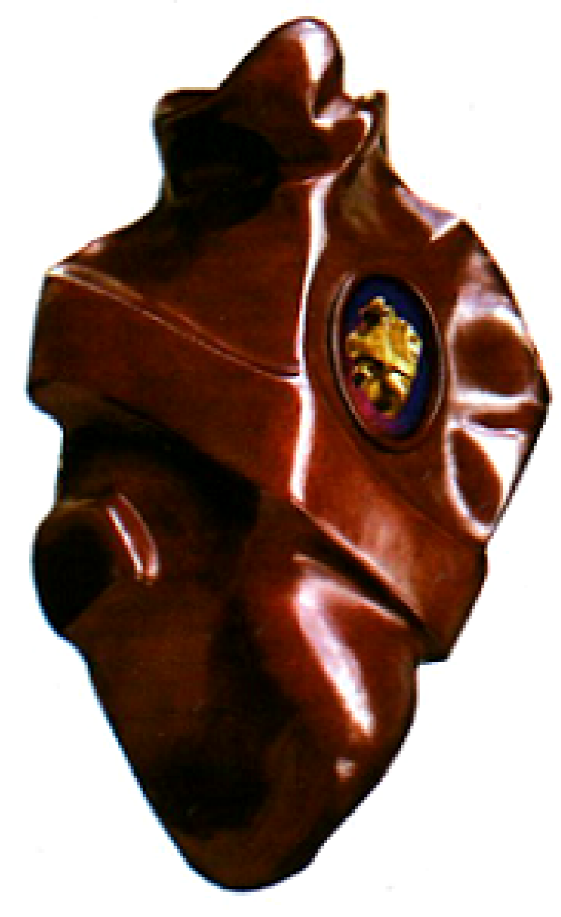

IMAGEN 461

Escultura en la categoría de bronces Sursum corda

2001

(Dro 24 quilates

Diseño y modelado en barro, cera perdida,

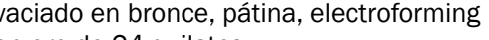
en oro de 24 quilates

Coleción: del artista

Comentario: forma parte de la Instalación

a

esperanza"

parte de la instalación ganadora de la

Medalla de Oro "Magnus Laurentis

Medicis"

Bienal Internacional del Arte

Contemporáneo de Florencia, Italia. 2001 


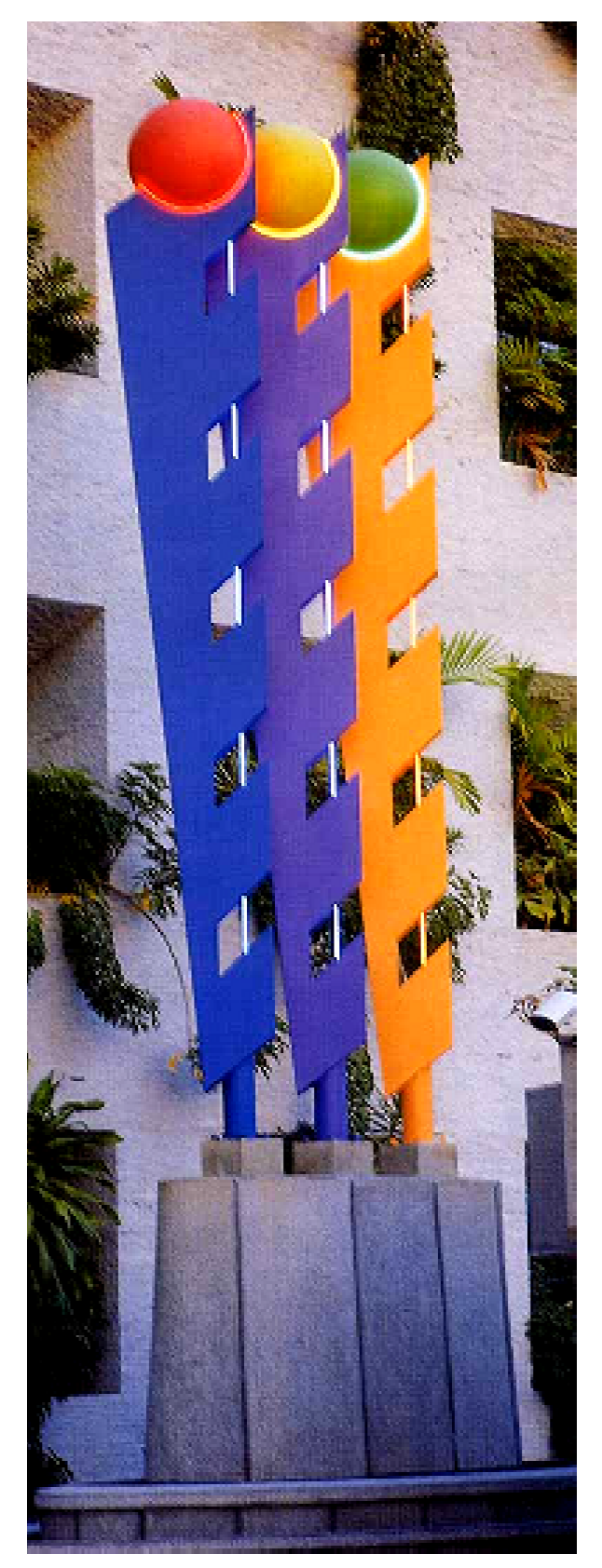

IMAGEN 462

Escultura en la categoría de formatos monumentales Imágenes ascendentes I

1998

Hierro, vidrio rojo, amarillo y verde, luces de cuarzo hidroxílico, lacas, motor hidráulico Soldadura eléctrica, laqueado en hierro, soplado en vidrio, ensamblaje de elemento luminico

$747 \times 545 \times 268 \mathrm{~cm}$

Colección: Grupo Imagen Publicidad (Consolidación de Vepaco y Cablevisión).Caracas, Distrito Capital 


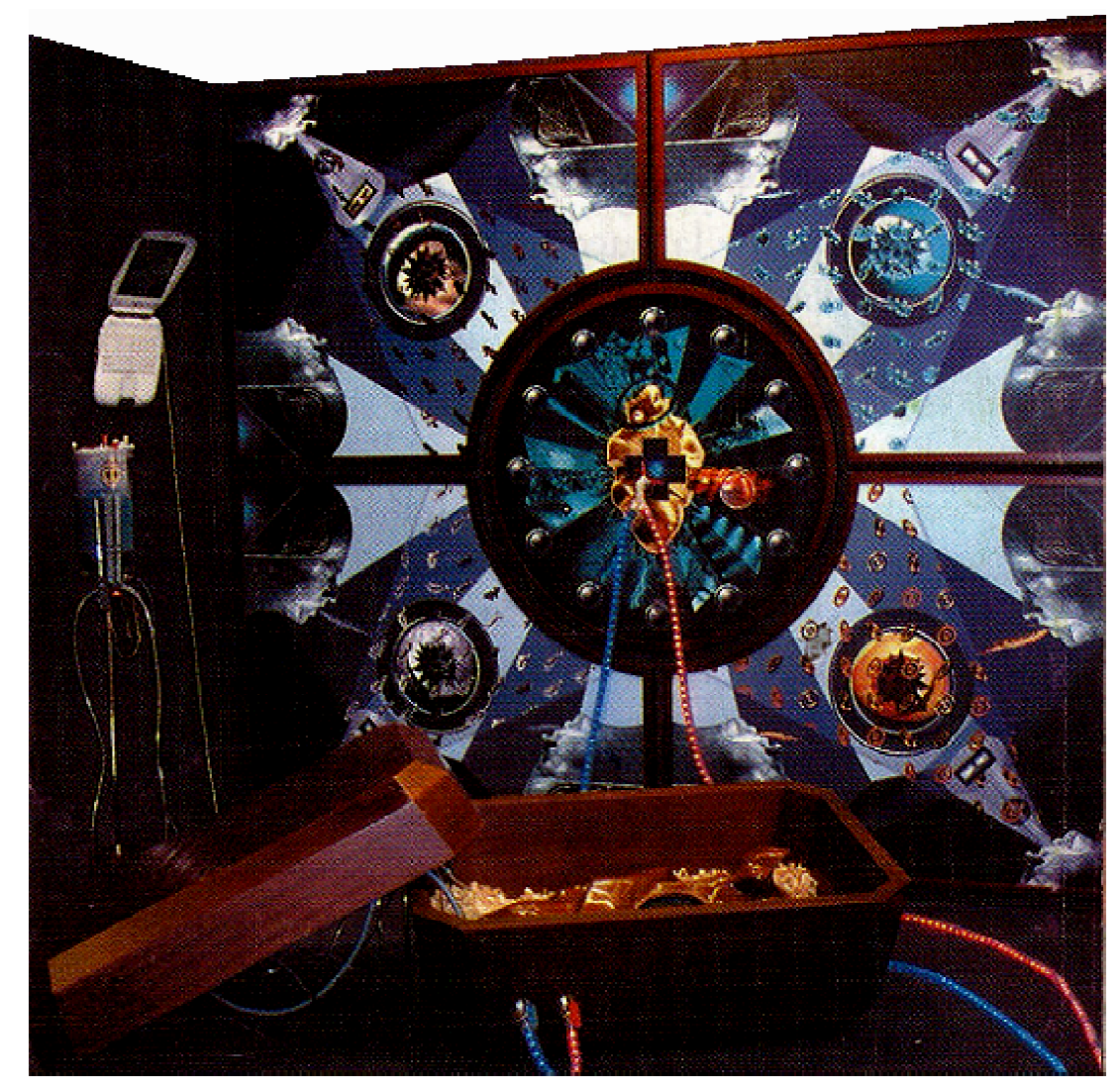

IMAGEN 463

Escultura en la categoría de Instalación Mult-Matérica Soplo de vida, todavía hay esperanza

2001

Material del conjunto: Pintura, bronce, madera, computadora Macinstosh i-Book, oxigenador de sangre, conectores, cables, mangueras lumínicas, sonido, luz fija y estroboscópica, pintura cibernética

Diseño y modelado en barro, fundición a la cera perdida, electro-forming, pulitura, patinado, ensamblaje de elemento lumínico y metálico

$300 \times 300 \times 250 \mathrm{~cm}$
Colección: del artista

Comentario:

- Instalación Multi-Matérica: fusión de escultura, ciber-pintura y orfebrería, que consta de un pentatíptico y una caja en madera, dentro de ella un corazón en bronce y a su vez éste,

contiene una réplica del corazón en miniatura bañada en oro.

- Ganadora de la Medalla de oro "Magnus Laurentis Medicis". Bienal Internacional del Arte Contemporáneo de Florencia, Italia. 2001. 


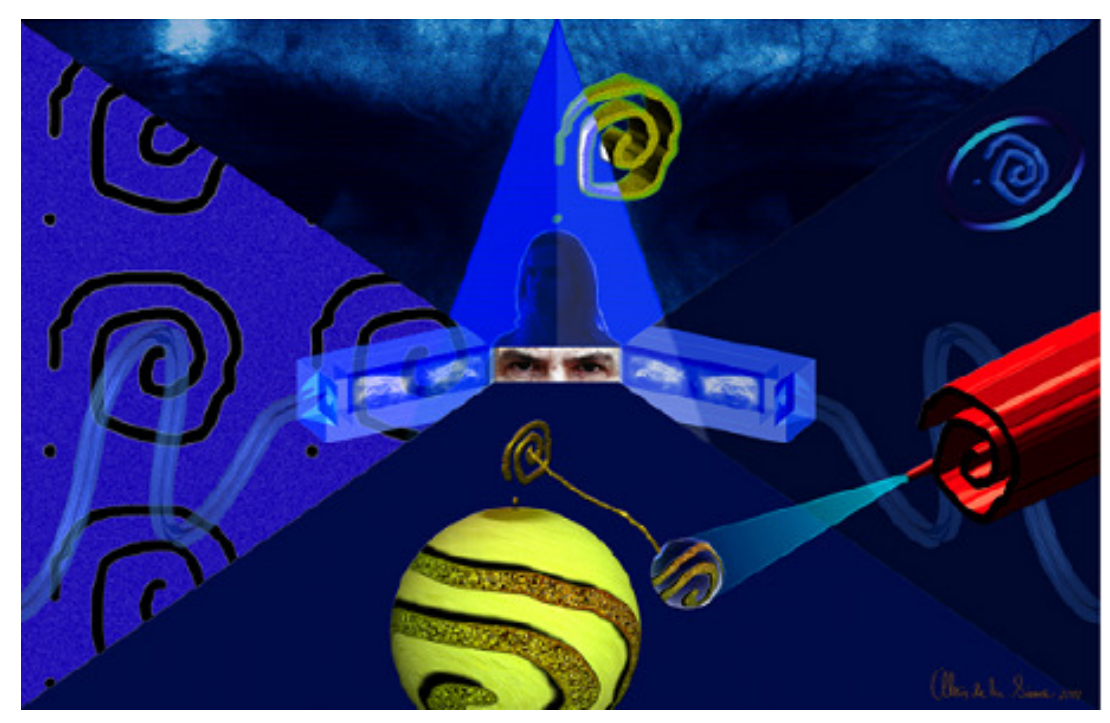

IMAGEN 464

Obra de categoría de pintura cibernética

Omnia posibilia sunt videnti

2001

Material del conjunto: Pintura, madera, computadora, sonido, luz fija y estroboscópica,

pintura cibernética

Composición pictórica en digital creada en ambiente cibernético. Impresión digital sobre material ilford Jet artist stretch Canvas (Medium Glossy)

$210 \times 142 \mathrm{~cm}$

Colección: del artista

Comentario:

- Forma parte del proyecto de la Instalación Multi-Matérica Soñando con los ojos abiertos

realizado para la exposición de la 50 edición de la Bienal de Venecia en al año 2003.

- Pintura cibernética expuesta en la Mega exposición II. Galería de Arte Nacional. Caracas,

Distrito Capital. 2005. 
Inicia sus estudios en la Escuela Nacional de Teatro de Instituto Nacional de Cultura y Bellas Artes. Caracas, Distrito capital. Venezuela.

1970

Se aparta del teatro y se introduce en el arte de la orfebrería.

1974

Inaugura su pequeña galería "Alexis Pour Vous", en el Centro Comercial Centro Plaza, urbanización Los Palos Grandes. Caracas, Distrito Capital. Venezuela.

1975

Se traslada a Londres donde realiza seminarios sobre "Corrientes Antiguas de Orfebrería", en el British Museum of London. Londres. Inglaterra.

1976

Realiza su primera exposición individual "Alexis de la Sierra AT The Francesca Paolozi Gallery”. Nueva York. USA. 48 creaciones en orfebrería.

- Se introduce en el medio expositivo; participa en una exposición colectiva "Primer Salón de la Nueva Orfebrería Venezolana”, Museo Ciudad Bolívar. Puerto Ordáz, Ciudad Bolívar. Venezuela. 8 creaciones en orfebrería.

1977

Obtiene una beca de estudios a través del Tratado Bilatera "Andrés Bello del Pacto Andino"; obtiene el titulo en Artes Plásticas, con dos menciones; una en Escultura y la otra en Color, en la Pontificia Universidad Católica de Chile. Chile.

1980

Obtiene el Premio en la tendencia de orfebrería, en el VIII Salón Nacional de las Artes del Fuego. Valencia, estado Carabobo. Venezuela. Conjunto de seis obras tituladas "Proyectos escultóricos"

1981

Obtiene el Premio en la tendencia de orfebrería, en el IX Salón Nacional de las Artes del Fuego. Valencia, estado Carabobo. Venezuela. Conjunto de dos obras tituladas "Homenaje a Bianca Castafiore". 
Exposición individual "Alexis De la Sierra at The Gallery At Grove Isle", en Coconut Grove. Miami, Florida. USA. 50 obras escultóricas y creaciones de orfebrería.

1983

Obtiene el Premio en la tendencia de orfebrería, en el X Salón Nacional de las Artes del Fuego. Valencia, estado Carabobo. Venezuela. Conjunto de cinco obras tituladas "Pectorales de Aluminio".

1984

Inaugura su galería privada "Galería Alexis De la Sierra" en la calle Madrid con Nueva York, en la Urbanización las Mercedes. Caracas, Distrito Capital. Venezuela.

1985

Inaugura su escuela de orfebrería privada "Escuela de Orfebres Alexis De la Sierra" adosada a su galería privada, en la Urbanización las Mercedes. Caracas, distrito Capital. Venezuela.

- Exposición individual "Discos y Cápsulas Lumínicas de Alexis De la Sierra", Museo de Arte Contemporáneo de Panamá. Panamá. 12 esculturas de gran formato.

1986

Exposición individual “Levitantes Lumínicos de demás Volúmenes de Alexis De la Sierra", Sala de Exposiciones INTERALÚMINA. Puerto Ordáz, Ciudad Bolívar. Venezuela.

- Exposición individual "Materias y Luz", Galería Alexis De la Sierra. Caraca, Distrito capital. Venezuela.

- Obtiene el Premio Nacional de las Artes del Fuego, en el X Salón Nacional de las Artes del Fuego. Conjunto de cinco obras tituladas "Pectorales Ceremoniales".

- Escenografía, Sala Ríos Reyna, Teatro Teresa Carreño. Noche de Gala del Primer Festival Internacional de videos y Televisión, FUNDARTE. Para la cual intervino el escenario con las novedosas esculturas lumínicas en levitación. Así mismo, FUNDARTE comisionó a De la Sierra, el diseño y la realización de las Escultura-Premio entregadas a los galardonados. Para ello el artista empleó el mármol negro con plata 1000 . Caracas, distrito Capital. 
Invitado de Honor al XVI Salón Nacional de las Artes del Fuego, "En orden a su brillante trayectoria y méritos artísticos", Galería Braulio Salazar. Valencia, estado Carabobo. Venezuela.

Exposición individual "100 Horas, 100 obras de Alexis De la Sierra", Museo de Arte Contemporáneo Francisco Narváez. Porlamar, estado Nueva Esparta. Venezuela. 58 esculturas gran y mediano formato, 38 obras pequeño formato, 15 obras de orfebrería.

- Exposición de Carácter didáctico “El Taller de Alexis De la Sierra: Crisol de la Nueva Generación de Orfebres Venezolanos", Galería Braulio Salazar. Valencia, estado Carabobo. Venezuela.

- Exposición individual "La Furia del silencio", en la Galería Alexis De la Sierra. Caracas, Distrito Capital. Venezuela.

- Exposición individual "Estereorradianes, Levitantes Lumínicos y Hebillas Escultóricas", Galería Alexis De la Sierra. Caracas, Distrito Capital. Venezuela.

1988

Exposición individual "Canto a Las Mercedes: un jardín de volúmenes lumínicos", Galería Alexis De la Sierra. Caracas, Distrito Capital. Venezuela.

- Exposición individual "Domus Auratii, la caza del Pez Dorado", Galería Alexis De la Sierra. En la Caracas, Distrito Capital. Venezuela.

- Se introduce en el estudio del Arte Cibernético.

1989

Invitado de Honor en el XVI Salón Nacional de Artes del Fuego, en orden a su brillante trayectoria y méritos artísticos, Galería Braulio Salazar. Valencia, estado Carabobo. Venezuela.

- Exposición individual "Alexis De la Sierra: Una Retrospectiva”, Galería Lozano \& Lozada. Valencia, estado Carabobo. Venezuela.

- Exposición individual "Los Cinco Arcos de los Sentidos", Galería Alexis De la Sierra. Caracas, Distrito Capital. Venezuela. 
- Exposición individual “Los Hijos de Poseidón”, Galería Alexis De la Sierra. Caracas, Distrito Capital. Venezuela.

- Exposición individual "Roraima”, Galería Alexis De la Sierra. Caracas, Distrito Capital. Venezuela.

1991

Exposición individual “Vulcano”, Galería Alexis De la Sierra. Caracas, Distrito Capital. Venezuela.

- Exposición individual "Anatomosis”, Galería Alexis De la Sierra. Caracas, Distrito Capital. Venezuela.

1992

Exposición individual “Les Fleurs du Mal”, Galería Alexis De la Sierra. Caracas, Distrito Capital. Venezuela.

- Exposición individual “Homenaje a Baudelaire”, Galería Alexis De la Sierra. Caracas, Distrito Capital. Venezuela.

- Exposición individual "Caprichos de Plata”, Galería Alexis De la Sierra. Caracas, Distrito Capital. Venezuela.

1993

Exposición individual “Les Fenétres”, Galería Alexis De la Sierra. Caracas, Distrito Capital. Venezuela.

1994

Exposición individual "Sculptor of light, sculptor of silver", Venezuelan Art. Center Gallery, Consulado de Venezuela. En Nueva York. USA.

1995

Exposición individual antológica conmemorativa a los 25 años dedicados a la orfebrería y su difusión en Venezuela "Alexis De la Sierra: El Orfebre", Museo de Arte Contemporáneo de Caracas Sofía Imber. Caracas, Distrito Capital. Venezuela. 142 obras, entre pequeño, mediano y gran formato.

- La Galería de Arte Nacional lo invita para exhibir su obra como uno de los 10 Maestros contemporáneos más destacados en las Artes del Fuego en Venezuela, evento titulado "10 Presencias de las Artes del Fuego". Su participación individual se titula: "Los Misterios de Merlín" 10 objetos mágico-religiosos. 
Obtiene la medalla de Plata en "The Optima Desing Awards: Celebrating Excelencet". Trenton, New Jersey. USA. Pinturas en Arte Cibernético.

1997

Obtiene la medalla de Bronce en "The Optima Desing Awards: Celebrating Excelencet". Trenton, New Jersey. USA. Pinturas en Arte Cibernético.

1998

Exposición individual "La hora de la faja del Orinoco", Centro de Arte la Estancia. Caracas, Distrito Capital. Venezuela.

1999

Inaugura una nueva Galería/Escuela de Orfebres, titulada: "De la Sierra \& Pervilhac at the Hilton" dentro de las instalaciones del Hotel Caracas Hilton. Caracas, Distrito Capital. Venezuela.

2001

Obtiene la Medalla de Oro "Magnus Laurentis Medicis" en la III Bienal Internacional de Arte Contemporáneo. Florencia. Italia. Con la Instalación Multimatérica: Soplo de vida, todavía hay esperanza. Esta obra converge tres disciplinas artísticas: Orfebrería/Escultura/Cyber-Pintura.

2002

Inaugura otra Galería privada. "De la Sierra, Paris \& Pervilhac Gallery" en el Distrito de Arte y Diseño en la 3740 N.E Second Avenue. En Miami, Florida. USA.

2003

Inicia la actividad docente con el "Taller de Diseño Electrónico Alexis De La Sierra", dentro de las instalaciones del Hotel Intercontinental dentro del Centro Comercial Paseo las Mercedes. Caracas, Distrito Capital. Venezuela.

- En calidad de Artista Invitado, participa en la "Mega exposición I" en el Museo Alejandro Otero y el Museo de Arte Contemporáneo de Caracas. En homenaje al artista plástico venezolano Jesús Soto.

Exposición individual "Candelabros y otros artes ígneos por Alexis De la Sierra”. The De La Sierra, Paris \& Pervilhac Gallery. Miami, Florida. USA. 19 Candelabros titulados "Círculo de los Guardianes: Fuego y Hielo", y 6 pinturas ígneas de gran formato tituladas "Geometrías Sagradas del 
Infinito".

- Celebra los 25 años de actividad docente, despliega una impresionante exposición de las mejores obras de sus alumnos, en el Centro de Arte la Estancia. En la ciudad de Caracas, Venezuela.

- En calidad de Artista Invitado, participa en la "Mega exposición II", Muestra panorámica del Arte Venezolano del año 2000 al 2005, en la Galería de Arte Nacional. Caracas, Distrito Capital. Venezuela. 1 Pintura cibernética: Omnia posibilia sunt videnti.

- Exposición individual "Alexis De la Sierra: an artist's Universe: The Melding of 3 Disciplines: Precious Metals, Sculpture \& Cyber-Painting", formando parte del circuito de Art. Besel Miami Design District, en De la Sierra, Paris \& Pervilhac Gallery. Miami, Florida. USA.

2006

En calidad de Artista Invitado, participa en el "II Salón Nacional de Orfebrería", en el Museo de la Estampa y el

Diseño Carlos Cruz-Diez. Caracas, Distrito capital.

Venezuela. Con 1 obra: en Orfebrería Escultórica Néctar negro.

Inaugura la Galería "Portafolio", donde fusiona las actividades docentes con su galería privada, dentro del Centro Comercial Terras Plaza, en la Urbanización Terrazas del Club Hípico. Caracas, Distrito Capital. Dentro de esos espacios se establece:

1. Galería privada "Alexis De la Sierra" con exposiciones permanentes de sus obras en Orfebrería, Escultura y Ciber-pinturas.

2. La "Escuela de Orfebres Alexis De la Sierra", conjuntamente a una pequeña Galería para exhibir las obras de los alumnos destacados y las exposiciones anuales de los alumnos.

3. "Taller de Diseño Electrónico Alexis De la Sierra". La cual luego denomina: "Taller de Diseño Digital Multimedia Alexis De la Sierra" 
Los espacios de la nueva sede, están diseñados para cada necesidad, y por ende, comodidad, seguridad y optimización del impacto visual de las obras bidimensionales y tridimensionales.

2008

Celebra sus 40 años de actividad artística, para la cual desarrolla una serie de actividades dentro de "Portafolio", que varían desde conferencias, talleres, exposiciones didácticas y exposición anual de sus alumnos de orfebrería y de arte digital.

\section{9-2010}

Temporalmente dedicado solo a la docencia entre orfebrería y diseño digital.

Elabora más de 50 pinturas digitales en gran formato, expuestas en su galería privada y vendidas. ${ }^{208}$.

208 Pervilhac, I (2007). Etapas investigativas De la Sierra. Escultura, Material inédito. Correo electrónico artemaneger@delasierra.com 
En este trabajo, logramos en primera instancia, el objetivo general de la investigación el cual se orientó al estudio de la orfebrería en la creación escultórica venezolana contemporánea bajo la influencia de la obra y docencia del orfebre Alexis De la Sierra, desde el año 1976 hasta el año 2010.

Considerando que la disciplina de la orfebrería y la escultura confluyen en la orfebrería escultórica, realizamos una exhaustiva investigación sobre ambos contextos artísticos en Venezuela desde antes de la colonización española hasta el año 2010. En tal sentido, pudimos conocer cuáles fueron las características más importantes durante su desarrollo y cuáles fueron los principales factores que impulsaron la orfebrería hacia una tendencia escultórica. Así como también, pudimos evidenciar dentro de ambos contextos, el vínculo y la repercusión de la obra de Alexis de la Sierra.

El inicial estudio con el cual se obtuvo el DEA "Producción Artística de Alexis de la Sierra en la Venezuela actual", resultó imprescindible para el desarrollo de esta nueva investigación de la Tesis Doctoral.

Es importante mencionar que en la presente investigación, se abordó el contexto artístico de la orfebrería y escultura exclusivamente en Venezuela, debido a que el tema de estudio transcurre y repercute directamente sobre artistas venezolanos dentro de ese país.

La presente investigación se abordó en una primera instancia, bajo la tipología de la investigación exploratoria, debido a que hasta ahora había sido un tema poco estudiado; por lo tanto, la recopilación de la información en gran parte, se realizó en base a entrevistas, encuestas y afines. Por otra parte, también se abordó la investigación, bajo la tipología de la investigación descriptiva y analítica. Todo esto con la finalidad de que la documentación recopilada, beneficiará el estudio de ambas tendencias en el país y con ello facilitar el análisis tanto de las obras como de los factores que han repercutido en el desarrollo de la disciplina de la orfebrería hacia una tendencia escultórica. En tal sentido podemos afirmar, que la metodología seguida en esta investigación se basó en la recopilación, descripción y el análisis de la orfebrería y la escultura venezolana, desde el periodo de la colonia hasta la fecha del 2010.

Consideramos con verdadera significación los aportes arrojados con esta investigación, los cuales señalamos en el siguiente orden:

- Se establecen unas bases teóricas sobre la disciplina de la orfebrería en la creación escultórica en Venezuela. 
- Se recopila información fidedigna, de la orfebrería en la creación escultórica venezolana, a través de algunos textos, diarios, revistas, páginas web, catálogos de exposiciones, revistas e inclusive, material inédito como entrevistas personales, telefónicas o por correo electrónico.

- Se obtienen y se presentan las características más importantes con respecto a la formación y producción de los orfebres venezolanos; las cuales fueron abordadas de manera fidedigna, a través de un trabajo de campo. Estos datos se utilizaron para crear el perfil del orfebre venezolano actual.

-Se presentan las características más importantes por décadas, para una mayor comprensión de la evolución de la orfebrería venezolana.

-Se elabora un análisis técnico, formal y conceptual de las obras de algunos orfebres, fundamentándonos exclusivamente en aquellos orfebres cuyas obras han sido expuestas y obtenido premios en salones de arte en Venezuela; donde se pudo revelar la influencia de Alexis De la Sierra dentro de este contexto artístico.

Consideramos que la investigación realizada con esta Tesis Doctoral, logra un compendio verdaderamente importante sobre el desarrollo de la orfebrería en la creación escultórica venezolana contemporánea; la cual servirá de antecedente, sobre este tópico a futuros investigadores. Considerando el vacio bibliográfico que existe en Venezuela con respecto a la orfebrería venezolana de la época actual, sería de gran valor, el poder contar con esta información en los archivos de los museos y otros organismos de arte contemporáneo en el país.

Del mismo modo, consideramos que la realización del marco teórico el cual refiere al contexto artístico de la orfebrería y la escultura en Venezuela supone un valor importante, puesto que, hemos elaborado una periodización breve pero minuciosa con sus respectivas imágenes, sobre cómo ha trascendido el trabajo de Alexis De la Sierra, tanto en el medio expositivo como su enseñanza para el desarrollo de la orfebrería escultórica en la Venezuela actual.

En esta investigación de la Tesis Doctoral, logramos conocer, analizar y presentar, como este artista consigue la convergencia entre las disciplinas de la orfebrería y la escultura. Por otra parte, concluimos que su producción artística, es el punto de partida de la orfebrería en la creación escultórica venezolana contemporánea. Para llegar a estas conclusiones, hemos realizado una breve periodización del contexto artístico sobre cómo ha sido el desarrollo de ambas disciplinas en Venezuela y la confluencia entre la orfebrería y la escultura. 
Esta investigación, permite dejar unas bases sólidas en donde se demuestra que la orfebrería escultórica es una disciplina artística autónoma y puede ser apreciada como una nueva tendencia del arte venezolano de la actualidad.

De igual forma, hemos podido analizar la influencia del trabajo artístico de Alexis De la Sierra en el periodo 1976-2010. Desde el punto de vista de docencia; hemos podido comprobar, que cumpliendo labores en este medio, ha logrado transmitir esta nueva concepción de la orfebrería a sus alumnos. De igual forma, su influencia artística se ha propagado mediante la inducción de sus alumnos al medio expositivo. Por ello, su influencia en el país, ha logrado que poco a poco la orfebrería se apropie de semblantes cada vez más artísticos/escultóricos, y que otros talleres de enseñanza, centren su educación con convicción y seriedad; para que sus alumnos, se enfrenten con propiedad ante las exigencias del medio expositivo actual. 


\section{BIBLIOGRAFÍA}

- "Artesanías Colombianas, las ciudades de oro: colección Colombia adentro". (1996). Medellín, Colombia. Colina.

- Codina, C. (2000). “La joyería”. Barcelona, España. Colección Artes y Oficios. Parramón S.A.

- Duarte; C. (1970) "Historia de la Orfebrería en Venezuela". Monte Ávila Editores, Caracas. 515 pp.

- Jiménez, M. (1997). "Historia de Venezuela 7". Tercera etapa de Educación Básica. Venezuela. Oxford University Press-Harla Venezuela C.A.

- McGrath, J. (1995) "The enciclopedia of Jewerly-Making Techniques". Philadelphia, London. Running Press.

- Palenzuela, J. (2002). “Escultura en Venezuela 19602002". Caracas, Venezuela. La Galaxia.

- Pineda, R. (1978). “La Tierra Doctorada”. Caracas, Venezuela. Ernesto Armitano Editor.

Agendas:

- Universidad de Los Andes. (2004). “Agenda 2004. Alma Mater". Venezuela. Universidad de los Andes. Gráficas EI Portatítulo, Diciembre 2004. s/n.

\section{Catálogos:}

- Guevara, R., Asprino A., Imber, S. y Pervilhac I. (1995). "Alexis de la Sierra. El orfebre". Alexis De la Sierra. Vulcain D'outre-Mer Museo de Arte Contemporáneo de Caracas Sofía Imber, Septiembre 1995. Edit. Arte.

- Instituto de las Artes de la Imagen y el espacio y Mota, J. (2006). "Il Salón Nacional de Orfebrería". Museo de la Estampa y del Diseño Carlos Cruz-Diez, Agosto 2006. IAME.

Ministerio de la Cultura y el Consejo Nacional de la cultura. (2005). "I Salón Nacional de Orfebrería". Centro de Arte La Estancia, Agosto 2005. EME3 producción. 
- Perán, E. (1981). "Primera Bienal Nacional De Escultura". La escultura en Venezuela. Museo De Arte Contemporáneo "Francisco Narváez".

- Pervilhac, I. (2005). "Tierra, Arte y Cultura en Venezuela". Exposición didáctica colectiva. No XV. XX Aniversario. Centro de Arte La Estancia, diciembre 2005. Impresos Amendar C.A.

- Rodríguez. B. (1987). "100 Horas, 100 Obras. Alexis de la Sierra". Museo de Arte Contemporáneo Francisco Narváez, Agosto 1987. Ernesto Armitano Editor.

\section{Conferencias:}

- Suárez. F. (1999). "La enseñanza de los oficios artesanales como alternativa tecnológica para el desarrollo: Los Talleres Artesanales de la Universidad de los Andes". Universidad Pedagógica Experimental Libertador. VIII Jornadas sobre Investigación y Docencia en la Ciencia de la Historia. Julio 1999. Barquisimeto, estado Lara. Venezuela.

\section{Diarios:}

Giancola, L. (2006). "Alexis De la Sierra inicia taller de Diseño Electrónico. Una actividad de nueve meses de duración". El Diario de Caracas. 10 de julio de 2006. Cultura.

- Moreno, E. (2005). “Alexis De la Sierra 20 años formando orfebres".El Mundo. Diario de la Tarde.17 de febrero de 2005. C 17.

\section{Tesis para Licenciatura:}

- Dávila Rojas, Victmary. "Panorama de la Joyería Artística Contemporánea. Década 70, 80, 90 de Venezuela". Tutor: Merisol León. Tesis de Licenciatura. Venezuela. Departamento de Historia del Arte. Universidad de los Andes. Mérida, Venezuela, 2000. 
- Castillo, L. (2004). "Dar clases es lo mejor que me ha pasado como artista. Enseñar al Fuego". Todo en domingo. $\mathrm{N}^{\circ}$ 230. 29 de Febrero 2004.

- García, M. "Alexis De la Sierra Orfebrería sin límites". Arte Facto (Edición especial). № 3 (2010). Diciembre. pp: 036039. www.revista-artefacto.com.ve

- Hernández, A. (2008). "Todos somos artistas potenciales". El Impulso. 22 de diciembre de 2008. C. 12.

- Marín, C. (2003). "Alexis De la Sierra. Más allá de sí mismo" Revista. Ocean Drive. Vol.4. N ${ }^{\circ}$ 5. AgostoSeptiembre.

\section{Páginas web:}

- Action Painting. Movimientos y Estilos. Más de arte.com. http://www.masdearte.com/item movimientos.cfm?noticia id=3382 [Accesado: Julio 18 2008).

- Ciudad Universitaria de Caracas, su máxima obra.

Colección Síntesis de las Artes.

http://www.centenariovillanueva.web.ve/CUC/Sintesis Art es/Frames_Sintesis_Artes.htm [Accesado en: Febrero 10 2007].

- Claudo Kalán. www.claudokalan.com/ [Accesado en: Noviembre 22 2008].

- Colección de Arte. Víctor Varela.

http://www.bcv.org.ve/BLANKSITE/c3/colecarte/valera in dex.htm [Accesado en: Mayo 5 2008].

- Conferencias y Talleres. Taller de de Diseño Electrónico Alexis De La Sierra. Lunes 20 de Agosto de 2007. analítica.com.

http://www.analitica.com/va/arte/actualidad/cyt/745869

2.asp [Accesado en: Enero 10 2008].

- $\quad$ Catálogo Zitman - Scribd

www.scribd.com/doc/30974217/Catalogo-Zitman

[Accesado en: Diciembre 8 2012]. 
- Currículum de Alexis De la Sierra. (1986). http://galeria.uc.edu.ve/actual.php?id=45 [Accesado en: Septiembre 22 2010].

- Currículum de Ana Mercedes Carvallo Parés. (2005). http://galeria.uc.edu.ve/actual.php?id=9 [Accesado en: Septiembre 19 2010].

- Currículum de Víctor Rodríguez. (1994). http://galeria.uc.edu.ve/actual.php?id=53 [Accesado en: Septiembre 19 2010].

- Disidentes.Todacultura.com

http://www.todacultura.com/movimientosartisticos/diside ntes.htm [Accesado en: Mayo 5 2007].

- $\quad$ El Arte de Juan Loyola. (2009)

elartedejuanloyola.blogspot.com/ [Accesado: Diciembre 13 2011].

- El fotograbado. -Manual del grabado calcográfico. http://www.manualdegrabado.com/ES/fotograbado.html [Accesado en: Octubre 10 2012].

- Estilo Joyero - El Esmalte a fuego.

www.estilojoyero.com.ar [Accesado en: Octubre 10 2012).

Exposiciones anteriores. 34 Salón Nacional de las Artes del Fuego. (2007). http://galeria.uc.edu.ve/actual.php?id=72 [Accesado en: Diciembre 15 2007].

- Exposiciones anteriores. 36 Salón Nacional de las Artes del Fuego. (2009). http://galeria.uc.edu.ve/actual.php?id=85 [Accesado en: Diciembre 15 2009].

Exposiciones anteriores. 37 Salón Nacional de las Artes del Fuego. (2010). http://galeria.uc.edu.ve/actual.php?id=89 [Accesado en Diciembre 9 2010]. 
- Francisco Narváez - Venezuela Tuya

www.venezuelatuya.com/.../narvaez.htm - Venezuela -

[Accesado en: Diciembre 10 2010].

- Galería Universitaria Braulio Salazar.

http://galeria.uc.edu.ve/

- Gaudí Este. http://www.gaudieste.com/ [Accesado en: Noviembre 13 2008].

- Grabado a buril -Wikipedia la enciclopedia libre. http://es.wikipedia.org/wiki/Grabado a buril [Accesado en: Octubre 10 2012].

- Informalistas y Gestualistas en el Arte venezolano de hoy. (2009)

http://www.latinartmuseum.com/arte venezolano.htm

[Accesado en: Mayo 23 2007].

- Jesús Rafael Soto. Wikipedia. La enciclopedia libre.

http://es.wikipedia.org/wiki/Jes\%C3\%BAs_Soto

[Accesado en: Mayo 23 2007].

- $\quad$ La escultura en la antigua Provincia de Venezuela.

Hernández, J.M.

http://museosdevenezuela.org/Documentos/Revista/Cons

ervacion2.shtml [Accesado en: Mayo 19 2008].

- $\quad$ La Historia Fraguada en Fuego. Exposición. XXI Salón Nacional de las Artes del Fuego. Fritz Küper. (1994). http://galeria.uc.edu.ve/resenas.php?id=50\&idexpo $=53 \&$ actual=1 [Accesado en: Febrero 18 2007].

- $\quad$ La Mega exposición: Una aventura sin precedentes.(2003). http://www.aporrea.org/actualidad/n11552.html [Accesado en: Abril 11 2008].

- $\quad$ Luis rodríguez de la sierra Figueroa 1875-1936 - puerto de lacruz .http://bernardocabo.blogspot.com.es/2010/08/lu is- rodriguez-figueroa-1.html [Accesado en: Octubre 12 2012].

- $\quad$ Mega exposición II: Arte Venezolano del siglo XXI. (2005). http://valencia.com.ve/2005/04/13/megaexposicin-iiarte-venezolano-del-siglo-xxi/ [Accesado en: Noviembre 12 2008]. 
- Mary Ann Scherr: Designer, Educator, Goldsmith, Jeweler. 2008]. (2011). www.maryannscherr.com/ [Accesado en: Junio 14 2012].

- Biblioteca de joyería - Raul Ybarra

www.raulybarra.com/biblioteca [Accesado en: Octubre 10 2012].

- Obra_Plastica_GEGOFundacion Gego.www.fundaciongego. com/tejeduras.html [Accesado en: Mayo 19 2008].

Platería Hispanoamericana Contemporánea. (2009). http://galeria.uc.edu.ve/actual.php?id=83 [Accesado en: Noviembre 6 2012].

- Simón Sorondo. www.simonsorondo.blogspot.com/ [Accesado en: Febrero 10 2007].

- Síntesis de las Artes de la Ciudad Universitaria de Caracas. Obra trascendente en el arte moderno del siglo XX. Prof. (M.Sc) Juán Pérez Hernández.

http://copred.rect.ucv.ve/BD Documentos/ip ponencia re sumen.pdf [Accesado en: Febrero 10 2007].

- Trayectoria del escultor Eloy Palacios hasta 1883 Resumen. Salvador, J. M. (Julio 2003). http://argos.dsm.usb.ve/archivo/38/5.pdf [Accesado en: Noviembre 11 2007].

- IV Salón Nacional de las Artes del Fuego. (1976). http://galeria.uc.edu.ve/actual.php?id=58 [Accesado en: Enero 21 2007].

- IX Exposición Colectiva de la ACAF. (2006).

http://galeria.uc.edu.ve/actual.php?id=16 [Accesado en: Febrero 10 2012].

- XXI Salón Nacional de las Artes del Fuego. (1994)

http://galeria.uc.edu.ve/gubs.php?id=53 [Accesado en: Enero 21 2007]. 
- $\quad$ XXII Salón Nacional de las Artes del Fuego. (1995).

http://galeria.uc.edu.ve/actual.php?id=54 [Accesado en: Enero 21 2007].

- $\quad$ XXIII Salón Nacional de las Artes del Fuego. (1996). http://galeria.uc.edu.ve/actual.php?id=55 [Accesado en: Enero 21 2007].

- $\quad$ XXV Salón Nacional de las Artes del Fuego. (1998). http://galeria.uc.edu.ve/gubs.php?id=58 [Accesado en: Enero 21 2007].

- XXVII Salón Nacional de las Artes del Fuego. (2000). http://galeria.uc.edu.ve/actual.php?id=62 [Accesado en: Enero 21 2007].

- $\quad$ XXX Salón Nacional de las Artes del Fuego. (2003). http://galeria.uc.edu.ve/actual.php?id=41 [Accesado en: Enero 21 2007].

- 31 Salón Nacional de las Artes del Fuego. (2004). http://galeria.uc.edu.ve/gubs.php?id=27 [Accesado en Enero 21 2007].

- 32 Salón Nacional de las Artes del Fuego. (2005). http://galeria.uc.edu.ve/actual.php?id=9 [Accesado en: Febrero 10 2007].

- 33 Salón Nacional de las Artes del Fuego. (2006). http://galeria.uc.edu.ve/actual.php?id=66 [Accesado en: Febrero 10 2007].

- 34 Salón Nacional de las Artes del Fuego. (2007). http://galeria.uc.edu.ve/actual.php?id=72 [Accesado en: Enero 21 2011].

- 35 Salón Nacional de las Artes del Fuego. (2008) http://galeria.uc.edu.ve/actual.php?id=79 [Accesado en: Enero 21 2011].

- 36 Salón Nacional de las Artes del Fuego. (2009). 
http://galeria.uc.edu.ve/actual.php?id=85 [Accesado en: Enero 21 2011].

- 37 Salón Nacional de las Artes del Fuego. (2010). http://galeria.uc.edu.ve/actual.php?id=89 [Accesado en: Marzo 9 2012].

\section{Material Inédito:}

- Alayón, M. (2010). "Estructura del curso y correo de alumnos". Entrevista personal. Caracas, Distrito Capital. [Junio 16].

- Benfele, P. (2012). "Obra en salones". Correo electrónico. patricia benfele@yahoo.com [Noviembre 13].

- Benítez, L. (2007). "Estructura del curso de orfebrería del año 1997". Correo electrónico. cuarzo53@hotmail.com [Accesado en Noviembre 2]

- Benítez. L. (2010). "Premios en orfebrería”. Entrevista personal. Caracas, Distrito Capital. [Junio 16].

- Cartay R. (2009). "Proyecto Alma Mater de la ULA". Entrevista personal. Mérida, estado Mérida. [Noviembre 11].

- Cedeño, I. "Estructura de enseñanza en taller anticlassic". Correo electrónico. ivan6558@hotmail.com [Accesado en: Julio 14 2011].

- Dao, Betsy. (2010). "Estructura de enseñanza y correos de alumnos". Entrevista personal. Caracas, Distrito Capital. [Junio 18].

- De la Sierra, A. (2010). "Producción en orfebrería”. Entrevista personal. Caracas, Distrito Capital. [Junio 18].

- De la Sierra, L. (2007). "Biografía y enseñanza a Alexis De la Sierra”. Entrevista telefónica.+58-4149721791. [Diciembre 16]

- Doumat, G. (2013). “Profesión y orfebrería”. Entrevista online. 
https://www.facebook.com/georgina.doumat?fref=ts [Enero 30].

Ferreira, J. (2012). “Datos sobre su producción”. Entrevista online.

https://www.facebook.com/julia.ferreiraorfebre?fref=ts [Accesado en: Enero 19 2013].

Flames, M. (2010). "Estructura del curso y diplomado taller Metta y correos alumnos". Correo electrónico.

metta888ve@yahoo.es [Accesado en: Mayo 29 2010].

- García, D. (2009). "Obra ganadora Bienal para Estudiantes de Universidad de Los Andes". Entrevista personal. Mérida, estado Mérida. [Noviembre 22].

- García, J. (2010). "Estructura de talleres de Especialidades Río Grande”. Entrevista personal. Caracas, Distrito Capital. [Junio 19].

- Galletti, U. (2010). "Estructura del taller y correos alumnos”. Correo electrónico ugallery@hotmail.com [Accesado en: Abril 17].

- Galletti, U. (2010). "Producción en orfebrería”. Entrevista personal. Caracas, Distrito Capital. [Accesado en: Junio 17].

- Guédez, G. (2012). “Datos de la producción de su hijo Ollantay Guedez”. Entrevista personal. Mérida, estado Mérida. [Marzo 19].

- Gramcko, C. (2010). "Imagen de la obra restaurada en 1996”. Correo electrónico. christiangramcko@gmail.com [Septiembre 24].

Gramcko. C. (2010). "Datos de la obra de Paco Porras". Correo electrónico christiangramcko@gmail.com [Accesado en: Septiembre 29 2010]. 
- Graterol, C. (2007). “De la Colonia hasta nuestros días. La Educación de la Orfebrería en Venezuela". 34 Salón Nacional de las Artes del Fuego. Ciclo de Conferencias conmemorativas al 34 Salón Nacional de las Artes del Fuego. Octubre 2007. Valencia, estado Carabobo. Venezuela. Correo electrónico. cvzla@yahoo.es [julio 16].

- Graterol, C. (2011). "Estructura de la enseñanza en R\&C orfebres y correos alumnos". Correo electrónico. cvzla@yahoo.es [Febrero 26].

- Hernández, A. (2013). "datos de formación y producción”. Correo electrónico. hernandezaris@yahoo.com [Enero 26].

- Karroum, N. (2012). "Premios de orfebrería en salones". Material inédito. Entrevista online.

https://www.facebook.com/nadia.karroum.3?fref=ts

[Accesado en: Diciembre 8 2012].

- Laverde, R. (2013). "Simbología en la producción de orfebrería". Entrevista online.

https://www.facebook.com/ricardo.laverde.1?fref=ts [Enero 27].

- Maury, M. (2013). "Datos sobre obras SNAF". Correo electrónico. mildedmaury@yahoo.es [Accesado en: Enero 15].

- Mota, J. (2007). “Obra actual de orfebrería”. Correo electrónico. julio30764@hotmail.com [Marzo 29].

- Njaim, M. (2013). "Producción de orfebrería”. Entrevista online. https://www.facebook.com/mariajosenjaim?fref=ts [Enero 31].

Palacios, J. (2010). “Enseñanza en Taller orfebrería Joanna Palacios". Entrevista personal. Caracas, Distrito Capital. [Abril 17].

- Palacios, J. (2010). "Datos de talleres y correos de alumnos”. Correo electrónico.

jp.tallerescueladeorfebreria@hotmail.com [Accesado en: Marzo 23]. 
- Palenzuela, C. (2007). s/n. En prensa. Caracas. Venezuela.

- Peralta, A, (2010). “Datos sobre la enseñanza”. Entrevista telefónica. 416-4035922. [Marzo 19].

- Pereira, D. (2007). "Orfebrería en Venezuela". Correo electrónico duglaspereira609@hotmail.com [Accesado en: Abril 14 2007], [Mayo 11].

- Pereira, D. (2009). "Datos sobre su producción en Orfebrería”. Entrevista Personal. Mérida, estado Mérida. [Noviembre 9].

Pervilhac, I (2007). Etapas investigativas De la Sierra. Escultura, Correo electrónico artemaneger@delasierra.com. [Accesado en: Septiembre 20].

- Pervilhac, I (2008). "Dirección de contacto alumnos Escuela de orfebres ADS". Correo electrónico. artemaneger@delasierra.com [Accesado en Marzo 13].

- Pervhilac, I. (2008). “Ficha Simbológica/Conceptual. Instalación Soplo de Vida Todavía hay Esperanza por Alexis De la Sierra. Bienal Internacional del Arte Contemporáneo de Florencia (2001)". Correo electrónico. artmaneger@delasierra.com [Accesado en: Enero 25]

- Pervilhac, I. (2008). "Omnia Posibilia Sunt Videnti”. Correo electrónico. artmanager@delasierra.com [Accesado en: Septiembre 13]

- Pervilhac, I (2008). "Participación de alumnos de Escuela de orfebres ADS en "SNAF" y "SNO"”. Material Inédito. Correo electrónico. artmanager@delasierra.com [Accesado en: Marzo 11].

- Pervilhac, I. (2010). "Arco de los 5 sentidos/4 imágenes $X$ WB”. Correo electrónico. delasierra@cantv.net [Accesado en: Octubre 25]. 
- Podolski, L. (2007). “Fundamentos en orfebrería”. Correo electrónico. Lucho@lutzpodolski.com [Accesado en: Noviembre 26].

- Rodríguez De la Sierra, J. (2010). “Premios en salones de orfebrería". Entrevista personal. Mérida, estado Mérida. [Enero 8]

- Suarez, F. (2008). "Programa de orfebrería de los talleres artesanales”. Correo electrónico. pacorfebre@hotmail.com [Accesado en: Febrero 28].

- Tucapel, A. (2006). "Participación en SNAF". Correo electrónico. abelardotucapel@gmail.com [Accesado en: Diciembre 13].

- Vera, R. (2006). "La orfebrería como medio de expresión plástica". II Salón Nacional de Orfebrería. Ciclo de Foros En la Candela- 6ta. Conferencia. 05 Octubre 2006. Museo de la Estampa y el Diseño Carlos Cruz Diez. Caracas, Venezuela. Correo electrónico abelardotucapel@gmail.com [Accesado en: Diciembre 17 2006].

- Vera, R. (2010). “Estructura en la enseñanza del Taller de la tierra y correos alumnos". Correo electrónico. tallerdelatierra@gmail.com [Accesado en: Abril 23].

- Vera, R. (2012). "Imágenes y fichas técnica de obras III Salón Nacional de Orfebrería”. Correo electrónico. vhrafier@yahoo.com [Accesado en: Enero 22]

- Zerpa, C. (2010). "Imagen y datos de Antijoya en Homenaje a Man Ray, Gargantilla de hojillas Gillete". Correo electrónico carloszerpa@gmail.com [Accesado en: Abril 03].

- Zerpa, C. (2010). "Imagen y datos de la obra Despecho". Correo electrónico carloszerpa@gmail.com [Accesado en: Agosto 11]. 


\section{ÍNDICE DE IMÁGENES}

IMAGEN 1 Mapa Político de Venezuela. https://www.google.com Images for mapa politico de venezuela [Accesado en: Diciembre 13 2009].

IMAGEN 2 (Imagen portada del texto) Jiménez Grazzina, Morella. "Historia de Venezuela 7" Tercera etapa de Educación Básica. 1997. Edit. Oxford University Press - Harla Venezuela C.A. Venus de Tacarigua.

IMAGEN 3 Vicente Díaz. (1796). Sagrario de Nuestra Señora de Coromoto. Basílica Catedral Parroquia Espíritu Santo, Guanare, estado Portuguesa. Venezuela. Plata, madera. Martillado, repujado, cincelado, ensamblaje. 3:34 x 1:71 x $57 \mathrm{~cm}$. Material inédito. Fotografiado por la autora. [Septiembre 18 2010].

IMAGEN 4 Detalle del repujado de la parte central inferior de Sagrario de Nuestra Señora de Coromoto. Material inédito. Fotografiado por la autora. [Septiembre 18 2010].

IMAGEN 5 Detalle de la Copa del Sagrario de Nuestra Señora de Coromoto. Material inédito. Fotografiado por la autora. [Septiembre 18 2010].

IMAGEN 6 Domingo Tomás Núñez. (1796). Sagrario, para llevar viático. Plata repujada, cincelada y dorada a excepción del cordero pascual. $19 \mathrm{~cm}$ alto. Sala del Orfebre - Museo Arte Colonial. www.quintadeanauco.org.ve/orfeb.htm [Accesado en: Diciembre 13 2009].

MAGEN 7 Francisco Porras. S/T. Cobre, esmalte al fuego. S/D. S/F. Gramcko. C. (2010). Material inédito. Correo electrónico christiangramcko@gmail.com [Accesado en: Septiembre 29 2010].

IMAGEN 8 Diadema de la imagen de Nuestra Señora de los Dolores. (1776). Plata, vidrio. Martillado, cincelado, repujado, sobredorado, engaste. S/D. Material inédito. Correo electrónico Artecolonialanauco@cantv.net [Accesado en: Septiembre 24 2010]. 
IMAGEN 9 Alexis De la Sierra. (1976). Brazalete: Plata 1000, marfil. Laminación, formación a martillo, engaste. S/D. Material inédito. Correo electrónico alexisdelasierra@cantv.net [Accesado en: Diciembre 11 2008].

IMAGEN 10 Harry Abend. (1971). Yuntas. Oro amarillo. Cera perdida. S/D. Material inédito. Correo electrónico alexisdelasierra@cantv.net [Accesado en: Noviembre 13 2010].

IMAGEN 11 María Teresa Torras. (1975). Collar. Plata 925. Laminación, tejido, ensamblaje. $22 \times 12 \times 3 \mathrm{~cm}$. XXV Salón Nacional de las Artes del Fuego. (1998).

http://galeria.uc.edu.ve/gubs.php?id=58 [Accesado en: Enero 21 2007].

IMAGEN 12 Carlos Zerpa. (1979). Antijoya en homenaje a Man Ray. Aluminio, clavos de acero. Ensamblaje S/D. Zerpa, C. (2010). "Imagen y datos de Antijoya en Homenaje a Man Ray, Gargantilla de hojillas Gillete". Material inédito. Correo electrónico carloszerpa@gmail.com [Accesado en: Abril 03].

IMAGEN 13 Carlos Zerpa. (1979). Gargantilla. Hojillas Gillette. Hojillas Gillette. Ensamblaje. S/D. Zerpa, C. (2010). "Imagen y datos de Antijoya en Homenaje a Man Ray, Gargantilla de hojillas Gillete". Material inédito. Correo electrónico carloszerpa@gmail.com [Accesado en: Abril 03].

IMAGEN 14 Alexis De la Sierra. (1986). Le cinquiéme plaisir d’argent. Plata Britania, textil. Cera perdida, texturización mecánica, macramé. Ensamblaje. 18 × 12 cm, 350 gr. Guevara, R., Asprino A., Imber, S. y Pervilhac I. (1995). Catálogo. "Alexis de la Sierra. El orfebre". Alexis De la Sierra. Vulcain D'outre-Mer. Museo de Arte Contemporáneo de Caracas Sofía Imber, Septiembre 1995. Edit. Arte. p: 34.

IMAGEN 15 Mary Ann Sherr. (S/F). Alianzas. Plata, oro $18 \mathrm{k}$. Laminación, grabado, oxidación. S/D. Mary Ann Sherr. Mary Ann Scherr: Designer, Educator, Goldsmith, Jeweler. (2011). www.maryannscherr.com/ [Accesado en: Junio 14 2012]. 
IMAGEN 16 Víctor Rodríguez. (1994). Lo que hice y donde lo hice. Conjunto: collar Laudan y el taller de Vulcano. Bronce, cobre, plata y aluminio. Tallado directo sobre metal, ensamblaje. $30 \times 12 \times 7$ cm. XXI Salón Nacional de las Artes del Fuego. (1994).

http://galeria.uc.edu.ve/gubs.php?id=53

[Accesado en: Enero 21 2007].

IMAGEN 17 Lourdes Silva. (1996). Collar II. Plata, oro 14 y 18 k, perlas barrocas, ébano fósil, cristal, cuernos de búfalo, madera petrificada, camafeo de coral. Embutido, forjado, kum-boo, ensamblaje. $46 \times 18 \mathrm{~cm}$. XXIII Salón Nacional de las Artes del Fuego. (1996). http://galeria.uc.edu.ve/actual.php?id=55

[Accesado en: Enero 21 2007].

IMAGEN 18 Ana Mercedes Carvallo. (2005). Trigal de maíz transgénico. Cobre, plata, oro, bronce, esmaltes al fuego, malla metálica, madera. Calado, embutido, baños electrolíticos, esmaltado, ensamblaje. 145 × 40 × 140 cm. 32 Salón Nacional de las Artes del Fuego. (2005).

http://galeria.uc.edu.ve/actual.php?id=9 [Accesado en: Febrero 10 2007].

IMAGEN 19 Rafier Vera. (2005). Primordialmente metal. Plata 950, madera de vera, cuarzo. Cera perdida, talla en madera, calado, micro mecánica, ensamblaje. S/D. Ministerio de la Cultura y el Consejo Nacional de la cultura. (2005). Catálogo. "I Salón Nacional de Orfebrería”. Centro de Arte La Estancia, Agosto 2005. EME3 producción. s/n.

IMAGEN 20 Samantha Fung. (2006). Deformaciones por conectividad. Plata, imanes. Dimensiones variables. 33 Salón Nacional de las Artes del Fuego. (2006).

http://galeria.uc.edu.ve/actual.php?id=66 [Accesado en: Febrero 10 2007].

IMAGEN 21 Elina Peduzzi. (2006). Semillero, 2006. Plata, oro, semillas de palma. $23 \times 22 \mathrm{~cm}$. Instituto de las Artes de la Imagen y el espacio y Mota, J. (2006). Catálogo. "Il Salón Nacional de Orfebrería". Museo de la Estampa y del Diseño Carlos Cruz-Diez, Agosto 2006. IAME. p: 57.

IMAGEN 22 Christian Gramcko. (2010). Se despide una perla (Homenaje a Elizabeth Schönn). Plata 925, acrílico, perla, papel 
impreso, grafito. Dimensiones variables. 34 Salón Nacional de las Artes del Fuego. (2007).

http://galeria.uc.edu.ve/actual.php?id=72 [Accesado en: Enero 21 2011].

IMAGEN 23 Christian Gramcko. (2010). Detalle de Se despide una perla (Homenaje a Elizabeth Schönn). Plata 925, acrílico, perla, papel impreso, grafito. Dimensiones variables. 34 Salón Nacional de las Artes del Fuego. (2007).

http://galeria.uc.edu.ve/actual.php?id=72 [Accesado en: Enero 21 2011].

IMAGEN 24 Pedro Ignacio Ramos. (Mediados del siglo XVIII). Lámpara del Sagrario. Plata. Repujado, cincelado S/D. Material inédito: correo electrónico. Gramcko, C. (2010). "Imagen de la obra restaurada en 1996". Material inédito. Correo electrónico. christiangramcko@gmail.com [Accesado en: Septiembre 24].

IMAGEN 25 Edecio Barazarte. (2007). Tiempo, retrospectiva y un secreto que me protege. Plata, fósil amonite, cristal, arena. Tejido, cera perdida, oxidación, articulación mecánica, ensamblaje. S/D. Vera, R. (2012). "Imágenes y fichas técnica de obras III Salón Nacional de Orfebrería". Material inédito. Correo electrónico. vhrafier@yahoo.com [Accesado en: Enero 22].

IMAGEN 26 Yolanda Sucre (2008). A buen entendedor. Plata 1000, 950 y 925, acero inoxidable, acrílico, porcelana. Técnica mixta. Dimensiones variables (3 piezas). 35 Salón Nacional de las Artes del Fuego. (2008).http://galeria.uc.edu.ve/actual.php?id=79 [Accesado en: Enero 21 2011].

IMAGEN 27 Nadia Karroum. (2009). En vía de extinción. Cobre, resina, plata. Baños electrolíticos, calado, reconstituido de piedras, ensamblaje. Dimensiones variables (73 piezas). 36 Salón Nacional de las Artes del Fuego. (2009).

http://galeria.uc.edu.ve/actual.php?id=85 [Accesado en: Enero 21 2011].

IMAGEN 28 Liliana Benítez. (2010). Caracas: ciudad portátil, mi sueño en blanco y negro. 37 Salón Nacional de las Artes del Fuego. (2010). http://galeria.uc.edu.ve/actual.php?id=89 [Accesado en: Marzo 9 2012]. 
IMAGEN 29 Talleres de producción artesanal Universidad de los Andes. 2010. Material inédito. Fotografiado por la autora. [Junio 23 2010].

IMAGEN 30 Escuela de Orfebres ADLS. 2009. Pervilhac, I. (2010). "Imágenes taller de orfebrería y Diseño electrónico". artmanager@delasierra.com [Accesado en: Diciembre 13].

IMAGEN 31 Taller de orfebrería Metta. 2008. Flames, M. (2010). "Estructura del curso y diplomado taller Metta". Material inédito. Correo electrónico. metta888ve@yahoo.es [Accesado en: Mayo 29].

IMAGEN 32 Escuela Taller de Orfebrería Anticlassic. 2010. Cedeño, I. (2011). "Estructura de enseñanza en taller anticlassic". Material inédito. Correo electrónico. ivan6558@hotmail.com [Accesado en: Julio 14].

IMAGEN 33 Ursi Galletti Galería. 2010. Galletti, U. (2010) "Estructura del taller y correos alumnos". Material inédito. Correo electrónico ugallery@hotmail.com [Accesado en: Abril 17].

IMAGEN 34 Galería Taller Orfebrería el Hatillo. 2010. Material inédito. Fotografiado por la autora. [Junio 18].

MAGEN 35 Taller Maritza Alayón. 2010. Material inédito. Fotografiado por la autora. [Junio 16].

MAGEN 36 R \& C Orfebres, Taller Escuela. 2010. Graterol, C. (2011). "Estructura de la enseñanza en R\&C orfebres y correos alumnos”. Correo electrónico. cvzla@yahoo.es [Accesado en: Febrero 26].

IMAGEN 37 Taller Escuela de Orfebrería Joanna Palacios. 2009. Palacios, J. (2010). "Datos de talleres y correos de alumnos". Material inédito. Correo electrónico.

ip.tallerescueladeorfebreria@hotmail.com [Accesado en: Marzo 23]. 
IMAGEN 38 Especialidades Río Grande. 2009. García, J. (2010). "Estructura de talleres se especialidades río grande y correos de alumnos". Material inédito. Correo electrónico. riocaracas@yahoo.com [Abril 15 2010].

IMAGEN 39 Taller Escuela de la tierra. 2009. Vera, R. (2010). "Estructura en la enseñanza del Taller de la tierra y correos alumnos". Material inédito. Correo electrónico. tallerdelatierra@gmail.com [Abril 23].

IMAGEN 40 Altar de la Patria. Monumento a la Batalla de Carabobo. (1830). Bronce. Modelado en arcilla, vaciado, patinado. Eloy palacios. http://www.google.co.ve/ Images for altar a la patria [Accesado en: Noviembre 11 2007].

IMAGEN 41 Pérez Mujica. (1921). Bacante. Bronce. Modelado y vaciado, patinado.

https://picasaweb.google.com/.../3j6jK6Uuru7oLfcB3Y24B9MTjN ZETY [Accesado en Marzo 2010]-

IMAGEN 42 Francisco Narváez 1936. Fuente del Parque Carabobo. Piedra artificial. Talla directa. http://www.google.co.ve/ Etapa Figurativa - Fundación Francisco Narváez, Museo de ...
www.fundacionnarvaez.com/e_paris.htm [Accesado en Abril 27 2011]

IMAGEN 43 Francisco Narváez. (1939.) Figura decorativa. Madera (caoba), tinta. Talla directa, entintado. $80 \times 40 \times 32 \mathrm{~cm}$. Material inédito. Correo electrónico. cinapgan@gmail.com [Diciembre 10 2012].

IMAGEN 44 Víctor Varela. (1957). Aroa. Lámina de hierro, laca color negro. Moldeado, soldadura eléctrica, laqueado. 1:60,5 x 1:29,5 x $98 \mathrm{~cm}$. Material inédito. Correo electrónico. cinapgan@gmail.com [Octubre 7 2010].

IMAGEN 45 Víctor Vasarely. (1954). Positivo - negativo. Aluminio. 2:96,5 x 5:20 x $22 \mathrm{~cm}$. "Positivo - Negativo" de Victor VasarelyCiudad Universitaria de ... 
patrimoniocuc.wordpress.com/.../obras-de-arte-sala-deconciertos-iii-posi. [Accesado en: Marzo 25 2011].

IMAGEN 46 Baltasar Lobo. (S/F). Maternidad. Bronce patinado. http://www.google.co.ve/ la integración de las artes en la biblioteca - Sistema de Información... www.sicht.ucv.ve:8080/biblioteca/historiag20.htm

[Accesado en: Marzo 25 2011].

IMAGEN 47 Francisco Narváez. La educación. Piedra de cumarebo. Talla directa.

patrimoniocuc.wordpress.com/2010/08/.../la-educacion-

francisco-narvae. [Accesado en: Marzo 25 2011].

IMAGEN 48 Jesús Soto, (S/F). Escultura Cinética. Varillas de hierro, lacas. Soldadura eléctrica, laqueado. S/D. http://www.google.co.ve/webhp?source=search_app\# [Accesado en: Marzo 25 2011].

IMAGEN 49 Alexander Calder. (1953). Nubes Acústicas ò platillos voladores. Estructuras estables acústicas suspendidas en metal y madera policromada. Dimensiones variables. La sintesis moderna de las artes - Arquine

www.arquine.com/blog/la-sintesis-moderna-de-las-artes/ [Accesado en: Marzo 25 2011].

IMAGEN 50 Cornelis Zitman. (1967). Columpio. Bronce patinado. 1:45 x 23,3 x $28 \mathrm{~cm}$. Catálogo Zitman - Scribd www.scribd.com/doc/30974217/Catalogo-Zitman [Accesado en: Diciembre 8 2012].

IMAGEN 51 Gertrud Goldschmidt. (1969). Reticulárea. Alambre de acero inoxidable y aluminio. Ensamblaje. Medidas variables. http://www.google.co.ve/ Imágenes de reticularia gego [Accesado en: Octubre 2011].

IMAGEN 52 Marcel Floris.1969. Sin título. Pletinas de hierro, formica de color blanco, nylon. Soldadura eléctrica, enchapado en fórmica, ensamblaje. 60,5 × 60 × $19 \mathrm{~cm}$. Material inédito. Correo electrónico cinapgan@gmail.com [Accesado en: Octubre 7 2010]. 
IMAGEN 53 Colette Delozanne. (1971). Habito un lugar indeciso (Homenaje a Trudi Eberstadt). Arcilla de alta temperatura.
60
38
$\mathrm{cm}$.

http://galeria.uc.edu.ve/snafanual.php?ano1=1970\&ano2=1979

[Accesado en: 25 Febrero 2010].

IMAGEN 54 Jesús Soto. (1971). Los penetrables. Hierro, nylon, plexiglás. Ensamblaje. S/D.

arteenlared.com/.../los-penetrables-de-soto-el-espectador-comoepicentro [Accesado en Abril 12 2011].

IMAGEN 55 Francisco Narváez. (S/F).Gran Volumen. Piedra. Talla directa. S/D. Cronología del artista Francisco Narváez www.fundacionnarvaez.com/francisco_narvaez2.htm [Accesado en: Diciembre 10 2010].

IMAGEN 56 Juan Loyola. (1983). S/T. Detalle de Loyola en plena acción del performance. El Arte de Juan Loyola

elartedejuanloyola.blogspot.com/ [Accesado en: Marzo 19 2010].

IMAGEN 57 Marisol Escobar. (1984).Homenaje a Magritte. Madera, paraguas, pigmentos. Talla directa, dibujo y pintura a mano alzada, ensamblaje. S/D. Arte Venezolano: La obra inusitada de Marisol Escobar

www.latinartmuseum.com/marisol.htm [Accesado en: Agosto 6 2008].

IMAGEN 58 Alexis De la Sierra. (1986). Pectoral Ceremonial: “Le Cinquième Plaisir d' Argent". Plata Britania, textil. Cera perdida, texturización mecánica, macramé, ensamblaje. 18 x 12 cm, 350 gr.

http://galeria.uc.edu.ve/snafanual.php?ano1=1980\&ano2=1989 [Accesado en Mayo 14 2010].

IMAGEN 59 Kelmis Fernández. (1989). Wisidatu (Shamán). Vidrio soplado, vidrio solido. Ensamblado, pulido al ácido, sandblasting. $80 \times 16,5 \times 16,5 \mathrm{~cm}$.

http://galeria.uc.edu.ve/snafanual.php?ano1=1980\&ano2=1989

[Accesado en Mayo 14 2010]. 
IMAGEN 60 Gaudí Esté (1992). Enchávez: Perro Nagual. Madera, clavos de acero, cincel de hierro. Talla directa, ensamblaje. $90 \times$ 80 x $30 \mathrm{~cm}$. Gaudí Esté. 1992. Esculturas de Gaudi Esté - Esté, Gaudi www.gaudieste.com/o_nagual.htm [Accesado en: Mayo 16 2010].

IMAGEN 61 Gaudí Esté. (1995).Sedicioso VI. Madera de cedro, pintura, poliuretano. Talla directa, ensamblaje. 1:13 x 1:20 x 27,5 $\mathrm{cm}$. Esculturas de Gaudi Esté - Esté, Gaudi www.gaudieste.com/o_sediciosos.htm [Accesado en: Mayo 16 2010].

IMAGEN 62 Pedro Barreto (1982). Sol. Pino de honduras, pintura. Talla directa, ensamblaje. S/D. pedro barreto escultor venezolano. http://www.google.co.ve/ Images [Accesado en Mayo 29 2010].

IMAGEN 63 Manuel de la Fuente. (2000). Alma Cosmográfica.Bronce RG5 y acero cortén, cemento, dispositivo eléctrico. Modelado en arcilla y vaciado a la cera perdida, patinado. 19: $33 \mathrm{~cm}, 1536 \mathrm{~kg}$. Alma Matery su espacio. Génesis Echeverría (2008) | Proyecto Arte ...

proyectoartemerida.wordpress.com/.../alma-mater-y-s... [Accesado en Mayo 29 2010].

IMAGEN 64 Rafael Martínez. (2003). Espiga del Chama. Láminas de acero policromado rojo y verde. Soldadura eléctrica, ensamblaje. $5: 40$ × 1:10 × $80 \mathrm{~cm}$. Alma Mater y su espacio. Génesis Echeverría (2008) | Proyecto Arte ...

proyectoartemerida.wordpress.com/.../alma-mater-y-s... [Accesado en Mayo 29 2010].

IMAGEN 65 Carlos Zerpa (2004). Despecho. Láminas de acero, lacas, cemento. Soldadura eléctrica, laqueado. $6 \times 4 \times 1 \mathrm{~cm}$. Material inédito. Correo electrónico carloszerpa@gmail.com [Accesado en: Agosto 11 de 2010].

IMAGEN 66 Oscar García Cuentas. (2004). Despertares. Bronce RG5. Vaciado en cera perdida, patinado. 4:40 x 1:20 x 1:00 cm. Material inédito. Fotografiado por la propia autora. [Enero 13 2010]. 
IMAGEN 67 Úrsula Bertram. (2001). Thinking. Tubo de hierro 5x5 $\mathrm{cm}$, láminas de cristal laminado, pinturas, guaya de acero. Soldadura eléctrica, ensamblaje y suspensión. 2:00 x 1:50 × $5 \mathrm{~cm}$. Alma Matery su espacio. Génesis Echeverría (2008) $\perp$ Proyecto Arte ...

proyectoartemerida.wordpress.com/.../alma-mater-y-s... [Accesado en Mayo 29 2010].

IMAGEN 68 Ramsés Larzábal. (2002).Me voy de casa, me llevo la pijama, mis juguetes. Hoy tengo la memoria ¿Me voy de casa? Porcelana, hilos, pigmentos, acrílico. 1:23 × $66 \times 38 \mathrm{~cm}$. http://galeria.uc.edu.ve/snafanual.php?ano1 $=2000 \& a n o 2=2009$ [Accesado en: Febrero 26 2011].

IMAGEN 69 Alberto Asprino (2003). Lecturas Reveronianas. Madera, Ensamblaje. S/D. Material inédito. Correo electrónico. albertoasprino@gmail.com [Accesado en: Septiembre 19 2010].

IMAGEN 70 Ani Villanueva. (2005). Lágrimas. 30 mangueras transparentes de plástico, agua, Luz artificial Instalación in situ, iluminación cenital. Dimensiones variables. VIII Bienal Nacional de Escultura abrió sus puertas en Nueva ...

globovision.com/.../viii-bienal-nacional-de-escultura-abrio-suspuertas-e. [Accesado en: Julio 19 2012].

IMAGEN 71 Alexis De la Sierra. (2003). Omnia Posibilia Sunt Videnti. Pintura cibernética.Composición pictórica en digital creada en ambiente cibernético. Impresión digital sobre material ilford Jet artist stretch Canvas (Medium Glossy) 210 x $142 \mathrm{~cm}$. Pervilhac, I. (2008). “Omnia Posibilia Sunt Videnti”. Correo electrónico. artmanager@delasierra.com [Accesado en: Septiembre 13].

IMAGEN 72 Roberto Mata. (2006). Autorretrato. Fotografía en B/N ampliada en plotter. El premio del Salón de Aragua me confirma que soy fotógrafo. (2006).

http://www.eluniversal.com/2006/12/13/til_art_108621.shtml

[Accesado en: diciembre 3 2012].

IMAGEN 73 Detalle de una de las muñecas de Reverón expuesta en el MOMA. 2007 Museo de Arte Moderno de Nueva York. (2007). Exposiciones - Retrospectiva de Armando Reveron en el MOMA 
IMAGEN 74 David García. (2007). Aves, Peces, Reptiles y Cuadrúpedos. Óleo sobre lienzo, cobre, plata, bronce. Técnica mixta, repujado, cincelado, collage. 1:30 x 1:00 cm. García, D. (2009). "Obra ganadora Bienal para Estudiantes de Universidad de Los Andes". Entrevista personal. Mérida, estado Mérida. [Noviembre 22].

IMAGEN 75 Bernardita Rakos. (2008). Arráncame la vida con el último beso de amor, arráncala, toma mi corazón. Madera, vinil, pintura acrílica, luz de meón, cuentas de plástico. Dimensiones variables. Bernardita Rakos ganó Primer Premio del VII Salón Pirelli ...bernarditarakos.com/articulos-y.../valencia-com-veversion-para-imprimir- . [Accesado en: Julio 25 de 2011].

IMAGEN 76 Elizabeth Quintero. (2010). Ser. Piedra, Concha marina, tiza. Talla en tiza, ensamblaje. $6.3 \times 3.6 \times 3 \mathrm{~cm}$. Material inédito. Fotografía de la autora [Diciembre 4 2010].

IMAGEN 77 Elisa Silva. (2010).Quiero tener un bebé como tú. Papel de algodón grueso, nylon transparente. Escritura en braille, ensamblaje. Dimensiones variables. Material inédito. Fotografía de la autora. [Junio 18 2010].

IMAGEN 78 Abelardo Tucapel. (1994). La mirada interna. Plata, fósil amonite, coral negro. Cincelado, repujado, granulado, pátina. $19 \times 13 \mathrm{~cm}$. XXI Salón Nacional de las Artes del Fuego. (1994). http://galeria.uc.edu.ve/gubs.php?id=53 [Accesado en: Enero 21 2007].

IMAGEN 79 Abelardo Tucapel. (1998). Metáfora del tiempo. Plata. Coral marrón, jaspe, azabache, colmillo de báquiro, engaste. $35 x$ $16 \mathrm{~cm}$. XXV Salón Nacional de las Artes del Fuego. (1998). http://galeria.uc.edu.ve/gubs.php?id=58 [Accesado en: Enero 21 2007].

IMAGEN 80 Duglas Pereira. (2008). Presencia alada. Plata 1000 y 950 , oro $18 \mathrm{~K}$. colmillos y dientes de báquiro, hueso, madera, cola de cachicamo, espinas de raya, láminas de carey, cuentas de coral 
blanco prehispánicos, placas líticas de serpentina de los andes venezolanos. Tejido, engaste, ensamblaje. $50 \times 25 \mathrm{~cm}$. 36 Salón Nacional de las Artes del Fuego. (2009).

http://galeria.uc.edu.ve/actual.php?id=85 [Accesado en: Enero 21 2010].

IMAGEN 81 Duglas Pereira. (2006). En extinción. Plata.925, fósil amonite, uña de perezoso, colmillo blanco de báquiro, rabo de cachicamo, tejido etrusco, engaste, oxidación. Material inédito. Correo electrónico duglaspereira609@hotmail.com [Accesado en: Febrero 10 2010].

MAGEN 82 Elina Peduzzi. (2005). América Siglo XXI. Plata, granate, oro 18 k. Reticulado, engaste, oxidación. S/D. Ministerio de la Cultura y el Consejo Nacional de la cultura. (2005). Catálogo: "I Salón Nacional de Orfebrería". Centro de Arte La Estancia, Agosto 2005. EME3 producción. s/n.

IMAGEN 83 Elina Peduzzi. (2006). Semillero 2006. Plata, oro, semillas de peonía. Trefilado, ensamblaje. $23 \times 22 \mathrm{~cm}$. Instituto de las Artes de la Imagen y el espacio y Mota, J. (2006). Catálogo: "II Salón Nacional de Orfebrería". Museo de la Estampa y del Diseño Carlos Cruz-Diez, Agosto 2006. IAME. p: 57.

IMAGEN 84 Lourdes Silva. (1996). Collar III. Plata, cuarzo rosado, oro $18 \mathrm{k}$. Embutido, forjado, kum-boo. 46 x $18 \mathrm{~cm}$. XXI Salón Nacional de las Artes del Fuego. (1994).

http://galeria.uc.edu.ve/gubs.php?id=53 [Accesado en: Enero 21 2007].

IMAGEN 85 A tempo. Titanio, niobio. Plata, perlas barrocas, aventurita, lapislázuli. Anodinado, martillado, fotograbado.28 x 20 cm. Lourdes Silva. (2005). 32 Salón Nacional de las Artes del Fuego. (2005). $\quad$ http://galeria.uc.edu.ve/actual.php?id=9 [Accesado en: Febrero 10 2007].

IMAGEN 86 Luis Macero. (2006). Orquídea 2006. Plata, acetato transparente, cobre, alpaca. Alambrismo, ensamblaje. $24 \times 16 \times$ $10 \mathrm{~cm}$. Catálogo: "Il Salón Nacional de Orfebrería". Museo de la Estampa y del Diseño Carlos Cruz-Diez, Agosto 2006. IAME. p: 112.

IMAGEN 87 Luis Macero. (2007). Con título. Metacrilato, piel, aluminio, bronce. Esmaltado, alambrismo, ensamblaje. 33 X 5,5 X 
IMAGEN 88 Lutz Podolski. (1998). Gargantilla. Plata, dientes de caballo, y tiburón fosilizado, cuero. Cera perdida, grabado con acido, burilado. 15 x 3,5 cm. XXII Salón Nacional de las Artes del Fuego. (1995). http://galeria.uc.edu.ve/actual.php?id=54 [Accesado en: Enero 21 2007].

IMAGEN 89 Lutz Podolski. (1999). Fuego. Plata. Cera perdida, cincelado, grabado, oxidación, ágata de fuego. S/D. Material inédito. Correo electrónico vickydavila 73@hotmail.com [Accesado en: Diciembre 16 2008].

IMAGEN 90 Mario Lacurcia. (2003). Hombre Pájaro. Plata 1000 y 950 , oro $18 \mathrm{k}$, turmalina. Filigrana, texturización, embutido, engaste, tejido, oxidación. 23 x 12 × 3 cm. XXX Salón Nacional de las Artes del Fuego. (2003). http://galeria.uc.edu.ve/actual.php?id=41 [Accesado en: Enero 21 2007].

IMAGEN 91 Mario Lacurcia. (2005). Medallón Ceremonial. Plata 1000 , oro $18 \mathrm{k}$ rosado, oro $14 \mathrm{k}$ amarillo, 14 topacios azules, 12 amatistas, 12 peridotos, cuero. Embutido, engaste, oxidación. Dije $15 \times 15 \times 2$, collar completo $60 \mathrm{~cm}$. 260 gr. Material inédito. Correo electrónico. vhrafier@yahoo.com [Accesado en: Enero 22].

IMAGEN 92 Patricia Benfele. (2007). La puertita del cielo. Plata. Vidrio murano. Trefilado, fundición de vidrio con soplete, fundición a la cera perdida. $26 \times 6 \times 3 \mathrm{~cm}$. 34 Salón Nacional de las Artes del Fuego. (2007). http://galeria.uc.edu.ve/actual.php?id=72 [Accesado en: Enero 21 2011].

IMAGEN 93 Patricia Benfele. (2007). Detalle de La puertita del cielo.

IMAGEN 94 Patricia Benfele. (2007). No es más que un sentimiento. Plata 950, oro $18 \mathrm{k}$, turquesas, fotografía. Entorchado, calado, engaste, ensamblaje. S/D. Benfele, P. (2012). Material inédito. Correo electrónico patricia_benfele@yahoo.com [Accesado en: Noviembre 13 2012]. 
IMAGEN 95 Patricia Benfele. (2007). Detalle de No es más que un sentimiento.

IMAGEN 96 Rosa Falena. (2003). Sinfonía del rhapis excelsa. Cobre, esmaltes al fuego. Repujado, esmaltado. $54 \times 33 \times 3 \mathrm{~cm}$. http://galeria.uc.edu.ve/actual.php?id=41 [Accesado en: Enero 21 2007].

IMAGEN 97 Rosa Falena. (2005). Estropajo Inn!!. Estropajo, Plata, caracoles de mar. Tejido en crochet, ensamblaje. $42 \times 23 \mathrm{~cm}$. http://galeria.uc.edu.ve/actual.php?id=9 [Accesado en: Febrero 10 2007].

IMAGEN 98 Ursi Galletti. (2000). El vuelo del Shamán. Plata 950, jaspe, fósil amonite, jaspe leopardo, colmillo de animal. pepa de samuro. Reticulado, corrugación, tejido de cadena. engaste, martillado. S/D. XXVII Salón Nacional de las Artes del Fuego. (2000). http://galeria.uc.edu.ve/actual.php?id=62

[Accesado en: Enero 21 2007].

IMAGEN 99 Ursi Galletti. (2004). Wonken. Plata 950, resina, plumas de Makiritare, huesos, colmillos de báquiro, piedras semipreciosas, fósiles, engaste. Construcción en hilo, inclusión en resina. 55 × 20 × 2,5 cm. 31 Salón Nacional de las Artes del Fuego. (2004). http://galeria.uc.edu.ve/gubs.php?id=27

[Accesado en Enero 21 2007].

IMAGEN 100 Ursi Galletti. (2004). Detalle de Wonken.

IMAGEN 101 Julio Mota. (1994). Pulsera/Marioneta/Violín. Plata 950 y 1000, terciopelo marrón, coral negro. Talla en coral, engaste, laminación, cera perdida, construcción. $5 \times 2 \times 2 \mathrm{~cm} / 10 \times$ $3 \times 1 / 5 \times 1 \times 1 \mathrm{~cm}$. XXI Salón Nacional de las Artes del Fuego. (1994). http://galeria.uc.edu.ve/gubs.php?id=53 [Accesado en: Enero 21 2007].

IMAGEN 102 Julio Mota. (1994). Detalle de Dije Violín. J. (2007). Material inédito. Correo electrónico. julio30764@hotmail.com [Accesado en: Marzo 29]. 
IMAGEN 103 Julio Mota. (1996). Ajuar de la Diosa del eterno retorno. Plata 1000, ágata. Embutido, cincelado, engaste. Pectoral 35 x 24 x 5 cm. Catálogo: "Il Salón Nacional de Orfebrería”. Museo de la Estampa y del Diseño Carlos Cruz-Diez, Agosto 2006. IAME. p: 125-126.

IMAGEN 104 Lucía Ramírez. (1994). Broches. Plata, cobre, turquesas, jaspe, ónix. Laminado, trefilado, engaste de bisel, repujado. 7,5 × 7,5/9 × 9,5/10 × 6,5 cm. XXI Salón Nacional de las Artes del Fuego. (1994). http://galeria.uc.edu.ve/gubs.php?id=53 [Accesado en: Enero 21 2007].

IMAGEN 105 Lucía Ramírez. (2010). Collar. Plata. Laminado, trefilado, cincelado, repujado, oxidación. S/D. Material inédito. Correo electrónico orfebres@gmail.com [Accesado en: abril 11 2012].

IMAGEN 106 Mary Peña. (2008). Proyección de vida de un diario abierto._Playa 1000 y 950, cacho de toro, resina, coral, nácar, papel. Laminado, collage, vaciado en resina. Dimensiones varias. 35 Salón Nacional de las Artes del Fuego. (2008).

http://galeria.uc.edu.ve/actual.php?id=79 [Accesado en: Enero 2011].

IMAGEN 107 Mary Peña. (2008). Detalle de Proyección de vida de un diario abierto.

IMAGEN 108 Mary Peña. (2009). 600 cc. Exigencias del Siglo XXI. Plata 950, Tubo de ensayo, nylon, moriche. Laminado, calado, construcción de sólidos limado, embutido, vidrio soplado, ensamblaje. $42 \times 14 \mathrm{~cm}$. 36 Salón Nacional de las Artes del Fuego. (2009). http://galeria.uc.edu.ve/actual.php?id=85

[Accesado en: Enero 2001].

IMAGEN 109 Aris Hernández. (2010). Collar tubular con pañoleta azul. Plata. Trefilado, tejido a máquina. $32 \times 28 \times 20 \mathrm{~cm}$. Material inédito Correo electrónico. "datos de formación y producción". hernandezaris@yahoo.com [Accesado en: Enero 26].

IMAGEN 110 Aris Hernández. (2010). Collar con hipérbolas. Plata, oro. Trefilado, tejido a máquina, baños electrolíticos. $32 \times 28 \mathrm{~cm}$. 
Material inédito. Correo electrónico "datos de formación y producción”. hernandezaris@yahoo.com [Accesado en: Enero 26].

IMAGEN 111 Carlos Graterol. (2006). Contra... el vudú de mis amigos. Plata 1000, cobre, titanio, esmaltes al fuego. Esmaltado, anodizado, $33 \times 15 \times 3 \mathrm{~cm}$. 33 Salón Nacional de las Artes del Fuego. (2006). http://galeria.uc.edu.ve/actual.php?id=66 [Accesado en: Febrero 10 2007].

IMAGEN 112 Carlos Graterol. (2009)...Canción que canta en el fondo oscuro del mar, la caracola. Plata 950, cobre, piedra de playa, esmalte sobre foil de cobre corrugado, pátina, soldaduras múltiples, construcción, engaste. 28 × $26 \mathrm{~cm}$. 36 Salón Nacional de las Artes del Fuego. (2009). http://galeria.uc.edu.ve/actual.php?id=85 [Accesado en: Enero 2001].

IMAGEN 112 Carlos Graterol. (2009). Detalle de ...Canción que canta en el fondo oscuro del mar, la caracola. 36 Salón Nacional de las Artes del Fuego. (2009).

http://galeria.uc.edu.ve/actual.php?id=85 [Accesado en: Enero 2001].

IMAGEN 114 Georgina Doumat. (2008). Alta costura. Plata 1000, perlas, cristales. Tejido a mano con una aguja, bordado, satinado. S/D. Doumat, G. (2013). Material inédito. Entrevista online. https://www.facebook.com/georgina.doumat?fref $=$ ts [Accesado en: Enero 30].

IMAGEN 115 Georgina Doumat. (2006). Sinuosidades. Plata 1000. Laminado, forjado. Construcción. Dimensiones varias. 33 Salón Nacional de las Artes del Fuego. (2006).

http://galeria.uc.edu.ve/actual.php?id=66 [Accesado en: Febrero 2007].

IMAGEN 116 Jaghanath Rodríguez. (2006). Encuentro entre el sol y la luna. Plata 1000 , oro 24 , chispa de brillante. Laminado, engaste, cincelado, texturización, ensamblaje. $22 \times 14 \mathrm{~cm}$. Catálogo: "II Salón Nacional de Orfebrería”. Museo de la Estampa y del Diseño Carlos Cruz-Diez, Agosto 2006. IAME. p: 87. 
IMAGEN 117 Jaghanath Rodríguez. (2006). Detalle de Encuentro entre el sol y la luna.

IMAGEN 118 Jaghanath Rodríguez. (2007). Pectoral Cinético. Plata 1000 , burilado, calado, satinado, ensamblaje. $32 \times 13 \times 1,5 \mathrm{~cm}$. Material inédito. Fotografía de la autora. [Enero 8 2010].

IMAGEN 119 Jaghanath Rodríguez. (2007). Detalle de Pectoral Cinético.

IMAGEN 120 María Teresa Torras. (1976). Collar. Plata 925. Laminado, calado, tejido, ensamblaje. $22 \times 12 \times 3 \mathrm{~cm}$. 1975. XXV Salón Nacional de las Artes del Fuego. (1998).

http://galeria.uc.edu.ve/gubs.php?id=58 [Accesado en: Enero 21 2007].

IMAGEN 121 María Teresa Torras. (1975). Collar. Plata 925. Laminado, construcción, ensamblaje. $18 \times 12$ × $8 \mathrm{~cm} .1975$. XXV Salón Nacional de las Artes del Fuego. (1998).

http://galeria.uc.edu.ve/gubs.php?id=58 [Accesado en: Enero 21 2007].

IMAGEN 122 Ollantay Guédez. (2007). Casi paz. Plata, colmillo de tigrillo, ónix negro, jaspe. Laminado, calado, embutido, construcción de sólidos, engaste, entorchado, tejido, vaciado directo. S/D. Material inédito. Correo electrónico. vhrafier@yahoo.com [Accesado en: Enero 22].

IMAGEN 123 Ollantay Guédez. (2010). S/T. Plata, esmeraldina, cuero. Laminado, calado, embutido, construcción de sólidos, engaste, oxidación. $7 \times 3,5 \times 3 \mathrm{~cm}$. Material inédito. Fotografía de la autora. [Marzo 19 2012].

IMAGEN 124 Simón Sorondo. (2000). Imperio incaico. Plata 950, oro 18 k, disco de pirita, granates en cabuchón, acerina, aves del paraíso, guayas de acero. Filigrana, engaste, cera perdida, mecanismos de articulación, engaste. 40 × 20 × $5 \mathrm{~cm}$. XXVII Salón Nacional de las Artes del Fuego. (2000). http://galeria.uc.edu.ve/actual.php?id=62 [Accesado en: Enero 21 2007]. 
IMAGEN 125 Simón Sorondo. (2005). Desfile colección PrimaveraVerano 2005-2006 de Laura Valenzuela. Pectorales en aluminio. Anillo para Laura Valenzuela. Plata 925. Dimensiones varias. Simón Sorondo. www.simonsorondo.blogspot.com/ [Accesaso en: Febrero 10 2007].

IMAGEN 126 Detalle de anillo para Laura Valenzuela. (2005).

IMAGEN 127 Alexis De la Sierra. (1986). Le premier plaisir d'argent. Plata Britania, textil. Cera perdida, texturización mecánica, macramé, ensamblaje. 17,5 x 10 cm, 301 gr. Guevara, R., Asprino A., Imber, S. y Pervilhac I. (1995). Catálogo. “Alexis de la Sierra. El orfebre". Alexis De la Sierra. Vulcain D'outre-Mer. Museo de Arte Contemporáneo de Caracas Sofía Imber, Septiembre 1995. Edit. Arte. p: 35.

IMAGEN 128 Alexis De la Sierra. (1989). Pectoral Ergonométrico II. Plata 1000, plata esterlina. Cera perdida, extrusión, formación a martillo, articulación mecánica, ensamblaje. 28,5 x 14,2cm, 248 gr. Guevara, R., Asprino A., Imber, S. y Pervilhac I. (1995). Catálogo. "Alexis de la Sierra. El orfebre". Alexis De la Sierra. Vulcain D'outreMer. Museo de Arte Contemporáneo de Caracas Sofía Imber, Septiembre 1995. Edit. Arte. p: 41.

MAGEN 129 Alexis De la Sierra. (1989). Cruz Obispal. Plata 1000, plata esterlina, oro 24 k, 2 amatistas. Cera perdida, texturización, engaste. $70 \times 13$ cm, 268 gr. Guevara, R., Asprino A., Imber, S. y Pervilhac I. (1995). Catálogo. "Alexis de la Sierra. El orfebre". Alexis De la Sierra. Vulcain D'outre-Mer. Museo de Arte Contemporáneo de Caracas Sofía Imber, Septiembre 1995. Edit. Arte. p: 30.

IMAGEN 130 Alexis de la Sierra. (2004). Guardianes de fuego y hielo. Plata 1000, piedras semipreciosas, cristal, textil, mármol, luz dicroica. Laminado, engaste, formación a martillo, reticulado, ensamblaje lumínico. 1:42 × $22 \mathrm{~cm}$. Material inédito. Fotografía de la autora. [Junio 18 2010].

IMAGEN 131 Alexis de la Sierra. (2004). Detalle de Guardianes de fuego y hielo. 
IMAGEN 132 Alexis de la Sierra. (2001). Soplo de vida todavía hay esperanza. Pintura, bronce, madera, oro $24 \mathrm{k}$. computadora Macinstosh i-Book, oxigenador de sangre, aserrín, conectores, cables, mangueras lumínicas, sonido, luz fija y estroboscópica, pintura cibernética. Diseño y modelado en barro, fundición a la cera perdida, electro-forming, patinado, ensamblaje de elemento lumínico y metálico. 3:00 x 3:00 x 2:50 cm. Pervhilac, I. (2008). “Ficha Simbológica/Conceptual. Instalación Soplo de Vida Todavía hay Esperanza por Alexis De la Sierra. Bienal Internacional del Arte Contemporáneo de Florencia (2001)". Material inédito. Correo electrónico. artmaneger@delasierra.com [Accesado en: Enero 25].

IMAGEN 133 Alexis de la Sierra. (2001). Sursum Corda. Bronce, oro 24 quilates. Diseño y modelado en barro, cera perdida, vaciado en bronce, pátina, electroforming en oro de 24 k. 85 x 55 x $30 \mathrm{~cm}$. Pervhilac, I. (2008). "Ficha Simbológica/Conceptual. Instalación Soplo de Vida Todavía hay Esperanza por Alexis De la Sierra. Bienal Internacional del Arte Contemporáneo de Florencia (2001)". Material inédito. Correo electrónico. artmaneger@delasierra.com [Accesado en: Enero 25].

IMAGEN 134 Christian Gramcko. (1998). Sobre el madero. Plata 950. Esmaltes al fuego. Cera perdida, esmaltado, engaste. S/D. Material inédito. Correo electrónico christiangramcko@gmail.com [Accesado en: Septiembre 24 de 2010].

IMAGEN 135 Domingo Tomás Núñez. (1796). Lámpara del sagrario, para llevar viático. Plata 800. Cincelado, repujado. Restaurada por Christian Gramcko en el año1996. S/D. Materia inédito. Correo electrónico christiangramcko@gmail.com [Accesado en: Septiembre 24 de 2010].

IMAGEN 136 Christian Gramcko. (2010). Se despide una perla (Homenaje a Elizabeth Schönn). Plata 925, acrílico, perla, papel impreso, grafito. Dimensiones variables. Exposiciones anteriores. 34 Salón Nacional de las Artes del Fuego. (2007). http://galeria.uc.edu.ve/actual.php?id=72 [Accesado en: Diciembre 15 2007].

IMAGEN 137 Christian Gramcko. (2010). Detalle de Se despide una perla (Homenaje a Elizabeth Schönn). 
IMAGEN 138 Claudia Padrón. (2003). Las guacas nos siguen en la curiara...se nos sale el corazón. Plata 925, colmillos de jabalí, peonías, plumas de guacamaya. $35 \times 12 \times 2 \mathrm{~cm}$. XXX Salón Nacional de las Artes del Fuego. (2003).

http://galeria.uc.edu.ve/actual.php?id=41 [Accesado en: Enero 21 2007].

IMAGEN 139 Claudia Padrón. (2008). Pinceles llenos de tinta. Plata 925, totuma, semillas. Técnica mixta. Dimensiones variables. 35 Salón Nacional de las Artes del Fuego. (2008).

http://galeria.uc.edu.ve/actual.php?id=79 [Accesado en: Enero 2011].

IMAGEN 140 Claudia Padrón. (2006). Sin título Cola de marta cibelina, bronce, plata 925, piedra. Laminado, martillado, ensamblaje. $18 \times 8 \times 4 \mathrm{~cm}$. IX Exposición Colectiva de la ACAF. (2006). http://galeria.uc.edu.ve/actual.php?id=16 [Accesado en: Febrero 2012].

IMAGEN 141 Claudo Kalán. (2006). Vida inteligente. Oro 18 k, Plata 1000, diamante, granate. Embutido, engaste, entorchado, remachado, tejido. $15 \times 12,5 \times 10 \mathrm{~cm}$. 33 Salón Nacional de las Artes del Fuego. (2006).

http://galeria.uc.edu.ve/actual.php?id=66 [Accesado en: Febrero 2007].

IMAGEN 142 Claudo Kalán. (2007). Animación suspendida... son mil años de viaje. Plata 925, construcción de sólidos, forjados, remaches. $15 \times 15 \times 12 \mathrm{~cm}$. 34 Salón Nacional de las Artes del Fuego. (2007). http://galeria.uc.edu.ve/actual.php?id=72 [Accesado en: Enero 21 2011].

IMAGEN 143 Claudo Kalán. (2007). Detalle de Animación suspendida son mil años de viaje.

IMAGEN 144 David García. (2003). Serie mujeres. Plateada marina. Plata 950, piedra agua marina, cobre. Laminado, repujado, engaste, entorchado, oxidación. 20 x $14 \mathrm{~cm}$. XXX Salón Nacional de las Artes del Fuego. (2003).

http://galeria.uc.edu.ve/actual. php?id=41 [Accesado en: Enero 21 2007]. 
IMAGEN 145 David Garcia. (2007).Serie reptiles. Del imaginario verde rosa. Madera, bronce, cobre. Fundición, repujado, engaste, forjado, pátinas, oxidación. $76 \times 61 \times 7 \mathrm{~cm}$. David García. (2006/7). 34 Salón Nacional de las Artes del Fuego. (2007).

http://galeria.uc.edu.ve/actual.php?id=72 [Accesado en: Enero 21 2011].

IMAGEN 146 David García. (2007). Aves, Peces, Reptiles y Cuadrúpedos. Óleo sobre lienzo, cobre, plata, bronce. Técnica mixta, repujado, cincelado, collage. 1:30 x 1:00 cm. David García. (2007). García, D. (2009). "Obra ganadora Bienal para Estudiantes de Universidad de Los Andes". Material inédito. Entrevista personal. Mérida, estado Mérida. [Noviembre 22].

IMAGEN 147 David García. (2007). Detalle de Aves, peces, reptiles y cuadrúpedos.

IMAGEN 148 Edecio Barazarte (2006). ¡Vuela papagayo, como mis pensamientos! Tríptico en madera policromada con escultura en plata 950 y 1000- Engaste, filigrana, trefilado, embutido, laminado, pintura, ensamblaje. $40 \times 28 \mathrm{~cm}$. Catálogo. "II Salón Nacional de Orfebrería". Museo de la Estampa y del Diseño Carlos Cruz-Diez, Agosto 2006. IAME. p: 52-53

IMAGEN 149 Edecio Barazarte (2007). Tiempo retrospectiva y un secreto que me protege. Plata, fósil amonite, cristal, arena. Tejido, cera perdida, oxidación, articulación mecánica, ensamblaje. S/D. Vera, R. (2012). "Imágenes y fichas técnica de obras III Salón Nacional de Orfebrería". Material inédito. Correo electrónico. vhrafier@yahoo.com [Accesado en: Enero 22].

IMAGEN 150 Edecio Barazarte. (2007). Detalle de Tiempo retrospectiva y un secreto que me protege.

IMAGEN 151 Gustavo Smitter. Raíces, 2006. (2006).Plata, alpaca, cobre, madera de bambú, ónix. Técnica mixta. $29 \times 19 \mathrm{~cm}$. Catálogo. "II Salón Nacional de Orfebrería”. Museo de la Estampa y del Diseño Carlos Cruz-Diez, Agosto 2006. IAME. p: 75 
IMAGEN 153 Gustavo Smitter. (2007). Psiquis. Alpaca, bronce, cobre, cables de teléfono, acrílico, madera. Construcción de sólidos, talla, ensamblaje. Dimensiones varias. Vera, R. (2012). "Imágenes y fichas técnica de obras III Salón Nacional de Orfebrería". Material inédito. Correo electrónico. vhrafier@yahoo.com [Accesado en: Enero 22].

IMAGEN 154 Haydee Pérez Criollo. (2005). Venezuela y sus recursos en las manos de Dios. Plata, azabache, oro, bronce, acero, diamante. Fundición a la cera perdida, laminación, extrusión, talla de azabache, ensamblaje. 36 × 34 x $63 \mathrm{~cm}$. Pervilhac, I. (2005). "Tierra, Arte y Cultura en Venezuela". Exposición didáctica colectiva. $N^{\circ}$ XV. XX Aniversario. Centro de Arte La Estancia, diciembre 2005. Impresos Amendar C.A. s/n.

IMAGEN 155 Haydee Pérez Criollo. (2006). Guayana adentro. Plata 759 y 1000, azabache, bejuco. Laminado, calado, engaste, alambrismo. 34 x $18 \mathrm{~cm}$. Catálogo. "Il Salón Nacional de Orfebrería". Museo de la Estampa y del Diseño Carlos Cruz-Diez, Agosto 2006. IAME. p: 66.

IMAGEN 156 Julia Ferreira. (2005). De la serie: De la net a la nasa. Atrapado en el Aire. Atrapado en el Agua. Atrapado en Tierra._Plata 950, ensamblaje por soldadura, engastado, pulido, Piedras. Dimensiones varias (3 piezas). 32 Salón Nacional de las Artes del Fuego. (2005). http://galeria.uc.edu.ve/actual.php?id=9 [Accesado en: Febrero 10 2007].

IMAGEN 157 Julia Ferreira. (2010). Sin títulos. Metacrilato, plata 925, circones, resina de poliéster. Laminado, engaste, vaciado en resina, ensamblaje. Caja: $7 \times 7 \times 3,5 \mathrm{~cm}$, anillo: 3 diámetro aprox. Ferreira, J. (2012). "Datos sobre su producción”. Entrevista online. https://www.facebook.com/julia.ferreiraorfebre?fref=ts [Accesado en: Enero 19 2013].

IMAGEN 158 Julia Ferreira (2010). Detalle de Sin títulos.

MAGEN 159 Julia Ferreira. (2010). De la serie: ¿por qué guardada? mejor compartida. Cachalote._Plata 1000, plata 925, Cobre, ágata, plástico termoformado, resina acrílica. Laminado, forjado, 
embutido, engastado, mokume-ganè, ensamblaje. $8 \times 7 \mathrm{~cm} .37$ Salón Nacional de las Artes del Fuego. (2010). http://galeria.uc.edu.ve/actual.php?id=89 [Accesado en: Marzo 9 2012].

IMAGEN 160 Julia Ferreira. (2010). Detalle De la serie: ¿por qué guardada? mejor compartida. Cachalote.

IMAGEN 161 Liliana Benítez. (2005). Orino 2005. Plata 1000, azabache. Forjado, incrustación de azabache. Pectoral $22 \times 18 \mathrm{~cm}$. Brazalete 13 x $8 \mathrm{~cm}$. Catálogo. "Il Salón Nacional de Orfebrería". Museo de la Estampa y del Diseño Carlos Cruz-Diez, Agosto 2006. IAME. p: 106-107

IMAGEN 162 Liliana Benítez. (2008). Hilanderos de poesía. Plata 925, cuerdas de guitarra, baño de plata. Fundición a la cera perdida, ensamblaje. Dimensiones varias ( 3 piezas). http://galeria.uc.edu.ve/actual.php?id=79 [Accesado en: Enero 2011].

IMAGEN 163 Liliana Benítez. (2010). Caracas: ciudad portátil, mi sueño en blanco y negro. Plata 925, acero, fotografía, resina, acrílico, transparencias. Vaciado en cera perdida, forja, construcción de sólidos, ensamblaje. $58 \times 42 \mathrm{~cm}$. 37 Salón Nacional de las Artes del Fuego. (2010). http://galeria.uc.edu.ve/actual.php?id=89 [Accesado en: Marzo 9 2012].

IMAGEN 164 Nadia Karroum. (2005). Celentéreo. Plata 1000, 950, titanio anodizado, embutido. $37 \times 37 \times 05 \mathrm{~cm}$. 32 Salón Nacional de las Artes del Fuego. (2005).

http://galeria.uc.edu.ve/actual.php?id=9 [Accesado en: Febrero 10 2007].

IMAGEN 165 Nadia Karroum. (2009). En vía de Extinción. Cobre, resina, plata. Baños electrolíticos, calado, reconstituido de piedras, ensamblaje. Dimensiones variables (73 piezas). 35 Salón Nacional de las Artes del Fuego. (2008). 36 Salón Nacional de las Artes del Fuego. (2009). http://galeria.uc.edu.ve/actual.php?id=85 [Accesado en: Enero 2001]. 
IMAGEN 166 Nadia Karroum (2009). Detalle de En vía de extinción.

IMAGEN 167 Nadia Karroum. (2007). Talismán. Plata 1000 y 950, azabache, cachitos de jabillo, pepa de zamuro, plumitas de pavo real, cristal de cuarzo, orring, caracoles. Laminado, embutido, forja, tejido, engaste, ensamblaje. Semillas de para-para, coral, colmillos de Payara. $62,5 \times 2,5 \times 16 \mathrm{~cm}$. Vera, R. (2012). "Imágenes y fichas técnica de obras III Salón Nacional de Orfebrería". Material inédito. Correo electrónico. vhrafier@yahoo.com [Enero 22].

IMAGEN 168 Rafael Bello. (2005). El espejo de la bruja. Asta de venado, bronce, latón, mármol blanco. Cera perdida, torneado, ensamblaje. Catálogo: "I Salón Nacional de Orfebrería". Centro de Arte La Estancia, Agosto 2005. EME3 producción. s/n.

IMAGEN 169 Rafael Bello. (2010). S/T Plata 950, Piedra labradorita. Cera perdida, engaste, articulación mecánica. S/D. Platería Hispanoamericana Contemporánea. (2009).

http://galeria.uc.edu.ve/actual.php?id=83 [Accesado en: Noviembre 6 2012].

IMAGEN 170 Rafier Vera. (2005). Primordialmente metal. Plata 950, madera de vera, cuarzo. Cera perdida, talla en madera, calado, micro mecánica, ensamblaje. S/D. Catálogo: "I Salón Nacional de Orfebrería". Centro de Arte La Estancia, Agosto 2005. EME3 producción. s/n.

IMAGEN 171 Rafier Vera. (2005). Sin Título. Plata 925, espinas de puercoespín, cacho de vaca, acrílico, hierro, escama y espina de pescado. Engaste, cera perdida, micro mecánica, ensamblaje. $24 \mathrm{x}$ 14 cm. 32 Salón Nacional de las Artes del Fuego. (2005). http://galeria.uc.edu.ve/actual.php?id=9 [Accesado en: Febrero 10 2007].

IMAGEN 173 Samantha Fung. (2005). Cuatro de siete. Plata1000, látex, circones, madera, Calado, Oxidación, ensamblaje. 50 × 24 x $8 \mathrm{~cm}$. 32 Salón Nacional de las Artes del Fuego. (2005). http://galeria.uc.edu.ve/actual.php?id=9 [Accesado en: Febrero 10 2007]. 
IMAGEN 174 Samantha Fung. (2006). Deformaciones por conectividad. Plata 900, imanes. Técnica mixta. Dimensiones variables (50 piezas). 33 Salón Nacional de las Artes del Fuego. (2006). http://galeria.uc.edu.ve/actual.php?id=66 [Accesado en: Febrero 2007].

IMAGEN 175 Samantha Fung. (2006). Modificación de Deformaciones por conectividad.

IMAGEN 176 Sonia Parisca. (2004). Amazona._Plata 1000, 950, dientes de jabalí y de búfalo de agua, semillas de para-para, turquesa, jaspe Morgan Hill Poppy, jaspe paisaje. Laminado, tejido, engaste, pátinas, remaches. $35 \times 15 \times 3 \mathrm{~cm}$. 31 Salón Nacional de
las Artes
del
Fuego.
(2004).

http://galeria.uc.edu.ve/gubs.php?id=27 [Accesado en Enero 21 2007].

IMAGEN 177 Sonia Parisca.(2007). Cesta. Alambre de cobre, madera. Tejido, patina. 19,5 X 16 X $16 \mathrm{~cm}$. Vera, R. (2012). "Imágenes y fichas técnica de obras III Salón Nacional de Orfebrería". Material inédito. Correo electrónico. vhrafier@yahoo.com [Accesado en: Enero 22].

IMAGEN 178 Tatiana Tischenko. (2006). Agua y Fuego...elementos extremos. Plata 1000, Ágata, ensamblaje, modelado en cera. Dimensiones variables (2 piezas) 33 Salón Nacional de las Artes del Fuego. (2006). http://galeria.uc.edu.ve/actual.php?id=66 [Accesado en: Febrero 2007].

IMAGEN 179 Tatiana Tischenko. (2008). Caminos entrelazados, vida independiente. Esmalte, ensamblaje, plumas, Guayas.150 x 70 x 15 cm. 35 Salón Nacional de las Artes del Fuego. (2008). http://galeria.uc.edu.ve/actual.php?id=79 [Accesado en: Enero 2011].

IMAGEN 180 Tatiana Tischenko. (2010). Momentos íntimos. Plata 1000, plata 950, nylon, canillas de lavamanos. Laminado, soldadura. Ensamblaje. Dimensiones variables. 37 Salón Nacional de las Artes del Fuego. (2010).

http://galeria.uc.edu.ve/actual.php?id=89 [Accesado en: Marzo 9 2012]. 
IMAGEN 181 Yolanda Sucre. (2005). Noche de etiqueta. Plata, cobre, esmaltes traslucidos, madera. Calado, repujado, laminado, fotograbado, esmaltado, oxidación, ensamblaje. 7,5 x 42 cm. 32 Salón Nacional de las Artes del Fuego. (2005).

http://galeria.uc.edu.ve/actual.php?id=9 [Accesado en: Febrero 10 2007].

IMAGEN 182 Yolanda Sucre. (2006). Viernes chiquito. Láminas de cobre, láminas e hilo de plata 950 y 1000, esmaltes opacos y transparentes. Martillado, embutido, cloisonné, soldadura, grabado en ácido nítrico. 13 × 90 × 57 cm. 33 Salón Nacional de las Artes del Fuego. (2006).

http://galeria.uc.edu.ve/actual.php?id=66 [Accesado en: Febrero 2007].

IMAGEN 183 Yolanda Sucre. (2008). A buen entendedor. Plata 1000, 950 y 925, acero inoxidable, acrílico, porcelana. Técnica mixta. Dimensiones variables (3 piezas). 35 Salón Nacional de las Artes del Fuego. (2008).

http://galeria.uc.edu.ve/actual.php?id=79 [Accesado en: Enero 2011].

IMAGEN 184 Ana Mercedes Carvallo. (2003). Vainitas suspendidas. Cobre, Plata, esmaltes al fuego, granito negro. Calado, embutido, construcción de sólidos, baño de plata, esmaltado, ensamblaje. 65 × 55 × 20 cm. XXX Salón Nacional de las Artes del Fuego. (2003).

http://galeria.uc.edu.ve/actual.php?id=41 [Accesado en: Enero 21 2007].

IMAGEN 185 Ana Mercedes Carvallo. (2003). Detalle de Vainitas suspendidas.

IMAGEN 186 Ana Mercedes Carvallo. (2004). Vainitas transgénicas. Cobre, plata, esmaltes al fuego, esténcil, madera. Calado, embutido, baños electrolíticos, esmaltado, champlevé, ensamblaje. $120 \times 30 \times 20 \mathrm{~cm} .31$ Salón Nacional de las Artes del Fuego. (2004). http://galeria.uc.edu.ve/gubs.php?id=27

[Accesado en Enero 21 2007].

IMAGEN 187_Ana Mercedes Carvallo. (2005). Trigal de maíz transgénico._Cobre, plata, oro, bronce, esmaltes al fuego, malla 
metálica, madera. Calado, embutido, baños electrolíticos, esmaltado, ensamblaje. 145 × 40 x $140 \mathrm{~cm}$. 32 Salón Nacional de las Artes del Fuego. (2005).

http://galeria.uc.edu.ve/actual.php?id=9 [Accesado en: Febrero 10 2007].

IMAGEN 188 Edymar Álvarez. (2006). Zancudos. Lienzo, plata, bronce, cobre, madera, acrílico, resina, ponchera de plástico. Pintura, talla, calado, vaciado en resina, embutido, ensamblaje.140 × $80 \times 70 \mathrm{~cm}$. Catálogo. "II Salón Nacional de Orfebrería". Museo de la Estampa y del Diseño Carlos Cruz-Diez, Agosto 2006. IAME. p: 56.

IMAGEN 188 Edymar Álvarez. (2006). Detalle de Zancudos.

IMAGEN 190 Edymar Álvarez. (2006-2007). La abeja y el colibrí.. Plata 950, cobre, bronce, aluminio, acrílico, semillas de Jabillo, tronco de Jabillo, bambú. Fusión de metal, embutido, extrusión, ensamblaje. 207 X 130 X 65,5 cm y 122,5 x 61 × $20 \mathrm{~cm}$. Vera, R. (2012). "Imágenes y fichas técnica de obras III Salón Nacional de Orfebrería”. Material inédito. Correo electrónico. vhrafier@yahoo.com [Accesado en: Enero 22].

IMAGEN 192 María Graciela García. (2006). Reflejo. Plata 950 y 1000, madera de: nogal, palo rojo, pino americano, lapislázuli turquesa, lluvia de oro, cuarzo lechoso, Vaciado en sepia, calado, talla en madera, incrustación de metal en madera, mosaico, ensamblaje. $30 \times 20 \times 20 \mathrm{~cm}$. Catálogo. "II Salón Nacional de Orfebrería". Museo de la Estampa y del Diseño Carlos Cruz-Diez, Agosto 2006. IAME. p: 120-121.

IMAGEN 193 María Graciela García. (2006). Detalle de la mirilla de Reflejo.

IMAGEN 194 María Graciela García. (2006). Detalle de la pieza del interior de Reflejo.

IMAGEN 195 María Graciela García. (2010). Tsunami. Plata 950, madera de palo santo, caliza. Reticulado, forja, talla en madera, 
oxidación, ensamblaje. 31 x 16,5 x 7,7 cm. Ag 134 gr. Archivo de la autora.

IMAGEN 196 María Graciela García. (2009). Aférrate. Plata 950, Caliza, hierro. Vaciado directo, cera perdida, forja, grabado, pátina, talla en piedra. $16 \times 16 \times 4 \mathrm{~cm} .1920$ gr. "Platería Hispanoamericana Contemporánea" (2010). Museo Pumapungo. Cuenca-Ecuador. 26 Octubre al 28 Noviembre.

IMAGEN 197 María Graciela García. (2009). Detalle de Aférrate.

IMAGEN 198 María Njaim. (2006). Bate que bate...Plata, azabache, vaso de licuadora de vidrio, vidrio. Extrusión, construcción, ensamblaje. 45 x 18 x 15 cm. 33 Salón Nacional de las Artes del Fuego. (2006).

http://galeria.uc.edu.ve/actual.php?id=66 [Accesado en: Febrero 2007].

IMAGEN 199 María Njaim. (2006).Detalle del interior de Bate que bate...

IMAGEN 200 María Njaim. (2006-2007). Cielo, sol y religión. Plata, aguamarina, topacio, granate rodolita, guante de caucho, fique. Laminado, calado, engaste: bisel y garras. Dimensiones variables. Vera, R. (2012). "Imágenes y fichas técnica de obras III Salón Nacional de Orfebrería". Material inédito. Correo electrónico. vhrafier@yahoo.com [Accesado en: Enero 22].

IMAGEN 201 Mildred Maury. (2005). Eterno - transitorio._Plata 1000, 950, piedras, resina, madera, guayas, materiales diversos. Grabado, oxidación, engaste, construcción, recostituido de piedas semipreciosas, oxidación, ensamblaje. $140 \times 130 \times 20 \mathrm{~cm}$. Dimensiones variables (6 piezas). 32 Salón Nacional de las Artes del Fuego. (2005). http://galeria.uc.edu.ve/actual.php?id=9 [Accesado en: Febrero 10 2007].

IMAGEN 202 Mildred Maury. (2005). Detalle de parte de afuera de visor de Eterno - transitorio. Maury M, (2013)."Datos sobre obras SNAF". Material inédito. Correo electrónico mildredmaury@yahoo.es [Accesado en: Enero 15]. 
IMAGEN 203 Mildred Maury. (2005). Detalle del interior del visor de Eterno - transitorio. [Accesado en: Enero 15].

IMAGEN 204 Mildred Maury. (2006). Unidos en la visión. Leonardo y Clara. Plata 950, piedras semipreciosas, madera, visores. Construcción, engaste, reconstituido de piedras, calado, oxidación, ensamblaje. $150 \times 45 \times 45 \mathrm{~cm}$. 33 Salón Nacional de las Artes del Fuego. (2006). http://galeria.uc.edu.ve/actual.php?id=66

[Accesado en: Febrero 2007].

IMAGEN 205 Mildred Maury. (2006). Detalle del interior Unidos en la visión. Leonardo y Clara. [Accesado en: Enero 15].

IMAGEN 206 Mildred Maury. (2007). Show. Plata 950, fotografía a color, visor. Construcción, engaste, oxidación, impresión láser, iluminación cenital. Ensamblaje. 150 × 20 × 20 cm. 34 Salón Nacional de las Artes del Fuego. (2007).

http://galeria.uc.edu.ve/actual.php?id=72 [Accesado en: Enero 21 2011].

IMAGEN 207 Mildred Maury. (2007). Detalle del exterior de Show. [Accesado en: Enero 15].

IMAGEN 208 Mildred Maury. (2007). Detalle de la fotografía del interior de Show. [Accesado en: Enero 15].

IMAGEN 209 Natalia Santamaría. (2006). Amenaza. Plata 950, cobre, esmalte, piedra labradorita, caja de madera. Laminado, martillado, esmalte sobre foil, tejido, engaste, embutido, patina, ensamblaje. $40 \times 66 \times 60 \mathrm{~cm}$. 33 Salón Nacional de las Artes del Fuego. (2006). http://galeria.uc.edu.ve/actual.php?id=66 [Accesado en: Febrero 2007].

IMAGEN 210 Natalia Santamaría. (2006). Detalle de Amenaza.

IMAGEN 211 Natalia Santamaría. (2006). Cachicamo trabaja pa 'lapa. Bronce, plata, esmalte, arena, botella de cerveza venezolana. Técnicas mixtas. Cachicamo: $29 \times 7,5 \times 8$, Botella: $10,5 \times 3 \mathrm{~cm}$. Catálogo. "II Salón Nacional de Orfebrería". Museo de la Estampa y del Diseño Carlos Cruz-Diez, Agosto 2006. IAME. p: 140-141. 
IMAGEN 212 Patricia Querini. (2003). Venezuela Lux Originalis Plata 1000 , citrinos, granates, iolitas. Laminación, cera perdida, repujado, engaste. $40 \times 25 \times 25 \mathrm{~cm}$. Pervilhac, I. (2005). "Tierra, Arte y Cultura en Venezuela”. Exposición didáctica colectiva. $N^{\circ} \mathrm{XV}$. XX Aniversario. Centro de Arte La Estancia, diciembre 2005. Impresos Amendar C.A. s/n.

IMAGEN 213 Patricia Querini. (2004). Sueño al compás de las olas. Plata, gotones de vidrio fundido, barras de vidrio, cordon de nylon. Fundicion a la cera perdida, extrusion, forja, engaste, tejido, ensamblaje, instalacion. 2:10 x $90 \mathrm{~cm}$. Pervilhac, I. (2005). "Tierra, Arte y Cultura en Venezuela”. Exposición didáctica colectiva. $N^{\circ} \mathrm{XV}$. XX Aniversario. Centro de Arte La Estancia, diciembre 2005. Impresos Amendar C.A. s/n.

IMAGEN 214 Patricia Querini. (2007). Bandeja margariteña. Plata 1000 para la bandeja, plata 950 para las asas. Laminación de plata, forja, modelado de asas en cera perdida, fusión de bordes con oxiacetileno, soldadura, desbastado, pulitura. 23,5 X 51,5 X $7,8 \mathrm{~cm}$. Vera, R. (2012). "Imágenes y fichas técnica de obras III Salón Nacional de Orfebrería". Vera, R. (2012). Material inédito. Correo electrónico. vhrafier@yahoo.com [Accesado en: Enero 22].

IMAGEN 215 Ricardo Laverde. (2004). Hrönir levitante._Ébano, oro $18 \mathrm{~K}$, plata 950, acrílico, resina, hierro, acero, semillas de peonía. Termoformado, encapsulado, repujado, talla en madera, vaciado en resina, ensamblaje. 180 × 52 × $40 \mathrm{~cm}$. 31 Salón Nacional de
las
Artes
del
Fuego.
(2004).

http://galeria.uc.edu.ve/gubs.php?id=27 [Accesado en Enero 21 2007].

IMAGEN 216 Ricardo Laverde. (2004). Detalle de Hrönir levitante. Laverde, R. (2013). Material inédito. Entrevista online. https://www.facebook.com/ricardo.laverde.1?fref=ts [Accesado en: Enero 27].

IMAGEN 217 Ricardo Laverde. (2007). Etéreo. Plata 1000, oro $18 \mathrm{k}$, coral rojo, peonías, paraparas, acrílico, instalación eléctrica. Termoformado, trefilado, talla, ensamblaje.45 × $15 \times 15 \mathrm{~cm}$. http://galeria.uc.edu.ve/actual.php?id=72 [Accesado en: Enero 21 2011]. 
IMAGEN 218 Ricardo Laverde. (2007). Detalle de Etéreo con luz artificial. Material inédito. Entrevista online. https://www.facebook.com/ricardo.laverde.1?fref=ts [Accesado en: Enero 27].

IMAGEN 219 Ricardo Laverde. (2010). Pez. Acrílico, Plata 1000, espinas de jabillo, semillas de peonia, Termoformado, encapsulado, laminación, embutido, tartarización mecánica, ensamblaje. S/D. Laverde, R. (2013). “Simbología en la producción de orfebrería”. Entrevista online. https://www.facebook.com/ricardo.laverde.1?fref=ts [Accesado en: Enero 27].

IMAGEN 220 Ricardo Laverde. (2010). Detalle de Pez.

IMAGEN 221 Víctor Rodríguez. (1994). Lo que hice y donde lo hice: collar Laudan y el taller de Vulcano. Bronce, cobre, plata y aluminio. Tallado directo sobre metal, ensamblaje. $30 \times 12 \times 7 \mathrm{~cm}$. XXI Salón Nacional de las Artes del Fuego. (1994).

http://galeria.uc.edu.ve/gubs.php?id=53 [Accesado en: Enero 21 2007].

IMAGEN 222 Víctor Rodríguez. (1995). Lumbreras. Bronce, plata, madera. Embutido, calado, ensamblaje. 70 × 40 × $20 \mathrm{~cm}$. XXII Salón Nacional de las Artes del Fuego. (1995).

http://galeria.uc.edu.ve/actual.php?id=54 [Accesado en: Enero 21 2007]. 


\section{GLOSARIO DE TÉRMINOS}

\section{Baños electrolíticos:}

También conocida como electroplateado, es una técnica que consiste en depositar capas finas de metal sobre la superficie de casi cualquier objeto, utilizando la electricidad. Se usa corriente eléctrica para mover pequeñas partículas o moléculas de metal con una carga eléctrica positiva, llamadas iones, a través de una solución química llamada electrolito, para depositarlas en un objeto o matriz que tiene carga eléctrica negativa. Entre los baños electrolíticos se pueden dar en: níquel, cobre, plata, oro y otros. McGrath, J. (1995). p: 6-18.

\section{Cera perdida:}

Esta técnica se basa en un método con el cual se obtiene un modelo (hueco o macizo) vaciado en metal. Partiendo de una forma modelada o tallada en cera, se cubre con un material refractario dejando una cavidad por un extremo del diseño. Una vez endurecido y seco el refractario, se somete a una temperatura alta y constante hasta fundir la cera del interior y mantenerse lo más caliente posible. Quedando vacio el espacio ocupado antes por la cera, se introduce por la cavidad dejada previamente, el metal fundido; una vez frío este refractario, se elimina, descubriendo el I modelo ya vaciado. Existen métodos artesanales e industriales para la realización de esta técnica e inclusive, existe la variante de vaciar modelos en plástico, madera, orgánico, papel, textil, entre otros materiales; lo cual, resulta una técnica muy útil para la obtención de modelos metálicos vaciados en serie. Datos aportados por la autora.

\section{Cincelado:}

Consiste en decorar el metal sin elevaciones, utilizando como base una superficie metálica de un grosor aproximado a $1 \mathrm{~mm}$ : pues, si es más fina, la superficie se deforma. Con la acción de un martillo, se golpea el cincel de metal o madera y con esta punta se va haciendo el dibujo tras golpes continuos y equidistantes, debe recocerse el metal con constancia para mantener su maleabilidad y evitar que se deforme y se abra. Datos aportados por la autora.

\section{Engaste:}

Las piedras han constituido desde siempre la esencia de la joyería y con el fin de ser mostradas surgió la técnica del engastado, como una especialización consistente en el montaje de las mismas sobre su montura. Existen muchos tipos de montura a partir de un perfil en tubo (charnela), hilo redondo, cuadrado, media caña en lámina y tiene varias denominaciones, de tipo garra, de carril, de bisel, pavé, entre otros. Codina, C. (2000). pp. 109-112. 
Esmalte sobre metal:

El esmalte puede definirse, como barniz vítreo aplicado por fusión al metal. Está formado por silicatos o fluosilicatos que constituyen la base, fundentes que ayudan a disminuir la temperatura de fusión (en algunos casos) y pigmentos minerales para dar el color. Los esmaltes tienen una gran resistencia a los elementos corrosivos naturales, por tanto suele ser usado como protector de metal y fines decorativos. Los ingredientes tienen al principio la forma de terrones o pastillas que más tarde se reducen a un polvo fino. Éste, seco o mezclado con agua o aceite, se aplica a mano sobre la superficie a recubrir. El objeto esmaltado se hornea a temperaturas muy altas y el esmalte se funde sobre la superficie metálica. Los esmaltes según su tonalidad presentan diferentes durezas: los esmaltes blandos funden a $750^{\circ}$, los medios funden entre $800^{\circ}-900^{\circ}$ y los duros funden entre $1000^{\circ}-1200^{\circ}$. Para asegurarse la uniformidad del esmalte es necesaria una temperatura constante. Los procedimientos para esmaltar son cinco: Pliqué-`a-jour (el esmalte trasparente es sostenido por un marco abierto para conseguir un efecto de vidriera), Base-taille (el metal el grabado en bajo relieve para ser cubierto luego por esmalte transparente), Champlevé (el metal se vacía a buril o con acido para después aplicar el esmalte dejándolo al mismo nivel), Cloisonné (sobre un base de metal se sueldan hilos siguiendo diferentes diseños que posteriormente se llenan de esmalte), Esmalte pintado (principalmente reproduce figuras, pero también paisajes y todo tipo de motivos). Estilo Joyero - El Esmalte a fuego. www.estilojoyero.com.ar

\section{Filigrana:}

Es un trabajo muy delicado realizado con finísimos hilos laminados de oro o de plata, enrollados dentro de una plantilla/armadura del mismo metal. La labor consiste en rellenar con hilos de filigrana los espacios vacíos de la plantilla/armadura. Estos hilos se consiguen después de fundir, estirar, torcer y aplanar el metal, mediante procedimientos que conjugan diversos elementos de la naturaleza con el esfuerzo humano. Requiere de un largo proceso de elaboración: fundir la aleación, forjar, laminar, diseñar la plantilla, soldar la plantilla. Luego vestir/rellenar la armadura: fundir la aleación, forjar, estirar, entorchar, laminar, enrollar, soldar y lavar. Los hilos que visten la armadura se sueldan entre ellas y a la armadura con soldadura en polvo, lo que supone, elaborar la soldadura, fundirla, limarla y posteriormente limpiarla. La filigrana es una técnica que impone su estilo. Se trabaja con las manos en dimensiones de miniatura. Su adecuado manejo requiere de una probada y controlada paciencia. Una actitud que únicamente se aprende con observación y práctica. "Artesanías colombianas, las ciudades de oro: colección Colombia adentro". (1996). pp. 19-25.

Forja: 
Consiste en golpear el metal con diferentes puntas de martillos, sobre diversos soportes, se controla la forma y el alargamiento del mismo y se consigue una transición armoniosa entre las partes gruesas y finas de una pieza; de este modo, pueden realizarse desde trabajos de gran formato a delicados detalles. La forja al igual que el laminado mejora la estructura interna del metal, al refinarse el tamaño de grano se consigue un metal más resistente que el metal fundido. Así mismo, como resultado de los sucesivos golpes, se obtienen superficies con unas texturas muy interesantes. El oro la plata y el cobre admiten muy bien el forjado, pues, son algunos de los metales más maleables y blandos que existen. A medida que se avanza el forjado, el metal se endurece, y por lo tanto, hay que efectuar sucesivos recocidos. Codina, C. 2000. p: 52.

\section{Fotograbado:}

Consiste en cubrir una plancha de cobre (en este caso) con una emulsión fotosensible, posteriormente se insola con luz UVA poniendo encima de la plancha una fotolito tramado. Si se quiere obtener una imagen con escala de grises, una vez revelado, se sumerge la plancha con diversas concentraciones de cloruro de hierro. La gran diferencia con el heliograbado es la trama regular y plana -mecánica- que reflejan las imágenes estampadas con este procedimiento. El fotograbado. -Manual del grabado calcográfico. http://www.manualdegrabado.com/ES/fotograbado.html

\section{Grabado con ácidos:}

o también conocido como aguafuerte. Es una forma de grabar el metal y tiene muchos usos en joyería; resulta muy útil por ejemplo para la aplicación en: la técnica del niello, esmaltes al fuego o incrustación de metal u otro material. El principio es sencillo: por un lado están los ácidos, que, como es bien conocido, atacan al metal y una vez preparados en su justa proporción llamaremos mordientes. Se puede grabar sobre cualquier superficie, pero cada una necesita un mordiente específico. El mordiente más conocido es el ácido nítrico, también está el percloruro de hierro, el clorhídrico y el agua regia que consta de ácido nítrico con clorhídrico. Codina, C. (2000). pp. 64-65.

\section{Grabado con buril:}

Es una técnica de huecograbado por la que se dibuja una plancha de metal excavando líneas sobre una matriz de metal ayudándose exclusivamente del buril, herramienta compuesta de un mango en cuyo extremo se ha sujetado una pieza alargada, de metal, con forma de cilindro al que se han excavado dos caras que se cortan en un arista y se han afilado en bisel. El buril recuerda en su forma a un arado, y el grabador lo utiliza se una forma semejante; haciendo surcos sobre la plancha, de manera que cuanto mayor es 
la presión que ejerce, consigue realizar una incisión más profunda sobre ella. Grabado a buril -Wikipedia la enciclopedia libre. http://es.wikipedia.org/wiki/Grabado_a_buril

\section{Granulado:}

Esta técnica consiste en un proceso de fusión de pequeñas esferas de oro o de plata, que oscilan entre $0,032 \mathrm{~mm}$ a 0,016 $\mathrm{mm}$ siguiendo un patrón decorativo, sobre una superficie que generalmente es del mismo metal. El proceso de granulación se distingue de otros procesos usados en orfebrería en que las piezas se unen por fusión sin utilizar ningún tipo de soldadura. Para llevar a cabo el proceso de fusión se eleva la temperatura, tanto en la superficie metálica como en los gránulos, hasta un punto en el cual ambos alcanzan su temperatura correcta y se sueldan entre sí. Si la temperatura alcanzada es demasiado elevada, la pieza puede fundirse totalmente ocasionando un problema irreversible. Por lo general la pieza se coloca sobre un bloque grueso de carbón al rojo vivo y sobre la superficie se aplica fuego con el soplete. Es un proceso muy lento y altamente meticuloso. Debe dejarse enfriar de manera natural, no puede someterse a un choque térmico, después si puede decaparse. Datos aportados por la autora.

\section{kum-boo:}

Es una técnica mediante la cual es posible unir finas láminas de oro sobre superficies de plata para lograr bellos motivos decorativos. Se trata de una técnica de origen coreano con la que antiguamente se decoraban objetos cotidianos y ceremoniales, en especial utensilios de cocina o de mesa, como cucharas, wols, etc. El término deriva de KUM, que significa (oro), y BOO que puede traducir como (adherido). Debido a la extrema delicadeza de la lámina de oro fino, una soldadura tradicional resulta imposible, para unir una lámina de oro de 24 quilates es necesario aplicar una difusión térmica sobre una aleación de plata mediante una combinación adecuada de presión y temperatura. Codina, C. (2000). p.34.

\section{Mokume Gané:}

MOKU: significa, (madera). ME: significa, (ojo). GANÉ: significa (metal) "Ojo de la madera o veta de la madera". El proceso de laminación envuelve sujetando varias capas de metales seleccionados no ferrosos, (normalmente se utilizan, cobre, bronce y plata) entre bloques de hierro y calentando el pedazo resultante en un horno, con condiciones cuidadosamente controladas de calor, presión y protección atmosférica. Permite que las capas se fusionen pero no se fundan. El pedazo resultante de metal fusionado es luego forjado y laminado para reducir su grosor. Los patrones únicos son creados mediante el grabado a mano y taladrado a través de las capas y luego pasando la lámina por el 
laminador para aplanar el área grabada. El proceso de grabado y laminado es repetido muchas veces para crear un patrón final donde se verán las vetas de los diferentes metales. (por lo menos nueve veces; al multiplicar las tres capas, originan la superposición de 27 láminas). Biblioteca de joyería - Raul Ybarra www.raulybarra.com/biblioteca

Niello: Incrustación decorativa de un esmalte negro en un fondo metálico, por lo general, previamente grabado. El nielo ó niel no es propiamente un esmalte, pero por su forma de aplicación y efecto sobre la superficie se halla históricamente ligado a esta técnica. Como material, posee la ventaja de ser fácil de preparar y aplicar, además, no se requiere un horno. El niello es una aleación compuesta de plata, cobre, plomo y azufre que una vez aplicado sobre plata u oro proporciona un gran contraste. Posee, además, la ventaja de fundir a baja temperatura, con lo que su aplicación no resulta excesivamente complicada. El niello es idóneo cuando se aplica en superficies previamente horadadas o grabadas con ácido, buril o cualquier técnica con la que se puedan realizar profundidades no superiores a un milímetro. Codina. C. (2000). p: 104 105

\section{Pátinas:}

Dentro de los tratamientos finales a los que se somete una pieza metálica se incluye la coloración. Al aplicar sobre la pieza metálica productos químicos se modifica el color de su superficie dando origen a una pátina. A la coloración se le denomina comúnmente "oxidación"; lo que significa: modificación por efecto del oxigeno del aire. Los colores más vistosos y variados suelen ser asociados a metales con un alto contenido en cobre en su aleación. Por este motivo la mayoría de los trabajos y los mejores resultados se alcanzan con metales como el cobre, el bronce o el latón. Son varios los factores que influyen en el proceso de oxidación; el calor y el enfriamiento aceleran dicho proceso, pero lo que determina el color resultante de la pátina es la proporción de los distintos productos químicos y la manera en que estos se aplican sobre la superficie del metal. Se suelen dar pátinas de distintas maneras; con calor (sol o soplete), inmersión en baño, pulverización o ducha, impregnación de serrín y atmósfera contaminante. Datos aportados por la autora.

\section{Repujado:}

A esta técnica también se le conoce como embutido. Consiste en realizar un dibujo a relieve en una superficie metálica así como también en superficie de cuero. El primer elemento necesario para llevar a cabo esta técnica es la lámina de metal (máximo $1 \mathrm{~mm}$ de grosor). Partiendo de un diseño dibujado en la lámina (anverso) y 
posteriormente cincelado todo el diseño, se repuja por el lado anverso. Consiguiendo como resultado el diseño en alto relieve. Datos aportados por la autora.

\section{Reticulado:}

Esta técnica consiste en alcanzar una textura superficial repleta de valles y crestas, generados mediante distintos enfriamientos del metal. Su procedimiento consiste, en fundir una aleación de plata como de ley 800. Se funde una lámina, y con la llama del soplete directo sobre ella, se formara una capa superficial rica en plata y debajo de ésta una fina capa rica en cobre, bajo la cual está la aleación del metal que posee un punto de fusión inferior. Esta diferencia entre los puntos de fusión interior y exterior hará que al aplicar calor, la plancha se convierta en una especie de bolsa de agua, ya que sólo se funde el interior de la misma, pues al tener más cobre en la aleación su punto de fusión es más bajo. Entre las dos capas se provoca una capa de oxido de cobre que se mantiene sólida mientras el interior se funde. Codina, c. (2000). p: 76.

Shibuichi: El principio de esta técnica es muy similar al reticulado puesto que, se constituye por una aleación alta en cobre: 40\% plata, $60 \%$ cobre ó 30\% plata, $70 \%$ de cobre. Y en su superficie se consiguen texturas similares a las arrugas de la piel. La aleación escogida se funde y vacía en una lingotera horizontal, se lamina hasta un grosor de 3 a $4 \mathrm{~mm}$. No debe decaparse en ningún proceso. Se coloca la lámina sobre bloque de magnesio para que la parte inferior no de refunda (el magnesio tiene la propiedad que no se calienta y por ende mantiene frio la superficie que este en contacto con ella), se aplica sobre la superficie de la lámina la llama directa del soplete, el punto final es cuando brotan pequeños volcanes en su superficie. Dejar enfriar sobre el magnesio, el color de esta lámina varía desde el marrón tabaco al rosado pasando por tonos plata. No intervenir con decapante, cepillo de grata, lija. Si esta lámina será soldada no debe usarse soldadura dura. Su apariencia es oxidada. Sin embargo, se recomienda para exagerar más la superficie frotar con bicarbonato en ciertas zonas para exagerar el brillo de la plata y conseguir mayor contraste. Datos aportados por la autora. 


\section{RESUMEN}

La presente Tesis Doctoral, se orienta al estudio de la orfebrería en la creación escultórica venezolana contemporánea, bajo la influencia de la obra y docencia del orfebre Alexis De la Sierra, desde el año 1976 hasta el año 2010.

Gracias a la obra de este artista venezolano, la disciplina de la orfebrería entra en el campo de la escultura y es reconocida a nivel de museo. Debido a la investigación constante de este artista, la orfebrería y la escultura se integran a procesos y métodos tecnológicos avanzados y con ello, logra desarrollar un lenguaje plástico que lo caracteriza como el pionero de la orfebrería escultórica en Venezuela.

La repercusión de la obra de Alexis De la Sierra y la labor docente en su propia escuela de orfebres, ha logrado revivir este arte milenario en el país. Podemos considerarlo como el principal artista venezolano de la historia de la orfebrería escultórica, como una nueva corriente artística en Venezuela. Hoy en día, la importancia que tiene esta disciplina en salones de arte en Venezuela y la apertura de una gran cantidad de talleres de enseñanza, se debe a este prolífico artista.

En este trabajo, se estudia en primer lugar, el contexto de la disciplina de la orfebrería y la escultura en Venezuela, desde la época de la colonia hasta el año 2010; considerando que ambas disciplinas confluyen en la orfebrería escultórica. En segundo lugar, se desarrolla un perfil del orfebre venezolano actual, fundamentado en un trabajo de campo. Así como también, se analiza la producción de algunos orfebres venezolanos, cuyas obras expuestas y premiadas en salones de arte en Venezuela dejan evidencia de la evolución que ha derivado de la disciplina de la orfebrería hacia una tendencia escultórica. Finalmente, se estudia y analiza la obra del orfebre Alexis De la Sierra, manifestando la importancia de su obra y docencia en la repercusión de la difusión y promoción de la orfebrería escultórica en Venezuela. 


\section{RESUM}

La present Tesi Doctoral, s'orienta a l'estudi de l'orfebreria en la creació escultòrica veneçolana contemporània, sota la influència de l'obra i docència de l'orfebre Alexis De la Serra, des de l'any 1976 fins a l'any 2010.

Gràcies a l'obra d'este artista veneçolà, la disciplina de l'orfebreria entra en el camp de l'escultura i és reconeguda a nivell de museu. A causa de la investigació constant d'este artista, l'orfebreria l'escultura s'integren a processos i mètodes tecnològics avançats i amb això, aconsegeuix desenvolupar un llenguatge plàstic que el caracteritza com el pioner de l'orfebreria escultòrica a Veneçuela.

La repercussió de l'obra d'Alexis De la Serra i la tasca docent a la seua pròpia escola d'orfebres, ha aconseguit reviure aquest art mill-lenari al país. Podem considerar-lo com el principal artista veneçolà de la història de l'orfebreria escultòrica, com una nova corrent artística a Veneçuela. Hui en dia, la importància que té aquesta disciplina en galleries d'art a Veneçuela i l'obertura d'una gran quantitat de tallers d'ensenyança, es deu a aquest prolífic artista.

En aquest treball, s'estudia en primer lloc el context de la disciplina de l'orfebreria i l'escultura a Veneçuela, des de l'època de la colònia fins l'any 2010, considerant que ambdós disciplines conflueixen en l'orfebreria escultòrica. En segon lloc, es desenvolupa un perfil de l'orfebre veneçolà actual, fonamentat en un treball de camp. Tambés' analitza la producció d'alguns orfebres veneçolans, les obres dels quals estan exposades premiades en galleries d'art a Veneçuela,deixant evidència de l'evolució de la que ha derivat la disciplina de l'orfebreria cap a una tendència escultòrica. Finalment, s'estudia i analitza l'obra de l'orfebre Alexis De la Serra manifestant la importància de la seua obra i docència en la repercussió de la difusió i promoció de l'orfebreria escultòrica a Veneçuela. 


\section{ABSTRACT}

This thesis focuses on the study of jewelry in contemporary Venezuela, in the creation of sculptures, under the influence of the work and teaching of goldsmith Alexis De la Sierra, from 1976 until 2010.

Thanks to the work of this Venezuelan artist, goldsmithing enters the field of sculpture and is recognized at the museum level. Due to the constant research of this artist, pottery and sculpture are integrated with advanced technological processes and methods, thus permitting the development of a plastic language that characterizes him as the pioneer of sculptural jewelry in Venezuela.

The impact of the work and teaching of Alexis De la Sierra in his own school of goldsmithing has resulted in a revival of this ancient art in the country. We can consider him as the main Venezuelan artist in the history of the sculptural metalwork, as a new artistic movement in Venezuela. Nowadays, the importance of this discipline in art salons in Venezuela is illustrated by the opening of a large number of educational workshops, and is due to this prolific artist.

Within this context, the artistic work of Alexis De la Sierra has been the base for the progress of the convergence between jewelry and sculpture, and we can consider him as the main Venezuelan artist in the history of sculptural metalwork, this being considered as a new artistic movement in Venezuela.

In the research presented here, we first study the context of the discipline of goldsmithing and sculpture in Venezuela, from colonial times to 2010, considering that both disciplines converge together in sculptural metalwork. Secondly, we develop a profile of the current Venezuelan goldsmith, based on fieldwork. Furthermore, we analyze the production of some Venezuelan goldsmiths, whose works have been exhibited and awarded in art salons in Venezuela, and give evidence for the evolution of the discipline of sculptural metalwork. Finally, we study and analyze the work and teaching of Alexis De la Sierra in relation to its importance on the dissemination and promotion of sculptural jewelry in Venezuela. 